

\section{REPORT}

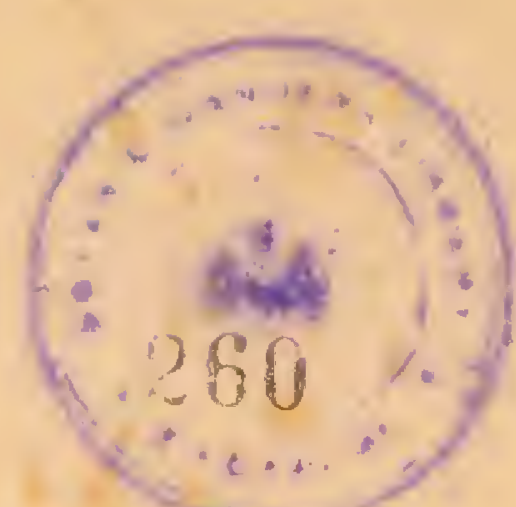

ON THE PRESENT SYSTEM OF

\section{FOREST CONSERVANCY}

IN THE

S'TRAITS SETTLEMENTS

WITH

- Suggestions for future Management

H. C. HILL,

Conserator of Fores's, H. W's Indiun forest Service. 
CONTENTS.

INTRODUCTION

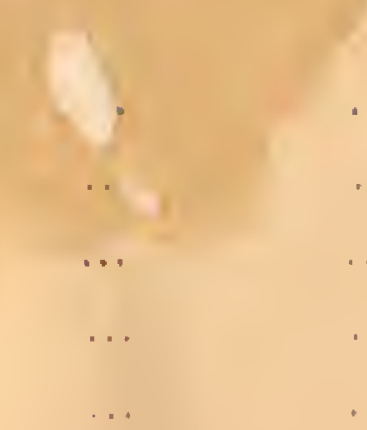

\section{GENERAL REMARKS}

PAST HISTORY OF FOREST CONSERVANCY

PRESENT POLICY ...

Suggestions for liuture Management

1. The unalienated Crown Lands of each District, inasmuch as they all vield timber and forest produce should, I submit, be considered and treated as forests, whether reserved or unreserved.

2. A special Forest Law should, in my opinion, be enacted ...

3. The reservation of certain additional arcas is desirable ... ... ib

4. The reserves should be sub-divided by cleared lines or inspection paths into blocks of a manageable size, say of 500- 1,000 acres each

5. The protection of certain reserves from fire should be undertaken ...

6. Where Gutta Percha (Palaquium sp.) are found in the reserves they should be weeded, i.e. cleared of the over head cover of weeds or other tree growth, which is interfering with their development ...

7. Plantations of Gutta Percha (Palaquium sp.) should be made in one or two selected localities

8. Yield and working-All mangrove tracts should be worked on a systematic plan of annual lellings fixed by area. The other reserves may well remain closed to the cutting of timber; but, meanwhile the most should he made of the timber found on unreserved Crown Lands (chiefly in the Dindings).

9. All minor forest produce should he utilized, as far as there is a demand for it, whether found in the reserves or on the unreserved Crown Lands

.

.

$\cdots$

Io. A certain number of Rangers trained in forest work should be employed, and I further suggest the appointment of a trained Forest Officer with experience, to inspect and adrise as to the carring out of any works, and on all matters connected with the administration of the forests

\section{Appendix A.}

Minute on the staff required to protect the forests, Penang and Province Wellesler.

\section{Appendix B.}

Minute on the staff required lor the protection of the forests in the Dindings.

\section{MAPS.}

\section{(Showing reserves}

Penang and Province Wellesley.

The Dindings.

Malacca.

Singapore, 


\section{INTRODUCT. N.}

Under instructions received from the Colons Office (Letter No. Io,4 I I oo,

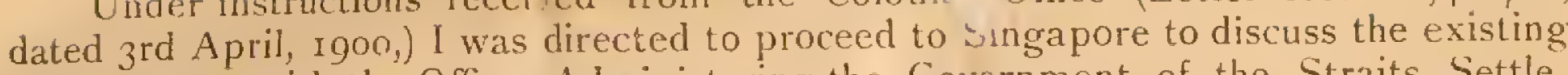
forest system with the Officer Administering the Government of the Straits Settlements and after conferring with that Officer and the Resident-General of the Federated Malay States to report whether, in my opinion, the present system of forest administration, conservation and development admit of improvement at a reasonable cost, and, if I considered any changes in the present system desirable, to suggest broad general rules, in accordance with which such changes should be carried out.

I was also asked to report what steps, if any, were considered desirable for developing the supply of gutta percha in the Colony and in the Federated Malay States.

In compliance with these orders I reported my arrival in Singapore on the $17^{\text {th }}$ May, Igoo. From that date till the ist June, I was occupied in studying the reports published from 1883 and in making excursions to different reserves and parts of the island. On each occasion I was accompanied by Mr. H. N. RidLEy, M.A., Director of the Botanic Gardens, and Mr. W. I. Carter, the Collector of Land Revenur, went out with us on two days.

From the 2 nd to the 1 th June I risited Malacca and with Mr. RidLey spent 6 days in going round to the different reserves.

We arrived at Penang on the 16 th June. Cnder the guidance of Mr. C. CurTtS, Assistant Superintendent of the Botanic Gardens, 4 days were given up to visiting

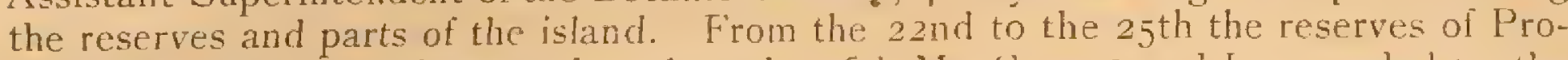
vince Wellesley were inspected and on the $26 \mathrm{th}_{\mathrm{s}} \mathrm{Mr}$. CuRTiS and I proceeded to the Dindings. Mr. RibleEY left us at Bukit Mertajam on the 24 th to return to Singapore. Five days were passed in the Dindings and on the 2nd July I reached the Perak road and took up the work in that State, having been met the day before by Mr. Doviglas, the Acting Forest Officer of Perak.

I desire to acknowledge, with many thanks, the cordial welcome and ready assistance in my work which has been afforded to me by the Officer Administering the Government, Sir J. Alexander Swettenham, K.C.M.G., by the Colonial Secretary, the Resident Councillors, and those District Officers whom I had the pleasure of meeting in the course of my tours and inquiries. Mr. RidLEY's knowledge of the reserves, and their composition, as well as his familiarity with all forest questions, enabled him to act as a most useful guide, and I am indebted to him and to Mr. CuRTIS for much of my information.

\section{General Remarks.}

The Colony known as the Straits Settlements consists of the three different Settlements, Singapore, Malacca and Penang, and the last named comprises the separate territories of Province Wellesley and the Dindings. While Singapore and Penang are Islands, Malacca and the other tracts are rectangular strips lying on the coast of the main peninsula. Province Wellesley is almost entirely, with the exception of the forest reserves, taken up for the cultivation of coco-nuts, paddy, sugar, tapioca or fruit and more recently of Para Rubber. Even the hills have been brought under the cultivation of nutmegs, areca-nuts and cloves.

The island of Penang is similarly highly cultivated, but being more hilly, it has a much larger percentage of forest reserves, and a larger proportion of land under spices and fruit trees.

The Dindings on the other hand is almost entirely under forest, cultivation being limited to scattered villages or hamlets.

Malacca is highly cultivated in part and its forests, outside reserves, are being rapidly cleared for the shifting cultivation of tapioca.

In Singapore coco-nuts, pine-apples, indigo. pepper, gambier and garden produce are grown. The cultivation of both pepper and gambier was at one time much more extensive, and it has been said to have declined because of the scarcity of wood for posts on which to train the pepper and for fuel for cooking gampier. It is believed, however, that a serious fall in prices is alone accountable for the abandonment of the cultivation of these crops. 
These brief general remarks may serve to explain that th z conditions, under which a system of forest conservancy can be applied, are by no means the same throughout the Colony. Permanent cultivation may in one part absorb nearly the whole of the land, while in another part only the shifting cultivation of such crops as tapioca and gambier is possible. If is without coubt the practice of shifting cultivation which has given rise to the belief in the minds of srme people that part of the Colony, and Singapore more part ularly, has been den d of forest. This however is not really the case. There $h$ been no actual der dation: for whenever land ceases to be cultivated a growth of arass, fern and soft woods quickly springs up on it. And, if this is not burnt or in, the forest soon re-establishes itself. This will be the more readily understood, if it is remembered

(1) That the mean annual temperature exceeds $80^{\circ}$, and that the range of temperature is from $66^{\circ}$ to $93^{\circ}$;

2) that the annual rainfall is about 100 inches well distributed over the year, and

(3) that the warm atmosphere is saturated with moisture to a high degree.

But, on the other hand, if the newly abandoned area is burnt over by regularly recurring fires, the young tree growth is killed out, the soil rapidly deteriorates under continuous exposure and the grass known as lalang (Imperala cylindrica) takes possession. Once this happens constant fires prevent any improvement in the condition and the area becomes permanently covered with grass. Another bad effect of temporary cultivation is the destruction of the more valuable hard wood forest, and its replacement by a young growth of soft woods. 'This would be disastrous if a fair proportion of the virgin forest were not set aside as forest reserves, as las been done in Malacca.

\section{Past History of Forest Conservancy.}

Considerable attention had been paid to the conservation of forest lands in the Straits Settlements prior to 1882, when the late Mr. CanTLEy, Superintendent of the Botanic Gardens, Singapore, was instructed to report on the forests and make recommendations for their better management. His report, published in $188_{3}$, sufficiently describes the progress made up to that time in protecting the forest lands at the disposal of the Crown, and it is scarcely necessary lor the purposes of this paper to make further reference to the measures which had previously been taken to secure the maintenance of forest areas. They are described as "no sufficient attempts to conserve the Government forest lands" although they were clearly not without result, as is shown by the reservation of 37,500 acres, which had already taken place in Malacca.

The recommendations made in 1883 are summarised in paragraph i 12 of the report, and shortly afterwards effect was given to them by the creation of a Department and the grant of money to carry them out.

The Director of the Botanic Gardens, Singaporc, was in charge of the Department and he had the services of the Assistant Superintendent at Penang and of a second Assistant at Malacca. The establishment was entirely protective and consisted of Forest Guards, the seniors of whom in Singapore were styled Lance-Corporals or Corporals.

From 1884 the felling of forests and the clearing of forest lands were prevented by the demarcation of reserves in Singapore, Penang and Province Wellesley, and in Singapore the planting up of certain areas, chiefly with exotic trees, was undertaken.

In I893-94 many plants of the Borneo iron wood-Bilian-Ensideroxylon Sihtergeri-were introduced.

From the Ist January, 1895 , in accordance with the recommendations of a Retrenchment Committee the forests and their protective establishments were transferred from the charge of the Officers of the Botanic Gardens to that of the Collectors of Land Revenue.

The work done and progress made during the years $1884-94$ is briefly referred to in the reports made by the Gardens Authorities in the year 1044 . Forest reserves had been selected and demarcated as follows :-

$\begin{array}{llllc}\text { Singapore } & \ldots & \ldots & 12,965 & \text { Acres. } \\ \text { Penang and Pulau Jerejak } & \ldots & 11,226 & \text { " } \\ \text { Malacca } \quad \ldots & \ldots & 42,000 & \text { ". }\end{array}$

and their protection from encroachment and theft had been assured, while fires were of less frequent occurrence. There was no doubt, as is claimed, murh perseverance in re-afforesting, more particularly in Singapore: but the results in this direction have not been commensurate with the expenditure. Many thousands of plants were put out, but either the areas planted were not secure from fire or the plantations were not 
sufficiently weeded and tended for the plants to grow up and establish themselves. Worcover from the number of exotic species selected the plantations were mostly of an experimental nature.

In Penang no attempt was made to artificially re-stock forest areas on a large scale. Mr. CurTis writes that no planting was done, partly on account of the expense, but mainly becaus' here was reason to believe that efficient protection during a sufficiently long period all that was require o re-stock the forest.

From is95 up to the iesent, existing. resc s have been protected and some further reservations have been made, chiefly in the Jindings and Province Wellesley. No planting has been done and the reserves have ueen gradually closed entirely to the extraction of all timber and forest produce of all kinds. The Collectors of Land Revenue are responsible for the upkeep of the boundaries, protection and closure.

\section{Present Policy.}

There can be no two opinions as to the soundness of the policy which has secured to the Colony $88,33^{6}$ acres of forest reserves, to be maintained permanently under forest growth.

The reserves are distributed over the different Settlements as follows:-

\begin{tabular}{|c|c|}
\hline Settlement. & Acres. \\
\hline Nalacca $\quad \ldots$ & $\cdots+9,+78$ \\
\hline Singapore Island & ‥ $12,428 \%$ \\
\hline Penang Island & $\ldots 10,122 \dagger$ \\
\hline Province Wellesley & $\ldots 6,308$ \\
\hline Dindings $\quad \ldots$ & ... 10,000 \\
\hline
\end{tabular}

The appended Maps $\|$ and statements show the positions of the different reserves and their areas.

The reserves thus formed occupy more than 9 per cent. of the area of the Colony which is 1,525 square milës; and in Malacca they cover 12.6I\% of the total area of the Settlement. Certain additions will no doubt be made to the reserves in both Penang and Singapore: and the arca of reserves in the Dindings will eventually stand at a much higher figure than at present, when surveys are made and the areas come to be accurately computed. The progress made in selecting, suitably demarcating and protecting these reserves from encroachment and theft is highly satisfactory and creditable to the Government as well as to the Department which carried out most of the reservations, and to the Collectors of Land Revenue who have supervised their protection since 1895 .

Protection from fire has not becn effective in some places and more attention should have been given to this important matter in Singapore, where experimental plantations, made at considerable cost, have been constantly burnt over and destroyed.

The improvement of the reserves by means of planting the more valuable indigenous trees ( $(h)$ of Mr. (ANTLEY's recommendations) has not been successful, or un dertaken upon right lines.- The introduction of the more valuable hard woods into a mixed forest by planting is not easy; and, indeed, may be said to be impossible unless the complete removal of the existing crop over more or less considerable areas be first undertaken, so as to admit of a complete young growth only springing up with the trees planted. The plants it is desired to raise may be delicate and shade requiring and it may be necessary to rear them by means of nurses or under a shelter wood, but even then their eventual development will depend on the gradual removal of such aids, and the area will come to be stocked with the planted species and such growth as may have sprung up with it. These considerations lead in most instances to the systematic planting up of compact areas, after the clearing off of whatever may be the existing growth. Exceptionally, as with teak planted by the Karens in Burma, means may be found to artificially increase the proportion of trees of a valuable species in a forest by dealing with isolated patches, but this is not the case as a rule and it may be accepted that, when costly planting is required, it should be arranged with the definite object of creating a new crop over a considerable and previously fixed upon area. The tract operated upon should be divided up into

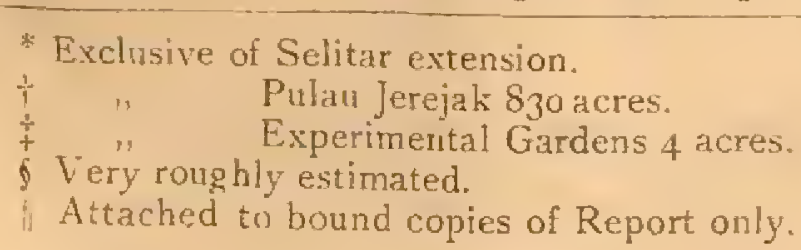


blocks by means of lines or roads or paths, that will serve to facilitaie inspection, protection, and the export of produce.

The utilisation of timber and forest produce from the reserves is at present in abeyance, but whenever demands have been met from the reserves the timber and produce have been disposed of as $f: o m$ the unfeserved Crown Lands. Under the Crown Lands Ordinance No. II $n^{r} 1886$ and Rules 5: inder that Ordinauce, licences to cut and remove timber $\quad$ Crown Jands are ated on payment of rates laid down in a Timber Roll. Th tre usually $25 \%$ a orem.

Hitherto the reserves have" deait with and repyrted on separately from unreserved Crown Lands. This enture to suggest is a mistake. All Crown Lands whether reserved or unreserved should in my opinion be treated as one and the same estate and be reported upon as such, different rules, rates, etc., being applied to the reserves.

I propose now to deal with the suggestions which I have to make for the further development of the system of forest conservancy in force, giving in each instance the reasons I have for the suggested action or change.

\section{SUGGESTIONS FOR FUTURE MANAGEMENT}

1. The unalienated Crown Lands of each District, inasmuch as they all yield timber and forest produce should, I submit, be considered, and treated as forests, whether reserved or unveserved.

This is the arrangement in Burma and I think it would tend to make reservation more appreciated, if each District Officer understood that the Reserves are only a part of his forests set aside to grow up until such time as the demand on them and the value of their production shall allow of their being worked, and also that the . remainder of the Crown Lands represent an estate, the produce of which in timber and minor products should be utilized to the utmost and made to yield revenue pending their alienation for cultivation. This revenue would go far to cover the cost of protection of the reserves and it seems to be right for one account to contain both the revenue from one part of Crown Lands and the expenditure on the other part. There would then be less desire to force sales and make "revenue from the reserves. It is the Crown Lands as a whole that should be considered in balancing the account. In the event of a forest law being enacted all Crown Lands, and not reserves only, should come under it.

2. A special Forest Laze should in my opinion be enacted.

The reasons which have induced all countries with large forest estates to adopt a special law for their forests need not be enumerated here. I may merely state that although the legal title of the Crown Lands which are taken up as reserves may be perfectly clear, and no rights of user ma exist over them, still it would be an advantage if a definite procedure were laid down and if power were given to a Settlement Officer to deal with alienated lands enclosed in the proposed reserves and to record rights of way and to watercourses. In some cases it may be equitable to create a right to the fruit of certain trees to which persons may lay claim.

Then the acts prohibited within a reserved forest and the penalties for offences should be clearly laid down. Power should also be taken to regulate and control fires both inside a reserve and in its vicinity. In unreserved Crown Lands the power to make certain species of trees reserved and to take more special measures for their protection would be useful in the Dindings and possibly the reservation of certain trees would be a good measure in Malacca, with a view to their being spared in the clearings for tapioca. The general power held under Ordinance No. II of i 886 to deal with timber and produce is sulficient of course as far as it goes, but it is too restricted. Even now I venture to think that it is open to doubt whether under Rules 59-6r made under that Ordinance the double charges made in the Dindings, the one for licences to cut timber and the other as royalty on timber extracted are strictly legal.

It is desirable also to have power to establish revenue stations, to which timber and produce shall be brought for the realization of Government dues, and to control timber and produce in transit until such time as the Government dues shall have been collected, and to provide for its release from control by marks or passes to show that its removal is authorised. This would simplify the collection of Government dues in the Dindings. 
commend the reservation of all areas where the trees (there are several species of Palaquium* yielding good Gutta Percha) are found growing naturally, or they can be planted with good prospect of success. Such an area is that in Penang to the North of the Government Hill Reserve and below an elevation of $I_{z}, 000$ feet at about which altitude the existing reserve botndary has baen taken. Other tracts may probably be found near the $R$ 'it Laksamana reserv or between it and the Pantai Acheh reserve. Small ared: e also available in I 'acca near Batang Malacca and Nyalas in the Jasin Listrict: in the Tebong Muk of the Alor Gajah District.

Bukit Langkap in the central District of Provine Nellesley may well be reserved.

In Singapore the mangrove tracts on the North or the island should be reserved so that a working scheme may be drawn up for the entire area of this class of forest. An adiditional reserve can probably be demarcated on the Bajau Hills near the Tuas River and it is for consideration whether Pulau Ubin should not be in great part reserved. In the Dindings where I understand the policy of Government is to eventually reserve some $20 \%$ of the total area, I am of opinion that a sufficient area has been taken up for the present, and that it will be better to wait till more land has been alienated and the trade in timber and forest produce has further developed for the conservation of any more extensive areas. A reserve may be formed on Bukit Undan opposite Lumut and Bukit Senangir may be maintained permanently under forest but there is no urgency in regard to their demarcation. A survey of the existing reserves, and indeed of the whole territory, is much needed; and, when this is made, I am satisfied that the reserved area will be found to greatly exceed the estimates of it. The unreserved mangrove tracts may well be reserved, since as a rule they can only be utilized for the production of fuel, and with the Tanjong Burong reserve be worked under a systematic plan such as will be described under another heading. Every encouragement should be given to traders to come and purchase timber and produce from the extensive unreserved Crown Lands and, if there is any risk of the more valuable trees being completely worked out, I would suggest that certain specific trees should be declared "reserved" such as Merbau ( Afzelia palembanica) Damarlaut (Shorea utilis) Chengal (Balanocarpus sp.) etc. The cutting of these could then be either entirely prohibited for a time or it could be restricted by placing a minimum limit on the size of trees to be felled and by charging higher rates.

4. The reserves should be sub-divided by cleared lines or inspection paths into blocks of a manageable size, say of 500-I,000 acres each.

This would facilitate the clearing and patrolling of the boundary lines: but it would chiefly be advantageous in permitting a more minute inspection and examination of the reserves than is at present possible. It is a hopeless task to search for gutta percha trees in, or gain any idea of the composition of, the large reserves in Malacca as they stand, whereas, if they could be dealt with block by block of reasonable size, it would be a simple matter. The lines or paths will usefully serve later on for the export of produce.

\section{The protection of certain reserves from fire should be undertaken.}

Wherever the reserves have been so demarcated as to enclose blanks overgrown only with ferns and lalang grass, or similar blanks within the reserves are traversed by roads, fires constantly occur and the blanks are not only made permanent. but are enlarged by the encroachment of the fires on the forest growth. This state of things is chiefly confined to Singapore and Province Wellesley: and I think the reserves could be easily protected by means of fire-lines such as are extensively used in India.

Where there is risk of fire a narrow line $5^{\prime}$ or $6^{\prime}$ parallel to the boundary or two lines parallel to the road (one on either side) should be cut and cleared at a distance of $50^{\prime}$ or even $100^{\prime}$, and the intervening grass be burnt under control once or twice a year as may be necessary. The grass cut from the narrow lines should be thrown to dry on the side to be burnt and to facilitate the burning and control of the fire, crosslines may be cut across the fire-lines.

Once the system were started, it would be easy to carry out and Forest Rangers could arrange to overlook and pay for the work.

* I use this name for the genus on the authority of Major Prain, I.M.S. 
6. Where Gutia Percha trees (Palaguium sp.) are found in the reserves they should be weeded, i. e. cleared of the overhead cover of weeds or other tree growth, which is interfing with their derelopment.

So far as is known these te ss are found in the "r. "ing reserves only :-

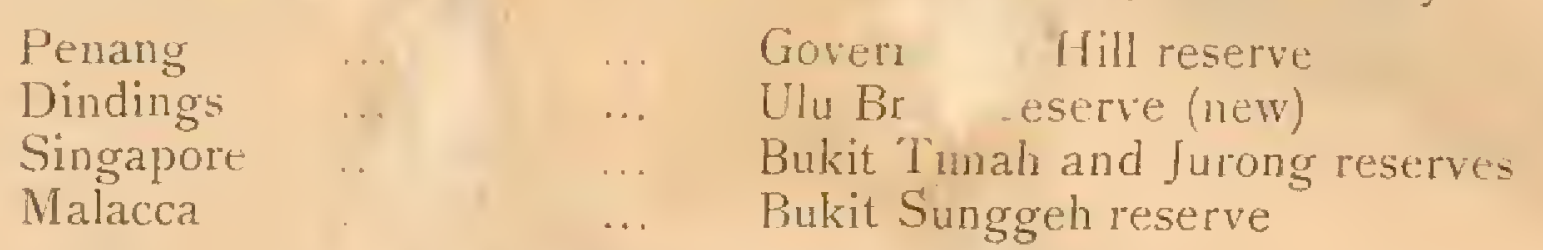

and over very limited areas: but it is difficult to understand the absence of the tree in the large Malacca reserves of the Jasin District, and it would be reasonable to assume that a more careful search would result in its being found; for it occurs in several places near them. But, on the other hand, it is claimed that the wild jungle tribes living there, having known and cut out every mature tree long ago, must know if it were to be found elsewhere than at that place in the Bukit Sunggeh reserve where they have pointed ont is trees.

Near Batang Malacca there is a wood with 26 trees and saplings, the largest being 30 feet in height with a girth of I' $3^{\prime \prime}$. Near Nyalas 65 trees and plants have been counted. At Tebong there are said to be 200 on an area of 19 acres the largest being about I' 6 " in girth. In the Batu Feringhi valley of Penang the trees and saplings are much more numerous and some of the trees are larger.

The largest trees known in the Colony are one or two situated on the Northern boundary line of the Dindings and those in a valley adjacant to the Botanic Gardens at Penang. These latter are 20 or more in number and 2 or 3 seeded last year. One measures $4^{\prime} 6^{\prime \prime}$ in girth. From these trees Mr. CURTIS raised some 800 or goo plants, 500 of which have been put out in the Ayer Kroh reserve in Malacca. It would seem that the old paren trees which have produced the young trees and saplings now found were entirely cut out between I 850 and 1870 when Gutta Percha was in great demand and that so clean a sweep of them was made that not a tree remains. The oldest of those at Penang are beginning to bear seed, and the object in view must be to foster all the natural growth that exists in order to lead a good number of trees on to maturity and seed-bearing. I am not in favour of any attempt being made to generally increase the proportion of the valuable gutta percha trees throughout the reserves by artificial means. It will be safer and better to concentrate operations on one or more extensive but compact plantations. I would propose that every locality where the trees grow or can be found in any appreciable numbers should be carefully gone over. The areas are unfortunately all too small to make it a heavy piece of work. All trees six inches in diameter and over should be enumerated in classes as follows :-

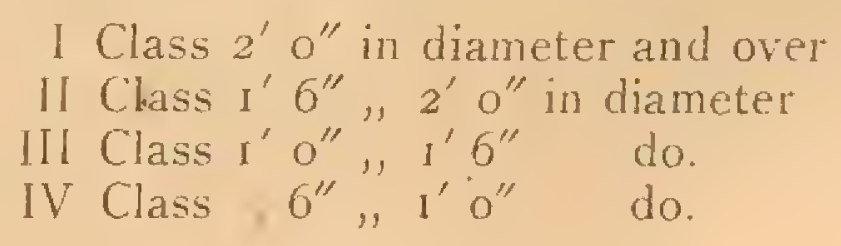

and each tree painted with a broad ring of white paint.

Each tree should be weeded by the felling, or killing by girdling, of trees overtopping it, interfering with its crown development or tending to suppress it. At the same time care must be taken not to make great openings in the canopy and thus expose the trees too suddenly to ai excess of light. Any healthy poles of $3^{\prime \prime}-6$ " in diameter should also have their crown freed and uncovered so as to admit of their development.

Seedlings and suppressed stems, often 3 or 4 feet high, and quite thin, with a tuft or two of leaves may be removed to nurseries and gradually hardened off for transplanting in the regular plantations, which it is proposed should be made.

\section{Plantations of Gutta Percha (Palaquium sp.) should be made in one or two} selected localities.

Hitherto the work of planting up certain areas has not been carried out on any systematic plan. At the beginning various trees mostly exotics were tried in Singapore but owing to fires or other causes little or no trace of them is now found.

In 1889 and 1892 some Para Rubber was planted, with which several acres are now found to be stocked in the Sembawang Reserve, and in the Ayer Kroh reserve in Malacca. Gluta Eenghas, Sterculia alata, Pithecolobium Saman, Artocarpus sp. 
Swietenia macrophylin, etc., were experimentally put out. The boundary lines and a protective fire belt were planted with Eugenia grandis which has grown well. Numerous plants of Dializm sp. were also planted.

Later in I 893-94 some thousands of Eusideroxvlon Schwageri were raised and planted out, but these ha: : succeeded owing ssibly to want of funds to tend the plantation, and to $t)$ se which was $m$ at that time in the management.

Some small areas hav, stocked in the $A$ Fagroea fragrans and Afzelia palembanica. Recer made in the Bukit Timah reserve of Gutta Percha, Vierbau (Afzelia palembanica) and Balam (Bassia sp.).

At Ayer Kroh 500 Gutta Percha plants have been planted out. In my opinion it would be well to discontinue the experimental planting of all sorts of indigenous and exotic trees and concentrate efforts on the formation of one or two large plantations of the most valuable indigenous tree. From its scarcity in the Colony, the narrow limits of its habitat and the value to the world of its product there is no more valuable tree than the Gutta Percha. The scarcity of any of the better hard woods or of woods suitable for construction need cause much less concern than that of Gutta Percha for the reasons, first, that the reserves still contain useful woods and, second, that sea-borne timber will always be forthcoming to meet the requirements of the Settlements. Operations have been begun at Ayer Kroh where land is available for the purpose and where supervision will be easy. "The soil is perhaps not that which would be selected for choice, as it is chiefly formed by laterite and the Gutta Percha is found growing naturally on the granitic soils, often amongst boulders of the same rock with but little soil. Still I believe it will mow at Ayer Kroh provided its exigencies as a shade-loving plant are recognised and it is protected by a shelter wood of old trees or by nurses, where it is planied in younger forest (blukar). Though shade-loving and consequently very delicate when young, its rate of develop. ment will depend on its gradual exposure to direct sunlight by opening out space over-head for its crown.

A second plantation should I think be started in Penang, whare all the valleys and such land as can be obtained not above r,oou feet may be planted with certainty of success from the Botanic Gardens round the Northern side of the island as far as Muka Head. It need hardly be said that no planting should be done where the tree occurs naturally. It would be well to undertake at each place the planting of at least a hundred acres a year, but unfortunately the difficulty in procuring seed and plants imposes a limit. Mr. CuRTIS made an excellent beginning last year in securing nearly I, Goo plants, and it may be hoped that these trees will continue to bear seed, and that others may come into bearing. It may be anticipated too that the Perak Officers will find means to collect and supply seeds or seedlings in numbers. In any case it is essential that plants should be economised and made to go as far as possible: and those at Ayer Kroh have been rightly put out at 20 feet apart which gives Iog to the acre, I am disposed to recommend that the plantation be completed with alternate lines of Tembusu (Fagroea fragrans) 6 feet apart, and with a Merbau (Afzelia sp.) between each Gutta Percha plant. The Tembusu has been experimented with and is sure to succeed.

The cost of these plantations should not exceed $\$ 25$ or $\$ 30$ an acre.

8. Yield and working. All mangrove tracts should be worked on a systematic plan of annual fellings fixed by area. Tho other reserves may well remain closed to the cutting of timber; but, meanwhile, the most should be made of the timber found on unreserved Crown Lands (chiefly in the Dindings).

The mangrove swamps yield a valuable supply of firewood for which there is a very considerable demand, the price in Singapore having risen per 1,000 pieces from $\$ 6$ in 1883 to $\$ 8$ now, while the piece is said to have grown gradually smaller until its average weight is $5 \mathrm{lbs}$. or less, instead of $7 \mathrm{lbs}$. as it was estimated to be by Mr. CANTLEY. The swamps can with difficulty be turned to any oiher purpose. The trees re-produce themselves from seed and the young forest is understood to grow up to a suitable and exploitable size in about 15 years. The areas have only to be mapped, divided into suitable blocks--each of which would provide a complete series of fellings-and each block marked off on the ground into I 5, or better still 20 felling a ceas (coupes) of more or less equal area. Each coupe can be sold by auction or otherwise. And if each coupe could be clean felled the arrangement would be simplicity itself, but in 
order to assure the reproduction by seed a certain number of seed bearers must be left after the first felling. These should be as far as possible Rhizophora and Bruguiera sp. and number about Io or I 5 to the acre. The clear felling of the rest of the crop will give the necessary light for the development of the seedlings and as soon as a dense crop is established, after probably some 5 years the s sed bearers can be removed. In this way each coupe wo' d be gone over twic' 'th an interval between the fellings-and is years would se before the time ue to remove a second crop. This treatment has not within knowledge been $a_{1}: d$, but I feel confident of the success of it from what I have erywhere observed o the natural reproduction.

The only mangrove fore sise in Singapore and the Dindings and these with those of Perak State (which alone are estimated to yield \$280,000 worth of fuel a year supply Railways, local Steamers, Smelting Works and other industries.

The closing of the reserves to the extraction of timber is in a general way quite the proper policy, so far as I am competent to judge. In Singapore but few of the reserves contain mature timber and then it is only in limited parts that it is found. The greater part is more or less young or only half-grown.

The large reserves of Malacca, rich in good mature timber, lie side by side with extensive areas covered with similar forest which is being cleared and burnt and so the time has not yet come for the timber to be valuable. The more accessible Sungei Udang Reserve had all the mature timber worked out of it before it was reserved and it is mostly young and very promising.

In the Dindings the unreserved lands yield more than there is a demand for.

The only mature forests in Province Wellesley are those which cover the tops of the hills. Tasek Glugor, the largest reserve, is only gradually growing up and the grassy blanks are being slowly overgrown by masses of young Tembusu "Fagroea fragrans".

The main reserve in Penang is that which comprises Government Hill and the water catchment area, and it should be strictly preserved both in the interests of the water supply and in view of future requirements, as the hill becomes popular and is more generally resorted to and built over. Private holdings within the catchment area should be acquired. Such reserves as Pantai Acheh and Laksamana would yield some timber but it is hardly necessary to make an exception in their case.

The workable forests are the unreserved areas in the Dindings the revenue on timber from which amounts to $\$ 9,000$ a year, and is capable of further development. In the remainder of the Settlements a few hundred dollars a year will represent the value of timber sold from Crown Lands.

This revenue is at present collected, in the Settlements generally, by means of licences issued on payment of rates laid down in a Timber Roll (scale of royalty schedule) and purporting to represent $25 \%$ of the value. The different trees are divided into 2 or 3 classes according to their values. In the Dindings, however, a different system is in force. Sawyers and wood-cutters pay a monthly tax of $\$ 3$ each and a further royalty or duty, at the rate of $15 \%$ of the value of hard woods, and $10 \%$ of the value of Meranti (Shorea and Hopea sp.) is levied on the converted timber.

It is rather remarkable that the royalty so collected is approximately the same as the sum received from the tax on wood-cutters and sawyers.

I have some doubt whether the tax on wood-cutters is provided for in the Crown Lands Act and Rules, and it is at best an awkward way of realising the value of the trees. Still it must be admitted that it has the advantage of being understood by the people.

The Government dues on Charcoal may continue to be realised as at present by a monthly charge of $\mathrm{m}$ per man employed on its manufacture, with the proviso on the licence that no tree of the reserved kinds is felled.

The charge for a licence under the rates fixed in the Timber Roll, which vary for every six inches of diameter, has the inconvenience that a person taking out a licence must find it difficult to state correctly the sizes of the trees he is proposing to cut.

The system in Upper Burma is to issue licences to fell trees, those for reserved and unreserved trees being in different form and colour, on payment of a fee for each tree and on condition that in addition to the fee paid for the licence, royalty at certain rates shall be paid on arrival of the timber at a certain place and that the timber shall not be converted or utilized or removed from that place until the royalty has been paid in full. The fees for licences vary from 4 to $\mathrm{I}_{5}$ cents for unreserved trees and are 32 cents per tree for reserved trees. The royalties charged on timber of the reserved kinds vary from $\$ 6$ to $\$ 16$ per ton of 50 cubic feet in the $\log$ and are 
double for converted liumber. On timber of the unreserved kinds in Upper Burma they are:

\begin{tabular}{|c|c|c|c|}
\hline & $\begin{array}{l}\text { For special } \\
\text { timl }\end{array}$ & $\begin{array}{l}\text { Other } \\
\text { woods. }\end{array}$ & \\
\hline $\begin{array}{l}\text { Logs } 43 \text { ft, in girth and over } \\
\text { Log } 2^{\prime}-45^{\prime \prime} \text { in girth } \\
\text { Posts I'o" to I' I I" in girth } \\
\text { Poles below I'o" in girth } \\
\text { Converted timber }\end{array}$ & $\begin{array}{l}82 . t \\
1.33 \\
\cdots \\
\cdots \\
5 \cdot 33\end{array}$ & $\begin{array}{r}\$ 0.66 \\
0.33 \\
6.66 \\
0.33 \\
1.33\end{array}$ & $\begin{array}{l}\text { each. } \\
\text { per roo. } \\
\text { ", } \\
\text { per ton. }\end{array}$ \\
\hline
\end{tabular}

I would suggest, if my proposal to declare certain trees reserved be acted upon, that licences be issued at a fixed fee per tree and that royalty be levied at $\$ 4$ per ton on all timber of the reserved kinds in the round, and at $\$ 8$ per ton on all converted timber. For unreserved woods a similar scale to that above might suffice.

Should the wood-cutter's tax be continued in the Dindings half the rates of royalty taken elsewhere might be prescribed for that territory.

9. All minor forest produce should be utilized, as far as there is a demand for it, whether found in the reserves or on the unreserved Crown Lands.

Such products as palms, canes (rotan) caoutchouc, wood-oil, resin, natural varnish, bark, leaves, flowers and fruits as well as seeds, creepers and grasses can not only be removed without doing harm to the timber trees and chief products, including even "Gutta Percha" the trees of which should be known and tended: but often with advantage to the main forest crop.

Their collection, as well as that of honey and wax, etc., may continue to be permitted on the present system of personal monthly tax both in and outside reserves: but I recommend that double the rates charged for unreserved lands be imposed on those collecting in reserves and it would be well that licences for the reserves should be of a different colour from the others.

10. A certain number of Rangers trained in forest avork should be employed, and I further suggest the appointment of a trained Forest Officer with experience to inspect and advise as to the carrying out of any works and on all matters connected with the administration of the forests.

The Department, as organized prior to 1895 , did much good work in connection with the selection and demarcation of the reserves: but once this work was accomplished and the protection of the demarcated areas was the chief business I am of opinion that the Government acted wisely in handing over to the Collectors of Land Revenue and District Officers the charge of the forest reserves. The districts are all small, compared with what is known as a District in India, for there are ten Officers for I,525 square miles. The unreserved Crown Lands had all along been in charge of the District Officers, and living within their districts they were, and still are, the best and cheapest agency for conserving the reserves. There may be the temptation to disafforest areas for which cultivators or planters are applying, but it may be assumed that the Government, which has determined on the reservation of a tract of land with the conviction that it ought to be maintained under forest, is sufficiently alive to the necessity for a continuous policy, and aware that such policy where tinber trees are concerned must, to be of any use, extend over a century or more.

In India the District Officer is responsible for the forests of his District, and the arrangement works well. I believe it is the only possible starting point for any reasonably economical system of forest conservancy in the Straits Settlements. A Department which consists of one, two or three highly paid scientific Officials and 20 or 30 Forests Guards or patrols cannot be effective and its development on practical lines would be too expensive to be justifiable. District Officers have their Land Office subordinates (Forest Rangers they have been rather inappropriately termed by the Crown Lands Act) to overlook the protective establishment employed for the reserves and assist in the supervision of their work of boundary clearing and of prevention of theft or encroachment. The same officers of themselves or through local headmen (Penghulus) protect, and control the exploitation from unreserved Crown Lands. So far nothing more is required hovond letting it be understood that all 
Crown Lands (whether reserved or unreserved) are to be trexted as a single estate and reported on as such, all revenue and expenditure from or on account of them falling under one head "Forests".

But wherever the forest reserves have to be more than protected; where works of improvement are called for or ystematic exploitation ic ;quired, then the District Officer requires the assistance of men with a spe , nowledge of forest work. A trained European expert wh uld relieve him of 1 of his responsibility, such as is employed in Districts in $I_{\text {. }}$ is out of the quest. Four such Officials would be required for the Colony. I ve considered what an be done under the circumstances and have come to the. conclusion that a certain number of Rangers trained to forest work must be employed to assist the District Officers wherever required. Such men can only be obtained from the Dehra Dun Forest School. They may be either Straits men, who, under such inducements as Government may think fit to offer, go to Dehra and obtain certificates or they may be private students who have obtained certificates and accept appointments. These latter would be either of European parentage born in India, Eurasians or English speaking natives. They would probably not accept less than $\$ 65$ a month to begin with and look for prospects of promotion. The Burma Government offers such men appointments on Rs. Ioo a month. If the proposals made in this report are acted upon, there will be employment for four or five Rangers certificated to be qualified for forest work. They can be used as follows:-

1. Singapore. To arrange for the working of the mangrove tracts and weed gutta percha trees in reserves.

I. Malacca. To carry out the Palaquium sp. plantation and tend the naturally growing gutta percha trees.

2. Dindings. One stationed at Lumut, the other at Bruas, to look after all forest work, leaving the Land Revenue Ranger to attend only to alienated lands or the alienation of forest lands. For the present one man vice the Forest Inspector would suffice, but in that case he should be at Bruas and do both the forest and land revenue work in the North leaving the Land Revenue Ranger to do both forest and land work from Lumut. It is, I think, a waste of energy to have two men, a Ranger (land revenue), and an Inspector (forest), dividing the work over the whole territory. It would be better to have one man in the North and the other in the South each doing both the land revenue and forest work of his division.

I. Penang. To plant gutta percha and weed and tend the naturally growing trees. (Mr. CuRTis can probably manage without this man for the present.)

Mr. Curtis, Assistant Superintendent, Botanic Gardens, Penang, may well continue to be employed to superintend the Palaquium plantations both at Malacca and Penang. He has already commenced the work in Malacca, takes a keen interest in it, and is well qualified to carry it out successfully. For this purpose he must visit Malacca and give considerable time in Penang to raising plants and laying out suitable areas for plantation. The actual work both at Malacca and, I think, at Penang should be carried out by the District Officers and their Rangers, Mr. CuRTIS merely inspecting, advising and helping in any way in his power. I would not burden him with the control of the Ranger, payment of coolies, etc.

But, if forest conservancy is to be properly carried out on a determined and lasting policy-and it is only in this way that any real progress may be looked for-I am strongly of opinion that the Government must have the benefit of professional advice on the spot, and the works must be under professional inspection and direction. I propose therefore that a Forest Officer, trained in Europe and with 8 or io years experience in Burma, should be appointed and his services divided between the Colony and the Federated States. Such an Officer could be obtained on 3 years' deputation from the Government of India, on payment to that Government of his pension contribution.

There are some Officers in the Colony who would not unnaturally prefer to have one or more of their own men, recruited for service in the Colony, trained in Forestry and rendered fit for the appointmient of Chief Forest Officer. This, however, after careful consideration on my part does not seem to be feasible for two reasons. Only a Cadet or quite young officer could be chosen as a student to go through a course of 2 a Cadet or quite young offer could be chosmany or at Cooper's Hill, and such officer would lack the administrative experience without which such a post could not be would lack the administrative experite officer were trained, there would always be the impossibility of replacing him when on leave by a thoroughly trained and experienced locum tenens. It must be clearly understood that nothing will be gained by creating the appointment and filling it by any but a professionally cducated Forester of some age and standing. 
The salary of an ificer deputed from India would have to be not less than $\$ 500$ (Ks. 750 ) a month with compensation and other allowances.

His Head Quarters might be at Kuala Lumpur or Singapore, but he would be required to devote a ce in period of the year to inspections of the forests and forest works of the Colsu. 1 to report on them dent Councillors after co $r$ with the Land available for advice to the forests or their forest policy.

he Colonial Secretary or Resi-nue Officers. He would be - matter connected with the iment in regard

H. C. HILL

Conservator of Forests.

Singapore, rith September, 1900 Her Majesty's Indian Forest Service. 
Appendix A.

llinute on the Staff required to protect the Forests, Penang and Prowince

It must be admitted that a Frrest Guard will not move about alone, and Guards. must either be employed in coupl as in Singapore, or er "uard must have a coolie to go with him. The latter is pr 'y the better anc aper arrangement, and the proposals for Penang appear 2 to be quite suita.

In the South West Distri a Forest Guards ha - to do all the work of looking after timber and produce rem. ed from Crown Lands under licences. Penghulus do this in Malacca. The new Forest Guard should probably have his Head Quarters at Balik Pulau and be in charge of Reserves $G . H . I$. in addition to the duty of controlling the timber and produce removed from Crown Lands, which brings in $\$ 600$ to $\$ 1,000$ a year. Guard.

The maintenance grant of $\$ 250$ will I assume provide for 3 coolies-one for each

In the North East District the third Guard is very necessary and I would suggest his being placed at Batu Feringhi where an extension of the reserve to include a large quantity of Gutta Percha trees is about to be proposed. The maintenance grant should provide for 3 coolies. Pulau Jerejak seems to require no special staff.

$$
\text { Province Wellesley. }
$$

In my opinion it will suffice for the present if a new Forest Guard is provided for the Bukit Mertajam District, and each of the 3 Forest Guards is given a coolie to help him in clearing the boundaries and to go about with him. The maintenance grant in the North (Senior) District Office should be further increased so as to allow of the road through the Tasek Glugor reserve, and part of the boundary of the Ara Kuda reserve being fire traced: but this may wait till I have sent in my report and explained what $l$ consider should be done.

\section{H. C. HILL, \\ Conservator of Forests.}

Lumut, 3 Fothune, 1900 .

\section{Appendix B.}

Minute on the Staff required for the protection of the Forest in the Dindings.

Following the arrangements in Penang that each Forest Guard should be assisted by a coolie, the number of Guards in the Dindings is sufficient. It is only necessary to provide a maintenance grant sufficient for the employment of, at present, six coolies, and later on probably seven coolies, say $\$ 700$ and $\$ 800 . *$

The Guards would be stationed as proposed by Mr. WOI.FERSTAN.

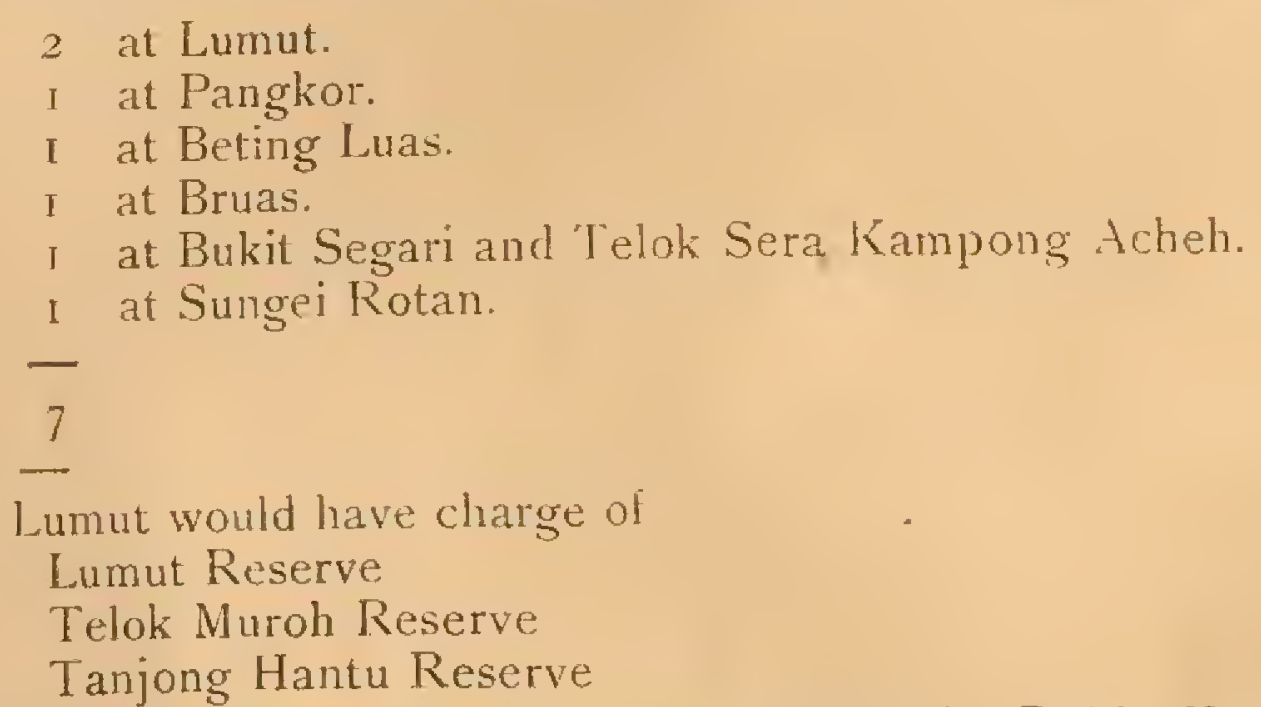

and later probably of a reserve it is proposed to make in Bukit Undan, North of Lumut.

For the Dindings 1 am disposed to recommend the appointment of 2 Forest Rangers for forest work only, to be located I at Bruas, I at Lumut: and to be held responsible for all the timber working and produce extraction from Crown Lands as well as for the protection of the Reserves. The system of having a Land Officer (Forest Ranger) responsible for the extraction of timber and produce from Crown Lands and a Forest Inspector to merely supervise the protection of the reserves, does not commend itself to me. It would be better I think, with the present staff, to have the two men in charge of all work in different divisions of the Dindings with their Head Quarters 20 Bruas and at Lumut. This question shall be dealt with more fully in my report, but in the meantime, if approved, the employment of six coolies might perhaps be sanctioned.

H. C. HILL, Conservator of Forests. 


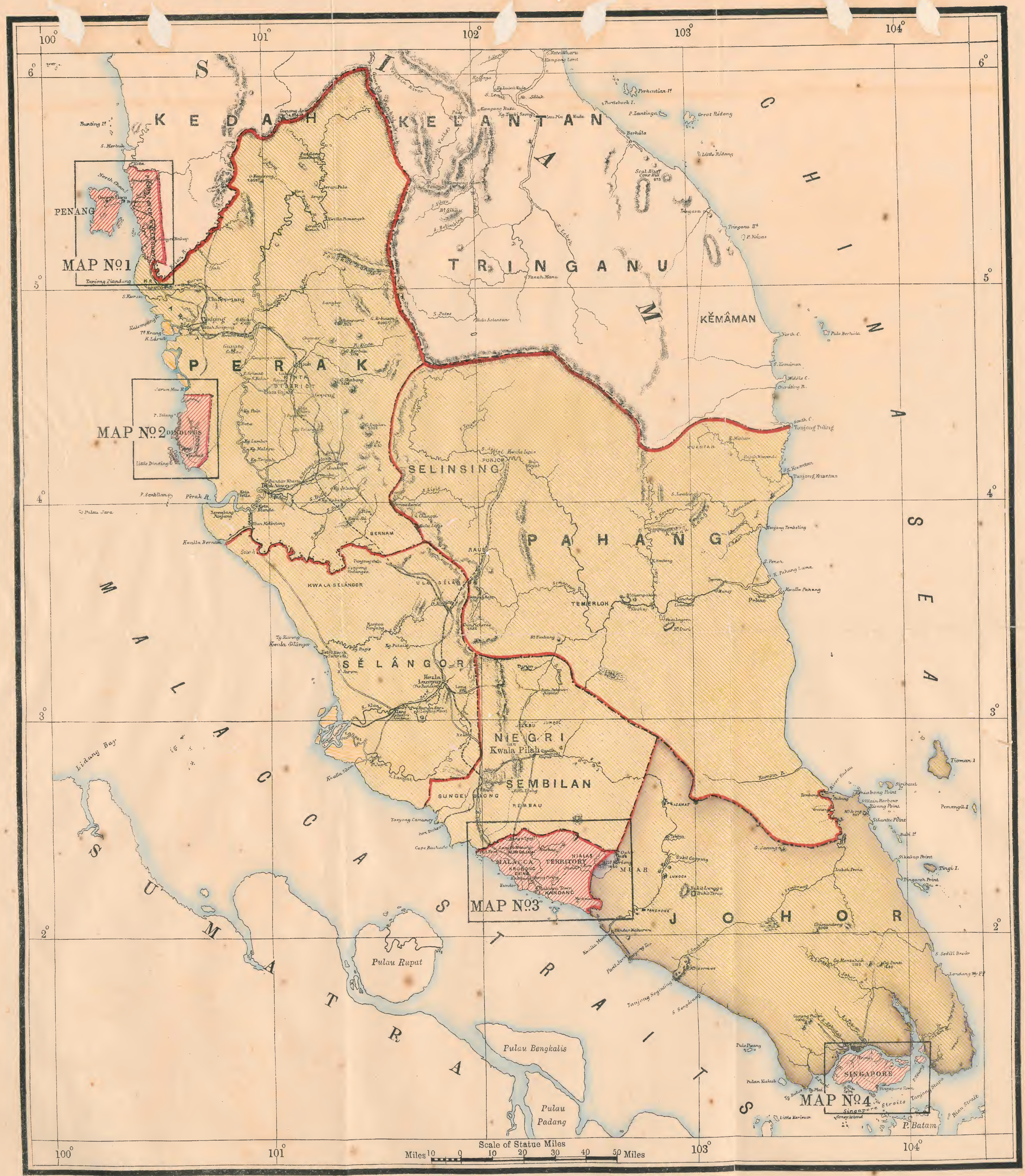




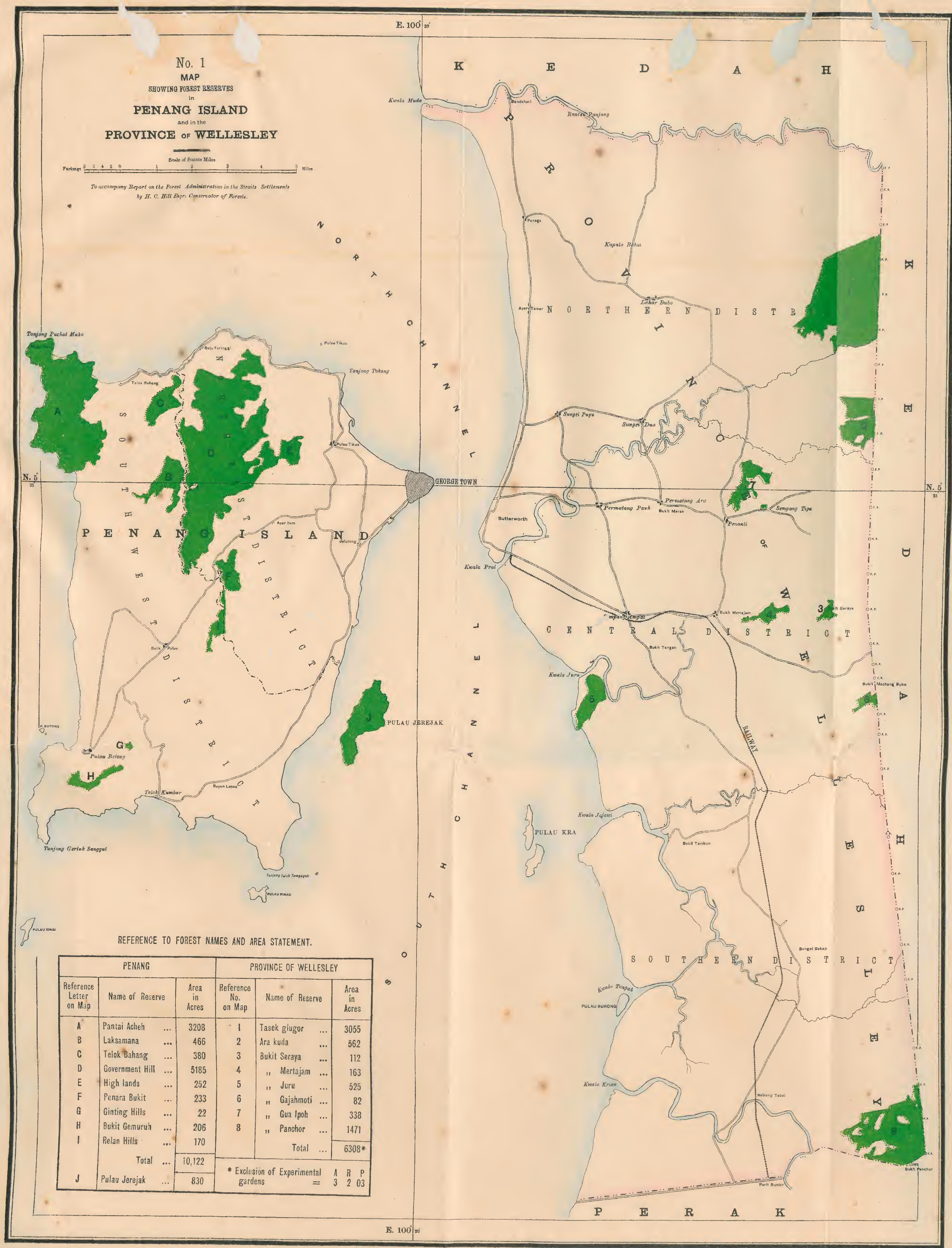

Regr. No. D. 938, For. - Oct. $1900-300$

Prepared in the Foreest Survey Office, Bengnl Presidency, Captain P.J. Gordon, I,S.C., Superintendent, from a tracing supplied by H. C. Hill, Esq., Conservator of Forests.

No. 197.S. 00 


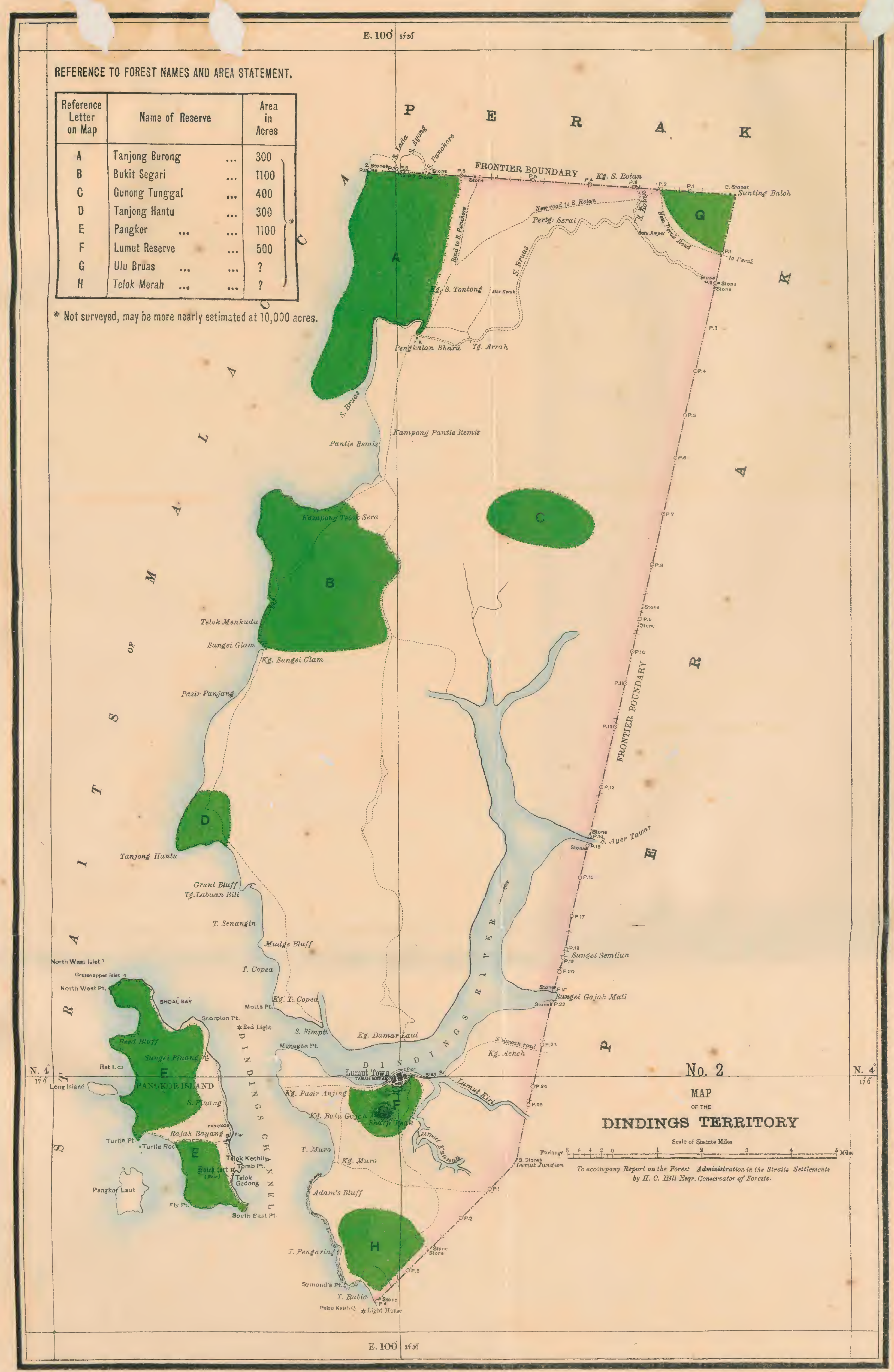

Prepared in the Forest Surver Office, Bengenl Presidency, Captain P. J. Gordon, L,S.C., Superintendent, from a tracing supplied by H. C. Hill, Esqu., Conservator of Forests. 


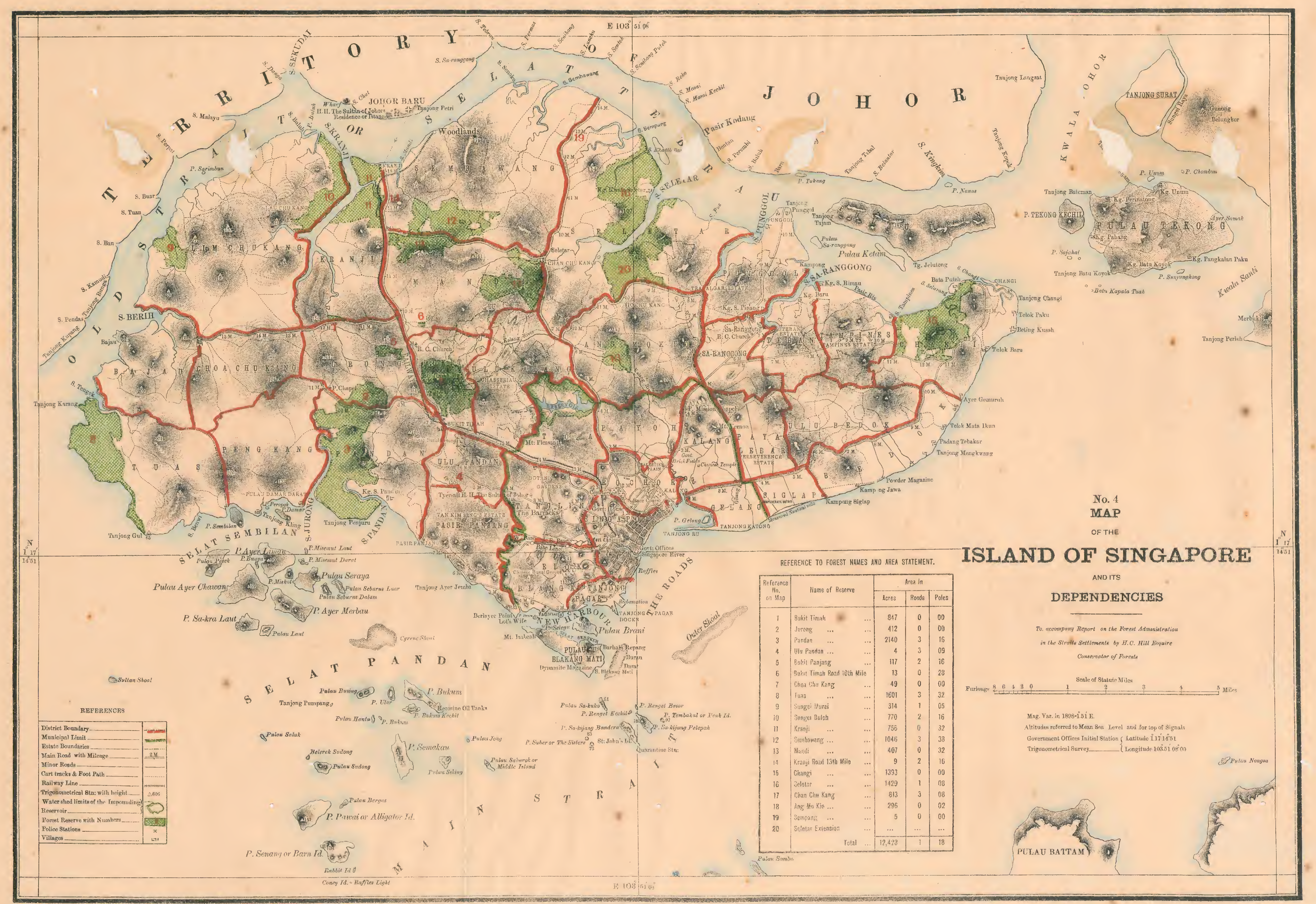




\section{STRATTS SETTLEMENTS}

Paper to be laid before the Legislative Council by Command of
His Excellency the Governor.

\section{Report on the Forest Reserves of the Straits Setttements during the year 1901.}

\section{SINGAPORE.}

1. The Reserves call for practically no report further thit that as may lu: wathered from the table below; they were periodically visited both by the Collector of la ad Revenue and the Forest Rangers.

\begin{tabular}{|c|c|c|c|c|c|c|}
\hline No. & Name of Reserve. & & Area. & $\begin{array}{l}\text { Number of } \\
\text { visits by } \\
\text { C. L. R. }\end{array}$ & $\begin{array}{l}\text { No. of visits } \\
\text { by Forest } \\
\text { Ranger. }\end{array}$ & Nature of Reserve. \\
\hline I & Bukit Timah & $\cdots$ & 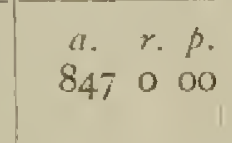 & 3 & 16 & $\begin{array}{l}\text { Hilly. Big jungle tailing off on the East } \\
\text { into scrub. }\end{array}$ \\
\hline 2 & Jurong & $\cdots$ & 412000 & 2 & 27 & $\begin{array}{l}\text { Swamp and hill mixed, tot nutuch good } \\
\text { jungle. }\end{array}$ \\
\hline 3 & Pandan & $\cdots$ & 2,140316 & 1 & 24 & $\begin{array}{l}\text { Almost all mangrove swamp, a little lit- } \\
\text { lang scrub. }\end{array}$ \\
\hline 4 & Ulu Pandan & $\ldots$ & 4309 & 6 & I3 & $\begin{array}{l}\text { A litrle patch of } 25 \text { years old jungle on } \\
\text { small hill. }\end{array}$ \\
\hline 5 & Bukit Panjang & $\cdots$ & 117216 & 2 & 12 & $\begin{array}{l}\text { Practically all lalang, with a crown of } \\
\text { fair jungle on hill top and some wild getat. }\end{array}$ \\
\hline 6 & $\begin{array}{l}\text { Bukit Timah Road } \\
\text { roth mile }\end{array}$ & ... & I 3028 & I & I 3 & Snall jungle on small hill. \\
\hline 7 & Chua Chu Kang .. & $\cdots$ & 49000 & 1 & I3 & Low-lying small jungle. \\
\hline 8 & Tuas & ... & 1,601332 & 2 & 10 & $\begin{array}{l}\text { Mustly matngrove swamp. Rest, except in } \\
\text { one place, poor jungle. }\end{array}$ \\
\hline 9 & Sungei Murai & ... & 314105 & 2 & 8 & $\begin{array}{l}\text { Mostly mangrove swamp. Good jungle } \\
\text { on onc or two hills. }\end{array}$ \\
\hline 10 & Sungei Buloh & $\cdots$ & $7702 \div 6$ & I & 6 & Mangroveswamp and poor jungle. \\
\hline II & Kranji & $\ldots$ & $756 \circ 32$ & 1 & 19 & Do. \\
\hline 12 & Sembawang & $\cdots$ & $1,04633^{8}$ & 0 & 12 & $\begin{array}{l}\text { Hilly. Good jungle and scrub getting } \\
\text { worse towards Chan Chu Kang. }\end{array}$ \\
\hline 1.3 & Mandi & $\ldots$ & 407 ० 32 & 2 & 15 & $\begin{array}{l}\text { Hilly, covered with bluker and scrub ex- } \\
\text { cept Bukit Mandi where the jungle is } \\
\text { good. }\end{array}$ \\
\hline 14 & Kranji Road, 13th m & & 92216 & I & 3 & High land, scrub covered. \\
\hline I 5 & Changi & $\cdots$ & $1,393 \quad 000$ & 1 & 15 & $\begin{array}{l}\text { Some fair jungle towards North and } \\
\text { East, the rest very poor. }\end{array}$ \\
\hline 16 & Selitar & $\cdots$ & $1,429 \quad 1 \quad 08$ & 1 & 11 & Mostly poor scrub and mangrove. \\
\hline 17 & Chan Chu Kang & $\cdots$ & 813309 & 2 & Io & $\begin{array}{l}\text { Several good patches of jungle; the rest } \\
\text { belter than in many reserves. }\end{array}$ \\
\hline Is & Ang Mo Kio & $\cdots$ & $296 \quad 002$ & 5 & 13 & All small serub and swamp growths. \\
\hline 19 & Sempang & $\cdots$ & $5 \circ 00$ & 1 & II & $\begin{array}{l}\text { Nice jungle on road side, swamp growths } \\
\text { at back. }\end{array}$ \\
\hline 20 & Selitar Extension & $\ldots$ & Not known & I & 8 & Mangrove swamp, poor scrub and lalang. \\
\hline
\end{tabular}

2. The Western Division Reserves were, as in previous years, well looked after, and the boundary paths widened to be a more efficient protection against fire from without, but those of the Northern Division were tended in a much iess satisfactory manner. To keep the paths clean enough to be a real protection against fire more men are required possibly everywhere, certainly in Nortbern Division.

3. There were, however, no fires of any importance-the chief causing the destruction in February of 100 acres of lalang and brushwood in Pandan Reserve, in March of 50 acres of the same in Mandi and Sembawang Reserves, while in Selitar 
and Ang Mo Kio Reserves smaller patches (of 5 and 2 acres) of lalang were burntand only two prosecutions in connertion with the Reserves-details as under:---

Northern Division

Eastern Division

Western Division

Pulo U bin

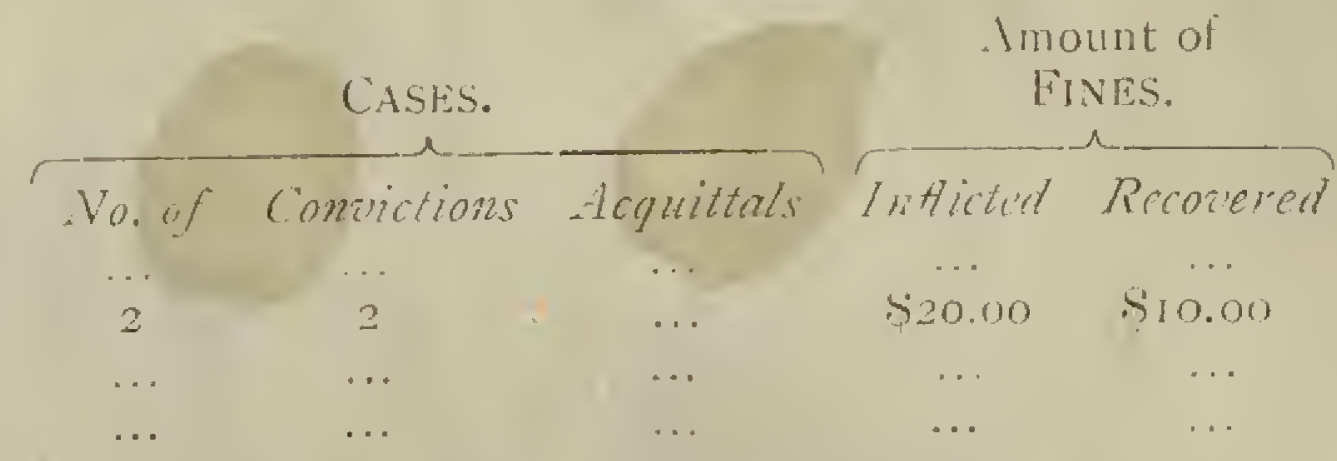

4. On the recommendation of Mr. HuL land in Pulo Uhin has been no longer open to alienation and that perhaps entitles it to inclusion in the Reserves. A Forest Ranger and granite-checker was appointed. Permission was given to the Railway Department to take red earth from the Bukit Mandi and XIIth mile Reserves, but no wood of any value has been destroyed and no great difference mado to them.

5. For a very short time a Sub-Forester trained in India was employed here, but, though paid a considerably higher salary than other Government emplyés of like standing, he was so little pleased with the pay and prospects of service under the Straits Government that without lutile delay he resigned his appointment and wht back lndia-wards.

6. There has been no destruction of getah trees this year, nor have any new ones been discovered. The few known trees have been frequently visited and softwood trees which overshadowed some of the Chan Chu Kang and Bukit Timah getah removed or girdled.

7. No progress was malte with the mangrove working plans. The wooddealers were too conservative to make any offer at all for standing mangrove per acre or per block and would do nothing but ask for the old morthly pass at so much a cutter, nor were there surveyors to spare for the work. Next year the Railway at least will want wood and another attempt should be made to get out working plans. It is to be hoped that Mr. BurN-Murdoch, the new Forest Officer, will then be able to advise as to this and generally as to the Singapore Reserves.

$S$. There was no revenue derived from them during the year.

9. The pay of the Forest Guards has been slightly improved, and the total expenditure for the year amounted to $\$ 1,106.26$ as against $\$ 1,0 \$ 5.15$ in 1900 .

W. LANGHAM-CARTER, Acting Collector of Land Revenue. 
PENANG.

North-Eastern District.

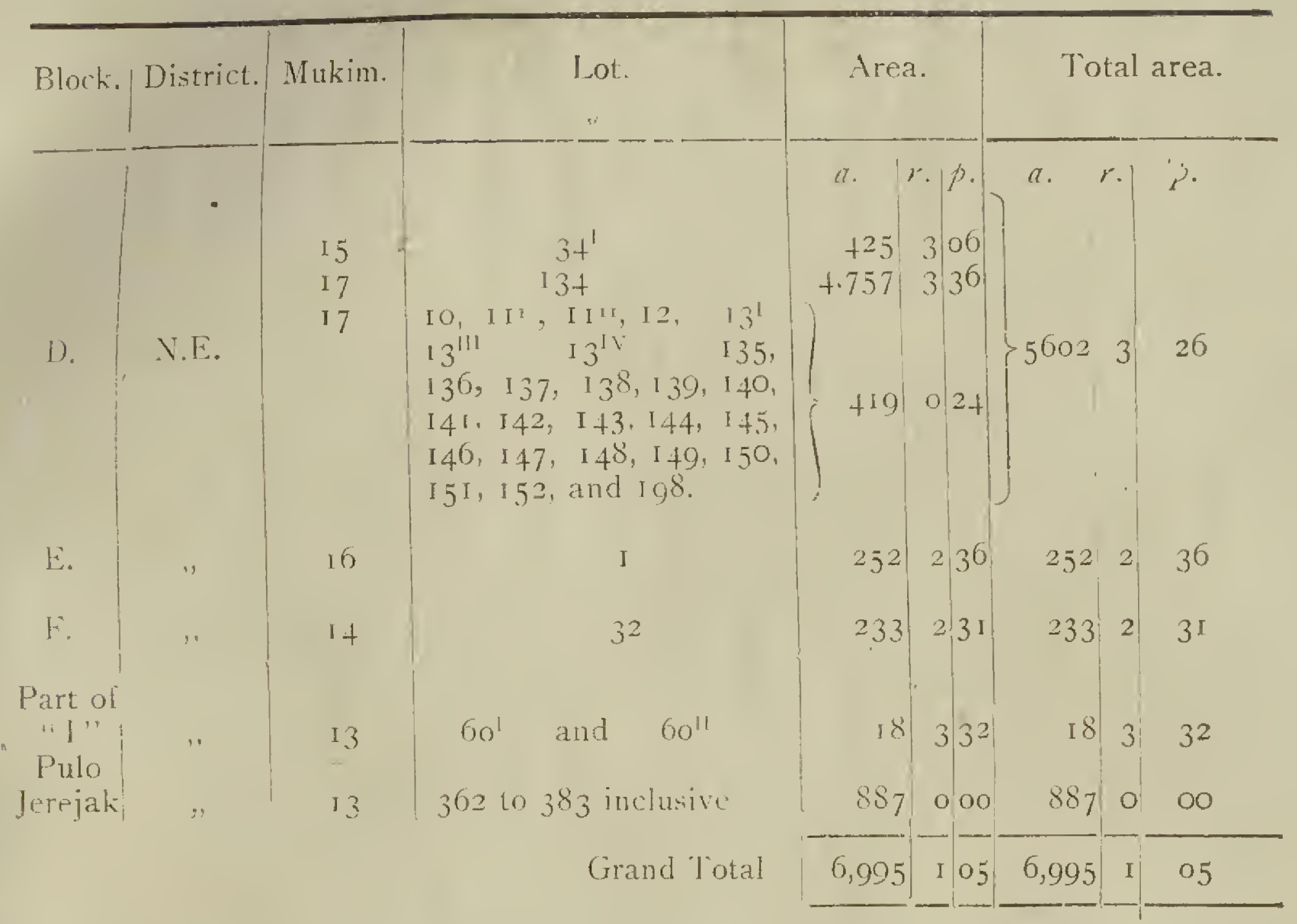

Pulo Jerejak Reserve was proclaimed by Government Notification No 720 , dated the 23rd May, Igor.

I. Mr. T. M. KindersheY was in charge of the Department till near the end of July and Mr. R. Scort for the rest of the year. Several visits were paid by them to the Reserves during the year. The Forest Ranger paid altogether 83 visits.

2. The staff employed was 3 Forest Guards and 3 coolies with several extra coolies during the latter part of the year.

3. There were ten prosecutions instituted during the year. Five of these were for illicit cuttings, one case was dismissed and in the other four fines amounting to $\$ 90$ were imposed; five were for trespass in the Reserves, one defendant was fined $\$ 20$ and the others were cautioned.

There have been no encroachments on the Reserves.

4. The reserve boundaries are all cleared with the exception of about 3 miles from Western Hill to Pondok Payong Batu Feringghi.

5. A fire took place in Block $D$ on the 27 th of February and 20 acres of the reserve between Bukit Terbakar and Bukit Timah were burnt.

\section{Getah.}

6. A piece of land (part of lot ro Mukim XVII) in Batu lieringghi was selected by Messrs. CuRTIS and KIndERSLEy for a getah plantation in June and the work of clearing started at once.

By the end of the year 35 acres had been cleared and 22 acres planted-with the following results :--

\begin{tabular}{lrrr} 
& & Planted. & Dled. \\
Seedlings & $\ldots$ & 300 & 30 \\
Stumps & $\ldots$ & 1,682 & 600 \\
Para Rubber & $\ldots$ & 250 & 30 \\
Kickxia Africana... & 12 & $\ldots$ \\
Rambongs & $\ldots$ & 6 & $\ldots$ \\
& & 2,250 & 660 \\
\hline
\end{tabular}


The trees were planted at distances of 20 leet apart by the advice of Mr. Cur'Is, the Assistant Superintendent of Forests.

Several visits were paid to the estate during the vear by the Collector of Land Revenue. An overseer has been engaged to see after it at a salary of $\$ 480$ per annum and he has had coolies, varying in number from 10 to $2 \mathrm{I}$, under him.

The following getah taban trees have been discovered during the year:-

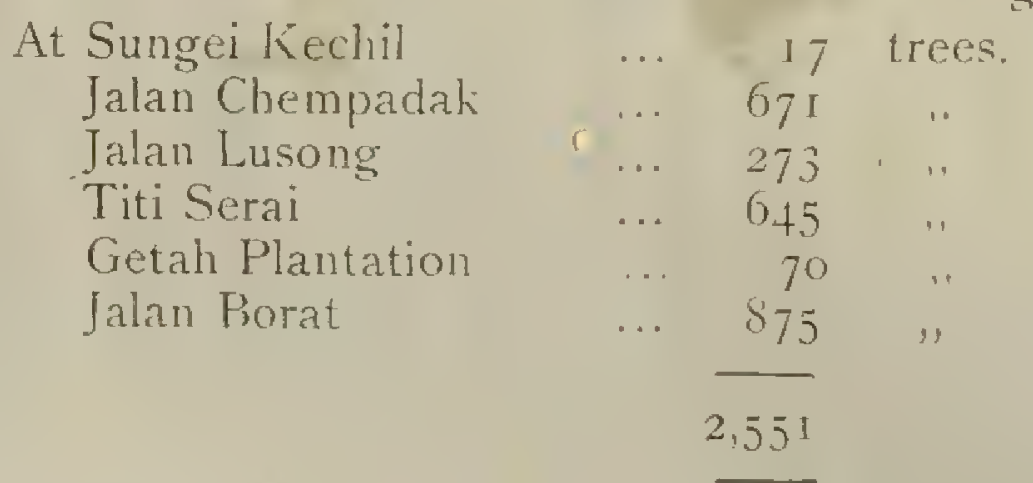

The undergrowth from around these trees has been cleared away and they have been marked with white zinc. A register of thcm is kept.

The following is a statement of expenditure for the year :-

$$
\begin{aligned}
& \text { Wages of overseer and coolies ... } \quad \ldots . \$ 956.86 \\
& \text { Tools and Miscellaneous Expenses... } \quad \ldots .9951 .81 \\
& \text { Passage of Forester Mr. E. G. BASTEN } \quad \text {.. I } 72.45 \\
& \text { Spent at Balik Pulau 1,311.12 } \\
& \text { … } 161.20 \\
& \$ 1,472.32
\end{aligned}
$$

7. The total expenditure by the department for the year is as follows:Salaries of Forest Guards

$\ldots+\$ 312.00$

$\begin{array}{ccccc}\text { Do. Coolies } & \ldots & \ldots & 349.42\end{array}$

$\begin{array}{llll}\text { Miscellaneous } & \cdots & \cdots & 72.00 \\ & \ldots & \ldots & 20.00\end{array}$

$$
\text { Expenditure on "Getah" } \quad \begin{array}{r}
753.42 \\
\frac{1,3 \text { II.I2 }}{\$ 2,064.54}
\end{array}
$$

\begin{tabular}{|c|c|c|c|c|c|c|c|}
\hline & Pantai Acheh & & Lot I 32 & Mukim & l & $\begin{array}{c}A \\
3,208\end{array}$ & $\begin{array}{r}r \\
0\end{array}$ \\
\hline$B$. & Laksamana & & .174 & !. & 11 & 465 & 2 \\
\hline$C$ & Telok Bahang & & $\Rightarrow \quad \mathrm{I} \& \mathrm{I}$ & ", & II & 380 & I \\
\hline$G$. & Genting Hills & & $" 247$ & $\because$ & VII & 21 & 2 \\
\hline$H$. & Bukit Gemuruh & $\left\{\begin{array}{l}8 x \\
\end{array}\right.$ & $\begin{array}{ll}\prime & 27 \& 52^{11} \\
\prime & 100\end{array}$ & , & $\left.\begin{array}{r}\text { VIII } \\
\text { IX }\end{array}\right\}$ & 205 & 3 \\
\hline 1. & Relau Hills (part) & $\{\varepsilon$ & $=\underset{I}{" 79^{1}}, 75,80^{11}$ & $4^{11}$ & $\left.\begin{array}{l}V \\
X\end{array}\right\}$ & $15 \mathrm{I}$ & 2 \\
\hline & & & & & Total & 4,433 & o \\
\hline
\end{tabular}

E. L. TALMA.

LAND OFFICE,

Acting Collector of Land Revenue.

Penang, 22nd February, rgo2.

\section{South-West District.}

The names and areas of the Forest Reserves in this district are as follows:- 
2. An addition to Telo' Bahang Forest Reserve for the purpose of forming a "getah taban" plantation was sanctioned during the year, but by the end of the year the block had not been surveyed.

3. The Reserves were visited during the year as follows:-

Forest Reserve $A$ on the 24 th March, I6th June, 18 th August and 8th December by me and, by the Forest Ranger, 24 times during the vear. Forest Reserve $B$ was visited by me on the I $5^{\text {th }}$ of March, the 3 rd May, the Ist September and the 3 rd Norember, and on thirteen occasions by the Forest Ranger.

Forest Reserve $C$ was visited by $m$ is on the 15 th March, the 3 ist May and the zoth September and by the Forest Ranger I 2 times. Forest Reserve $G$ was visited by me on the 28 th November and by the Forest Ranger twelve times.

Forest Reserve $H$ was visited by me on the $22 n d$ March and the gth June and ig times by the Forest Ranger.

Forest Reserve/ was visited by me on the 3 olh June, the I 5 th August, the 15 th Seplember, the 29th October and the zoth December and 28 times by the Forest Ranger.

4. The staff consisted of one Forest Ranger only part of whose time can be devoted to the Forest Reserves, one Forest Ranger's man, three Forest Guards, three coolies employed during the whole of the year and a fourth employed for seven months. Besides this, occasional coulies were employed to assist in clearng paths. The paths in all the Reserves were kept in good order.

5. Prosecutions. - There were two prosecutions in connection with Forest Reserve $I$; this is the newest of the Reserves and the survey of its boundaries was only finally completed at the end of 1900 ; it was then discovered that there were two small longstanding encroachments on lots which had been included in the Reserves and the encroachers were prosecuted, convicted and ejected. Two Chinese were also prosecuted for picking chestnuts in this Reserve. There were no other prosecutions in connection with the Forest Reserves.

6. There have been no fires during the year in any of the Reserves.

7. No reports have been received of wood-stealing from the Reserves nor have I seen any traces of it on my rounds. It is to be hoped that the increase in the staff which took effect during the year has rendered the commission of this offence more precarious.

8. In the new block which has been added to Forest Reserve $C$ the clearing of trees to give "getah taban" trees room and light has been proceeded with. Three coolies are employed in this work who are paid by the Collector of Land Revenue. A few "getah taban" trees bore fruit but it is extremely difficult to collect it, as bats appear to be very fond of it; only about I 50 seeds were brought in during the year. They were sent to Mr. CuRTis.

9. A "getzh taban" tree fell down during the year and I had it tapped and the getah with the dimensions of the tree were also forwarded to Mr. CuRTis.

\section{G. A. HEREFORD,} Acting District Officer

I5th February, 1902.

\section{PROVINCR WELLESLEY.}

\section{Northern District.}

1. The areas of the two Reserves remained the same as in Igoo. They are as follows :-

$$
\begin{array}{lllr}
\text { Tasek Glugor } & \ldots & \ldots & 3,055 \text { acres } \\
\text { Ara Kuda } & \ldots & \ldots & 56 z \text { acres }
\end{array}
$$

2. The Forest Ranger visited the Tasek Glugor Reserve 36 times and the Ara Kuda Reserve 3 I times during the year, and the Forest Guard, who lives close to the Tastk Glugor Reserve, paid constant visits of inspection. I myself visited the Ara Kuda Reserve on the 7 th of April, and the 2Sth July, and the Tasek Glugor Reserve on the 2nd, I6th and 23 rd of June, and the $7_{\text {th }}$ of July:

3. There were altogether 13 fires in the lasek Glugor Reserve during the year, 
by which about 500 acres of lalang and brushwood were consumed. There were also 2 fires in the Ara Kuda Reserve, which spread over an area of about 50 acres. The fires in both reserves originated in the lalang, but spread also to the big jungle and consumed parts of that, as well as the lalang and scrub jungle. They occurred mostly during the dry weather in February, March and April, when there was an exceptionally long drought, and the lalang was so dry that the slightest spark falling upon it was sufficient to originate a fire. A public road passes through the Tasek Glugor Reserve and another road skirts the Ara Kuda Reserve, so that in all probablity some of the fires were caused by persons throwing lighted natches into the lalang as they passed by.

4. In one of my visits to the Ara Kuda Reserve. I discovered a trifling encroachment of a few feet, made by some Chinese squatters, planting tapioca for Malakoff Estate. I called the attention of the Manager to the matier, and he promised to see that the boundary was striclly observed in future.

5. There are some Getah Jelutong trees scattered about in the Tasek Glugor Reserve. From one of these the Forest Ranger collected a specimen of Getal, which I forwarded to Mr. CuRTiS, and he very kindly sent it to England to be rcported on. He afterwards informed me that the specimen had been valued in England at fro. Ios. per ton. Reserves.

6. There were no prosecutions for trespass or for cutting limber in the

\section{M. WOODWARD, Acting Senior District Officer., D. W.}

\section{Central District.}

I. The Forest Reserves at present gazetted are :-

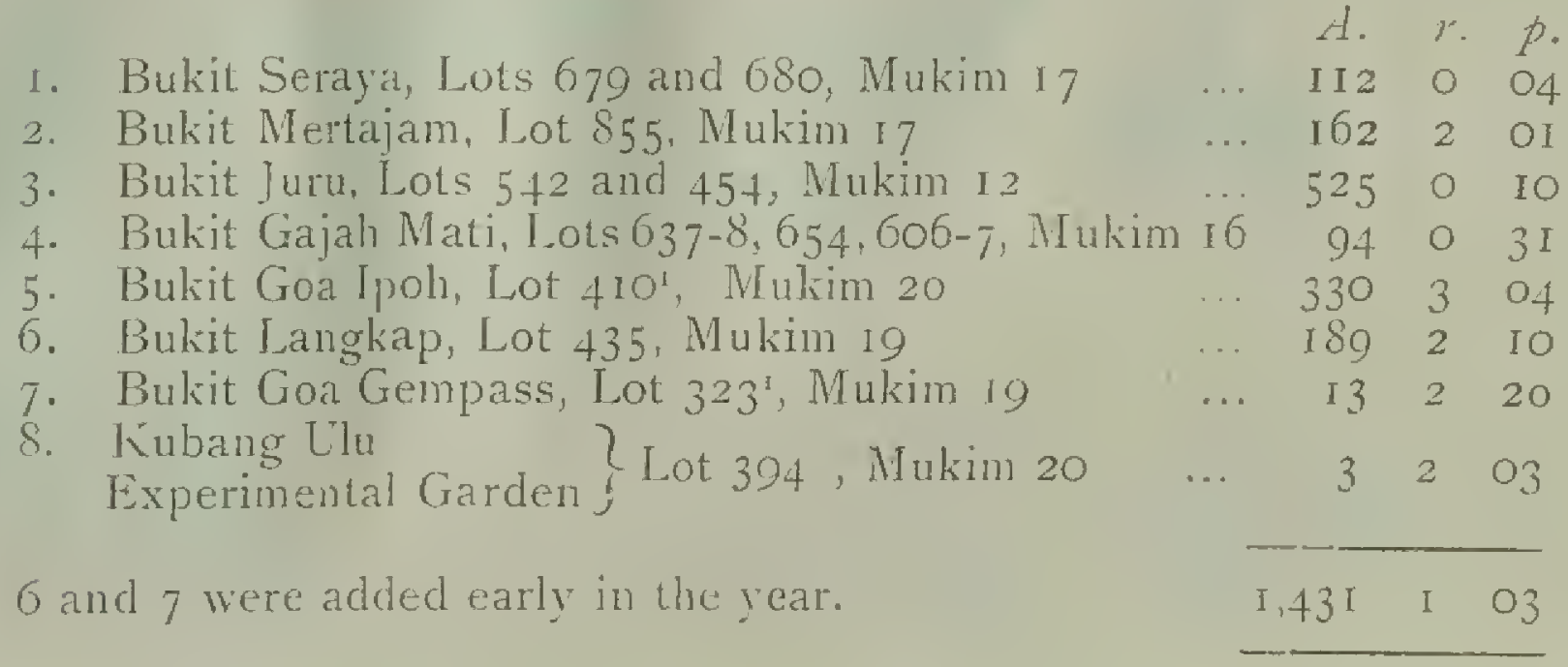

2. The visits paid to the Reserves are shown in the following table:-

$\begin{array}{llcr} & & \text { By District Officer. } & \text { By Forest } \\ \text { I. Bukit Seraja } & \ldots & 1 & 5 \\ \text { 2. Bukit Mertajam } & \ldots & 2 & 9 \\ \text { 3. Bukit Juru } & \ldots & 2 & 10 \\ \text { 4. Bukit Gajal Mati } & \ldots & 2 & 17 \\ \text { 5. Bukit Goa Ipoh } & \ldots & 2 & 8 \\ \text { 6. Bukit Langkap } & \ldots & \text { I } & 4 \\ \text { 7. Bukit Goa Gempass } & \ldots & 1 & 5 \\ \text { 8. Kubang Ulu } & \ldots & 3 & \end{array}$

est Ranger.
5
9
10
I
I 2
8
4
5

3. A Forest Gua:d was appointed for the first time and has proved useful in preventing encroachments. Owing to his appointment and the energy of the Forest Ranger more trespassers on the Reserves were summoned and fined.

4. Two coolies were employed for two months at $3^{\circ}$ cents a day to clear the boundaries of the Juru Reserve, which had become much overgrown. Now that there is a special rote for the Maintenance of Forest Reserves, the clearing of the boundaries can be carried on systematically. The boundaries of Bukit Langkap in particular require opening up, but there was some difficulty in obtaining Malay coolies owing to their dread of tigers. 
5. There were 5 prosecutions for trespass on the Reserves, viz.:-

$\begin{array}{cccc}\text { Bukit Goa Ipoh } & \ldots & \ldots & 6 \\ \text { ". Goa Gempass } & \ldots & \ldots & 6 \\ \text { "Langkap } & \ldots & \ldots & 2 \\ \text {, Gajah Mati } & \ldots & \ldots & \text { I }\end{array}$

The fines ranged from $\$ 5$ to $\$ 100$, and the total realised amounted to $\$ 345$

6. There were no fires of any importance.

7. The Kubang Ulu Experimental Gardens are still in the experimental stage. No use has been made of them.

\author{
W. PEEL \\ Acting District Offuces.
}

\title{
Southern District.
}

1. There is only one area in the Southern District containing $1,+7$ I acres and 2 poles, which has been set apart for the purposs of forming a Forest Reserve. This is situated on and round Bukit Panchor Ifill and is contiguous in the Kedah Boundary. The Reserve is known as the Bukit Panchor Forest Reserve.

2. The Reserve was visited five times br the District Officer during the year, viz: on 14th April, 28th June, 7 th July, I6th July and rin August, and eight times by the Forest Ranger.

It is visited daily by the Forest Guard unlese engaged in other duties and he keeps a diary of his inspections.

3. There were four prosecutions for timber cutting in the Forest Reserve and the offenders were all convicted before a Magistrite. The culprits were all Chines $\rightarrow$ working on the lands surrounding the Forest Reserve and the offences only amounted to petty thefts of the smaller kinds of trees. The? Forest Guard lives. however, too far from the Forest Reserve to be able really to keep an efficient check on such thefts arid it would be of a great advantage if a house could be erected for him near the Reservoir which would ensure his always being on the spot.

4. There is a large stock of valuable timber on the island of Pulo Kra which is not included in any Forest Reserve. All this timber grows on Crown land and should be maintained as far as possible. Passes were formerly granted to the inhabitants of the island to cut some of the less valuable trees for the purposes of their houses, but during the middle of the year it was found that it was impossible to keep a check on the timber cut under cover of the pass; thus a pas. was granted permitting the cutting of the poorer timber but advantage was taken to fell the more valuable woods. As there are no Government servants on the island except the police it was very difficult to hinder this practice. All passes were therefore stopped: this led to an open system of theft of the timber. Timber was openly felled and brought into the village with the connivance of the police. In October a prosecution was accordingly instituted against three men for theft of Government timber from the island and they were all fined; the conduct of the police was also brought to the notice of the police authorities and as a result all the police on the island were changed, and an entircly new batch quartered there.

5. The chief use of the Bukit Panchor Forest Reserve appears to be that it covers the catchment area of the Bukit Panchor Reservoir which supplies the village of Nibong Tebal with water. It therefore affords an easy method of ensuring the purity of the water. The Reserve though it contains much valuable timber is too small to ever really afford much profit from the culivation and sale of the woods growing therein. During the year a path was cleared round the whole of the Reserve and on the 18 th August I walked right round the Reserve accompanied by the Forest Guard; such of the Boundary pillars erected on the Boundary line between Kedah and this district as fall in the Reserve were found to be in good repair.

6. There are still some kampong lands planted chiefly with durians and betelnuts situated in the Reserve. During the early part of the year the owners of these lands, who are all Malays, were given by Government in cash half the estimated value of these lands in return for the surrender of their title deeds, and it was proposed to grant to them in lieu of their former titles indevisable and inalienable leases. It has 
now heen decided to buy these lands ontright and to offer to the owner as compensation the remaining half value of the land and proceedings are now being taken with this view. The Malays, huwever, having been offered such favourable terms by the first arrangement, now strongly object 10 be wholly dispossessed of these lands and the latter will therefore have to be compulsorily acquired under the Ordinance.

\section{H. C. SELLS, \\ District Offreer, Nibong Tebal.}

\section{Dindings.}

I. The Forest Reserve of thr: Dindings remain the same in number (8) as during Igoo. They were visited by the District Offeer and Forest Inspector or Ranger as shewn below:-

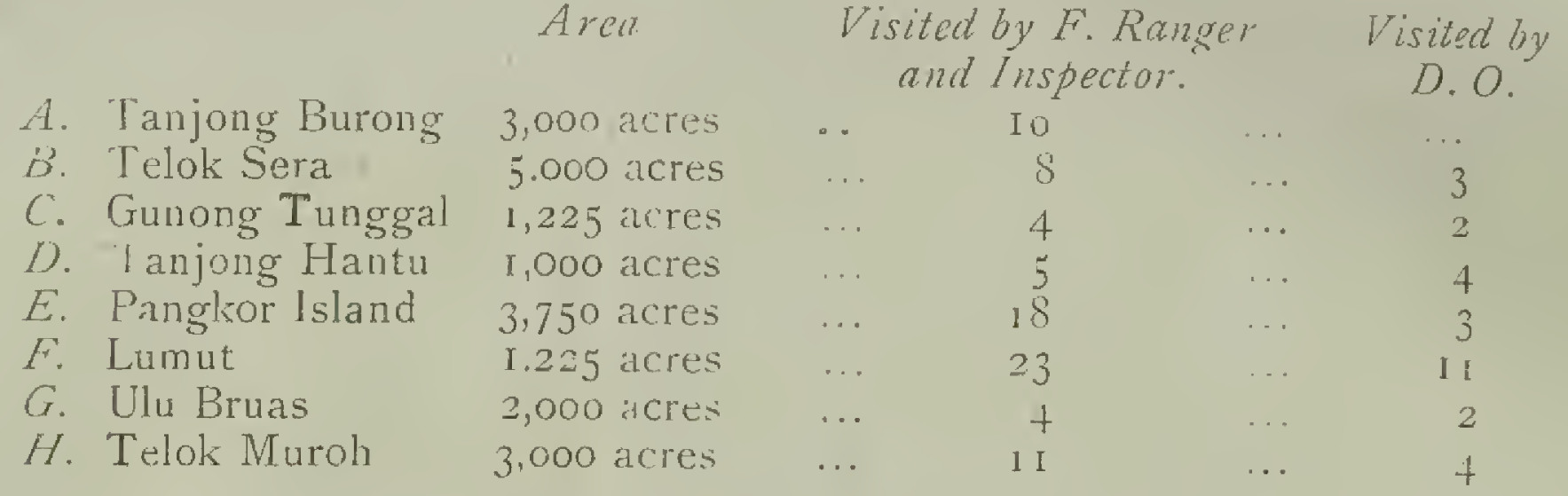

2. The areas given are guesses and should not be taken as at all accurate, as the Reserves, with the exception of Lumut, Pangkor and Ulu Bruas, have not yet been surveyed. In the case of Lumut and Pangkor Reserves the areas given are probably correct within a few acres. Ulu Bruas Reserve has been surveyed but the work has not yet been plotted and the area is not known.

3. Five prosecutions for trespass or illicit timber cutting in the Reserves accurred during the year, seven persons being involved. Fines to the amount of $\$ 145$ were imposed, of which $\$ 77.50$ were recovered. One case from Pangkor of negligence by which some damage by fire was done in the Reserves near Pasir Boga was discharged for want of evidence as to the identity of the accused, and one case of trespass in the Telok Sera Reserve was discharged on its merits.

4. Except in the Tanjong Burong Bakau Reserve, I do not think that any illicit timber cutting goes on in the Reserves. In the Tanjong Burong Reserves, however, much bakau is stolen. The reserve is separated from Perak Territory at Sungei Panchor only by the narrow river, and the Chinese fishing village of Sungei Hud on the l'erak side supplies itself with firewood and bakau poles from the Reserve almost with impunity. It is extremely difficult for the thieves to be caught in the act as the place can only be approached by water, and the Forest Guards are moreover afraid of the Chinese fishermen from the village rescuing any prisoners they may make. This occurred on one occasion in 1900 and one of the men concerned in that case was again caught stealing bakau in April, Igor. He was fined $\$ 50$, but did not pay and went to prison for six months. Everything is in favour of the law breakers and ther is no likelihood that timber stealing at this place will be stopped solong as the fishing village remains where it is. The rest of this Reserve extending down the coast as far as the Bruas River is free from the depredations.

The theft of big timber in any of the Reserves is almost impossible and it is not worth the risk to steal young timber or jungle produce that can be as easily and more safely found outside the Reserve.

5. The Staff of Forest Guards was maintained at a strength of 13 during the year, viz., six at $\$ 9$ per month and seven at $\$ 8$ per month. Three men were stationed at Bruas (one at $\$ 9 \mathrm{p} . \mathrm{m}$. and two at $\$ 8 \mathrm{p} . \mathrm{m}$.) and the other ten were stationed in pairs at Sungei Rotan, Sungei Batu, Beting Luas, Pangkor and Lumut, one man at \$9 p. m. and one at $\$ S \mathrm{p} . \mathrm{m}$. at each station. This number of guards may be considered adequate for the work to be done at present. In 1902 it has been decided to add two more blocks of forest land to the reserves, viz.:- the Batu Uridan and Telok Senanyin Hills. This will necessitate an increase of the staff for this year.

Many changes have taken place in the personnel of the Forest Guard staff. Some of the stations (Beting Luas and Sungei Batu for instance) are very isolated 
and unpopuldr, and it has been at times difficult to induce the Guard to remain when sent to these places.

6. An additional Forest Ranger for the Reserves to be stationed at Bruas at $\$ 65$ per month was sanctioned for Igor and Mr. A. Hoivell was appointed temporarily on $5^{\text {th }}$ April. He was transferred to Lumut on 23 rd Ap'ril; his place at Bruas being taken by WAN CHI, formerly Assistant Forest Ranger in the Northern District of Province Wellesley. The appointment has proved a very useful one and the present holder (IVAN CHI) has done his work very satisfactorily, though his ignorance of Enclish makes written comianication with him at times not as clear as it might be. He has combined the duties of Forest Ranger and Forest Inspector for the Forest Reserves at Pruas.

- Mr. Hovele's services as Forest Ranger, Lumut, were dispensed with on 3 rst July, and his place was taken by Mr. T. DE SuU\%, Forest Inspector. The latter appointment was left vasant till the end of the year in order to see whether one man could not advantageously perform the duties of Furest Ranger and Forest Inspector, is at Bruas. The duties overlap to a great extent, but it was found that the extent of the district and the distances between the Reserves and other places to be visited, combinerl with the fact that much of the travelling has to be done by boat and is therefore slow and uncertain, rendered the amalgamation of the two appointments undesirable. The vacancy of Forest Inspector was filled up late in December by the appointment of S. AliAGAPPEN, Assistant Forest Ranger, Bukit Mertajam, on 3 months' probation.

s. In Igor for the first time a certain amount of revenue, other than from the undecirable source of fines for illicit cutting was derived from the Reserves. Passes to cut jungle produce in the Reserves, (rotans, mengkuangs and bertams) were issued from September at double rates and the total amount of revenue so derived was \$246.no. By far the greater number of the passes were for rotan in the Telok Sera and Bukit Segari Reserve. Passes for nibong were not allowed in the Reserves as the culting and removing entails a considerable amount of damage to the young lorest wrowth. This is not so much the case with rotan or mengkuang, where hardly any damage is done.

9. Two small fires occurred during the year in the Reserves-one at Pangkor near Pasir Boga in September and the other in December at Tanjong Hantu. "The origin in each case was not discovered. In the former case about 25 acres of brushwood forming the fringe of the Reserve were damaged, but no trees of any value were included in the area burnt. In the fire at Tanjong Hantu the Reserve was just touched and $n o$ appreciable damage was done. This was due to a strong wind fortunately blowing the flames away from the Reserves and to a heavy downpour of rain which quenched the fire after it had been burning for about half a day. There are no houses in the vicinity of the spots where the fire seemed to have started; they must have been caused by the careless throwing of a match by a passer by.

IO. The much needed survey of the Forest Reserves has been begun this year. A surveyor has been stationed here for the last six months of the year. He was oceupied for some time in surveying a private estate at Bruas, but since the completion of that work has been engaged exclusively on the Reserves. Ulu Bruas and Lumut Reserves have been completely surveyed with the theodolite and Pangkor with the prismatic compass. The work has taken longer than I anticipated. The very rough and hilly nature of the country makes chaining and measurement very slow work. It may be possible after survey to alter the boundaries so as to avoid the steeper hills and so as to have less.tortuous lines. If so, it would be advisable to do so. At present the task of patrolling and inspecting the boundaries is a very arduous one.

1 $\mathrm{I}$. The proposed creation of new Reserves of all the bakau land in the Dindings has been deferred till the country has been surveyed. A proper working plan of these Reserves with a view to their being economically exploited could not possibIy precede a survey, and the proposal was premature. It would have killed the firewood trade and would have caused considerable loss of revenue if the bakau forests had been closed to timber cutters as completely as the other Reserves of ordinary forest land.

\section{F. J. HALLIFAX,} Acting District Officer.

Dindings, $15^{t h}$ Famuary, 1 g,o2. 
MALACCA

Central District.

\author{
FOREST OFFICE, \\ Malaica, Ith February, Is02
}

Sir,- - have the honour to forward the Annual Report on the Forest Reserves in the Central District.

2. The Central District includes the "Bukit Bruang" Reserve with extension and th: "Bukit Sebukor" Reserve.

3. The "Bukit Bruang" Reserve was inspected on various Fridays by the Forester and myself; and the whole boundary has been gone round about $2 \frac{1}{2}$ times The paths are kept clean and clear of all undergrowth.

4. The staff consists of a senicr and a junior Forest Guard, both of whom are nte lligent and energetic mer.

5. There was no prosecution during the year. Beyond the suspected cutting of bamboos on the edge of the Reserve, I saw no appearance of illicit cutting of wood in our inspections of the boundary.

6. The nursery in the "Bukit Bruang" Reserve at "Ayer Keroh" contains several beds of Tembusu (Fastata Fragrans), Merbau (Afrelia palembanica), Nibong (oncosperma tigillaria), Gelam (Melalencas leucadendron) Gombang (Dipterocarpus crinitus) sown in 1901 ; also 19,000 odd seeds of Para rubber (Hevea brasiliensis) were sown; about 500 rambong (Ficus elastica) cuttings and seedlings were raised during the year, about 500 Getah Sundih (Payena Leerii) seeds were sown and 10.500 getah taban (Palaquium sp.) cuttings were bedded.

In the Bukit Sebukor Nursery are a few beds of tembusu (Fagrae fragrans) and about 2,000 Para rubber (Hez'ea braziliensis) plants were raised and have since been put out in the said Reserve.

7. We purchased 6,2 I Getah taban (Palaquium sp.) plants and, through the kindness of the Acting Jirector, Botanic Gardens. Singapore, received i 8, 160 plants of the same species for which we paid freight charges only.

Of these 13,600 were put out direct into the forest at "Ayer Keroh" and at $20^{\prime} \times 20^{\prime}$ this gives an average of 125 acres (nearly) planted with this important variety of Gutta percha. The rest were bedded in the nursery and will be put out during the current year.

About 20 acres were close planted at $5^{\prime} \times 5^{\prime}$ with valuable timber plants in lalang ( $C$ ylindrica imperata) covered ground in the Bukit Bruang Reserve; and about 15 acres were planted with Para rubber (Hevec braziliensis) plants in the Bukit Sebukor Reserve at I $5^{\prime} \times 15^{\prime}$.

8. Expenditure:-

Only in the case of Contingent Expenses were the annual votes exceeded and that by a matter of 34 cents only. The only items of expenditure that need be specially mentioned are :--

(a) Salaries and wages of coolies and gardeners $\quad \begin{array}{ccc}S & c t s \\ 2,415 & 87\end{array}$

(c) Purchase of 4,775 Para rubber (Hevea brazili) plants... $68 \mathrm{r} 76$

(d) Purchase of 775 Para rubber (Hevea braziliensis) seeds. $42 \quad 45$

(d) Purchase of surveying instruments $\quad \ldots \quad \ldots \quad \ldots \quad$ I $80 \quad 35$

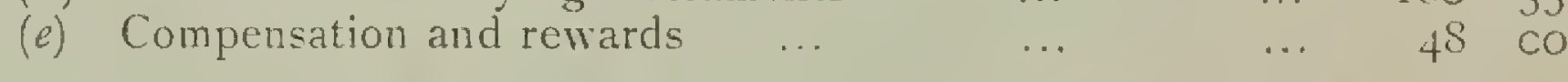

$\$ 3,368 \quad 23$

9. Revenue:- -

We started selling the material cut out in clearing for the planting of Getah taban (Palaquium sp.) plants, consisting of soft wooded and inferior species, in the month of August and at the close of the year realised By lease of the fruit trees in the "Bukit Sebukor Reserve" 20.00

\title{
Total $\$ 71.45$
}

Io. Miscellaneous:-

(i) Two ground fires occurred during the year. About 20 odd acres of lalang were burnt in March, destroying about 5 acres tembusu (Fagra fragrans) and 
other valuable trees planted in former years. The second fire occurred on the I 7 th of December and travelled over about 40 acres of lalang ground but did not reach any of the planted areas. Neither of these fires were serious in their nature and beyond warning the people to blame for them no action was taken.

(ii) The only other point that calls for attention is that we employ 12 women at a reduced rate for cutting smaller secondary growth where necessary.

1 have, \&c.,

\section{R. D. HUDSON=}

Superintendent, Govermment Plantations and Forests.

\section{Jasin District.}

\section{DISTRICT OFFICF,}

Fasin, 21st Fanuary, Igoz.

Sir,- I have the honour to forward my repo:t on the Forest Reserves of the Jasin District for the year $190 \mathrm{I}$.

2. There has been no alteration in the boundaries of the five Reserves during the year: their names and approximate areas are as follow's -

$\begin{array}{ll}\text { Ayer Panas } & 3,242 \text { Acres } \\ \text { Merlimaun } & 6,217 \\ \text { Batang Malaka } & 3,549 " \\ \text { Bukit Senggeh } & 9,430 \quad " \\ \text { Bukit Sedanan } & 7,806 \quad "\end{array}$

Total 30,244 Acres

3. The above were visited on the following occasions by the District Officer and Forest Rangers.

Ayer Panas:-

by the District Officer on and May

by the Forest Kanger on Sth March

by the Assistant Forest Ranger on 5 th December

Merlimau:-

by the District Officer on 22 nd December

by the Forest Ranger on Igth November

Batang Malaka:-

by the District Officer on $4^{\text {th }}$ May and on $j_{\text {th }}$ November

Bukit Senggeh :-

by the District Officer on 26th April and on I 7th December

Bukit Sedanan. by Assistant Forest Ranger on 2 Ist August and 5 th March

by District Officer on ist August.

4. The Staff in charge of each reserve is as follows:-

Ayer Panas, one Lance Corporal, one Guard.

Merlimau, Do. do.

Batang Malaka Do. do.

Bukit Senggeh $\}$ one Corporal, one Guard.

5. There was only one prosecution during the year, against a Chinaman who was convicted of cutting timber in the Bukit Sedanan Reserve.

6. The boundary lines of the Ayer Panas, Bukit Sedanan and Batang Malaka Reserves were kept well cleared. In the case of Bukit Senggeh on my visit in December I found the lines somewhat overgrown in places. I he Guards in charge have an enormously long boundary to look after and have also been obliged to devote ome time to the Getah Reserves at Bukit Senggeh and Nyalas. 
7. With regard to the Merimau Reserve so large a part of the boundary passes through swamp that it is hardly possible to kcep the lines clear, unless coolies are specially employed to do so. This is not, however, of very great importance as the swamp itself prevents all risk of encroachment.

\author{
I hatere, \&c., \\ S. CODRINGTON. \\ Acting District Ofticer.
}

\title{
Alor Gajah District.
}

\author{
DISTRICT OFFICE, \\ Alor Gajah, I6th 'fanuary', rooz.
}

Sir, - I have the honour to forward the following report on the Forest Reserves of this District of the year Igor.

Number and Area.

2. The Forest Reserves are four in number :-

$\begin{array}{lrr}\text { Bukit Panchor } & \text { area } & 3.356 \text { acres } \\ \text { Sungei Ldang } & \text { " } & 4.392 ", \\ \text { Brisu \& Sungei Siput " } & 5.268 ", \\ & & \$ 13,016\end{array}$

Inspections.

3. The above Forest Reserves were visited on the following occasions:-

Bukit Panchor by Districl Officer, Ioth May, 8th June, 4th July, 29th August, Ioth September, loth December, and 29th December.

Bukit Panchor by Forest Ranger, 25th April, ISth September, I8th, I th and 2oth December.

Sungei Udang by District Officer, Igth June, IGth October, and I gth December.

Sungei Udang by Forest Ranger, I6th and I 7 th May.

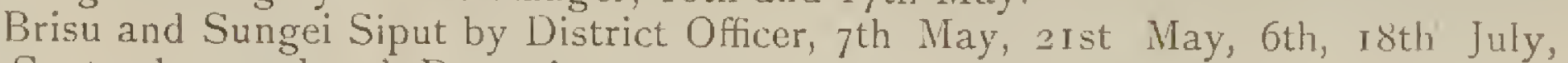
24th September, and i $7^{\text {th }}$ December.

Brisu and Sungei Siput by Forest Ranger, 2 Ist, 22nd March, I 5 th, I6th, 17 th and I8th April, Ist, 2nd, 3rd, 4th, 9th, roth and I Ith May, 4th, 5th June, I2th and I 3 th December.

4. The Staff at each reserve in I901 is shewn below:-

Bukit Panchor.-I Lance Corporal and I Guard.

Sungei Udang.-I Lance Corporal and I Guard.

Brisu and Sungei Siput-I Lance Corporal and I Guard at Brisu.

I Lance Corporal and i Guard at R. C. Kechil.

Prosecutions.

5. There was only one prosecution during the year when a man was fined $\$ 50$ for burning lalang in the Brisu Reserve.

\section{Revenue.}

6. The revenue from the reserves amounted to $\$ 287.60$ mainly from the sale of Durians and Dukus in the Bukit Panchor Reserve.

\section{Expenditure.}

7. The expenditure on the reserves for the year has been-

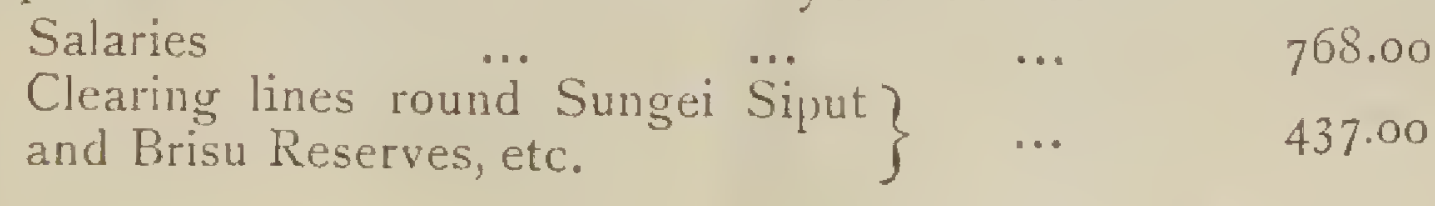


8. The paths and boundaries in the reserves at Bukit Panchor and Sungei Udang have been well kept.

9. New lines have been opened all round the Brisu-Sungei Siput Reserve and they are now in good order.

I0. A new Forest Station consisting of 2 Malay houses was built by the Public Works Department at the $25^{\text {th }}$ mile Ramuan China Kechil and a Lance Corporal and Guard are now stationed there.

I I. The station at Sungei Udang is now uninhabitable and part of it has fallen down. I trust the Public Works Department will attend to this early this year as owing to lack of funds it was unable to do so in I9o I.

12. No trace of illicit timber cutting was discovered in any of the reserves during the year.

13. A small area containing taban trees was discovered in Kemuning and was reserved.

\section{H. MARRIOTT,}

District Officer. 


\section{Annual Report on Forest Administration in the Straits Settlements for the year 1902.}

\section{Introductory.}

The forests of the Colony were under trie charge of the Collectors of I and Revenue, Singapore and Penang, and the District Officers, Province Wellesley, Dindings and Malacca, assisted on technical matters in Penang by Mr. C. CUklis, Assistant Superintendent of Forests, and in Malacca by Mr. GACiLIARul, a passed Dehra Dun student. The Chief Forest Officer visited each Settlement and many of the reserves and gave advice on some matters: his duties in the Federated Malay States were however too heavy for him to spare as much time as he could have wished to the Colony and his illness in November and December prevented lis compleling the 3 months in the Colony which is stipulated.

\section{CHAPTER 1.}

\section{Extension and Constitution of Reserved Forests.}

\section{Alteration in Area.}

I. From returns submitted (Form $/$ ) it is seen that in Penang Island an area of 34 acres was added to block D in North East district and an area of 236 acres to Telok Bahang reserve in the South West district. In Province Wellesley, the Ara Kuda reserve. 561 acres, was disafforested or thrown open to cultivation: also 1,294 acres of the Tasek Glugor reserve was abandoned, lining an area of 1761 acres to be maintained as a reserve. This was done on the advice of the Chief Forest Officer after he had risited both areas and considered the matter from every point of view. Most of the land abandoned was covered with "lalang" or rank grass and would have cost much money to reafforest, while cultiators were eager to take up the land, thus giving a better return 10 Government. No other alterations were effected in the area of Forest Reserves.

This table shews the proportion of area reserved to areil of the Colony at the close of 1902 .

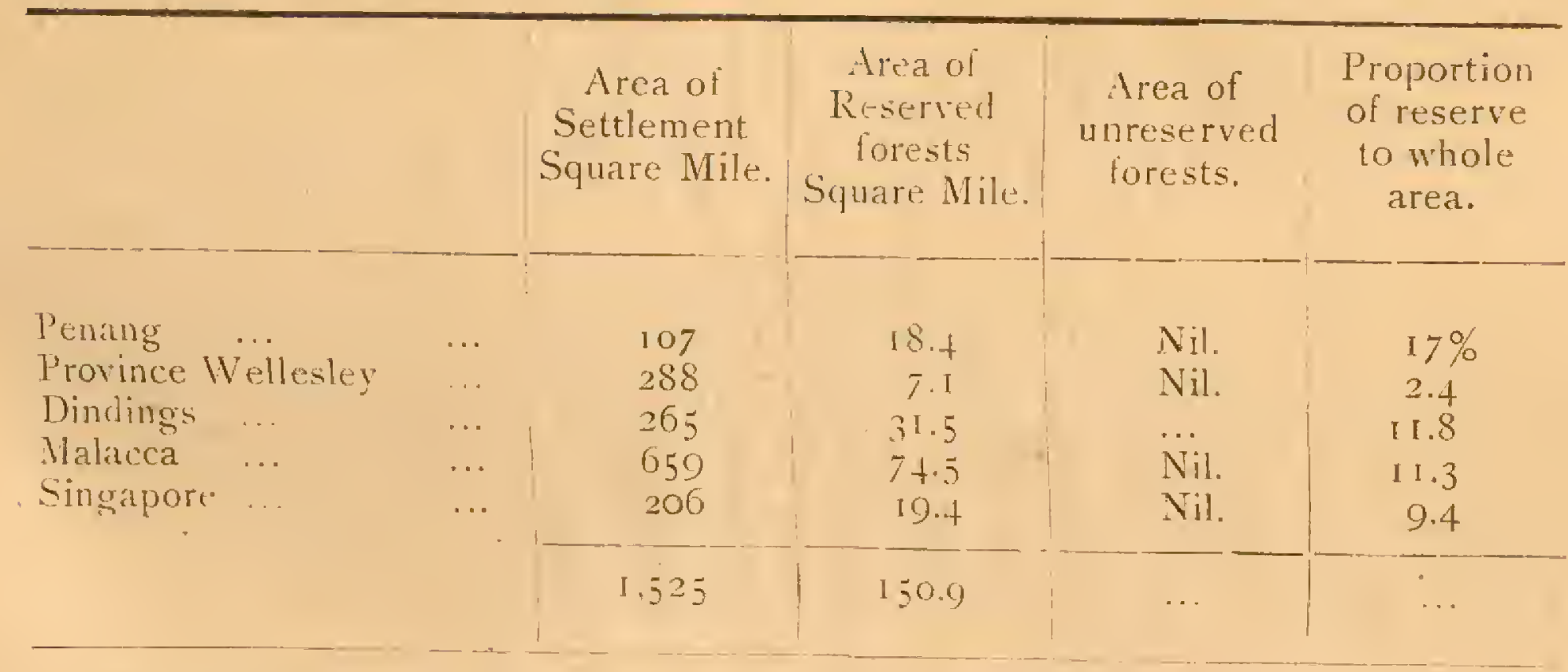

The Colony has thus an area of 10.2 per cent. of Forest Reserve which is very satisfactory, being in fact about the ideal amount, and will some day prove a source of considerable revenuc.

\section{Demarcation.}

\section{Sec Form 3 .}

2. The two small additions to the Penang Reserves were demarcated, and boundaries kept clear. The cost is not shewn in this form as it was incurred in the shape of payment to a regular staff of Forest Guards who also had other duties. In Malacca the boundaries were also kept clear by the staff of Forest Guards. The information sent in is very incomplete. 
Surveys.

See fiorm t.

3. The small arras adled in Penang were surveyed. In the bindings the lorest Ruserves were completely surveyed, but the results of the survey are not vet ready and the maps not yert malle.

\section{CHAPTER II.}

\section{Management of State Forests}

\section{Working Plans.}

1. None have yet been made. The necessity has hardly yet arisen txcept in the case of Mangrove Reserves and in these in Singapore and the Dindings the work should be put in hand as soon as officers have been found to fill the posts provided for

In Malacca some of the Rearres may be worked in the near future under revular plans. These however cannot be made until we háve good large-seale maps.

\section{Communications and Buildings}

See Form 6.

2. In Penang clearing of boundaries and paths wherever required was dome at a cost of $82 \mathrm{I} 4$

In Malacca, Forest Guards" quarters were erected at Selandar at a cost of \$255.y0, coolie ines at Bukit Bruang at $\$$ I $_{+}$, while $\$ 208$ were spent on repairs. In the Federated Malay States we are building small houses for the Forest Guards at from Sroo to $\$ 250$, and this should be done in the Colony when more revenue is received.

\section{Protection of Forests and Breaches of Rules.}

3. The staft was chiefly occupied in every Settlement in patrolling boundaris of resirves and keeping them clear.

In Penang there were 13 caces of illicit extraction of timber or other forest produce with il convictions.

In Province Wellesley there were if cases with I 6 convictions. No damage was done by fire. In the Dindings there were 43 prosecutions; the number of convictions is not stated but $\$ 264.50$ was received from fines by the Court.

In Malacca there were $\$$ cases with 6 convictions, one case being compounded for 420. The cases are few except in the Dindings where there are Chinese timber cutters In Singapore 6 persons were charged and all convicted.

Practically speaking there are no forest rules, the only law relating to the forests at all is found in Ordinance No. $\mathrm{X}$ of $\mathrm{I}_{88}$. The passing of a Forest Enactment and rules thereunder is now engaging the attention of the Chief Forest Officer.

\section{Sylviculture.}

\section{Improvement of Forest Growth}

4. Wost of the Forests of the Colony are at present recuperating, having been reserved when in a rery poor state. In Penang therc is large forest on the hills, but the majority of the reserves in the Island were constituted chiefly with a view to the prevention of crosion of the soil on the steep hill sides, and to the preservation of at regular supply of water, rather than to a successful timber supply. In the Province the small area reserved consists chiefly of hill tops, except 'Tasek Glugor where there will soon be exploitable timber.

In the Dindings and Malacca we find the best forest. In the former the reserved areas are all hilly except Tanjong Burong which consists of Bakau (Mangrove). Nothing has been done to improve natural growth so far, except to allow the reserves a complete season of rest.

In Malacca the best reserves are Bukit Sedanan, Batang Malacca, Bukit Singgeh and Merlimau. These forests contain large timber trees, chief of which are RambeiDaun (Shorea Acuminata) Gombang (Diptero-carpus Crimtus) producing a good wood oil, Resak (shorea). Kelat of several kinds, Jelutong (Dyera Maingayi,) Kayu Gharu (Aquilaria Malaciensis) or eagle wood, used for incense. Medang (Crypatocarru Griffithiana), Tembusu (Fagr xa Fragrans), Tampinis, Kumuning (Mairraya exotica), besides several useful varieties of canes. 
In singapore the reserves contain lithe bat seconditry growth, and the Manghose forests cxamined by me are stibl young and none the worse of a further period of rest.

In Malacca the nabural reproduction of Tembusu and Tampinis is reported at rery sood. Getain Taban (Palaquim) is scarce, the only natural tress seen hy me being near Nyalas.

\section{Cultural Operations.}

In Penany naturally grown seedlings of Getah Talyal were assisted by clearing if undergrowth interfering with their growth, in Block C. in the Sonth West ristrict.

\section{Artificial reproduction.}

Sie Form 8 .

In Penang about 5 acres were atded bringing the area ip, to 40 acres, in the addition to main Range $D$.

In I 889-1900 planting of Getah Taban was commenced and carried on till $190 \mathrm{I}$ 3co seedlings were planted from seed obtained from a tree in the Waterfall Girdens and rere successful. 1,682 saphings were purchased by the Director of Gardens, Singapore, from Borneo and forwarded to Penang in boxes. These and the seedlings were planted 20 feet by 20 feet in partial shade and where natural shade was insufficient para rubber was planted betweon the lines. The following table gives the result of these in 1902 .

\begin{tabular}{|c|c|c|c|}
\hline $\begin{array}{c}\text { Discription of trees planted in Septem. } \\
\text { ber-Octoher loor. }\end{array}$ & No. of Trues. & $\begin{array}{l}\text { Reported } \\
\text { alive in May } \\
\text { J } 902 .\end{array}$ & Dearl in 1902. \\
\hline $\begin{array}{l}\text { Palaquium Getah seedlings from trees } \\
\text { growing in Waterfall Valley, Penang ... }\end{array}$ & 300 & 252 & 48 \\
\hline $\begin{array}{l}\text { Palaquium Sp. Sapplings without } \\
\text { leaves sent up from Singapore Botanic } \\
\text { Gardens } \\
\text {... }\end{array}$ & 1,682 & 250 & $1,+32$ \\
\hline Para Rubber (Hevea brasiliensis) & 250 & & \\
\hline $\begin{array}{cccc}\text { Kickxia elastica } & \text { (seeds from } & \text { W. } \\
\text { trica). } & \ldots & & \end{array}$ & 12 & I 86 & 82 \\
\hline Rambong (Ficus clastica) & 6 & & \\
\hline
\end{tabular}

In 190 I the trees of Palaquium in the Waterfall Valley produced a good crop of seeds which were collected from day to day and planted in boxes in the Waterfall Garden. As soon as these were $2-3$ inches high they were potted off singly in five inch pots and grown on until the end of April when planting was recommenced by supplying the vacancies caused by losses in Igoo and further extending the plantation so long as plants were available.

Description of trees planted Ipril-May 1902.

No. of

Trees.

Palaquinm Getah seedlings from trees growing in Waterfall Valley,

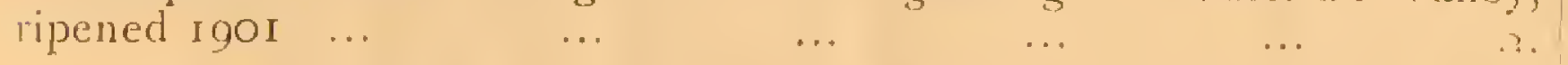

Para Rubber (Hevea brasiliensis) planted in more open places to shade $\begin{array}{lllllll}\text { Palaquium } & \ldots & \ldots & \ldots & \ldots & \ldots & \ldots\end{array}$ 1,890

Kickxia elastica SEeeds from W. Africa in Igoo planted as an

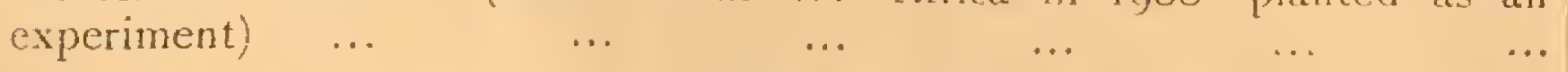


In order to have a few young trees under closer observation than is possible with Getah Taban planted in Waterfall Gardens, P'enang. those in the plantation commenced in Igor at Batu Ferringgi 1, ooo plants at twent: feet apart were slanted in the: Waterfall Valley on the eastern slope of the knoll on which formerly stood the Assistant Supcrintendent's house.

Fifty of these are scedlings from trees growing in the Valley close by, and lifty are plants raised from cuttings by Mr. BURCH.IRD at Indragiri in Sumatra.

The fifty cuttings are planted to the south and the seedlings on the north, that is towards the higher ridge.

The planting was done the first week ta July, rgor, the blukar having becn first thimned out but not sufficient to expose the plants to full sun.

All these plants were about one year old and 6-Io inches high when planted they are now growing well.

In order to find out the number of Getah Taban trees growing in the Batu Feringgi Reserve, a careful search was made with the following result. The following Table gives the number of trees at circumferences varying from 6 inches to 6 feet at breast high. The total number was 3,907.

Getah Taban trees growing naturally in Batu Feringgi Reserve tabulated according to sizes.

\begin{tabular}{|c|c|c|c|c|c|c|c|c|c|}
\hline & $\begin{array}{l}\text { No. of } \\
\text { Trees. }\end{array}$ & $\sigma^{\prime \prime}$ & $I^{\prime}$ & $1^{\prime} 6^{\prime \prime}$ & $2^{\prime}$ & $3^{\prime}$ & $t^{\prime}$ & $5^{\prime}$ & $6^{\prime}$ \\
\hline Sungei Kechil & 17 & $\ldots$ & 7 & 2 & 5 & I & 1 & 1 & $\cdots$ \\
\hline Jalan Chempedak & 601 & 310 & 188 & $5^{8}$ & $3 I$ & 8 & 3 & 2 & I \\
\hline Titi Serai & 634 & 304 & I97 & 69 & 39 & 23 & 2 & $\cdots$ & $\cdots$ \\
\hline Jalan Burot & 875 & 574 & 199 & $6 I$ & 27 & 13 & 1 & $\cdots$ & $\cdots$ \\
\hline Jalan Lusong & 368 & 233 & 68 & 33 & 12 & 9 & 2 & I & 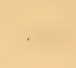 \\
\hline Jalan Titi dua $\quad \ldots$ & 390 & 251 & 87 & 30 & 13 & 8 & I & $\cdots$ & $\cdots$ \\
\hline Talan Pondok Payong & $84 \mathrm{I}$ & 576 & I 83 & 50 & 14 & I 8 & . & $\cdots$ & ․ \\
\hline Talan Kabong Ah Tek & 54 & 44 & 5 & 2 & I & 2 & $\cdots$ & $\cdots$ & $\cdots$ \\
\hline Jalan Tinggi Basap ... & 39 & 35 & 4 & $\ldots$ & .. & $\cdots$ & $\cdots$ & $\cdots$ & $\cdots$ \\
\hline \multirow[t]{2}{*}{ Getah Plantation } & 87. & 48 & 18 & 12 & 7 & 2 & $\cdots$ & $\cdots$ & $\cdots$ \\
\hline & 3,906 & 2,385 & 956 & 317 & $1+9$ & $8_{4}$ & IO & t & I \\
\hline
\end{tabular}

This plantation was visited by the Chief Forest Officer in February, J902. The failure of a great number of the transplants was undoubtedly due to the fact that the roots had been cut off too short. The work has been in the hands of the Land Officer assisted hy an lnspector, Mr. CURTS giving arlvice only from lime to time. He will in future be in sole charge of this work.

In Malacca 8 acres were planted up with Getah Sundik (Payena) in Bukit Bruang; and 125 acres of Getah Taban (Paloquinnn) upkept, 4.5 acres were also planted up with Tembusu, Rambong, Mahogany and Para, making an area of 70 acres. Getah Taban Plants were bought at a cost of $\$ 1,500$ and put into the nursery. The Chief Forest Officer visited the plantations and is of opinion that no more transplants of Getah Taban should be purchased from other countries, but that if possible seed should be sought for and bought. In view of the extensive tracts of naturally grown Getah Taban in the Federated Malay States it seems inadvisable to plant this species in the Colony at a great cost and with put poor results.

In Singapore, Mr. RIDI.EY superintended the planting operations; 14,000 trees, chicfy Gutta Percha were planted. Some of the trees in the forest fruited, and secr was obtained.

$\$ 592.13$ was spent during the year.

\section{Experiments.}

In Province Wellesley 2 acres Lalang land in the Tasek Giugor reserve was planted up with Teak sown in situ from seed obtained from Burna. The seeds wercsown 6 feet by 6 feet. It is too early as vet to report as to the result. The climate and situation are as farourable a any that can be obtained in such southern latitudes.

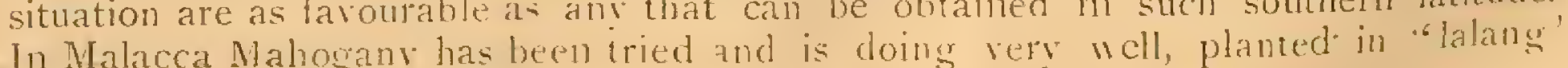
blanks. 


\title{
Exploitation.
}

As licences to cut trees were issued on the system of charging royalty according to diameter, and no cut timber measured, no figures are available.

In the I)indings royalty or export duty is levied on measurements, but no figures have been supplied. It is hoped that the system of measurement of all timber cut, and the charging of royalty and export duty at a fixed rate per ton of 50 cubic feet may be introduced during I903. This has been done all over the Federated Malay States with excellent results. The work of the Chief Forest Officer with regard to the Native States has been so heavy that it has been found quite impossible for him to introduce this system in the Colony during the year. The exploitation of timber is however comparatively trifling, whereas in the Native States it is very heary and the first thing to be put in order.

\section{CHAPTER HI}

Financial Results

SEE FOR. it FOR PARTiCula'rs.

The following table gives:-

\begin{tabular}{|c|c|c|c|c|}
\hline & Revenue. & Exp-nditure. & Surplus. & 1)eficit. \\
\hline $\begin{array}{ll}\text { Penang } & \ldots \\
\text { Province } & \text { Well sly } \\
\text { Dindings } & \ldots \\
\text { Malacca } & \ldots \\
\text { Singapore } & \ldots\end{array}$ & $\begin{array}{rl}8 & i \\
6+8 & 00 \\
487 & 00 \\
10.327 & 21 \\
1.170 & 13 \\
611 & +2\end{array}$ & $\begin{array}{cc}\quad 8 & i \\
1,338 & 00 \\
1,163 & 00 \\
2,753 & 29 \\
2,53+ & +5 \\
1,1+9 & 39\end{array}$ & $\begin{array}{l}\quad+c . \\
\cdots \\
7.57392 \\
\cdots \\
\cdots\end{array}$ & 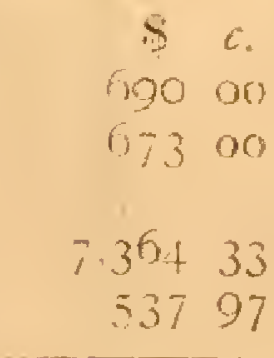 \\
\hline & ${ }^{1} 3,24376$ & $+9.93 i+$ & 7.57392 & 9,26530 \\
\hline
\end{tabular}

In l'enang the cost of stat is nearly covered by revenue, the deficit being due to planting and clearing of boundaries.

in Province Wellesley cost of staff is covered by receipts, but cost of planting, etc., causes a deficit. In the Dindings there is a surplus of $\$ 7.573 .92$, timber bringing in a revenue of $\$ 6,566.21$. This is very satisfactory and I have no doubt it will increase with an imploved system of charging rovaly and export duty. In Malacca there is a large deficit of $\$ 7,364$, but this I hope will be remedied in the near future. The reasun is that large amounts were spent on plantations and also that there were 2 European officers in charge at the commencement of the year, one on $\$ 2,+00$ with compensation the other on $\$ 780$. The former was transferred to the Native States on I 5 th February, Igoz. The expenditure will be much retuced therefore in 1903 , and a certain amount of revenue derived from the reserves which have hitherto been entirely closed. There is no reason why in a year or lwo the Colony should not shew a small surplus in is Forest account.s. The neth leficit amounts to $\$$ I,79I.

\section{Administration.}

The staff of liorest Rangers were occupied partly on land work and partly on forests. This has been remedied and a scheme was submitted by the Chict Forest Officer to His Excellency the Govemor for a permanent Forest Staff for the Colony, see appendix $B$. The staff of liorest Guards were chiefly employed in patroling and clearing reserve boundaries. The general control has been in the hands of the Collectors of land Rovenu: and District Officers.

\author{
A. W. BURN-MURDOCH, \\ Conservator of Forests.
}


FORM NO. I.

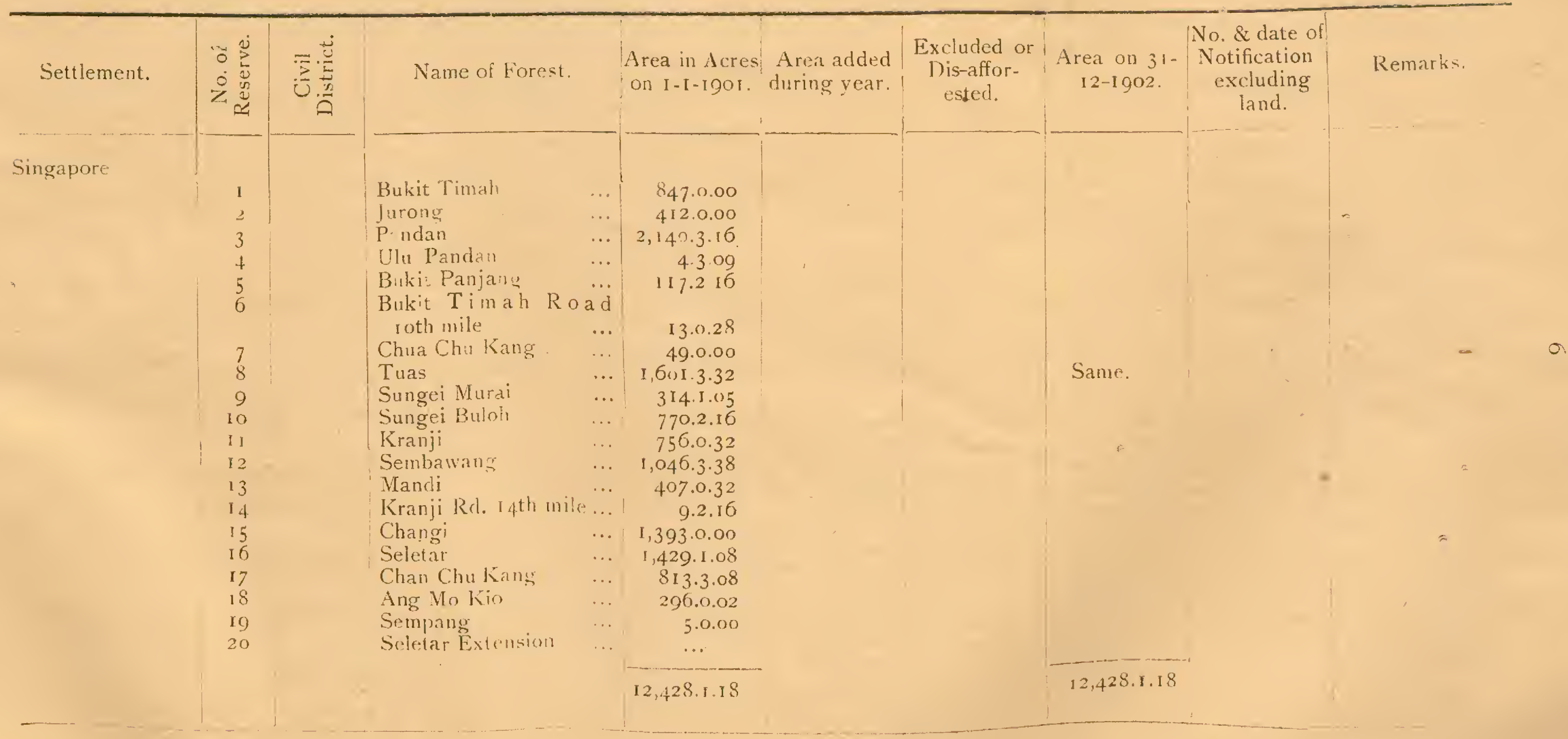


Form No. I

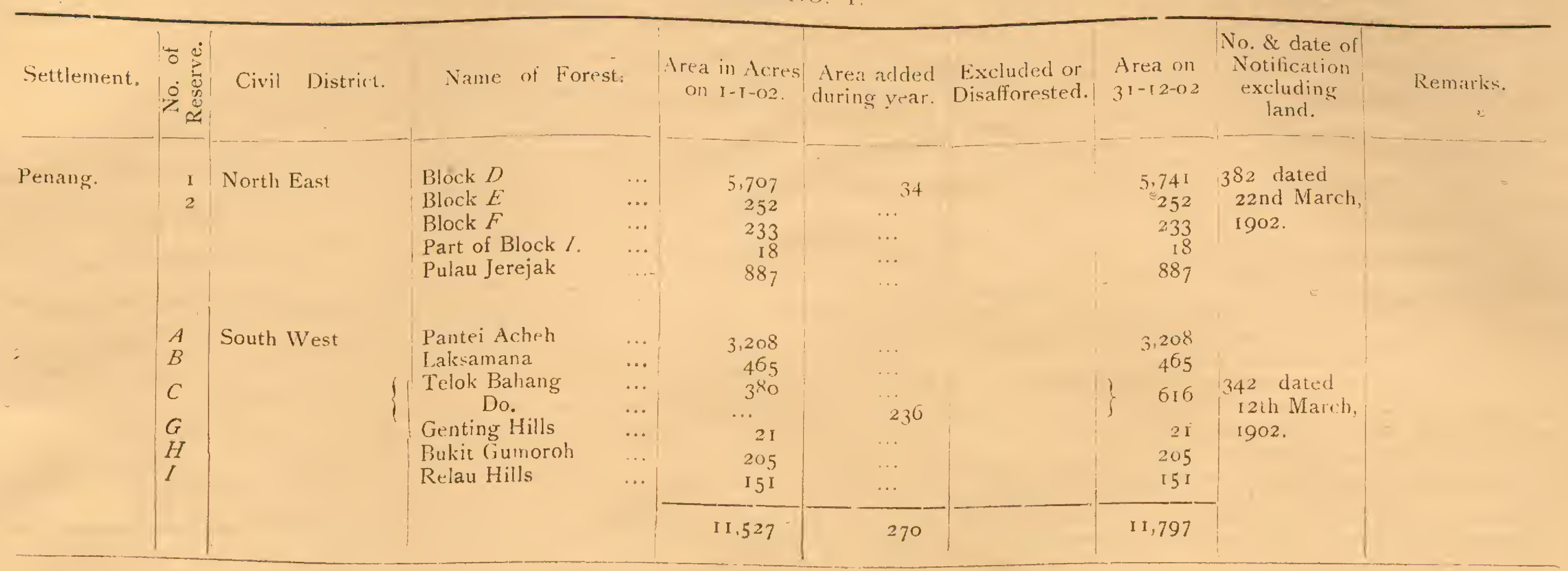


ForM No. I.

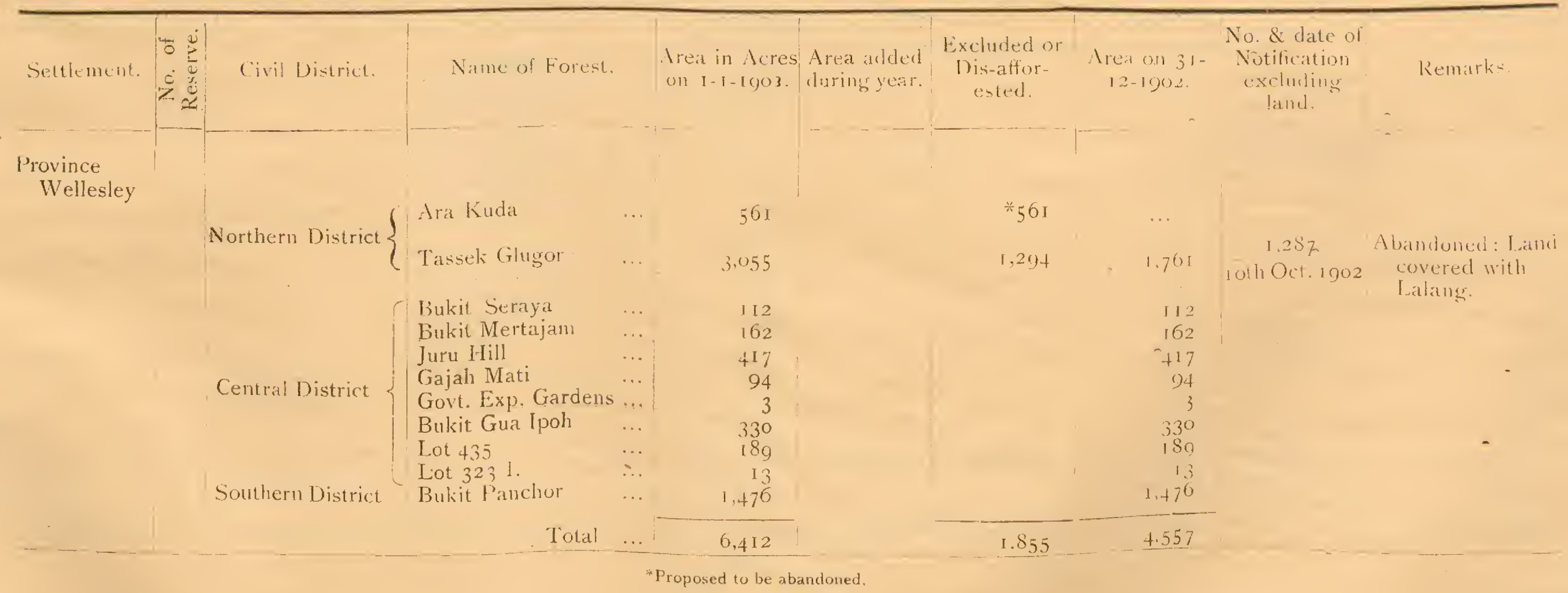


FORM NO. I

\begin{tabular}{|c|c|c|c|c|c|c|c|c|c|}
\hline Settlement. & 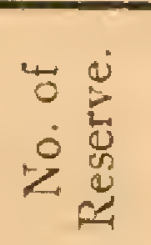 & $=\frac{5}{0.0}$ & Name of forest. & $\begin{array}{l}\text { Area in Acres } \\
\text { on } 1-1-1902 .\end{array}$ & $\begin{array}{l}\text { Area added } \\
\text { during year. }\end{array}$ & $\begin{array}{l}\text { Excluded or } \\
\text { Dis-affor- } \\
\text { ested. }\end{array}$ & $\begin{array}{c}\text { Area on } \\
3^{1-12-1902}\end{array}$ & $\begin{array}{c}\text { No. \& date of } \\
\text { Notification } \\
\text { excluding } \\
\text { land. }\end{array}$ & 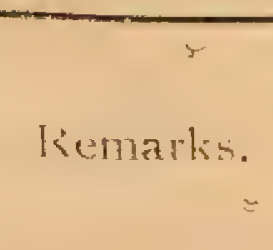 \\
\hline \multicolumn{10}{|l|}{ Dindings } \\
\hline \multirow{8}{*}{$=$} & A & & Tanjong Burong & 3,000 & & & $\begin{array}{l}3,000 \\
5,000\end{array}$ & $\cong$ & \\
\hline & $\mathrm{B}$ & & Telok Seral & $\begin{array}{l}5,000 \\
I, 225\end{array}$ & & & $\begin{array}{l}5,000 \\
1,22 \tilde{5}\end{array}$ & 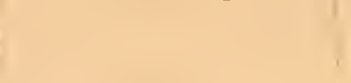 & \\
\hline & $\mathrm{D}$ & & Tanjong Hantu & 1,000 & & & 1,000 & & \\
\hline & $\mathrm{E}$ & & Pangkor Island & 3,750 & & & 3,750 & & \\
\hline & $E$ & & Lumut & 1,225 & & & 1,223 & & \\
\hline & G & & Ulu Bruas & 2,000 & & & 2,000 & & \\
\hline & $\mathrm{H}$ & & Telok Muroh & 3,000 & & & 3,000 & & \\
\hline & & & Total & 20,200 & & & 20,200 & & \\
\hline
\end{tabular}


FORM No. I.

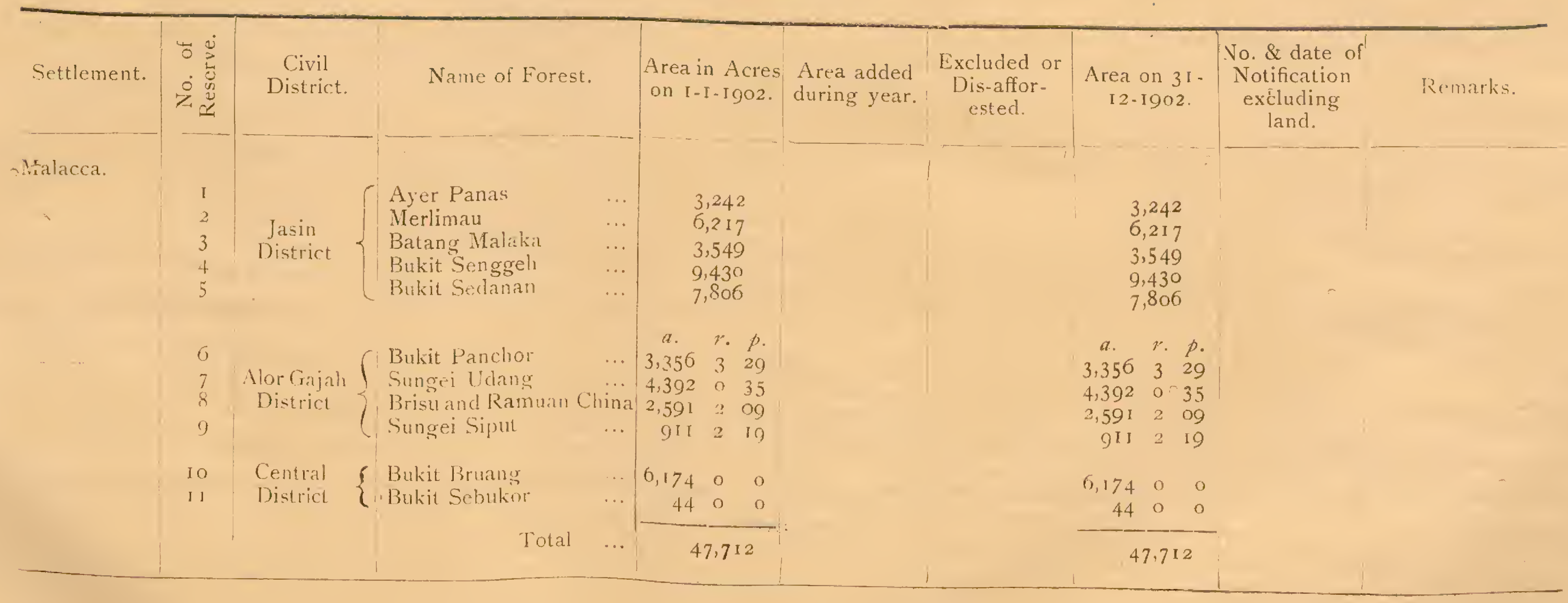


FORM NO. 2 .

Statement shewing progress made in forming new Reserves during the yedr-1902.

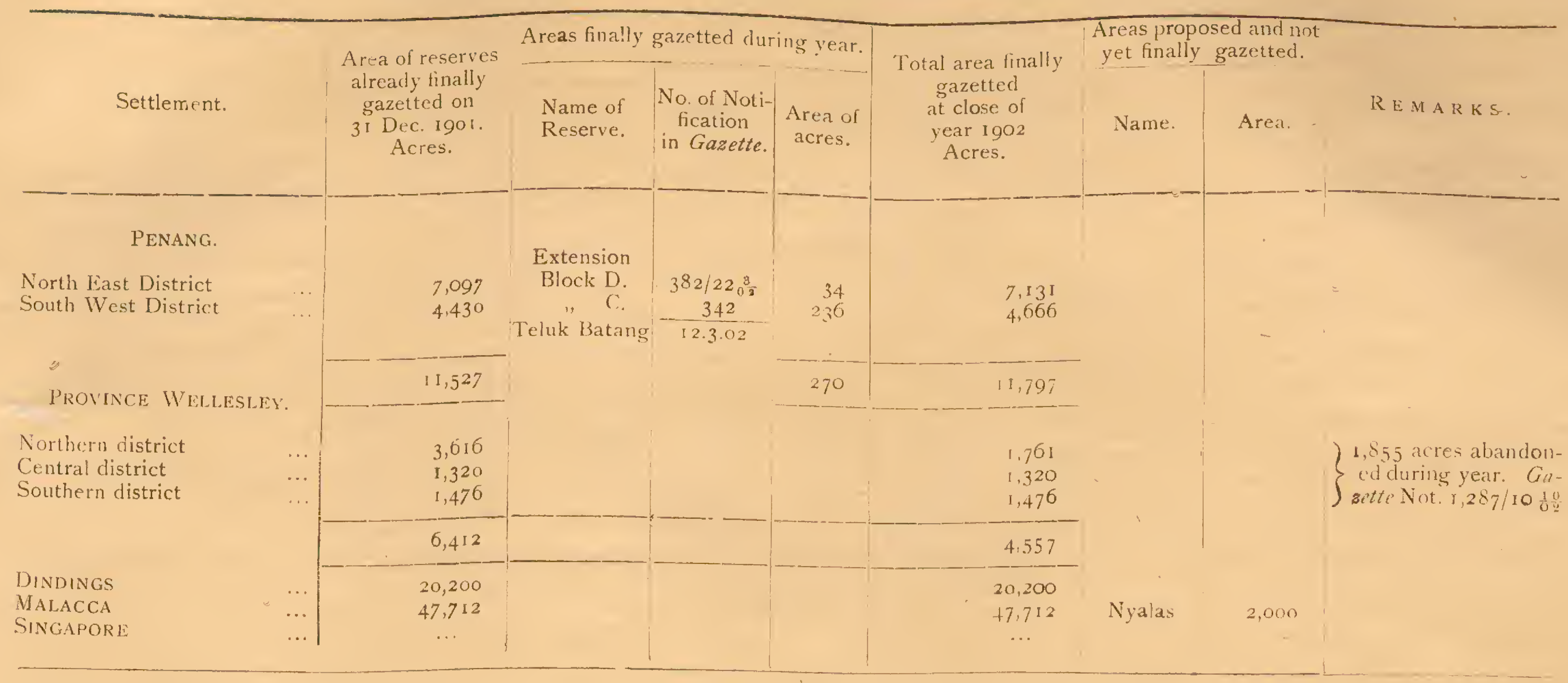


FORM No. 3

Ficord of Dewarcation and Maintenance of Boundaries for 190?,

\begin{tabular}{|c|c|c|c|c|c|c|c|c|c|c|c|}
\hline $\begin{array}{c}\text { Seitlement and name } \\
\text { of Forest. }\end{array}$ & & 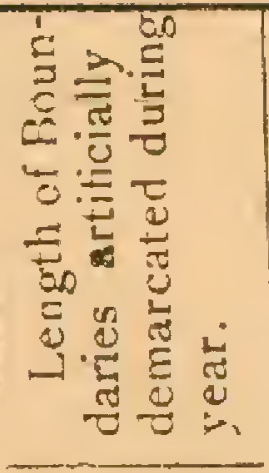 & 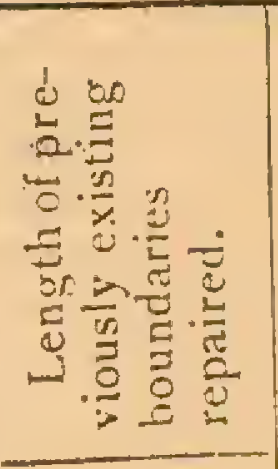 & 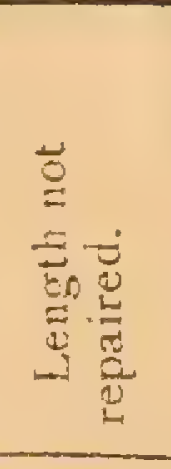 & 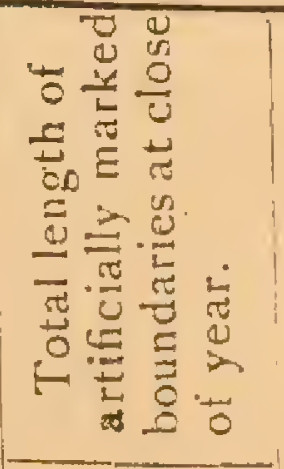 & 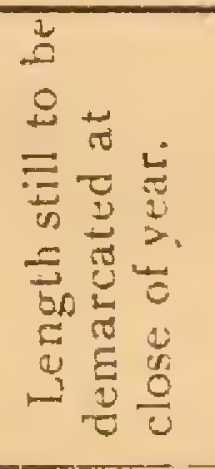 & 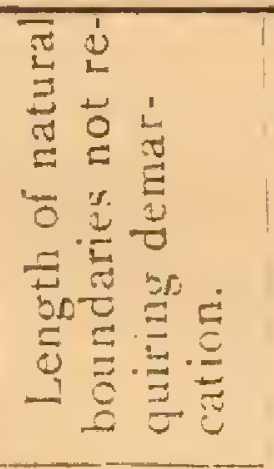 & 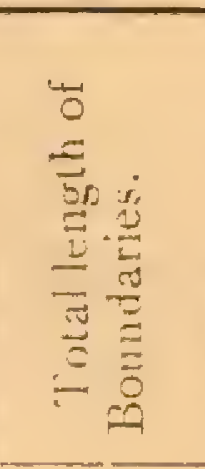 & $\begin{array}{l}\text { Exper } \\
\text { New } \\
\text { Work. }\end{array}$ & $\begin{array}{c}\text { diture. } \\
\text { Kepatirs. }\end{array}$ & Remarks. \\
\hline 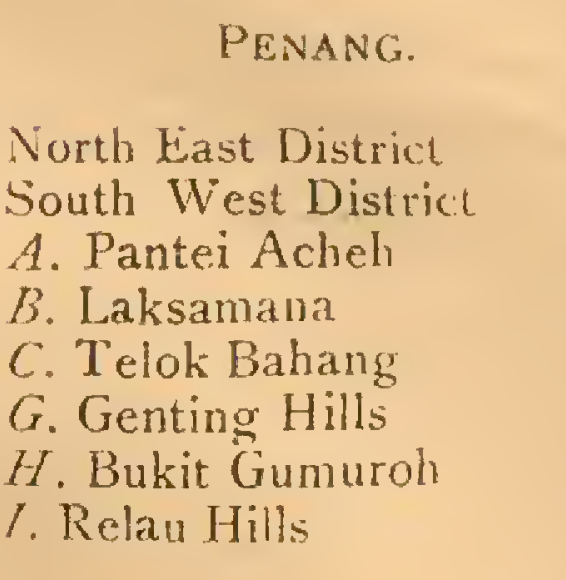 & \begin{tabular}{l|}
$\cdots$ \\
$\cdots$ \\
$\cdots$ \\
$\cdots$ \\
$\cdots$ \\
$\cdots$ \\
$\cdots$ \\
$\cdots$
\end{tabular} & $\begin{array}{c}\text { M. F } \\
\ldots \\
\ldots \\
\ldots \\
\ldots \\
2.7 \\
\ldots \\
\ldots \\
\ldots\end{array}$ & $\begin{array}{l}\text { M. F. } \\
\text { Nil. } \\
\ldots \\
9.4 \\
6.5 \\
5.0 \\
0.6 \\
5.2 \\
4.6\end{array}$ & Nil. & $\begin{array}{l}\text { M. F. } \\
37.4 . \\
\cdots \\
9.4 \\
6.5 \\
5.0 \\
0.6 \\
5.2 \\
4.6\end{array}$ & Nil. & $\begin{array}{c}\mathrm{M} . \mathrm{F} \\
8.3 \\
\ldots \\
5.4 \\
\ldots \\
\ldots \\
\ldots \\
\ldots \\
\ldots\end{array}$ & $\begin{array}{c}\text { M. I. } \\
45 \cdot 7 . \\
\cdots \\
15.0 . \\
6.5 \\
7.7 \\
0.6 \\
5.2 \\
4.6\end{array}$ & & & \\
\hline Total & & 2.7 & 35.7 & & $69 \cdot 3 \frac{1}{2}$ & & $13 \cdot 7 \frac{1}{3}$ & 86.2 & & & \\
\hline
\end{tabular}


FORM NO. 3 .

Record of Demaration and Maintenunce of Boundaries tor rooz.

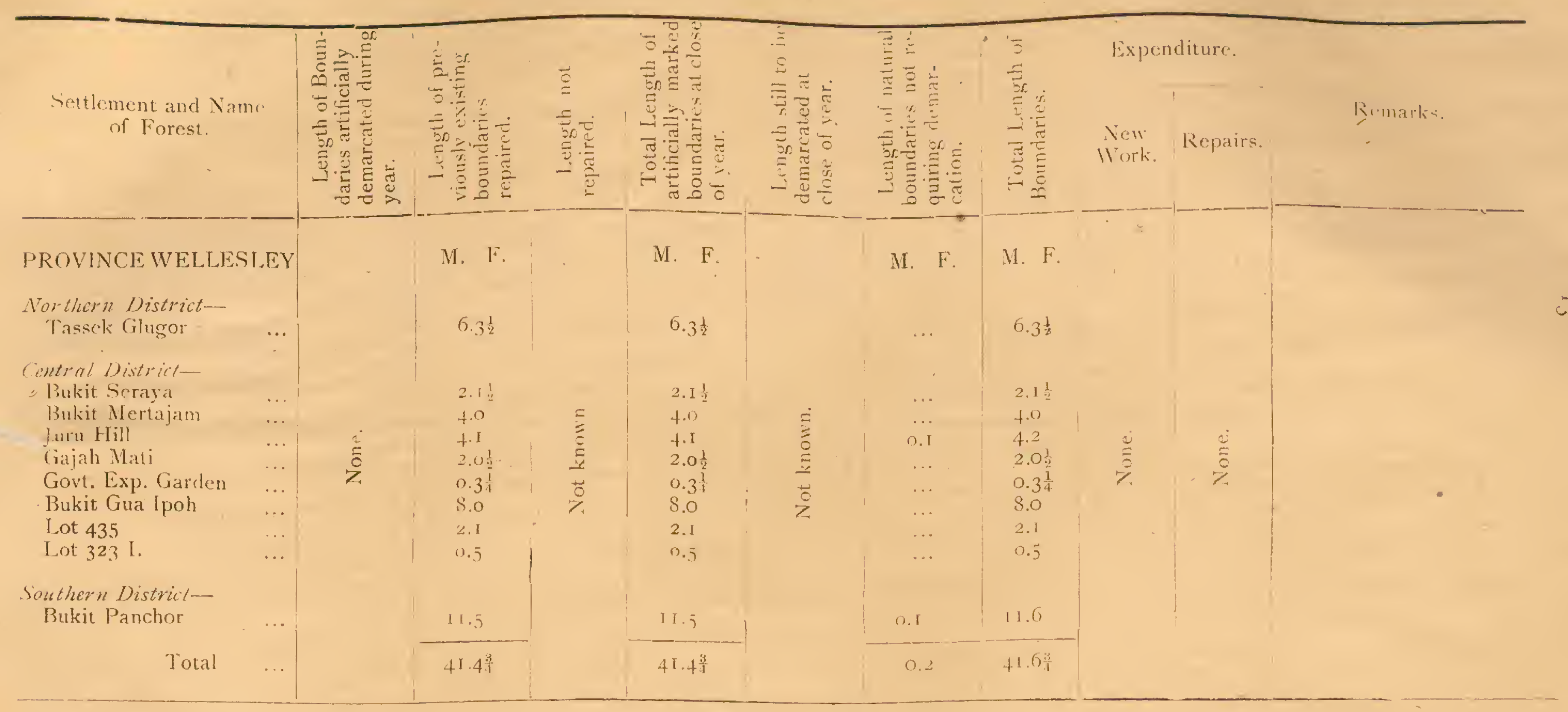


FORM NO. 3

Record of Demarcation and Maintenance of Boundaries for 1902.

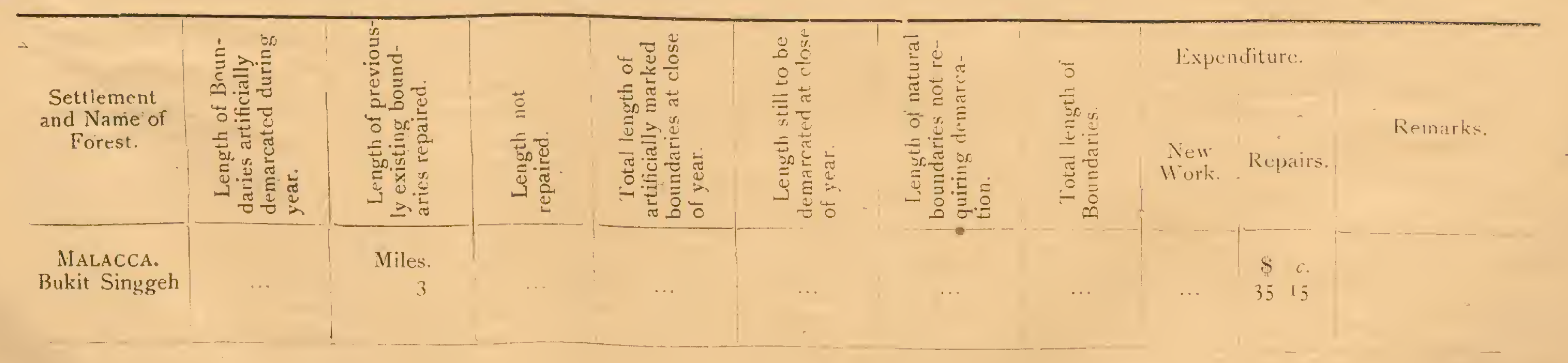


FORM NO. 4

Statement of Area Swrueyed and Unsurge red during the yerol 1902.

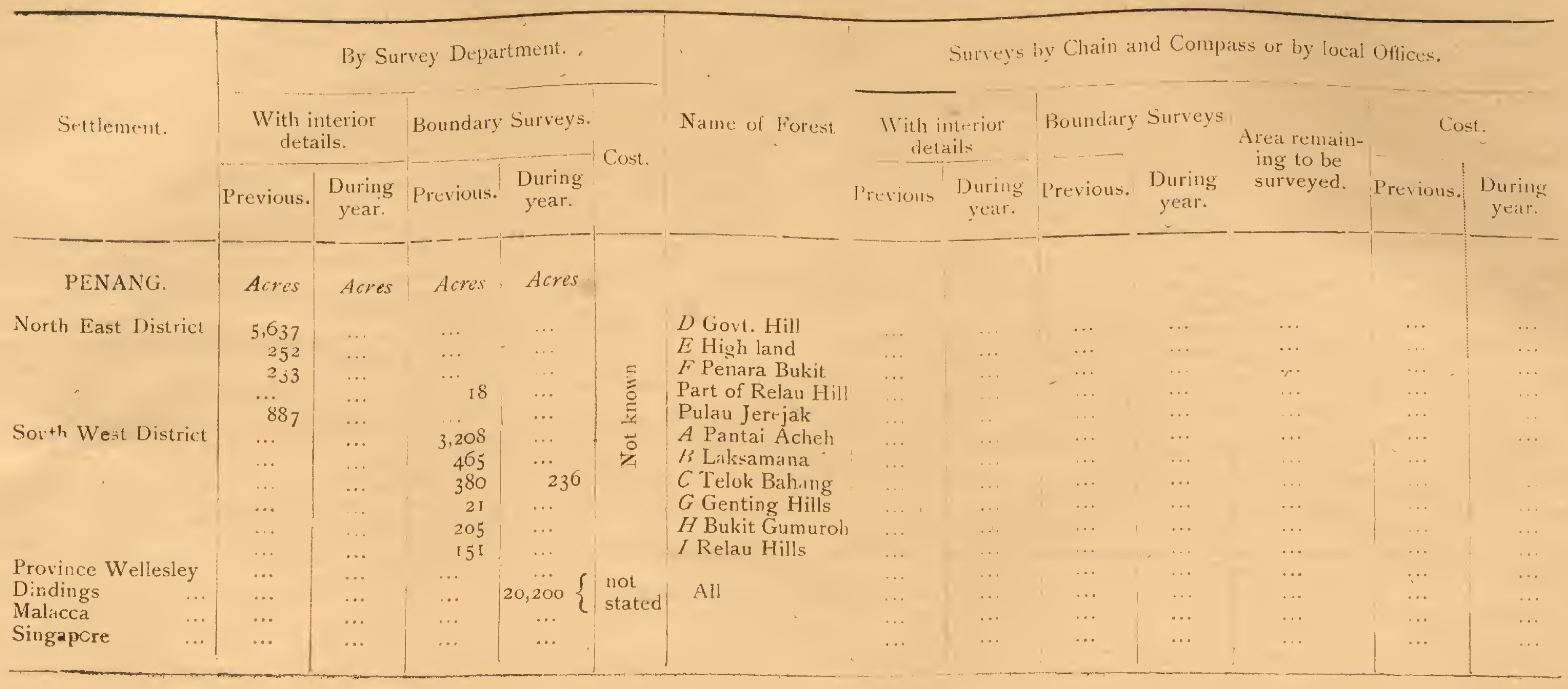


FORM No. 6.

Communications and Buildings 1902.

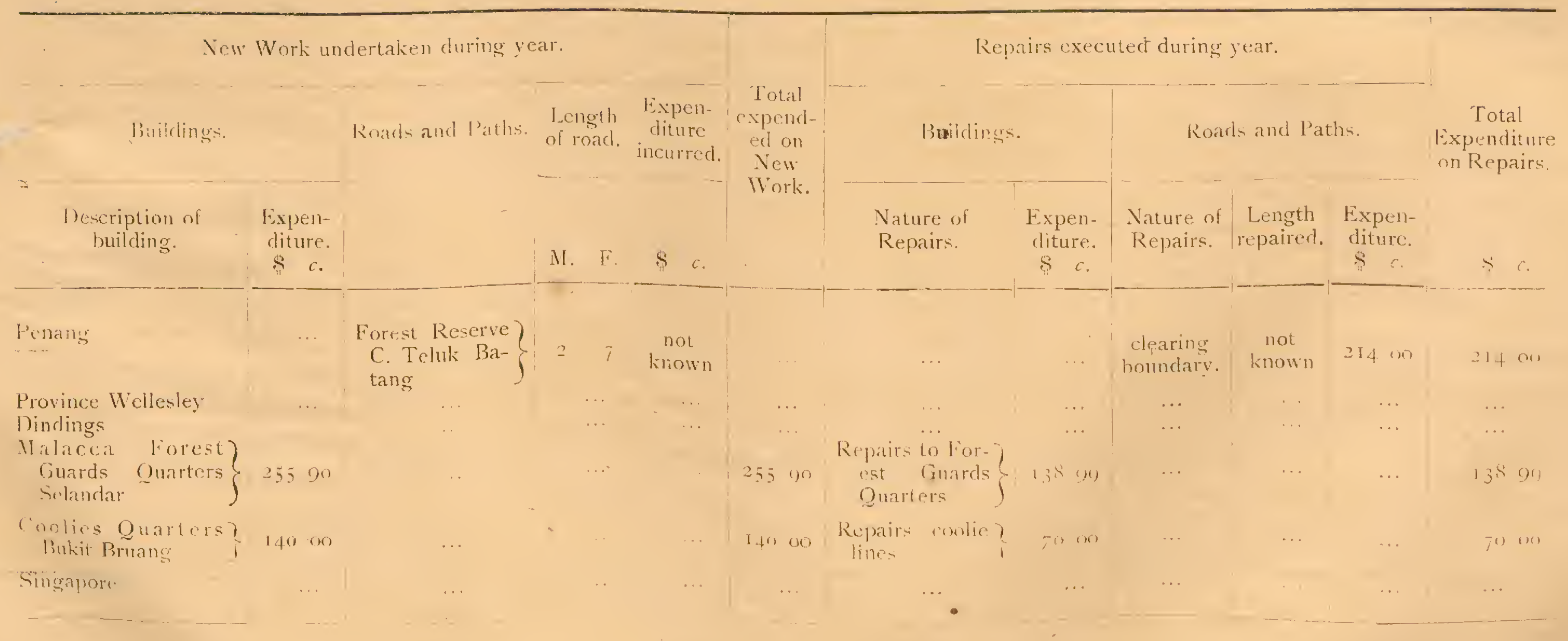


[FORM No. 7 .

Kegister of Breaches of Forest Risles for 1003.

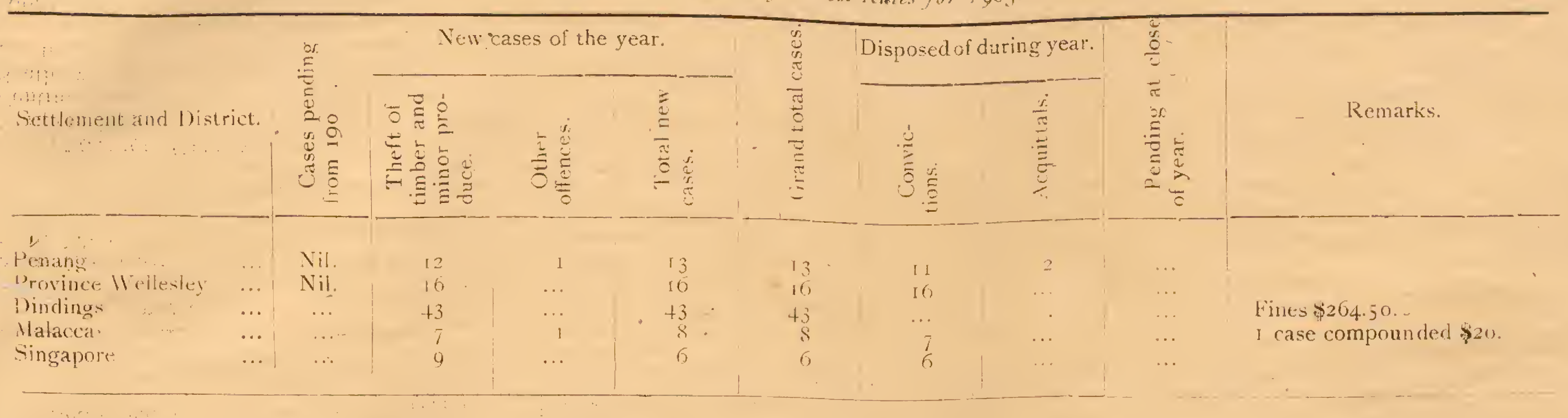


FORM No. 8.

Area of Plantations.

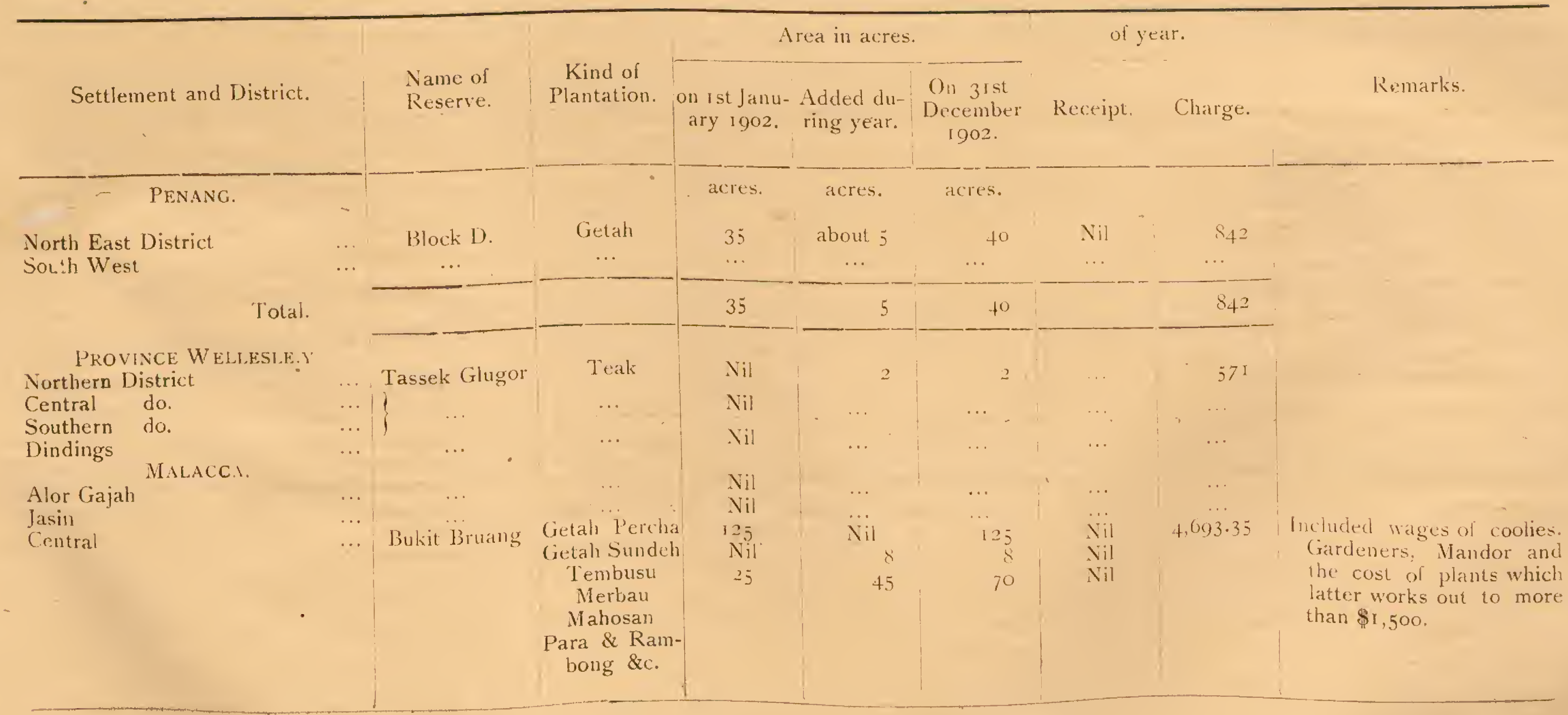


SINGAPORE.

FORM NO. I .

Summary of Revenue and Expenditure 1902.

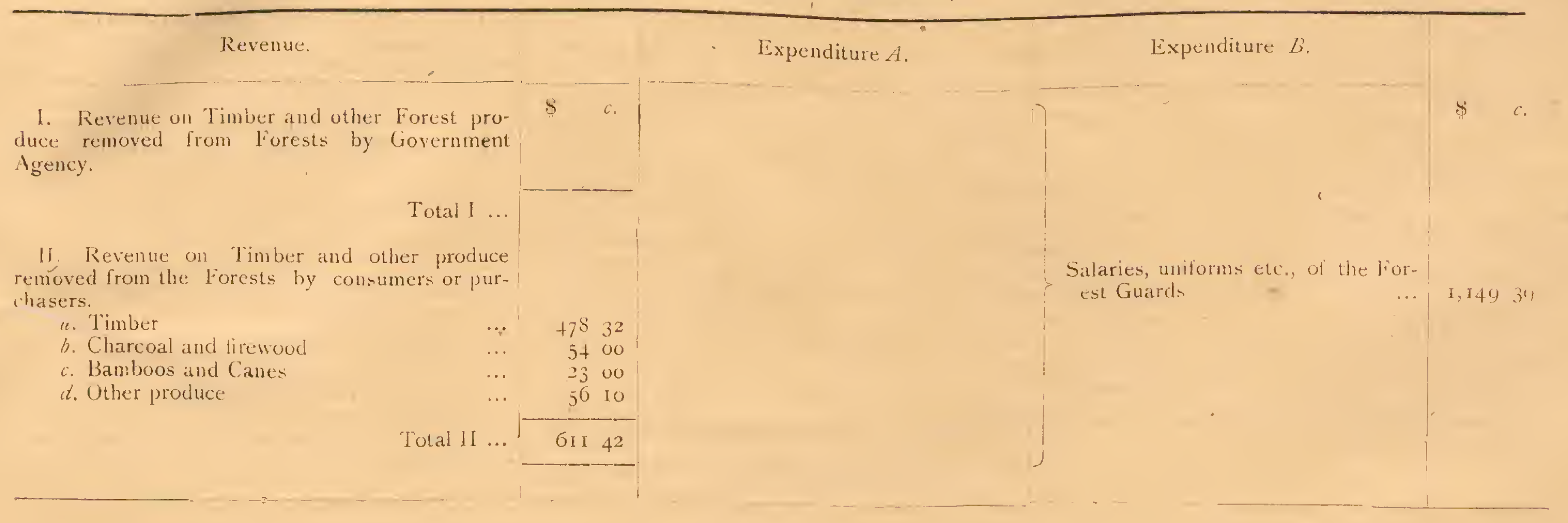


PENANG-NORTH EAST AND SOUTH WEST DISTRICTS

FORM NO: II.

Summary of Revenue and Expenditur' 1002

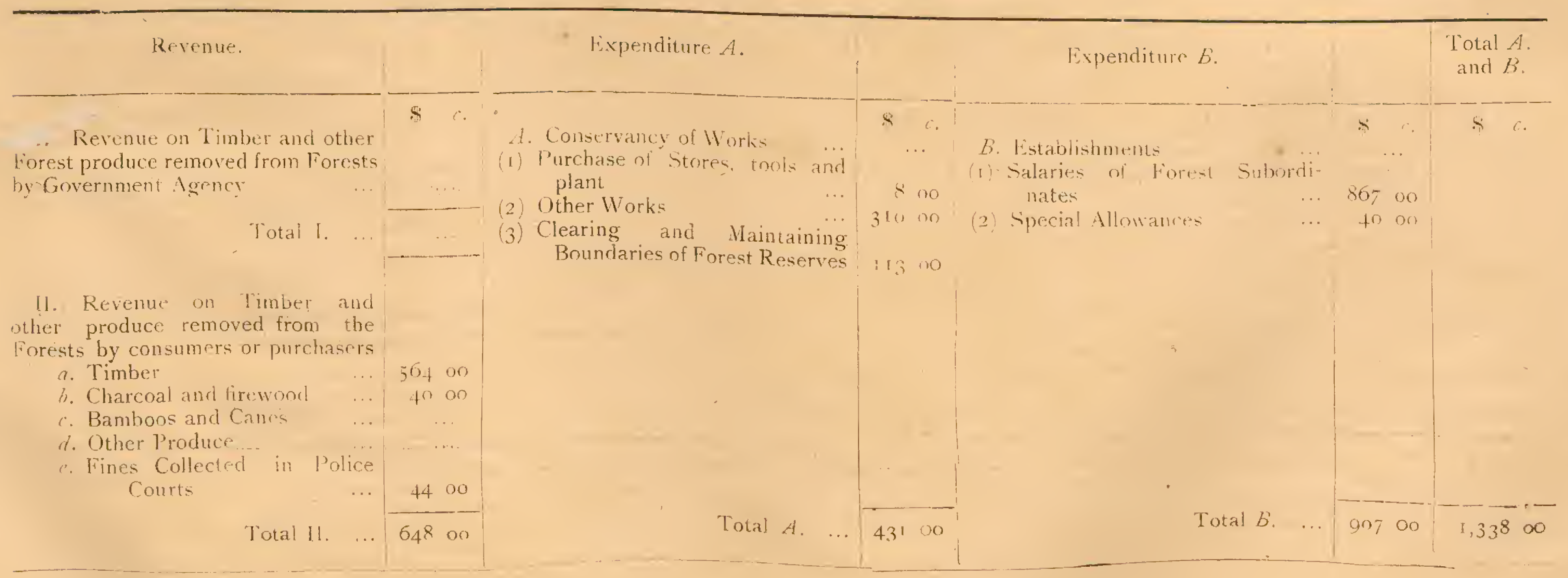


PROVINCE WELLESIEY.

FORM No. II

Summary of Revenue and Expethature 1002.

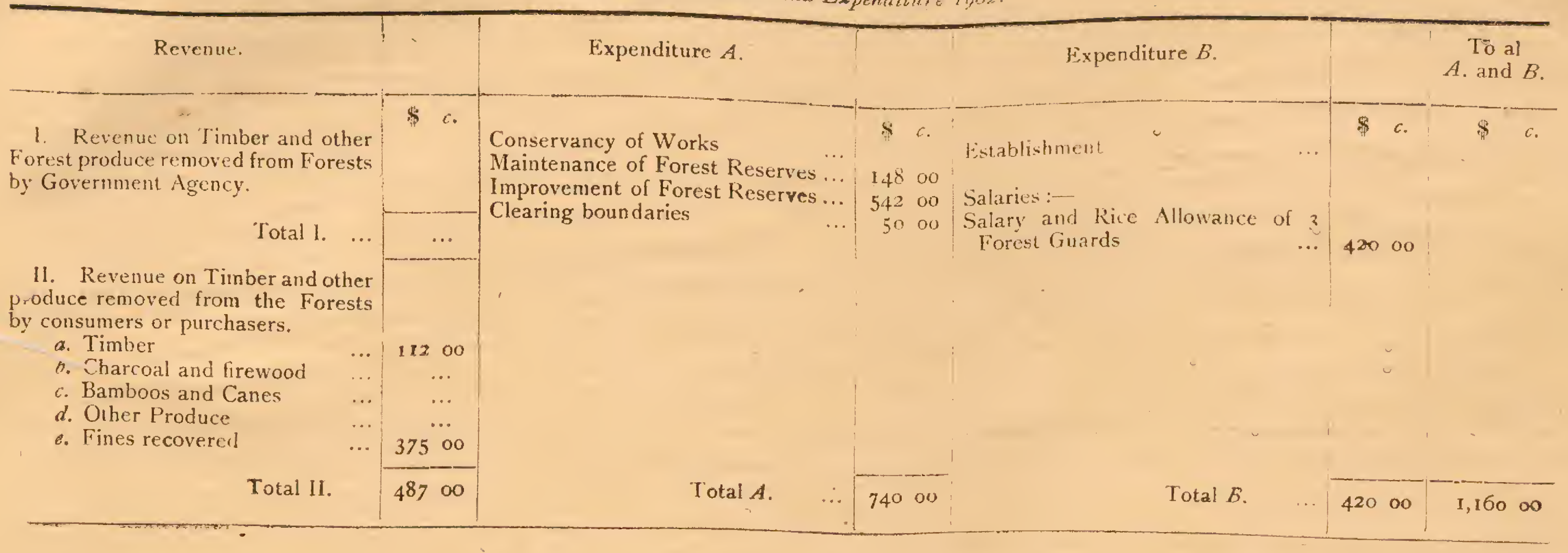




\section{DINDINGS}

FORM No. IT.

Summary of Revenue and Expenditure 1002.

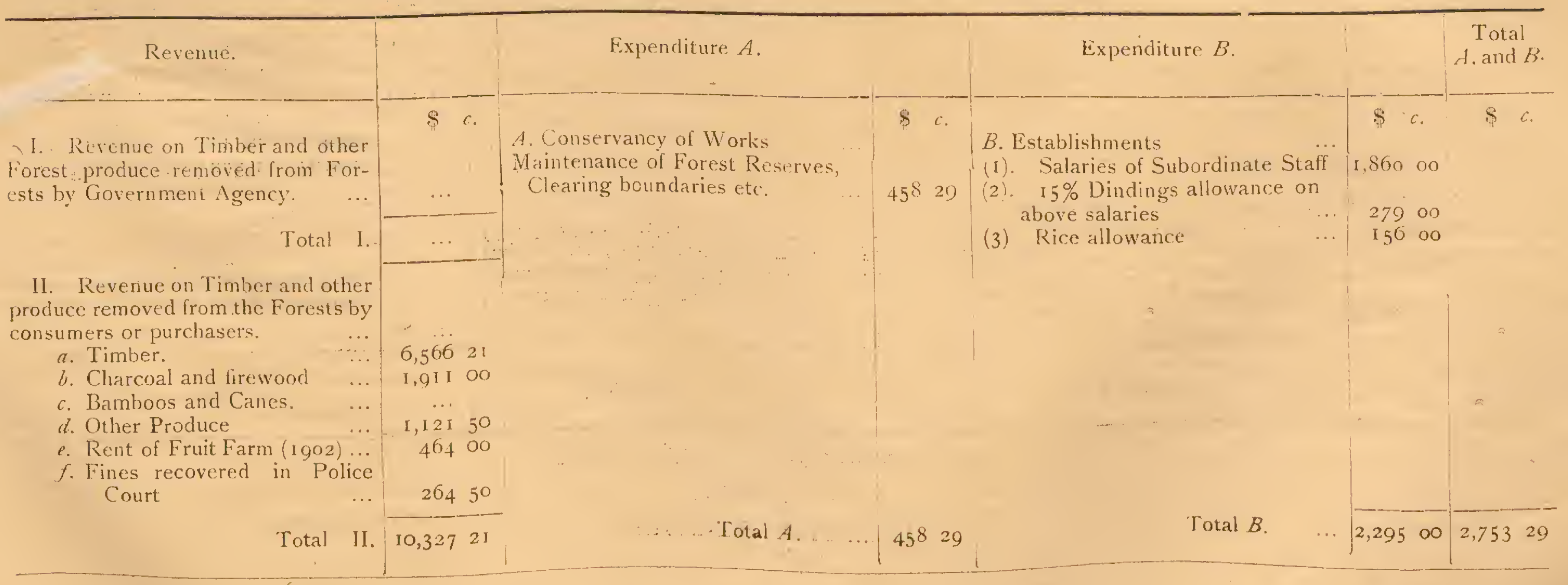




\section{MALACCA.}

FORM NO. II

Summary of Revenue and Expenditure 1902

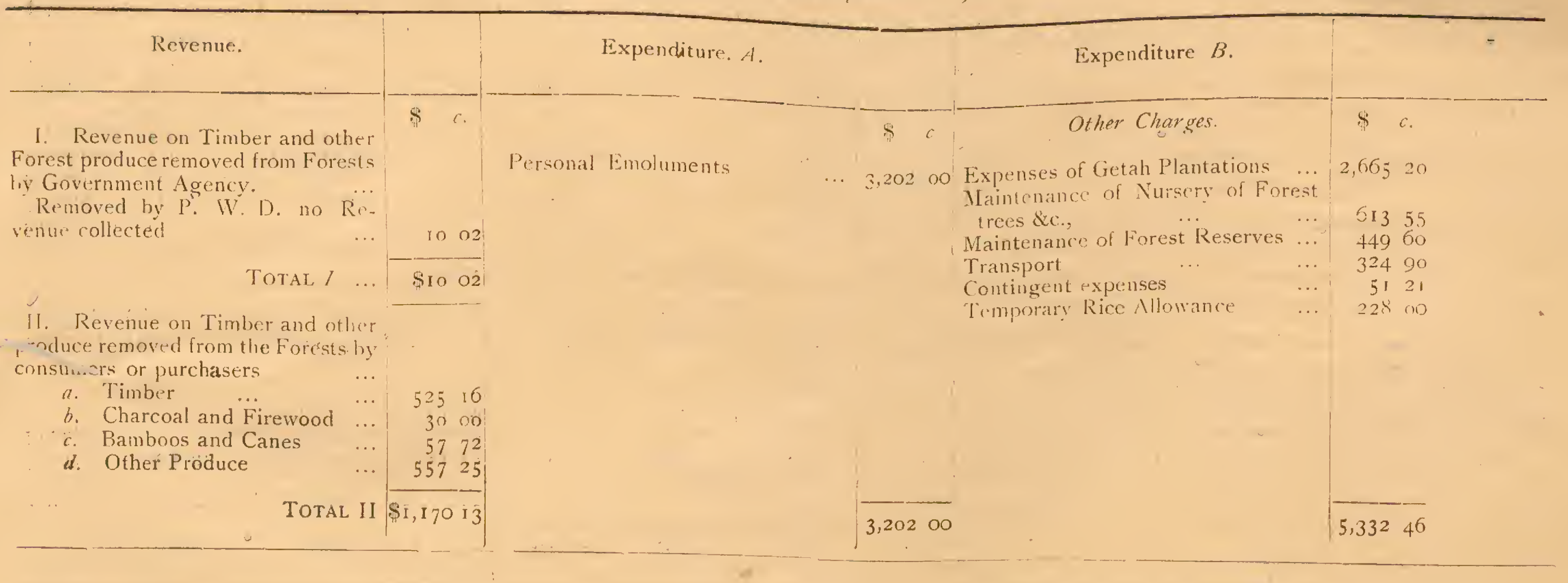


APPENDIX B.

Sterling Salaries for the Forest Department Straits Settlements.

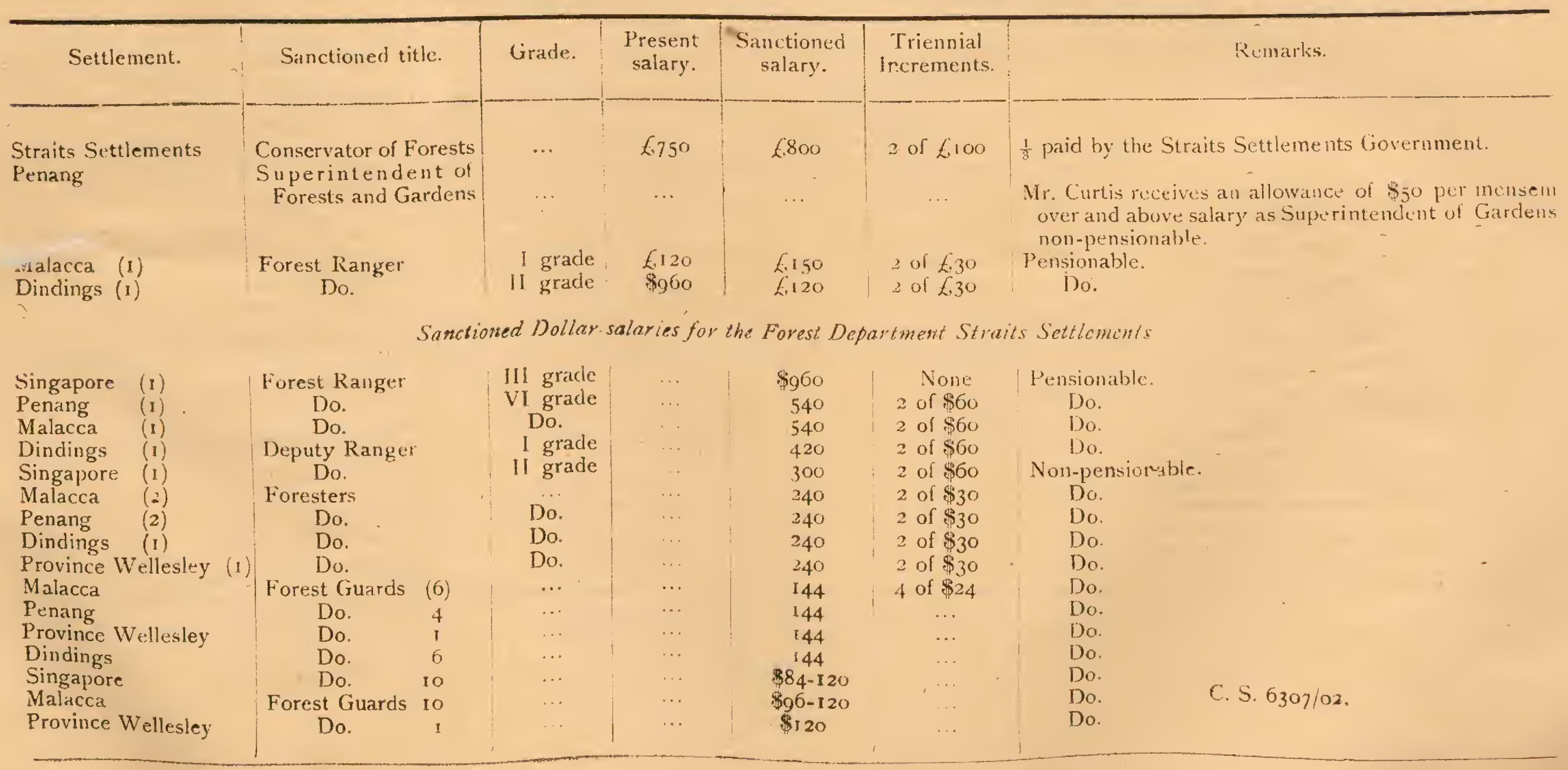


Paper to be laid before the Legislative Council by Command of $\mathrm{H}$ is Excellency the Governor

\section{Annual Report on Forest Administration in the Straits Settlements for the vear 1903.}

\section{CHAPIER I.}

\section{Extension and Constitution of Reserved Forests.}

\section{Alteration in Area.}

I. The areas are shewn in Form 1 of appendix to this Report. The area in Singapore remained unchingid!.

In Penang and Province. Wellesley no change occurred, the area reserved being sufficient.

In the Dindings about 1,200 acres of the 'Tanjong Burong Reserve were given up for Padi cultivation, the Mangrove Forest on the area being cut under licence in the ordinary way before cultivation takes place. To compensate for this a block of Mangrove Forest near Batu Undan was added, Teluk Senanyin Reserve is shewn for the first time in the report. The areas in Ulu Bruas, Lumut and Telok Muroh Reserves were supplied by the Survey Department and the alterations in area shewn in Form I are therefore merely due to correct survey, the areas shewn hitherto having been merely estimated, not to any actual alteration in area.

In Malacca an areat of 494 acres was excluded from the Bukit Panchor Reserve and alienated for Tapioca cultivation.

The total area of reserved forest in the Colony is 94,558 acres.

2. This table shews the proportion of Reserves to total area in each Colony, the average being in.it per cent, practically the same as in 1902 .

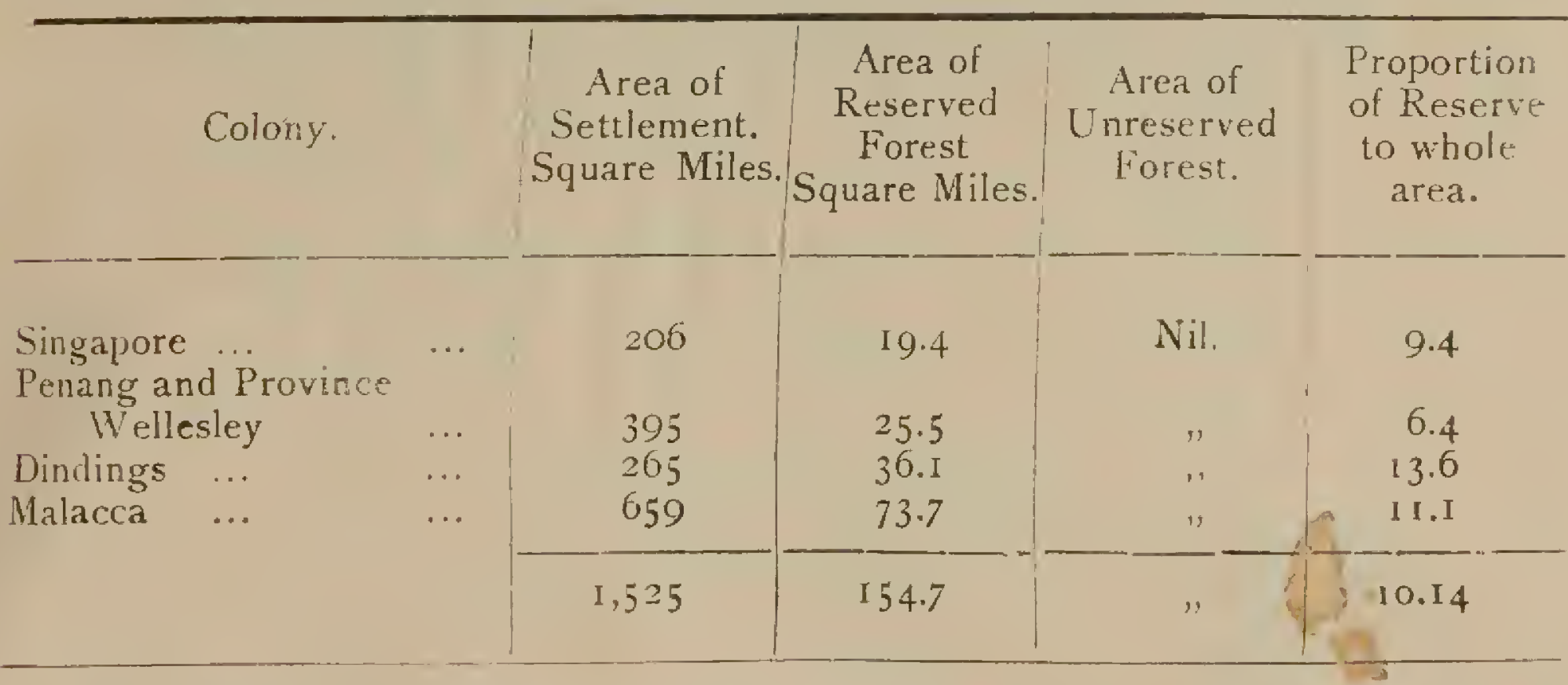

By reserves however is meant simply areas which are set aside and demarcated for forest conservation, as these areas have never been legally notified as reserves under any Ordinance as has been the case in all other countries where forest management receives attention.

\section{Reserve Proposals.}

3. In Malacca an area of 2,468 acres near Nyalas was proposed as a reserve and demarcated, this work in the Colony may now be said to be complete as no further available areas are to be found and the percentage of reserved forests is sufficient.

\section{Demarcation and Repairs tó Boundaries.}

4. In the Dindings the boundaries were all kept clear by men on daily labour wages, the cost howerer is not stated. The Batu Undan Reserve extension boundaries were not completed. 
In Penang 65 miles of boundary lines were kept clear at a cost of $\$ 300$ and in Province Welleslev 22 miles for $\$ 150$ about $\$ 5$ ror mile. In Malacca 98.5 miles of boundary were kept clear by Forest Guards and 8 miles new boundary cleared by contract at a cost of \$200. Particulars are shewn in Form 3. 477 Notice Boards bearing the words "Forest Reserve" in English and Malay were placed round the boundaries in Penang at about $\frac{1}{4}$ mile apart and Ioo in the Province Wellesley.

\section{Surveys.}

5. In the Dindings, Ulu Bruas, Lumut and Telok Muroh Reserves were surveyed and tracings supplied, other areas were also taken in hand but iot completed.

in Malacca the Nyalas Reserve was survered, an area of 2,468 acres, by the Survey Department, and a boundary survey of Merlimau and Ayer Panas Reserves was made by Mr. GaGirardi, the Forest Ranger. See Form $t$.

\section{CHAPTER II.}

\section{Management of State Forests.}

\section{Working Plans.}

6. A Rough Working Plan for 32,77 I acres in Malacca was drawn up by the Forest Ranger and in now under consideration of the Conservator of Forests. It provides for division of this working circle into 60 compartments each with an average area of 550 acres, the plan being to cut out all marketable trees of 7 feet in girth and over, in 2 coupes each year, thus going over the whole area in 30 years, isolated trees howerer being left as seed bearers. It is not yet possible to give a reliable forecast of the amount of timber which the area will yield annually, but in compartment No. I Ayer Panas block 550 acres in area 546 trees have been marked for fellno and in compartment No. 1 in Merlimau of the same area 1,417 trees, of all kinds. Taking the average yield as 2 trees per acre we should get about 4,000 tons of timber per annum at a very low estimate. As however rate of growth of the species concerned is not known the prescription for fellings will be for the first 30 years kept at a very low figure, so as to be sure that the capital of the forest is not being encroached upon.

7. The necessity for a certain amount of felling however is obvious for the reason that there are many over mature trees in the forests which are deteriorating and which will in time lose all value.

In Penang and Province Wellesley and Singapore the forests are not yet ready for exploitation.

In the Dindings the necessity for exploitating the Reserves has not yet arisen, there being a sufficiency of timber elsewhere, but certain reserves are annually exploited as regards Canes and Jungle Produce.

\section{Paths and Buildings.}

8. In Province Wellesley a Forest Station and Forest Guards' Quarters were erected for $\$ 500$ at 'Tasek Glugor.

In the Dindings See Form 6.

\section{Protection of Porests and Forest Offences.}

9. Forest Law.-No Forest Ordinance has yet been passed in the Colony, and the laws are very inadequate. Proposals for new Forest Rules in the Dindings were sent up by the Conservator of Forests and have since come into force.

10. In Singapore there were 2 cases both resulting in convictions.

In Penang there were 13 cases of prosecution for illicit timber cutting with 6 convictions and 7 acquittals, and fines to the amount of \$195 recovered.

In Province Wellesley only 4 cases were taken to Court resulting in 3 convictions and I acquittal.

In the Dindings there were 69 cases, mostly of cutting timber or frewood without a pass.

There were 168 accused, 92 of whom were Chinese and I 6 Malays.

Seventy-two Chinamen and I 4 Malays were convicted and $\$ 726.40$ realised in fines.

In Malacca there was an increase in the number of cases, there being I 9 convictions out of 25 cases. 
11. In Province Wellesley about 3 miles of the boundary of Tasek Glusor Reserve was fire traced. A cleared line has been cut and evergreen bamboo planted along one side of it for part of the distance. This is necessary owing to frequent "Lalang" fires.

\section{Improvement of Forest Growth.}

\section{(i) Natural Reproduction.}

12. In the Dindings, Mr. BoRGEs, Forest Ranger, who was trained at Dehra Dun Forest School, has mate many ureful inspections and observations on the forest. He reports that there are very few hard wood trees in the pole stage but plenty seedlings and small saplings. Natural regeneration is reported as good. The reserves contain a good deal of Ebony (MTaba Buxifolia). "As regards Mangrove it has been found that there is more mature forest than was hitherto supposed, wherever extraction is at all difficult. Near the mouths of streams and creeks over felling has always occurred.

13. In Malacca the Forest Ranger, Mr. Gagliardi, reports that the natural reproduction of the following species was good. Tembusu (Fragroa fragrans), Tampinis (Shetia Sidrowlun), Mermbli (Hopea and Shorea of various species). No Getah Taban (Palajuinm) trees were observed in flower or in fruit. There are 22.5 Tahan trees in the Jasin district and 505 in Alor Gajah.

\section{(ii) Artificial Reproduction and Cultural Operations.}

14. See Form 8 .

In Penang. The area of the Getah Taban plantation at Batu Feringgi which stood at 40 acres at the beginning of the year, was further increased by about 10 acres. 1,095 Taban tres were planted, a few of which were used as supplies where racancies had occuried. The plants have grown well, the tallest of those originally planted in I 889 and 1890 being breast high. The Kickxia and Rambongs have not done so well, the ground eviclently being too dry for them. The same remark applies to the few Para Rubber which were planted as shade for the Getahs.

$$
\text { Description of trees planted in } 1903 \text {. }
$$

\begin{tabular}{cc|c} 
& & No: of trees. \\
Palaquim Getah seedlings. & 878 \\
", & stumps. & -17 \\
& & $\mathrm{I}, 095$ \\
\hline
\end{tabular}

A further io acres of jungle has been opened up and partly holded in anticipation of planting during 1904 .

15. Teak. - The experiment of growing Teak in the Province at Tasek Glugor is only moderately successful. The two acres planted in 1902 have been weeded on 2 occasions. About half the number planted died, and were replaced. A curious feature 0 ? the plantation is the irregularity of growth shown; in some cases the young rlants are five feet in height which leaves as big as Rhubarb-whilst growing next to them under apparently the same conditions are plants only a few inches high. It is very doubtful if it will ever pay to plant Teak through lalang grass. This plantation was visited by the Conservator of Forests during the year.

I6. In Malacca no addition was made to the area of Gutta Percha (Palaquium) plantations, which remain at I 25 acres, and 8 acres of Getah Sundik (Payena Laerii). This is not a regular plantation. The young plants are put out in the forest under shade, the undergrowth being cleared. Blanks were filled in during the year from the nurseries.

Plants purchased during the year 2,492; total number received from ist April, I9o I, to 3 ist December, $1903,60,000$. Number now alive in the forest is only about 7,000 , and 2,400 in the nurseries. This is not satisfactory, and I am satisfied that the fault lies in the fact that the plants are many of them half dead on arrival. See remarks of Consesvator of Forests in the Amnual Report for IÇOI, page 4 , in which he does not recommend the purchase of any nore transports should be purchased from other countries, and that if possible seed should be obtained. It is possible that the locality is not suitable to 1 aban. The whole area was cleared of undergrowth to give more room to the Taban. 
17. In Singapore. The plantation of Gutta Percha, about 30 acres was upkept during the year.

\section{(iii) Experiments.}

18. Experiment.-Mr. CURTIS' system of Marcotting with the help of bamboo pots and also with coconut fibre instead of the bamboos was tried. The first experiment was successful in the case of tour plants but the latter up to date have not thrown out any roots although they look promising. The pldnting of Tembusu, \&c. was done in "Lalang" with very good results. A few of the Para Rubber trees were tapped at "Bukit Sebukor" and the price realised was for the clean rubber $4 s \cdot 5 d \cdot / 3 s \cdot 7 d$.

\section{Exploítation.}

I9, One thousand and fifty-five $(1,055)$ Licences were issued in Penang and the Drovince during the year to cut timber firewood, Kassows and Bertams bringing in a revenue of $\$ 846.55$. In every case these were cut outside the Forest Reserves. Most of the poles cut classed as timber, were used for fishing stakes-a number of the larger sizes however being used for the construction of houses. Form $V$ shews the classification. The licences were issued by the Collector of Land Revenue and the District Ufficers but the work of supervising and checking the cutting was carried out by the Forest Staff.

20. In the Dindings felling fees amounted to $\$ 1,983$, and sawyers fees to $\$ 1,949$, this gives 66 I cutters and 649 sawyers, an average per month of $\$ 55$.

$\$ 3,135.80$ was paid on timber as royalty, but no relurns a re available for tonnage extracted. Under the new system since introduced such returns will be available for I g04. The estimated amount of timber cut is however 2,000 tons.

2r. Bakau (Mangrove) realised $\$ 9,486.30$, an enormous increase on former years, the chief reason being an influx of Chinese cutters who came to the Dindings from Perak owing to restrictions in cutting at Matang, also because the fee for cutting was smaller. This was remedied on October Ist, 1903, the fee being raised to $\$ 5$ per man per mensem, and the number of cutters reduced. Of this amount $\$ r, 969$ was realised Jy the Mangrove felled in Tanjong Burong Reserve (see para. I) \$1 26 was collected on charcoal, and $\$ 369$ for kongsi licences, the charge being $\$ 1$ per mensem for each kongsi as rent for temporary occupation of Crown land.

22. Rotans realised $\$ 408$ and miscellaneous Forest produce $\$ 5$ I 4 .

23. In Malacca passes were issued to cut and remove timber and royalty charged according to diameter, a very faulty system. \$I,5or were realised on timber \$6I7.2 I on firewood and charcoal, $\$ 294.88$ on Bamboos and Canes, 76.20 on India Rubber, and $\$ 942.24$ on other Forest Produce. See Form 10.

24. In Singapore, timber realised $\$ 532.50$, firewood and charcoal $\$ 888$, bamboos and canes $\$ 13.50$ and the produce $\$ 53.90$.

\section{Financial Results}

See Form I I for particulars.

\begin{tabular}{|c|c|c|c|c|c|}
\hline Settlement. & $\begin{array}{c}\text { Revenue. } \\
\text { I } 902 .\end{array}$ & $\begin{array}{l}\text { Revenue } \\
1903 .\end{array}$ & $\begin{array}{c}\text { Expenditure. } \\
\text { I } 903 .\end{array}$ & Surplus. & Deficit. \\
\hline $\begin{array}{ll}\text { Singapore } & \ldots \\
\text { Penang and } & \\
\text { Province Wellesley } \\
\text { Dindings } \\
\text { Malacca } & \ldots\end{array}$ & $\begin{array}{r}\mathrm{I}, \mathrm{I} 35 \\
10,327 \\
\mathrm{I}, \mathrm{I} 70\end{array}$ & $\begin{array}{rl}\$ & c \\
\mathrm{I}, 487 & 90 \\
& \\
\mathrm{I}, 060 & 55 \\
20,759 & 55 \\
3,659 & \mathrm{I} 7\end{array}$ & $\begin{array}{cc}8 & c . \\
5,09+ & 48 \\
3,04+ & 36 \\
3,795 & 46 \\
7,470 & 79\end{array}$ & $\begin{array}{c}\$ \quad c \\
\ldots \\
\ldots \\
\begin{array}{c}\ldots, 964 \\
\ldots\end{array}\end{array}$ & 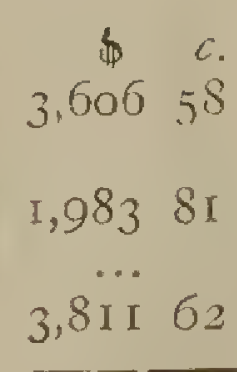 \\
\hline " & I 3,243 & 26,967 I 7 & 19,405 O9 & $7,562 \quad 08$ & \\
\hline
\end{tabular}

25. The Revenue for Dindings however includes $\$ 2,062$ revenue derived from fruit farms, etc., while I do not think should be included in forest revenue. In I902 the total deficit for the Colony was $\$ 1,791$ while in 1903 there is a profit of $\$ 7,562.08$, due to the Dindings revenue. Both Singapore and Malacca however have shewn an 
increase, the former temporary, the latter permanent and likely to increase. Malacca expenditure has dropped from $\$ 8,534$ in 1902 to $\$ 7,470$ and yet more useful work has been done than for some years past. This is partly due to saving on salary of the Superintendent of Forests who was transferred to the Federated Malay States Government in I902, February.

The above figures include $\frac{1}{3}$ rd share of the salary of Conservator of Forests $\$ 2,870.61$ and $\frac{1}{3}$ rd of Pension Contribution $\$ 855.99$.

The latter charge will not be continued in 1904 owing to the fact that the Conservator of Forests has permanently joined the servire of the Colony and Federated Malay States.

\section{Establishment.}

26. In Singapore the forest work was undertaken by the Collector of Land Revenue with the assistance of a Deputy Ranger. The appointment of Ranger III Grade at \$960 not yet having been filled owing to the want of a suitable candidate.

27. In Penang the work of the Forest Department was taken over by Mr. CURTIS, Superintendent of Gardens, who received an allowance for the extra work entailed. Mr. CuRTis unfortunately fell ill in February and was obliged to retire from the service which is a great misfortine for Government. Mr. Fox replaced him soon afterwards.

28. Mr. BORGes was appointed as Forest Ranger II Grade on July 29 th in the Dindings and has shewn himself a useful and energetic officer, taking an interest in his forests. The District Officer, Dindings, is practically in charge of the forests and has done much to further the efficiency and utility of the Department during the year. Mr. ABrams was appointed as Deputy Ranger VI Grade, Penang, and also a VI Grade Clerk. The Deputy Ranger, Penang, Mr. Renganathen was convicted of extortion and dismissed the service. Four boatmen were added to the staff for patrol duty.

29. In Malacca the forests were managed by Mr. GAGLIARDI under the Honourable Resident Councillor, the licence work of the Department being done by the Collector of Land Revenue and the District Officers. Mr. GaGLiardid good work in surveying and examining Forest Reserves, and submitted valuable countings of tree which are the first of the kind made so far, and are to be found in Appendix $B$ to this report.

The subordinate staff are reported to have worked well.

30. The title of Conservator of Forests was adopted for the Chief Forest Officer on ist January, I903, as being usual wording in other parts of the world. Mr. A. M. BURN-MURDOCH held the appointment throughout the year: still on deputation from the Indian Forest Service. He visited each Settlement during the year, spending 42 days on tour in the Colony besides a certain portion of his time in work in office on Colonial matters.

His risits to the Colony were as follows:-

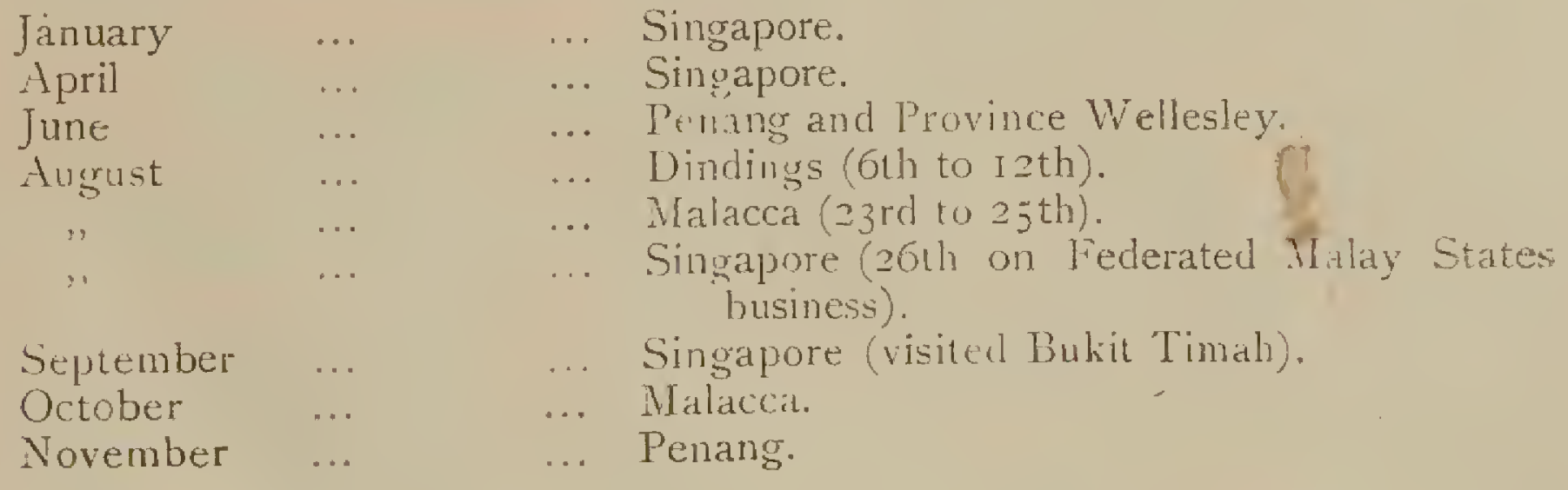

\section{A. M. BURN-MURDOCH, \\ Conservator of Forests,}

Federated Malay States \& Straits Settlements. 
APPENDIX $A$.

Dimension at Breast height.

Enumeration Survey of 55 acres of 5 acres each in the Ayer Panas Reserve. Nos. I to 9.

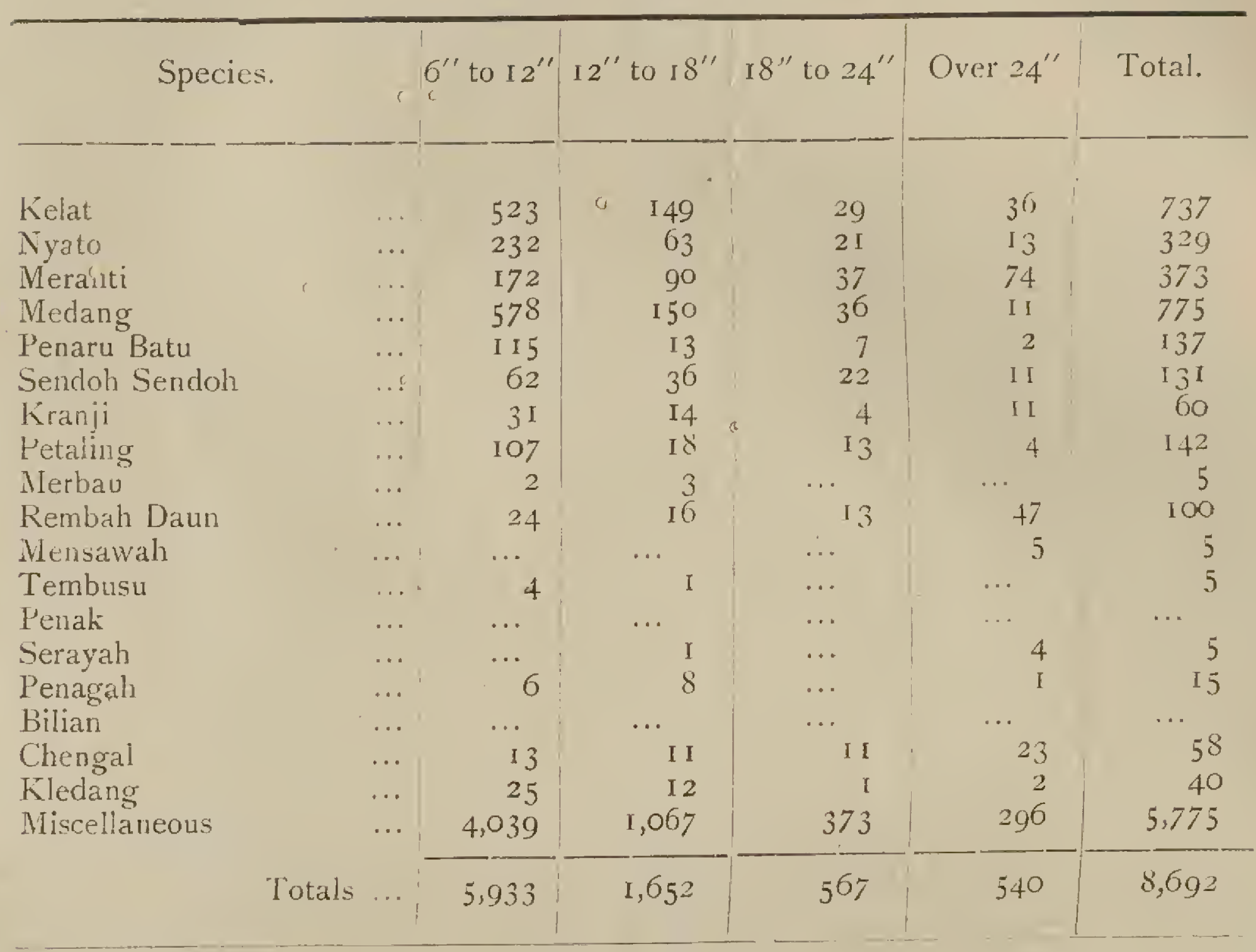

APPENDIX $B$.

Valuations Surveys, Merlimau 4-IO acres Coupes.

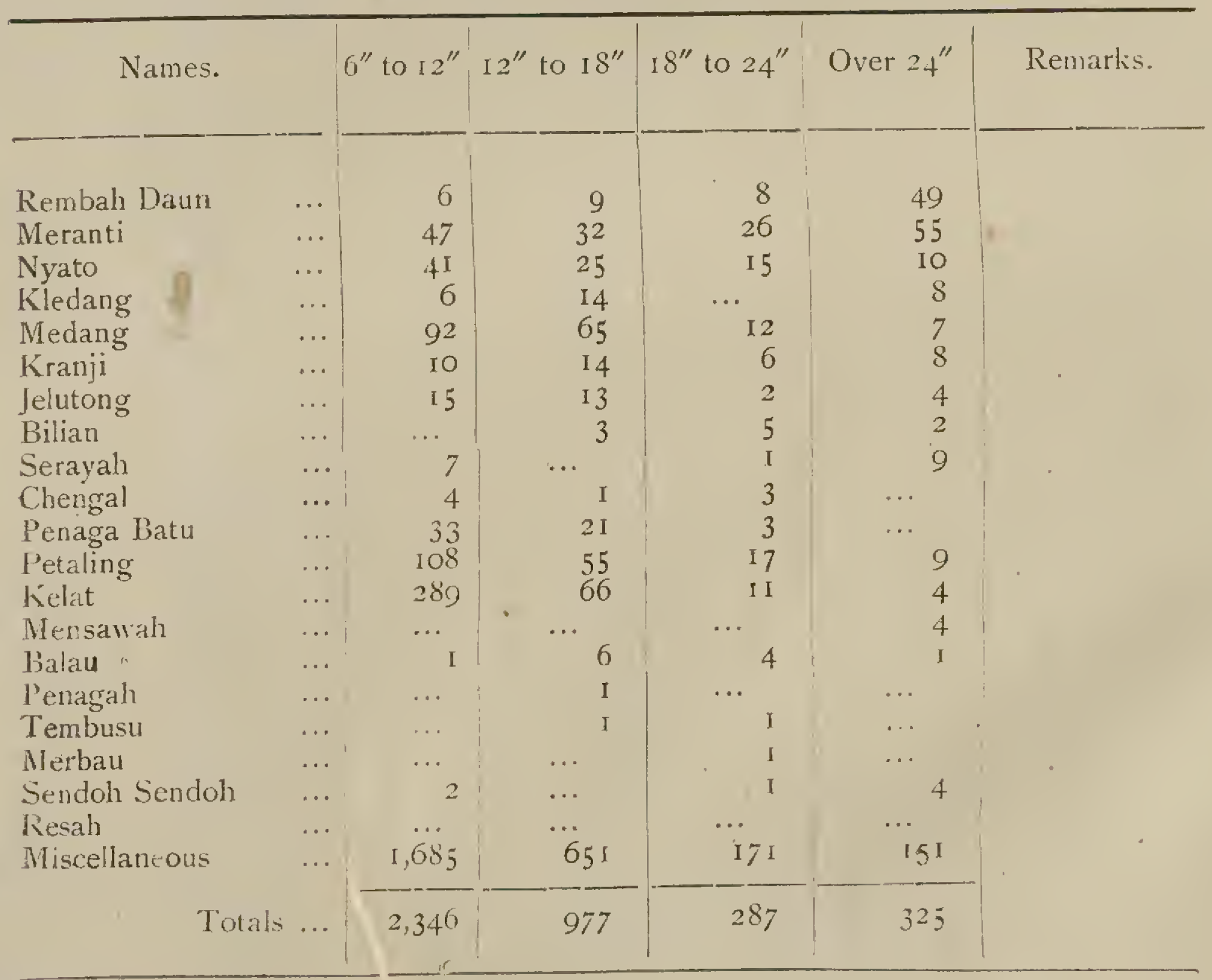


FORM NO, I,

\begin{tabular}{|c|c|c|c|c|c|c|c|c|c|}
\hline Settlement. & 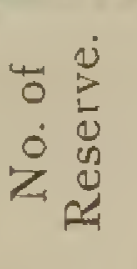 & 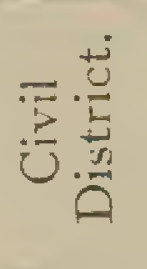 & Name of Forest. & $\begin{array}{l}\text { Area in Acres } \\
\text { on I-I-1903. }\end{array}$ & $\begin{array}{l}\text { Area added } \\
\text { during year. }\end{array}$ & $\begin{array}{l}\text { Excluded or } \\
\text { Dis-affor- } \\
\text { ested. }\end{array}$ & $\begin{array}{l}\text { Area on } 31- \\
\text { 12-1903. }\end{array}$ & $\left|\begin{array}{c}\text { No. \& date of } \\
\text { Notification } \\
\text { excluding } \\
\text { land. }\end{array}\right|$ & Remarks. \\
\hline Singapore & $\begin{array}{r}1 \\
2 \\
3 \\
4 \\
5 \\
6 \\
\\
7 \\
8 \\
9 \\
10 \\
11 \\
12 \\
13 \\
14 \\
15 \\
16 \\
17 \\
18 \\
19 \\
20\end{array}$ & & 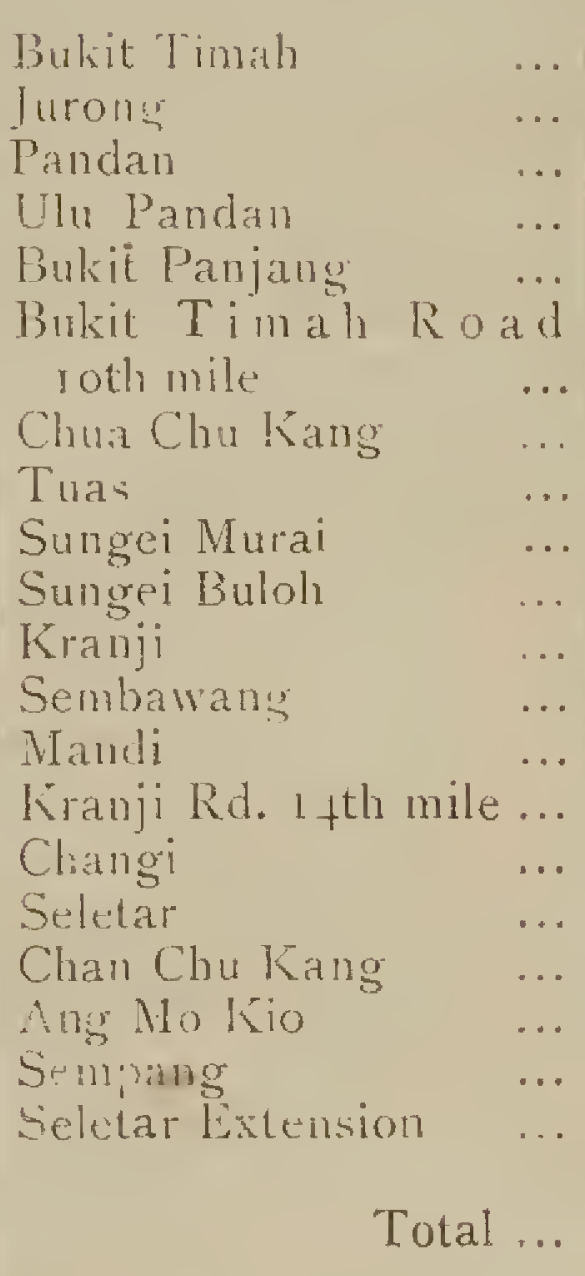 & $\begin{array}{r}847.0 .00 \\
412.0 .00 \\
2,140.3 .16 \\
4.3 .09 \\
117.2 .16 \\
13.0 .28 \\
49.0 .00 \\
1,601.3 .32 \\
314.1 .05 \\
770.2 .16 \\
756.0 .32 \\
1,046.3 \cdot 38 \\
407.0 .32 \\
9.2 .16 \\
1,393.0 .00 \\
\text { J,429.1.08 } \\
813.3 .08 \\
296.0 .02 \\
5.0 .00 \\
\cdots \\
12,428.1 .18\end{array}$ & & & $12,428.1 .18$ & - & - \\
\hline
\end{tabular}


FORM No. 1.-Continued.

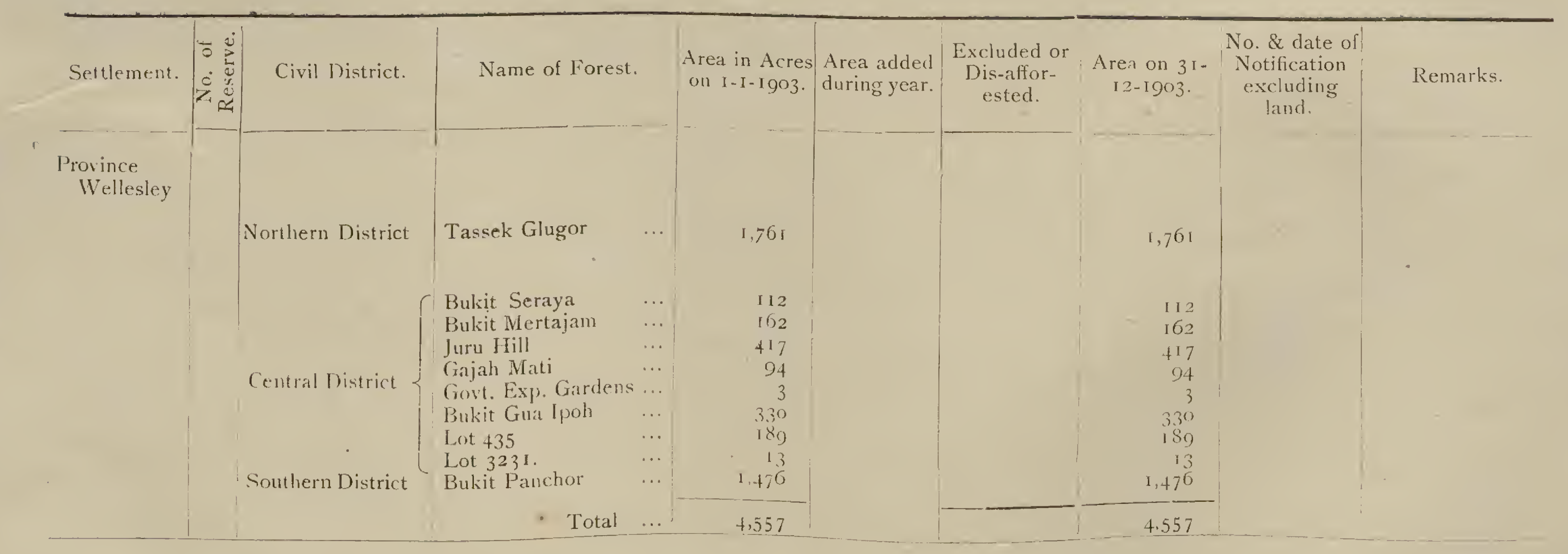


liokM NO. 1.-Continued.

\begin{tabular}{|c|c|c|c|c|c|c|c|c|c|}
\hline Settlement. & 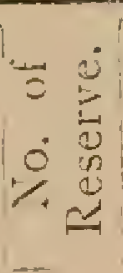 & Civil District. & Name of Forest. & $\begin{array}{c}\text { Area in Acres } \\
\text { on I-I-O3. }\end{array}$ & $\begin{array}{l}\text { Area added } \\
\text { during year. }\end{array}$ & $\begin{array}{c}\text { Excluded or } \\
\text { Dis- } \\
\text { afforested. }\end{array}$ & $\begin{array}{l}\text { Area on } \\
3 \text { I- } 12-03\end{array}$ & $\mid \begin{array}{c}\text { No. \& date of } \\
\text { Notification } \\
\text { excluding } \\
\text { land. }\end{array}$ & Remarks. \\
\hline \multirow[t]{3}{*}{ Penang. } & $\begin{array}{l}\text { I } \\
2\end{array}$ & North East & $\begin{array}{l}\text { Block } D \\
\text { Block } E \\
\text { Block } F \\
\text { Part of Block } I \\
\text { Pulau Jerejak }\end{array}$ & $\begin{array}{r}5.741 \\
252 \\
233 \\
18 \\
887\end{array}$ & $\begin{array}{l}\cdots \\
\cdots \\
\cdots \\
\cdots \\
\cdots\end{array}$ & & $\begin{array}{r}5,7+1 \\
252 \\
233 \\
18 \\
887\end{array}$ & & . \\
\hline & $\begin{array}{l}A \\
B \\
C \\
G \\
H \\
Y\end{array}$ & South West & $\begin{array}{l}\text { Pantei Acheh } \\
\text { Laksamana } \\
\text { Telok Bahang } \\
\text { Do. } \\
\text { Genting Hills } \\
\text { Bukit Gumoroh } \\
\text { Renau Hills }\end{array}$ & $\begin{array}{r}3,208 \\
465 \\
380 \\
236 \\
21 \\
205 \\
151\end{array}$ & $\begin{array}{l}\cdots \\
\cdots \\
\cdots \\
\cdots \\
\cdots \\
\cdots\end{array}$ & & $\left\{\begin{array}{r}3,208 \\
465 \\
616 \\
21 \\
205 \\
15 \mathrm{I}\end{array}\right.$ & - & \\
\hline & & & & $1 \pm, 797$ & & & 11,797 & & \\
\hline
\end{tabular}


Form No. I.-Continued.

\begin{tabular}{|c|c|c|c|c|c|c|c|c|c|}
\hline Settlement. & \begin{tabular}{l}
$\overrightarrow{0}$ \\
$\dot{0}$ \\
$\dot{0}$ \\
\hdashline \\
\hdashline
\end{tabular} & 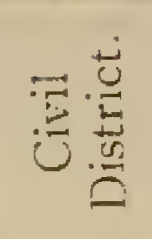 & Name of Forest. & $\begin{array}{l}\text { Area in Acres } \\
\text { on I-1-I } 903 .\end{array}$ & $\begin{array}{l}\text { Areá added } \\
\text { during year. }\end{array}$ & $\begin{array}{l}\text { Excluded or } \\
\text { Dis-affor- } \\
\text { ested. }\end{array}$ & $\begin{array}{c}\text { Area on } \\
3 \text { I-I } 2-1903\end{array}$ & $\begin{array}{c}\text { No. \& date of } \\
\text { Notificatior } \\
\text { excluding } \\
\text { land. }\end{array}$ & Remarks. \\
\hline Dindings & $\begin{array}{l}\mathrm{A} \\
\mathrm{B} \\
\mathrm{C} \\
\mathrm{D} \\
\mathrm{E} \\
\mathrm{F} \\
\mathrm{G} \\
\mathrm{H} \\
\mathrm{I} \\
\mathrm{J}\end{array}$ & & $\begin{array}{l}\text { Tanjong Bruang } \\
\text { Telok Serai } \\
\text { Gunong Tunggal } \\
\text { Tanjong Hantu } \\
\text { Pangkor Island } \\
\text { Lumut } \\
\text { Ulu Bruas } \\
\text { Telok Muroh } \\
\text { Batu Undan } \\
\text { Telok Senangin }\end{array}$ & $\begin{array}{l}3,000 \\
5,000 \\
1,225 \\
1,000 \\
3,750 \\
1,225 \\
2,000 \\
3,000 \\
\cdots \\
\cdots\end{array}$ & $\begin{array}{r}26 \\
13 \\
5,000 \\
1,000\end{array}$ & $\begin{array}{l}\mathrm{I}, 200^{*} \\
= \\
1,25^{\circ} \\
674\end{array}$ & $\begin{array}{l}1,800 \\
5,000 \\
1,225 \\
1,000 \\
3,77^{*} \\
1,28^{*} \\
750^{*} \\
2,326^{*} \\
5,000 \\
1,000\end{array}$ & 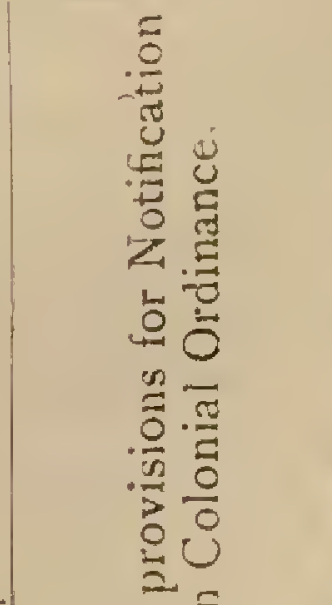 & $\begin{array}{l}\text { *Alienated } \\
\text { *Corrected area } \\
\text { *Corrected area } \\
\text { *Correcied area } \\
\text { *Corrected area }\end{array}$ \\
\hline & & & Total & 20,200 & 6,039 & $3, \mathrm{I} 24$ & & $2^{\circ}$ & \\
\hline
\end{tabular}


Form No. I.-Conlimued.

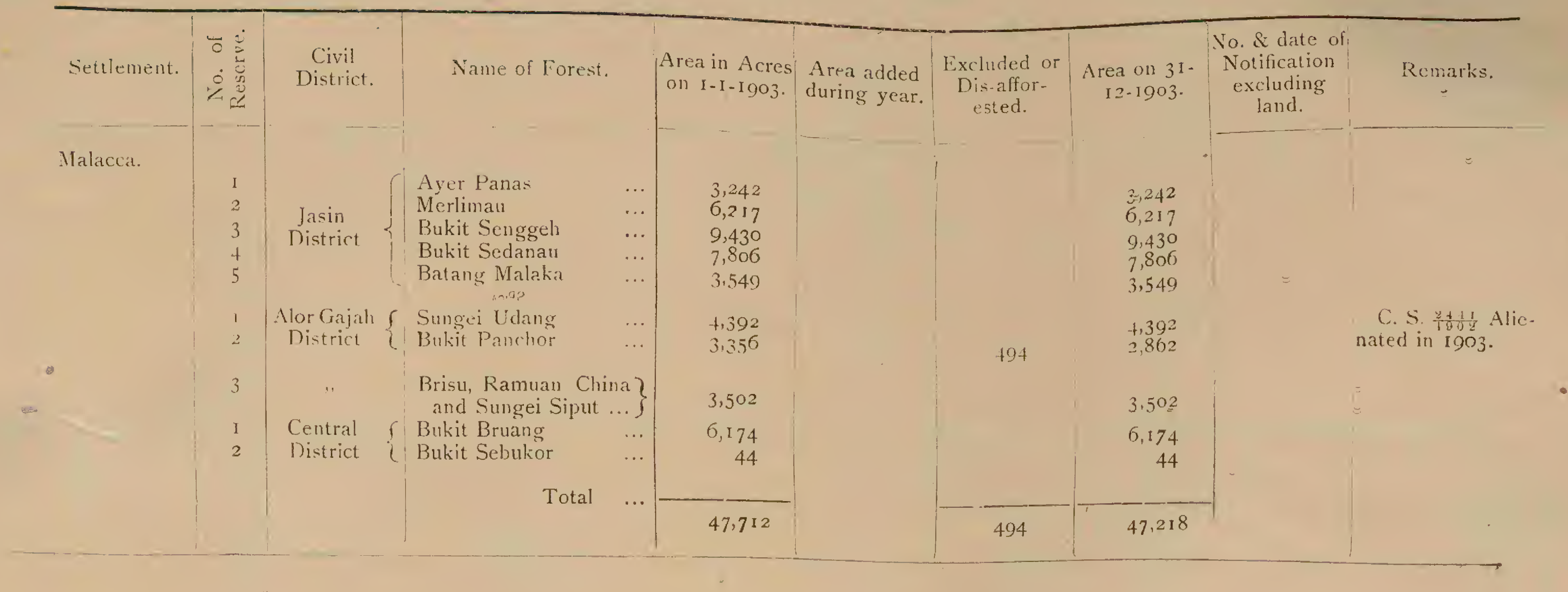


FORM No 2.

Statement shewing progress mad: in forming new Reserves during the year 1903.

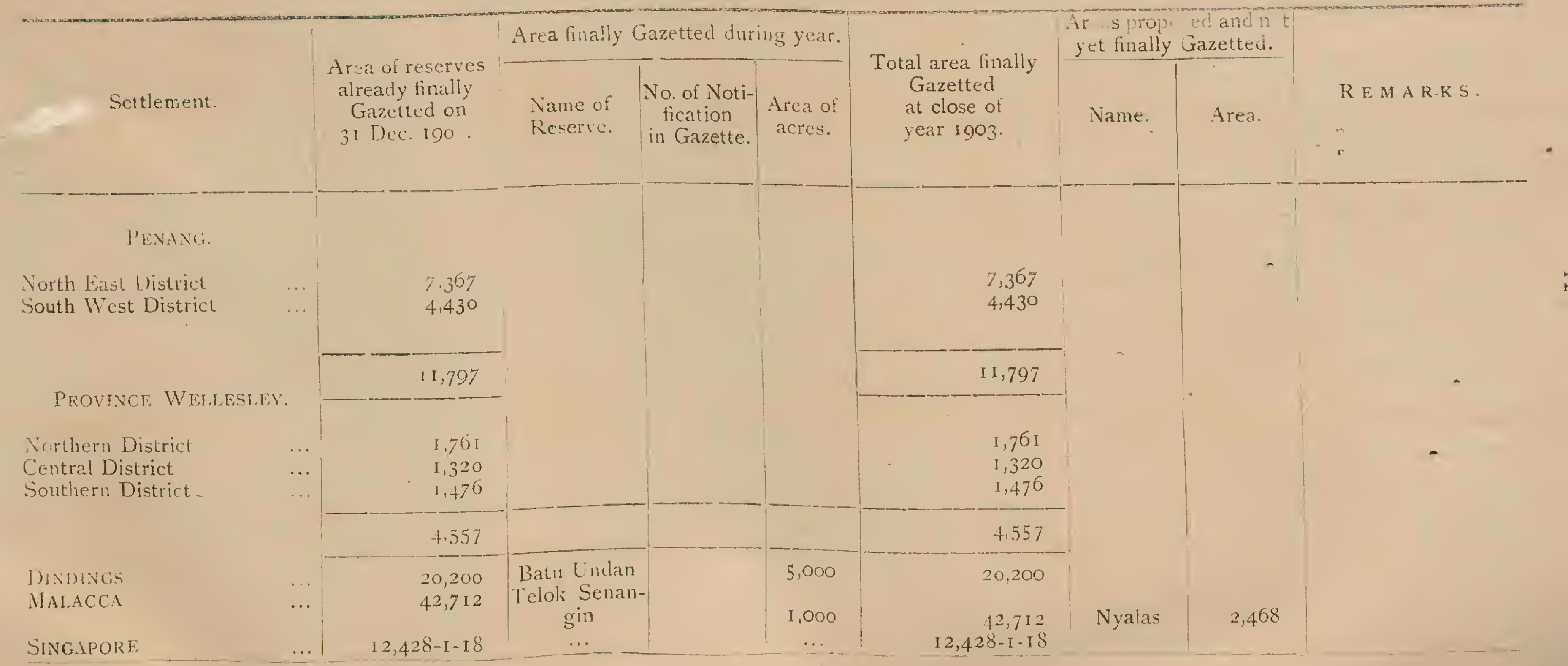


FORM NO. 3 .

Record of Denaration and Maintenance of Boundaries for rgo3.

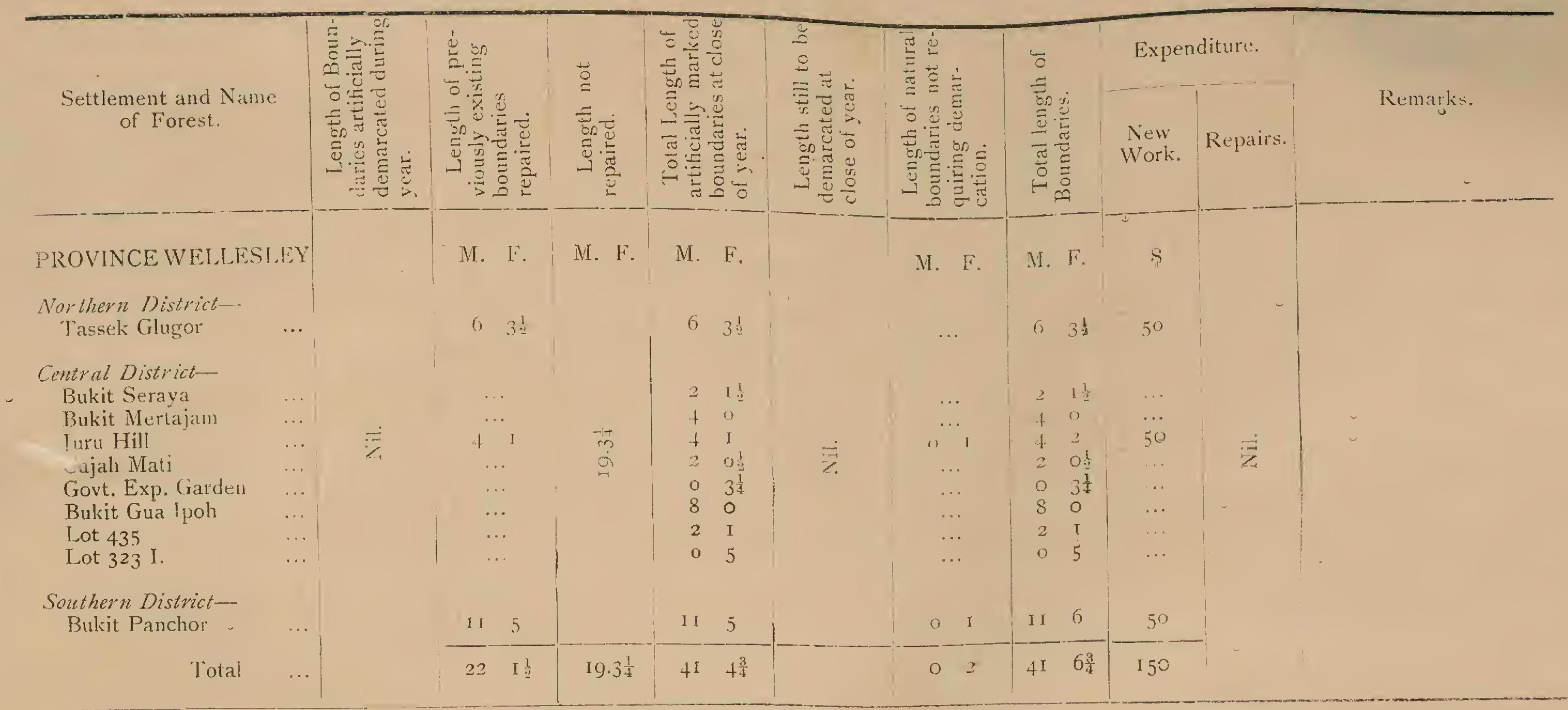


FORM Nu, 3.--Contimed.

Record of Dematration and Maintenance of Boundarits for 1903.

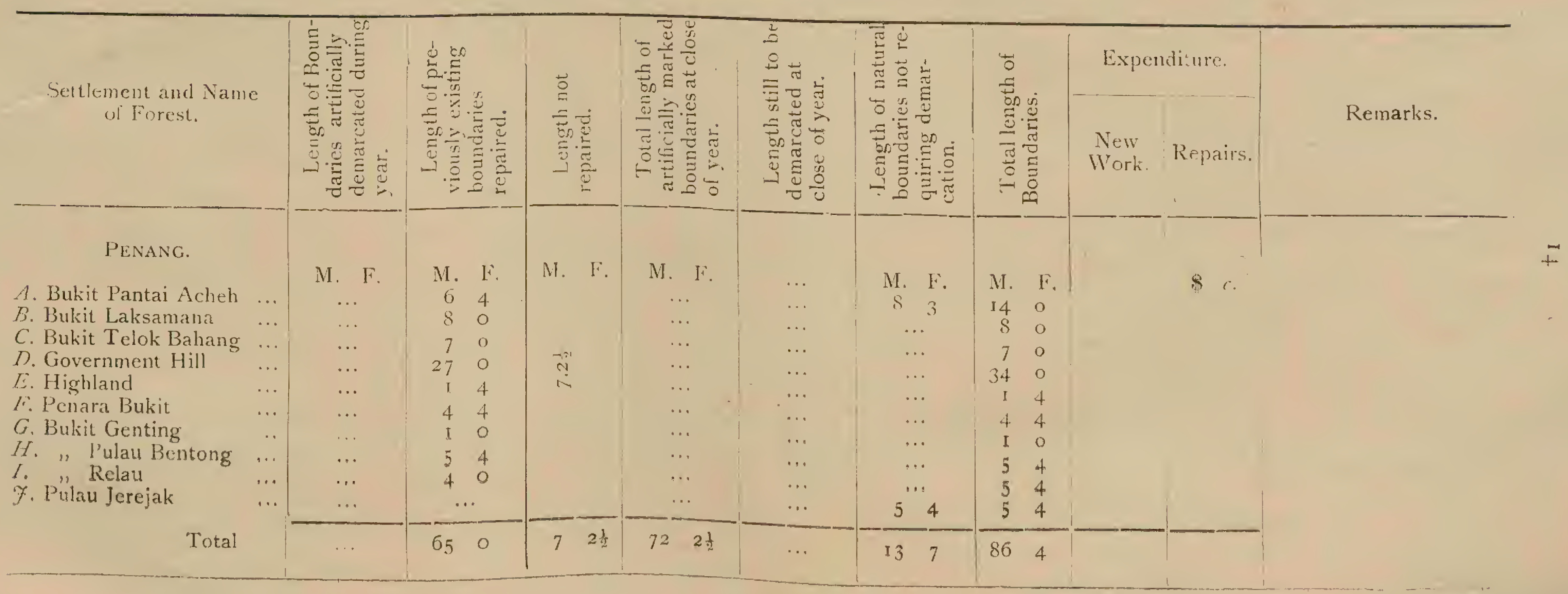


Form No. 3.-Continued.

Record of Demarcation and Maintenance of Boundaries for 1903.

\begin{tabular}{|c|c|c|c|c|c|c|c|c|c|c|}
\hline $\begin{array}{l}\text { Settlement } \\
\text { and Name of } \\
\text { Forest. }\end{array}$ & 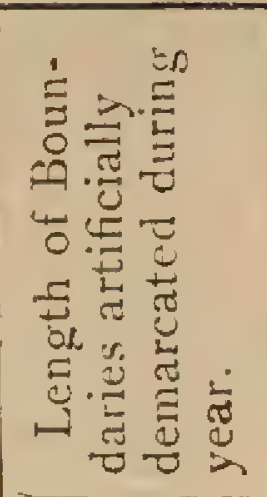 & 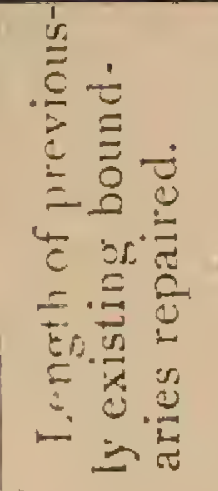 & 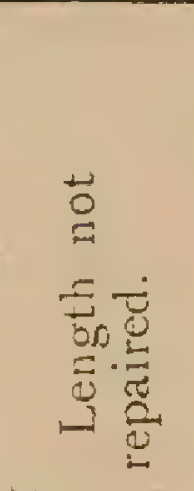 & 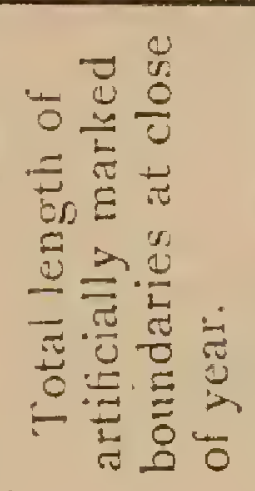 & 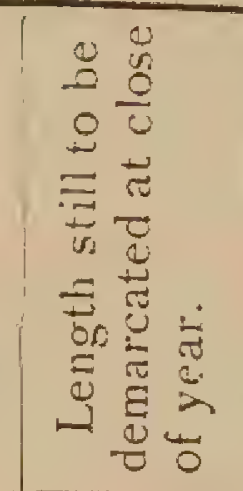 & 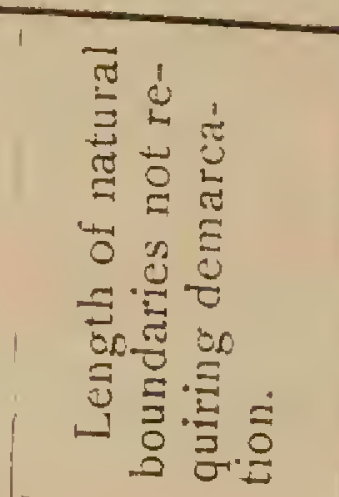 & 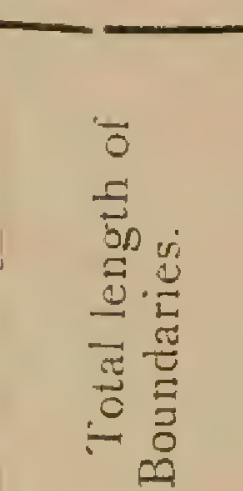 & Expen & diture. & Remarks. \\
\hline $\begin{array}{l}\text { WALACCA. } \\
\text { SINGAPORE. }\end{array}$ & $\begin{array}{cl}\text { M. } & \text { F. } \\
8 & 0\end{array}$ & $\begin{array}{cc}M & F \\
98 & 5 \\
& \text { No }\end{array}$ & $\begin{array}{l}\text { Nil. } \\
\text { record, }\end{array}$ & $\begin{array}{l}\text { M. F. } \\
106 \quad 5 \\
\text { but all be }\end{array}$ & Nil. & $\begin{array}{l}\text { Not Known } \\
\text { kept in order. }\end{array}$ & $\begin{array}{c}\text { M. } \\
106 \\
106\end{array}$ & $\begin{array}{c}\$ \\
200\end{array}$ & $\cdots$ & $\begin{array}{l}\text { The approximate length of boundaries of all } \\
\text { Malacciti is here sh wa. The boindldaries were } \\
\text { kept in repairs by torest Guards. No addition- } \\
\text { al expense except in the cass of the "Nyalas." } \\
\text { New reserve was incurred. }\end{array}$ \\
\hline
\end{tabular}


FORM No. 4.

Statement of Arca Surveyed and Unsuraeyp during the year igos.

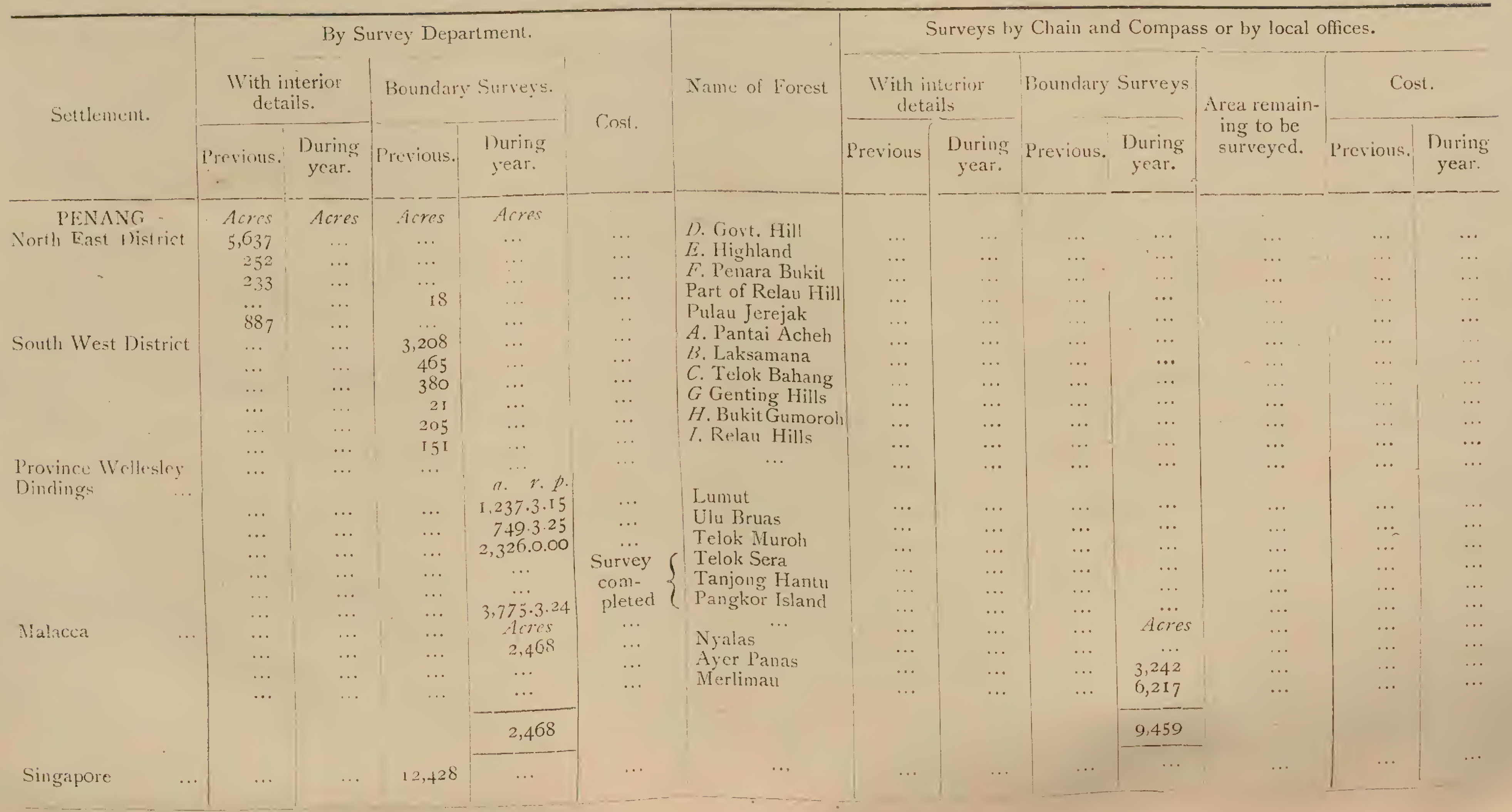


FORM No. 6

Communications and Buildings 1903.

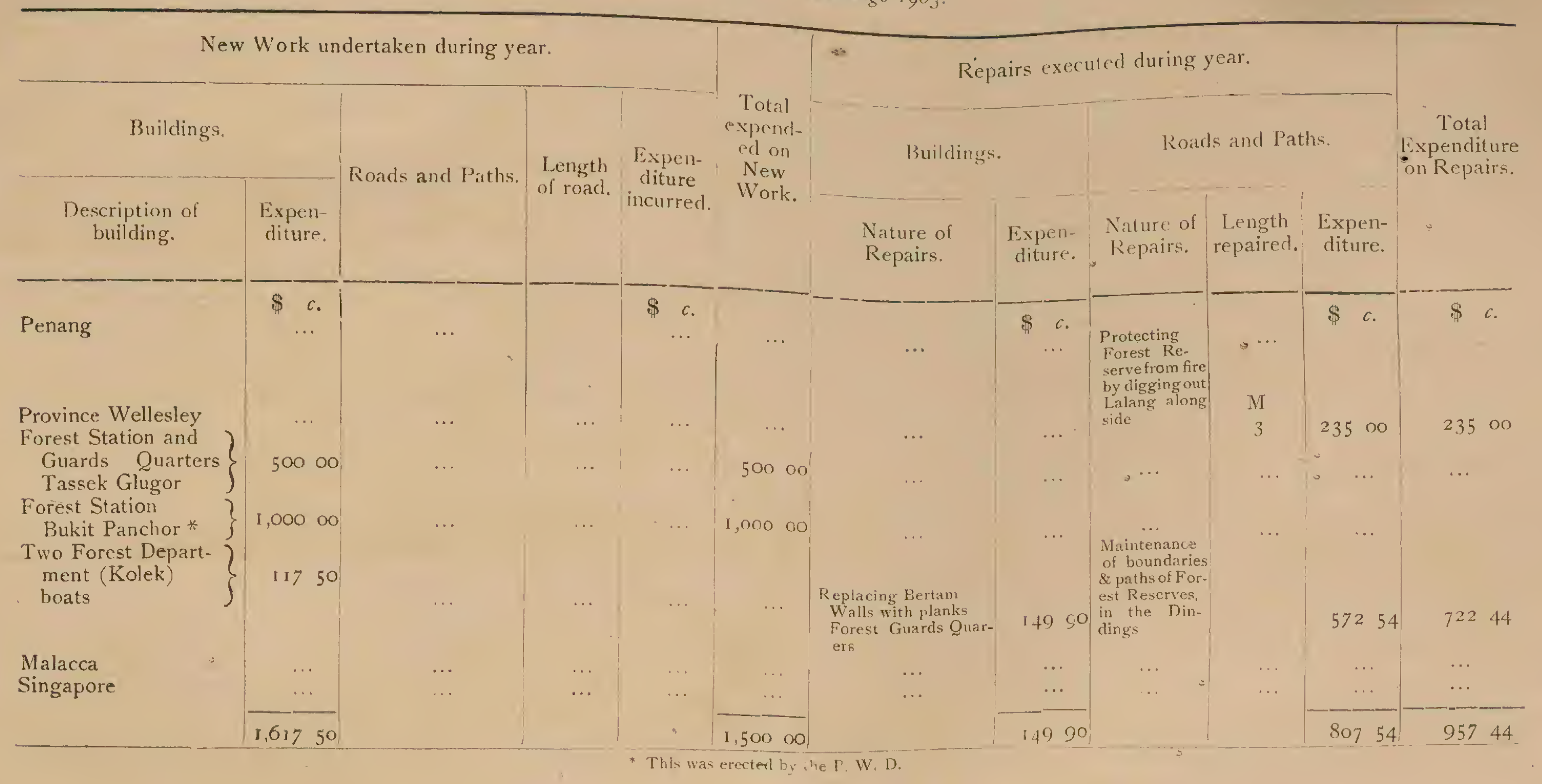


FORM NO. 7 .

Register of Breaches of Forest Rules for 1903.

\begin{tabular}{|c|c|c|c|c|c|c|c|c|c|}
\hline \multirow[b]{2}{*}{ Settlement and District. } & \multirow{2}{*}{ 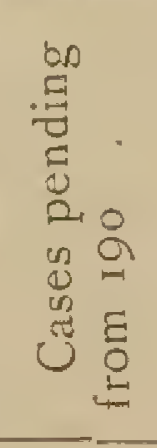 } & \multicolumn{3}{|c|}{ New cases of the year. } & \multirow{2}{*}{ 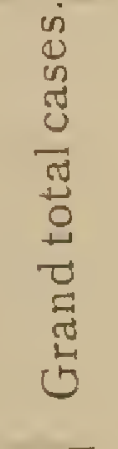 } & \multicolumn{2}{|c|}{ Disposed of during year. } & \multirow{2}{*}{ 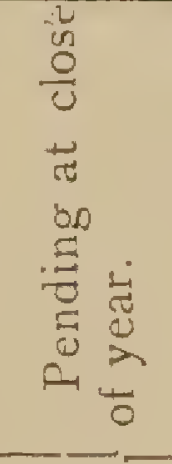 } & \multirow[b]{2}{*}{ Remarks. } \\
\hline & & 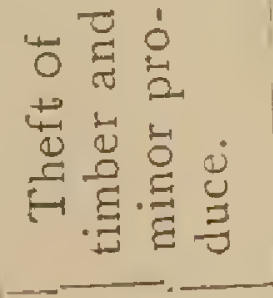 & 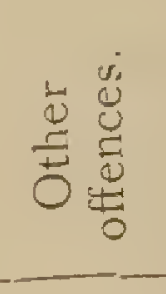 & 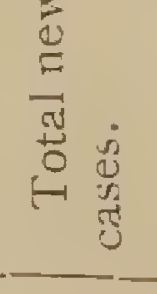 & & 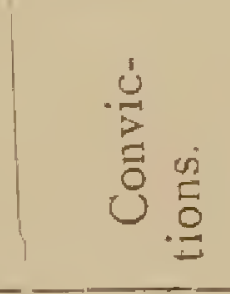 & 离 & & \\
\hline $\begin{array}{l}\text { Penang } \\
\text { Province Wellesley }\end{array}$ & $\cdots$ & $\begin{array}{r}13 \\
4\end{array}$ & $\begin{array}{l}\cdots \\
\cdots\end{array}$ & $\begin{array}{r}13 \\
4\end{array}$ & $\begin{array}{r}13 \\
4\end{array}$ & $\begin{array}{l}6 \\
3\end{array}$ & $\begin{array}{l}7 \\
1\end{array}$ & & $\begin{array}{l}\text { Fines } \$ \text { I } 95.00 \\
\quad " \quad \$ \text { I } 9.00\end{array}$ \\
\hline Dindings & $\cdots$ & 91 & I9 & 110 & 110 & 88 & 22 & $\ldots$ & $\begin{cases}\prime \prime & \text { Inflicted } \$ 842.00 \\
" & \text { Realised } \$ 726.40\end{cases}$ \\
\hline $\begin{array}{l}\text { Malacca } \\
\text { Singapore }\end{array}$ & $\begin{array}{l}\ldots \\
\cdots\end{array}$ & $\begin{array}{r}25 \\
2\end{array}$ & $\begin{array}{l}\cdots \\
\cdots\end{array}$ & $\begin{array}{r}25 \\
2\end{array}$ & $\begin{array}{r}25 \\
2\end{array}$ & $\begin{array}{r}19 \\
2\end{array}$ & $\begin{array}{c}6 \\
\cdots\end{array}$ & $\begin{array}{l}\cdots \\
\cdots\end{array}$ & $\$ 35$ Realised in Fine. \\
\hline
\end{tabular}


FORM No. 8.

Area of Plantations.

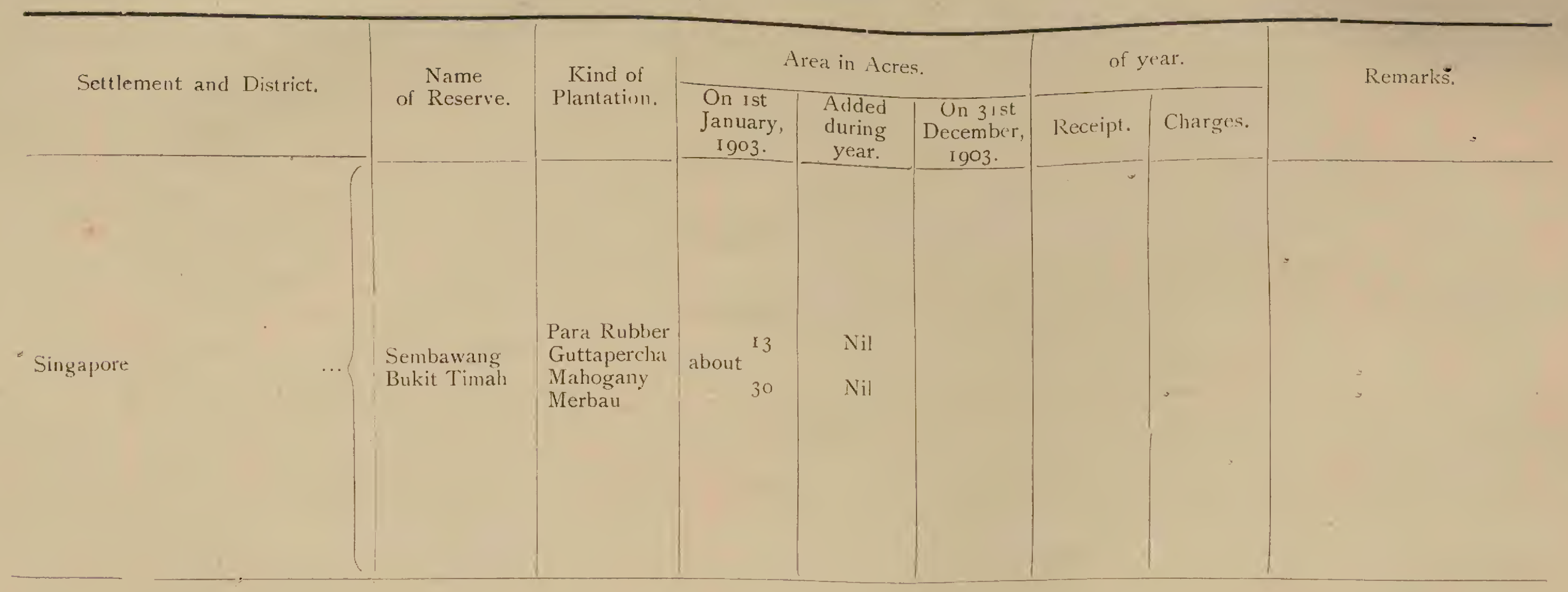


FORM No. 8.-Continued.

Area of Plantations.

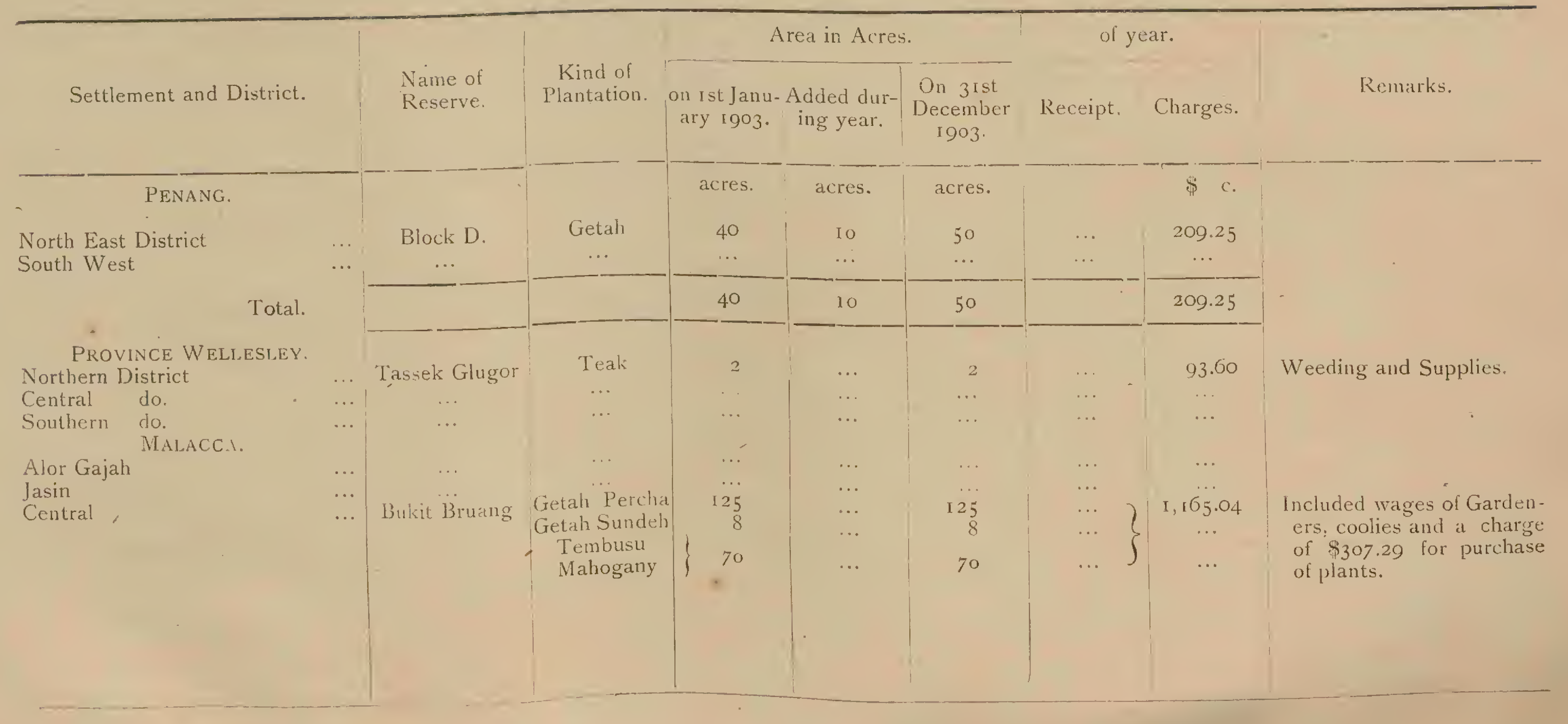


FORM No.' 10.

Outturn of Minor Forest produce.

\begin{tabular}{|c|c|c|c|c|c|c|c|c|c|}
\hline \multirow[t]{2}{*}{ State. } & \multirow{2}{*}{ District. } & \multirow{2}{*}{$\begin{array}{l}\text { Description of } \\
\text { produce. }\end{array}$} & \multicolumn{2}{|c|}{ By purchasers. } & \multicolumn{2}{|c|}{ Tree grants. } & \multicolumn{2}{|c|}{ Total. } & \multirow{2}{*}{ REMARKS. } \\
\hline & & & Quantity. & Value. & Quantity. & Value. & Quantity. & Value. & \\
\hline Singapore & 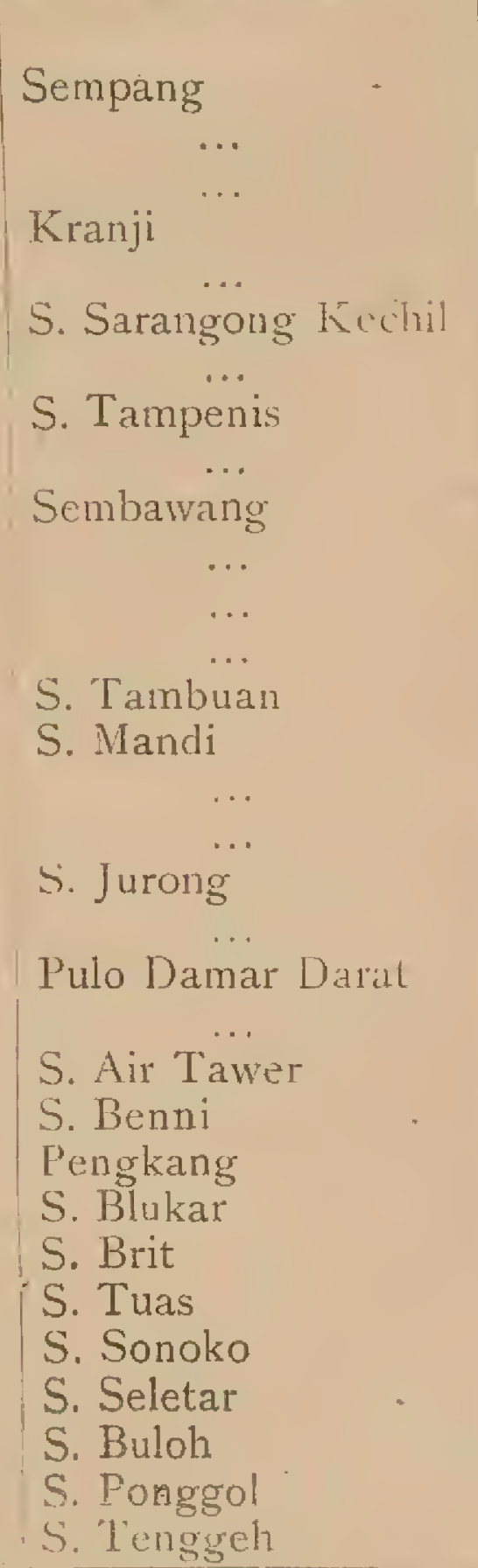 & $\begin{array}{l}\text { Rciam } \\
\text { Nibong } \\
\text { Nengkuangs } \\
\text { Ratian } \\
\text { Nibongs } \\
\text { Do. } \\
\text { Mengkuangs } \\
\text { Resam } \\
\text { Nengluangs } \\
\text { Do. } \\
\text { Resam } \\
\text { Rattan } \\
\text { Nibongs } \\
\text { Mengkuangs } \\
\text { Resam } \\
\text { Mengkuang } \\
\text { Nibongs } \\
\text { Resam } \\
\text { Mengkuang } \\
\text { Do. } \\
\text { Resam } \\
\text { Meingkuarg } \\
\text { Do. } \\
\text { Do. } \\
\text { Do. } \\
\text { Do. } \\
\text { Do. } \\
\text { Nibongs } \\
\text { Do. } \\
\text { Do. } \\
\text { Do. } \\
\text { Do. }\end{array}$ & 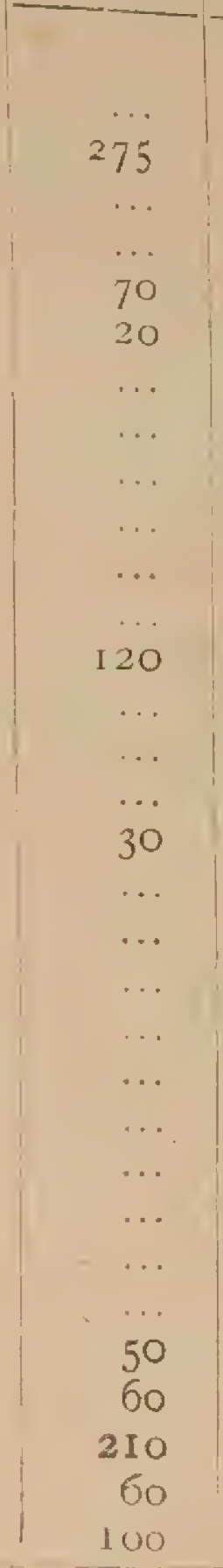 & $\begin{array}{rr}\$ & c \\
\text { I } & 50 \\
27 & 50 \\
\text { I } & 50 \\
1 & 00 \\
7 & 00 \\
2 & 00 \\
0 & 60 \\
1 & 20 \\
2 & 10 \\
9 & 30 \\
0 & 60 \\
6 & 00 \\
\text { I } 2 & 00 \\
4 & 50 \\
0 & 60 \\
0 & 60 \\
3 & 00 \\
1 & 20 \\
3 & 00 \\
\text { I } & 80 \\
1 & 80 \\
0 & 60 \\
\text { I } & 20 \\
0 & 60 \\
0 & 60 \\
0 & 90 \\
0 & 60 \\
5 & 00 \\
6 & 00 \\
21 & 00 \\
6 & 00 \\
10 & 00 \\
\end{array}$ & $\bar{z}$ & $\vec{F}$ & $\begin{array}{c}275 \\
\ldots \\
\ldots \\
70 \\
20 \\
\ldots \\
\ldots \\
\ldots \\
\ldots \\
\ldots \\
\ldots \\
120 \\
\ldots \\
\ldots \\
30 \\
\ldots \\
\ldots \\
\ldots \\
\ldots \\
\ldots \\
\ldots \\
\ldots \\
\ldots \\
\ldots \\
\ldots \\
50 \\
60 \\
210 \\
60 \\
100 \\
\end{array}$ & $\begin{array}{rr}\$ & c \\
1 & 50 \\
27 & 50 \\
1 & 50 \\
1 & 00 \\
7 & 00 \\
2 & 00 \\
0 & 60 \\
1 & 20 \\
2 & 10 \\
9 & 30 \\
0 & 60 \\
6 & 00 \\
12 & 00 \\
4 & 50 \\
0 & 60 \\
0 & 60 \\
3 & 00 \\
1 & 20 \\
3 & 00 \\
1 & 80 \\
1 & 80 \\
0 & 60 \\
1 & 20 \\
0 & 60 \\
0 & 60 \\
0 & 90 \\
0 & 60 \\
5 & 00 \\
6 & 00 \\
21 & 00 \\
6 & 00 \\
10 & 00 \\
\end{array}$ & $\begin{array}{l}\text { By monthly Passes } \\
\text { Pass good for } 2 \text { months } \\
\text { By monthly Passes }\end{array}$ \\
\hline
\end{tabular}


Form No, Io.-Continued.

Outturn of Minor Forest Produce.

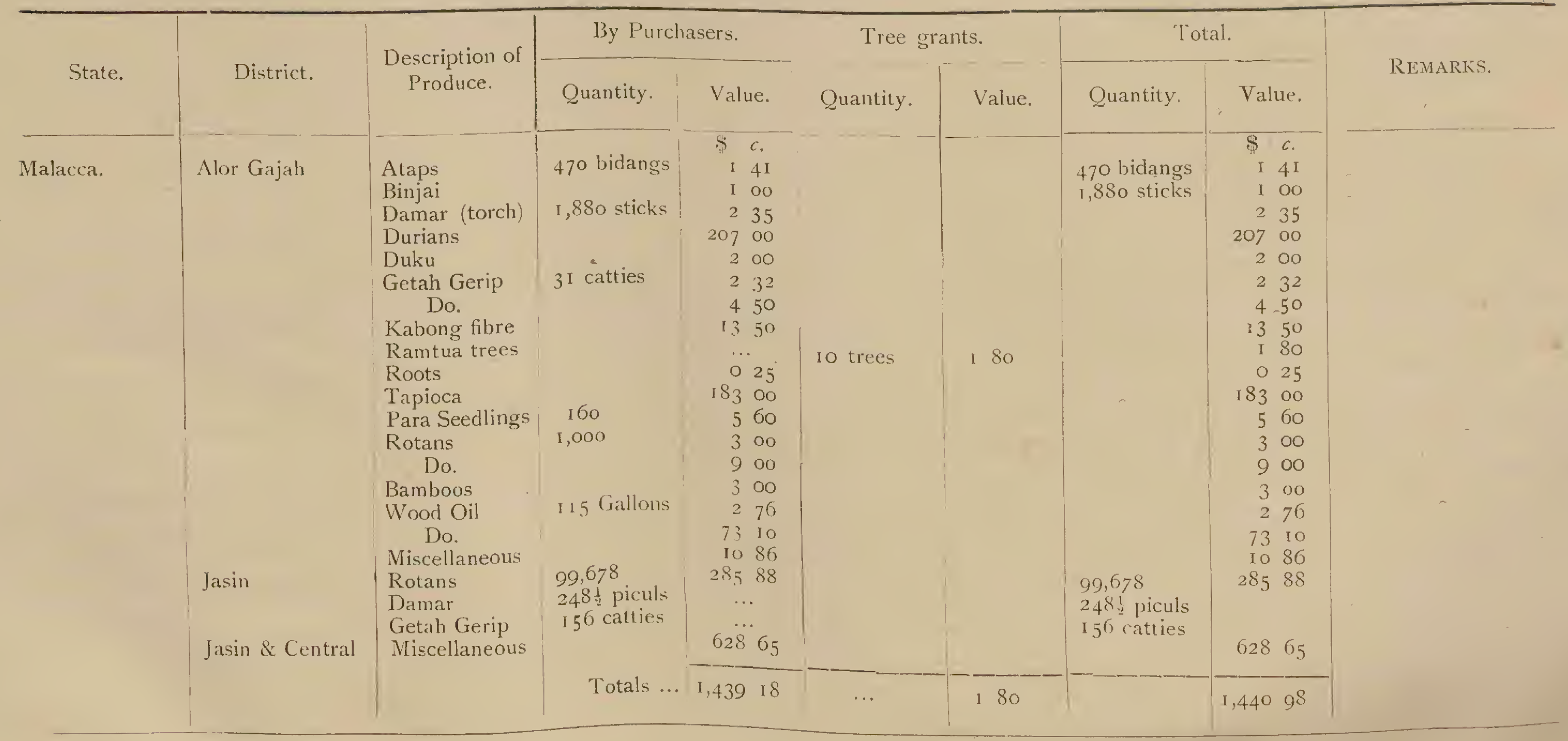


FORM NO. IO.-Continued.

Outturn of Minor Forest Produce.

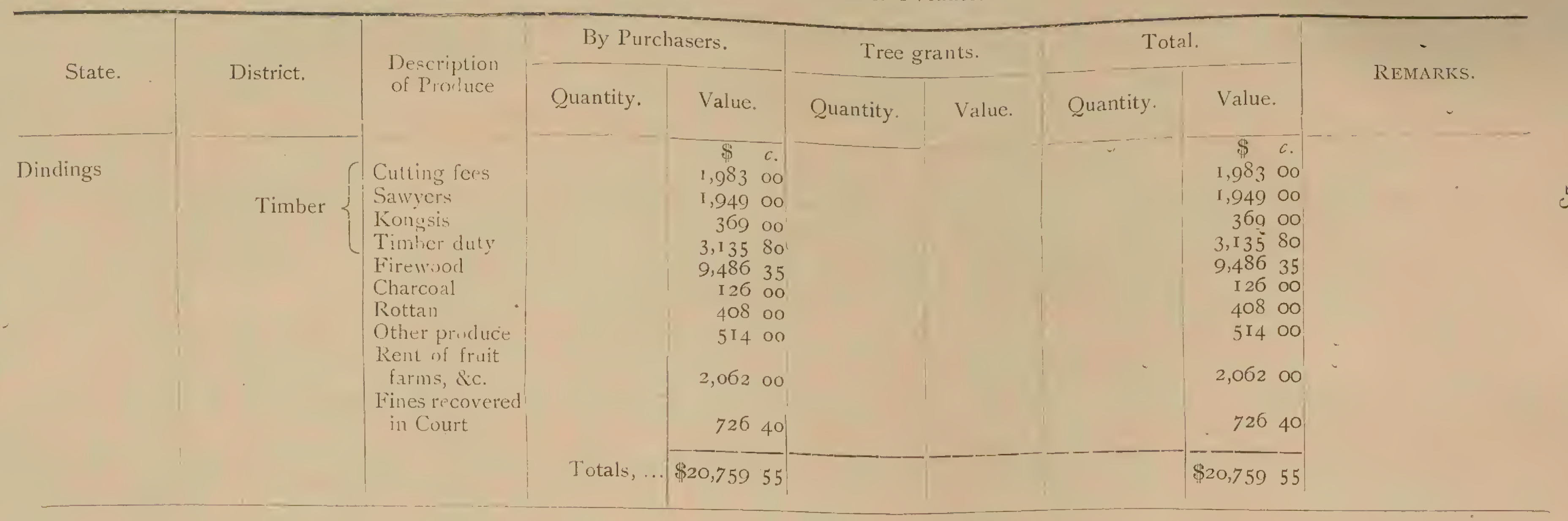


SINGAPORF.

FORN NO. II.

Summary of Retenue and Expenditure 1903.

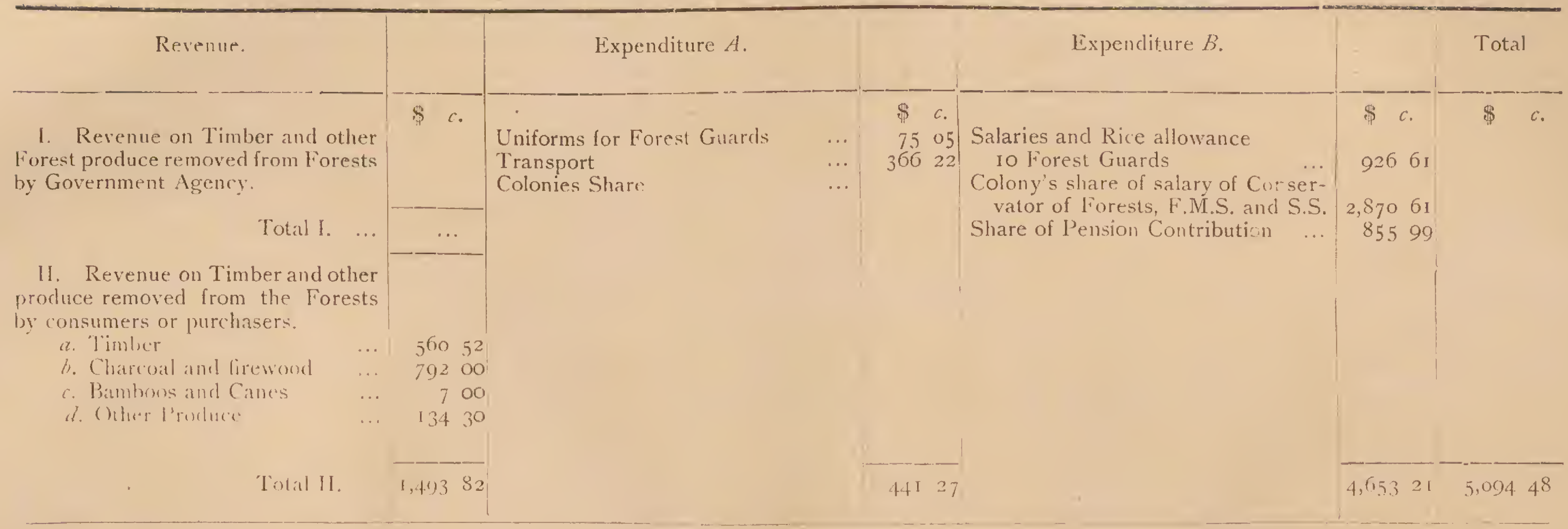


PENANG

ForM No, II

Sumumry of Revenue and Expenditure 1903.

\begin{tabular}{|c|c|c|c|c|c|c|}
\hline Revenue. & & Expenditure $A$. & & Expenditure $B$. & & Total. \\
\hline $\begin{array}{l}\text { 1. Revenue on Timber and other } \\
\text { Forest produce removed from Forests } \\
\text { by Government Agency }\end{array}$ & $\begin{array}{r}8 . \\
\ldots \\
\end{array}$ & $\begin{array}{l}\text { Conservancy of Works } \\
\text { Purchase of Stores, tools and } \\
\text { planks } \\
\text { Other Works }\end{array}$ & $\mid \begin{array}{cc}\$ & c . \\
500 & 00 \\
154 & 39 \\
822 & 72\end{array}$ & $\begin{array}{l}\text { Establishment } \\
\text { Salaries of Forest Subordinates } \\
\text { Special Allowalices }\end{array}$ & $\begin{array}{l}\$ \% \\
I, 386.90 \\
I, 056.39 \\
254.62\end{array}$ & $\begin{aligned} \$ \quad c \\
\mathrm{I}, 927 \cdot 34 \\
2,097 \cdot 9 \mathrm{I}\end{aligned}$ \\
\hline $\begin{array}{l}\text { II. Revenue on Timber and } \\
\text { other produce removed from the } \\
\text { Forests by consumers or purchasers. } \\
\text { a. Timber } \\
\text { b. Charcoal and firewood } \\
\text { c. Bamboos and Canes } \\
\begin{array}{l}\text { a. Other Prnduce } \\
\text { e. Miscellaneous }\end{array}\end{array}$ & $\begin{array}{rr}737 & 80 \\
29 & 40 \\
19 & 67 \\
59 & 65 \\
214 & 00\end{array}$ & $\begin{array}{l}\text { Clearing and Maintaining } \\
\text { Boundaries of Forest Revenue. }\end{array}$ & 45023 & & & \\
\hline
\end{tabular}




\section{DINDINGS.}

\section{FORM No. II.}

Sunmary of Revenue and Expenditure 1903

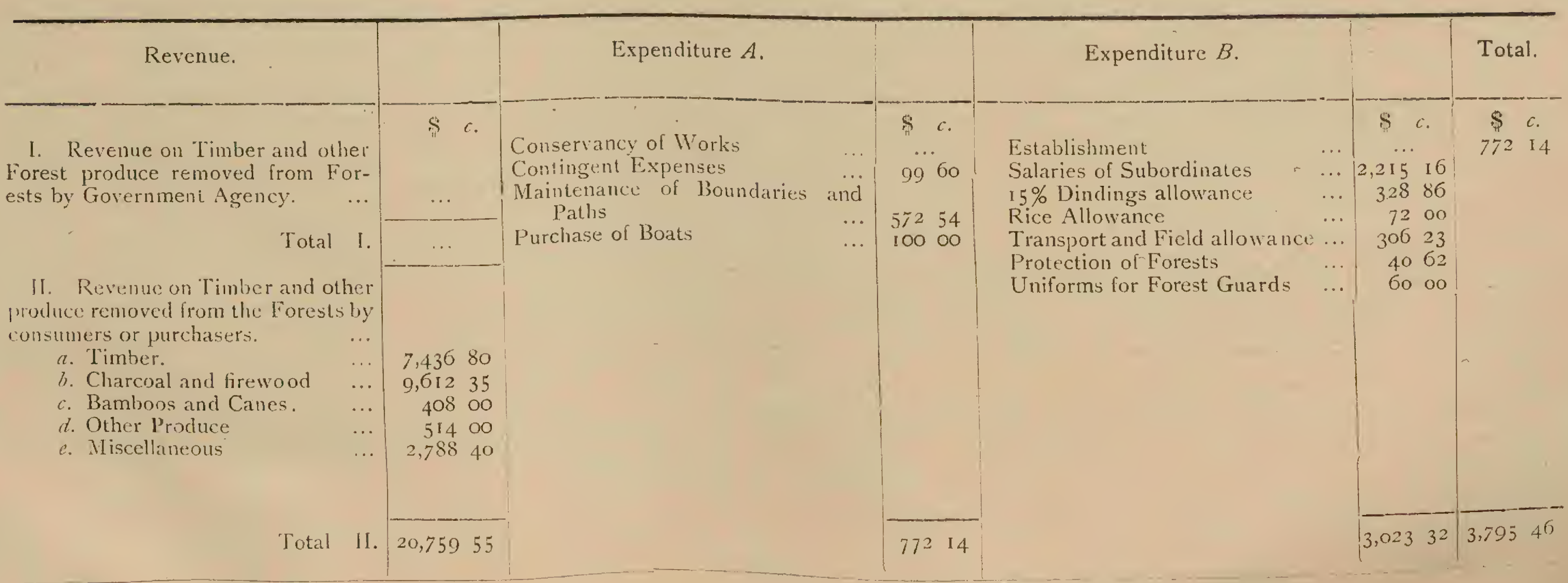


MALACCA.

Forar No. i I

Summary of Revenue and Lixpenditure 1903.

\begin{tabular}{|c|c|c|c|c|c|c|}
\hline Revenue. & & Expenditure $A$. & & Expenditure $B$. & & Total. \\
\hline 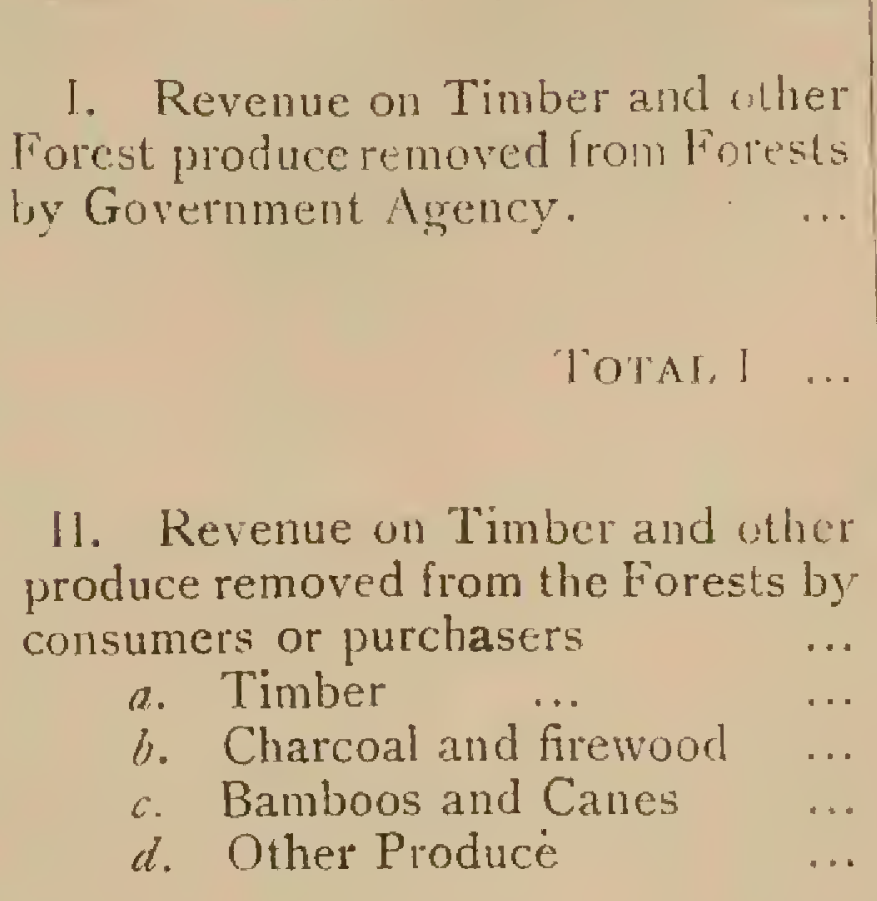 & $\mid \begin{array}{rr}1,502 & 87 \\
698 & 12 \\
300 & 88 \\
1,140 & 10\end{array}$ & Personal Enoluments & 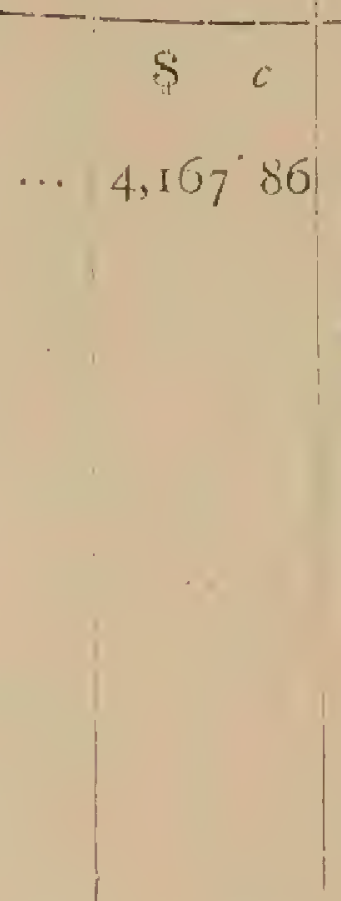 & 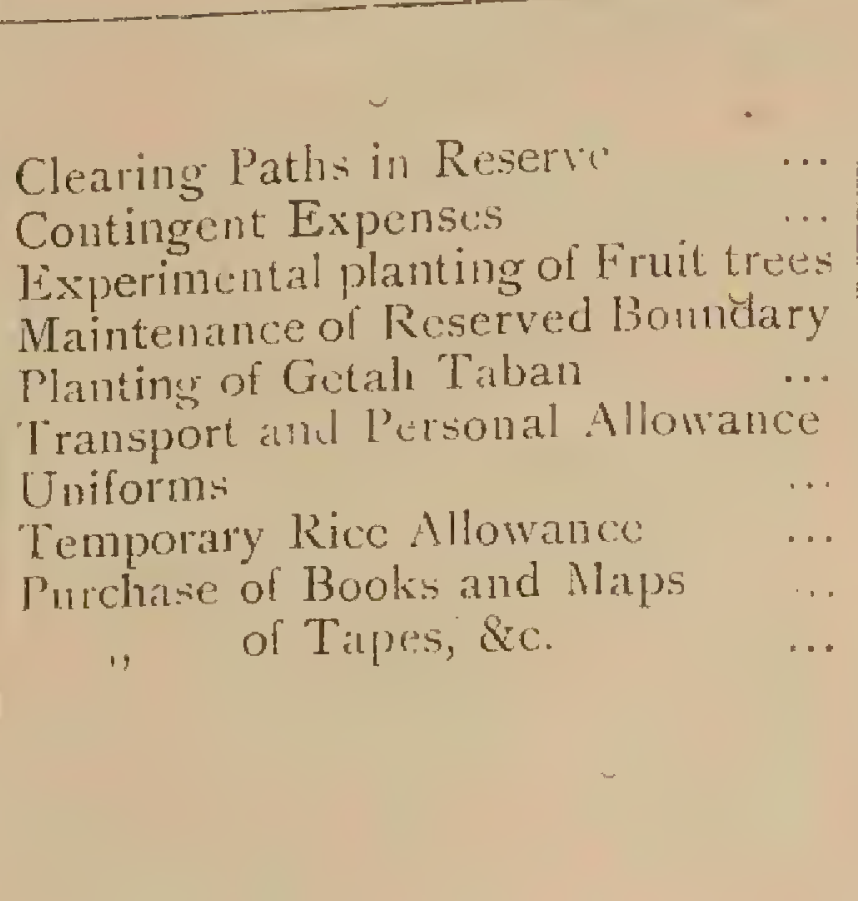 & $\begin{array}{rc}\$ & 6 \\
226 & 50 \\
122 & 14 \\
84 & 42 \\
200 & 00 \\
1,663 & 04 \\
554 & 13 \\
191 & 00 \\
192 & 00 \\
\ldots & \\
67 & 39\end{array}$ & 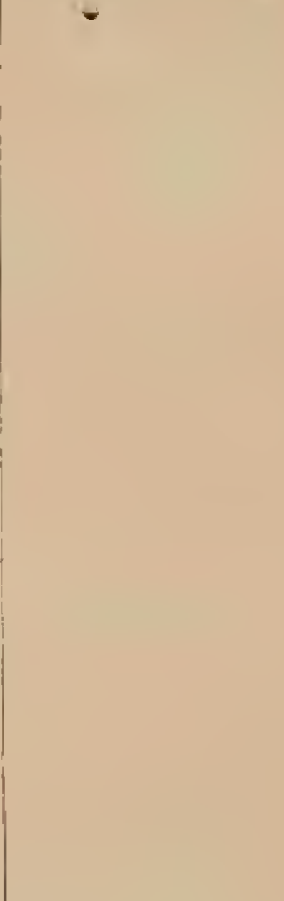 \\
\hline TOTAI, II & $3,659 \quad 17$ & & 4,16786 & & $\left|\begin{array}{ll}3,302 & 93\end{array}\right|$ & 7,47079 \\
\hline
\end{tabular}

A. M. BURN-MURDOCH,

Conservator of Forests, Federated Malay States

and Straits Settlements. 


\section{Annual Report on Forest Administration in the Straits Settlements for the Year 1904.}

\section{CHAPTER I. \\ Extension and Constitution of Reserved Forests. \\ I. Alteration in Area.}

1. The only alterations occurred in Malacca where 52 acres were excluded from the Bukit Bruang Reserve and an area of 2,468 acres taken up as a reserve at Nyalas. This area contains a good deal of secondary growth.

An area statement of all reserves is given in Form I of Appendix to this report.

2. This table shews the proportion of reserves to the total area of each Settlement, the percentage being $10^{\prime} 3$ as against $1^{\prime} 14$ in 1903 .

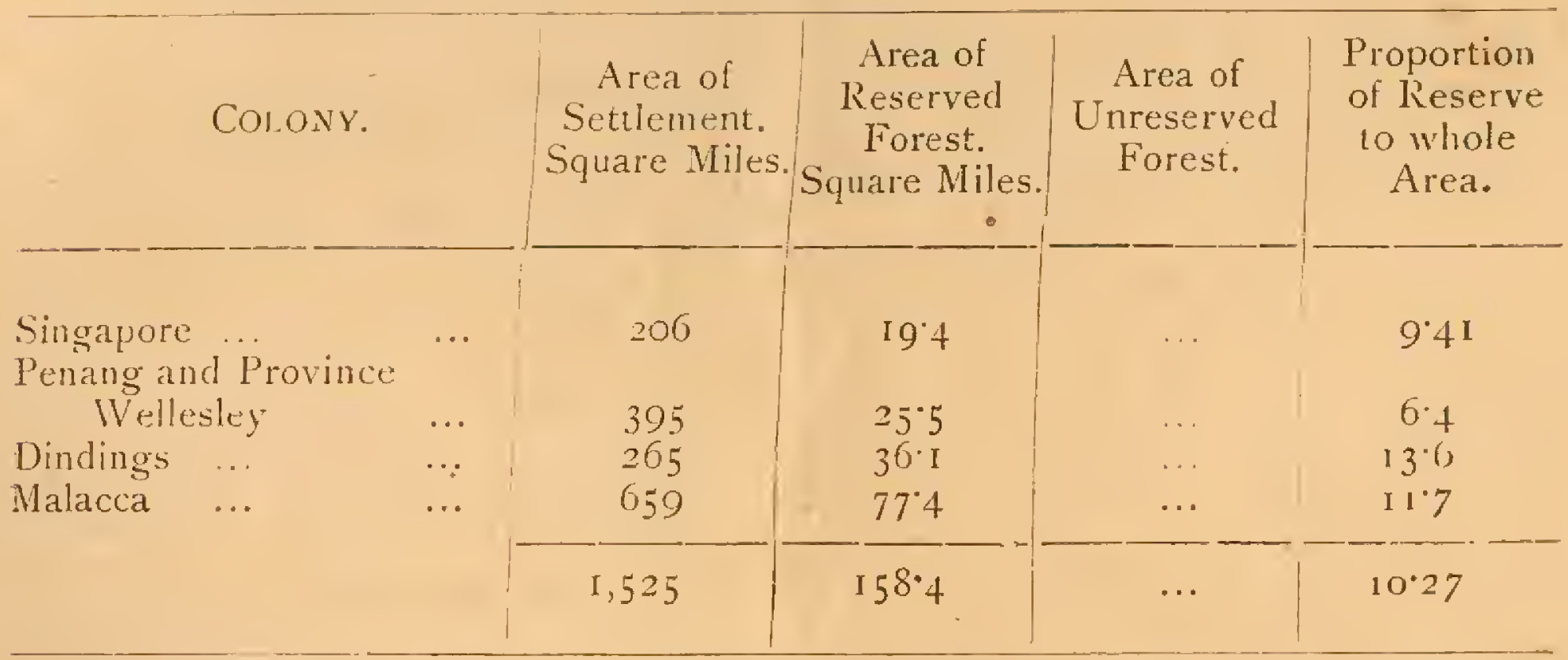

3. I regret that so far no steps have been taken to enable the Government to legally constitute these areas as reserved forests. These so-called reserves are merely portions of Crown land marked out and for the present set aside to be dealt with by the Forest Department. Instructions were issued by Government during. the year, however, to the effect that no felling of trees inside a "Reserve" may be permitted without the permission of the Conservator of Forests.

\section{Reserve Proposals.}

4. There is nothing to record under this head, no more reserves are at present required, except Mangrove.

\section{Demarcation and Repairs to Boundaries of Reserves.}

5. In Singapore boundaries were kept clear by the Fórest Staff.

In Penang 69 miles of boundaries were gone over and cleared at a cost of $\$ 329.75$, averaging $\$ 4.77$ per mile. In Province We!lesley i4 miles only were cleared for \$160.60 at the comparatively high figure $\$ I I .42$ per mile. This is owing to the difficulty of getting coolies in such outlying places as Tassek Glugor and Bukit Panchor, who refuse to work for the same pay as the coolies in Penang. In opening the boundaries of Bukit Langkap in the Province, an encroachment by a Chinese squatter was discovered, who had planted up about one acre with Tapioca. As both the boundary of this reserve as well as the boundary of Bukit Gua Ipoh was ill-defined, the services of a surveyor were applied for and granted, and the work was proceeding at the close of the year. The squatter was evicted, prosecuted, and fined $\$ 25$. In the Dindings there are 60 miles of artificial boundaries, the remainder consisting of Government roads and bridle paths, the Sea Coast and river banks. 
The artificial boundaries of most of the reserves (Tanjong Burong, Batu Undan and Telok Moroh excepted) were cleared at a cost of \$299.40. As about 40 miles were done the average cost was $\$ 7.48$ per mile.

No particulars are given as to Malacca, but the boundaries, about I00 miles, were kept clear at a cost of $\$ 497.15$.

For details see Form 3 .

\section{Surveys}

6. In the Dindings, the following reserves were surveyed :-

$\begin{array}{llll}\text { Telok Sera } & \ldots & \ldots & 5,000 \text { acres. } \\ \text { Gunong Tunggal } & \ldots & \ldots & \text { I,225 " } \\ \text { Tanjong Hantu } & \ldots & \ldots & \text { I,000 " }\end{array}$

but have not yet been plotted. These areas are approximate only. Gunong Tunggal Reserve was surveyed by the Deputy Ranger but cannot be plotted at present.

In Malacca, Nyalas Reserve was surveyed, 2,468 acres, and a rough survey of Merlimau and Ayer Panas, 9,459 acres, by the Forest Rangrer.

\section{CHAPTER II. \\ Management of Crown Forests. \\ I. Working Plans.}

7. The plan mentioned in paragraph 6 of the report for 1903 , in Malacca, received the sanction of His Excellency the Governor but the full number of trees was not felled. No other plans are in existence, but Mr. Borges, Forest Ranger, Dindings, made suggestions for a rough plan of working for the Dindings which are under connideration. See Form 5.

\section{Paths and Buildings. Form 6.}

8. In Province Wellesley, the Forest Station at Tassek Glugor was whiterashed at $\$ 2.48$.

In the Dindings, two attap and bertam Malay houses were erected at Changkat Resam for the accommodation of the Guards; these buildings were erected by the Guards themselves with the help of the boatmen, and the expenditure on them amounted to only $\$ 33.80$.

In Malacca, the Forest Guards' quarters were repaired at Ayer Panas at a cost of \$21.65. Paths were cleared in one or two reserves, cost included under paragraph 5 .

\section{Protection of Forests.}

\section{FOREST LAWS.}

9. No Forest Ordinance has yet been passed in the Colony, and except in the Dindings the rules are wholly inadequate, especially in Malacca.

Proofs of a draft Forest Enactment for the Federated Malay States have now been printed and are under the consideration of Government, and it is my intention to submit this draft enactment to the Government of the Straits Settlements as soon as it has been criticised by the British Residents and others in the Federated Malay States. The framing of a Forest Law I consider to be essential, and the opinion of Mr. H. C. HiLL, late Inspector-General of Forests in India, was also strongly expressed in his report on the Forests of the Colony on this point.

io. On February ist, the new Dindings Timber Rules were brought into operation, they are practically identical with those in force in the Federated Malay States. Under them the timber is worked on the licence system, royalty being paid on the tonnage output, instead of on a combined system of personal passes issued at a monthly fee per man with a low royalty calculated on different dimensions for planks, logs, etc.

I. The present system has worked smoothly and effectively since its introduction; all men in the kongsis are given free sub-licences to shew that they are entitled to work there, and the managers have no inducement to try to introduce unlicensed workers. Formerly, it paid them to do this so long as they could conceal their presence from the Forest Officers.

12. The minimum diameter for cutting mangrove was raised to six inches during the year, which will further encoulage regeneration. 
13. $\Lambda$ Teak built life boat with the buoyancy tanks was purchased for use along the coast as the Malay boats in use were not trustworthy in bad weather and had very little capacity for impedimenta, when out for several nights.

\section{FOREST OFFENCES,}

For particulars see Form 7 .

14. In Singapore, there were 12 cases during the year. There were 12 convictions.

15. In Penang, prosecutions for illicit timber cutting rose from I 9 in I 903 to 30 in 1904, out of which there were 28 convictions and two acquittals. The fines realised amounted to $\$ 255.60$. In Province Wellesley four cases only were prosecuted and in each case a conviction was obtained, the fines amounted to $\$ 65$.

16. No persons were charged with offences in the reserves and no traces of illiciz cutting discovered.

The list of Police Court cases shows as great a diminution in numbers as in seriousness, and the proportion of undetected offences is now probably much smaller than in former years. This is attributed to three causes-(I) the diminished number of firewood cutters working in the Dindings River, (2) the lack of inducements to hardwood kongsi managers to try to keep illicit cutters at work under the new royalty system, and (3) improved supervision of checking of current passes by the staff under the direction of the Forest Ranger. Of 46 persons charged, 40 were Chinese and 6 Malays; 43 were con. victed, two acquitted and one escaped from custody after arrest and was not recaptured.

17. In Malacca, there were 26 cases, 16 convictions and Io acquittals, a poor percentage, and it seems probable that there have been undetected cases. Owing to the absence of Forest Laws, however, it is perhaps surprising that anything can be proved against offenders.

18. No fires were reported during the year.

\section{Inprovement of Forests.}

\section{Natural Reproduction.}

Ig. There is no mention made of this most important subject in any of the reports sent in to ine, but the remarks contained in the 1903 report, paragraph 12 , apply.

\section{ARTIFICIAL REPRODUCTION.}

20. Particulars are shewn in Form 8. In Singapore, the gutta percha plantation was up-kept during the year, about 30 acres.

21. In Penang, the teak plantation at Tassek Glugor was weeded on two occasions during the year and blanks filled, and inspected by the Conservator of Forests. So far this small trial shews teak will not do here, at least in such a locality as 'Tassek Glugor. The cost was $\$ 79.40$.

The gutta percha plantation at Batu Ferringi has been weeded and cleared, an additional three acres were planted up with 283 trees. Some of the plants planted in 1889 are now over six feet tall. The old trees of a seed-bearing age fruited in August, and a considerable quantity of young plants have been raised. It was only by covering the trees as well as we could with old fishing nets that it was possible to save any of the fruits from the attacks of bats, squirrels, monkeys, etc., which are extremely fond of them.

22. The Government plantations of gutta percha (Getah Taban) at Ayer Kroh were not enlarged during the year. The area remains at I 25 acres.

Some 15 acres of "blanks" in the Bukit Bruang Reserve were planted with mahogany and tembusu plants, bringing up the total area to 85 acres.

1 he gutta percha trees are-planted under shade and on the whole are doing well The seedlings received from Borneo and Sumatra have turned out badly and no more sucls plants will be purchased.

Para rubber.- There are some valuable rubber trees, at Irast 20 years old, at Bukit Sebukor. The seed crop is used for distribution to planters, and some experimental tapping produced rubber sold in London at $5 / 8$ a $1 \mathrm{~b}$.

The total cost of planting, weeding, clearing undergrowlh, tools, etc., was $\$ 2$, i 0 i. 33

The Conservator paid two visits to the plantation during the year. Records kept have been insufficient.

There are no plantations in the Dindings.

23. Great difficulty is experienced in procuring young gutta purcha plants, and in spite of effurts to ubtain seed throughout the year in the Federated Malay States, the Conservatcr of Forests only succeeled in obtaining about 50 seeds, out of which 10 germinated. 


\section{v. Exploitation.}

\section{Timber and Fuel.}

24. No returns are available from Singapore, but licences were issued to cut man-grove $\$ 69$ r. 40 , and for timber $\$ 468.40$.

In Penang although the number of licences issued during the year were a little more than half those of the year previous, 546 as against 1,055 , a slightly increased revenue was obtained, $\$ 854.5^{2}$ as against $\$ \$ 46.55$. These passes were, as usual, to cut timber, etc., outside the Forest Reserves and were of the usual pole size and chiefly used for fishing stakes and construction of native houses.

Timber realised $\$ 656.32$, Charcoal and Firewool $\$ 4.62$.

25. Marking Fees.-In the Dindings, 651 Class I trees were marked for felling, the charge being 5 I.OO per tree; this item is included in the hardwood royalty figures given below. One hundred and fifteen Class II trees were also marked, but no fees vere charged for them.

Hardwood Timber.-During the year felling operations were on in seven localities and four saw-yards were worked. A Chinaman who had taken up 20 acres of land for agricultural purposes also set up a small saw-yard to utilise the timber on his own land.

The record of timber extracted dates from March Ist, and amounts to 85,062 cubic feet ( $I, 7 \mathrm{OI} \cdot 2$ tons); of this $2,88+$ cubic fect $(57.7$ 10ns) was cut on alienated land and paid no royalty, the record being kept for checking purposes only; the balance of $82, \mathrm{I} 7 \mathrm{~s}$ cubic feet ( $1,643.5$ tons) paid royalty according to the classification of the timber. From the amount of royalty and fees paid in Jantary and Fobmary nofer the old system $(1,09.425)$ a further 360 tons may be estimated, making a total of atout 2,000 10ns. I think that this figure nay be taken as iarly correct as the arerage monthly tonnage from March ist works out at I 70 tons a month.

In 1903, the tonnage was estimated at 2,000.

27. The trade is chiefly confined to converting CJass $I$. B. (Meranti, etc.) timber into planks and scantlings, but a certain amount of Class $I$. $A$. (Merban, Chengai, Resak, etc.) timber is also exported in baulks. The revenue on timber was $\$ 7,476.28$ ats compared with $\$ 7: 436.80$ in 1903 .

28. Fircrood and Charcoal. - This source of revenue shews a great drop from the figures in 1903 and there will be a further fall in 1905 . I the explanation is simple. The Mangrove Forests require protection from over-working and the maximum number of cutters allowed has been reduced. An average of 75 cutters per mensem have been working in the Dindings River which will be maintained in 1905 .

29. $\$ 2,423.20$ was derived from cutting fees on the land alienated for padi cultivaion at Tanjong Burong. The District Officer says, "this item now disappears. I "reuret that the scheme fell through owing to the applicants refusing to carry out thei: "part of the agreement, but the land has not been constituted a part of the reserve "again as it is highly desirable from an agricultural point of view, that there shall be "land a ailable to extend the present bexdang. About 400 acres were cleared and the "Gorernment received $4,342.20$ in fees during 1903 and $190+$."

30. The revenue derived from charcoal was all derived fiom one person, a Chinaman who useles timber on his land by convering it into charconl. No licences to bum charonal on Crown Land have been issued for several years.

Sagars-Seven licences were issner to local Malays to malie "Sagors" from hardwood timber (Chengai principally) lying on Crown Land either abandoned by cutters or brought down by the weather. Ten per cent was charged on the value of the output and a large number of sagors and boat ribs were manufactured.

Tengal Bark. (Ceriops Candolleana.)-This is a bye-product obtained by firewood cutters and used for tanning sails. bakau bark is mixed with the tengah. Royaliy at the rate if 81.50 per thousand $i$ charged and realiced the comparatively large sum of $\$ 108.57$, 1epresenting $27,23 \$$ bundles.

Bakau Poles. - These were cut on licence for fishing stakes, royalty being paid at schedule rates.

3. The revenue from charcoal and firewood was $\$ 6,966$.I5, as against $\$ 9,612.35$ in 1903 .

32. In Malacca a small number of merbau and resak trees were felled in the Tebong and Batang Malacca Reserves for the cutting of sleepers for the Railway, under the supervision of Mr. BORGES. Royalty was paid at the rate of 22 cents per sleeper or about $\$ 5.00$ per ton of 50 cubic feet measurements.

33. Some miscellaneous felling was permicted in the Reserves at Merlimau and Ayer Panas under permits from the District Officer, Jasin. Royalty was paid 
on diameter measurements of trees in accordance with the Malacca timber roll. This method of calculating royalty is unsatisfactory and Government will be asked to sanction new rules in this respect at an early date.

\section{Other Pronuce.}

See Form I I. \$ 156.08 .

34. In Singaporc but little was extracted. In Penang, jungle produce produced

35. In the Dindings, 360 passes were issued for bamboos and canes, realising $\$ 1,065$ as against $\$ 40 \$$ in 1903 . The fee was raised from 50 cents (\$I in the Reserves) to $\$ 3$ per month, more applications for passes are received than entertained.

Other fungle Produce.-The fee-was raised from 50 cents (Nibong \$I) to $\$ 2$ per mensem, and $\$ 946$ were collected. This represents 503 passes and here again applications for passes had to be refused in the interests of the growing crop In I903, $\$ 5$ I4 were realised from 690 passes.

36. In Malacca, the Hon'ble Resident Councillor says "Passes for jungle "produce at $\$ 3$ per man per month in the reserves were issued during the early "part of the year. They were stopped on the recommendation of Mr. GAGLIARDI " and will be resumed when a proper system of rotation has been organised."

"Cutling Liccnces. - The system at present in force is very defective, as there is "no prop r supervision over the operations of holders of licences. The services of the "Forest Staff will be used to supervise all fellings on Crown Lands whether inside

"reserved forests or not."

"37. The system of free permits to agriculturists for timber for their ow $n$ use "is also liable to abuse and wilt-have to be restricted. - The District Officer, Alor "Gajal, issued nearly 700 free permits against 300 revenue permits."

\section{CHAPTER III.}

\section{Financial Results.}

Particulars are shewn in frorm II.

\section{x. Revenue.}

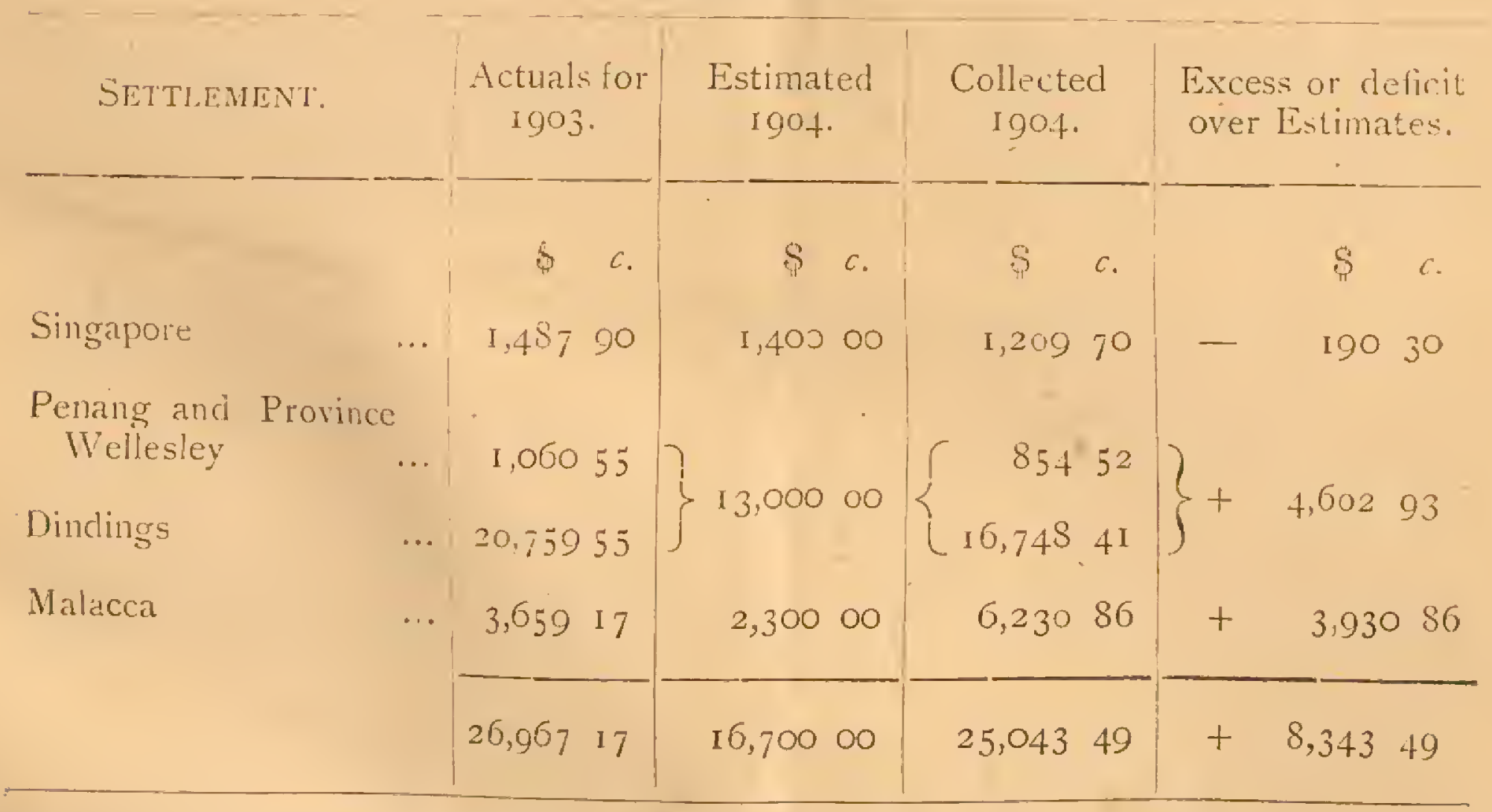

38. An increase in Malacca of $\$ 2,571.69$ and a decrease in the Dindings of $\$ 4,011.14$ over 1903 .

As explained already in pardgraph 28 , the falling off in the Dindings is due to the reduction of the number of permils to cut mangrove, and the figures for 1904 represent more nearly the normal yield of the forests, which was before exceeded, also revenue for fruit farms included in 1903 not now included. 'The increase in Malacca is satisfactory and normal. 


\begin{tabular}{|c|c|c|c|c|c|}
\hline SETTLEMENT. & & $\begin{array}{l}\text { Expenditure } \\
\text { I903. }\end{array}$ & $\begin{array}{c}\text { Estimated } \\
\text { 1904. }\end{array}$ & $\begin{array}{l}\text { Expenditure } \\
\text { I } 904 .\end{array}$ & Savings. \\
\hline \multirow[t]{2}{*}{$\begin{array}{ll}\text { Singapore } & \ldots \\
\text { Penangand Province } \\
\text { Weilesley } \\
\text { Dindings } & \ldots \\
\text { Malacca- } & \ldots\end{array}$} & $\begin{array}{l}\cdots \\
\cdots\end{array}$ & $\begin{array}{cc}\$ & c \\
5,094 & 48 \\
& \\
3,044 & 36 \\
3,795 & 46 \\
7,470 & 79\end{array}$ & $\left\{\begin{array}{r}12,28200 \\
8,44800\end{array}\right.$ & $\begin{array}{cc}\$ & c \\
6,296 & 45 \\
& \\
3,929 & 53 \\
5,246 & 27 \\
7,754 & 86\end{array}$ & $\begin{array}{rr}3106 & 20 \\
693 & 14\end{array}$ \\
\hline & & 19,40509 & 29,32200 & 23,227 II & 6,09489 \\
\hline
\end{tabular}

The total expenditure was $\$ 23,227$. I I as against $\$ 19,405.09$ in 1903 , the increases are chiefly due to rise in Conservator's salary, Colonial share $£ 340$ instead of $£, 250$ and the salary of Ranger II Grade, Dindings, at $£ \mathrm{I} 20$ for the whole year, in 1903 only half the year. Of the total $\$ 23,227$.I I, $\$ 16,030.4$ I was spent on salaries and allowances

40. The following is a statement of revenue and expenditure and shews a net surplus of \$I,8 I $6.38:-$

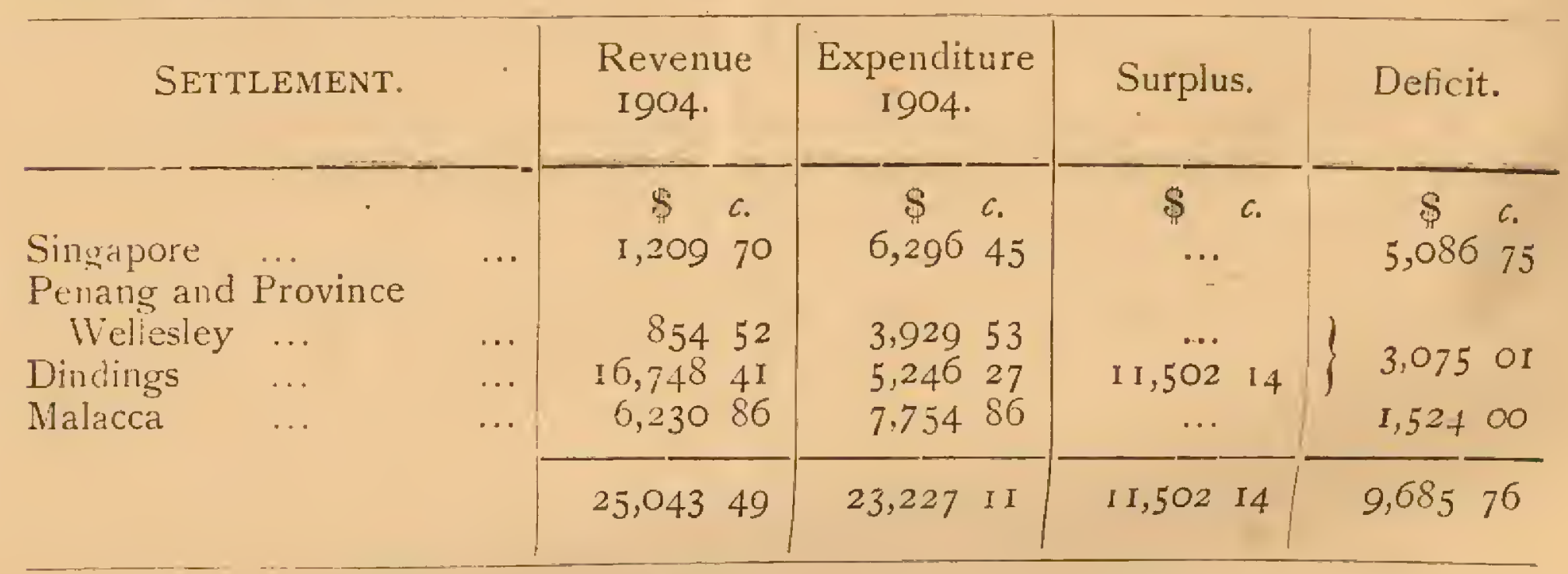

This is on the whole financially satisfactory, as it must be remembered that the bulk of the Forest Reserves in the Colony are recuperating from excessive working in the past, from a purely forest point of view it is probable that a fairly large deficit should be shewn annually, but it is questionable whether it would be wise to expend large sums of money in planting, for instance, gutta percha at great cost, when there are practically unlimited supplies next door in the Federated Malay States growing wild and only needing a comparatively small expenditure to help them on.

\section{CHAPTER IV.}

\section{Establishment.}

4I. In Singapore, the post of Forest Ranger III Grade is still vacant, but I think should be filled.

42. In Penang, there was no change in the staff during the year. In the subordinate staff the Forest Guard, CHE MAT, stationed at Balik Pulau, died in June and was replaced by HARON. Forester TAMBY KECHIL, stationed in the Province, was detected making a false entry in his Journal and was reduced from $\$ 20$ to $\$ 15$ per month. The rest worked well.

43. In the Dindings, the Department was as hitherto under the control of the District Officer, subject to the supervision of the Conservator of Forests, Federated Malay States and Straits Settlements. The District Officer writes, "Mr. BoRGES was "in charge of the outside work during the year with the exception of the months of "Uclober and November when he was lent to Malacca temporarily. Mr. BoRges has "now been permanently appointed to Malacca, a loss to the Dindings as he has done "very good work here; he knows the district and people in it and has shewn great zeal "and energy in carrying out his duties. I hope that a trained Forest Ranger will suon "be obtained to replace him as one is absolutely necessary to carry out the Timber "rules beneficially. 
"Mr. L. PASQual was appointed Deputy Ranger on 9th February, I904, and "Mr. C. J. Fox, Forest Department Clerk on 25th March; buth Officers have "performed their duties satisfactorily."

There were several changes among the Foresters and Forest Guards; the present staff is I think more efficient than it used to be-the men having been trained.

44. In Malacca, the Department was in charge of Mr. GaGLiardi. Forest Ranger, Grade II, up to the 26 th June. On his resignation the appointment of Forest Ranger was vacant until the arrival of Mr. BoRGES from the Dinfings in October. This officer returned to the Dindings on roth December, on the completio i of the service for which he had been temporarily transferred, i.e. to supervise the fellings of timber for Railway sleepers in the Forest Reserves at Tebong and Batang Malacca.

45. There was no alteration in the subordinate staff during the year. This consists of two Foresters at $\$ 240$ each and I6 Forest Guards at rates varying from $\$ 96$ to \$144. The vacancy for a Clerk at $\$ 300$ was not filled up all necessary clerical work having been prepared by the Forest Ranger in charge and in the Land and District Offices.

46. The services of Mr. A. M. BURN-MURUOCH, Conservator of Forests, were permanently transferred from India to the Colony of the Straits Settlements and the Federated Malay States on Ist January, I 904, and his salary raised to $£ \mathrm{I}, 020$ per annum rising by triennial increments of $£ 60$ to $£, 1,200$ per annum.

One-third share is paid by the Colonial Government and two-thirds by the Federated Malay states.

He visited each Settlement during the year spending 37 days on tour in the Colony besides a certain proportion of his time in office work connected with Colonial matters.

His visits to the Colony were as follows :-

\begin{tabular}{|c|c|c|c|}
\hline January & $\cdots$ & $\ldots$ & Dindings. \\
\hline February & $\cdots$ & $\ldots$ & Dindings ( Ist to 2 nd ) \\
\hline March & $\cdots$ & $\cdots$ & Dindings ( 16 th to Igth) \\
\hline April & $\cdots$ & $\cdots$ & Singapore (I 7 th to 2 Ist) \\
\hline May & $\cdots$ & $\ldots$ & Singapore \\
\hline June & ... & $\cdots$ & Malacca (4th to 6th) \\
\hline$"$, & $\cdots$ & $\cdots$ & Penang ( $\mathrm{I} 6$ th to I8th) \\
\hline July - & $\cdots$ & $\cdots$ & Penang (I4th to 20 th) \\
\hline August & ... & $\cdots$ & Malacca (28th to 3 oth). \\
\hline November & ... & ... & Singapore (6th to 9th) \\
\hline December & $\ldots$ & ... & Singapore (I Ith to I 4 th) \\
\hline
\end{tabular}

A. M. BURN-MURDOCH,

Conservator of Forests,

Federated Malay States $\xi^{\circ}$ Straits Settlements. 
FORM NO. I.

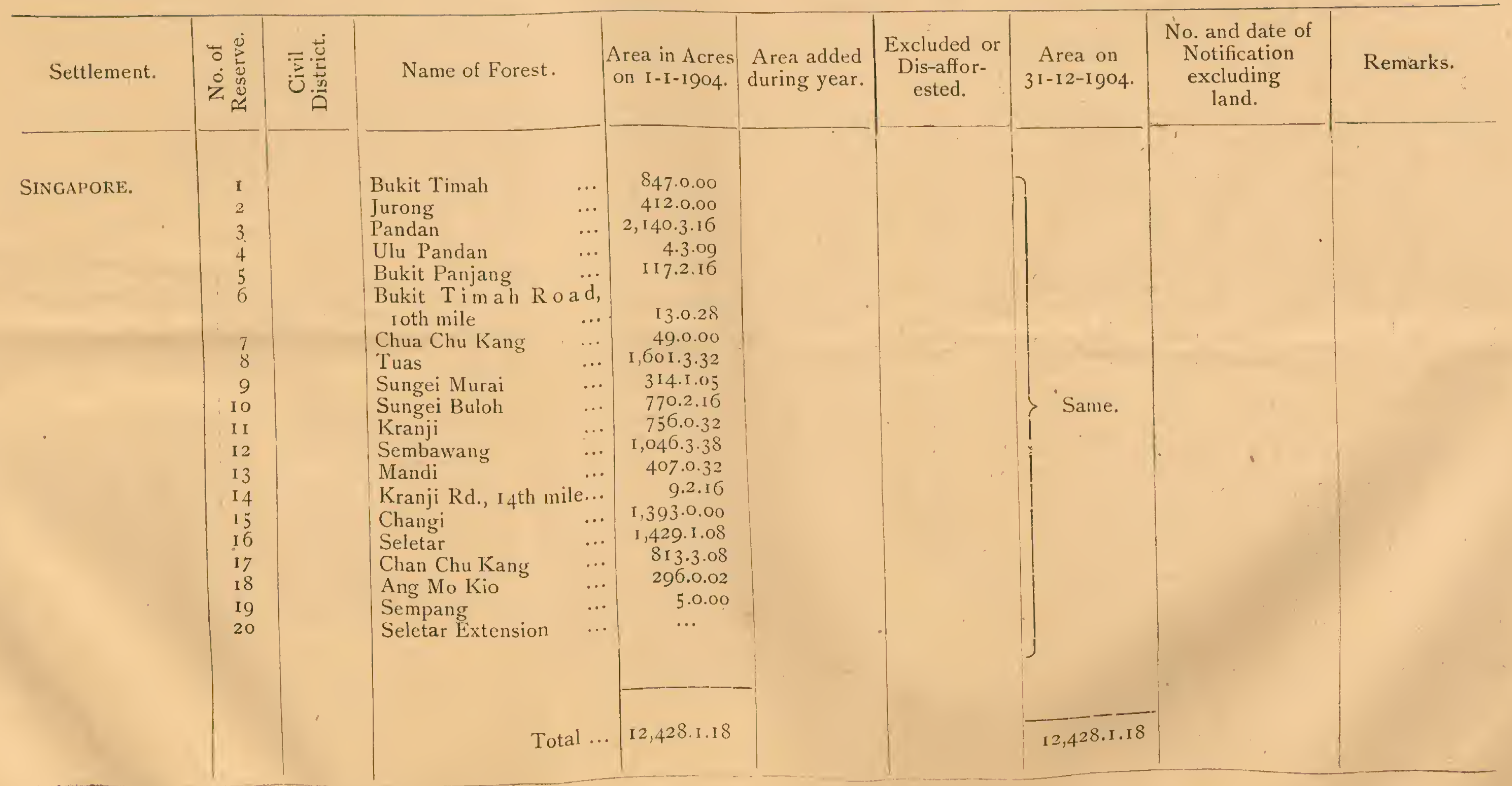


FORM No. 1,- Continued.

\begin{tabular}{|c|c|c|c|c|c|c|c|c|c|}
\hline setlement. & 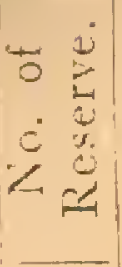 & Civil District. & Name of Forest. & $\begin{array}{l}\text { Area in Acres } \\
\text { on I-I-190 } 4\end{array}$ & $\begin{array}{l}\text { Area added } \\
\text { during year. }\end{array}$ & $\begin{array}{l}\text { Excluded or } \\
\text { Dis-affor- } \\
\text { ested. }\end{array}$ & $\begin{array}{c}\text { Arca on } \\
3-12-1904\end{array}$ & $\begin{array}{c}\text { No. \& date of } \\
\text { Notification } \\
\text { excluding } \\
\text { Iand. }\end{array}$ & Remarks. \\
\hline \multirow[t]{2}{*}{$\begin{array}{l}\text { PROVINCI: } \\
\text { WELILESLEE: }\end{array}$} & & $\begin{array}{l}\text { Northern District } \\
\text { Central District } \\
\text { Southern District }\end{array}$ & $\begin{array}{lc}\text { Tassek Glugor } & \ldots \\
\text { Bukit Scraya } & \ldots \\
\text { Bukit Mertajam } & \ldots \\
\text { Juru Hill } & \ldots \\
\text { Gajah Mati } & \ldots \\
\text { Govt. Exp. Gardens } \\
\text { Bukit Gua Ipoh } & \ldots \\
\text { Lot } 435 & \ldots \\
\text { Lot 3231. } & \ldots \\
\text { Bukit Panchor } & \ldots\end{array}$ & $\begin{array}{r}1,761 \\
112 \\
162 \\
417 \\
94 \\
3 \\
330 \\
189 \\
1.3 \\
1,476\end{array}$ & & & Same & & \\
\hline & & & Total ... & 4,557 & & & 4,557 & & \\
\hline \multirow[t]{2}{*}{ PLANG. } & $\begin{array}{l}A \\
B \\
C \\
G \\
H \\
I\end{array}$ & 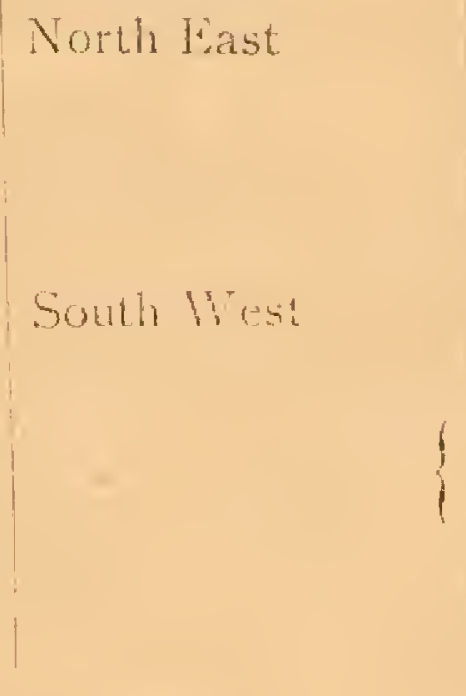 & 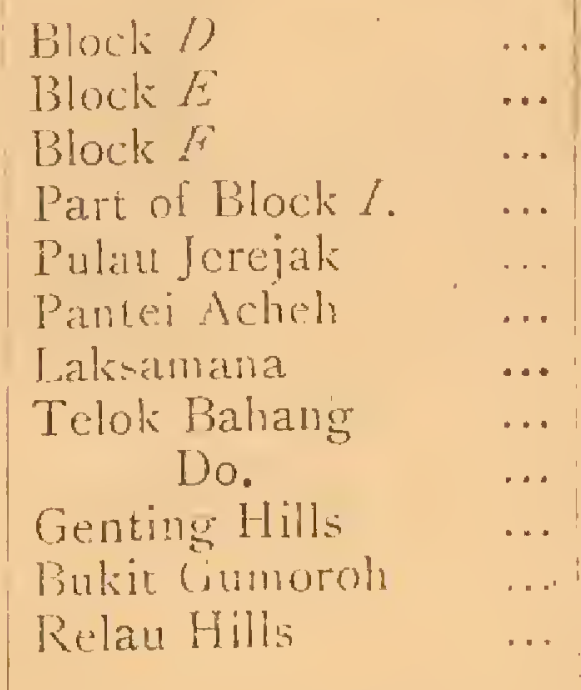 & $\begin{array}{r}5,741 \\
252 \\
233 \\
18 \\
887 \\
887 \\
3,208 \\
465 \\
380 \\
236 \\
21 \\
205 \\
151\end{array}$ & & & Samc & & \\
\hline & & & Total & 11,797 & & & 11,797 & & \\
\hline
\end{tabular}


FORM NO. I.-Continued.

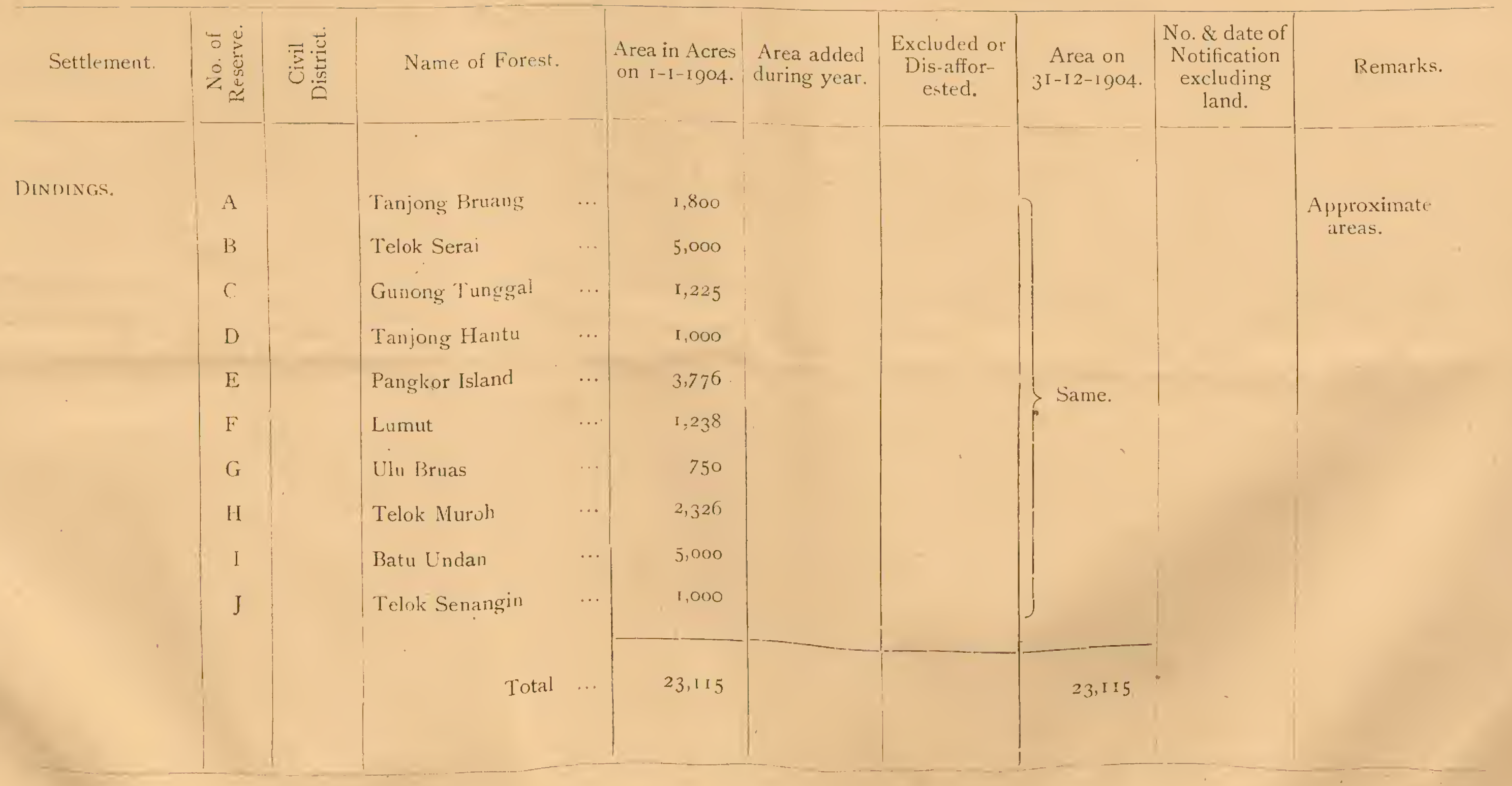


Form NO. I_-Concluded.

\begin{tabular}{|c|c|c|c|c|c|c|c|c|c|}
\hline Settlement. & 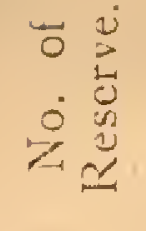 & $\begin{array}{c}\text { Civil } \\
\text { District. }\end{array}$ & Name of Forest. & $\begin{array}{l}\text { Area in Acres } \\
\text { On I-I-I DO }\end{array}$ & $\begin{array}{l}\text { Area added } \\
\text { during year. }\end{array}$ & $\begin{array}{l}\text { Excluded or } \\
\text { Dis-affor- } \\
\text { csted. }\end{array}$ & $\begin{array}{c}\text { Area on } \\
\text { 31-12-1904. }\end{array}$ & $\begin{array}{l}\text { No. \& date of } \\
\text { Notification } \\
\text { excluding } \\
\text { land. }\end{array}$ & Remarks. \\
\hline \multirow[t]{5}{*}{ MALACCA. } & $\begin{array}{l}\text { I } \\
2 \\
3 \\
4 \\
5 \\
5 \\
6\end{array}$ & $\begin{array}{c}\text { Jasin } \\
\text { District }\end{array}$ & $\begin{array}{l}\text { Ayer Panas } \\
\text { Merliman } \\
\text { Bukit Senggeh } \\
\text { Bukit Sedanan } \\
\text { Batangy Malaka } \\
\text { Nyalas }\end{array}$ & $\begin{array}{l}3,242 \\
6,217 \\
9,430 \\
7,806 \\
3.549\end{array}$ & 2,468 & & $\begin{array}{l}3,242 \\
6,217 \\
9,430 \\
7,806 \\
3,5,49 \\
2,468\end{array}$ & & \\
\hline & $\begin{array}{l}\mathrm{I} \\
2\end{array}$ & $\begin{array}{c}\text { Alor Gajah } \\
\text { District }\end{array}\{$ & $\begin{array}{l}\text { Sungei Udang } \\
\text { Bukit Panchor }\end{array}$ & $\begin{array}{l}4,392 \\
2.862\end{array}$ & & & $\begin{array}{l}+392 \\
2.862\end{array}$ & & \\
\hline & 3 &, & $\left.\begin{array}{c}\text { Brisu, Ramuan China } \\
\text { and Sungei Siput ... }\end{array}\right\}$ & $\begin{array}{r}2,591 \\
9 \mathrm{II}\end{array}$ & & & $\begin{array}{r}2,591 \\
911\end{array}$ & & \\
\hline & $\begin{array}{l}\text { I } \\
2\end{array}$ & $\begin{array}{l}\text { Central } \\
\text { District }\end{array}$ & $\begin{array}{l}\text { Bukit Bruang } \\
\text { Bukit Sebukor , } \quad \ldots\end{array}$ & $\begin{array}{r}6,174 \\
44\end{array}$ & & 52 & $\begin{array}{r}6,122 \\
44\end{array}$ & C. S. $2736 / 04$ & \\
\hline & & & Total & 47,218 & 2,468 & $5^{2}$ & 49,634 & & \\
\hline
\end{tabular}


FORM No. 2.

Statement shemng progress made in forming new Reserves during the year 1904.

\begin{tabular}{|c|c|c|c|c|c|c|c|c|}
\hline \multirow[b]{2}{*}{ Settlemient. } & \multirow{2}{*}{$\begin{array}{l}\text { Area of reserves } \\
\text { already finally } \\
\text { Gazetted on } \\
31 \text { Dec. } 1904 \text {. }\end{array}$} & \multicolumn{3}{|c|}{ Area fina!ly Gazetted during year. } & \multirow{2}{*}{$\begin{array}{c}\text { Total area finally } \\
\text { Gazetted } \\
\text { at close of } \\
\text { year I } 904 \text {. }\end{array}$} & \multicolumn{2}{|c|}{$\begin{array}{c}\text { Areas proposed and not } \\
\text { yet finally Gazetted. }\end{array}$} & \multirow{2}{*}{ Remarks. } \\
\hline & & $\begin{array}{l}\text { Name of } \\
\text { Reserve. }\end{array}$ & $\begin{array}{l}\text { No. of Noti- } \\
\text { fication } \\
\text { in Gazette. }\end{array}$ & $\begin{array}{l}\text { Area of } \\
\text { acres. }\end{array}$ & & Name. & Area. & \\
\hline $\begin{array}{l}\text { North Last District } \\
\text { South Wrst District }\end{array}$ & $\begin{array}{l}7,367 \\
4,43^{\circ}\end{array}$ & & & & $\begin{array}{l}7,367 \\
4,43^{\circ}\end{array}$ & & & \\
\hline P'ROVINCE WELIESLEY. & 11,797 & & & & 11,797 & & & 4 \\
\hline $\begin{array}{l}\text { Northern District } \\
\text { Central District } \\
\text { Southern District }\end{array}$ & $\begin{array}{l}1,761 \\
1,320 \\
1,476\end{array}$ & . & & & $\begin{array}{l}1,761 \\
1,320 \\
1,476\end{array}$ & & & \\
\hline . & 4,557 & & & & 4.557 & . & & \\
\hline DINDINGS. & 23, I I $5-0-00$ & & & & 23,1 I $5-0-00$ & & & \\
\hline MALACCA. & $47,218-0-00$ & Nyalas & & 2,468 & $49,634-0.00$ & & & $\begin{array}{l}\text { C. S. } 273^{6 / 04} \text {. } \\
52 \text { acres disafforested. }\end{array}$ \\
\hline SINGAPORE: & $12,4,28-1-18$ & & & & $12,428-I-18$ & & & \\
\hline
\end{tabular}


FORM NO. 3.

Recoril of Demarcation and Maintenance of Boundaries for 1904.

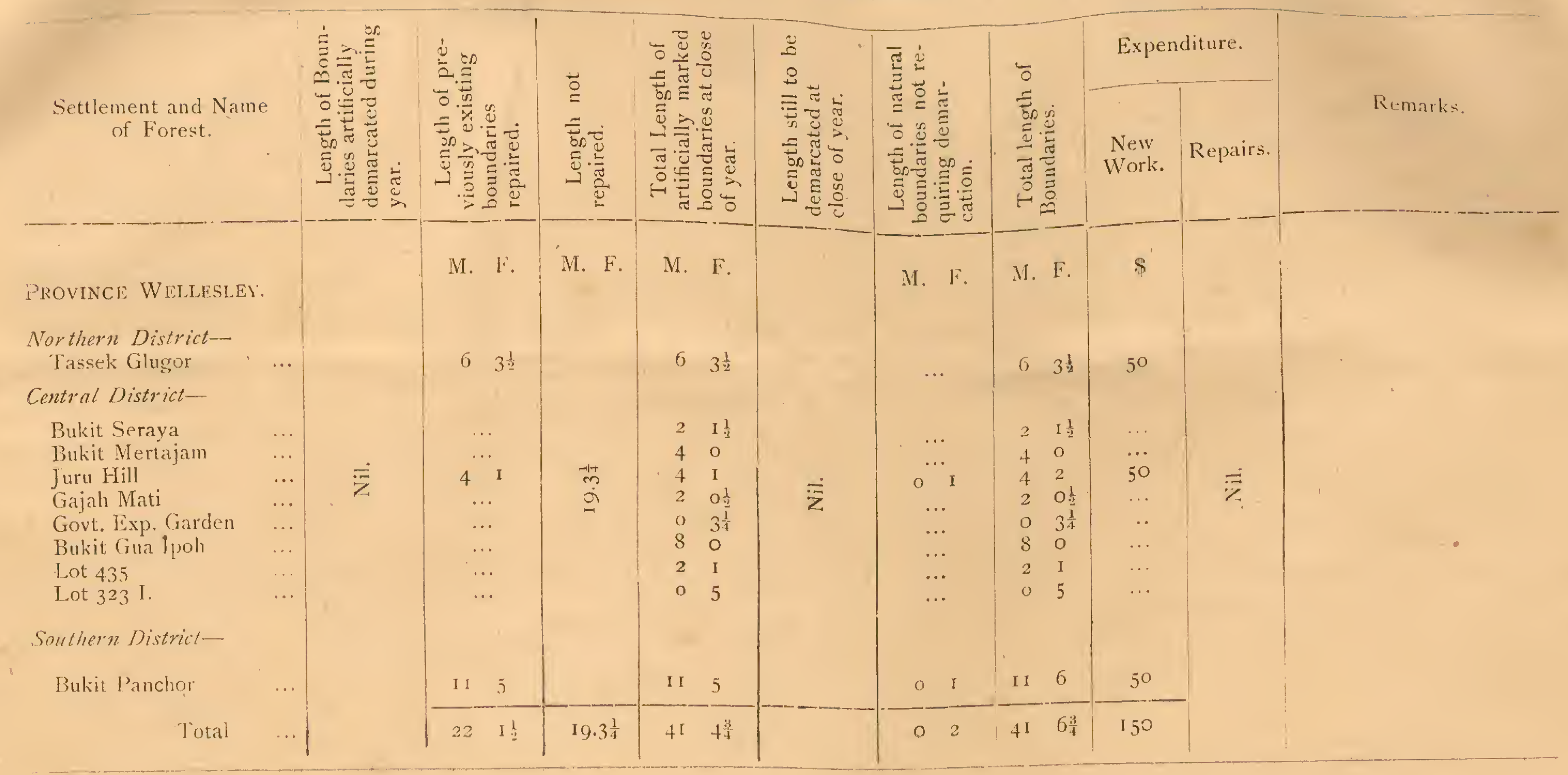


FORM No, 3--Concluded.

Record of Demarcation and Maintenance of Boundaries for 1904

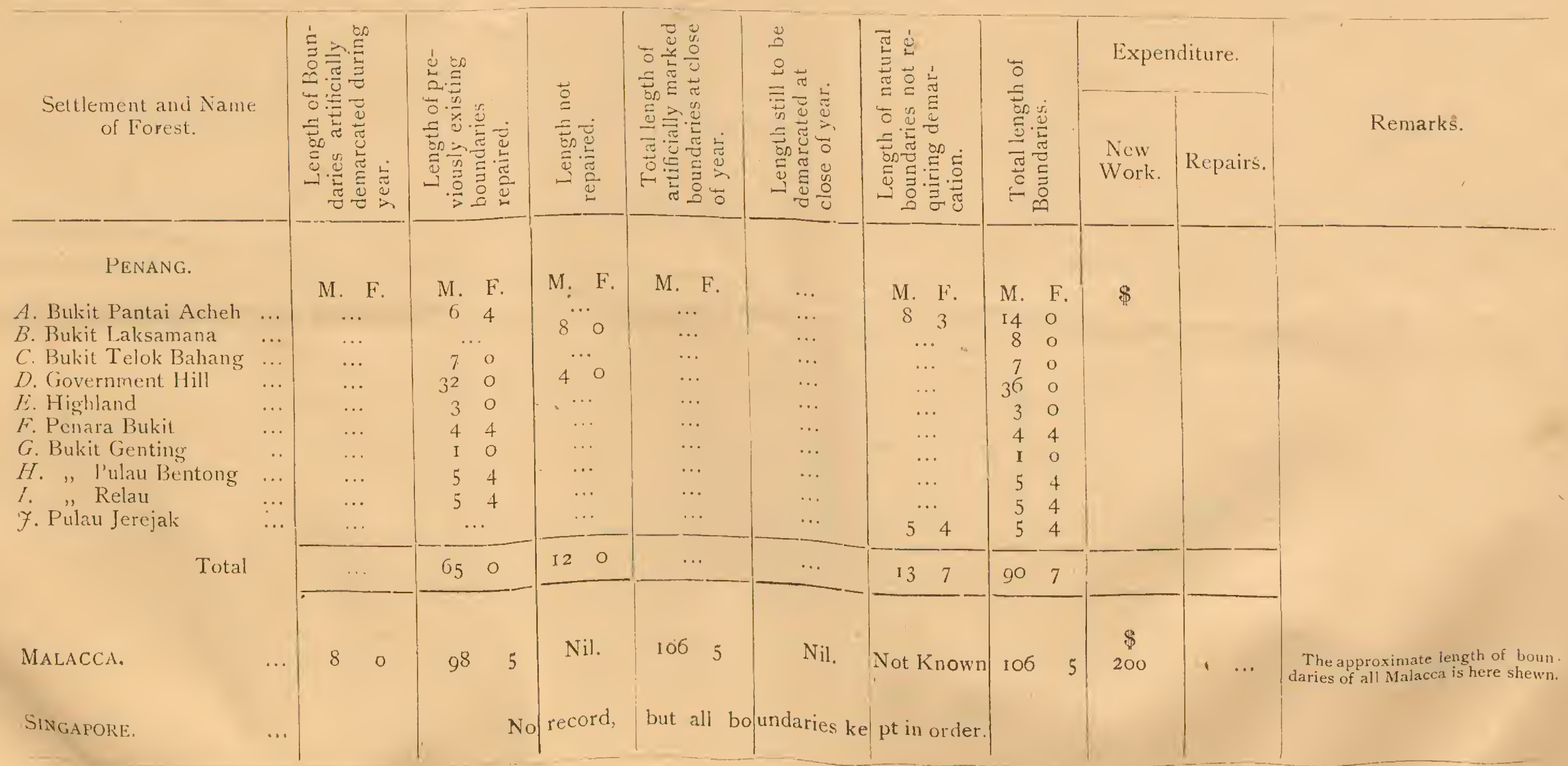


FORM NO. +

Statement of Area Suiveyed and Linsurveyed during the year. 1904 .

\begin{tabular}{|c|c|c|c|c|c|c|c|c|c|c|c|c|c|}
\hline \multirow{3}{*}{ Settlement. } & \multicolumn{5}{|c|}{ By Survey Department. } & \multicolumn{8}{|c|}{ Surveys by Chain and Compass or by local offices. } \\
\hline & \multicolumn{2}{|c|}{$\begin{array}{c}\text { With interior } \\
\text { details. }\end{array}$} & \multicolumn{2}{|c|}{ Boundary Surveys. } & \multirow{2}{*}{ Cost. } & \multirow{2}{*}{ Name of Forest. } & \multicolumn{2}{|c|}{$\begin{array}{l}\text { With interior } \\
\text { details. }\end{array}$} & \multicolumn{2}{|c|}{ Boundary Surveys. } & \multirow{2}{*}{$\begin{array}{l}\text { Area remain- } \\
\text { ing to be } \\
\text { surveyed. }\end{array}$} & \multicolumn{2}{|c|}{ Cost. } \\
\hline & $\begin{array}{c}\text { Pre- } \\
\text { vious. }\end{array}$ & $\begin{array}{c}\text { During } \\
\text { year. }\end{array}$ & Previous. & $\begin{array}{l}\text { During } \\
\text { year. }\end{array}$ & & & Previous & $\begin{array}{c}\text { During } \\
\text { year. }\end{array}$ & Previous. & $\begin{array}{l}\text { During } \\
\text { year. }\end{array}$ & & Previous. & $\begin{array}{l}\text { During } \\
\text { year. }\end{array}$ \\
\hline PENANG. & Acres & Acres & Acres & Acres & & & & & & & & & \\
\hline $\left.\begin{array}{l}\text { North East } \\
\text { District }\end{array}\right\}$ & $\begin{array}{c}5,637 \\
-25^{2} \\
233 \\
\cdots \\
887\end{array}$ & $\ldots$ & I 8 & $\cdots$ & $\cdots$ & $\begin{array}{l}D . \text { Govt. Hill } \\
E \text {. Highland } \\
F \text {. Penara Bukit } \\
\text { Part of Relau Hill } \\
\text { Pulau Jerejak }\end{array}$ & 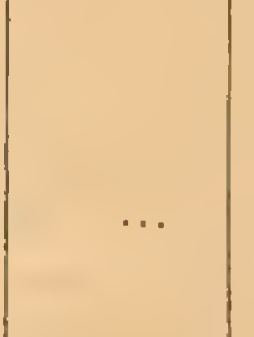 & & $\cdots$ & $\cdots$ & $\cdots$ & & $\cdots$ \\
\hline $\left.\begin{array}{l}\text { South West } \\
\text { District }\end{array}\right\}$ & $\cdots$ & $\cdots$ & $\begin{array}{r}3,208 \\
465 \\
380 \\
21 \\
205 \\
151\end{array}$ & $\cdots$ & $\cdots$ & $\begin{array}{l}\text { A. Pantai Acheh } \\
\text { B. Laksamana } \\
C . \text { Telok Bahang } \\
G \text { Genting Hills } \\
H . \text { Bukit Gumoroh } \\
\text { I. Relau Hills }\end{array}$ & 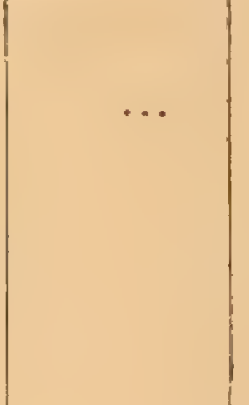 & $\cdots$ & $\cdots$ & $\cdots$ & $\cdots$ & & $\cdots$ \\
\hline $\left.\begin{array}{l}\text { PROVINCE } \\
\text { WELLESLEI'}\end{array}\right\}$ & $\cdots$ & $\cdots$ & $\ldots$ & $\cdots$ & $\cdots$ & $\cdots$ & $\ldots$ & .. & $\cdots$ & $\ldots$ & $\cdots$ & $\ldots$ & $\cdots$ \\
\hline DINDINGS. & $\cdots$ & $\cdots$ & $\begin{array}{l}\text { Suryeyeri } \\
\text { not plot- } \\
\text { ted }\end{array}$ & $\cdots$ & $\cdots$ & A. T'jong Burong & $\ldots$ & .. & $\cdots$ & $\begin{array}{l}\text { Surveyed } \\
\text { not plot- } \\
\text { ted }\end{array}$ & 1,800 & $\cdots$ & $\cdots$ \\
\hline
\end{tabular}


FORM No. t-Concluded.

Statenent of Area Surveyed and Unsurveyed during the year 1904.

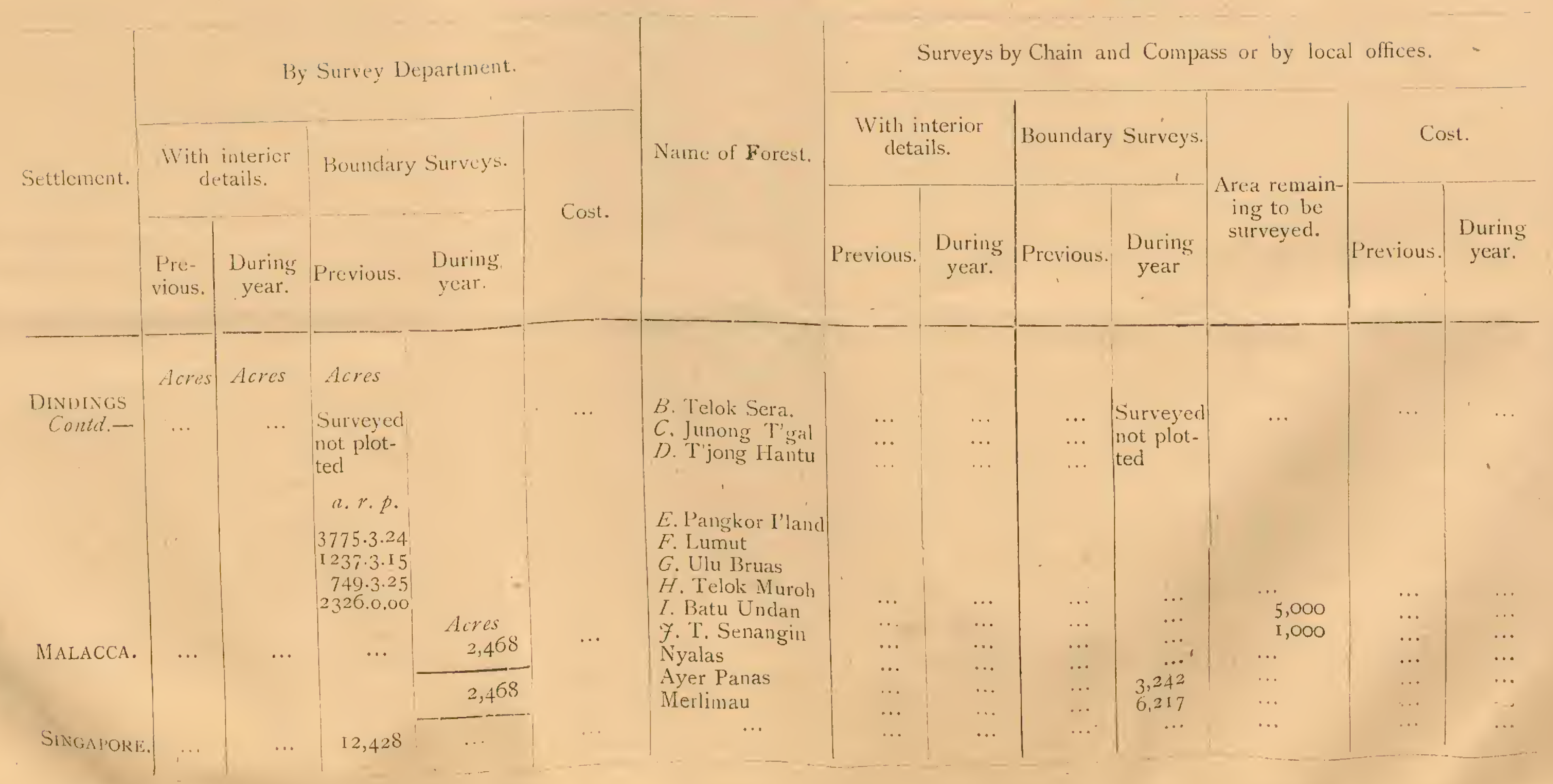


FORM NO. 5.

Progress made in Working 'Plans during 1904.

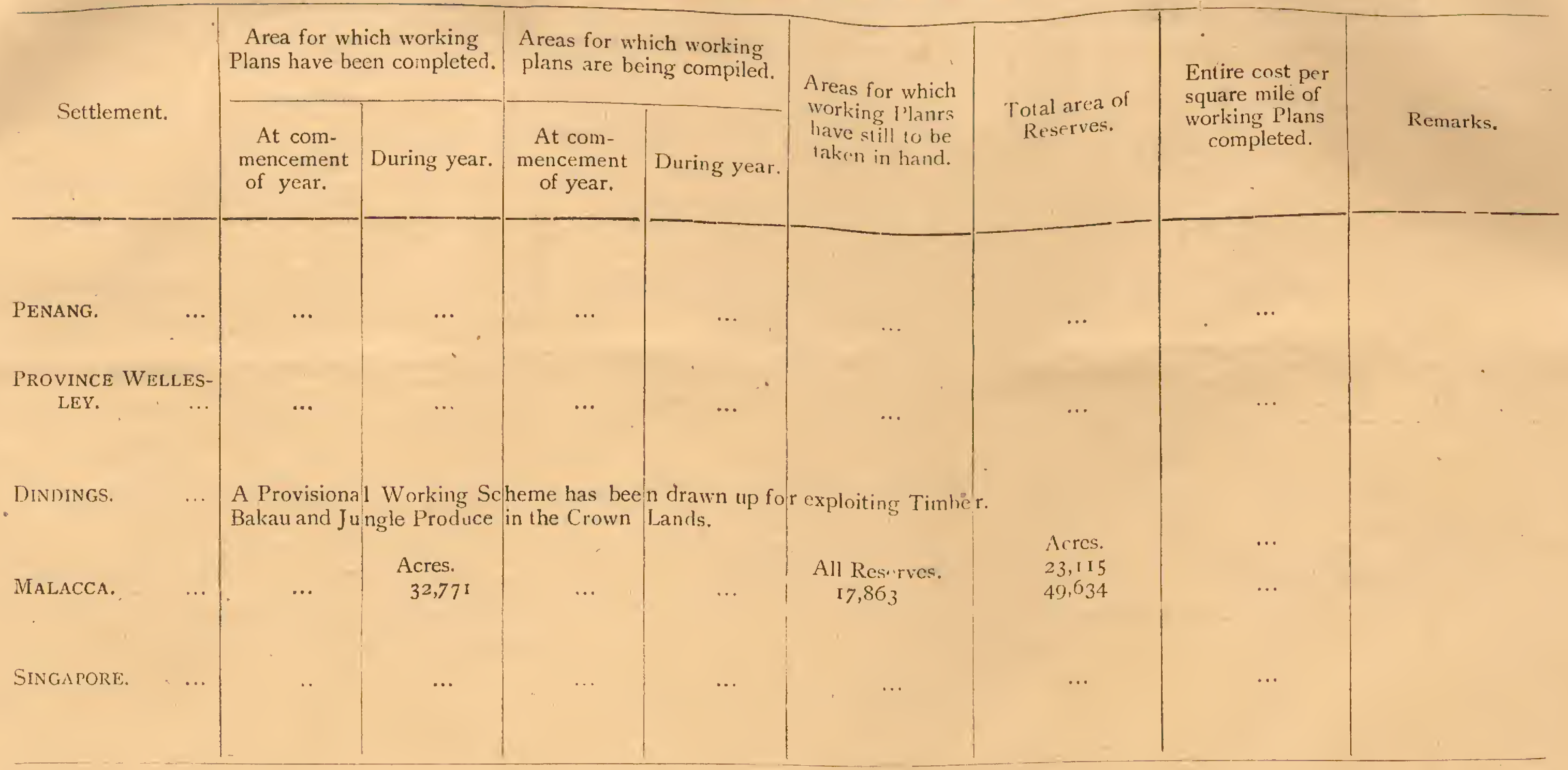


FORM No. 6.

Communications and Buildings igof.

\begin{tabular}{|c|c|c|c|c|c|c|c|c|c|c|c|}
\hline \multicolumn{5}{|c|}{ New Work undertaken during year. } & \multirow{3}{*}{$\begin{array}{l}\text { Total } \\
\text { expend- } \\
\text { ed on } \\
\text { New } \\
\text { Work. }\end{array}$} & \multicolumn{5}{|c|}{ Repairs executed during year. } & \multirow{3}{*}{$\begin{array}{l}\text { Total } \\
\text { Expenditure } \\
\text { on Repairs. }\end{array}$} \\
\hline \multicolumn{2}{|l|}{ Buildings. } & \multirow[b]{2}{*}{ Roads and Paths. } & \multirow{2}{*}{$\begin{array}{l}\text { Length } \\
\text { of road. }\end{array}$} & \multirow{2}{*}{\begin{tabular}{|l} 
Expen- \\
diture \\
incurred.
\end{tabular}} & & \multicolumn{2}{|c|}{ Buildings. } & \multicolumn{3}{|c|}{ Roads and Paths. } & \\
\hline $\begin{array}{l}\text { Description of } \\
\text { building. }\end{array}$ & $\begin{array}{c}\text { Expen- } \\
\text { diture: }\end{array}$ & & & & & $\begin{array}{l}\text { Nature of } \\
\text { Repairs. }\end{array}$ & $\begin{array}{l}\text { Expen. } \\
\text { diture. }\end{array}$ & $\begin{array}{c}\text { Nature of } \\
\text { Repairs. }\end{array}$ & $\begin{array}{l}\text { Length } \\
\text { repaired. }\end{array}$ & $\begin{array}{l}\text { Expen- } \\
\text { diture. }\end{array}$ & \\
\hline PENANG. & $\$ \cdots c$ & $\cdots$ & $\cdots$ & $\begin{array}{c}\$ c \\
\ldots\end{array}$ & $\cdot \ldots$ & $\cdots$ & $\begin{array}{c}\$ \quad c . \\
\ldots\end{array}$ & $\cdots$ & $\ldots$ & $\$ \quad c$. & $\$ c$ \\
\hline PŔOVINCE WELLESLEY. & $\cdots$ & $\cdots$ & $\cdots$ & $\cdots$ & $\cdots$ & $\cdots$ & $\ldots$ & $\cdots$ & $\cdots$ & $\ldots$ & $\cdots$ \\
\hline $\begin{array}{l}\text { Forest Station, } \\
\text { Tassek Glugor } \\
\text { Dindings. }\end{array}$ & $\cdots$ & $\cdots$ & $\cdots$ & $\cdots$ & $\cdots$ & $\begin{array}{l}\text { Lime washed and } \\
\text { coal tarred }\end{array}$ & 248 & $\cdots$ & $\cdots$ & $\cdots$ & $\cdots$ \\
\hline $\begin{array}{l}\text { Forest Guards Quarters } \\
\text { at Chengkat Resam.. } \\
\begin{array}{l}\text { Purchase of Whale } \\
\text { boat ... }\end{array}\end{array}$ & $\begin{array}{ll}33 & 80 \\
395 & 90\end{array}$ & $\ldots$ & $\cdots$ & $\cdots$ & -3380 & $\cdots$ & $\cdots$ & $\begin{array}{c}\text { Clearing } \\
\text { boundary } \\
\text { paths. } \\
\vdots \\
\vdots . .\end{array}$ & $\begin{array}{cc}\text { M. F. } \\
40 . & \text { Oo } \\
& \\
\ldots\end{array}$ & 29940 & $\begin{array}{l}29940 \\
\ldots\end{array}$ \\
\hline & & . & & & 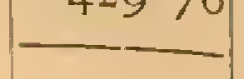 & .. & $\cdots$ & & $1=2$ & $\cdots$ & 29940 \\
\hline MALACCA. & $\cdots$ & $\ldots \ldots$ & $\cdots$ & $\cdots$ & $\cdots$ & $\begin{array}{l}\text { Repairs to Forest } \\
\text { Guards Quarters at } \\
\text { Ayer Panas. }\end{array}$ & 2165 & \begin{tabular}{|l} 
Clearing \\
boundaries \& \\
paths of Forest \\
Reserves.
\end{tabular} & $\begin{array}{c}\text { Not } \\
\text { known. }\end{array}$ & 497 I 5 & $\cdots$ \\
\hline SINGAPORE. & $\cdots$ & $\cdots$ & $\cdots$ & $\cdots$ & $\cdots$ & . & & $\cdots$ & $\cdots$ & $\cdots$ & $\cdots$ \\
\hline
\end{tabular}


FORM No. 7 .

Register of breaches of Forest Rules for 1904

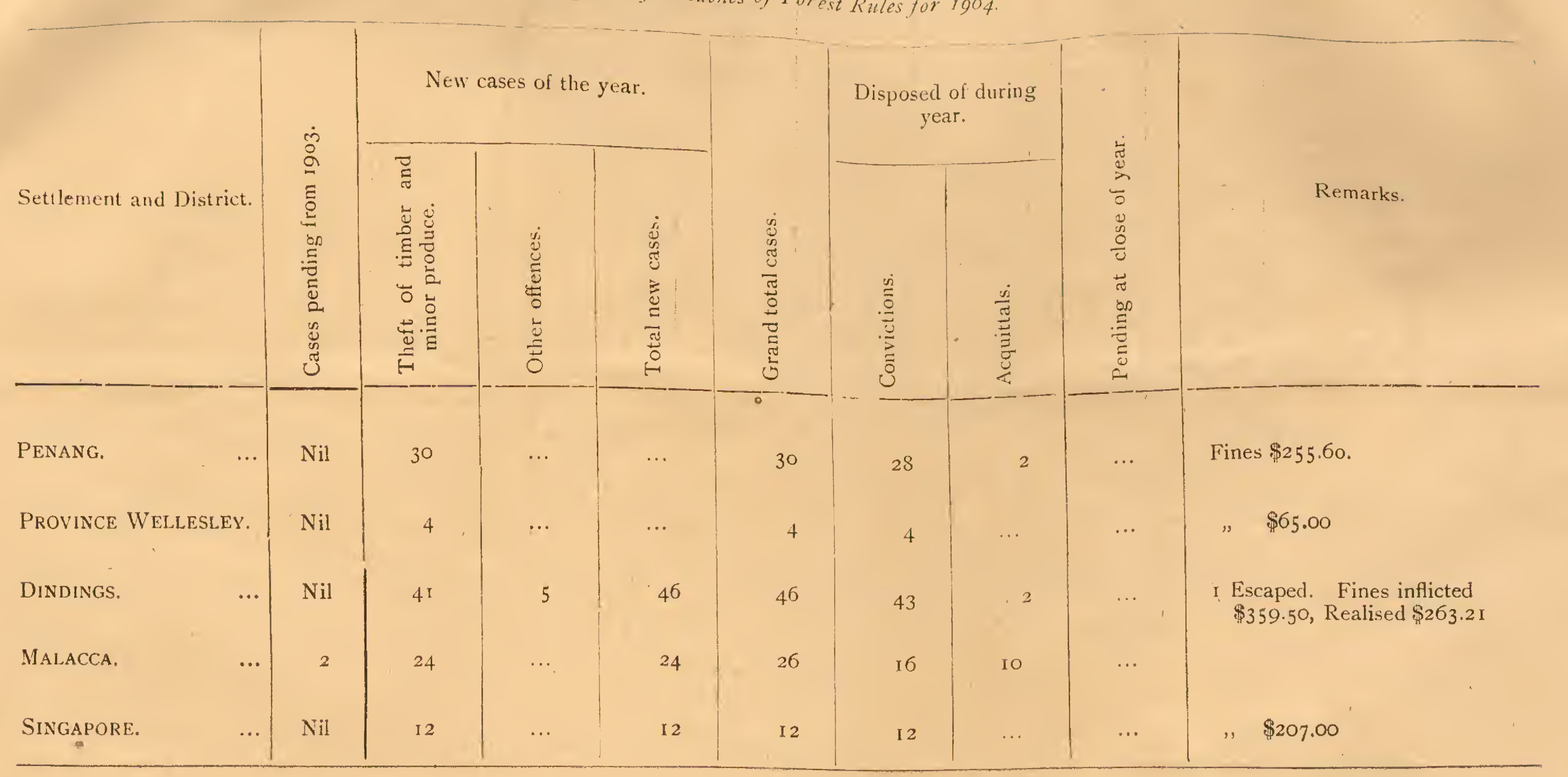


FORM No. 8.

Area of Plantations.

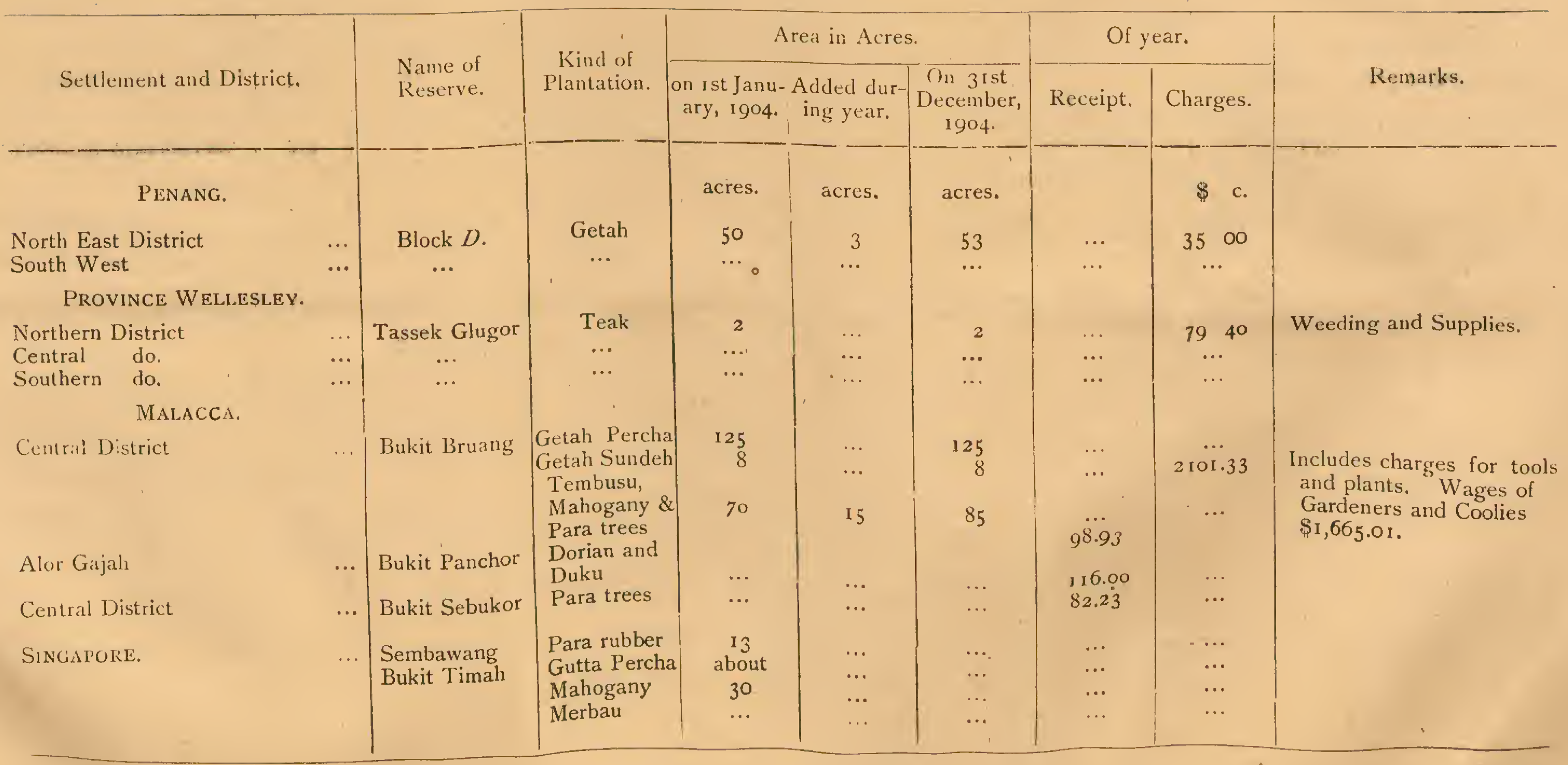


FORM No. 9 .

Outhurn in cubic feet of Timber and Fuel during 1904 .

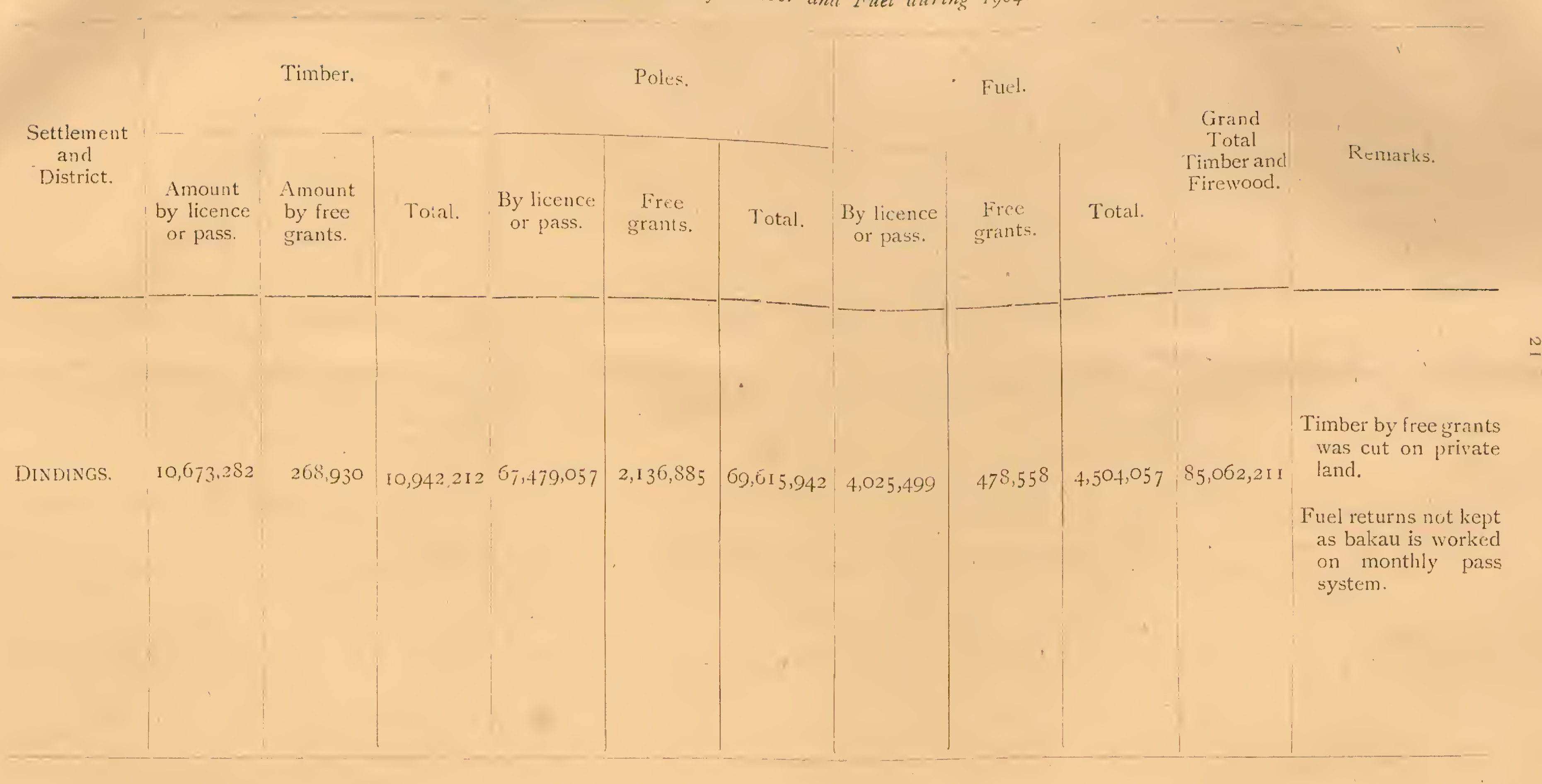


FORM NO.

Outturn of Minor Forest Produce.

\begin{tabular}{|c|c|c|c|c|c|c|c|c|c|}
\hline \multirow{2}{*}{ State. } & \multirow{2}{*}{ District. } & \multirow{2}{*}{$\begin{array}{l}\text { Description of } \\
\text { Produce. }\end{array}$} & \multicolumn{2}{|c|}{ By Purchasers. } & \multicolumn{2}{|c|}{ Free grants. } & \multicolumn{2}{|c|}{ Total. } & \multirow{2}{*}{ Remarks. } \\
\hline & & & Quantity. & Value. & Quantity. & Value. & Quantity. & Value. & \\
\hline SINGAPORE. & $\begin{array}{l}\text { Sempang } \\
\text { Kranji } \\
\text { S. Sarangong Kechil } \\
\text { S. Tampenis } \\
\text { Sembawang } \\
\text { S. Tambuan } \\
\text { S. Mandi } \\
\text { S. Jurong } \\
\text { Pulo Damar Darat } \\
\text { S. Air 'Tawer } \\
\text { S. Benni }\end{array}$ & $\begin{array}{l}\text { Resam } \\
\text { Nibong } \\
\text { Mengkuang } \\
\text { Rattan } \\
\text { Nibong } \\
\text { Do. } \\
\text { Mengkuang } \\
\text { Resam } \\
\text { Mengkuang } \\
\text { Do. } \\
\text { Resam } \\
\text { Rattan } \\
\text { Nibong } \\
\text { Mengkung } \\
\text { Resam } \\
\text { Mengkuang } \\
\text { Nibong } \\
\text { Resam } \\
\text { Mengkuang } \\
\text { Do. } \\
\text { Resam } \\
\text { Mengkuarg } \\
\text { Do. }\end{array}$ & \begin{tabular}{c|} 
\\
$\ldots$ \\
275 \\
$\ldots$ \\
$\ldots$ \\
70 \\
20 \\
$\ldots$ \\
$\ldots$ \\
$\ldots$ \\
$\ldots$ \\
$\ldots$ \\
$\ldots$ \\
120 \\
$\ldots$ \\
$\ldots$ \\
$\ldots$ \\
30 \\
$\ldots$ \\
$\ldots$ \\
$\ldots$ \\
$\ldots$ \\
$\ldots$ \\
$\ldots$
\end{tabular} & $\begin{array}{rc}\$ & c . \\
\text { I } & 50 \\
27 & 50 \\
\text { I } & 50 \\
\text { I } & 00 \\
7 & 00 \\
2 & 00 \\
0 & 60 \\
\text { I } & 20 \\
2 & 10 \\
9 & 30 \\
0 & 60 \\
6 & 00 \\
12 & 00 \\
4 & 50 \\
0 & 60 \\
0 & 60 \\
3 & 00 \\
1 & 20 \\
3 & 00 \\
1 & 80 \\
1 & 80 \\
0 & 60 \\
\text { I } & 20\end{array}$ & 总 & 를 & $\begin{array}{c}\ldots \\
275 \\
\ldots \\
\ldots \\
70 \\
20 \\
\ldots \\
\ldots \\
\ldots \\
\cdots \\
\ldots \\
\ldots \\
120 \\
\ldots \\
\ldots \\
\cdots \\
30 \\
\ldots \\
\cdots \\
\ldots \\
\ldots \\
\ldots \\
\ldots\end{array}$ & $\begin{array}{rc}\$ & c . \\
1 & 50 \\
27 & 50 \\
1 & 50 \\
1 & 00 \\
7 & 00 \\
2 & 00 \\
0 & 60 \\
1 & 20 \\
2 & 10 \\
9 & 30 \\
0 & 60 \\
6 & 00 \\
12 & 00 \\
4 & 50 \\
0 & 60 \\
0 & 60 \\
3 & 00 \\
1 & 20 \\
3 & 00 \\
1 & 80 \\
1 & 80 \\
0 & 60 \\
1 & 20\end{array}$ & $\begin{array}{l}\text { By monthly Pass } \\
\text { Pass good for } 2 \text { months } \\
\text { By monthly Pass }\end{array}$ \\
\hline
\end{tabular}


FORM No. to-Continued.

Outhurn of Minor Forest Produce.

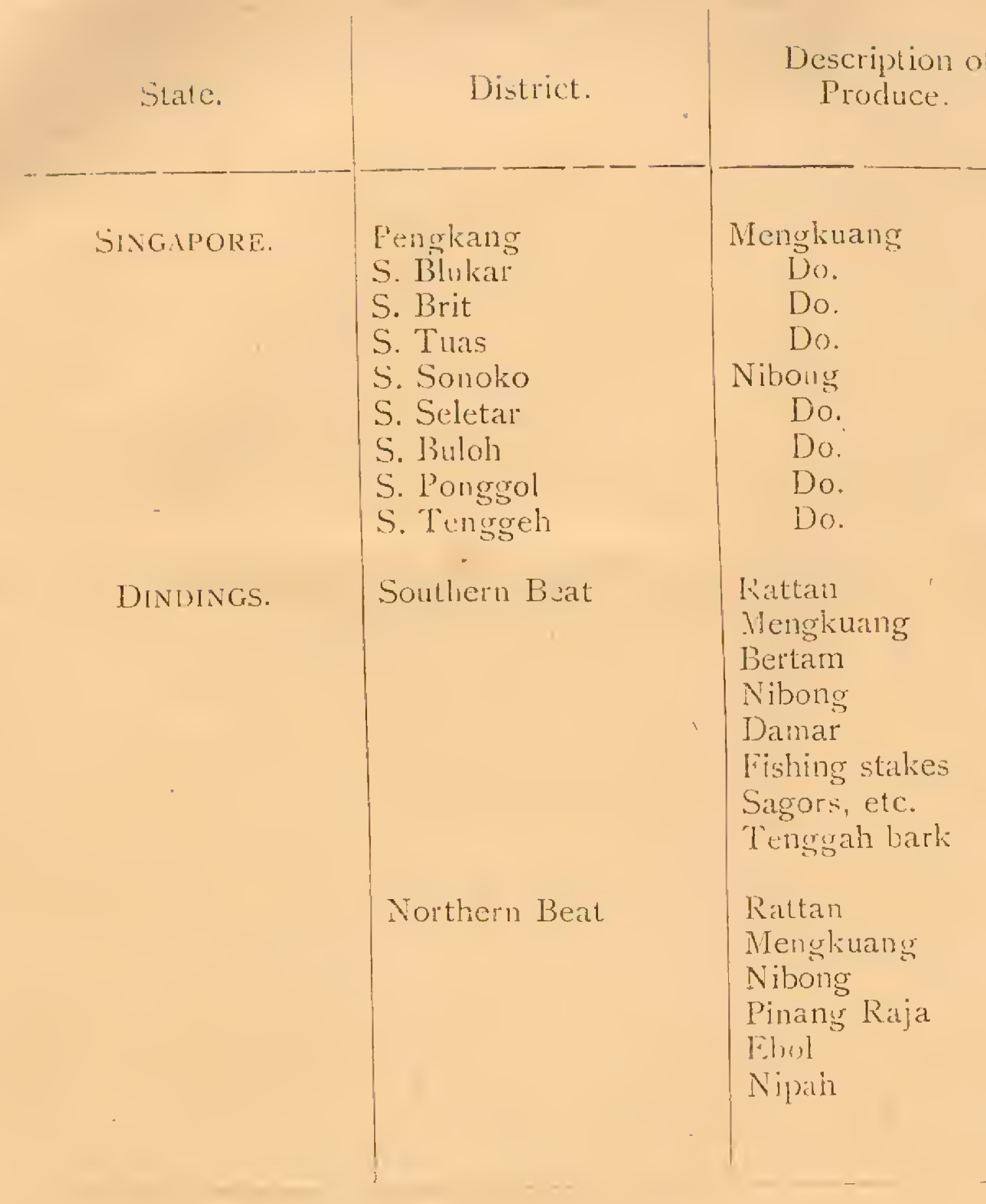

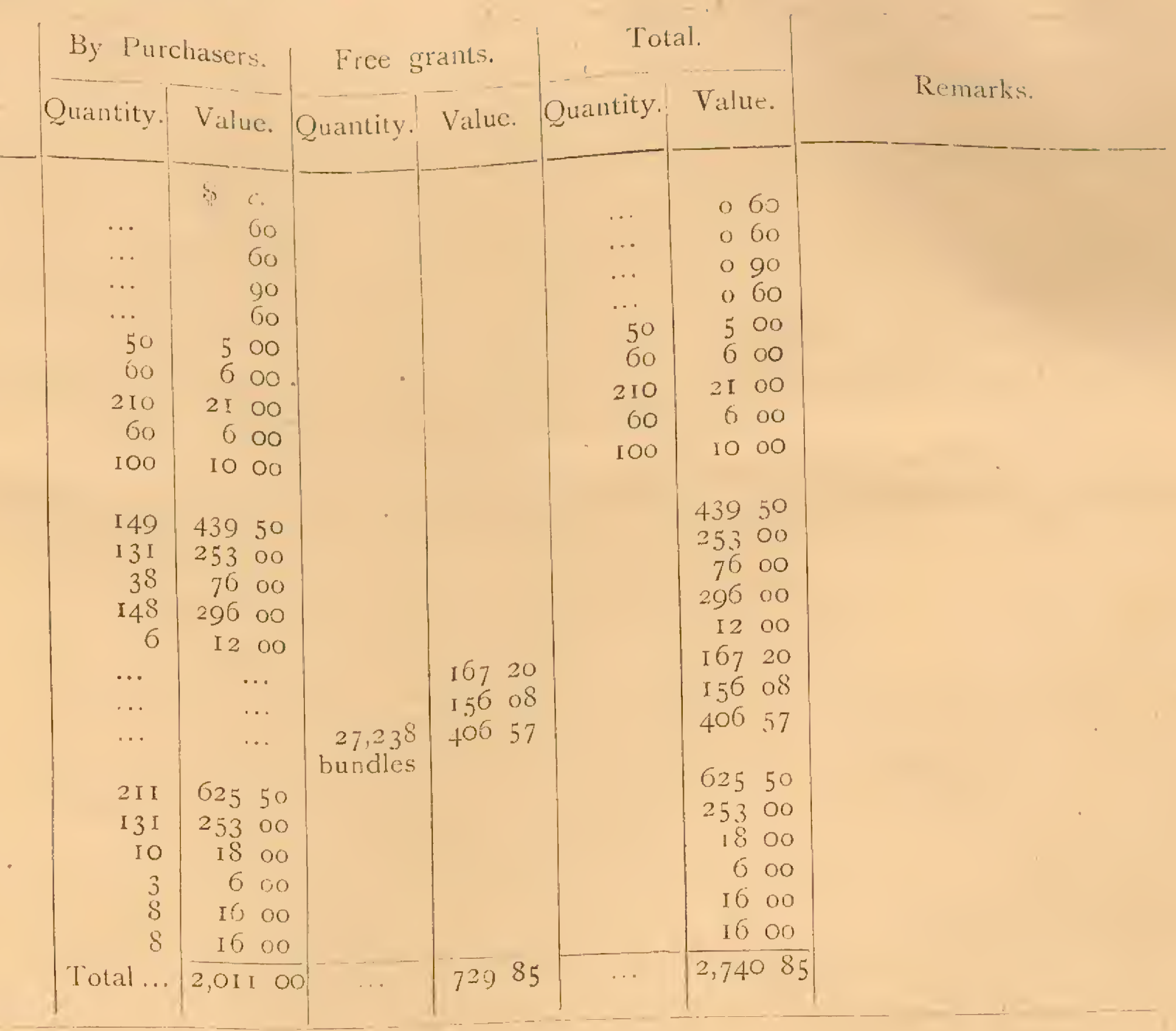


FORM NO. 10,-Conciuded.

Outurn of Minor Forest Produce.

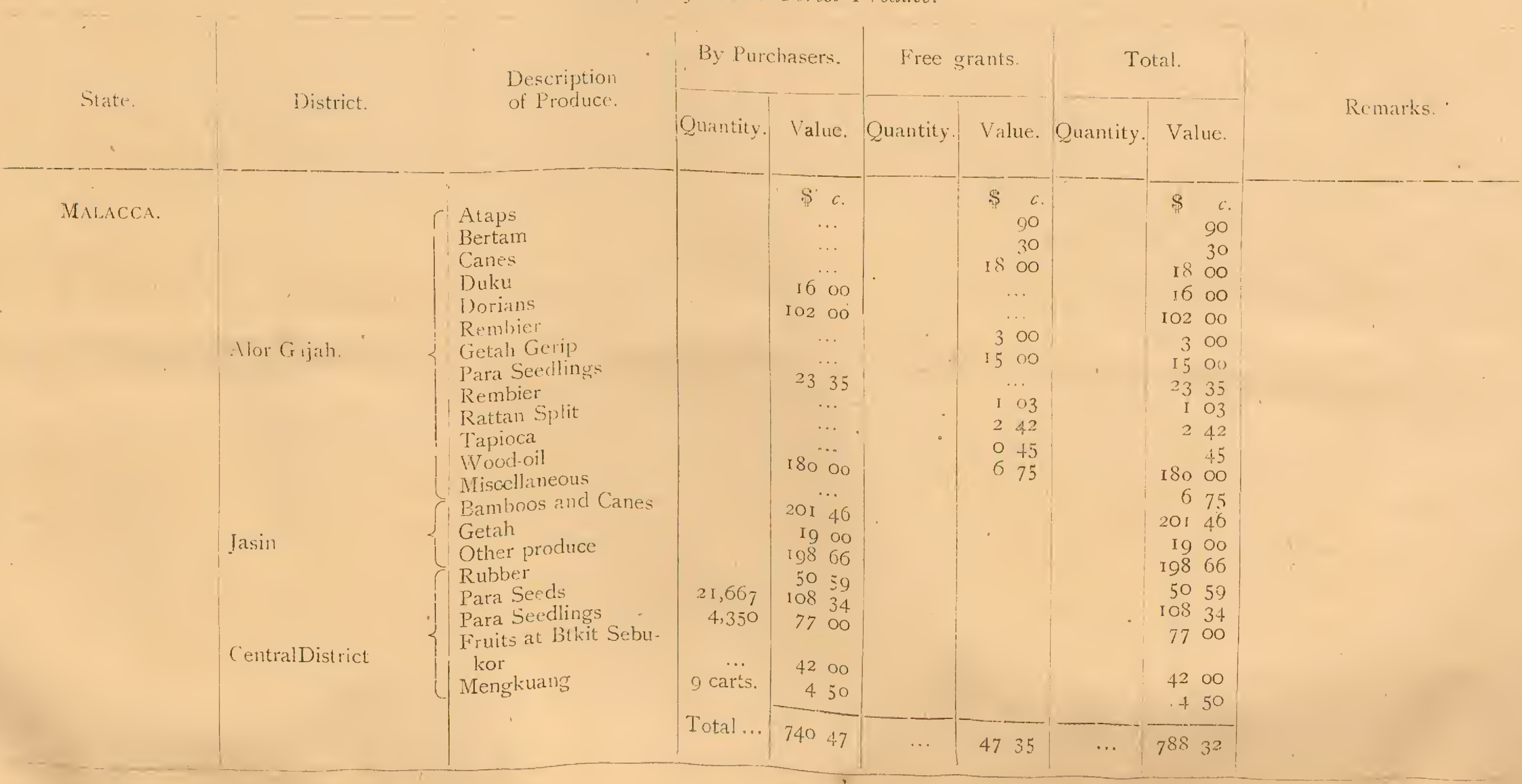


SINGAPORE.

FORM NO, I I.

Summary of Revenue and Expenditure 1904.

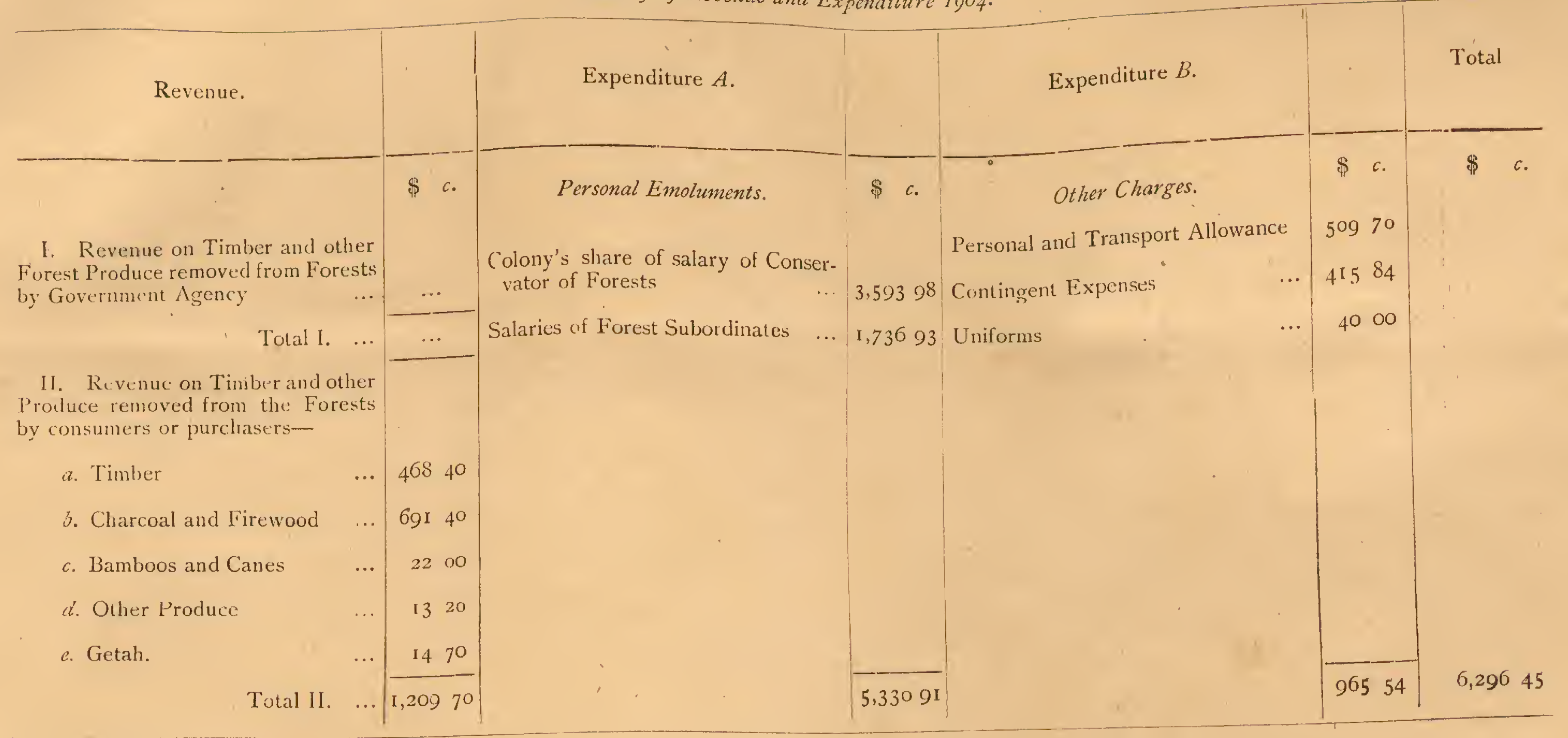


PENANG AND PROVINCE WELLESLEY.

FORM NO. II,-Continued.

Summary of Revenue and Expenditure $190_{4}$.

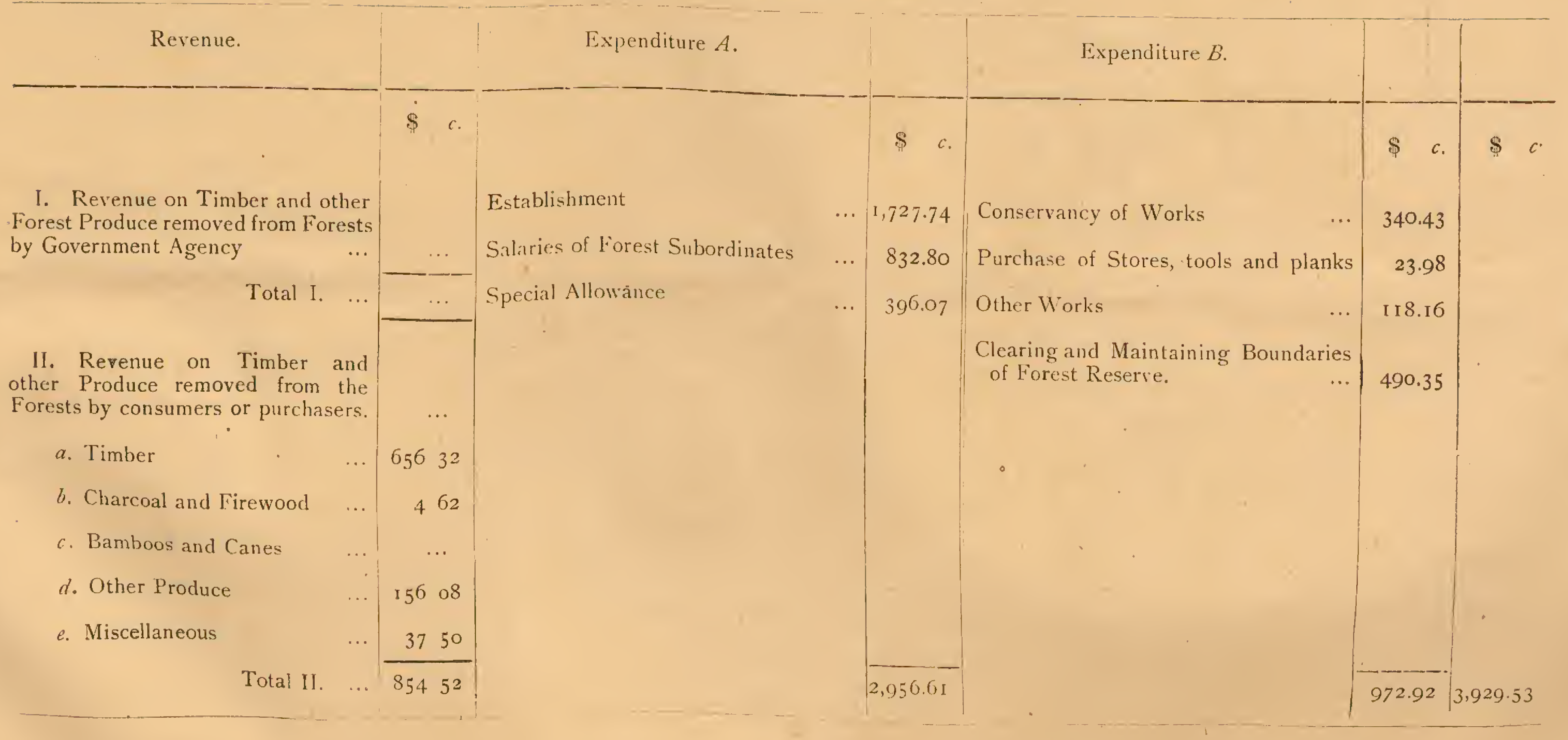




\section{DINDINGS.}

FORM NO, II,-Continued.

Sunmary of Rea'enue and Expenditure root.

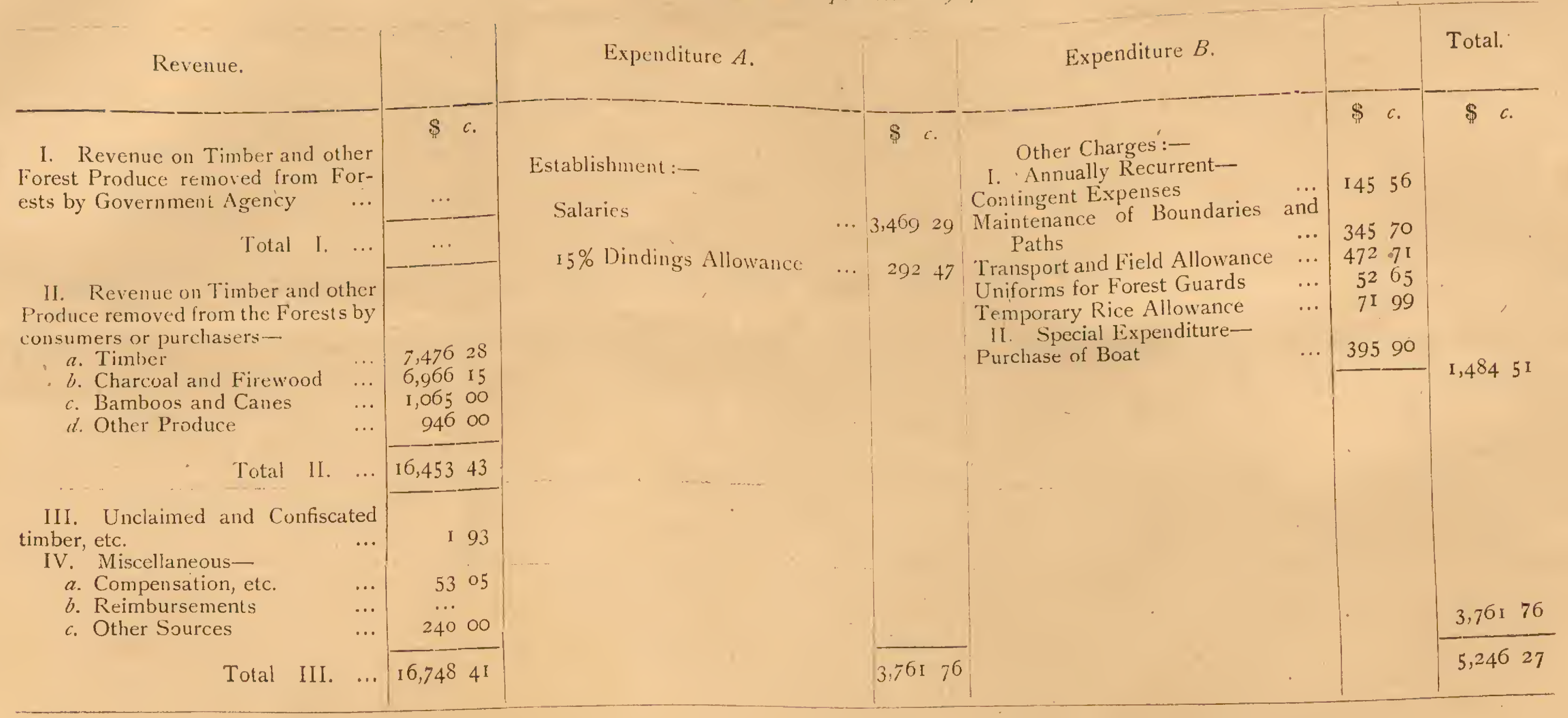




\section{MALACCA,}

FORM No. II.-Concluded.

Summary of Revenue and Expenditure 1904.

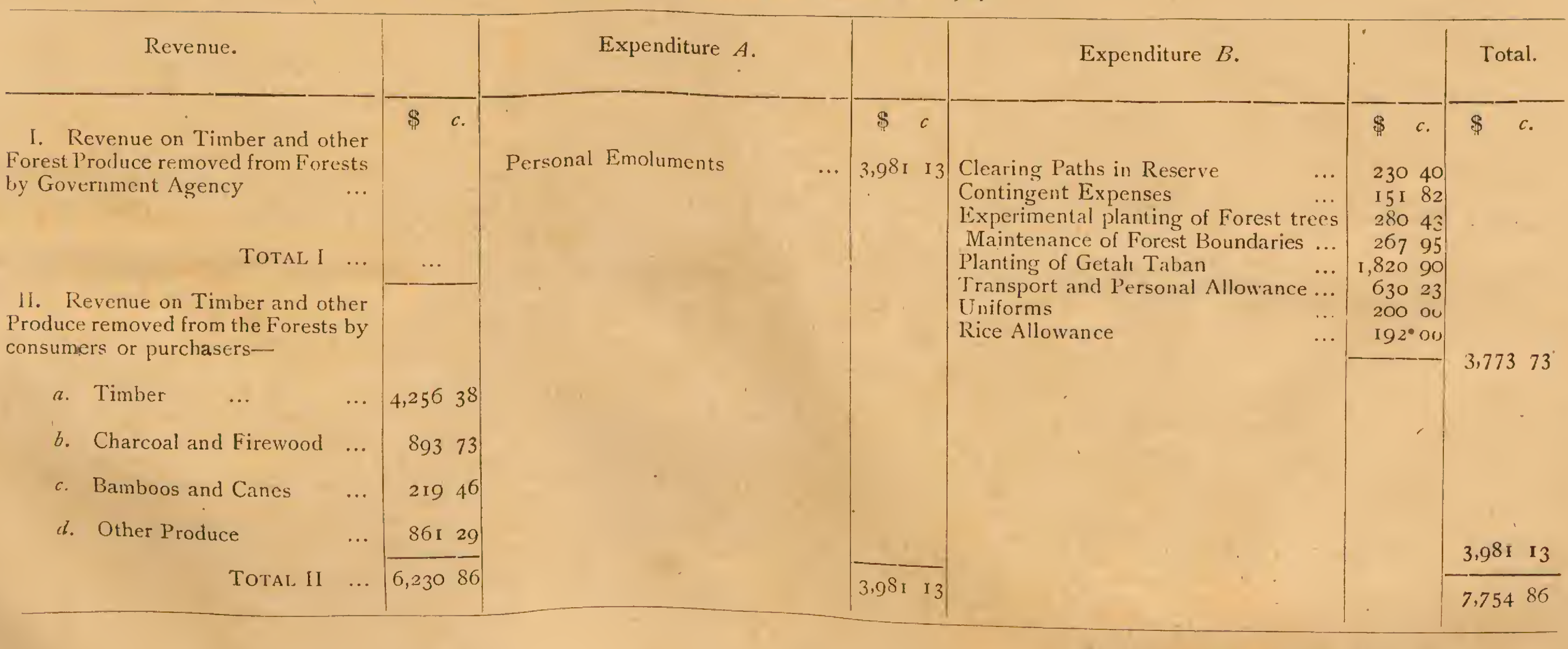

A. M. BURN-MURDOCH,

Conservator of Forests, Federated Malay States

and Straits Settlements. 


\section{Annual Report on Forest Administration in the Straits Settlements for the Year 1905.}

\section{CHAPTER I. \\ Extension and Constitution of Reserved Forests. \\ I. Alteration in Area.}

[ See FORM I. ]

1. This table shew's the Forest Reserves in the Colony.

The only alteration in area was effected in Malacca, 3 acres being excluded from Bukit Sebukor Reserve.

\begin{tabular}{|c|c|c|c|c|}
\hline- & $\begin{array}{c}\text { Area of } \\
\text { Settlement: } \\
\text { Square Miles. }\end{array}$ & $\begin{array}{c}\text { Area of } \\
\text { Reserved } \\
\text { Forest: } \\
\text { Square Miles. }\end{array}$ & $\begin{array}{c}\text { Area of } \\
\text { Unreserved } \\
\text { Forest: } \\
\text { Square Miles. }\end{array}$ & $\begin{array}{c}\text { Average propor- } \\
\text { tion of Forest } \\
\text { Reserve to } \\
\text { whole Area. } \\
\%\end{array}$ \\
\hline $\begin{array}{l}\text { Singapore } \\
\text { Penang and Province } \\
\text { Wellesley } \\
\text { Dindings } \\
\text { Malacca }\end{array}$ & $\begin{array}{l}395 \\
265 \\
659\end{array}$ & $\begin{array}{l}19 \cdot 4 \\
25 \cdot 5 \\
36 \cdot 1 \\
77^{\circ} 4\end{array}$ & $\begin{array}{l}186 \cdot 6 \\
369 \cdot 3 \\
228 \cdot 9 \\
581 \cdot 6\end{array}$ & $\begin{array}{r}9 \cdot 4 \text { I } \\
6 \cdot 45 \\
\text { I } 3 \cdot 62 \\
\text { I I.74 }\end{array}$ \\
\hline Total & $I, 525$ & I $58^{\circ} 4$ & $1366^{\circ} 6$ & $10 \cdot 32$ \\
\hline
\end{tabular}

2. The above areas I regret to say have not been legally constituted Forest Reserves so that with a change of policy they may all be lost to the Crown.

\section{Reserve Proposals.}

[ See FORM 2.]

3. No more Reserves were proposed.

\section{Demarcation and Repairs to Boundaries.}

\section{[ See Form 3.]}

4. Singapore boundaries were upkept by the Forest Guards.

In Penang the boundaries of five Reserves were cleared, 44 miles at a cost of $\$ 339.45$ or $\$ 7.7$ I per mile. In Province $W^{\top}$ ellesley, 14 miles were cleared and bridges renewed at a cost of $\$ 158$, averaging $\$$ I I.28 per mile.

In addition, all the Reserves were measured by the Survey chain of Ioo feet and mile posts erected, thus facilitating reference to one's position in any part of the Reserve.

5. Dindings.-Fifty-seven miles 37 chains of boundaries were cleared on contract at a cost of $\$ 277.24$ or an average of $\$ 4.83$ per mile which is much cheaper than similar work elsewhere. As a rule the boundaries are more easily upkept as they get older.

6. Malacca.-All boundary repairs have been done by the Forest Staff with the exception of inspection paths in Bukit Bruang Reserve which cost \$ro8.50.

None made during the year.

\section{Surveys.}




\section{CHAPTER 【}

\section{Management of Crown Forests.}

\section{Working Plans.}

7. No further Working Plans have been made during the year. Malacca and the Dindings are worked on a rough plan.

Contents of Reserves.-An enumeration of the contents of the Forest Reserves in Penang was begun during the year. So far, one Reserve (Pantai Acheh) only has been finished. The following table shews the number of first and second class timber trees over $3^{\prime}$ girth.

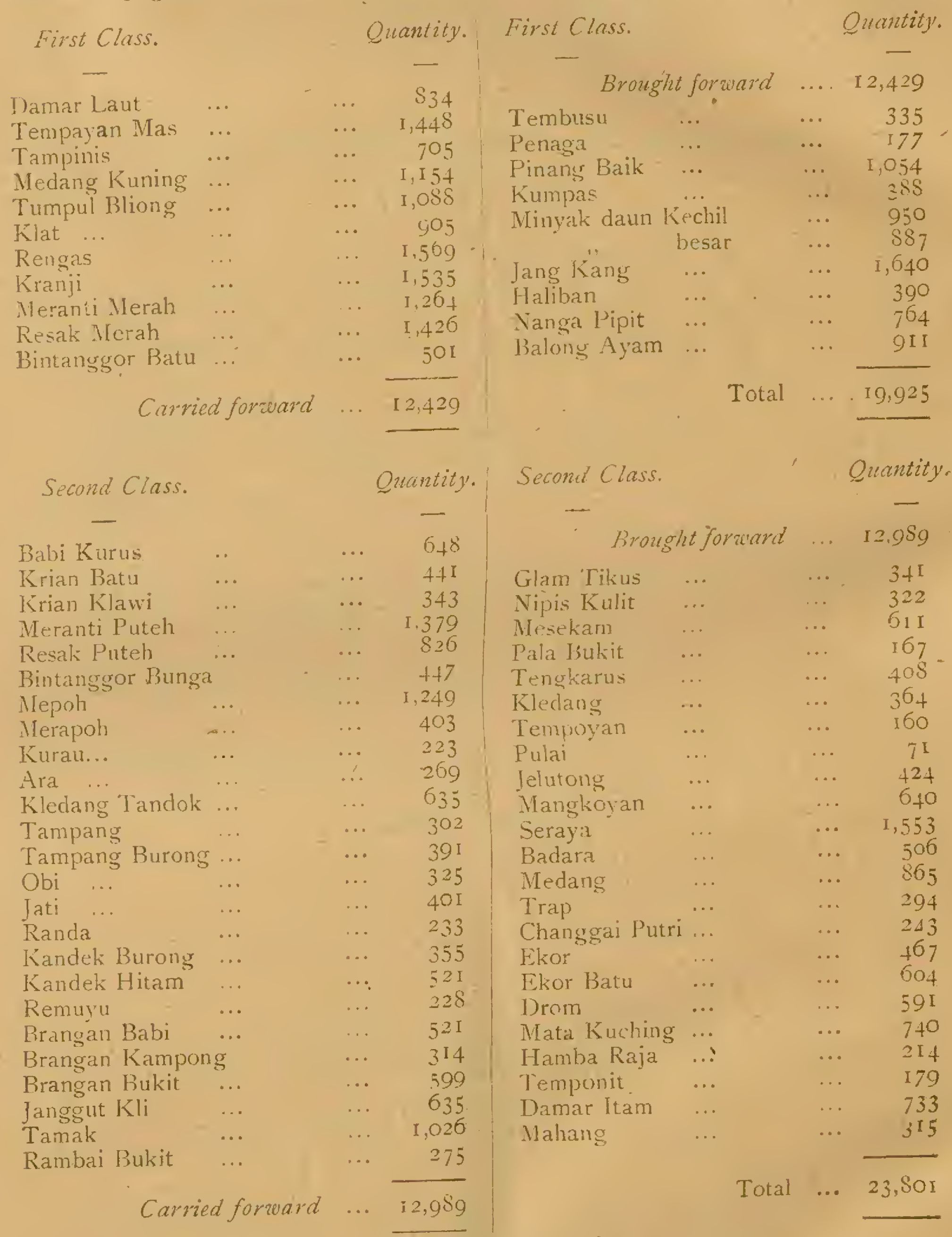

\section{Buildings.}

8. Penang.-Four new Forest Guards Stations were erected, viz., at Penara Rukit, Balik Pulau, Telok Bahang and Batu Ferringgi. They are all built on the same plan which consists of a front room used as an office and which can also be used by the Superior Forest Officers on tour. The Forest Guards' Quarters are at the back 
and connected with the front room by a passage. The cost of each was $\$ 500$, the main heavy wood being supplied from the forest. The Forest Guards' Station in Province Wellesley was colour washed and repairs effected at a cost of $\$ 3$.

9. Malacca.-Forest Stations were erected at Chabau and Sempang Ampat at a cost of $\$ 450$ each. Repairs to other Stations cost $\$ 183.44$.

\section{Protection of Forests.}

10. Several fires occurred in Penang but did very slight damage.

I1. Malacca.-On July $24^{\text {th }}$ new Timber and Jungle Produce Rules were brought into force. This obviated the issue of removal passes, monthly permits to cut being issued.

I2. The Forest Staff duties are now increased by having the supervision of the unreserved Crown Lands as well as Forest Reserves.

The Settlement of Malacca is divided into $S$ Forest patrol beats. If strict cultivation clauses continue to be enforced Forest Revenue should increase.

The Police have given help in checking loads of wood entering the towns.

The following table gives the number of loads of timber passing into Malacca for 3 months:-

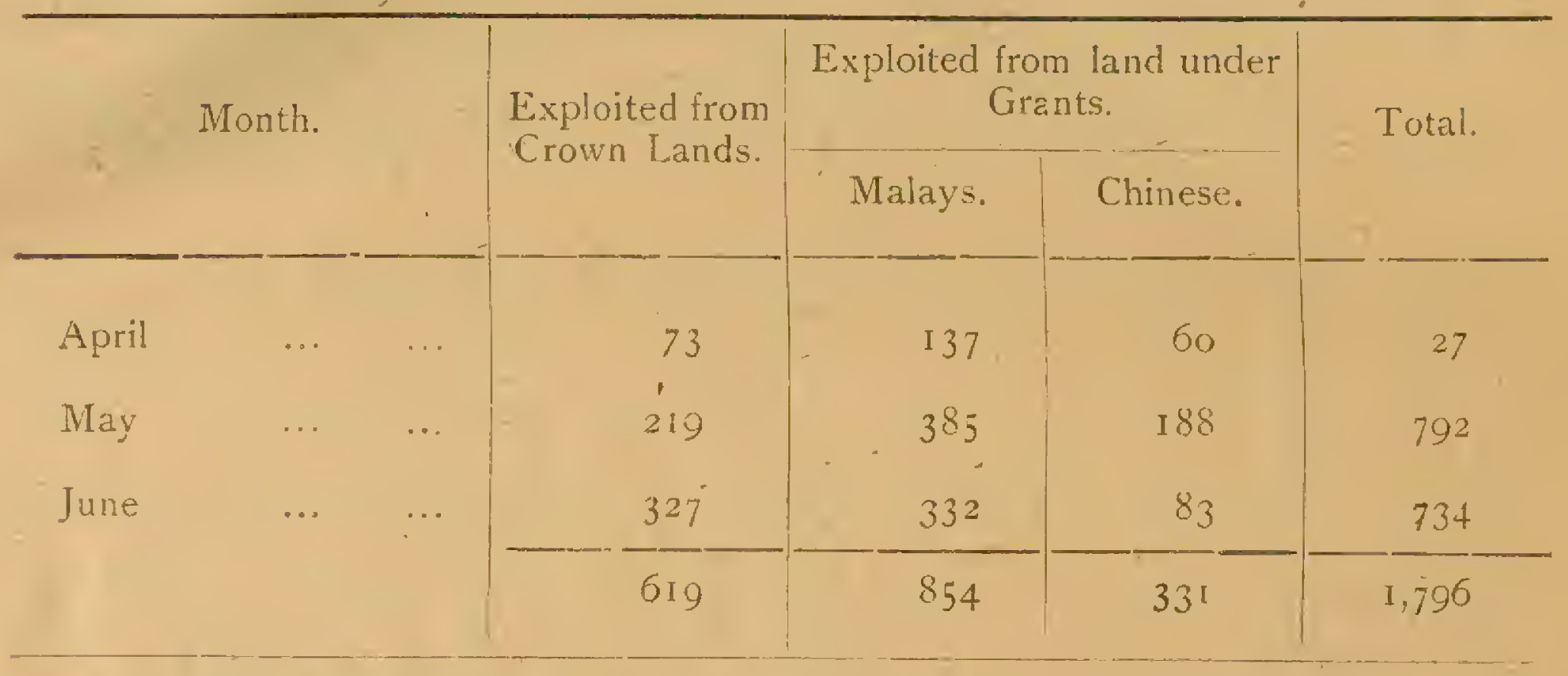

I am pleased to say there has been a decrease in free permits issued as compared with the previous year as only the holders of the permits may cut and not employ paid labour as they did previously.

I. Dindings.-One large and two small Malay fishing boats were purchased for the use of the Deputy Ranger and Forest Guards at $\$ 50, \$ 30$ and $\$ 20$ respectively.

\section{Forest Offences.}

\section{[ See FORM 7.]}

14. There were only two cases in Singapore as against twelve in I 904.

15. Penang.-Fifteen cases were brought into Court for illicit timber cutting; none of a serious character.

There were 12 convictions, 5 acquittals, $\$ 79$ fines realised.

There were 7 cases in the Province, 5 convictions, 2 acquittals, fines $\$ 500$.

The Forest Station at Tasek Glugor was broken into on 3 rd November. The lock of an almeirah was forced and various cooking utensils, lamps, etc., were stolen, together with sorne tools and some Forest Guards' clothing, valued at \$20.

16. Dindings.-There were 43 cases which resulted in 33 convictions and fines were imposed aggregating $\$ 263$ compared with $\$ 46$ in 1904 .

I7. Malacca.-The list of cases detected shows an increase owing to better supervision of unreserved Crown Lands by the Forest Staff, 67 as against 26 in 1904 . The Penghulus were formerly in charge of this werk. Fourteen cases were compounded by the department for $\$ 124.63$ Four cases of encroachment on Crown Lands were reported to the Collector of Land Revenue and resulted in fines $\$ 17.32$; two persons were convicted for setting tire to Crown Lands. Seven persons were charged with offences in Reserves. 


\section{Improvement of Forest.}

(1) NATURAL REPRODUCTION.

18. Dindings.-Two species, Meranti Bakau and Meranti Bunga, were preserved for production of seed. Seedlings of Meranti as a rule are plentiful everywhere in the Reserves.

19. Malacca.-The naturally grown trees of Taban are mostly too young for seeding. There are 165 trees in Jasin District and 360 in Alor Gajah.

The gregarious growth of Tampinis is very gratifying at Bukit Bruang. It is scattered in groups almost all over the Reserve and its tendency is to increase. There are also a few Bintanggor seedlings found.

\section{(II) Artifictal Reproduction.}

\section{[See FORM S. ]}

20. Penang.- The Getah Taban plantation was at Batu Ferringgi increased by 15 acres, 200 young plants were used in supplying vacancies in previous plantings. There are 68 acres planted altogether and the plants are doing fairly well. The older ones were cleared as were also those in the valley near the Botanic Gardens.

The experimental Teak Plantation at Tasek Glugor was cleaned twice during the year and blanks filled in, but I think as a whole the plantation is very inferior. It is proposed to allow the Manager of Malakoff to plant a portion of the Reserve on which lalang is growing with tapioca, teak to be planted at the same time. This will save us much expense and lessen the danger of lalang fires, and may be worth tryins as an experiment.

21. Pulau Ferejak.-This island is the Leper and Quarantine Station for the Settlements. The stations being on the east side of the Island the rest of the Island is Forest Reserve. Formerly on the western side were a number of squatters who had planted over 2,000 coconut trees. Several applications have been received asking for leases to farm them, they were however rrfused for obvious reasons. On the other hand it was thought undesirable to allow these coconits to be abundoned, and on the recommendation of the Acting Conservator, $\mathrm{Mr}$. STEPIENS, the Gorernment sanctioned a scheme for placing a caretaker in charge who would be able to look after them. Some additional assistance was given him in cleaning round the trees, and already an improvement is noticeable. A small house has been erected for the guard. The cost of this experiment so far including the cost of the house amounts to $\$ 322.39$.

22. Malacca.-Artificial reproduction is entirely confined to Bukit Bruang Reserve.

Merbau, Penak, and Penaga have been planted through blukar (secondary growth) in lines cut 3 feet wide and they are doing very well. There were planted 2,200 Merbau, 873 Penak and I, o I o Penaga seedlings.

The large-sized inferior woods have been cut out to admit light; I 50 Taban plants were raised by marcottage. Caterpillars which attack Taban were systematically destroyed.

\section{Exploitation.}

\section{See FORM 9. ]}

\section{(I) Timber and Fuel.}

23. From Singapore there is no available information, so that we have merely the sums realized by the sale of passes to indicate the quantity cut. Probably about 260 tons have been cut exclusive of Bakau firewood.

From Penang, Province Wellesley and Malacca no figures are available owing to the pass system being in vogue.

24. In Malacca the Forest Department tried to supply the Public Works Department with seasoned timber but it was only on a small scale.

There is a vote of $\$ 2,000$ in the estimates for the Public Works Department and I trust it will be more successful in 1906.

A sum of $\$ 377.45$ was realized by the sale of seed, etc., at Ayer Kroh.

25. Penang and Province Wellesley.-Seven hundred and eighty-seven passes were issued as against 546 for 1904 , the revenue received being $\$ 771.79$ as against $\$ 854.52$ in the previous year. The Superintendent of Forests and Gardens does not 
explain this apparently contradictory statement. The passes in 1905 must have been used for small amounts.

26. Dindings.-There were 7 Kongsis cutting timber and fuel during the year, chiefly Meranti and Nyato with a minor quantity of Chengal and Merbau.

About 70,259 cubic feet were extracted from Crown Lands on which royalty was paid and 4 I 5 cubic feet for private land paying no royalty, a considerable falling off as compared with Igo4.

As regards fuel, 704 passes to cut Mangrove were issued at $\$ 5$ per man per mensem, and 48 free passes for the use of the Government Launch. This shews a large decrease over 1904.

Cutting had to be restricted to certain areas.

\section{Minor Forest Produce.}

27. In Penang realized $\$ 1+7 \cdot 70$.

In the Dindings 22,997 bundles of Tengah bark were exported at a royalty of $\$ 1.50$ per 1,000 bundles. This bark produces a valuable tannin.

Four hundred and thirty passes were issued for Canes realising $\$ 1,290$, and 479 passes for other produce realizing $\$ 958$.

28. In Malacca the right to collect wood oil (Dipterocarpus Crinitus) was sold for $\$ 125$ in Sungai Udang Reserve.

The fruit trees in Bukit Panchor realized only $\$ 5.85$ as compared with $\$ 128$ in 1904 owing to failure of crop.

CHAPTER III.

Financial Results.

Particulars ate shewn in Form $\mathrm{rr}$.

(I) REVENUU.

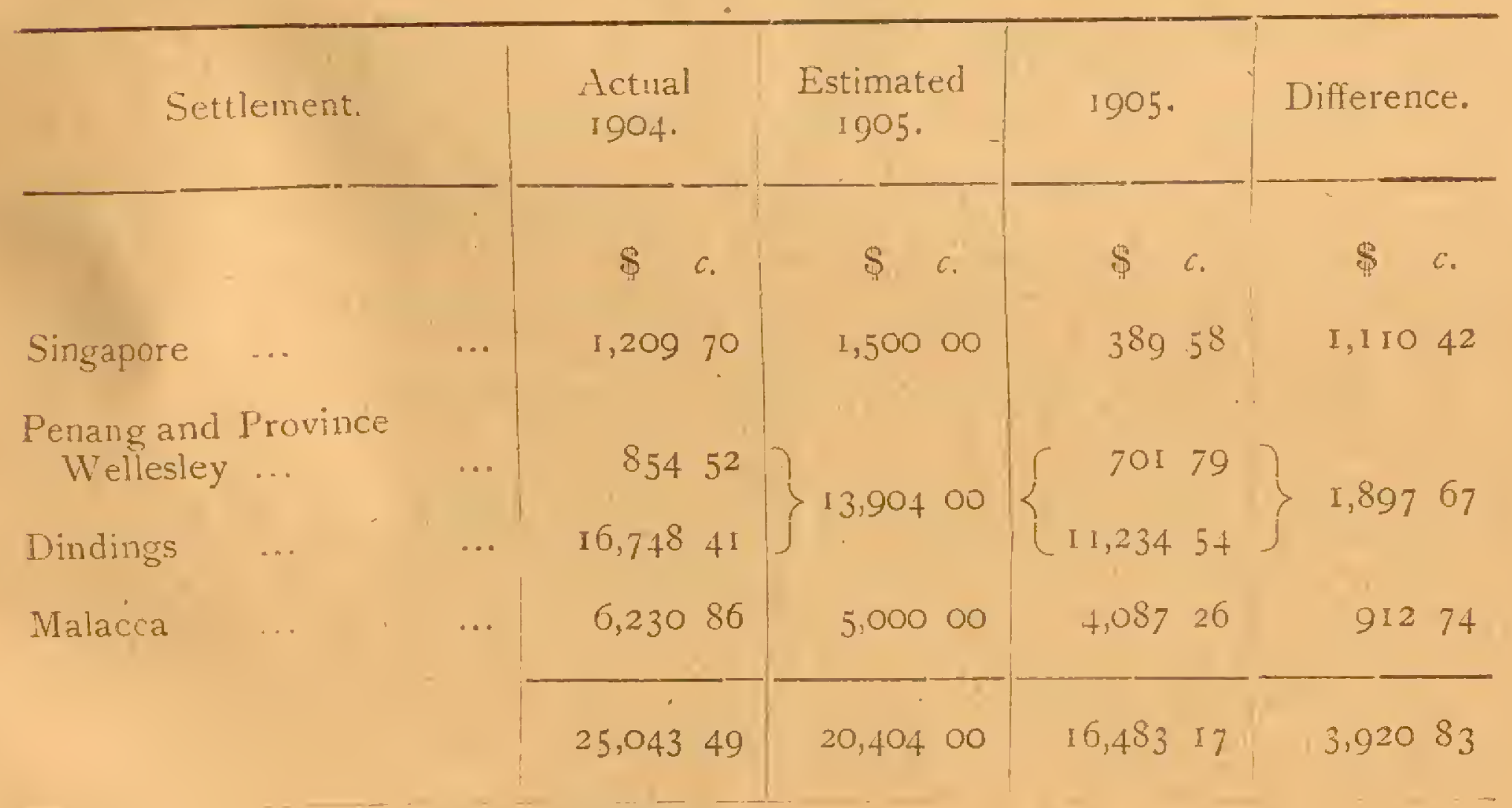

29. The falling off in Singapore is due to issue of less Mangrove passes.

30. In Penang and Province Wellesley there is a decrease of $\$ 82.73$. .

31. In the Dindings $\$ 13,250$ was estimated and $\$ I I, 23+$ realized, this is due to a drop in timber and fuel, caused by stopping of cutting in the Lumut Kanan Coupe, and also to the fall in price of timber in the second half of the year. The Dindings timber cutters held over large quantities of timber in hopes of a rise in prices. Various other causes are given by the District Officer which I consider satisfactory.

Malacca. - The falling off in revenue occurred in Timber, Bamboos and Canes and other produce. Firewood shews a slight increase. 
The fall is put down by the Forest Ranger to the small demand. \$4,087.26 were realized as compared with $\$ 6,230.86$ in 1904 .

(II) EXṔENDITLRE.

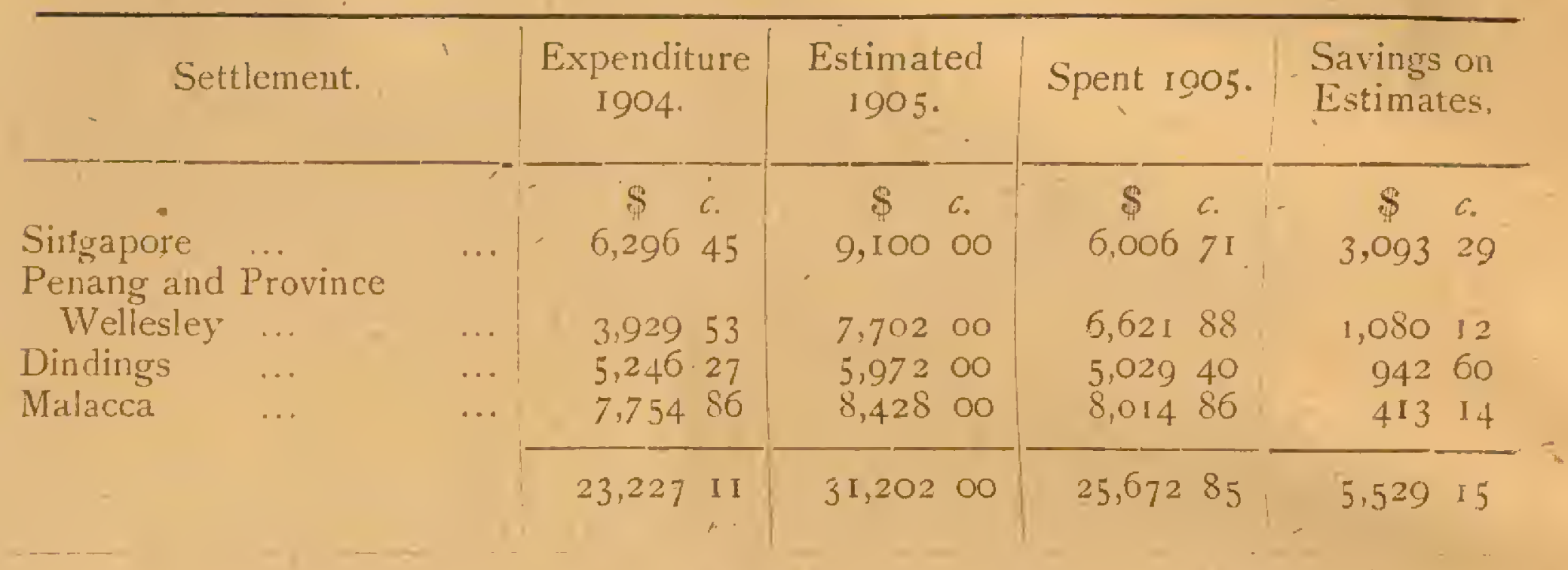

33. The total expenditure was $\$ 25,672.85$ against $\$ 23,227$. I I in 1904 .

The increases occur in Malacca, Penang and Province Wellesley.

In Malacca this was due to the appointment of a Forest Ranger, Grade 1, at $f_{1} 50$ and a Clerk at $\$ 300$, the increase over 1904 is $\$ 260$. In Penang and Province Wellesley the expenditure increased by $\$ 2,692$, of which $\$ 2,000$ was due to the erection of quarters for Forest Guards.

\section{CHAPTER IV.}

\section{- Establishment}

34. Mr. Burn-Murdoch, Conservator of Forests, proceeded on leave on ith April, rgo5, and Mr. A. B. Stephens, Deputy Conservator, Perak, acted for him till the end of the year.

35. In Penang, Mr. Fox continued to hold the post of Superintendent of Forests.

36. In the Dindings, Mr. G. H. O'HARA was appointed Forest Ranger, Grade II, on E. 20 , succeeding Mr. V. P. BURGES who was transferred to Malacca.

Both these officers have shewn themselves energetic and capable.

Mr. Pasqual, Deputy Ranger, Grade I, and Mr. C. J. Fox, Forest Clerk, Dindings, are well reported on. One Forest Guard was dismissed in September for neglect of duty and disobedience of orders.

37. Malacca.--Mr. Borges was transferred to Malacca and promoted to E. I $500 \mathrm{om}$ January rst, I90弓. Kroh.

A Forest Ranger, Grade VI, is in charge of the Government Plantations at Ayer

A Forest Clerk was appointed on 2nd February but the post was abolished on the resignation of this clerk in June, the Acting Conservator of Forests not being in favour of Revenue Collection by the Forest Department. Many changes touk place among the Forest Guards owing to dismissals, resignations, retirements and death.

Thirty-eight days were spent in tours in the Colony and in journeys to and from by the Conservator and Acting Conservator during the year. The Acting Conservator made a thorough tour of the Singapore reserves.

\section{A. M. BURN-MURDOCH,}

Conseriator of Forests,

Federated Malay States \& Straits Settlements. 
Tori No.

\begin{tabular}{|c|c|c|c|c|c|c|c|c|c|}
\hline Settlement. & 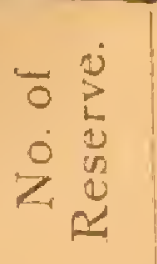 & $=\frac{\ddot{3}}{\bar{z}}$ & Name of Forest.' & $\begin{array}{l}\text { Area in Acres } \\
\text { on } 1-1-1905 .\end{array}$ & $\begin{array}{l}\text { Area added } \\
\text { during year. }\end{array}$ & $\begin{array}{l}\text { Excluded or } \\
\text { Dis-affor- } \\
\text { ested. }\end{array}$ & $\begin{array}{c}\text { Area on } \\
31-12-1905 \text {. }\end{array}$ & $\begin{array}{l}\text { No. and date of } \\
\text { Notilication } \\
\text { excluding } \\
\text { land. }\end{array}$ & Remarks. \\
\hline SINGAPORE. & $\begin{array}{l}\text { I } \\
2 \\
3 \\
4 \\
5 \\
6 \\
\\
7 \\
8 \\
9 \\
10 \\
11 \\
12 \\
13 \\
14 \\
15 \\
16 \\
17 \\
18 \\
19 \\
20\end{array}$ & & $\begin{array}{lc}\text { Bukit Timat } & \ldots \\
\text { Jurong } & \ldots \\
\text { landan } & \ldots \\
\text { Uhu Pandan } & \ldots \\
\text { Bukit Panjang } & \ldots \\
\text { Bukit Timall Ro } & \ldots \\
\text { roth mile } & \ldots \\
\text { Chua Chu Kang } & \ldots \\
\text { Tuas } & \ldots \\
\text { Sungai Murai } & \ldots \\
\text { Sungai Buloh } & \ldots \\
\text { Kranji } & \ldots \\
\text { Sembawang } & \ldots \\
\text { Mandi } & \ldots \\
\text { Kranji Rd., I th mile } & \ldots \\
\text { Changi } & \ldots \\
\text { Seletar } & \ldots \\
\text { Clan Chu Kang } & \ldots \\
\text { Ang Mo Kio } & \ldots \\
\text { S.mpangr } & \ldots \\
\text { Seletar Extension } & \ldots\end{array}$ & $\begin{array}{r}847.0 .00 \\
4.12 .0 .00 \\
2,1.40 .3 .16 \\
4.3 .09 \\
117.2 .16 \\
\\
13.0 .28 \\
49.0 .00 \\
1,601.3 .32 \\
314.1 .05 \\
770.2 .16 \\
756.0 .32 \\
1,046.3 .38 \\
407.0 .32 \\
9.2 .16 \\
1,393.0 .00 \\
1,429.1 .08 \\
813.3 .08 \\
296.0 .02 \\
5.000 \\
\cdots\end{array}$ & 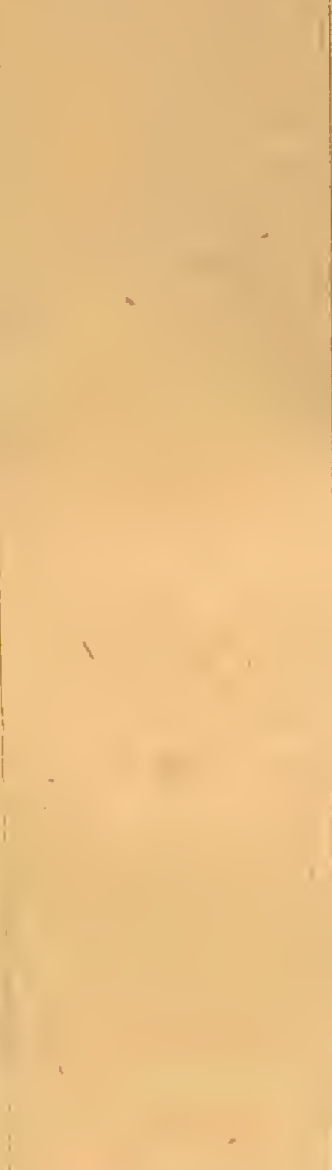 & - & Sane. & . & \\
\hline & & & Tutal ... & I $2,428, \pi, I S$ & & & $12,428.1 .18$ & & \\
\hline
\end{tabular}


FORM NO. 1.-Continued.

\begin{tabular}{|c|c|c|c|c|c|c|c|c|c|}
\hline Settlement. & 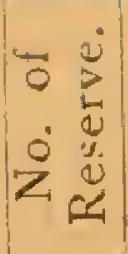 & Civil District. & Name of Forest. & $\begin{array}{c}\text { Area in Acres } \\
\text { on I-I-I } 905 .\end{array}$ & $\begin{array}{l}\text { Area added } \\
\text { during year. }\end{array}$ & $\begin{array}{l}\text { Excluded or } \\
\text { Dis-affor- } \\
\text { ested. }\end{array}$ & $\begin{array}{c}\text { Area on } \\
31-12-1905\end{array}$ & $\begin{array}{l}\text { No. and date of } \\
\text { Notification } \\
\text { excluding } \\
\text { land. }\end{array}$ & Remarks. \\
\hline \multirow[t]{2}{*}{$\begin{array}{l}\text { Province } \\
\text { WeLLESLEY. }\end{array}$} & & $\begin{array}{l}\text { Northern District } \\
\text { Central District } \\
\text { Southern District }\end{array}$ & $\begin{array}{ll}\text { Tasek Glugor } & \ldots \\
\text { Bukit Seraya } & \ldots \\
\text { Bukit Mertajam } & \ldots \\
\text { Juru Hill } & \ldots \\
\text { Gajah Mati } & \ldots \\
\text { Govt. Exp. Gardens } & \ldots \\
\text { Bukit Gua Ipol } & \ldots \\
\text { Lot } 435 & \ldots \\
\text { Lot } 3,23 \text { I } & \ldots \\
\text { Bukit Panchor } & \ldots\end{array}$ & $\begin{array}{r} \\
1,761 \\
112 \\
162 \\
417 \\
94 \\
3 \\
330 \\
189 \\
13 \\
1,476 \\
\end{array}$ & & $=$ & Same & & \\
\hline & & & Total .. & 4,557 & & & $-4,557$ & & ? \\
\hline \multirow[t]{2}{*}{ PENANG. } & $\begin{array}{l}\mathrm{A} \\
\mathrm{B} \\
\mathrm{C} \\
\mathrm{G} \\
\mathrm{H} \\
1\end{array}$ & North East & $\begin{array}{l}\text { Block } D \\
\text { Block } E \\
\text { Block } E \\
\text { Part of Block } 1 . \\
\text { Pulau Jerejak } \\
\text { Pantai Acheh } \\
\text { I_aksamana } \\
\text { Telok Bahang } \\
\text { Do } \\
\text { Ginting Hills } \\
\text { Bukit Gumoroh } \\
\text { Relau Hills }\end{array}$ & $\begin{array}{r}5.741 \\
252 \\
233 \\
18 \\
887 \\
3.208 \\
465 \\
380 \\
236 \\
21 \\
205 \\
151 \\
\end{array}$ & & & Sane & - & 1 \\
\hline & & & Total & $1 \mathrm{I}, 797$ & & & 11.797 & & \\
\hline
\end{tabular}


FORM NO. I.-Continued.

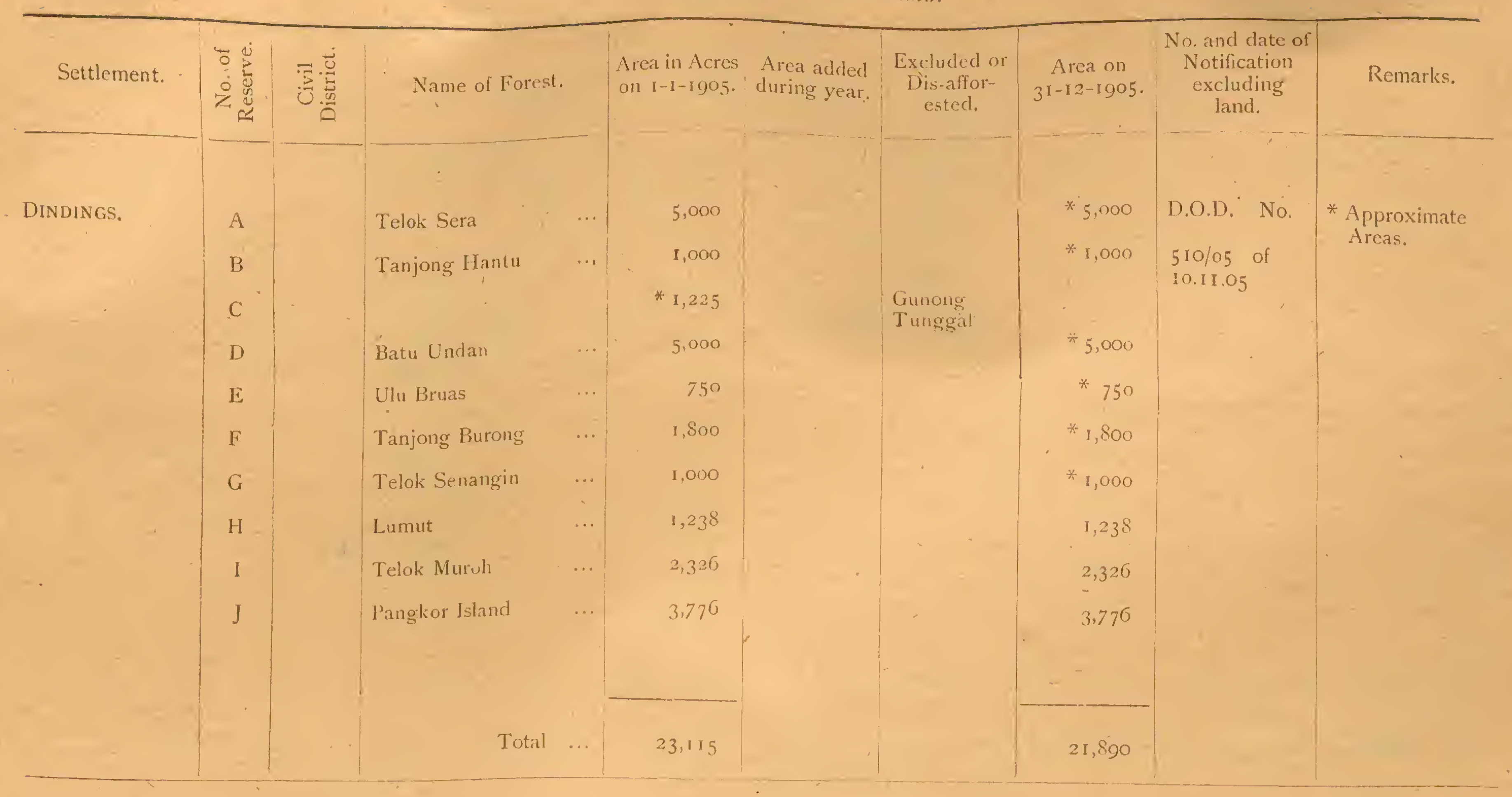


FORM NO. I-Concluded.

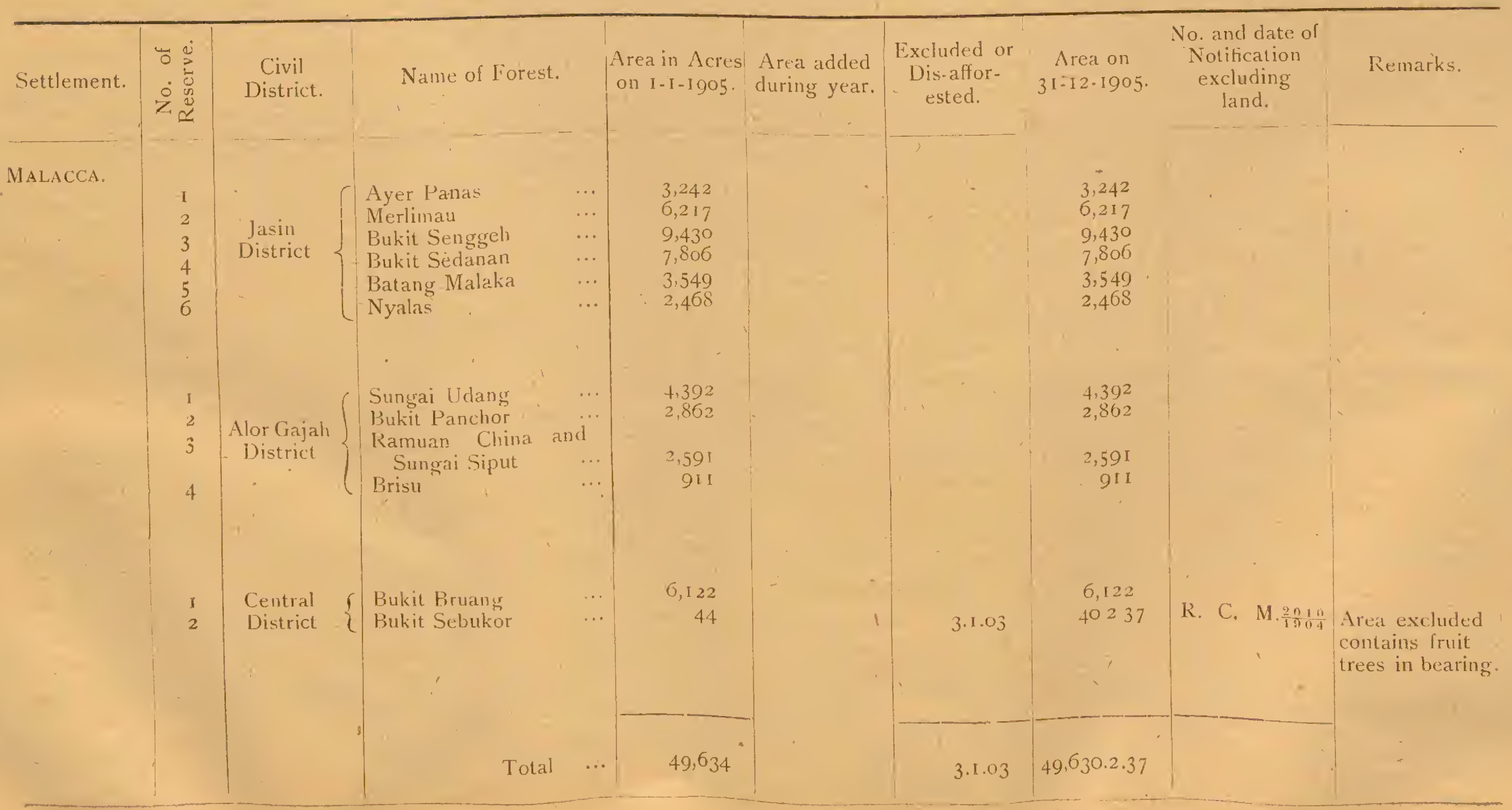




\section{FORM No, 2.}

Statement, shewng Progress made in forming new Reserves during the year 1905.

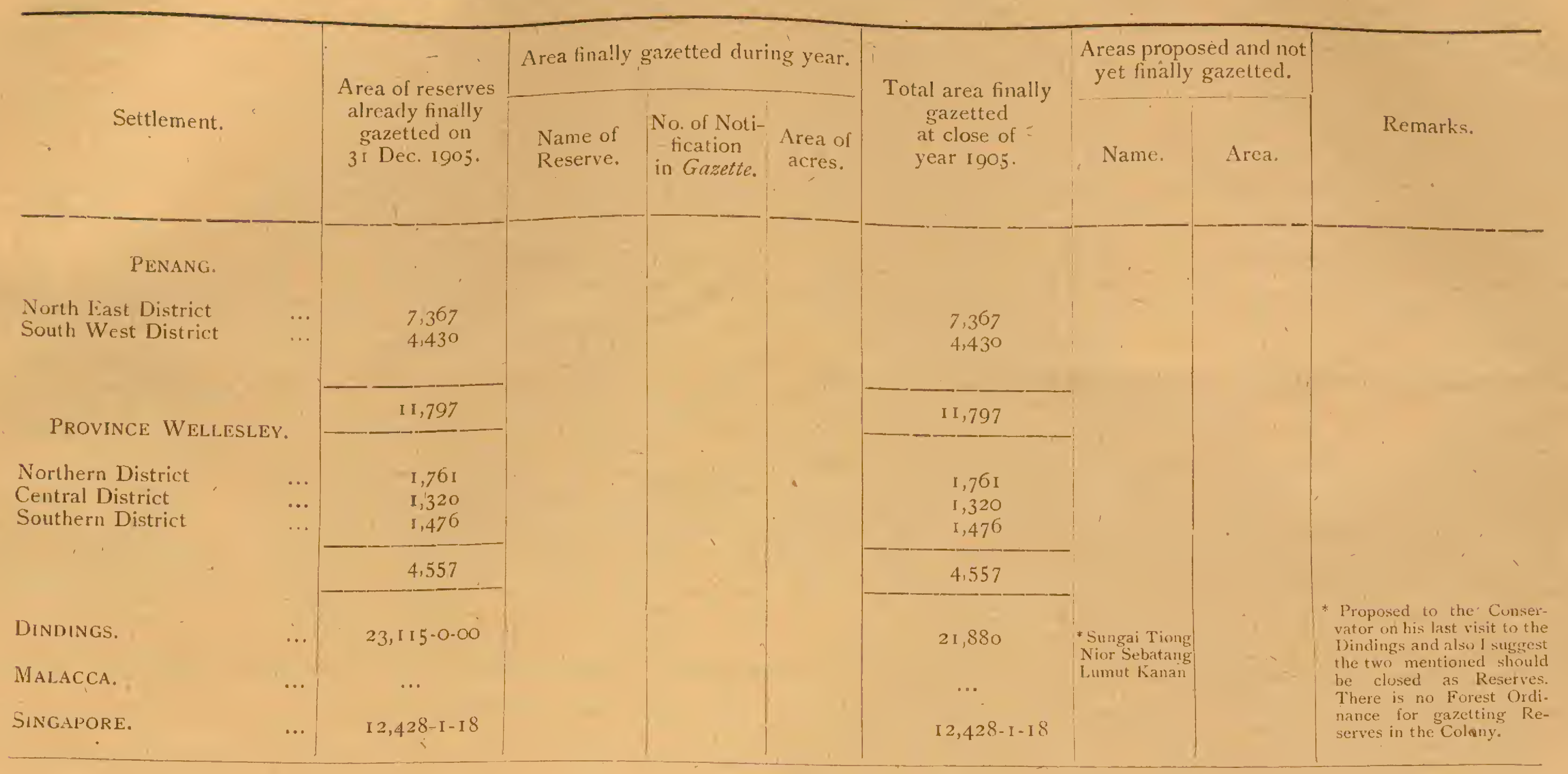


FORM NO. 3.

Record of Demaration and Menintenance of Boundaries for 1905.

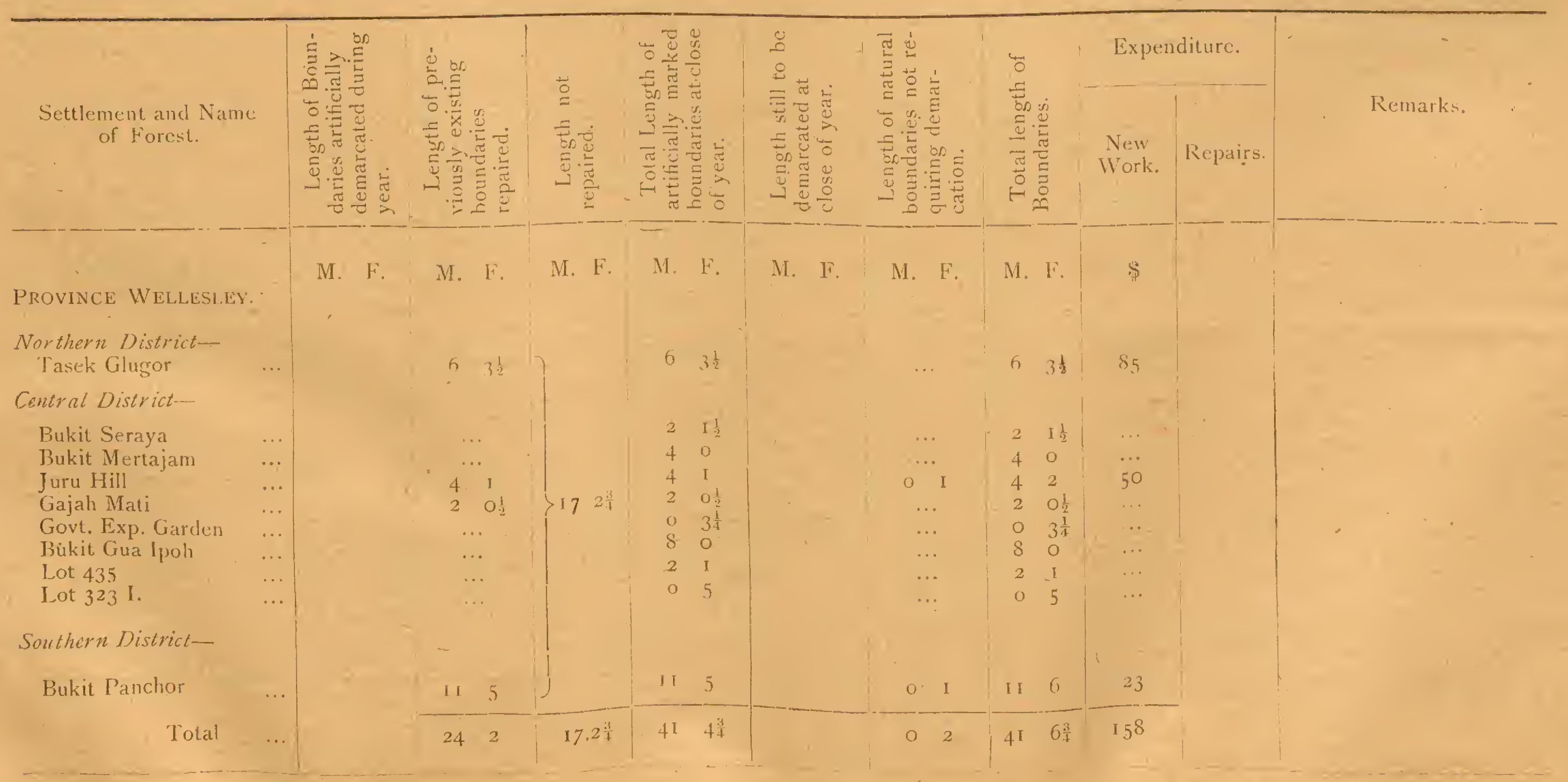


FORM NO. 3.-Concluded.

Record of Demarcation and Maintenance of Boundaries for 1905.

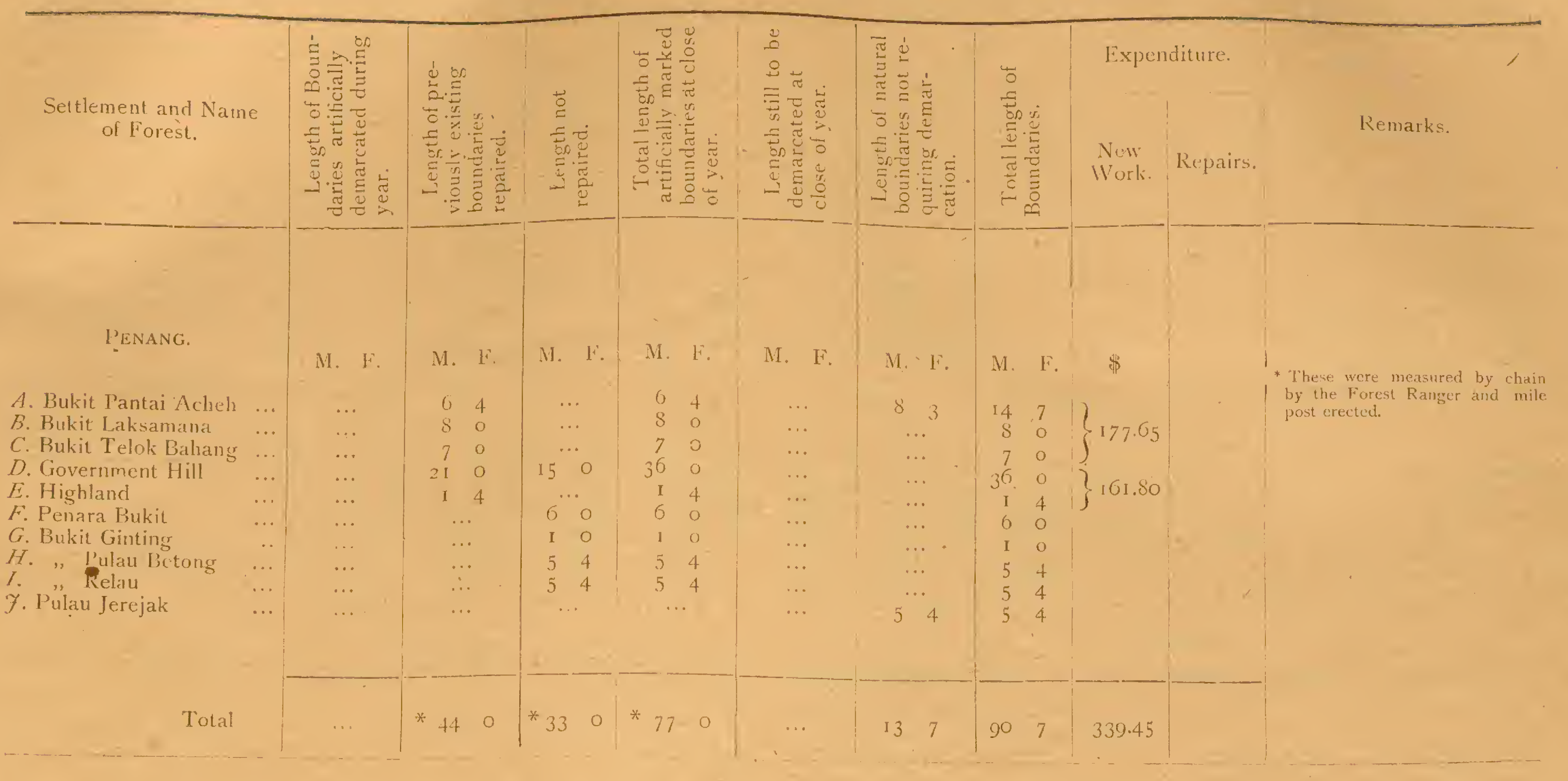
is 
FORM NO. 3.-Concluded.

Record of Demarcation and Maintenance of Boundaries for 1905.

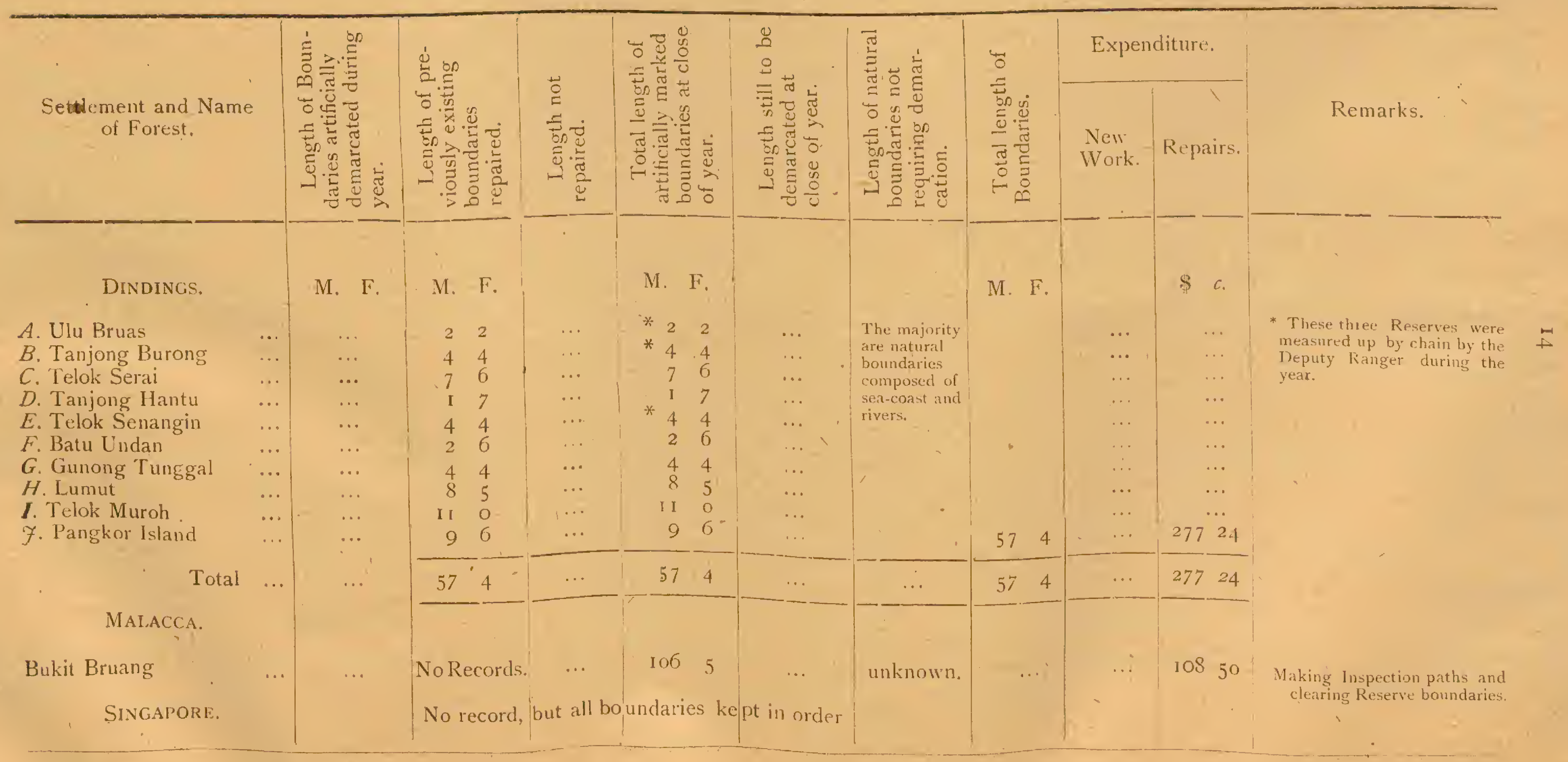


FORII No. 4.

Statcment of Area Surveyed and Unsurveyed during the year 1g05.

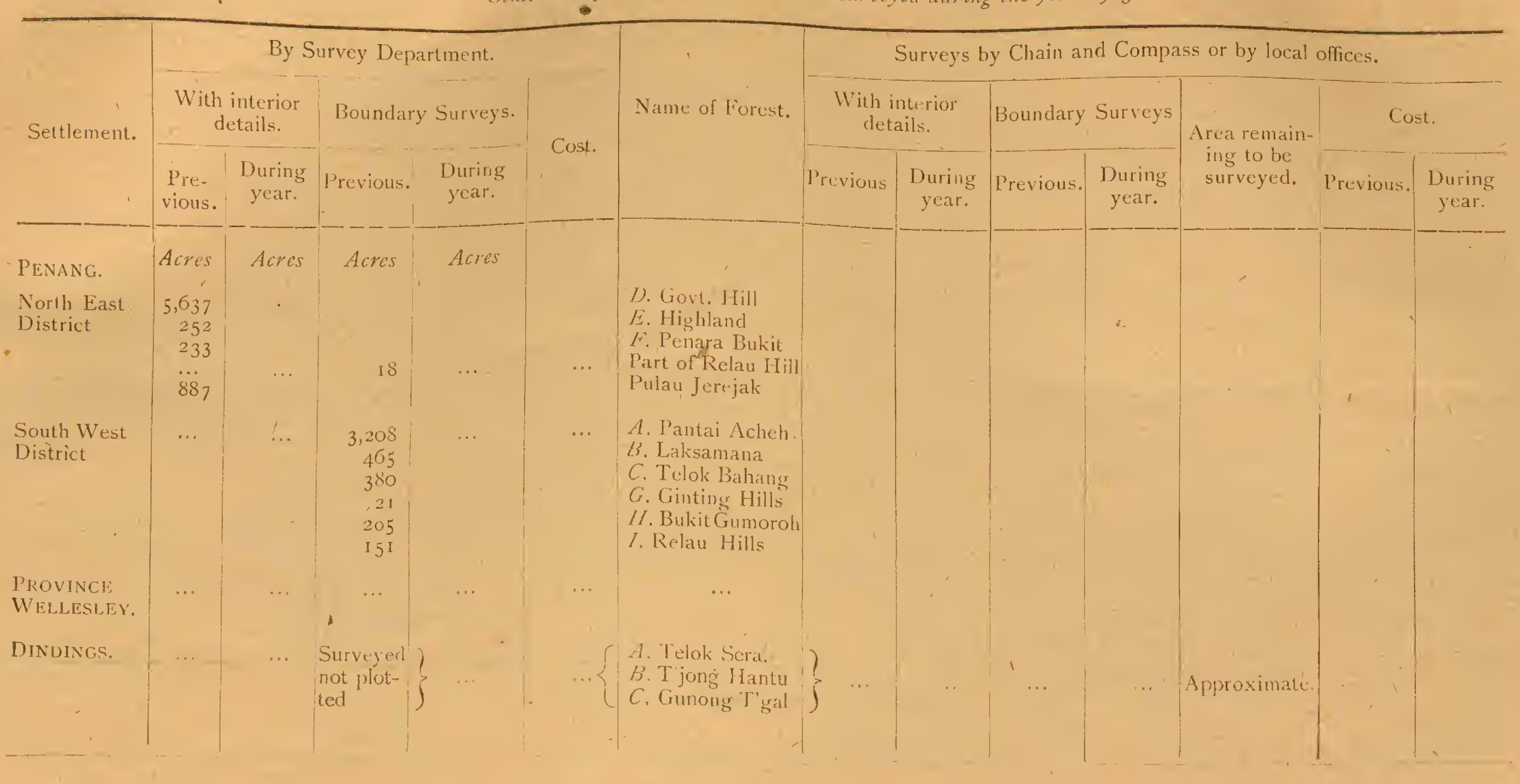


FORM No. + Concluded

Shatement of Area Survcyed and Unsurveyed during the year 190.5.

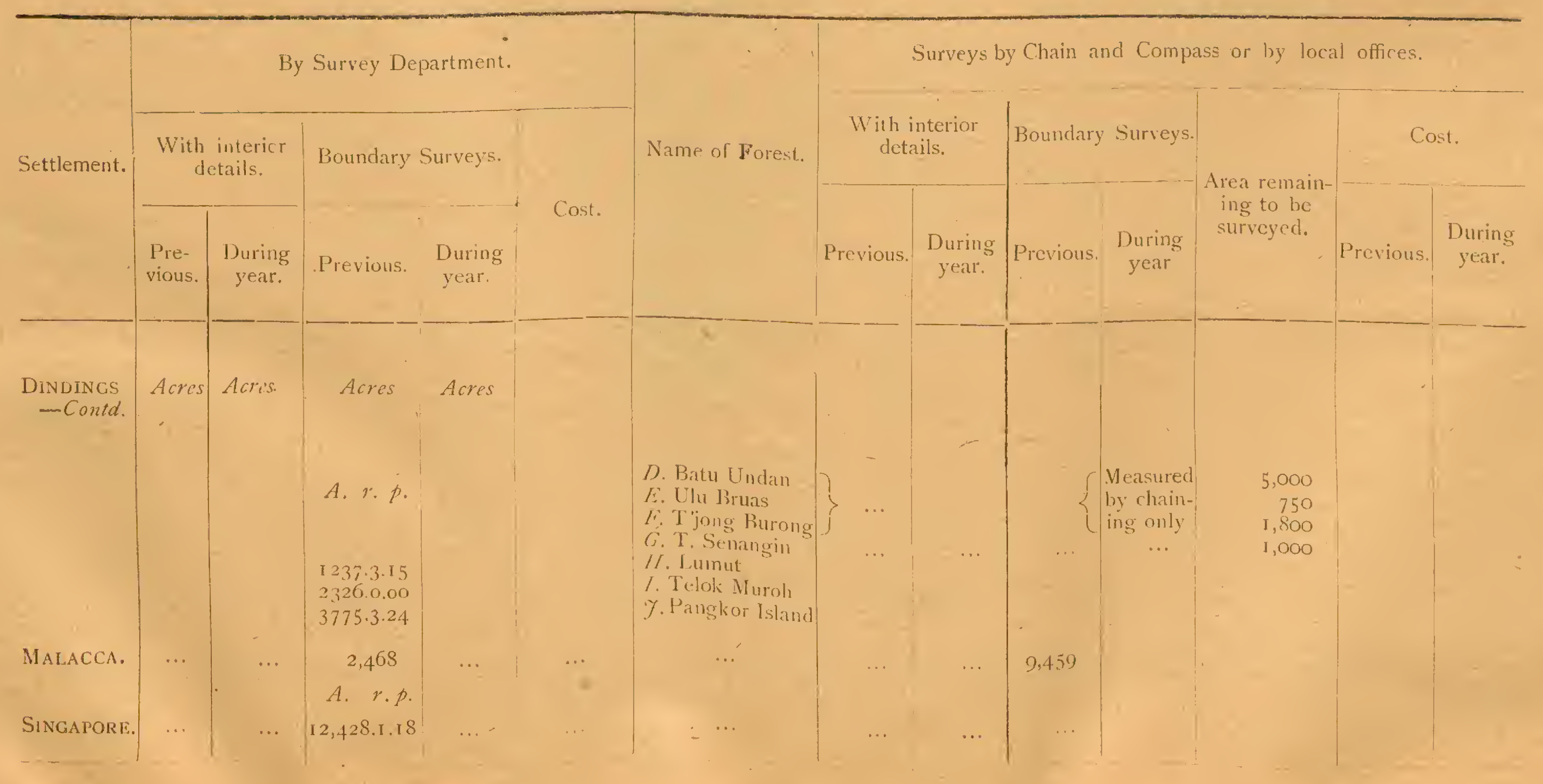


FORM NO. 5.

Progress made in Working Plans during 1905.

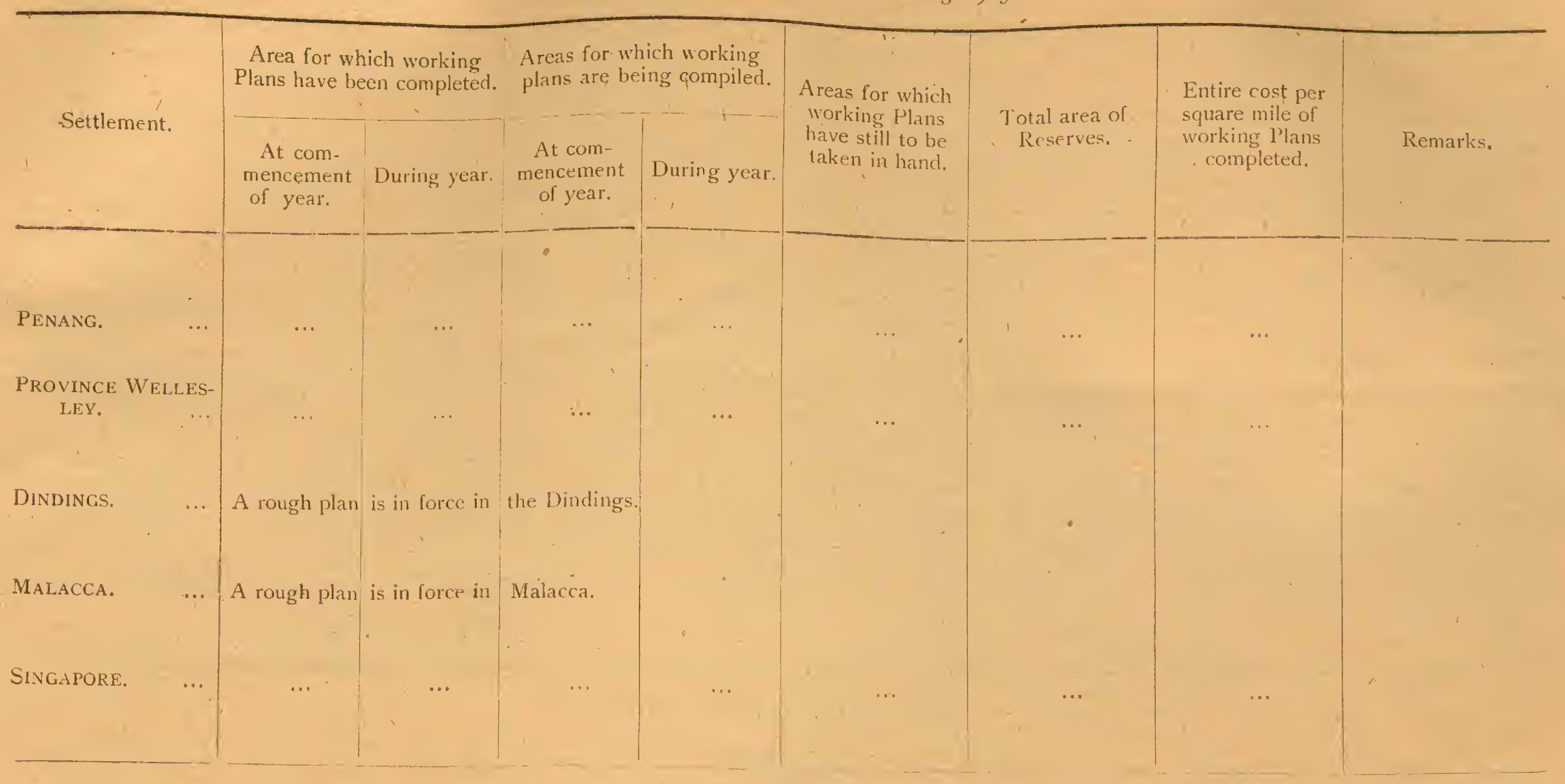


FORM NO. 6.

Communications and Buildings 1905.

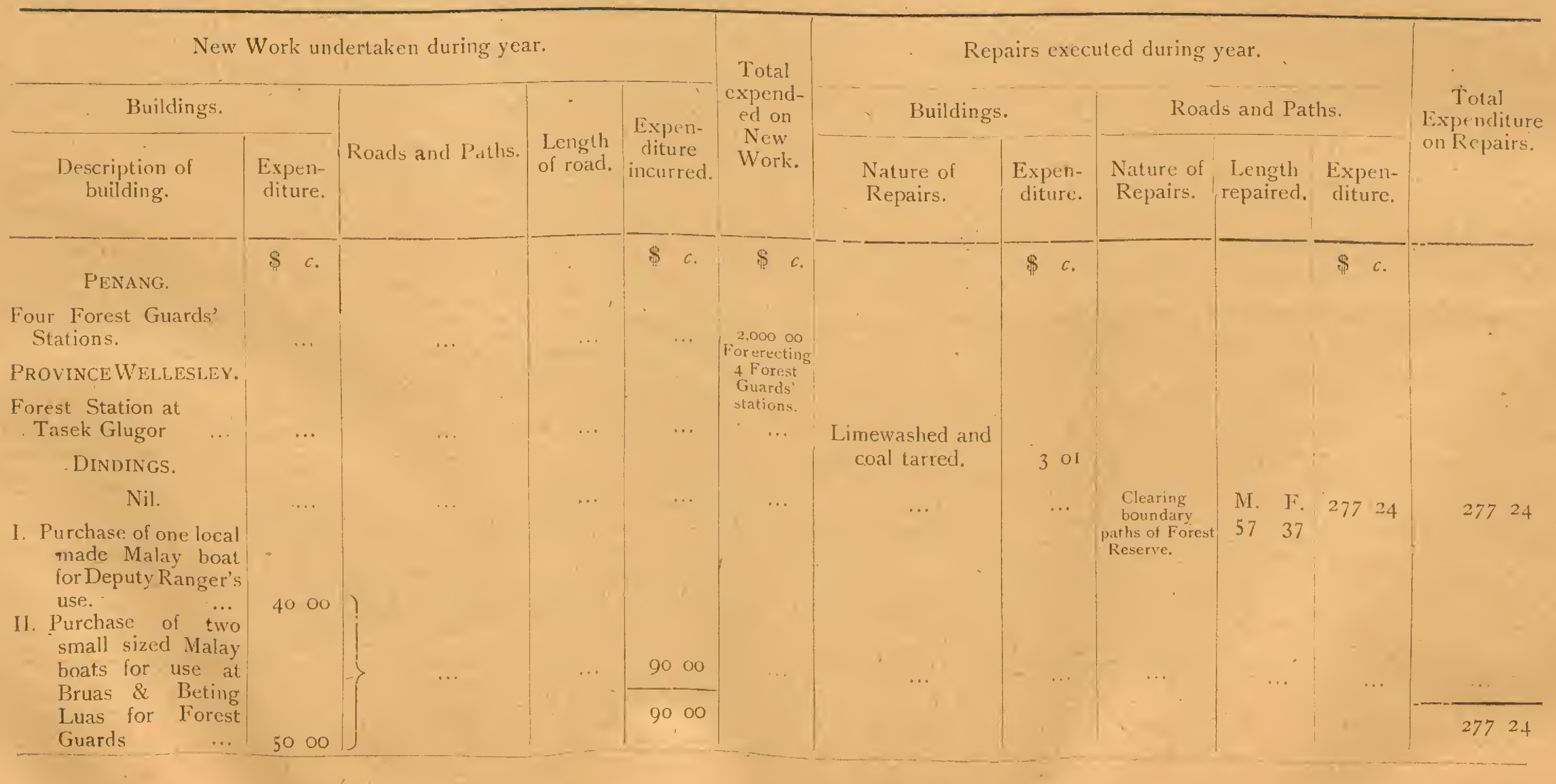


FORM No, 6,-Concluded.

Communications and Buildings rgog.

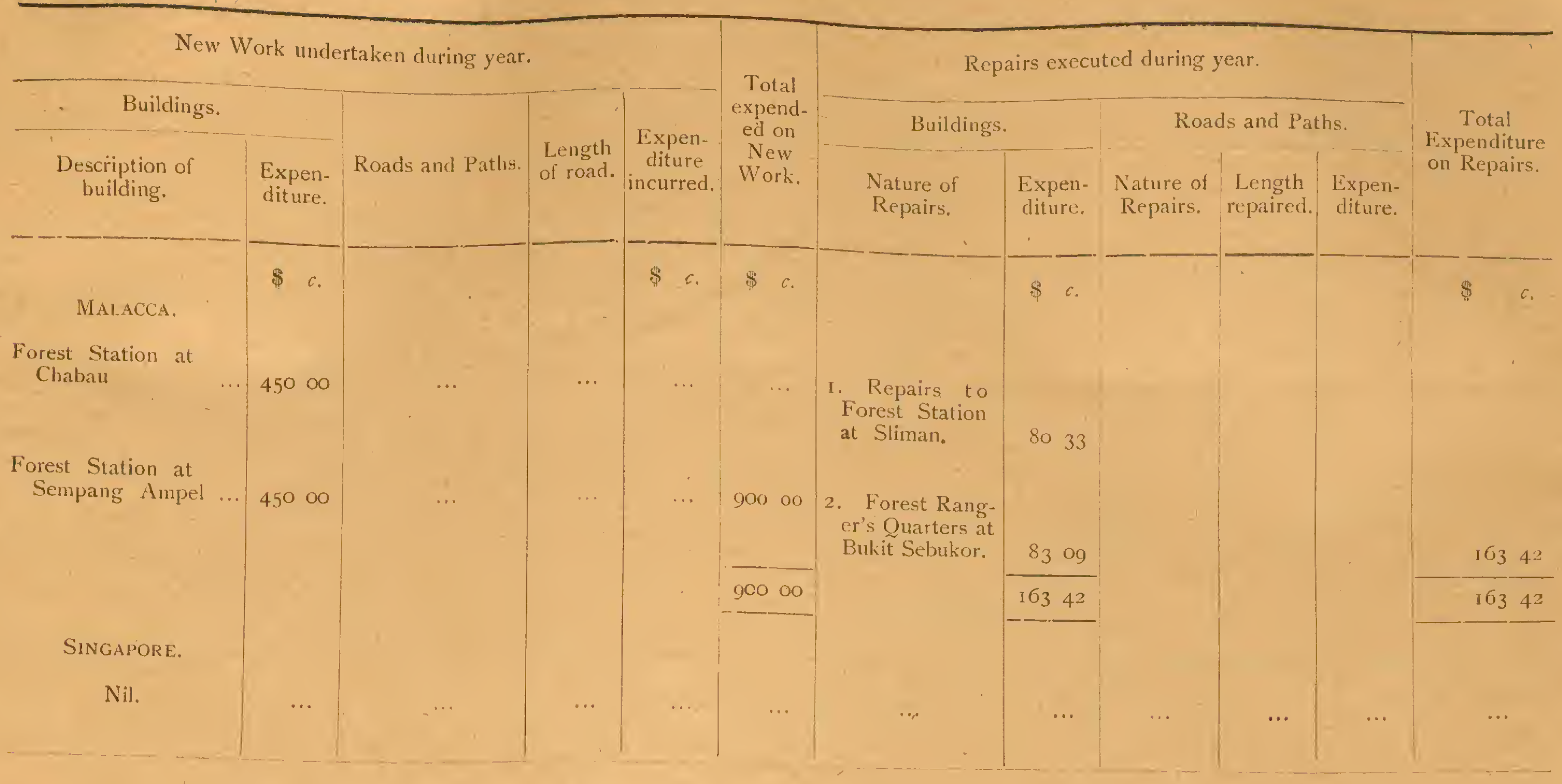


lOKM No. 7 .

Register of Breaches of Forest Rules for 1905.

\begin{tabular}{|c|c|c|c|c|c|c|c|c|c|}
\hline Settlement and District. & 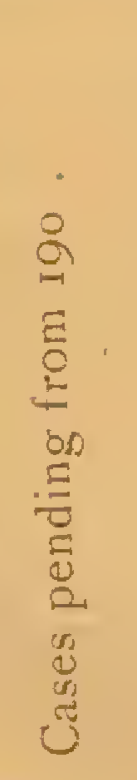 & 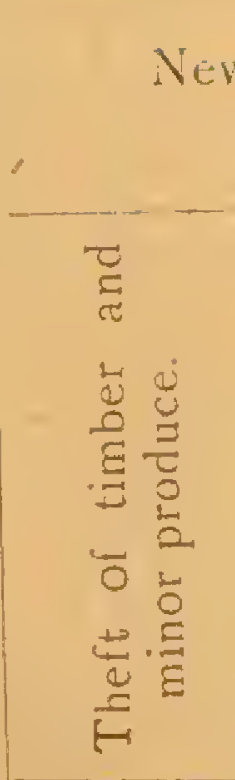 & 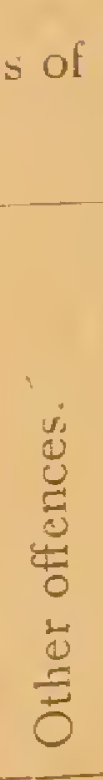 & 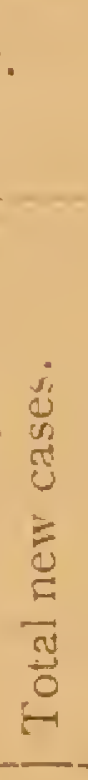 & 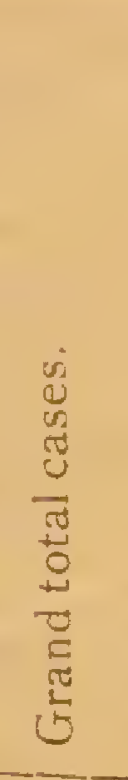 & $\begin{array}{r}\text { Disposed } \\
\text { ye }\end{array}$ & Luring & 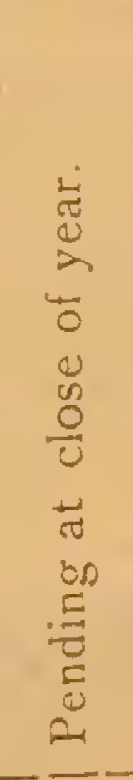 & Remarks. \\
\hline PENANG $\quad \ldots$ & Nil & 15 & ..' & $\cdots$ & 15 & 12 & 3 & $\cdots$ & Fínes $\$ 79$. \\
\hline Province Wellesley & Nil & 7 & $\cdots$ & $\cdots$ & 7 & 5 & 2 & $\cdots$ & $" \quad \$ 100$ \\
\hline DINDINGS & Nil & $3^{8}$ & 5 & 43 & 43 & 33 & 10 & $\mathrm{Nil}$ & $\begin{array}{l}\text { Fines inflicted } \$ 263 \text {. Fines re- } \\
\text { alised } \$ 198 .\end{array}$ \\
\hline $\begin{array}{l}\text { MALACCA } \\
\text { SINGAPORE: }\end{array}$ & $\cdots$ & 65 & 2 & 67 & 67 & $4 \mathrm{I}$ & 9 & I & $\begin{array}{l}2 \text { Absconded. } 14 \text { Compounded } \\
\text { for } \$ 124.63 \text {. Fines inflicted } \\
\text { in Court } \$ 504 \text {. }\end{array}$ \\
\hline WESTERN DIVISION $\ldots$ & Nil & 2 & $\cdots$ & 2 & 2 & 2 & Nil & Nil & Fines \$I 50. \\
\hline
\end{tabular}


FORM No. 8.

Area of Plantations.

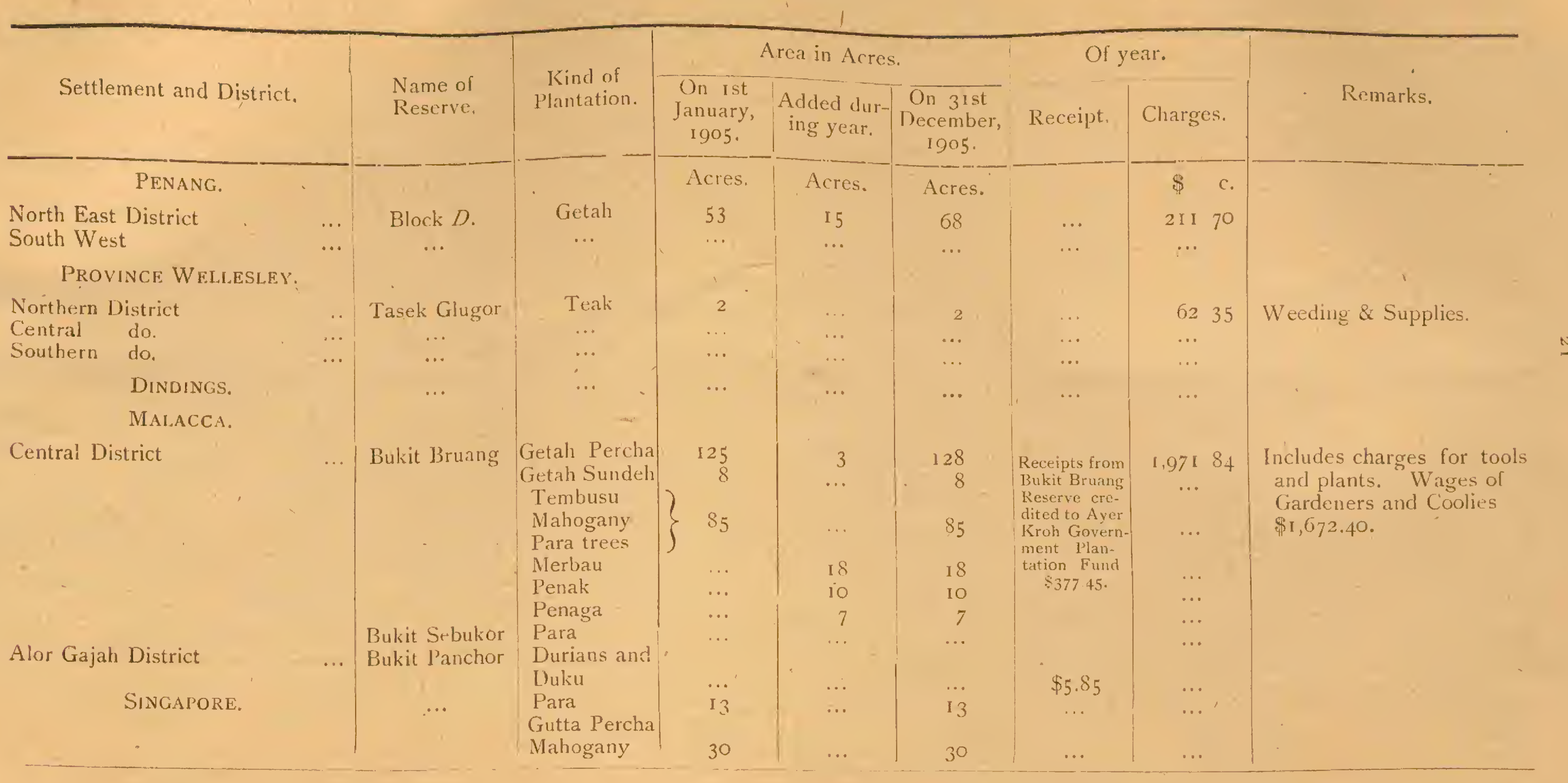


HORM NO. 9.

Outurn in Cubic Feet of Timber and Fuel during Igos.

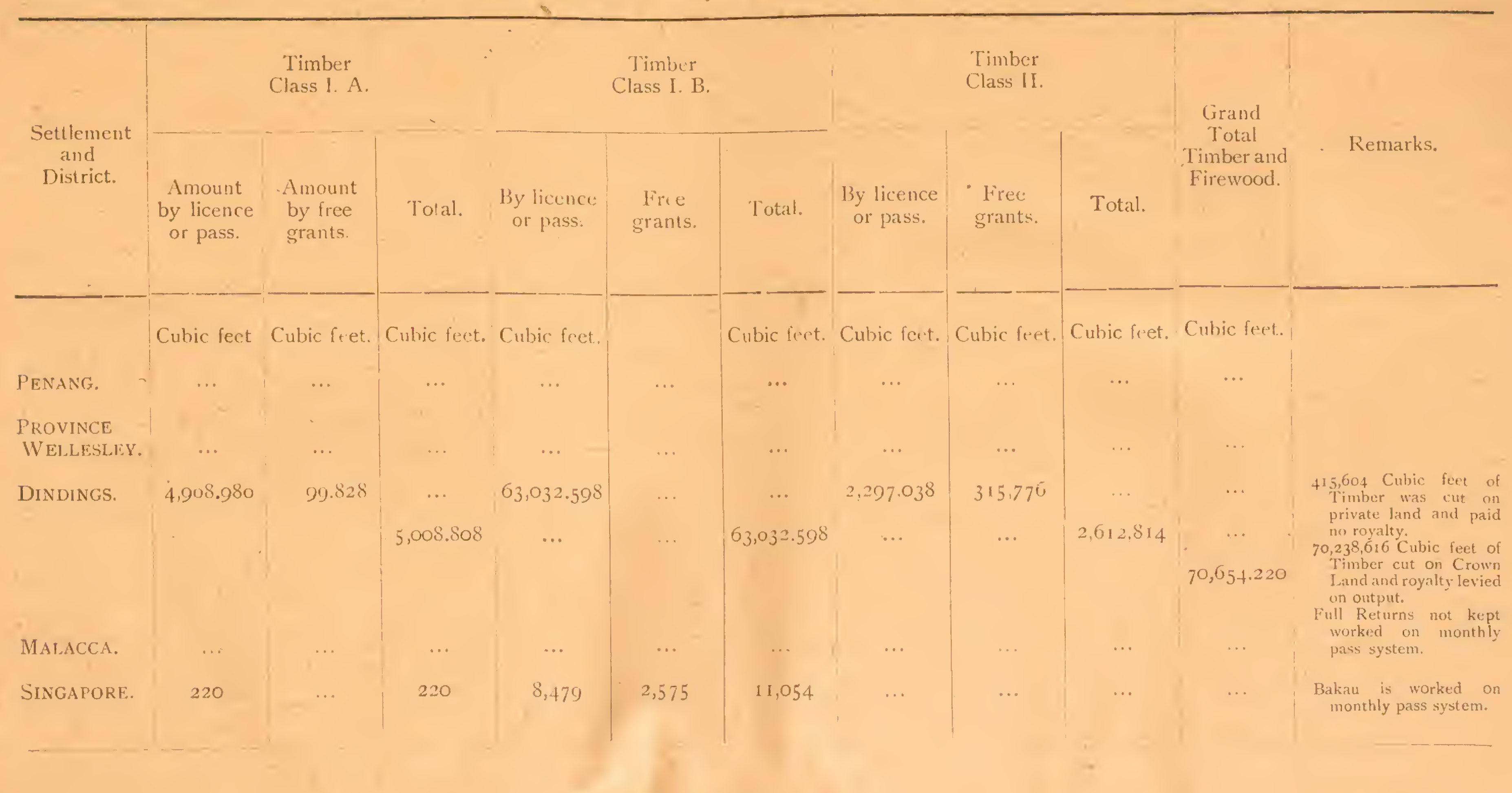


FORM No, 10.

Outurn of Minor Forest Produce.

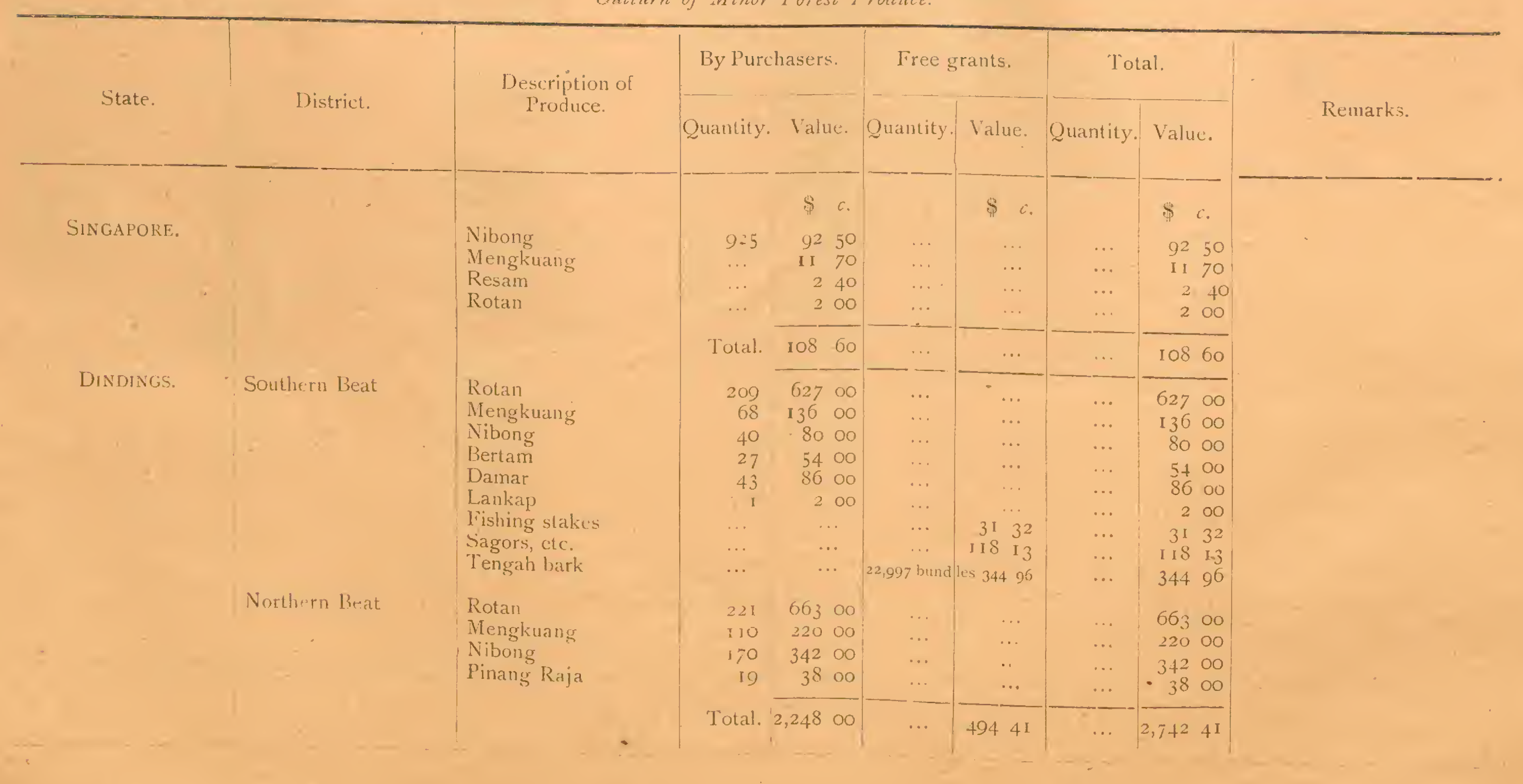


FORM No, ro.-Continued.

Outturn of Minor Forest Produce.

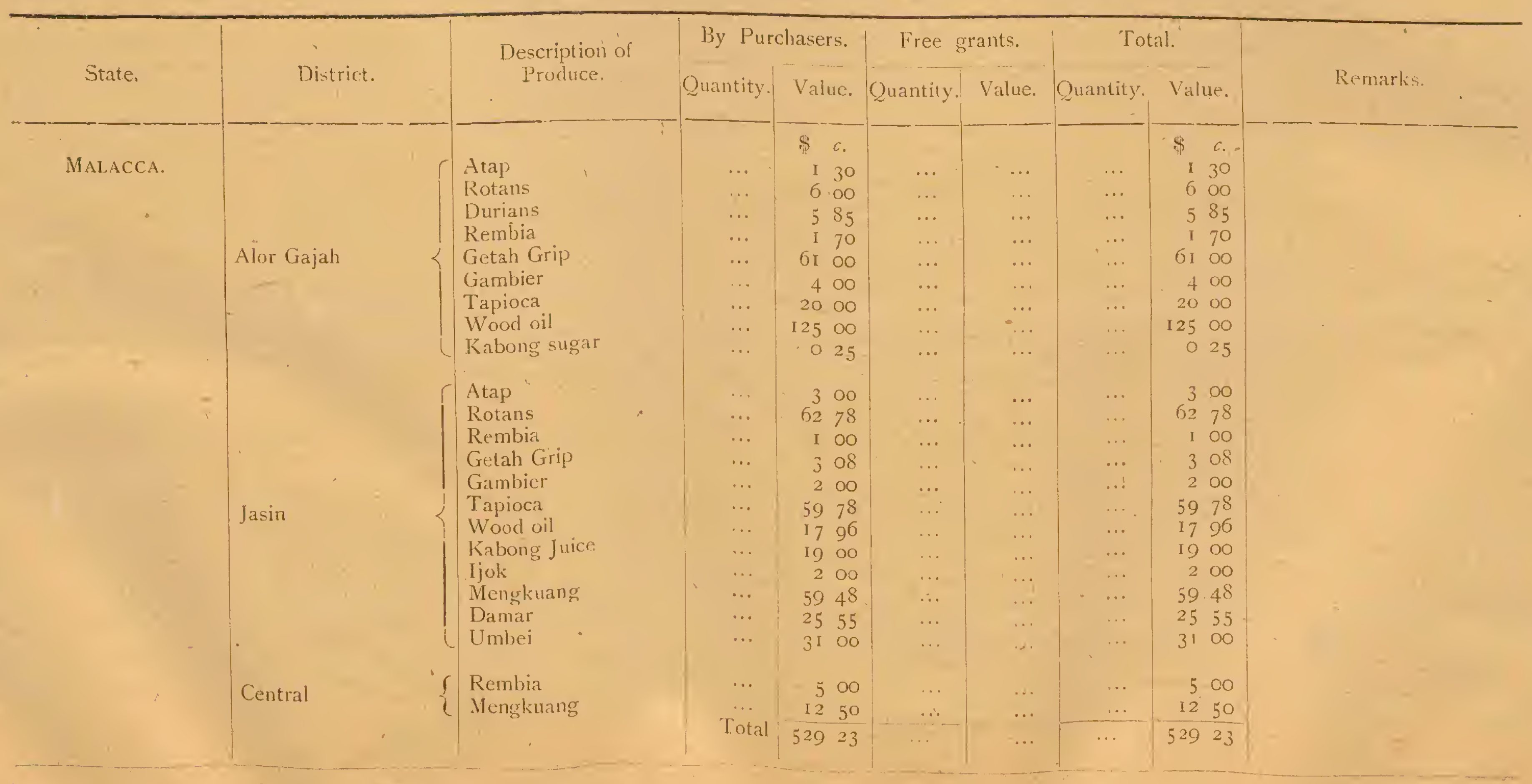


FORM NO. II

Summary of Revenue and Exponduture roog.

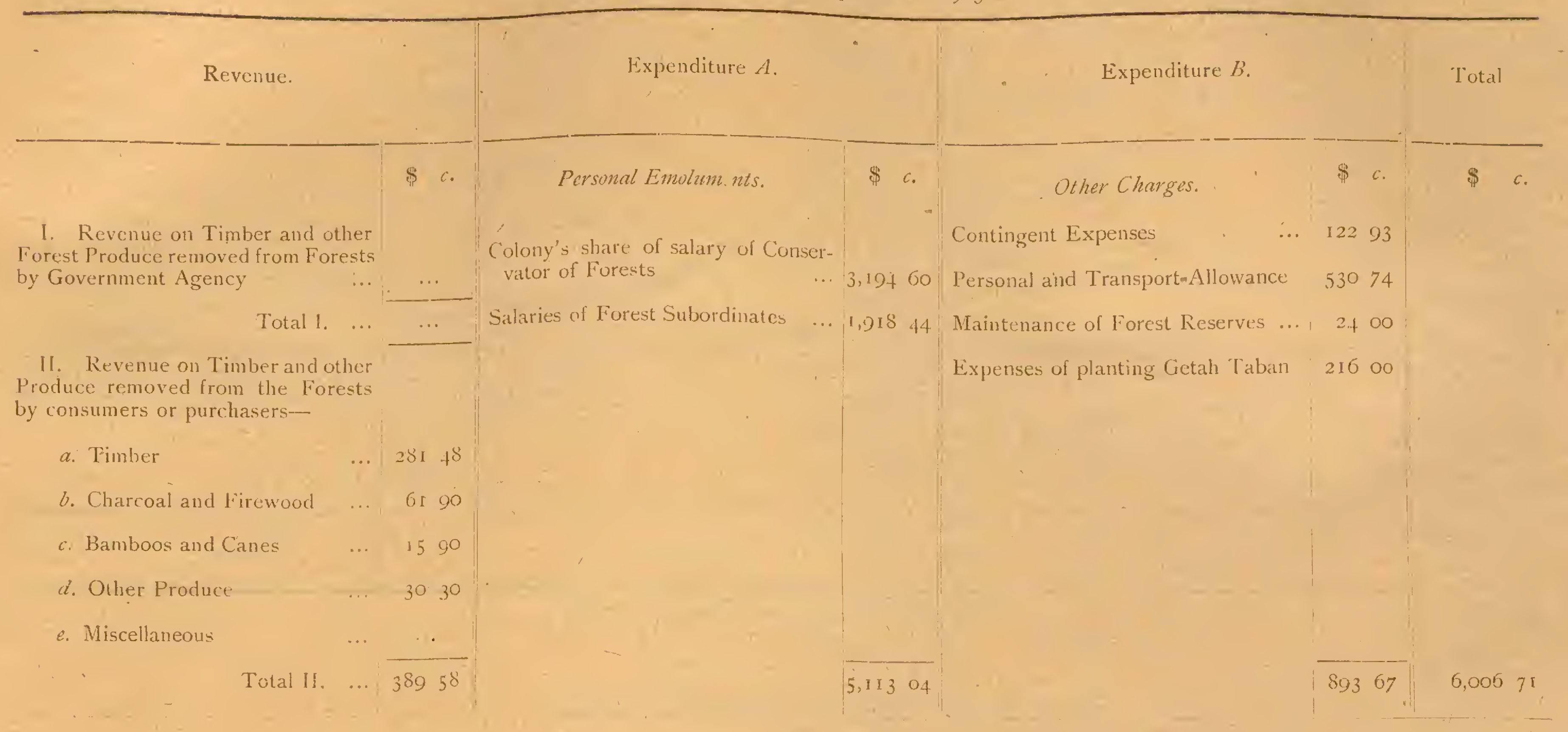

in

forests

consumers or purchasers-

Total 11. ... 38958

\section{SINGAPORE.}

Summary of Revenue and $t$ 
PENANG AND PROVINCE WELLESLEY.

FORM No. II.-Contimued.

Summary of Revente and Expenditure 1905.

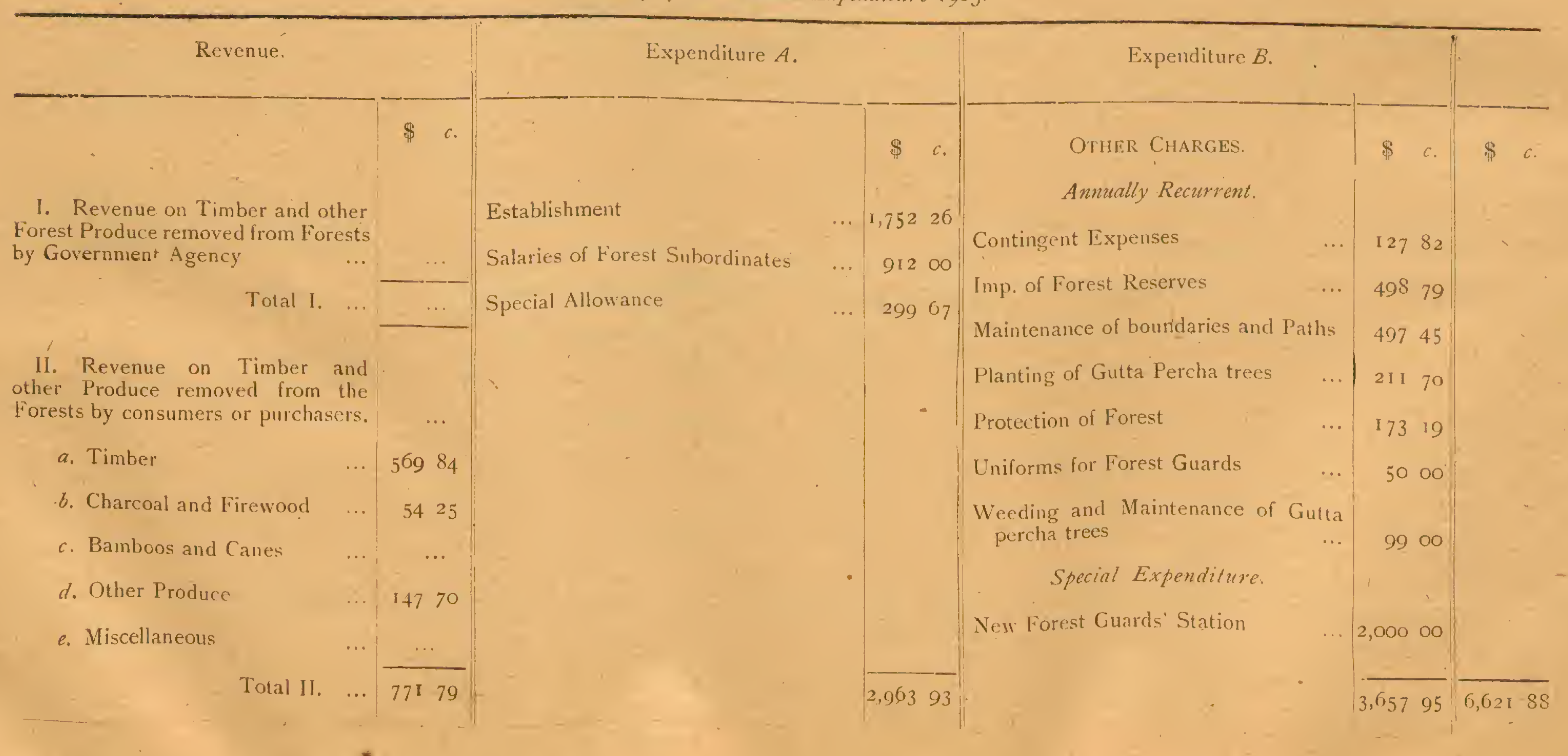


DINDINGS

FORM NO. I1.-Continued.

Summary of Rerenue and Expendilure 1905.

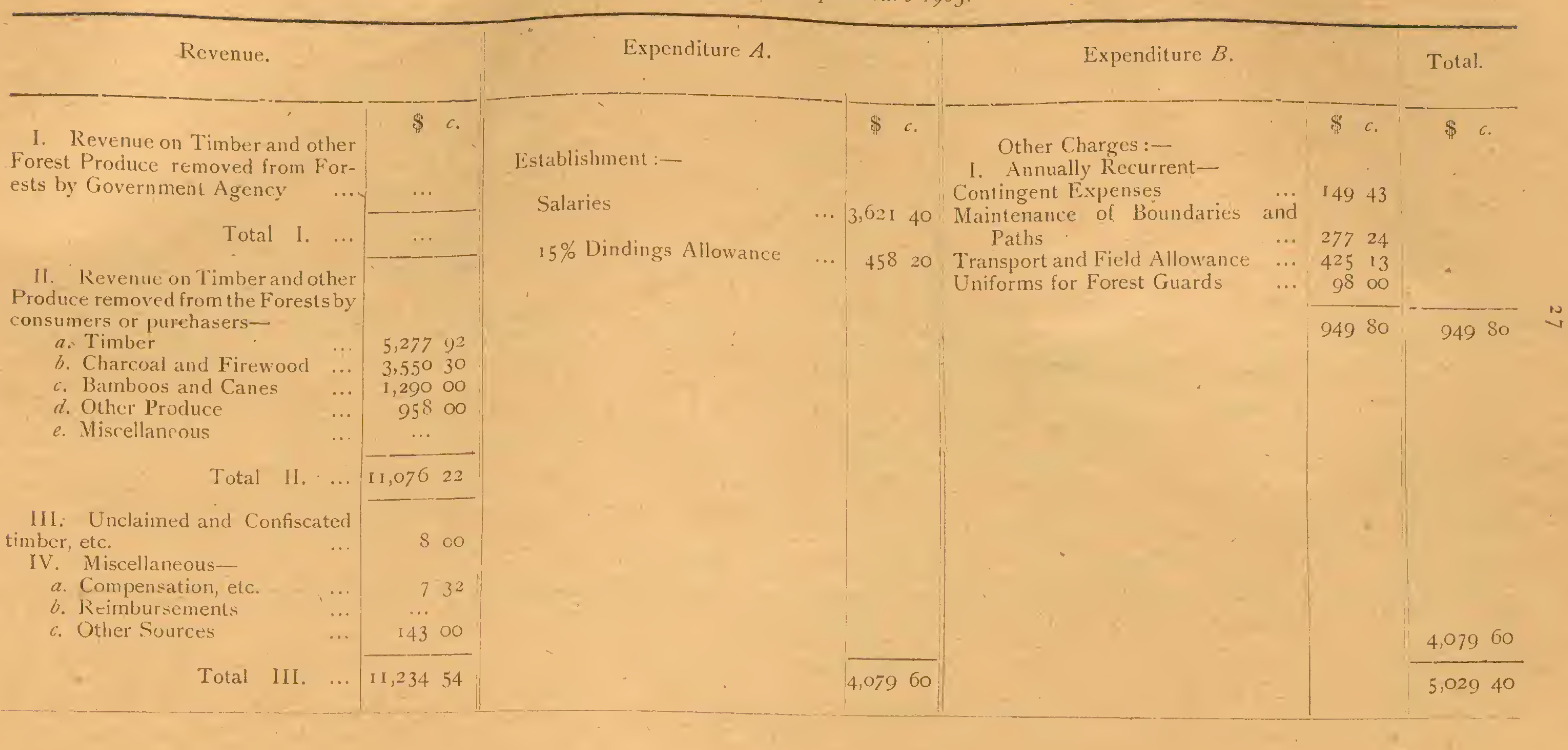


MAI.ACCA.

FORM NO. I ,-concluded.

Summary of Revenue and Expenditure 1905.

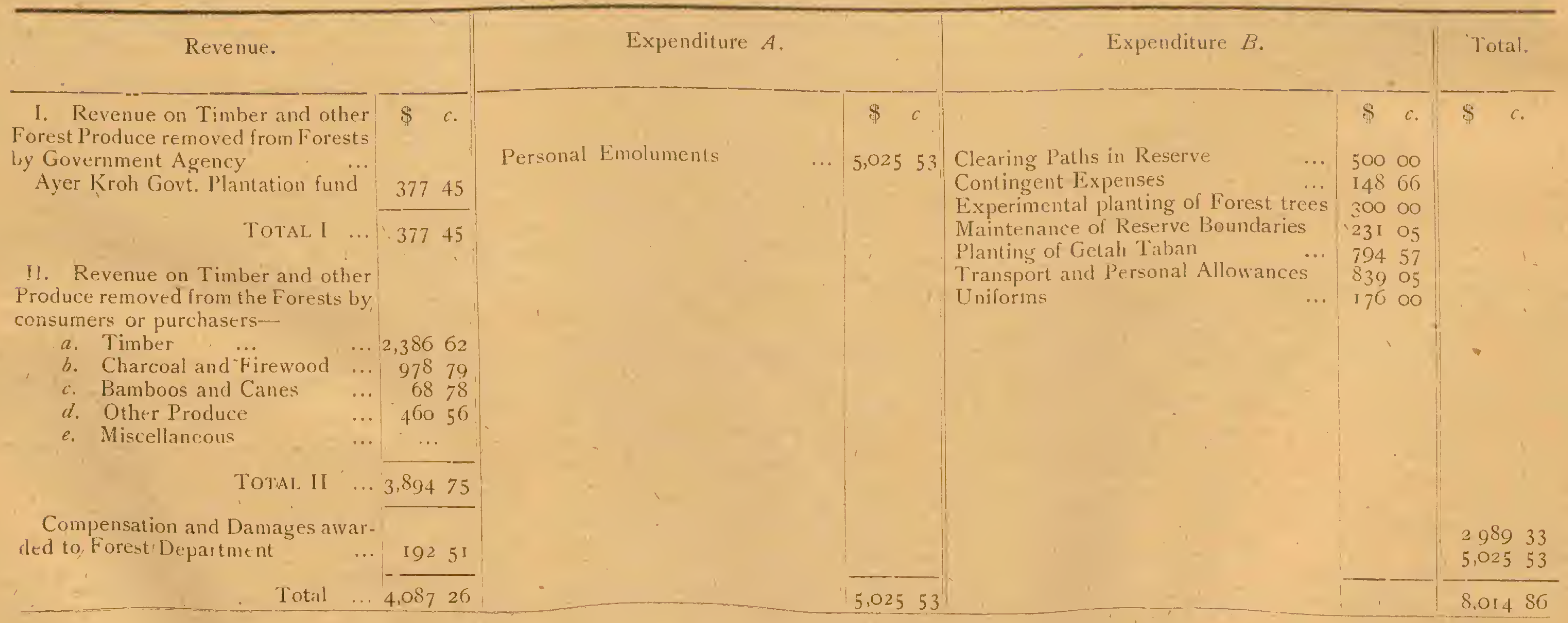




\title{
STRAITS SETTLEMENTS.
}

\author{
Paper to be laid before the Legislative Council by Command of \\ His Excellency the Governor.
}

\section{Annual Report on Forest Administration in the Straits Settlements for the year 1906.}

\section{PART I.}

\section{Extension and Constitution of Reserved Forests.}

\section{I... Alteration in Area.}

1. The following table shews the areas of the forest reserves in relation to the whole areas of the various Settlements, a small increase will be noticed in Singapore, by the inclusion for the first time in the returns of Seletar extension, and an addition of 623 acres to the Pandan Reserve, vide Form $I$. *

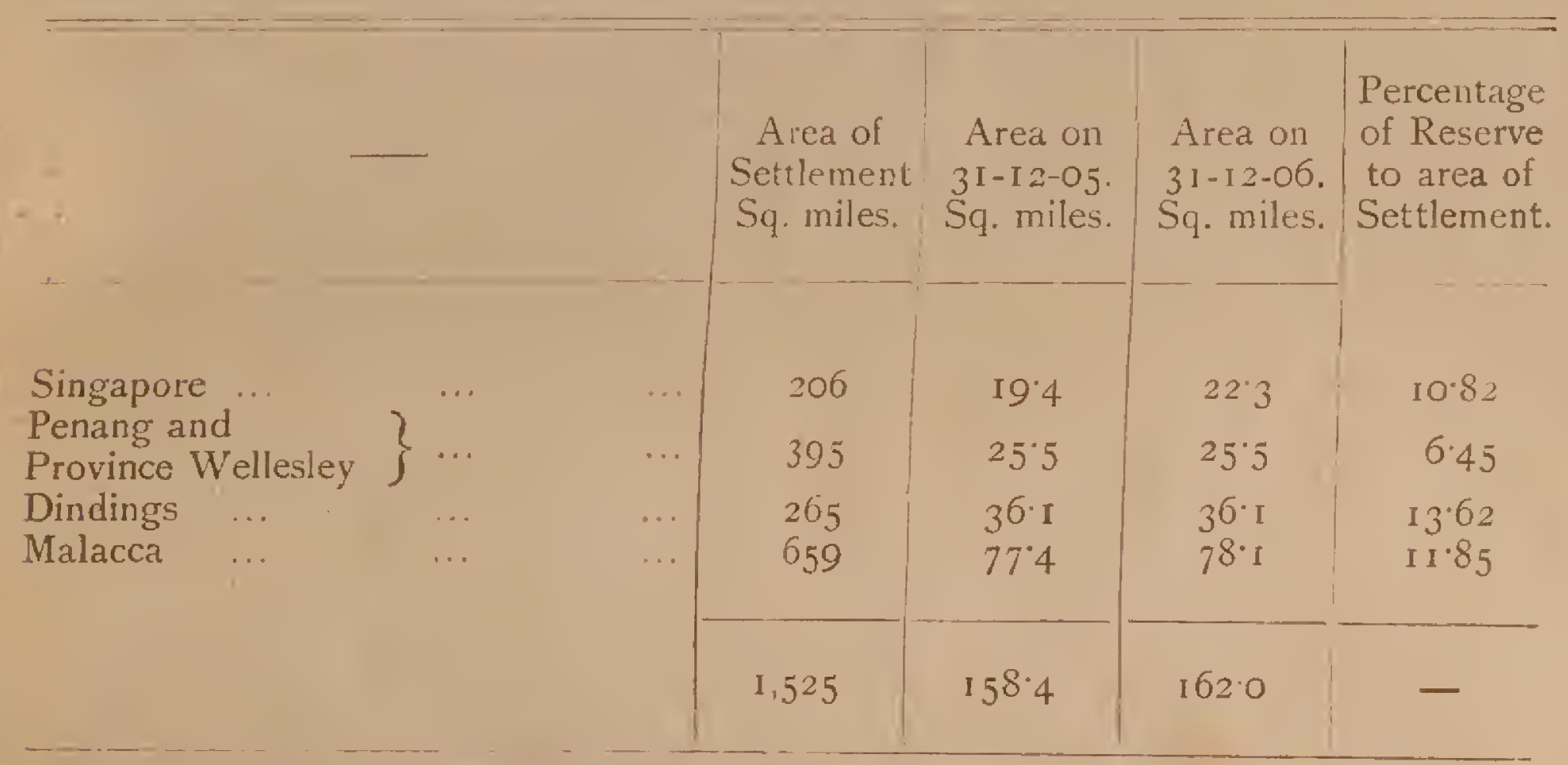

Four small areas in Singapore varying in extent from 4 to 13 acres respectively have been omitted from the list of Reserves as they are not worth up-keeping.

2. Some small alterations will be found in Form $I *$ as regards area of Malacca Reserves, being merely corrections owing to more correct surveys and one or two small excisions. No reserves in the Colony have as yet been legally constituted.

\section{Reserve Proposals.}

3. The only proposed addition was the area added to Pandan Reserve, above mentioned. It contains valuable Mangrove forest, and is situated to the West of the Sungai Jurong.

In Malacca, a few small patches of Gutta Percha forest were proposed. An extension of Batu Undan forest reserve was considered, but not yet finally included or demarcated.

\section{Demarcation and Up=keep of Boundaries.}

4. In Singapore, the boundaries were well kept by the Forest Guards, except part of Sungai Buloh Reserve, which was inaccessible owing to the absence of a boat for the men in charge, which was however purchased late in the year. up-keep.

There are $91 \frac{1}{2}$ miles of cut lines and $34^{\frac{1}{2}}$ of natural boundaries requiring no

5. In Penang, 66 miles were recleared and in Province Wellesley, 41 miles at a cost of $\$ 566.65$ against $\$ 497.45$ in 1905 , nearly double the length being cleared in Igo6.

\footnotetext{
* Not printed,
} 
6. In the Dindings, $52 \frac{1}{2}$ miles were recleared by contract and cost $\$ 335.12$ or $\$ 6.40$ per mile. The boundaries are in good order.

7. In Malacca, 107 miles of boundary were recleared at a cost of $\$ 397.70$, and trees growing on the boundaries felled.

\section{Surveys,}

8. No surveys were made during the year, although 6 Reserves remain to be surveyed in the Dindings. the year.

Plans of Malacca and Singapore Reserves were supplied to the Conservator during

\section{PART II.}

\section{Management of Crown Forests and Reserves.}

\section{Working Plans,}

9. No regular working plaus are in force, but the Dindings and Malacca Crown Lands were exploited by licensees on a rough plan.

\section{Paths and Buildings.}

10. In Singapore, no buildings were erected nor charges incurred.

I 1. In Province Wellesley, coolie lines were erected at a cost of $\$ 97.52$ at Bukit Seraya by the Public Works Department.

I2. In the Dindings the Forest Guards' quarters at Beting Luas were pulled down and rebuilt at Changkat Resam by the Forest Guards themselves. A boat was purchased for $\$ 80$ for the use of the Staff.

13. In Malacca, a new forest station was built at the $14 \frac{1}{2}$ mile, Merlimau Road, at a cost of $\$ 500$; repairs to other stations were effected at a cost of $\$ 288.26$.

Paths in reserves were cleared at a cost of $\$ 392.85$.

\section{Protection of Forests.}

I4. Forest Laws.-The proposed forest Ordinance has not yet been passed, but in December a draft was submitted by the Conservator of Forests to the Government, based on the draft enactment adopted at the Conference of Residents in Kuala Lumpur, part II dealing with the procedure for constitution of reserved forests being much abridged and simplified.

An alteration was effected in tixe Malacca Timber and Jungle Produce Rules, by which timber could be cut under monthly permit in Reserves.

15. Fires.-No serious fires occurred during the year, but 5 persons were convicted in Malacca for burning lalang.

\section{Forest Offences.}

16. There were 16 cases in Singapore as against 2 in 1905, resulting in 16 convictions, fines inflicted amounting to $\$ 33^{8} ; 8$ cases related to reserved forests.

In Penang and Province Wellesley, there were 37 prosecutions; resulting in 29 convictions, $\$ 282$ being realized in fines.

This shews a great increase over 1905 .

In the Dindings, there were 16 prosecutions and 15 convictions, with one acquittal, fines amounting to $\$ \mathrm{I} 4 \mathrm{O}$. The decrease in the number of cases is due to better supervision and probably to the fact that the Rules are better understood. ( 43 cases in 1905 with 33 convictions).

In Malacca, 84 cases of forest offences were dealt with, resulting in 53 convictions and 13 acquittals. Fourteen cases were compounded, 3 accused absconded and one case was struck out, leaving 2 cases pending at the close of the year.

This shews an increase over I905. Of these, I3 cases were concerned with. offences in forest reserves.

\section{Improvement of Forests.}

(a) Natural Reproduction.

17. There is little to report under this head, Meranti reproduces itself well in the Dindings and Tampinis in Mal- ca. 
Eight hundred and twenty-four Taban trees (Gutta percha) have been counted in small blocks growing on Crown Land, of which 14 are over 2 feet in girth.

A few saplings of Resak and Petaling have been noticed.

\section{(3) ARTificial, REproduction.}

[For PARTICulars See Form 8**]

18. In Singapore the Io acre block of Para rubber in Sembawang reserve was reeded at a cost of $\$ 65.95$.

Of the Bukit Timah plantation of Gutta percha, 97 acres in extent, 50 acres were clatred of undergrowth at a cost of $\$ 83.70$. The gutta percha plants are planted in lines in the forest, and are doing well. No addition was made to the area.

19. In Penang $\$ 14+30$ were spent on weeding and clearing in the Baty Ferringgi Gutta percha plantation, no additional area was planted, owi ys to want of seed. The plants appear to be healthy.

The areat of this plantation at the close of the year was 68 acres.

20. The 2 acre plantation at Tasek Glugor canno' be called a success. A fire trace 15 feet wide was cut rouni 2 sides during the year, to prevent lalang fires crossing.

Pulau Ferejak-This island has been handed over to the charge of the Medical Department, who collect the revenue on the coconuts,

At Bukit Mertajam over 4,00o seedlings of Mahogany and Albizzia were planted out on the slopes of the hill.

$2 \mathrm{I}$. There are no plantations in the Dindings.

22. In Malacca 38 acres were planted during the year with Chengal (Balanocarpus maximus) Penaga (Alesua ferrea) Merbau (Afzelia Palembanica) and Nibong
(Oncosperma tigillaria).

At Ayer Kroh most of the Chengal planted out in 1905 died, owing, it is thought, to insufficient time being allowed in the nurseries. Fifty-two Gutta percha plants were raised by "Marcottage." The Conservator inspected the plantations during the year, which now amo!nts to 294 acres in area. The results obtained are very satisfactory.

The receipts from Para trees and Orchards were $\$ 55.5$ and the expenditure on the plantations $\$ 1,550$.

\section{Exploitation,}

\section{(SeC FORM $9^{*}$ )}

\section{(r) TIMHER AND FUHi,}

23. In Singapore 210 tress were cut under passes, and 12,379 poles, realizing $\$ 303$ revenuc. 3,048 poles and small trees were cut under free passes.

No cutting was permitted in reserved forests. Passes were issued to cut Firewood and realized $\$ 696$.

24. In Penang and Province Wellesiey no figures are available but the quantity of timber and firewood cut and collected was less than in 1905 , the revenue being $\$ 455$
as against $\$ 624$ in 1905 .

Penang is supplied with timber and fuel lrom Kedah and Perak forests.

25. In the Dindings felling was carried on in 7 localities and four saw yards were in use, cutting being allowed in Tclok Sera, Gunong Tunggal and Batu Undan reserves, all trees being marked before felling by the Forest-Ranger.

Twelve thousand two hundred and twelve cubic feet of timber were extracted from the reserves or 244 tons, and from other forests 39,540 cubic feet or 790 tons, but of this amount 129 cubic fect ( $2 \frac{1}{2}$ tons) were cut on alienated land and produced no revenue. The out-turn of timber shews a falling off as compared with 1905 .

About 1,788 cubic feet of class I timber and $+1,444$ cubic feet of class II were supplied to the Public Works Department during the year.

26. The average number of Mangrove firewrod-cutters during the year was 65 ,
fing under $\$ 5$ monthly passes. launches.

Forty-eight passes were istued free to the Government firenood contractors for

The vul-put of linewoul slightly excecded that of 1905 in the Dindings. 
27. In Malacea, limber was cut under passes and the amount therefore not known, but fecs realized $\$ 2,858$ als agrainst $\$ 078$ in igo5.

The fublic Works Department were supplied with timber free of royalty, which would have amounted to $\$ 05$.

\section{(b) MINOR FORIST PRODUCE.}

28. In Singapore, small amounts of Nibong, Mengkuang, Rotan and Resam were extracted bringing in a small revénte.

29. In Penang and Province Wellesley, Bamboos, Canes and other produco realized $\$ 100$ as against $\$ 147$ in 1905 .

30. In the Dindings, 200,760 bundles of Tengah bark were collected, and bamboos and canes were cut under monthly permit, form $I 0$ shews the revenue realized but the amount cut cannot be accordingly estimated.

1. In Malaccat there was a considerable increase in revenue on minor forest producc. The right to collect woud oil from Depterocarpus Crinitus was sold in the Sungai Udang reserve for $\$ S 0$ and $\$ 40$ in the Nyalas reserve.

In all $\$ 976$. Io was realized on minor produce taken from reserves.

\section{PART III}

\section{Financial Results.}

\section{PARTICULARS IN FORM II.**}

I. Revenue shews an increase over Igo5 of $\$ 79$. I 8 .

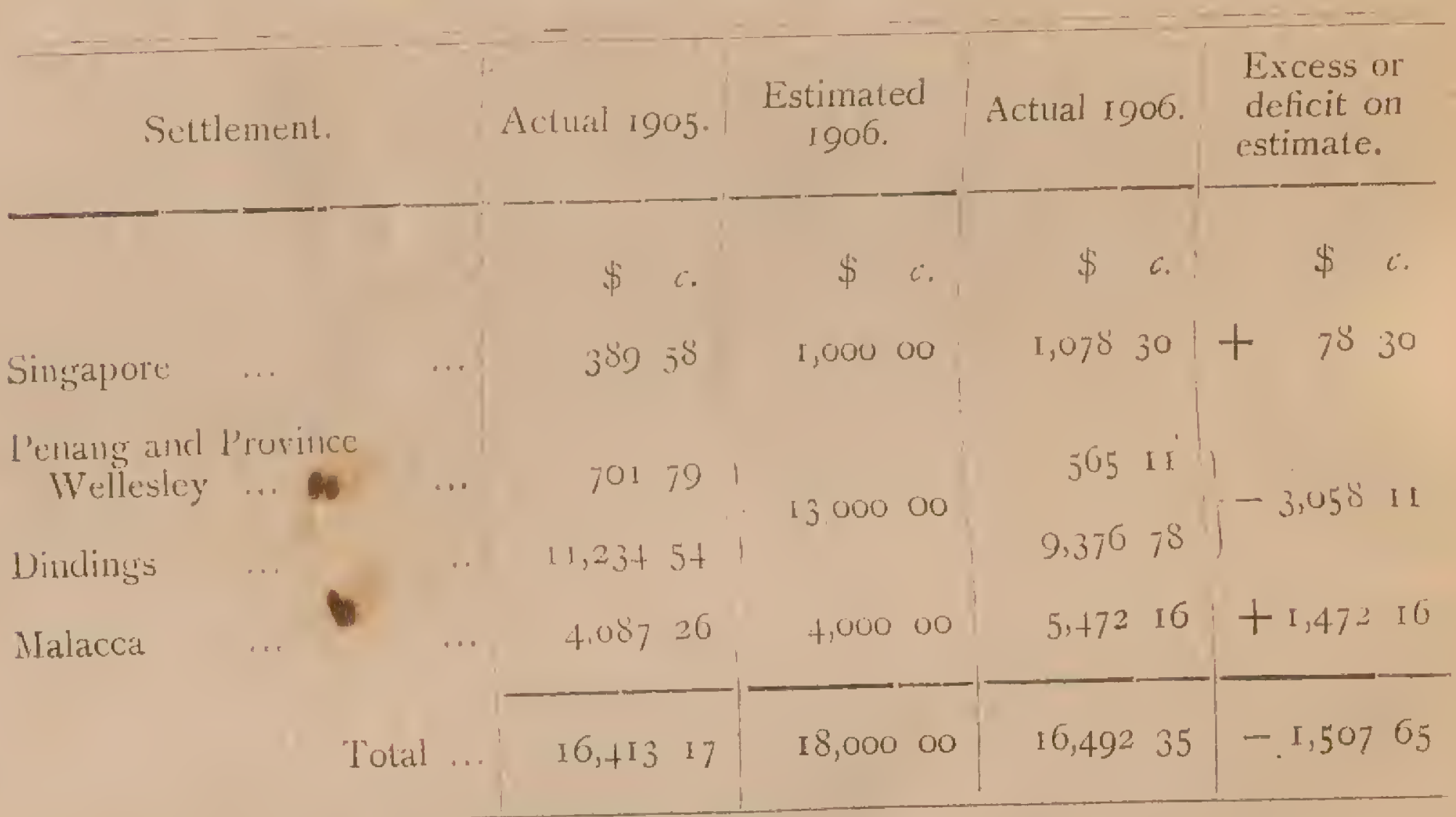

32. The increase in Singapore is due chiefly to issue of passes to cut Mangrove.

33. In Penang and Province Wellesley there was a decrease in revenue, $\$ 565$ as against $\$ 701$ in 1905 .

34. In the Dindings there was a fall in timber revenue, from $\$ 5,277$ in rgo5 to $\$ 3,87 \mathrm{~S}$ in Igo6, wines to the lact that the Neor Sebatang and Batu Undan Timber Kongsis" had to be closed down through scarcity of timber, it was then necessary for the timber cutters to move to a new locality and build new sheds, etc. during which time no timber was exported.

There was also a fall in Jungle produce, chiefly on Bamboos and Canes, due to the fact that many of the workers left the Dindings Torritory to take up jungle lelling work on rubber cstates.

The revenue may, however, be taken as but little below normal, Laking into consideration the state of the forests.

35. In Malacca the increase is due chiefly to the expluitation of minor lorest produce also to an inrrease in imber fees. 
II. Expenditure.

FOR DETAILS See ForM H1. *

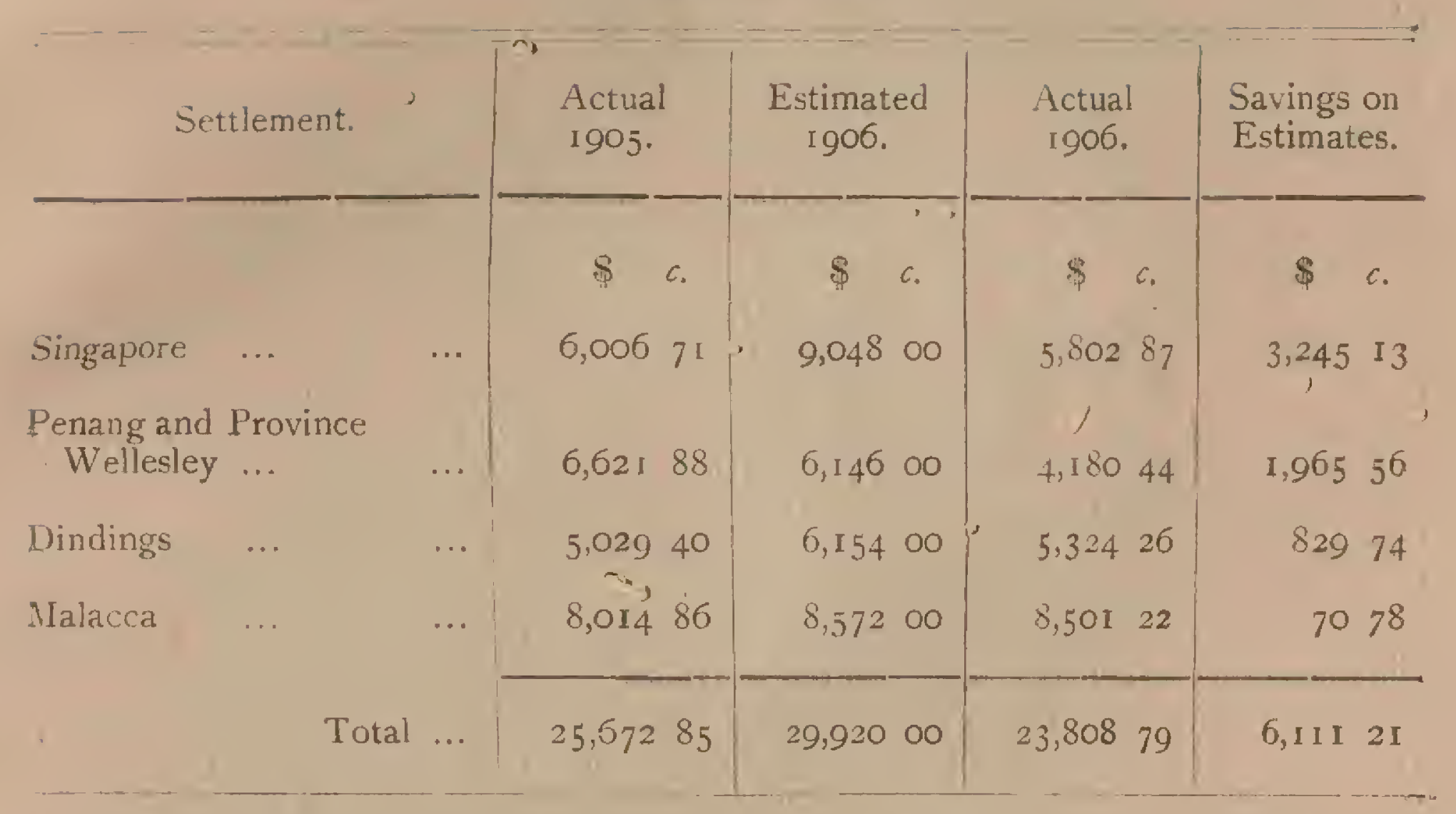

36. The Singapore expenditure apart from Conservator only, amounted to $\$ \mathbf{I}, 924$; one-third of the Conservator's salary and his Colonial Transport expenses are included under Singapore votes.

37. In Penang and Province Wellesley there was a saving of $\$ 1,965$ on the amount estimated, included in the above figures, but $\$ 214.64$ were spent on travelling expenses of Mr. O'HARA to Dehra Dun, and $\$ 364$ advanced to the Director of the Forest School for his education, which sums are not included in the above table.

38. In Malacca. The vote for planting Gutta Percha trees was extended by $\$ 450$.

\begin{tabular}{|c|c|c|c|c|}
\hline Settlement. & $\begin{array}{l}\text { Revenue } \\
\text { ig06. }\end{array}$ & $\begin{array}{c}\text { Expenditure } \\
\text { I906. }\end{array}$ & Surplus. & Deficit. \\
\hline & $\$ \quad c$. & $\$ \quad c$. & $\$ c$. & $\$$ \\
\hline Singapore $\quad \ldots$ & 1,07830 & $5,802 \quad 87$ & & 4,72457 \\
\hline $\begin{array}{c}\text { Penang and Province } \\
\text { Wellesley } \ldots\end{array}$ & 565 II & $4, \mathrm{I} 80 \quad 44$ & 9 & 3,6 I 333 \\
\hline Dindings & $9,376 \quad 78$ & $5,32+26$ & $4,052,52$ & $\ldots$ \\
\hline Malacca & 5,472 I6 & $8,501 \quad 22$ & $\cdots$ & 3,02906 \\
\hline Total ... & 16,49235 & $23,808 \quad 79$ & $4,052 \quad 52$ & I 1,36896 \\
\hline
\end{tabular}

A deficit of $\$ 7,316.44$ as compared with a deficit of $\$ 9,259.68$ in 1905 .

39. The Revenue in Singapore will probably shew an increase in 1907 as it is proposed to work the Pandan Reserve for fuel on a regular system.

\section{Establishments.}

40. Mr. A. B. Stephens, acted as Conservator from Ist January, 1906, to I3th April, igo6, when Mr. A. M. Burn-MurdoCH returned from leave and resumed charge.

41. In Penang, Mr. Fox, Superintendent of Forests and Gardens went on leave in April; the Collector of Land Revenue, Penang, carrying on his duties.

In June, an arrangement was made by which .Ir. W. H. MILl.ER, Forest Ranger, Lower Perak, was to visit the Settlement for a week e ery 2 months. He paid

$$
\text { * Not printed. }
$$


three visits, in July, September, and in November. This arrangement is far from satisfactory leaving the subordinate staff too much to their own devices.

42. In the Dindings Mr. G. M. O'HARA, Ranger, II Grade, held charge under the District Officer till March when he left to undergo the training at Dehra Dun Forest School, being replaced by Mr. J. E. Askey, of the Federated Malay States Forest Service, also Ranger, II Grade, who has performed his dutıes steadily and well, although hampered by sickness.

The Deputy Ranger, Mr. PAsqual, was appointed Sanitary Inspector, Bukit Mertajam, in November. The health of the Ranger and Clerk has been bad, Malaria appearing to be very prevalent.

43. In Malacca, Mr. V. P. Borges, Ranger, I Grade, held charge throughout the year and has done good work. The forest 'scheme was amended (Forests 7,024/06) as far as concerned Sterling paid Rangers. The scheme for forest guards was also altered (C. S. 4,066/05\%, the alteration, however, as concerns other settlements appears to have been wrongly published during the absence of the writer of this report, who approached the Government with the object of revising the whole scheme, and introducing annual increments as in the Federated Malay States. This matter is to be considered when forwarding 1908 estimates.

44. The subordinate staff have given satisfaction in Singapore, Malacca and the Dindings, but were unsatisfactory in the Province.

45. The Conservator during the year made a tour of inspection in Singapore, visiting all the more important forest reserves, also a tour of inspection in the Alor Gajah District in Malacca as well as Bukit Bruang reserve. He paid two short visits to the Dindings, inspecting on the latter occasion the Batu Undan reserve, and visited Penang on two occasions. Over a month was spent on such tours besides a considerable portion of his time in office business in which he is assisted by a clerk on a salary of $\$ 600$ paid from Colonial votes.

He has made use of his private motor car on Government work in Malacca, but the Colony does not pay any share of his motor car allowance. The Colony has paid one-third share of his salary, but on the other hand were the Conservatorship of the Colony a separate appointment, there would be additional expenses in the way of office establishment which are now borne by the Federated Malay States.

A. M. BURN-MURDOCH, Conservator of Forests,

Federated Malay' States and Straits Settlements. 


\title{
STRAITS SETTLEM ENTS.
}

Paper to be laid bef $\because$ re the Legislative Council by Command of His Excellency the Governor.

\section{Annual Report on Forest Administration in the Straits Settlements for the Year 1907.}

\section{PART I. \\ Extension and Conctitution of Reserved Forests.}

\author{
( See FORM I.*)
}

I. The areas of reserved forests remain the same as in 1906 in Penang and Province Wellesley.

In Singapore, an area of 570 acres to the West of the Jurong River was added to the Pandan Mangrove Reserve, bringing the total area of Pandan Reserve up to 3,334 acres.

In the Dindings, I, 500 acres were added to the Batu Undan Reserve, and I,200 acres re-included in the Tanjong Burong Mangrove Reserve.

In Malacca, two small areas were excised from Ayer Panas for tin mining, but contained very poor forest. A small corner of Bukit Sedanan Reserve was cut off by the Railway Department, 242 acres in all.

The form below shows the areas of reserved forests in relation to the whole areas of the various Settlements as on 3 Ist December, I907.

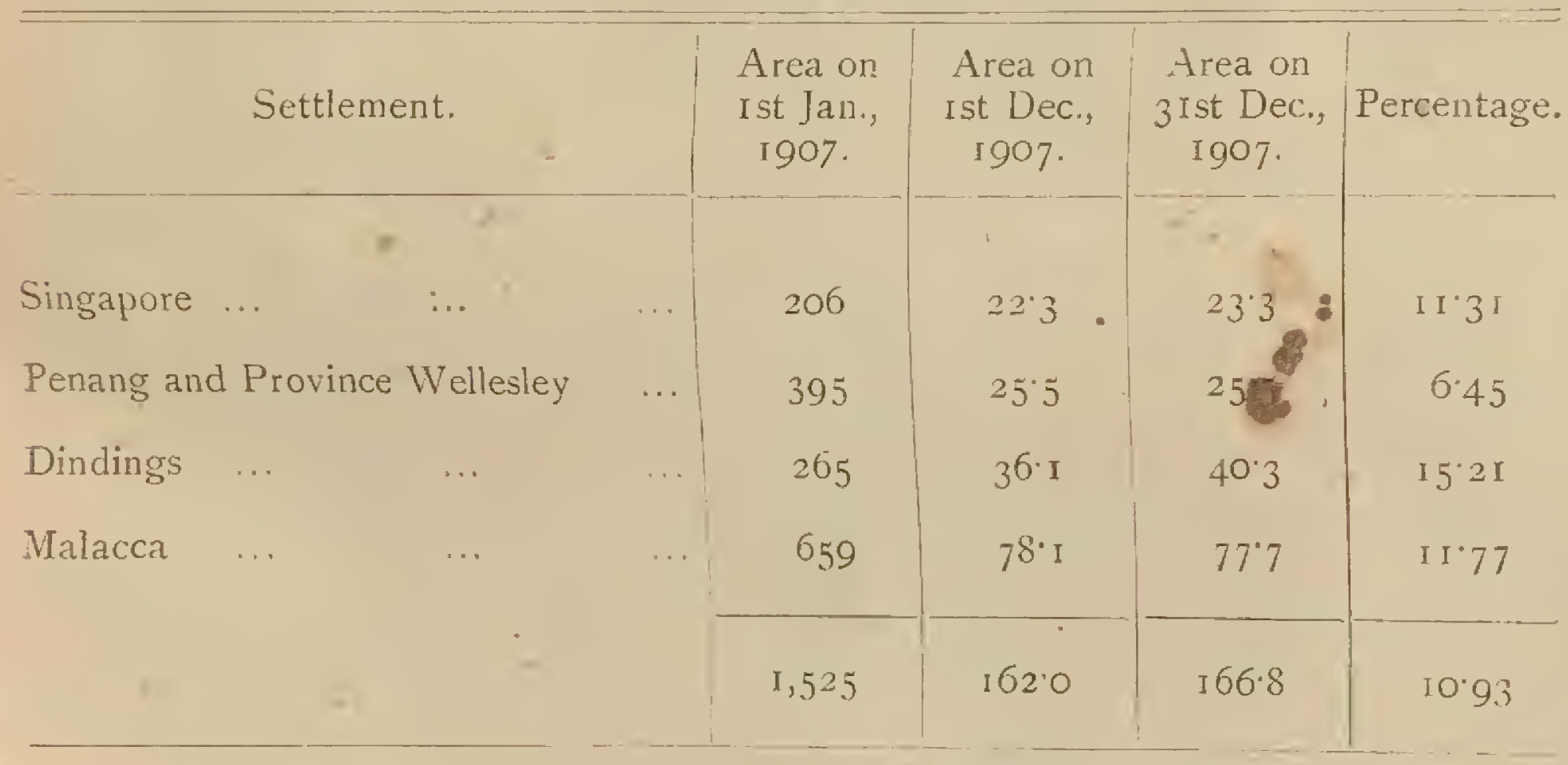

\section{Reserve Proposals.}

2. There are no further extensions under consideration at present, nor are there likely to be any more. Belts of forest half a mile wide connecting the various resurves are kept as a protection against pests.

\section{Demarcation and Up-keep of Boundaries.}

\section{(See Form $3 \cdot *$ )}

3. The repairs to boundaries in Singapore were carried out by Forest Guards and inspected by the newly appointed Forest Ranger, who reports them in good order. There are 126 miles of boundaries.

4. In Penang, 44 miles of boundaries were recleared at a cost of $\$ 290$, and in Province Wellesley 26 miles at $\$ 160$.

$$
\text { * Not printed. }
$$


5. In the Dindings, $4 \frac{1}{2}$ miles of new boundaries were cut out and surveyed by the Forest Ranger at $\$ 244$, and $57 \frac{1}{2}$ miles of old boundaries recleared for $\$ 307$.

Fifty-two steel reserve posts and plates were er cted at salient points on the boundaries and where cut by roads, etc., as in the Federated Malay States.

6. In Malacca, 62 miles of boundaries were recleared at a cost of $\$ 2$ I 8 , the balance $45^{\frac{1}{2}}$ miles not requiring much attention was upkept by the Forest Guards. Twenty boundary plates werr c.ected along various boundaries.

\section{Surveys.}

7. Tracings of all reserve boundaries in Singapore and Malacca were supplied to the Conservator of Forests by the Superfintendent of Works and Surveys. In the Dindin's, six reserves remain unsurveyed.

\section{PART 11. \\ Management of Forests.}

WORKING PIANS.

8. The Malacca Reserves are worked according to a rough-working plan, compartments being marked out and worked in Ayer Panas, Merlimau and Sungai Udang Reserves, and inspected by the Conservator.

It is expected that both the Tanjong Burong Mangrove Reserve, Dindings, and the Pandan Reserve in Singapore will be opened to working in Igos under a regular working plan.

\section{Paths and Buildings.}

9. In Prorince Wellesley, the Tasek Glugor Station is in bad repair.

In the Dindings, the path in Lumut Reserve was cleared by boatmen. Quarters were built for the Forest Clerk by the Public Vorks Department and minor repairs effected where necessary.

10. In Malacca, a new Forest Station was built at the I 2 th mile near Sungai Udang Reserve and cost $\$ 525$, repairs to other Stations cost $\$+69$. Paths in reserves were cleared at a cost of $\$ 8$ I as per Form 6 *

\section{Protection.}

I1. The draft Forest Ordinance as submitted by the Conservator of Forests in December, I906, was still under consideration by the Solicitor-General and has not yet been passed in Council.

12. In Penang, Forest Rules were drafted by the Conservator and approved by His Excelleney the Governor in Council, the rates of royalty on timber and forest produce being ampletely revised, and provision made for issuing of passes to cut and collect forest proflice in reserved forests with sanction of the Conservator.

In Malacca, Rule I of the Rules was amended.

\section{Forest Offences.}

I3. In Singapore, there were 20 cases brought to Court, resulting in Ig convictions, as against $16 \mathrm{in}$ igo6. This I think is due to more inspection by the Forest Ranger.

I4. In Penang, there were 23 cases of illicit cutting of timber, of which seven were acquitted. Fines realized \$3 I5.

In Province Wellesley, there were four cases and three convictions.

Ij. In the Dindings, there were 40 prosecutions and 29 convictions, a bad percentage. Eight hundred and three dollars tines were inflicted, of which $\$+23$ were realized, the other offenders going to gaol.

16. In Malacca, there were 85 cases resulting in 45 convictions and nine acquittals, 26 cases were compounded for $\$ 215$, three pending at the close of the year, one withdrawn and one absconded. Fines in Court amounted to $\$ 724$, of which $\$ 70$ were awarded to the Forest Department as compensation, and $\$ 57$ was realized by sale of confiscated forest produce. Thirteen of the offences were concerned with reserved forests.

\section{Improvement of Forests.}

\section{NATURAL. RERRODLCTION.}

1\%. Meranti seedlings w re reported as plentiful in the Dindings in most places. - In Malacca, Ktsai- seedlings are reported as plentiful in Bukit Senggeh,

$$
\text { * Not printed. }
$$


Bukit Sedanan and Batang Malacca Reserves, Bintangor reproduced itself well in Bukit Bruang Reserve also Tampinis. Ebony, Belian and Seraya are plentiful in Sungai Udang Reserve, also saplings of Medang and Bintangor in the Sungai Siput Reserve. Rambei Daun and Meranti reproduce themselves well.

\section{Artificial Reproduction.}

I8. In Singapore, the go acres of Gutta Percha in Bukit Timah Reserve was greatly improved during the year, costing $\$ 460$. The ro acres of Para planted about Io years ago in Sembawang Reserve were cleared.

I 9. In Penang, the plantation at Batu Ferringgi, 68 acres was upkept at a cost of $\$ 2$ 12, and the Experimental Teak Plantation at Tasek Glugor for $\$ 62$. The latter is not a success. The soil at Batu Ferringgi does not appear to be very suitable for the growth of Taban planting and operation's have been discontinued.

\section{DETAILS WILL BE FOUND IN FORM 8, "}

20. In Malacca the whole area planted now amounts to 297 acres, costing \$1,766 in upkeep. Revenue derived therefrom principally from the tapping of Para and from fruit trees was $\$ 445$. The blocks of bluker forest in the Bukit Bruang Reserve planted up previously, were Lrskept, and half an acre of Gutta Percha planted with 60 plants from Marcottes, and 3 acres of Penak (Balnnocarpus) planted I $6 \frac{1}{2}$ feet apart in lines cut in the bluker. It is reported that Gutta Percha plants were not attacked by the caterpillars as usual. The reverse was the case in Selangor where the attacks were unusually severe.

The Tembusu planted in lalang grass in 1904, 6 feet by 6 feet have suppressed the lalang.

21. Improvement fellings were made in the Taban and Tembusu blocks where necessary, other inferior species of trees being cleared to give room and light.

22. The nursery is well stocked and contains at present 20,000 seedlings of the following species :-

Penak, Merbau, Penaga, Resak and Nibong also a few hundred Niato and Kledang.

The Penak seed was obtained from Pahang, the Penaga (Mesua ferrea) from Negri Sembilan and the Resal (Shorea sp:) from Bukit Senggeh Reserve in Malacca.

23. Para Rubber.-Five hundred trees were leased out to a Malay to tap. The Conservator inspected the tapping which had been done in September and October, I907. It was very badly done, the trees having been damaged by careless tapping. The work was taken away, from this man. Sanction was obtained on the recommendation of the Conservator to tap departmentally in rgo8, and a drying shed was erected.

A mangle was purchased, and the profits should increase under this head. The Forest Ranger, Malacca, was sent to Taiping to study the methods of tapping and curing rubber in force in the Forest Department plantation there, as a high price hadbeen obtained for the sheet turned out.

\section{Exploitation.}

(See FORM 9**)

TIMBER AND FUEL.

24. In Singapore, no felling was permitted in reserved forests, passes were issued to cut frewood on Crown Land and realized $\$ 4$, r I 2, as against $\$ 696$ in 1905.

25. In Penang and Province Wellesley no figures are available, but the revenue derived from licences was $\$ 49$ I, as against $\$ 455$ in I 906 .

26. In the Dindings, timber extracted from reserved forests amounted to 87 tons of 50 cubic feet, and Class $I B 720$ tons; in free grants to the Public Works Department 33 tons from Crown Lands, and alienated land 79 tons, Class $I A$. 24 $\mathrm{I}^{+}$tons Class $B /$, I 2 tons Class $I I$. The revenue realized was $\$ 4,798$ against $\$ 3,898$ in 1906 .

Firewood was cut under passes and realized $\$ 3,870$, a slight decrease over I 9o6,

\section{In Malacca.}

\section{RESERVED FORESTS.}

27. In Merlimau, 445 trees of Class I, in Ayer Panas 136 trees, and in Sungai Udang I 7 trees were marked by the Forest Ranger for felling in the compartments allotted, and 450 were felled during the year. Besides this 46 Merbau, Belian and Resak trees were marked in Forest Reserves for the supply of toams and planks for the 
Public Works Department. The removal of Class // timber was unrestricted inside the compartments for the year, but passes were issued for its felling and removal. For royalty realized (see Form $I I^{*}$ ).

28. The $\$ 303$ shown is revenue due by the Public Wrorks Department but not in reality credited to the Department.

No figures are available for tonnage of timber removed as the pass system is in force, except the small amount supplied to the Public Works Department. Passes in reserves realized $\$ I, 269$ and on un reserved Crown Lands $\$ 2,620$.

29. Firewood-cutters' passes realized $\$ 460$, of which $\$ 436$ was derived from Gelam (Melaleuca).

Charcoal realized $\$ 258$, total $\$ 7$ I8, an increase over I 906 of $\$ 5 \mathrm{I}$.

s

Minor Forest Produce.

30. In Singapore tealized $\$ 84$, chiefly Nibong, Resam, Mengkuang and Rotan, as against $\$ 29$ in 1906 .

In Penang, Bertam, Palas, and Beetle-nut stems were much in demand, revenue realized $\$ 199$, as against $\$ 88$ in 1906 .

31. In the Dindings, $\$ 8$ I 4 was realized on bamboos and canes as against $\$$ 7o2 in I 906 , and other produce realized $\$ 8$ I 6 as against $\$ 734$ in 1906, of which $\$ 272.93$ was realized in royalty on Tengah bark. (Ceriops Candollana.)

32. In Malacca, the right to collect wood oil from Dipterocarpus Crinitus was sold in the Sungai Udang Reserve for $\$ 80$ and in Nyalas Reserve for $\$ 40$.

Para Rubber realized $\$ 205$ and sale of seeds and seedlings $\$ 173.50$. In all $\$ 990$ were obtained from jungle produce and rubber, as against $\$ 976$ in 1906 .

PART III.

Financial Results.

Particulars in Form i i.*

33. The following statement shows the comparison of revenue in 1906 and 1907:--

\begin{tabular}{|c|c|c|c|c|}
\hline Settlement. & $\begin{array}{l}\text { Actual } \\
\text { I906. }\end{array}$ & $\begin{array}{l}\text { Estimated } \\
\text { I907. }\end{array}$ & $\begin{array}{l}\text { Actual } \\
\text { I } 90 \%\end{array}$ & $\begin{array}{l}\text { Excess or } \\
\text { delicit on } \\
\text { Estimate. }\end{array}$ \\
\hline & $\$ \quad c$. & $\$ \quad c$. & $\$ \quad c$ & $\$ \quad c$. \\
\hline Singapore $\quad \ldots, \quad \ldots$ & 1,07830 & 800 oo & 4,39745 & +3.59745 \\
\hline $\begin{array}{l}\text { Penang and Province } \\
\text { Wellesley ... }\end{array}$ & 565 II & I, OOO 00 & 77785 & $-\quad 22215$ \\
\hline Dindings & 9,37678 & 10,00000 & 10,59378 & +59378 \\
\hline Malaccá & $5,472 \quad$ г 6 & 6,000 oo & $6,5.5454$ & $+\quad 55454$ \\
\hline Total ... & $16,492 \quad 35$ & I 7,800 oo & 22,32362 & $+4,52362$ \\
\hline
\end{tabular}

34. The above includes $\$ 159$ revenue due by Public Works Department in the Dindings, and $\$ 303$ in Malacca not actually credited in the Treasury.

Total revenue shows an increase over 1906 of $\$ 5,83 \mathrm{I}$, of which $\$ 3,468$ is due to increased revenue on firewood in Singapore, owing to the throwing open of unreserved mangrove forests to firewood-cutters under $\$ 3$ monthly passes.

35. Malacca shows an increase of over $\$ \mathrm{r}, 000$, due to removal of timber from reserved forests by pass holders.

36. In the Dindings, the chief increases are about $\$ 650$ on timber, bamboos and canes \$I 2. Marking fees $\$ 225$.

In Penang and Province Wellesley about $\$ 100$ on timber and $\$$ Ioo on other produce.

* Not printed. 


\section{Expenditure.}

(See Form i i * ${ }^{*}$ )

37. This form shows the total expenditure in each Settlement as compared with 1906 and estimates for $; 07$ :-

\begin{tabular}{|c|c|c|c|c|c|}
\hline \multicolumn{2}{|c|}{ Settlement. } & \multirow{2}{*}{$\begin{array}{c}\begin{array}{c}\text { Actual } \\
1906 .\end{array} \\
\$, c .\end{array}$} & $\begin{array}{c}\text { Estimated } \\
1907 .\end{array}$ & $\begin{array}{c}\text { Actual } \\
\text { I } 907 .\end{array}$ & $\begin{array}{l}\text { Savings on } \\
\text { Estimates. }\end{array}$ \\
\hline & & & $c$. & $\$ \quad c$. & $\$ \quad c$. \\
\hline Singapore $\quad .$. & ... & 5,80287 & 8,35400 & $7,767 \quad 5 \mathrm{I}$ & $5^{86} \quad 49$ \\
\hline $\begin{array}{l}\text { Penang and } \\
\text { Wellesley ... }\end{array}$ & $\begin{array}{r}\text { Province } \\
\qquad . .\end{array}$ & $4,180 \quad 44$ & $5,990,00$ & $4,961 \quad 46$ & ) \\
\hline Dindings & .. & 5.32426 & 6,66700 & 5,80450 & ) \\
\hline Malacca & & 8,50122 & 9,13000 & $8,582 \quad 48$ & $5475^{2}$ \\
\hline & Total ... & $23,808 \quad 79$ & $30,14 \mathrm{I} O 0$ & 27, I I 595 & $3,025 \quad 05$ \\
\hline
\end{tabular}

38. The expenditure exceeds that of 1906 by $\$ 3,307$, due chiefly to the following items:-

One thousand dollars was sent to the Dehra Dun College to pay the expenses of the training of Mr. G. M. O'HARA.

In Singapore, an increase on salaries of $\$ 1,467$, due to the appointment of a Forest Ranger, Grade III, and increment of Conservator of Forests. Transport and Personal Allowances about $\$ 300$, owing to Forest Ranger.

In the Dindings, about $\$ 400$, chiefly due to boundary marks and their erection.

\section{Administration.}

A revised Scheme for the department was sanctioned during the year and is appended to this report. The only increase to the staff during the year was that of the Forest Ranger, Singapore, who is in Grade III, $\$ 720$ to $\$ \mathrm{r}, 080$ per annum.

Mr. A. M. BuRn-MURDOCH held charge of the post of Conservator of Forests throughout the year till I 3 th December when he was granted vacation leave for o nc month.

In Penang, the department was managed by the Collector of Land Revenue with the assistance of Mr. MilleR, who paid visits every second month until the arrival of Mr. DERRY on ist July.

One Forest Guard in Penang resigned.

In Singapore, the Collector of Land Revenue has directed the work and all forest revenue has been collected in his office.

In the Dindings, Mr. ASkEY, Forest Ranger, was in charge of the forest work under the District Officer till March when he was transferred owing to bad health. $\mathrm{He}$ was succeeded by Mr. KEUN from Selangor who will hold charge till the return of Mr. O'HARA from Dehra Dun.

The forest clerk has suffered much from Malaria.

The Deputy Ranger was well reported on until December when he appears to have neglected his work. 'Two Forest Guards had their increments stopped for' six months and one died from Malaria.

In Malacca, Mr. V. P. Borges continued as Forest Ranger in charge of the forests, and the Ayer Kroh Plantation was supervised under his direction by Ranger SHEIKH AMAT BIN IMAM MUdiN.

Two Forest Guards were sentenced to four months' rigorous imprisomment for receiving illegal gratifications. Generally speaking the staff has worked well.

\section{A. M. BURN-MURDOCH,} Conservator of Forests, Federated Malay States and Straits Settlements. 
Scheme of Salaries for the Subordinate Officers of the Forest Department; Straits Settlements

(Vide Secretary of State's Desbatch No. 3 of 3rd Fanuary, I908.)

\begin{tabular}{|c|c|c|c|c|c|c|}
\hline Appointments. & & Grade. , & \& Salary. & Place. & & $\begin{array}{c}\text { Increments, } \\
\text { Annual. }\end{array}$ \\
\hline Forest Rangedr & $\ldots$ & 1 & $£ 160-£ 220$ & Malacca & $\ldots$ & E,10 \\
\hline Do. & $\ldots$ & II & E, $130-f_{1} 160$ & Penang & $\ldots$ & $£ 10$ \\
\hline Do. & $\ldots$ & I & $f, 160-f, 220$ & Dindings & $\ldots$ & $£ 10$ \\
\hline Do. & $\cdots$ & III & $\$ 720-\$ 1,080$ & Singapore & $\cdots$ & $\$ 60$ \\
\hline Do. & $\ldots$ & IV & $\$+20-\$ 660\}$ & $\begin{array}{l}\text { Penang } \\
\text { Malacca } \\
\text { Dindings }\end{array}$ & $\begin{array}{l}\cdots \\
\cdots \\
\cdots\end{array}$ & $\$ 30$ \\
\hline Foresters & ... & $\cdots$ & $\$ 240-\$ 360$ & $\begin{array}{l}\text { Singapore } \\
\text { Malacca } \\
\text { Penang } \\
\text { Dindings } \\
\text { P.Wellesley }\end{array}$ & $\begin{array}{l}(1) \\
(2) \\
(2) \\
(1) \\
(1)\end{array}$ & Four of $\$ 30$ \\
\hline Forest Guards & $\ldots$ & $\cdots$ & $\$ 120-\$ 192$ & Singapore & (IO) & Six of $\$ \mathrm{I} 2$ \\
\hline Do. & $\cdots$ & $\cdots$ & $\left.\$ I_{44}-\$ 2 I 6\right\}$ & $\begin{array}{l}\text { Penang } \\
\text { Dindings } \\
\text { P. Wellesley } \\
\text { Malacca }\end{array}$ & $\begin{array}{l}(\mathrm{I} 2) \\
(\mathrm{I} 6)\end{array}$ & $\left\{\begin{array}{c}\operatorname{Six} \text { of } \\
\$ \mathrm{I} 2\end{array}\right.$ \\
\hline
\end{tabular}

I. Eorest Rangers, Grade II, will not be eligible for promotion to Grade I, until they have passed an examination in Forest Law and in the Malay Language, which latter shall include:-

(i) Being able to converse freely in Malay on all matters connected with their duties;

(ii) Being able to take down a report without the help of an interpreter; and

(iii) Passing an elementary examination in vocabulary.

2. All sterling appointments and those of Forest Rangers, Grade III, will be pensionable, except where the officer is under agreement or on deputation.

3.-(i) In the case of annual increments the first increment in each case will date from the Ist January or the Ist July next subsequent to the completion of a year's service.

(ii) List of officers eligible and recommended for increment will be sent in triplicate to the Colonial Secretary in December and June of each year for approval, and, if approved, one copy will be sent to the Conservator, and one to the AuditorGeneral, who will issue the necessary warrants after satisfying himself that the officers affected are eligible for the increments under the scheme.

(iii) The Conservator will certify on these lists that the conduct of every officer recommended for an increment has been good, and that he has performed his duty in a satisfactory manner.

(iv) It will be his duty to refuse the increment for which any officer is eligible, in every case in which such officer has been guilty of misconduct or has failed in the performance of his duty.

4.--(i) Officers holding appointments as Forest Rangers, Foresters and Forest Guards are entitled, until further . tice, to occupy Government Quarters free of rent. 
Subordinate StafF.

The following table s.'nus the strength of the Forest Subordinate Staff in the Department at the close of the year:-

\begin{tabular}{|c|c|c|c|c|c|c|c|c|c|c|}
\hline Settlement. & $\begin{array}{c}\text { Rangers } \\
\text { Grade } \\
\text { I. }\end{array}$ & $\begin{array}{c}\text { Rangers } \\
\text { Grade } \\
\text { II. }\end{array}$ & $\begin{array}{c}\text { Rangers } \\
\text { Grade } \\
\text { III. }\end{array}$ & $\begin{array}{l}\text { Rangers } \\
\text { Grade } \\
\text { IV. }\end{array}$ & $\begin{array}{l}\text { Deputy } \\
\text { Rangers } \\
\text { Grade } \\
\text { I. }\end{array}$ & $\left\{\begin{array}{c}\text { Feputy } \\
\text { Rangers } \\
\text { Grade } \\
\text { II. }\end{array}\right.$ & $\begin{array}{l}\text { Forest- } \\
\text { ers. }\end{array}$ & $\begin{array}{l}\text { Forest } \\
\text { Guards. }\end{array}$ & $\begin{array}{c}\text { Resig- } \\
\text { nations. }\end{array}$ & $\begin{array}{c}\text { Dismis- } \\
\text { sals. }\end{array}$ \\
\hline $\begin{array}{l}\text { Singapore... } \\
\text { Penang, } \\
\text { Province } \\
\text { Wellesley } \\
\text { and } \\
\text { Dindings } \\
\text { Malacca ... }\end{array}$ & I & $\ldots$ & $\begin{array}{l}\cdots \\
\ldots\end{array}$ & . & $\cdots$ & $\cdots$ & 5 & $\begin{array}{l}\text { I I } \\
\text { I } 6\end{array}$ & $\cdots$ & $\cdots$ \\
\hline Total & 2 & $\ldots$ & I & 2 & I & $\ldots$ & 7 & 37 & 2 & 2 \\
\hline
\end{tabular}




\title{
Annual Report on Forest Administration in the Straits Settlements for the Year 1908.
}

\section{PART I.}

\section{Extension and Constitution of Reserved Forests.}

\author{
(See FORM I FOR ARea Statement.)
}

x. The areas of reserved forests in Singapore, Penang, Province Wellesley and Mitlacca remain unchanged.

In the Dindings, the Tanjong Hantu Reserve was reduced to 538 acres and the area of Tanjong Burong Reserve found on survey to be increased by 1,672 acres.

The statement below shows the area of reserved forests in relation to the whole area of the Settlements as on 3 ist December, 1908, in square miles.

\begin{tabular}{|c|c|c|c|c|c|}
\hline 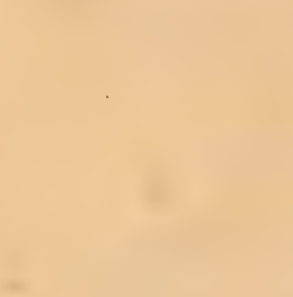 & Settlement. & \begin{tabular}{|} 
Area of \\
settlement \\
in square \\
miles.
\end{tabular} & $\begin{array}{l}\text { Area of } \\
\text { reserves on } \\
\text { Ist Jan., } \\
\text { Igos, } \\
\text { sq. miles. }\end{array}$ & $\begin{array}{c}\text { Area of } \\
\text { reserves on } \\
\text { 3ist Dec., } \\
\text { Igo8, } \\
\text { sq. miles. }\end{array}$ & Percentage. \\
\hline Singapore & $\cdots$ & 206 & $23 \cdot 3$ & 233 & II'3I \\
\hline Penang and & Province iVellesley & 395 & 255 & 25.5 & 645 \\
\hline Dindings & $\cdots$ & 265 & $40^{\circ} 3$ & $4 I^{\prime} 2$ & 1554 \\
\hline Malacca & $\cdots$ & 659 & $77^{\circ} 7$ & $77^{\prime} 7$ & $11 \cdot 77$ \\
\hline$=$ & Total & 1,525 & $166 \cdot 8$ & $167 \cdot 7$ & 10.99 \\
\hline
\end{tabular}

Reserve Proposals.

2. No new reserves were proposed during the year.

\section{Demarcation and Up-keep of Boundaries.}

(See Form 3. *)

3. In Singapore repairs to boundaries were as usual carried out by Forest Guards. There are 9 I miles of such boundaries. Boundary stones were placed round Pandan Reserve. The Forest Ranger reports them all in good order except portions of Seletar.

4. In Penang, 62 miles of boundaries were re-cleared at a cost of $\$ 339$, and 2 I miles in Province Wellesley at a cost of $\$ 5_{5} 8$. Boundaries were under the charge of the Superintendent of Forests and Gardens who inspected portions.

5. In the Dindings, 62 miles of boundaries were re-cleared at a cost of $\$ 295$. 
6. In Malacca, $9+$ miles were re-cleared at a cost of $\$ 392$; they are in good order. Twenty-three iron reserve boundary plates and posts were erected along boundaries. Those boundaries inspected by the Conservator were found to be in good order.

\section{Surveys.}

7. The boundary of the Pandan extension was surveyed during the year, and the Forest Ranger made a rough survey of the Changi Mangrove areas, and parts of Sungai Murai, Kranji and Sungai Buloh.

8. In the Dindings the Tanjong Burong Reserve was surveyed and the area found to be 4,672 acres, instead of the 3,000 acres previously estimated. The Batu Undan boundary was surveyed by the Forest Ranger with prismatic compass. In Malacca the felling coupes in Ayer Panas, Nerlimau and Sungai Udang were surveyed roughly departmentally, also the Government plantations at Ayer Kroh and Bukit Sebukor.

PART II.

\section{Management of Forests.}

WORKING PLANS.

9. In Singapore, an area of one-twentieth of the area of Mangrove in the Pandan Reserve was leased, or I00 acres, and realized $\$ 600$. Similarly in Changi Reserve an area of $\$ 0$ acres was leased for $\$ 210$. The leases allow of felling of all trees over four inches in diameter for a period of one year. The contracts were signed on $28 \mathrm{th}$ October and 15 th November, respectively.

This is the first time that systematic working of any of the Singapore forests has been introduced. The produce is restricted to firewood.

IO. In Penang and Province Wellesley there is no systematic extraction of forest produce from reserved forests.

I I. In the Dindings the Tanjong Burong working plan could not be arranged as the survey was in progress; it will take effect early in 1909.

12. In Malacca the reserves are worked according to a rough plan in Merliman, Ayer Panas, Sungai Udang and Bukit Sedanan. Extraction of timber was permitted in these reserves in marked coupes, all Class I trees being selected by the Forest Ranger.

The following trees were marked for felling :-

\begin{tabular}{|c|c|c|c|c|}
\hline Merlimau & $\cdots$ & & & 1427 \\
\hline Ayer Panas & $\cdots$ & $\cdots$ & $\cdots$ & 27 \\
\hline $\begin{array}{l}\text { Sungai Udang } \\
\text { Bukit Sedanan }\end{array}$ & & $\begin{array}{l}\ldots \\
\ldots\end{array}$ & $\begin{array}{l}\ldots \\
\ldots\end{array}$ & $\begin{array}{r}132 \\
85\end{array}$ \\
\hline
\end{tabular}

Only 20 Resak trees were felled in Bukit Sedanan and it was found unprofitable to exploit the area owing to heavy cost of transport. One hundred and thirt $y$-nine trees marked during 1907 were felled.

\section{Paths in Reserves and Buildings.}

13. In the Dindings a path was cut by the boatmen from the reservoir at Lumut through the Lumut Reserve across the gap in the hill. In Malacca paths in reserves were cleared at a cost of $\$ 193$.

14. Repairs to existing buildings were carried out in all Settlements by the Public Works Department. In Malacca a drying-shed for the rubber obtained from the Government plantations at Ayer Kroh and Bukit Bruang was erected at a cost of $\$ 435$.

\section{Protection.}

\section{Legal.}

I5. New Forest Rules for Penang and Province Wellesley were drafted by the Conservator and came into force on Ist January, 1908. A Forest Ordinance was passed in November 1908, but is not yet in force, and awaits the preparation of 
accurate descriptions of the boundaries of reserved forests. Revised rules for all Settlements under this Ordinance were drafted and submitted by the Conservator towards the close of the year.

$$
\text { Fire. }
$$

16. In Malacca, i 8 persons were punished for causing lalang fires. About 36 acres of lalang in the Bukit Bruang Reserve were burnt, but no damage was done to the forest.

\section{Forest Offences.}

$$
\text { (Form } 7^{*} \text { shous particulars.) }
$$

I 7. There were 131 new cases of breaches of rules during the year as against I 43 in 1907 , and three cases were pending at commencement of the year in Malacca. There were 107 convictions. Three cases were pending at the close of the year in Singapore. This gives a percentage of convictions of 82 per cent. Besides the above in Malacca 43 cases were compounded for $\$ 201.4 \$$.

I8. There was a falling off of prosecutions in the Dindings, due no doubt to the decline in the timber industry. In Penang there were 2 I convictions out of 22 cases.

\section{Improvement of Forests.}

\section{Natural Reproduction.}

19. In Singapore natural reproduction of Gutta-percha is said to be good in the Pandan and Bukit Timah Reserves, and Tampinis in Sungai Buloh and Changi. In Penang some old Gutta-percha trees in the Gardens seeded, and I,350 seedlings were obtained. Natural reproduction of the important species is reported as good in the Dindings. In Malacca there was a poor seed year.

\section{Artificial Reproduction.}

20. In Singapore the Gutla-percha plantation in Bukit Timah of 97 acres was upkept at a cost of $\$ 588$, and 10 acres of Para Rubber in the Sembawang cost $\$ 6_{5}$ for weeding and clearing. In Bukit Timah a nursery was made and seedlings of Guttapercha trees taken from the forests and planted, afterwards being planted out in the plantation to fill up blanks. This plantation was not made on a cleared area, but seedlings planted out in lines under cover of the forests. Forest trees were cut out here and there to give light to the Gutta-percha which have shown great improvement. The Conservator visited both areas during the year.

21. In Penang the Batu Feringgi plantation of Gutta-percha was upkept at a cost of $\$ 125.85$. A small number of Manicoba rubber trees and Lagos silk rubber were planted near the forest station at 'I asek Glugor, as an experiment, but were not very successful.

22. In the Dindings I 30 seedlings of fruit trees were obtained from the Botanic Gardens, Penang, and planted out at Lumut.

23. In the Bukit Bruang Reserve, Malacca, three acres of lalang were planted up with Tembusu and eight acres of belukar $\dagger$ with Kledang. The area of the plantations in this reserve was on 31 st December, Igo8, 279 acres, and there are two acres of Para at Bukit Sebukor. The plantations consist of Para, Merbau, Penak, Nibong, Kledang, Penaga, Gutta-percha and a few Mahogany. The Para was tapped, the expenditure thereby incurred being met from the vote for "Upkeep of Plantations, Ayer Kroh."

The Conservator inspected the plantations. There are 720 Para trees with an average girth of $24 \frac{1}{4}$ inches. Great improvement was noticed in the Getah Sundik Block.

The Penak nursery was twice attacked by the larva of Nacaduba. The plantation was surveyed departmentally, boundary stones put in and a plan supplied to the Conservator.

24. In the Merlimau Reserve 3,000 Merbau seeds were dibbled in over the area which has been exploited wherever small clearings were made by felling of large trees. 


\title{
Exploitation.
}

\author{
(See FORM 9.*) \\ A.-From Reserved Forests.
}

25. In Singapore felling of Mangrove for firewood was commenced in the Pandan and Changi Reserves, in October and November; returns of the amount of firewood extracted will be given during 1909. In Penang and Province Welleslev five permits were issued for cutting of timber, and six for extraction of minor produce from reserves.

26. In the Dindings the Telok Sera, Batu Undan, and Lumut Reserves were exploited, all trees being selected and marked by a Forest Officer. Seven hundred and thirty-three tons (of 50 cubic feet) were extracted, of which 185 were of Class I-A, i.e., Damar Laut, etc.; 527 of Class I- $B$, i.e., Meranti, Medang, etc. ; and a few tons of Class II timber, a slight fall as compared with 1907.

27. In Malacca timber in reserved forests was cut in blocks marked out for the purpose in Merlimau, Ayer Panas, and Sungai Udang Reserves. These areas were inspected by the Conservator. Five hundred and twenty-five trees of Class I were felled, and $\$$ r,22 r revenue realized.

\section{B.-From Crozen Land.}

28. In the Dindings 47 tons of timber were supplied free of royalty to the Public Works Department. Two hundred and forty-two tons of Class I timber were removed by licensees, and licences were issued to make Sagors (boats) out of dead and fallen Chengal and Sama Rupa trees.

29. In Malacca permits were issued to cut timber on Crown Land, and realized $\$ 2,769$, as compared with $\$ 2,620$ in 1907 .

Fuel.

30. In Singapore permits to take firewood from Crown Land realized $\$ 4,302$, as compared with $\$ 4,112$ in 1907 . In the Dindings firewood was cut under $\$ 5$ monthly permits, there was a considerable fall in revenue under this head explained in paragraphs 35 and 37 . In Malacca firewood permits realized $\$ 380$, of which $\$ 338$ was derived from Gelam trees. Charcoal realized $\$ 303$, some of which was made from the unutilizable timber left after felling and conversion of Irees in the Merlimau Reserve.

\section{Minor Forest Produce.}

3I. Bamboos and Canes.-Under this head $\$ 5 \$ 9$ was collected, of which $\$ 548$ was derived from the Dindings.

Other forest produce realized $\$ I, 719$, of which $\$ 770$ was derived from the Dindings and $\$ 664$ from Malacca, as compared with $\$ 2,070$ in 1907.

32. The produce used in Singapore was Nibong, Resam, and Mengkuang, realizing $\$ 129$, a rise of $\$ 45$ over 1307 . In Penang there was a fall of about $\$ 43$. In the Dindings the produce chiefly used was Nibong, Mengkuang, Bertam and Tengah bark : there was a slight fall under this hearl. In Malacca wood-oil was collected from Dipterocarpus crinitus, and realized $\$ 105$, as compared with \$120 in I907.

33. The Government Para plantation in Bukit Bruang and Sebukor was tapped under supervision of the Forest Ranger, and yielded $513 \mathrm{lbs}$. of sheet rubber and 242 lbs. of scrap. The revenue realized from this source was $\$ 1,68_{3}$, but actual value $\$ 1,82$ I as a final payment for the last consignment was not made till February, I909. Of this sum only $\$ 1$, Igo was credited to revenue, the cost of the drying-shed being met from an advance which was repaid from receipts by rubber sales. The sale of Para, Tembusu and Penaga seed realized $\$ \mathrm{r} \mathrm{I} 2$. 
PART 111 .

\section{Financial Results.}

(See FORM I I).

34. This table shows the comparative Revente for 1907 and 1908:-

\begin{tabular}{|c|c|c|c|c|}
\hline Settlement. & $\begin{array}{c}\text { Revenue } \\
1907 .\end{array}$ & $\begin{array}{l}\text { Estimated } \\
\text { revenue } \\
\text { I } 908 .\end{array}$ & $\begin{array}{l}\text { Actual } \\
\text { revenue } \\
\text { igo8. }\end{array}$ & $\begin{array}{l}\text { Excess or } \\
\text { deficit over } \\
\text { Estimate. }\end{array}$ \\
\hline & $\$ \quad c$. & $\$$ & $\$ \quad c$. & $\$$ \\
\hline $\begin{array}{l}\text { Singapore } \\
\text { Penang and Province }\end{array}$ & 4,39745 & 4,00000 & 4,98430 & $+9^{8}+30$ \\
\hline Wellesley $\ldots$ & 77785 & I,, 00000 & 1,08377 & $+\quad 8377$ \\
\hline $\begin{array}{ll}\text { Dindings } & \ldots \\
\text { Malacca } & \ldots\end{array}$ & 10,59378 & I I,, 000 OO & $8,940 \quad 25$ & $-2,05975$ \\
\hline Malacca & $6,554 \quad 54$ & 6,00000 & 7,2063 I & $+\mathrm{I}, 2063 \mathrm{I}$ \\
\hline Total ... & 22,32362 & $22,000 \mathrm{CO}$ & 22,2 I $4 \quad 63$ & +21463 \\
\hline
\end{tabular}

35. The above figures include $\$ 173.65$ revenue due on timber supplied free to the Public Works Department in the Dindings. No timber appears to have been supplied free to the Public Works Departmont in Malacca. There has been an increase in revenue in every case except the Dindings, where the estimate for 1908 was based on the assumption that the Tanjong Burono Mangrove Reserve would be thrown open to working. The survey, however, was not completed in time to permit of this.

36. The increase in Singapore is due to the opening of two coupes in the Pandan and Changi Mangrove Reserves. 'T he small increase in Penang and P'rovince Wellesley may I think be ascribed to the revised rates of royalty introduced with the revised rules.

37. In the Dindings, the Gunong Tunggal Reserve had to be closed to felling, and Batu Undan was only worked for a short time; there was a decline in timber revenue of $\$ 453$ and in firewood of $\$ 9$ Io, owing to the fact that the available area of Mangrove forest containing trees of sufficient wirth is much reduced. Certain areas are now closed to recuperate. The working of the Tanjong Burong Reserve in Igog should raise the revenue to the normal level. The fall in revenue was met by a large saving in expenditure.

38. In Malacca, the rise in revenue is due to the sale of rubber. There was a fall in other minor forest produce.

\section{Expenditure.}

(See FORM II.)

39. This statement shows the total expenditure in each Settlement, as compared with 1907 and estimates for 1908 :-

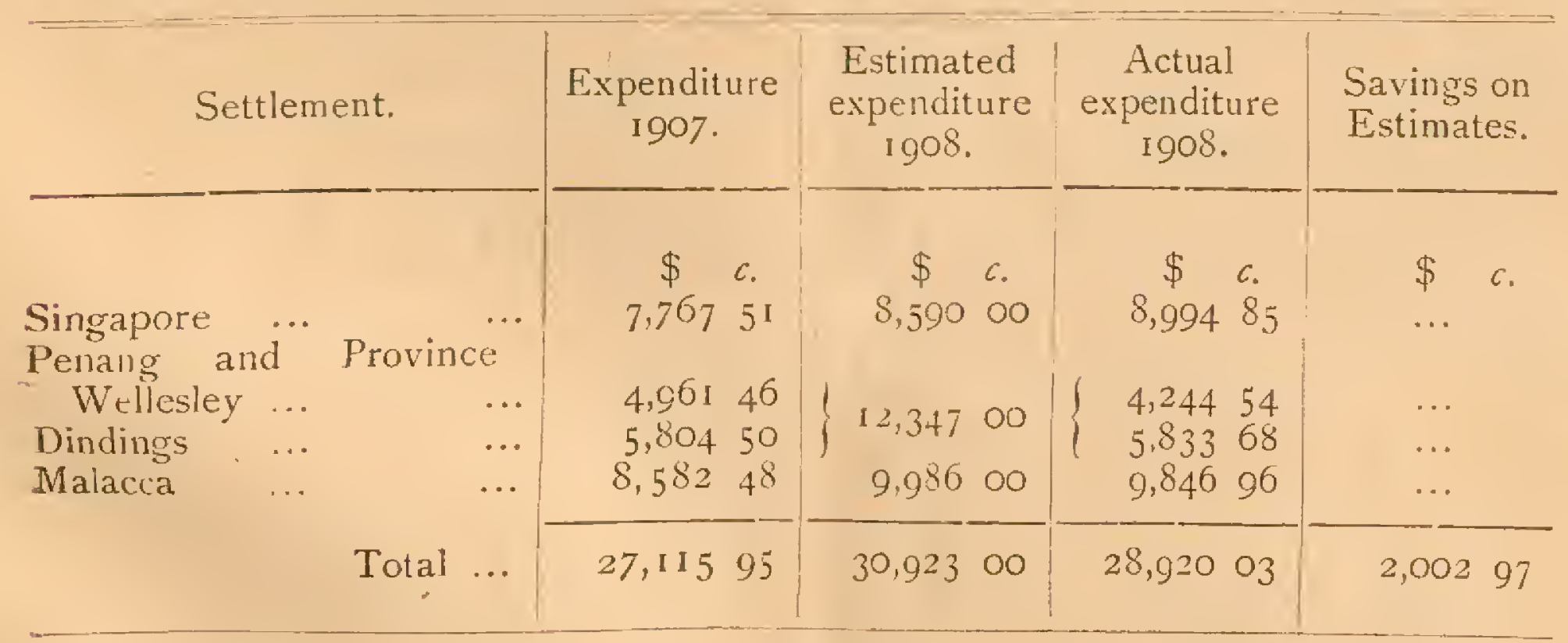


The expenditure exceeds that of 1907 by $\$ 1,874$. In Singapore the increase was due to expenses on the working plans for opening of two reserves to felling, increment to Conservator's clerk, and allowance to the General Assistant to Conservator ; also to Personal and Transport Allowances of the Forest Ranger.

40. In Penang, and Province Wellesley there was a reduction of $\$ 7 \mathrm{I} 6.92$ as compared with I907, due to there being no student to pay for at Dehra Dun Forest College as in 1907.

41. In the Dindings the expenditure remained much the same as in 1907 ; in Penang, Province Wellesley and Dindings there was a saving on the estimates of $\$ 2,270$. In Malacca there was an increase of $\$ 1,265, \$ 587$ in salaries and $\$ 678$ in other charges, due to increments, and to upkeep of Ayer Kroh plantation and upkeep of reserve boundaries.

\section{Administration.}

42. Mr. A. M. Burn-Murdoch held the appointment of Conservator of Forests throughout the year. He was on short leave from Ist to I I th January and 27 th to 3 Ist December.

He visited the following reserved forests during the year:-

Singapore.-Bukit Timah, Sembawang, Kranji and Mandi Reserves.

Penang and Province Wellesley.-Tasek Glugor Reserve.

Dindings.-Lumut, Telok Muroh, Pangkor and Tanjong Burong Reserves.

Malacca.--Bukit Bruang, Sungai Udang, Nyalas and Bukit Panchor.

43. Mr. Fox, the Superintendent of Forests and Gardens in Penang, superintended the forest work in Penang and was responsible for the reserved forests. The Land Office issued licences for Crown Land and collected revenue.

In Singapore the Forest Ranger was in charge of the reserves under the superin. tendence of the Col' ctor of Land Revenue who supervised the work generally and in whose office all forest revenue was collected.

In the Dindings the District Officer had general direction of the department and was assisted by Mr. KeUn, Forest Ranger, Federated Malay States, until 3oth April, when Mr. O'HARA, the Forest Ranger, returned from Dehra Dun and resumed his duties as Forest Ranger, Grade II.

In Malacca, Mr. Borges continued to be in charge of the forest department.

\section{Subordinate Staff.}

On the whole the subordinate staff has worked satisfactorily. One Forester died in Malacca; he had served with Government since 1884 and had a good record. His widow was granted a compassionate allowance. There were two dismissals in Singapore

The staff of the department as it stoor at the close of the year is given below :-

\begin{tabular}{|c|c|c|c|c|c|c|c|c|}
\hline \multirow{2}{*}{ SETTLEMENT. } & \multicolumn{4}{|c|}{ RANGERS. } & \multirow{2}{*}{ Foresters. } & \multirow{2}{*}{$\begin{array}{l}\text { Forest } \\
\text { Guards. }\end{array}$} & \multirow{2}{*}{$\begin{array}{l}\text { Resigna. } \\
\text { tions. }\end{array}$} & \multirow{2}{*}{$\begin{array}{c}\text { Dismis- } \\
\text { sals. }\end{array}$} \\
\hline & $\begin{array}{c}\text { Grade } \\
\text { I }\end{array}$ & $\begin{array}{c}\text { Grade } \\
\text { II }\end{array}$ & $\begin{array}{c}\text { Grade } \\
\text { III }\end{array}$ & $\begin{array}{c}\text { Grade } \\
\text { IV }\end{array}$ & & & & \\
\hline Singapore & $\cdots$ & $\ldots$ & I & $\ldots$ & $\ldots$ & 10 & I & 2 \\
\hline Penang \& P. Wellesley & $\cdots$ & $\ldots$ & $\cdots$ & I & I & 6 & $\cdots$ & ... \\
\hline Dindings ... & $\ldots$ & I & .. & I & 2 & 6 & I & $\cdots$ \\
\hline Malacca ... & I & .. & $\cdots$ & I & 2 & I6 & $\cdots$ & .. \\
\hline Total $\ldots$ & I & 1 & I & 3 & 5 & 38 & 2 & 2 \\
\hline
\end{tabular}

KUALA LUMPUR, 6th March, 1909
A. M. BURN-MURDOCH, Conservator of Forests,

Federated Malay States and Straits Settlements. 
FORM NO, 1

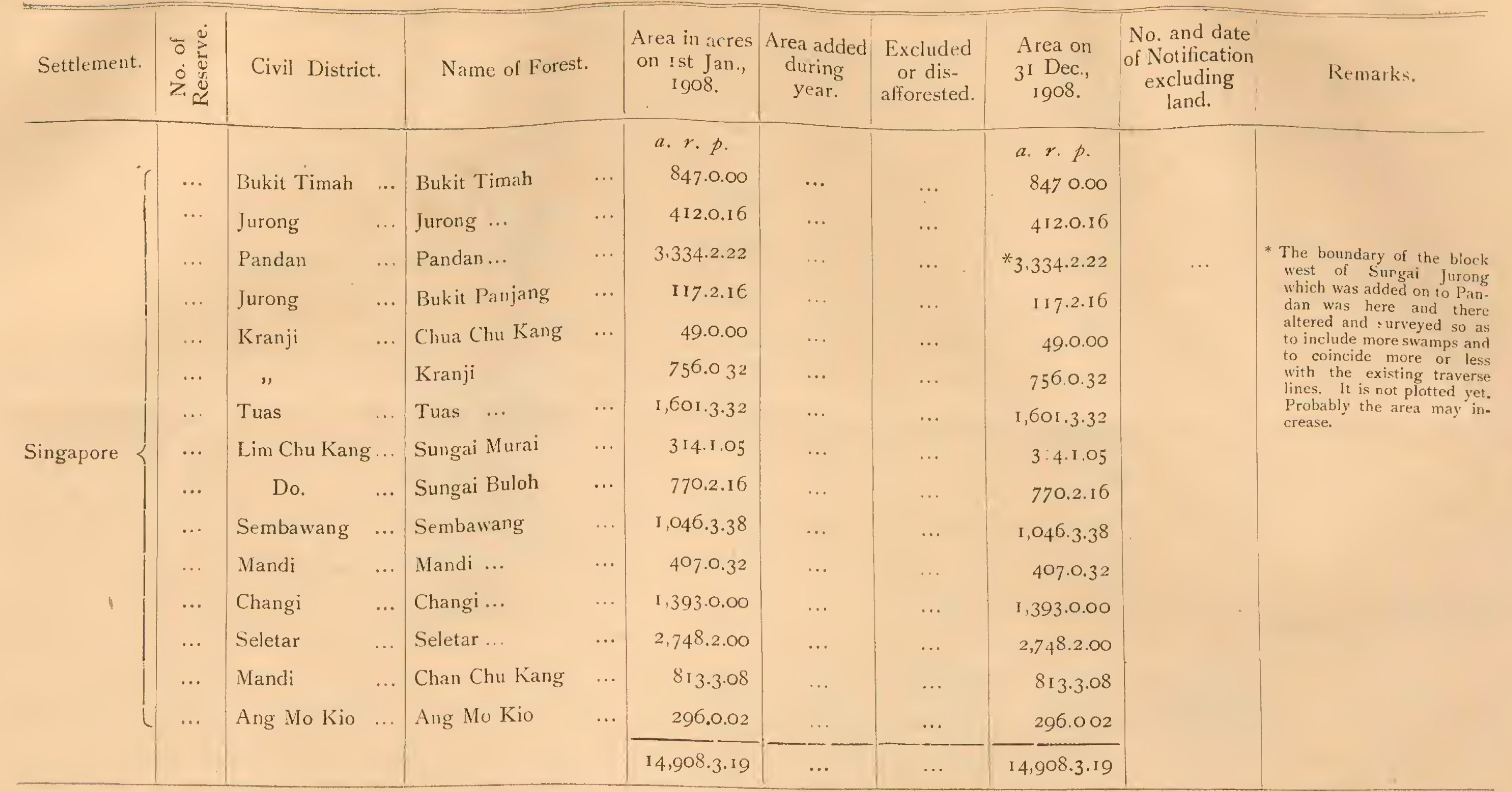


FORM NO. I.-Continued.

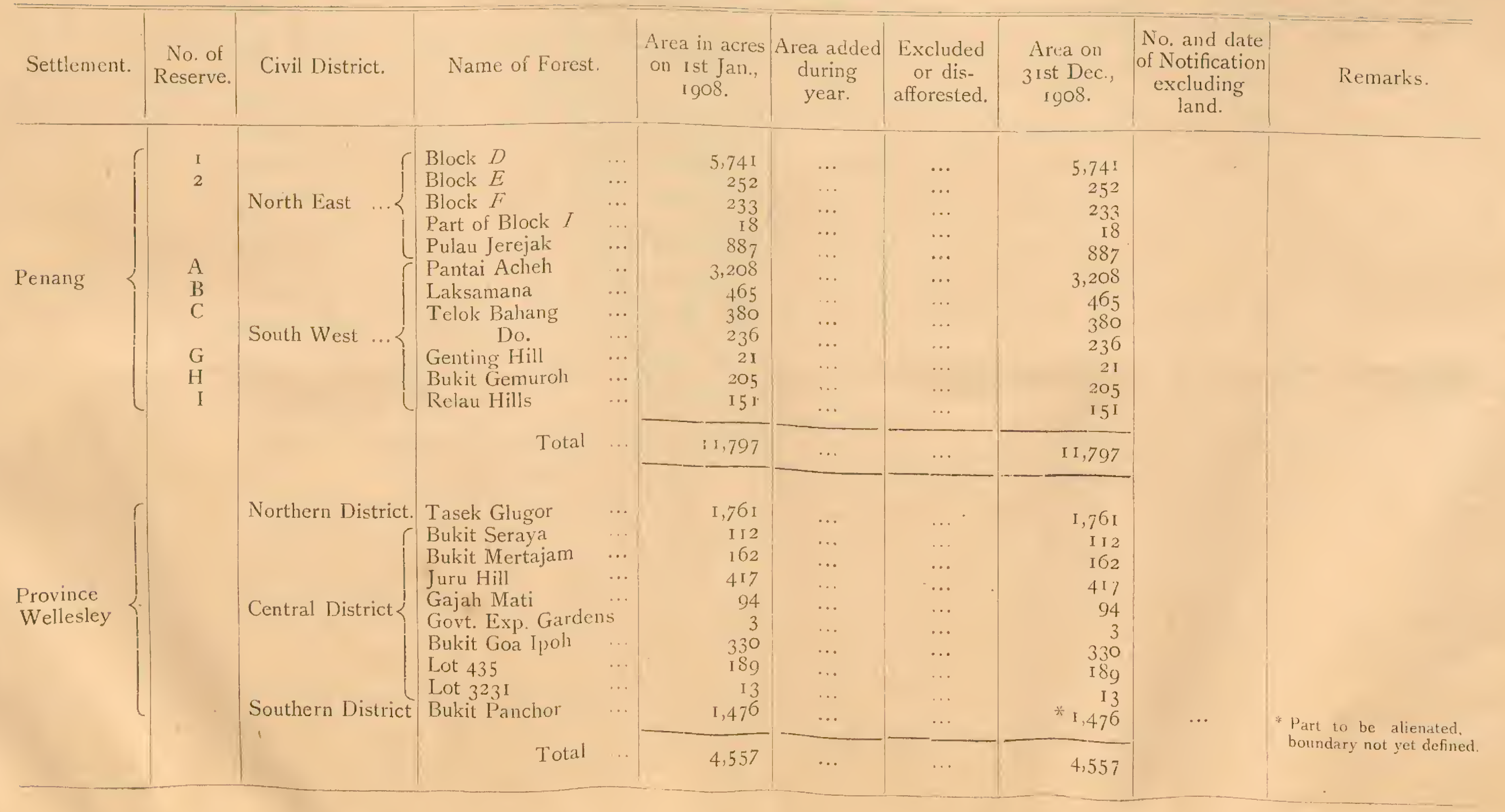


FORM No. 1.-Continued.

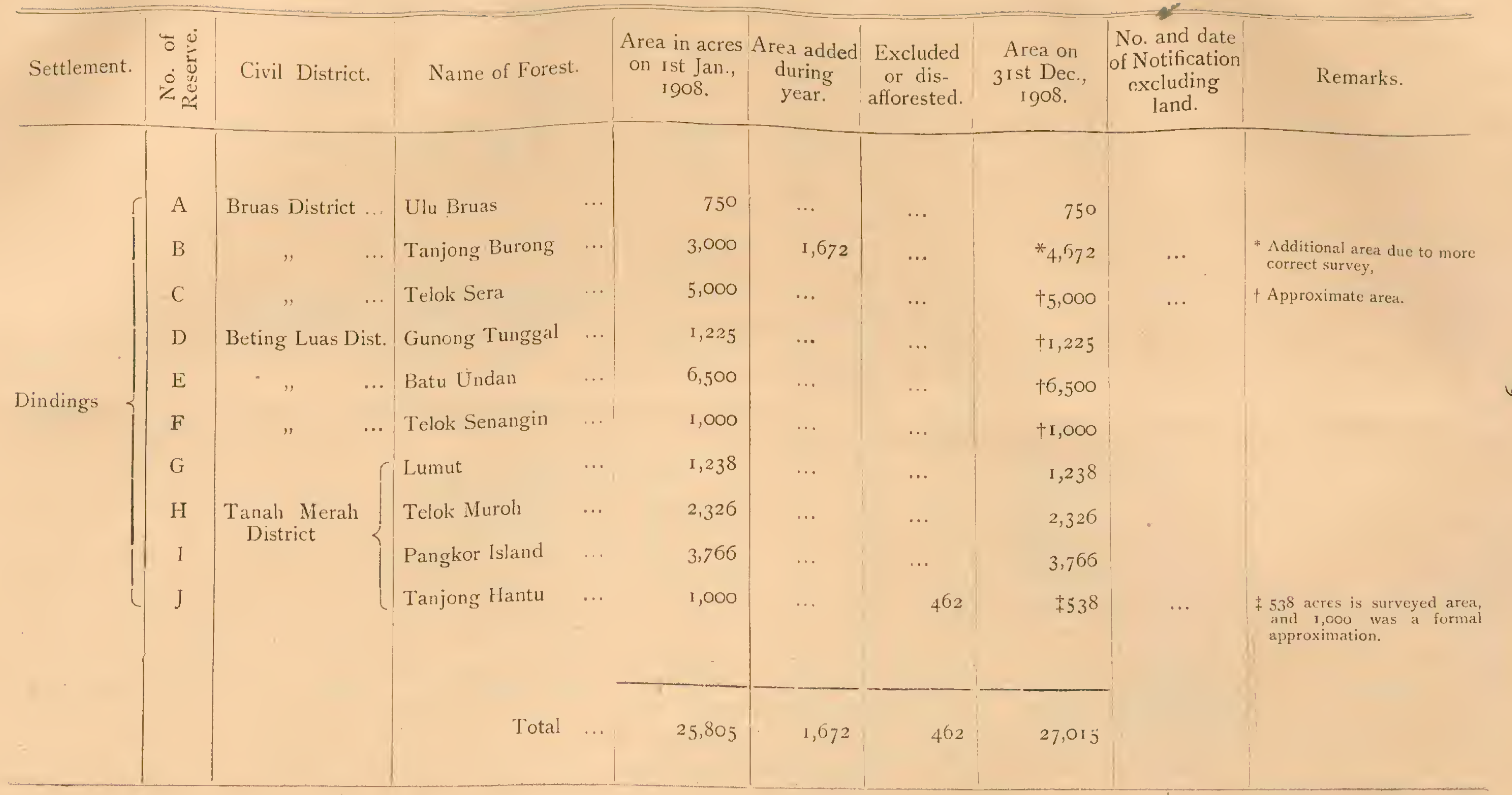


FORM No. 1.-Concluded.

\begin{tabular}{|c|c|c|c|c|c|c|c|c|c|}
\hline Settlement. & 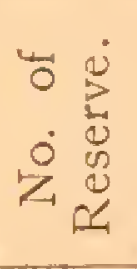 & Civil District. & Name of Forest. & $\begin{array}{c}\text { Area in acres } \\
\text { on Ist Jan., } \\
\text { Igo } 8 .\end{array}$ & $\begin{array}{c}\text { Area added } \\
\text { during } \\
\text { year. }\end{array}$ & $\begin{array}{l}\text { Excluded } \\
\text { or dis- } \\
\text { afforested. }\end{array}$ & $\begin{array}{c}\text { Area on } \\
\text { 3ist Dec., } \\
\text { rgo8. }\end{array}$ & $\begin{array}{c}\text { No. and date } \\
\text { of Notification } \\
\text { excluding } \\
\text { land. }\end{array}$ & Remarks. \\
\hline \multirow{4}{*}{ Malacca ... } & $\begin{array}{l}1 \\
2 \\
3 \\
4 \\
5 \\
6\end{array}$ & Jasin District... & $\begin{array}{ll}\text { Ayer Panas } & \ldots \\
\text { Merlimau } & \ldots \\
\text { Bukit Senggeh } & \ldots \\
\text { Bukit Sedanan } & \ldots \\
\text { Batang Malacca } & \ldots \\
\text { Nyalas } & \ldots\end{array}$ & $\begin{array}{c}a \cdot r \cdot p \cdot \\
3,460 \cdot 3 \text { O4 } \\
6,2 \mathrm{I} 6 \cdot 3.06 \\
9,526.0 .34 \\
7,593 \cdot 3 \cdot 38 \\
3,549.0 .00 \\
2,468.3 .0 \mathrm{I}\end{array}$ & $\begin{array}{l}\cdots \\
\cdots \\
\cdots \\
\cdots \\
\cdots \\
\cdots\end{array}$ & $\begin{array}{l}\cdots \\
\cdots \\
\cdots \\
\cdots \\
\cdots \\
\cdots\end{array}$ & $\begin{array}{c}a \cdot r \cdot p \cdot \\
3,460 \cdot 3.04 \\
6,2 \mathrm{I} 6 \cdot 3 \cdot 06 \\
9,526.0 .34 \\
7,593 \cdot 3 \cdot 38 \\
3,549 \cdot 0.00 \\
2,468.3 .01\end{array}$ & & \\
\hline & $\begin{array}{l}\text { I } \\
2 \\
3 \\
4\end{array}$ & $\begin{array}{l}\text { Alor Gajah } \\
\text { District. }\end{array}$ & $\begin{array}{l}\text { Sungai Udang } \\
\text { Bukit Panchor } \\
\text { Ramuan China and } \\
\begin{array}{l}\text { Sungai Siput } \\
\text { Brisu }\end{array}\end{array}$ & $\begin{array}{r}4,392.035 \\
2,852.300 \\
\\
2,591.2 .09 \\
911.2 .19\end{array}$ & $\begin{array}{l}\cdots \\
\cdots \\
\cdots \\
\cdots\end{array}$ & $\begin{array}{l}\cdots \\
\cdots \\
\cdots \\
\cdots\end{array}$ & $\begin{array}{r}4,392.0 .35 \\
2,852.3 .00 \\
\\
2,591.2 .09 \\
911.2 .19\end{array}$ & & \\
\hline & \multirow[t]{2}{*}{$\begin{array}{l}1 \\
2\end{array}$} & \multirow[t]{2}{*}{ Central District. } & $\begin{array}{l}\text { Bukit Bruang } \\
\text { Bukit Sebukor }\end{array}$ & $\begin{array}{r}6,103.0 .28 \\
44.2 .27\end{array}$ & $\begin{array}{l}\cdots \\
\cdots\end{array}$ & $\begin{array}{l}\cdots \\
\cdots\end{array}$ & $\begin{array}{r}6,103 \cdot 0.28 \\
44.2 .27\end{array}$ & & \\
\hline & & & Total & 49,7 I I .2 OI & $\ldots$ & $\cdots$ & $49,7 \mathrm{II} \cdot 2.0 \mathrm{I}$ & & \\
\hline
\end{tabular}


ForM No. 8.

Area of Plantations.

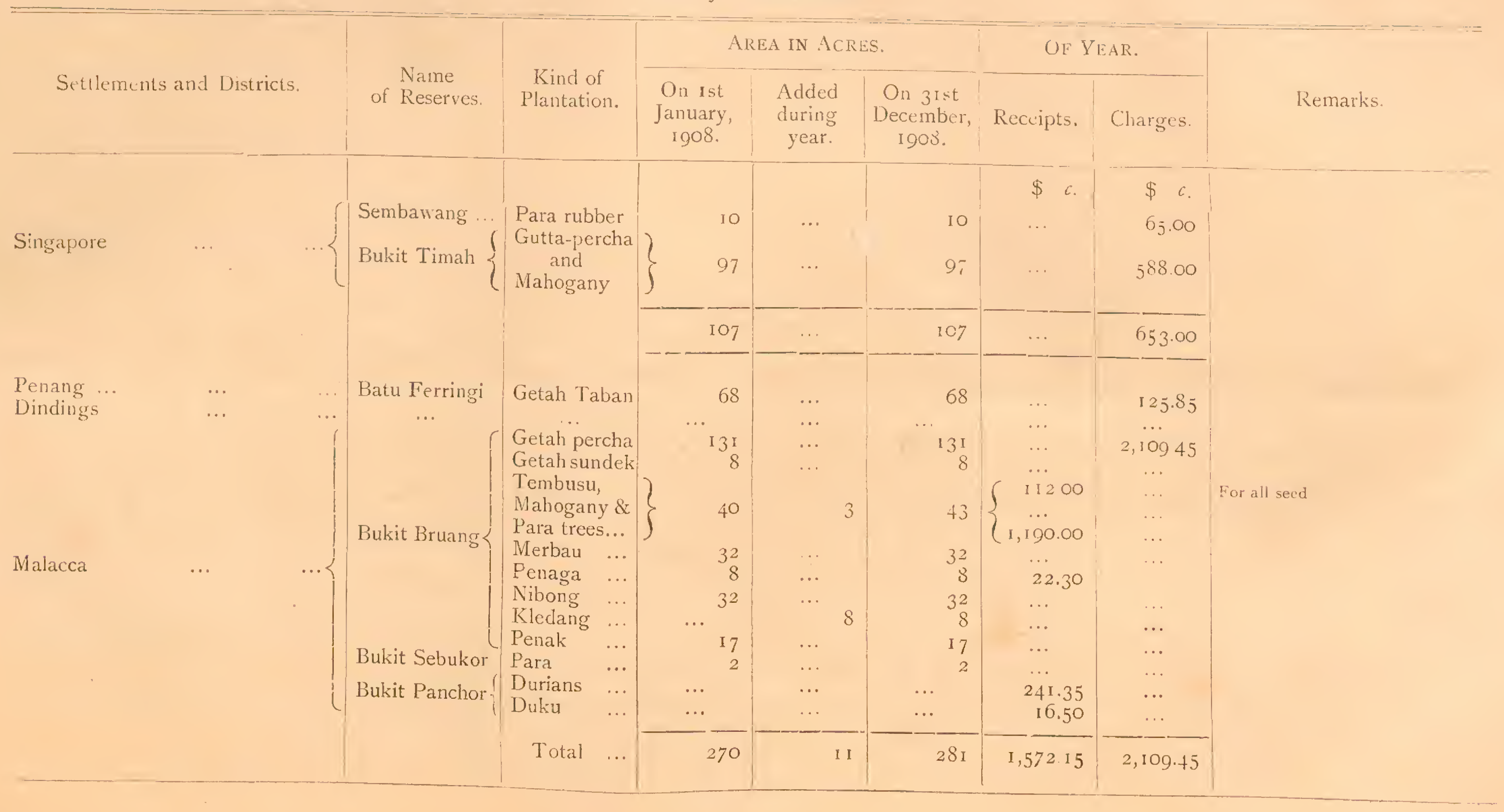




\section{SINGAPORE,}

FORM NO. IJ.

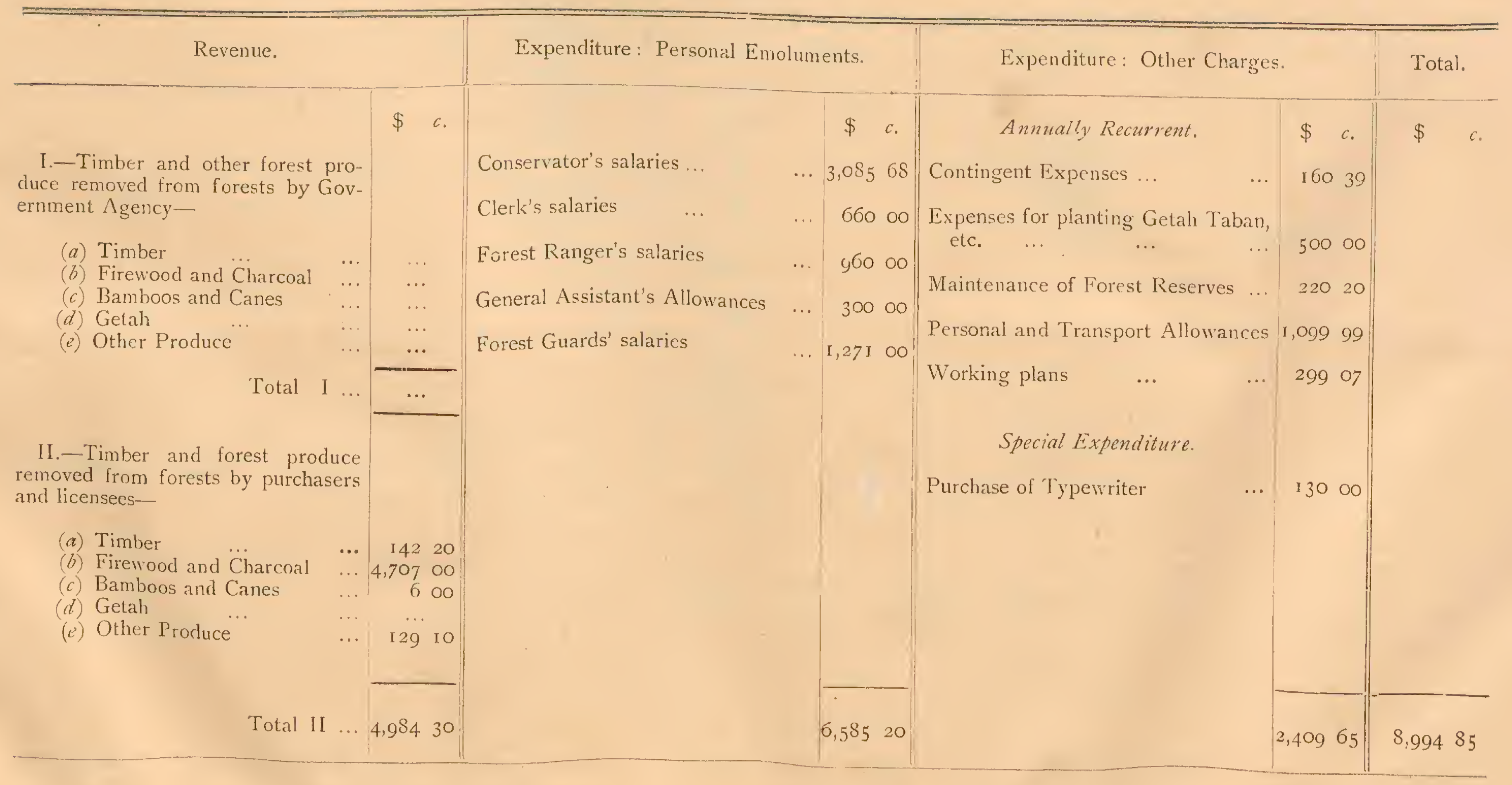


PENANG AND PROVINCE WELLESLEY.

FORM NO. II-Continued.

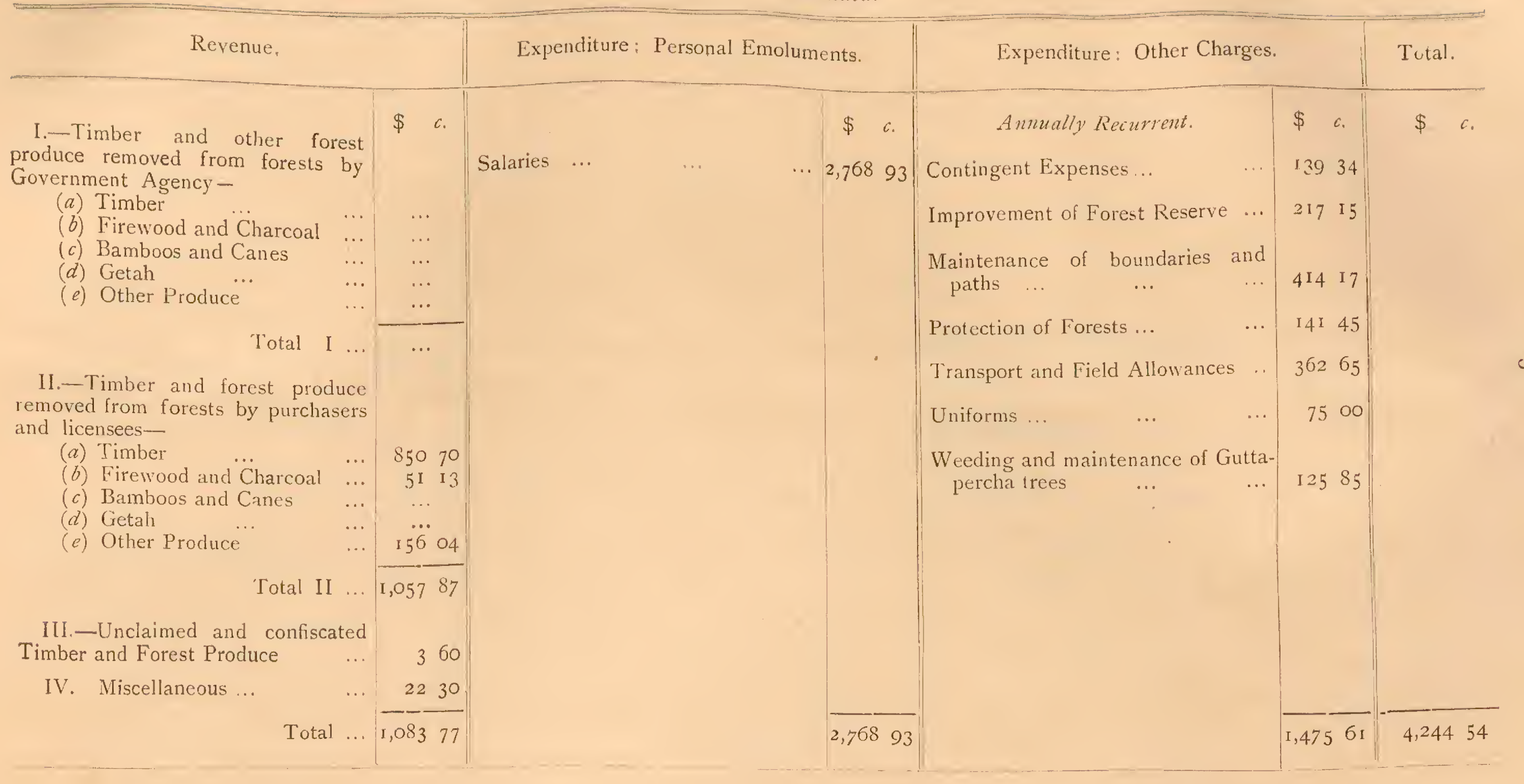




\section{DINDINGS.}

FORM No. I I-Contmued

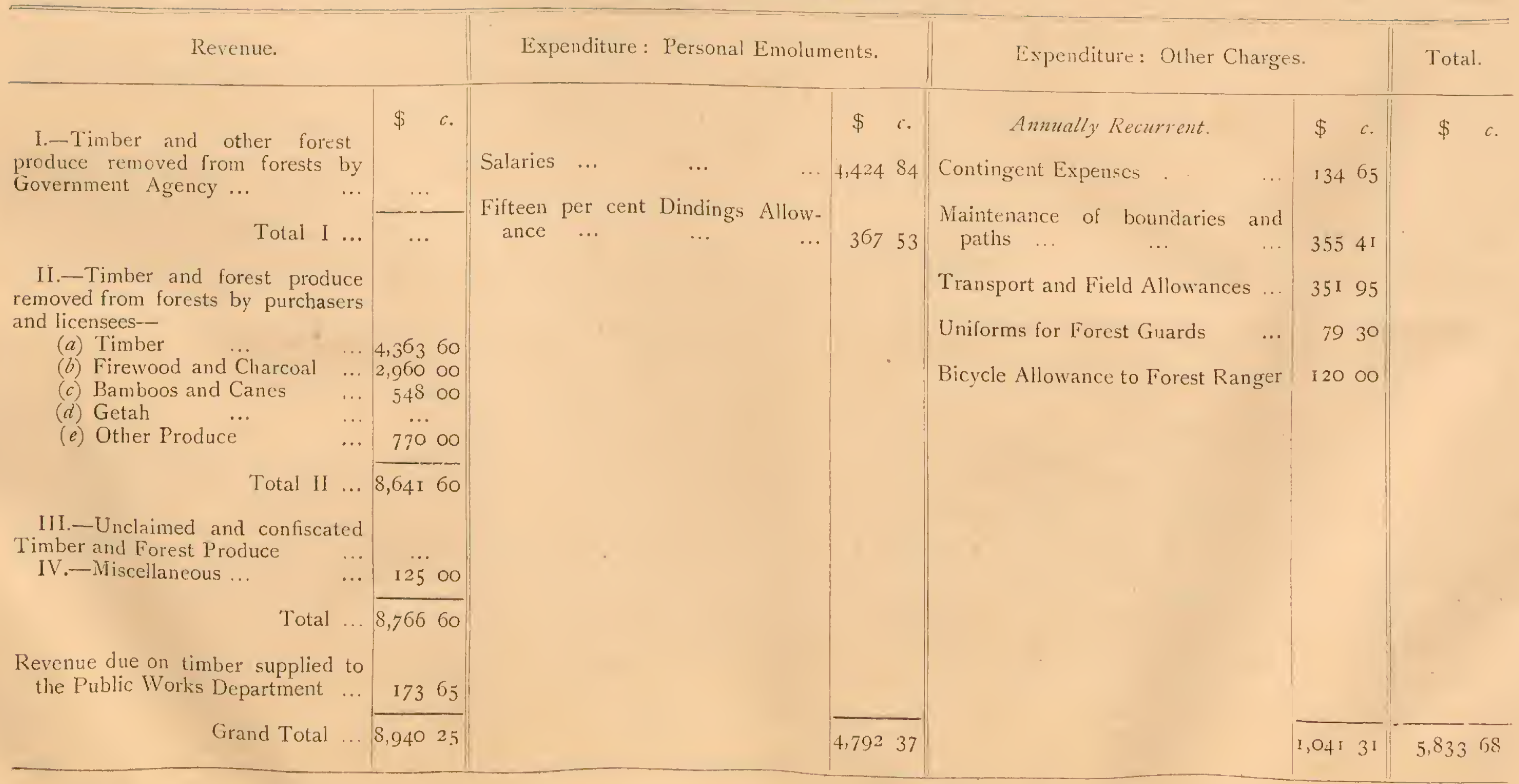


MALACCA.

FORM NO. II,-Concluded.

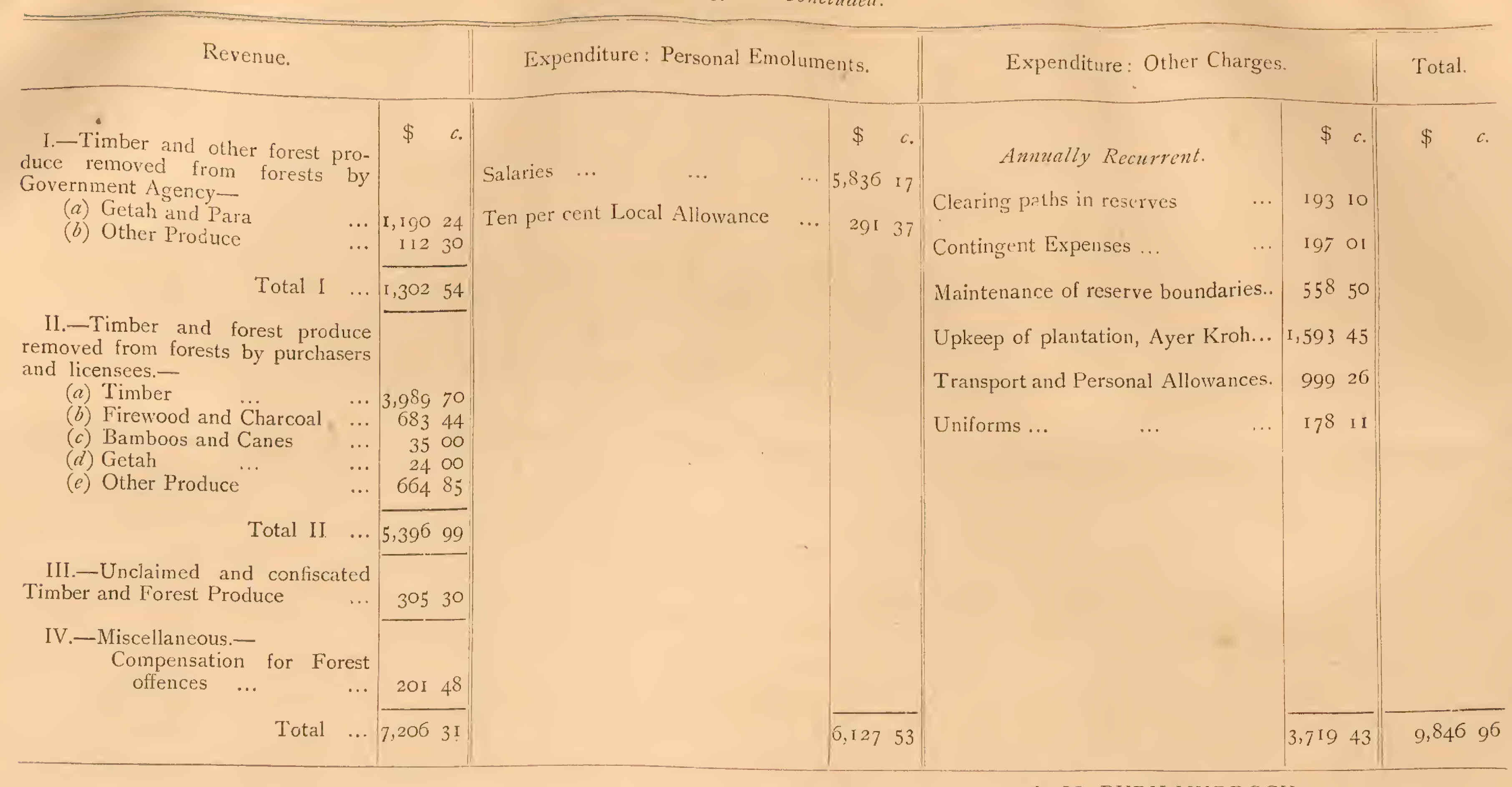

A. M. BURN-MURDOCH,

Conservator of Forests,

Federated Malay States and Straits Settlements. 


\section{Annual Report on Forest Administration in the Straits Settlements for the Year 1909}

\section{PART I.}

\section{Extension and Constitution of Reserved Forests.}

I. In October, I909, the Forest Ordinance came into force, and for the first time provision was made for the legal constitution of reserved lorests, and the procedure to be adopted laid down. In order to comply with this Ordinance it is necessary to notify in the Gazette all areas it is proposed to reserve, and accordingly revised descriptions of all boundaries were undertaken, and during the year the following were completed and notified in the Gazette as proposed reserves, details being shown in Form 2:-

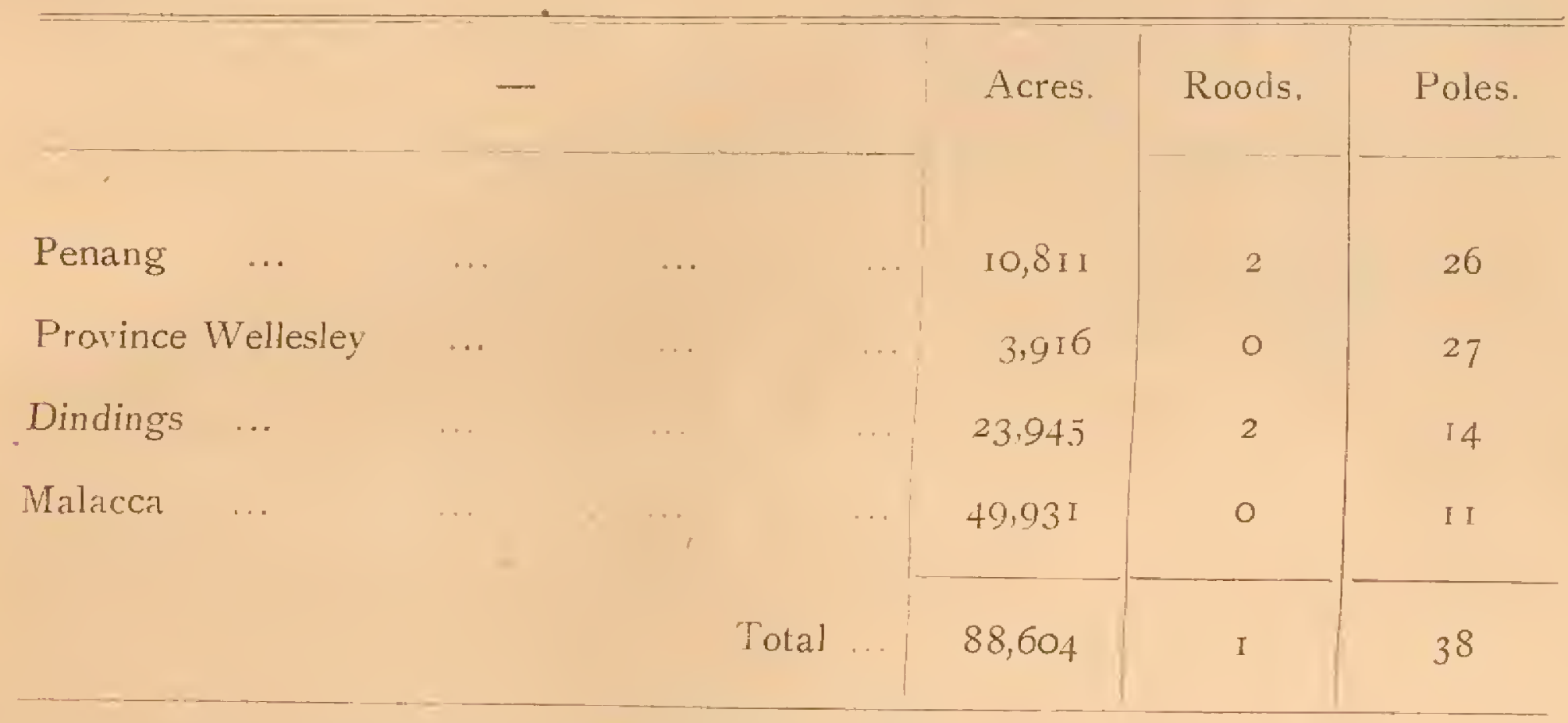

2. Pulau Jerejak, formerly treated as a reserve, has been omitted, as it has been handed over to the Medical Department. In Singapore the completion of the revised descriptions was delayed owing to need for further survey of Sembawang reserve, and to the fact that certain areas have had to be handed over to the Municipality, as falling within the extended water catchment area. Chan Chu Kang reserve has been handed over and part of Sembawang.

3. The area of reserved forests when all the procedure shail have been gone through will be practically the same as before, and it is hoped that early in IgIo, all may be complete.

4. The Bukit Timah reserve has sustained great damage owing to the opening of granite quarries to supply the works on the Harbour Schemes.

\section{Demarcation and Up-keep of Boundaries.}

5. In Singapore the boundaries of the reserves were kept clean by the staff of forest guards and were inspected by the Forest Ranger. I hey are in good order. In Penang and Province Wellesley $68 \frac{1}{2}$ miles of boundaries were cleared at a cost of $\$ 274$, not including Tasek Glugor reserve which was kept clean by the forest guards in charge. This shows a reduction as compared with rgo8. .

6. In the Dindings the boundaries of all reserves were cleared on contract, 62 miles, $\$ 4<5.60$ being spent; they are now all in good order, and in Igro will be upkept almost entirely by forest guards and boatmen. The District Officer inspected inany of the reserves and the Conservator inspected those of Tanjong Hantu, Telok Senangin, parts of Lumut, Telok Muroh and Pangkor reserves, also the southern boundary of Telok Sera and a portion of Tanjong Burong reserves. 
7. In Malacca 392 miles of boundaries were re-cleared at a cost of $\$ 227.60$; the remainder, 68 miles, required no clearing. The Forest Ranger inspected efficiently and the Conservator inspected portions of the Bukit Bruang and Ayer Panas reserves.

\section{Surveys.}

8. The Forest Ranger, Singapore, made a rough survey of the Kranji and North Seletar reserves in Singapore Island with a view to systematic exploitation of the mangrove forests. In Penang and Province Wellesley there were no other new surveys.

\section{PART II.}

\section{Management of Forests.}

\section{WORKING PLANS.}

9. In Singapore two coupes were opened for Igog, one in the Kranji No. I reserve of 30 acres, and one in Changi No. 2 of 27 acres, and the mangrove forest in these couves was sold by tender for $\$ 120$ and $\$ 175.50$. The contracts were signed in December, 1909. In 1908, coupes No. I Pandan and No. I (hangi were worked during the year for firewood.

Io. In Malacca the Merlimau, Ayer Panas and Sungai Ldang reserves were worked under a rough working plan. Extraction of marked trees was permitted in certain areas in these reserves, the following trees being marked:-

$\left.\begin{array}{llll}\text { Merlimau reserve } & \ldots & \ldots & \text { I } 54 \\ \text { Ayer Panas rescrve } & \ldots & \ldots & 49 \\ \text { Sungai Udang reserve } & \ldots & \ldots & \text { So }\end{array}\right\}$ thees of Class I not less $6 \mathrm{ft}$. in girth.

Besides this 49 Class 1 trees were marked for felling in Cape Rachado forest.

11. In the Dindings an area of about 200 acres in the Tanjong Burong Mangrove reserve was leased to a firewood cutter for $\$ 500$, but no tenders were received for the right to cut firewood in 1910 .

\section{Paths in Reserves.}

12. In the Dindings old paths were maintained in the Lumut reserve by the forest ouards and boatmen and the old path from Sungai Puyu (near Tanjong Hantu) to Telok Sera running along near the sea coast and through the Telok Sera reserve was cleared. This path had not been touched for about 20 years.

13. In Malacca inspection paths in the Sungai Udang and Batang Malaka reserves were kept open at a cost of $\$ 26.80$.

\section{Buildings.}

14. In Penang the forest guards' quarters were re-ataped and repaired at a total cost of $\$ 2 .+6.92$.

In the Dindings, quarters were built for four forest boatmen at Lumut and one at Pengkalan Bahruat a cost of $\$ r .843 .75$. \$600 were spent. in enlarging the Forest Ranger's quarters at Lumut, and other minor repairs were carried out by the Public Works Department.

In Malacca the Ranger's quarters were repaired.

\section{Protection.}

15. The Forest Ordinance XXIl of 1908 came into force on Ist October, 1909, and two sets of rules, one for Malacca and the Dindings and the other for Singapore and Penang, came into force on 1 st October, 1909. These rules considerably lessen the royalty to be paid on timber extracted from the Dindings, this measure being in part necessitated by the abolition of export duty on timber exported from Perak, Selangor and Negri Sembilan in Igo8, which placed those States at an advantage over the Dindings which formerly had a higher rate of royalty. The rate is now the same as in those States of the Federated Malay states. 


\section{Fire Protection.}

16. An improvement in protection from fire is reported in Province Wellesley where lalang fires are apt to be of frequent occurrence, especially to the northeast near Tasek Glugor.

I 7. There were two cases of lalang fires in the Seletar reserve, and abuut I 5 acres was.burnt. Two small areas suffered in the Dindings for which \$I 5 damages were recovered.

18. The Forest Ranger, Malacca, says nothing of lalang fires, which used to be very prevailing in Malacca. The new Forest Ordinance gives powers in this respect. Fires are confined almost entirely to grass lands, high forest is not subject to fire, being evergreen.

\section{Forest Offences.}

19. The following were the cases taken to Court:-

\begin{tabular}{|c|c|c|c|c|c|c|c|}
\hline \multirow[b]{2}{*}{$\begin{array}{l}\text { Case pending } \\
\text { from 190\%. }\end{array}$} & \multicolumn{3}{|c|}{ New cases of the year. } & \multirow[b]{2}{*}{$\begin{array}{l}\text { Grand } \\
\text { total } \\
\text { cases. }\end{array}$} & \multicolumn{3}{|c|}{ Disposed of during year. } \\
\hline & $\begin{array}{l}\text { Theft of } \\
\text { timber } \\
\text { and } \\
\text { minor } \\
\text { produce. }\end{array}$ & $\begin{array}{c}\text { Other } \\
\text { offences. }\end{array}$ & $\begin{array}{c}\text { Total } \\
\text { new } \\
\text { cases. }\end{array}$ & & $\begin{array}{l}\text { Convic- } \\
\text { tions. }\end{array}$ & $\begin{array}{c}\text { Acquit- } \\
\text { tals. }\end{array}$ & $\begin{array}{l}\text { Pending at } \\
\text { close of year. }\end{array}$ \\
\hline 2 & $\cdot 68$ & 7 & 75 & 77 & 59 & I 6 & 2 \\
\hline
\end{tabular}

Added to this, 22 cases were compounded in Malacca and two cases dealt with departmentally in Singapore. Of the cases taken into the Courts 59 out of 75 resulted in convictions, 78 per cent of convictions, a poor percentage. \$55 I were realized as compensation in Malacca and $\$ 28$ in Singapore.

20. There was a large falling off in cases in Malacca.

\section{Improvement of Forest.

\author{
Natural Reproduction.
}

2I. Natural reproduction of Tampines (Slatiu sideroxylon) is reported as good in Pandan and Sungai Buloh reserves. Damar laut (Shoren utilis) reproduced itself well in the Dindings.

22. In Malacca it is reported that natural reproduction of the more important species was good, especially in the Merlimau. Ayer Panas and Sungai Udang reserves, particularly Resals (Shorea harbata). Serayah (Shorea accuminata) and Bintangor (Calophrllum inopliyllum).

\section{Artificial Reproduction.}

\section{(Vide FORM 8)}

23. In Singapore the 97-acre plantation of gutta-percha trees in Bukit Timah was upleept at a cost of $\$ 609$. Useless forest trees overshadowing the young gutta-percha trees were thinned out. A nursery was also upkept, and blanks in the plantation supplied. A nursery of para rubber was made. The so-acre block of para rubber in Sembawang reserve was handed over to the Municipality during the year. The department realized $\$ 200$ for rubber by lease of the trees.

24. No new planting was done in Penang, but the Batu Ferringi gutta-percha plantation was weeded at a cost of \$75.25. The Manicoba rubber and Lagos silk rubber planted near Tasek Glugor were not a success, doubtless owing to the poor and sandy soil.

25. In the Dindings nurseries of Chengal and Merbau were made at Lumut, and 10,000 seeds of the former and 5,000 of the latter obtained from Selangor were sown. The Merbau have succeeded, but the Chengal (Balanocarpus maximus) has failed. A para nursery was also made, from seeds obtained at Lumut, and a few Damar laut and Kulim (Sorodocarpus borneensis).

26. In Malacca the forest plantations were under the financial control of the newly formed Gardens Committee, the area remains the same, vide Form 8. Wherever 
space could be found near Ayer Kroh, para was planted out, 350 seedlings being put out during the rear. $\$ 3,49$ r.38 was realized by sale of rubber, and $\$ 2,570.94$ was incurred in upkeep of the plantation, wages of tappers, purchase of mangle, nurseries, etc., \$30 was realized by sale of the old mangle and $\$ 2$ Io by sale of fruit in the Panchor reserve. Nurseries of hard wood irees were made in Ayer Panas, Merlimau and Sungai Udang reserves, and in the latter reserve seedlings of Merbau and Resak were transplanted out in the forest in places where extraction of large trees has taken place recently.

27. The Conservator of Forests inspected the plantation at Ayer Kroh early in December and was very dissatisfied with the manner in which tapping had been carried out. He spent several days in giving instructions as to the proper method of tapping, this matter was reported in his report for December, 1909.

28. During the year $2,085 \mathrm{lbs}$. of dry rubber were sold, full payments on the last two consignments were not yet received. The revenue realized is credited to the Gardens Committee, and is not included in the forest revenue for-igog. In rgIo, no vote will be granted for upketp of plantation, and the cost of upkeep will be defrayed from the proceeds of the sale of rubber, and any balance remaining over credited to forest revenue.

\section{Exploitation.}

\section{A.-From Reseried Forests.}

29. In Changi and Pandan reserves firewond and piles were extracted as follows :-

$$
\text { Changi, Coupe No. I, } 30 \text { acres } \quad \ldots \quad\left\{\begin{array} { c } 
{ 1 0 8 , 3 0 0 \text { billets of frewood. } } \\
{ 1 , 7 7 7 \text { piles. } } \\
{ \text { Pandan, Coupe No. I, roo acres } }
\end{array} \quad \left\{\begin{array}{c}
1,178,750 \text { billets, for which } \$ 8 \text { Io } \\
\text { was realized by the Department. }
\end{array}\right.\right.
$$

30. In Penang 12 permits were issued and 29 trees were felled by licensees, and 27 for other forest produce.

3I. In the Dindings the Telok Sera and Lumut reserves were worked by Chinese and 54 tons (of 50 cubic feet) Class I $A$ timber and $3+4$ tons of Class I $B$ were extracted, all trees being selected and marked previously by a iorest officer. The figures for 1908 were 185 tons and 527 tons, so that a large decrease is shown. The trees extracted were mostly Damar laut, Meranti and Nedang.

The first coupe in the Tanjong Burong reserve was leased for the year for $\$ 500$. The lessee gave a great deal of trouble.

32. In Malacca trees of Class I were selected for felling by the Forest Ranger in the Merlimatx, Ayer Panas and Sungai Udang reserves, and \$709 revenue paid hy the permit holders who were permited to extract these selected trees. In addition they were allowed to cut any trees of second class.

$$
\text { B.-From Crown Land. }
$$

33. In Singapore permits for trees realized $\$ 171.75$, and in Penang and Province W ellesley, \$98r.

34. In the Dindings 195 tons of Class I A timber were extracted from Crown ands and 119 tons of Class I $B$ and 2 tons of Class II. A few licences were issued for the extraction of remmants of Class I trees left in the f.rest. $\Lambda$ bout 5 o tons of timber were granted free of royalty to the Public Works Department for buildings and bridges, etc.

35. In Cape Rachado forest, Malacca, 49 Class I trees were selected and permits issued for their extraction. The revenut from timber on Crown lands amounted to $\$ 3,3$ I 5 , as compared with $\$ 2,769$ in 1908 .

\section{Fuel.}

36. In singapore permits for fuel realized $\$ 4,25 \mathrm{I}$, as compared with $\$ 4,707$ in 1908. The fee for permits was raised from $\$ 3$ to $\$ 5$ on ist October, 1909 .

37. In the Dindings 396 permits were issued for firewood on Crown land and realized $\$ 1,980$, and in Malacca permits realized $\$ 435.77$ as compared with $\$ 380$ in 1908. 
Charcoal realized $\$ 369$ in Malacca, of which $\$ 60$ was derived from charcoal made from refuse timber in reservel forests.

\section{Minor Forest Produce.}

38. The revenue collected under this head may be sten in Form Io*.

39. In Singapore bamboos and canes realized a small sum, and $\$ 200$ was derived from the ro acres of para in Sembawang reserve. Other minor produce in Singapore consisted of Nibongs, and shows a rise of $\$ 87$.

40. In the Dindings there was a rise of $\$ 75$ in bamboos and canes owing to some new working in Bruas River. Other produce showed a rise of $\$ 272$, and consisted chiefly of Nibong, Mengkuang, Bertam, Damar, Pinang-raja and Tengah bark.

41. In Malacca there was an increase of about \$140. Wood oil realized \$12, rotan $\$ 42$ and fruit trees $\$ 210.50$.

The para rubber trees in Ayer Kroh and Bukit Sebukor were tapped departmentally throughout the year. The yield was $1,194 \frac{3}{4} \mathrm{lbs}$. sheet and $291 \frac{1}{2} \mathrm{lbs}$. scrap and $\$ 3,491.38$ was realized during the year, a further payment of $\$ 766.59$ was made in January, and a further payment of $\$ 255.23$ is still due on consignment No. 6 . None of this money was credited to revenue, however, as the plantation is managed by a Gardens Committee. In I9IO part of the balance of revenue after defraying all expenses will he credited to torest revenue. \$138.53 was credited to revenue, being a payment due on rubber produced in I 908 before the Girdens Committee took over the revenue.

\section{PART III.}

\section{Financial Results.}

42. This table shows the comparative revenue for 1908 and 1909 :-

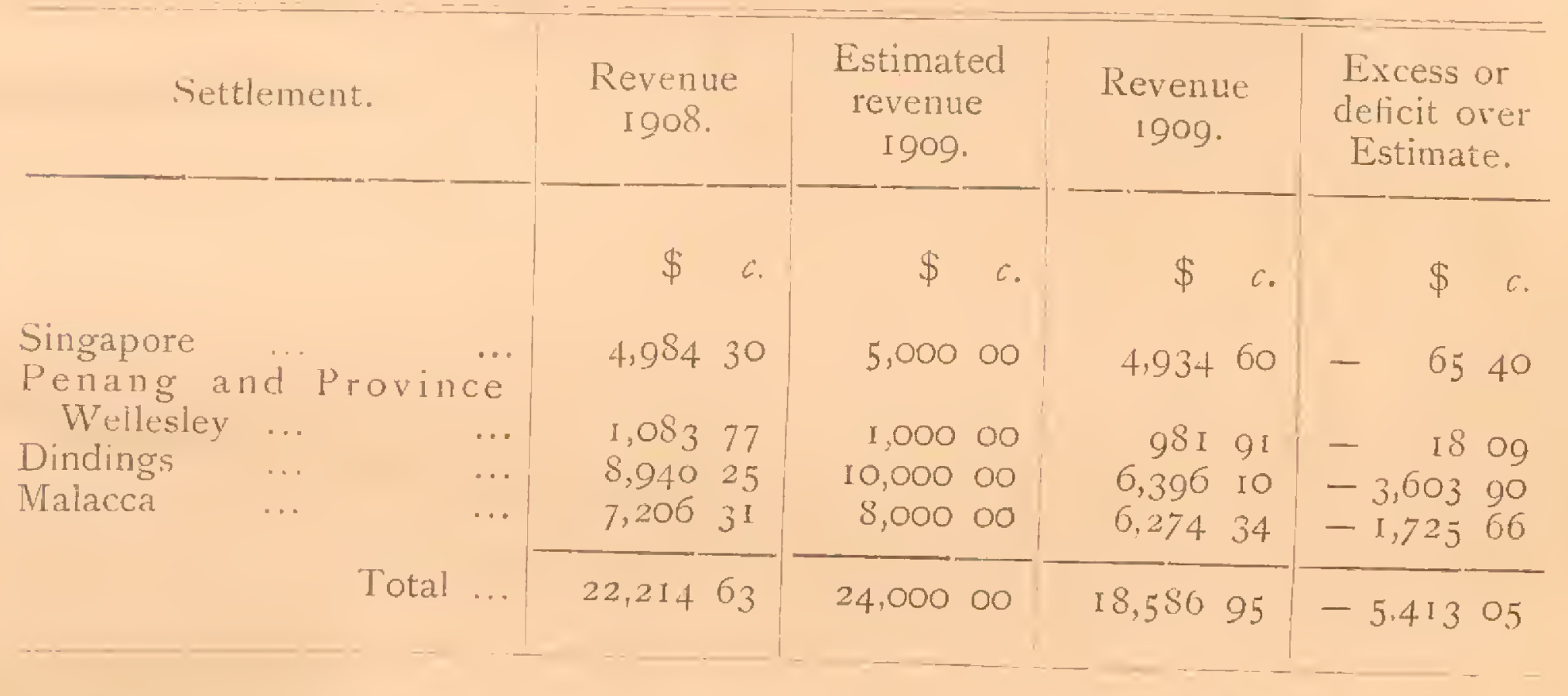

43. The decrease in revenue in the Dindings is due entirely to timber and firewood. Timber fell off more than $\$ 2,000$, and firewood and charcoal about $\$+80$, and is due to causes beyond the control of the Forest Department. The most favourably situated localities have been worked out in lormer years, and the only extensive tract of unreserved Crown land containing valuable timber is that portion lying on each side of the Bruas-Lumut Road, detween the 6 th and roth miles, nearly all the land to the east of this road will soon be alienated. Of that to the west a considerable area is first-class land for rubber cultivation, but in the steep hills which are situated about half way between this road and the sea there exists still a valuable supply of Chengal timber.

The supply of timber on alienated land, from which the department derives no royalty and the timber cut on free passes, is almost sufficient to meet the small local demand. The alienation of land and diminution of valuable forest is also a factor.

The rates of royalty on timber were lowered in October in the hopes of giving a stimulus to the timber trade, i.e., the Penang trade.

44. In Malacca the revenue decreased by about $\$ 1,000$ due entirely to the fact that in 1908 \$I, I 90 was credited to revenue by the sale of para rubber, while as already

$$
\text { * Not printed. }
$$


stated, in 1909 the proceeds of sale of rubber have been credited to the Gardens Committee. The revenue on timber, firewood and charcoal shows an increase. In 1910 an increase in total revenue is assured.

\section{EXPENDITURE.}

45. This statement shows the total expenditure in each Settlement, as compared with 1908 and estimates for 1909 :-

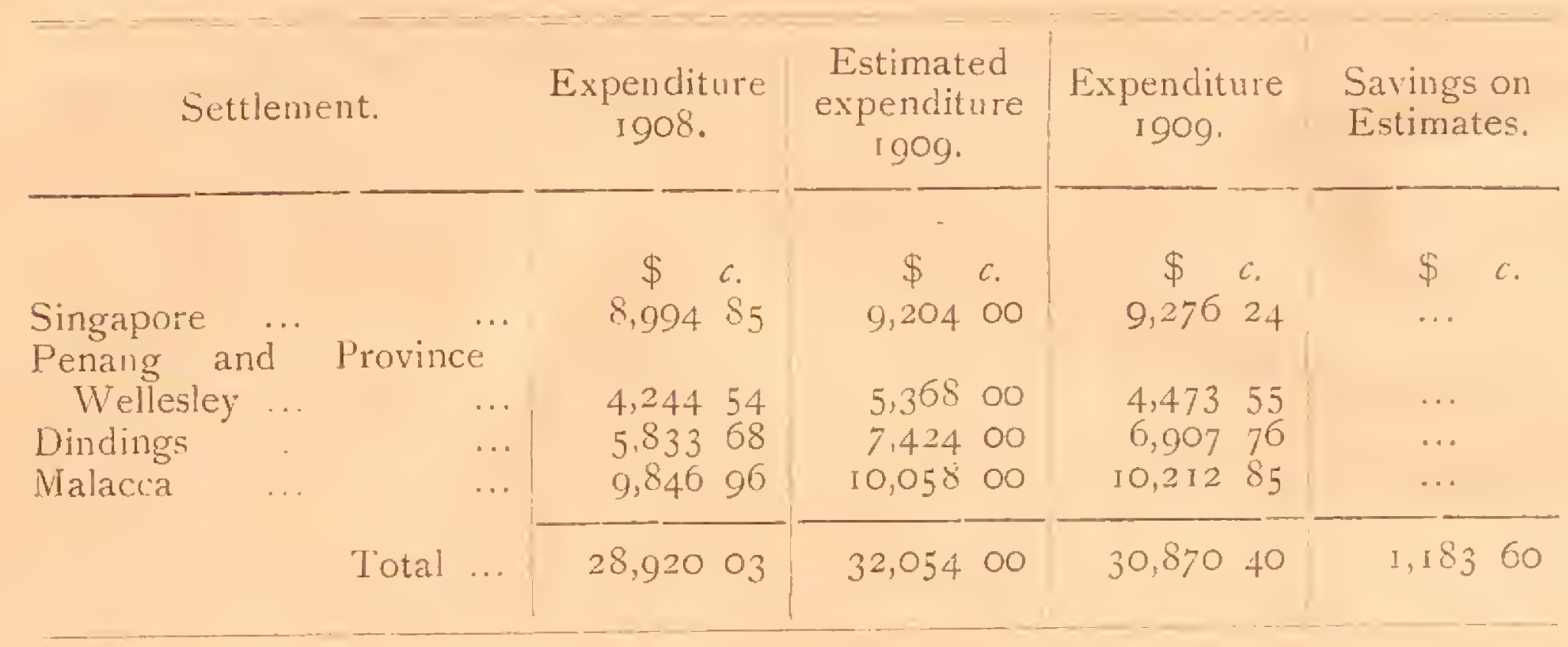

Under Singapore is included one-third salary of the Conservator of Forests and his travelling expenses and other small expenses of Conservator's office in connection with colonial work.

There is an increase over Igo8 of $\$ 1,950.37$ and a saving on the total estimates of $\$ 1,183.60$. The increase is mainly accounted for in salaries, under increments in all Settlements and in other charges in the Dindings.

The deficit of revenue over expenditure, was $\$ 12,28.3 .45$. In I9IO the expenditure in Malacca will be much reduced as the upkeep of plantation will be met from the proceeds of sales of rubber.

\section{Administration.}

46. Mr. A. M. BURN-MURvOCH held the appointment of Conservator of Forests throughout the year. He visited the following forest reserves throughout the year.:-

Singapore.-Bukit Timah and Pandan reserves.

Penang and Province Hellesley, - Telok Bahang, Government Hill and Penara Bukit reserves.

Dindings.-Lumut, Tanjong Burong, Telok Sera, Telok Muroh, Tanjong Hantu and Telok Senangin.

Malacca.-Ayer Kroh and Ayer Panas reserves.

He also insperted the rubber plantation in Malacca (Ayer Kroh and Bukit sebukor) the Baitu Feringgi plantation, Penang, and spent a month actually travelling in the Colony besides a considerable amount of time spent on office work in connection with colonial work.

47. Mr. V. P. Bokies, Forest Ranger, Grade I, held charge of the Malacca forests till Ist October when he proceeded on leave and Mr. (i. M. O'HARA relieved him. Mr. O'HARA continued as Forest Ranger, Dindings, till the end of August and was sent to Malacca in September in order to be instructed in tapping and other work before taking over from Mr. BoRGEs. He suffered much from malaria in the Dindings. During September and October the District Officer, Dindings, carried on the work, but in November, IBRAHIM, Forest Ranger, Grade II, Federated Malay States, was lent to the Colony to carry on the work under Mr. J. LORNIE.

48. In Penang Mr. Fox continued as Superintendent of Forests and Gardens and drew the usual allowance from the department.

49. In Singapore Mr. T. C. MAl.Aya PILlaI continued as Forest Ranger throughout the year. 


\section{Subordinate Staff.}

50. In Singapore a forester was appointed on \$240. One forest guard resigned and two were dismissed.

5I. In Penang the Forest Clerk, Mr. AERIA, died on Ioth March and was replaced by Mr. L. S. IngRAM. The Ranger, Foresters and Forest Guards remained unchanged during the year.

52. In the Dindings, J. SANib BIN ABDuLLA, Forest Ranger, Grade IV, was badly reported on, and his increment due on Ist July was deferred. "The increment of one Forest Guard was withheld.

The work of the other members of the staff was satisfactory.

53. In Malacca one Forest Guard was dismissed for absence without leave. The staff are reported to have given satisfaction.

54. The following was the staff employed during the year:-

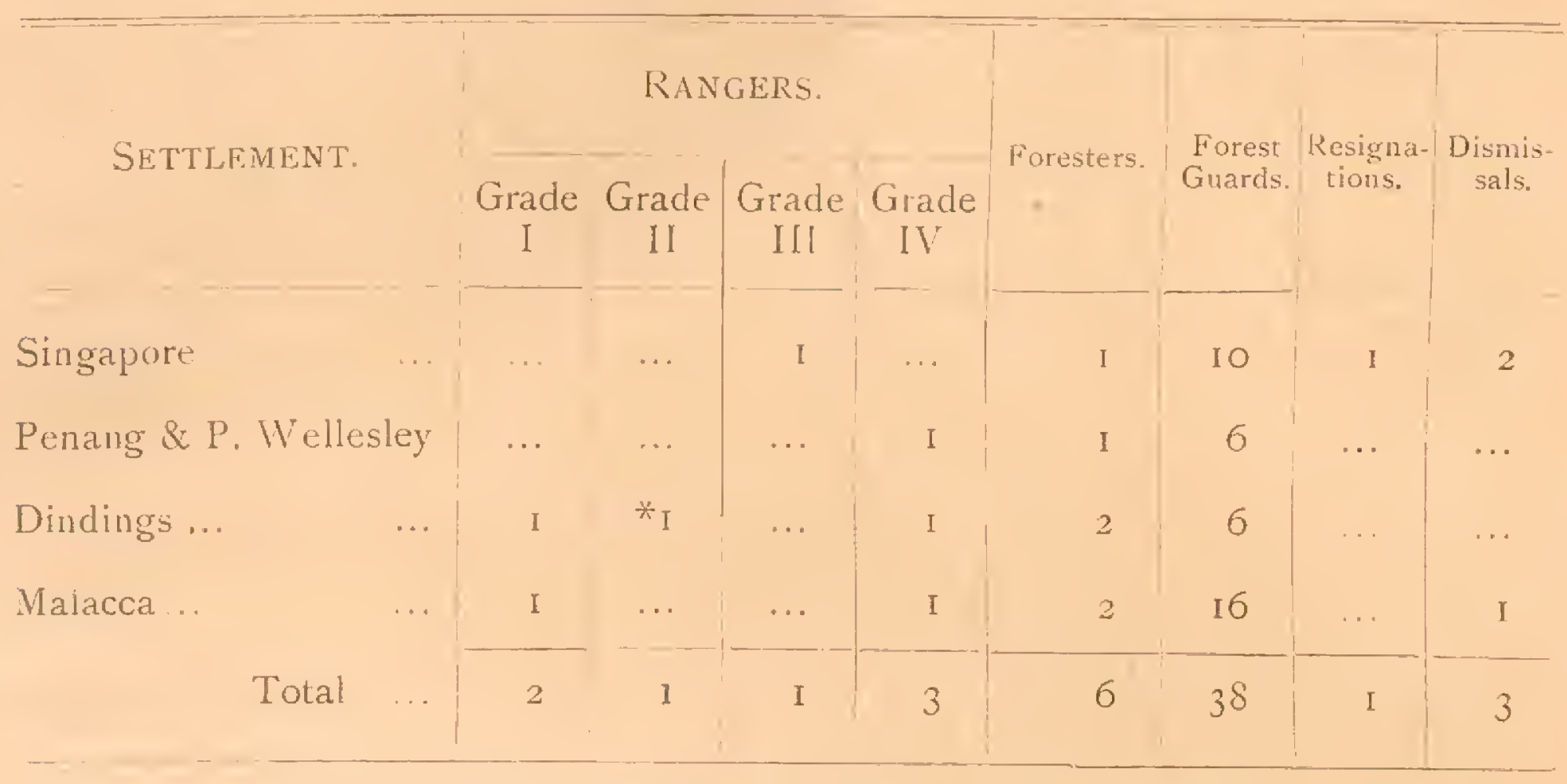

* Vice Mr. O'HaRA, Forest Ranger, Grade I, transferred to Malacca.

KUALA LUMPUR,

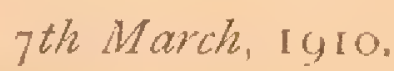

A. M. BURN-MURDOCH, Conservator of Forests,

Federated Malay States and Straits Settlements. 
Form No. I

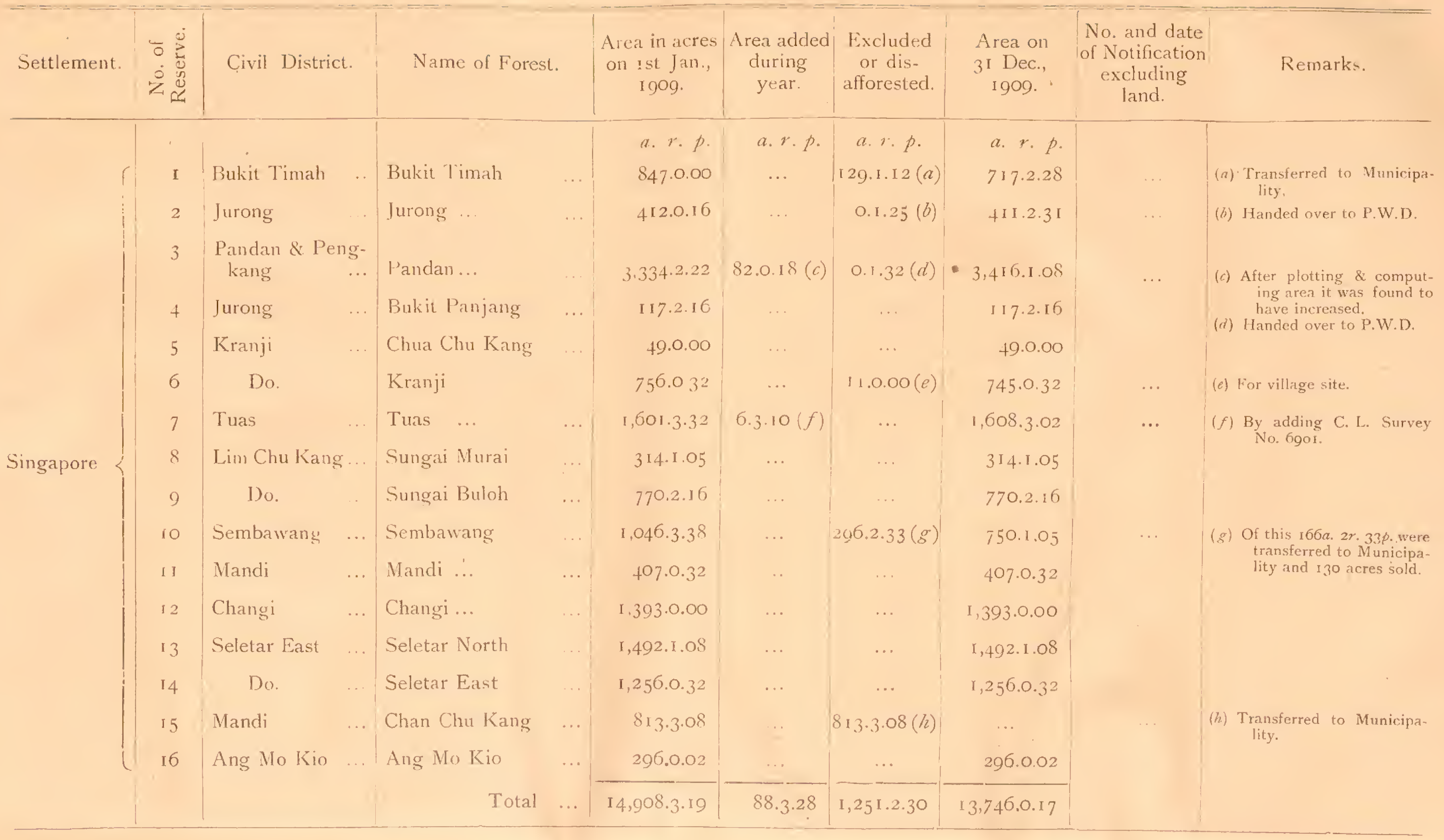


Form No. I.-Continued.

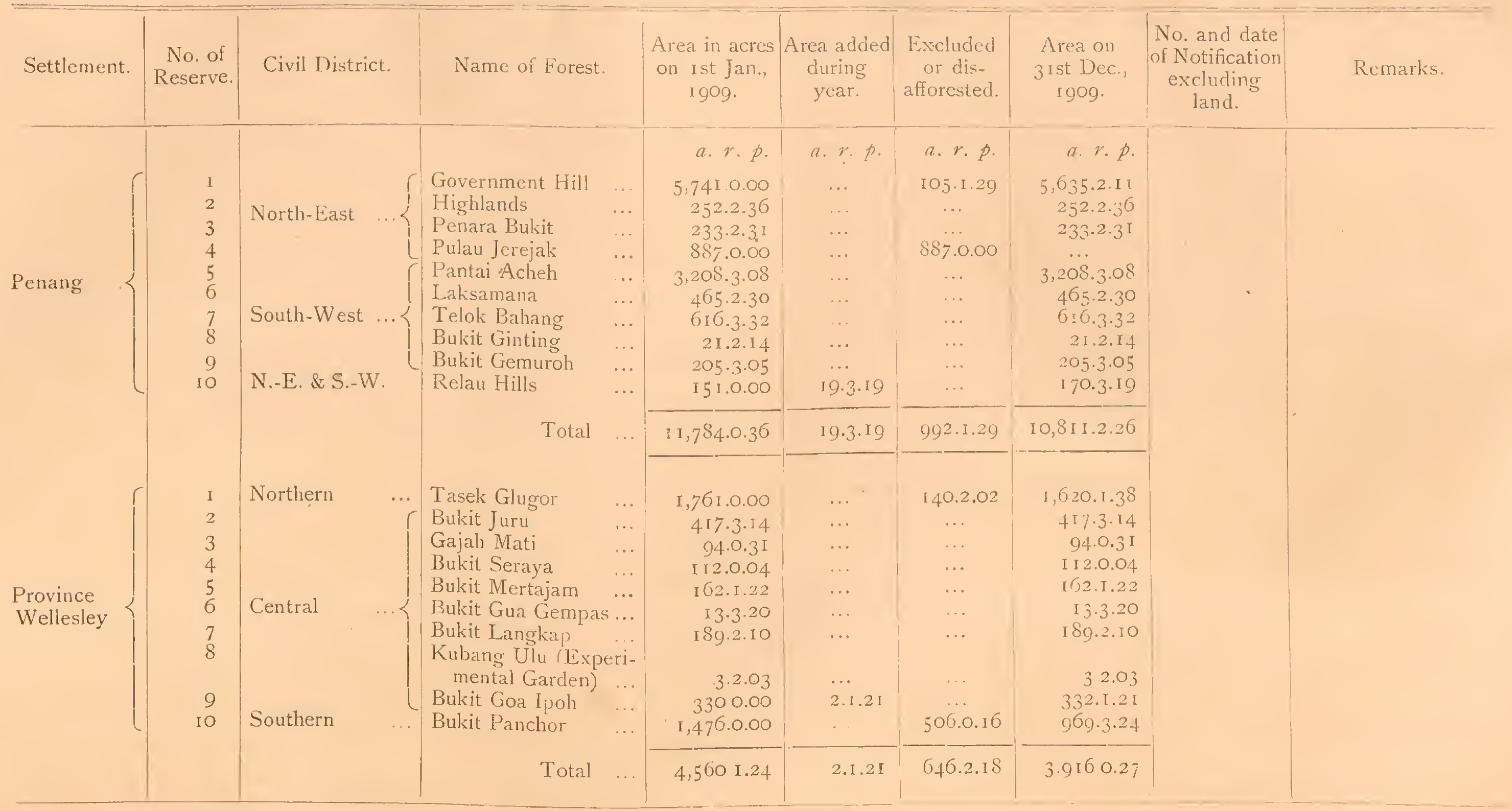


FORM NO. I.-Continued.

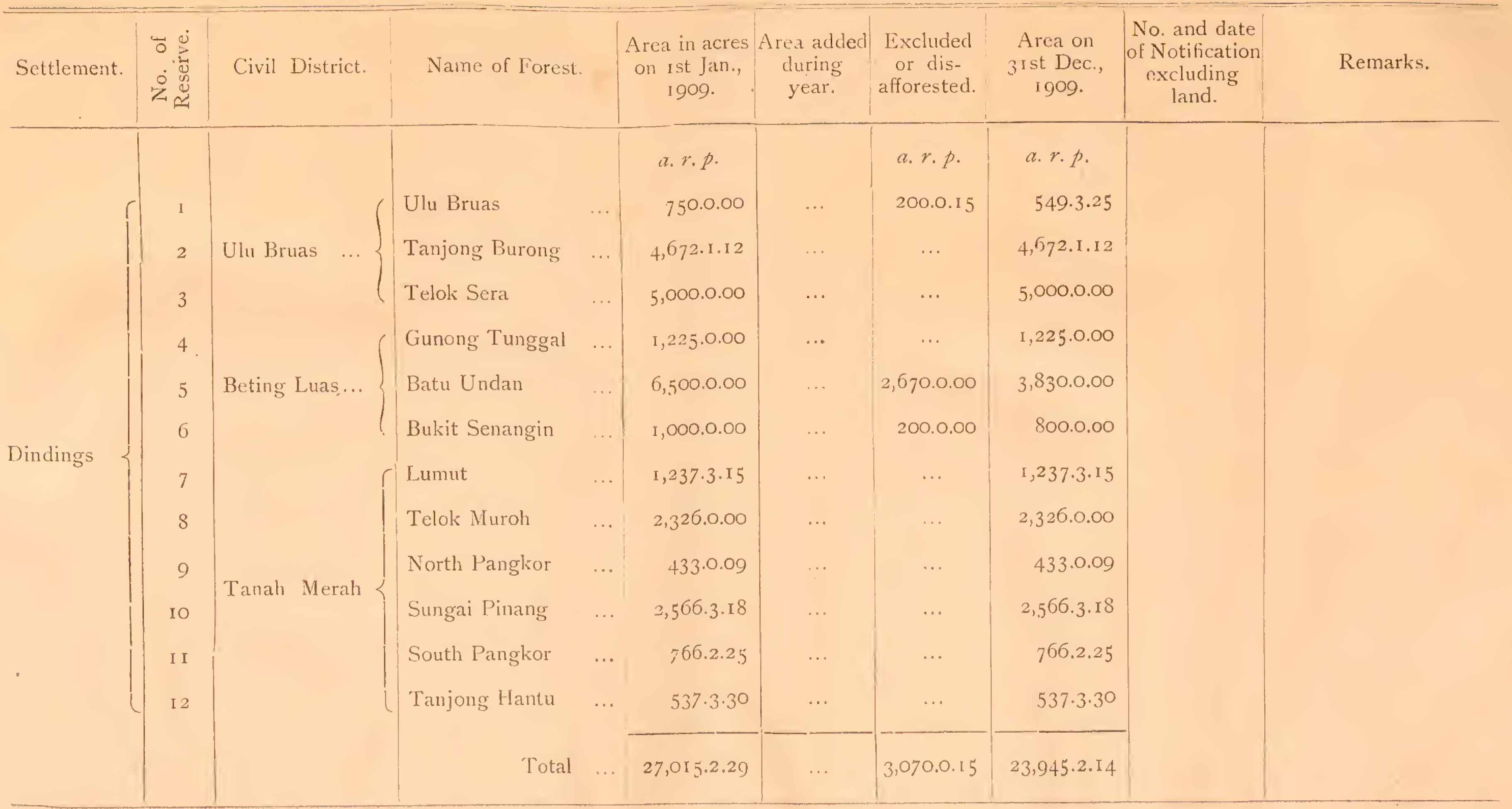


FORM No. i.-Concluded.

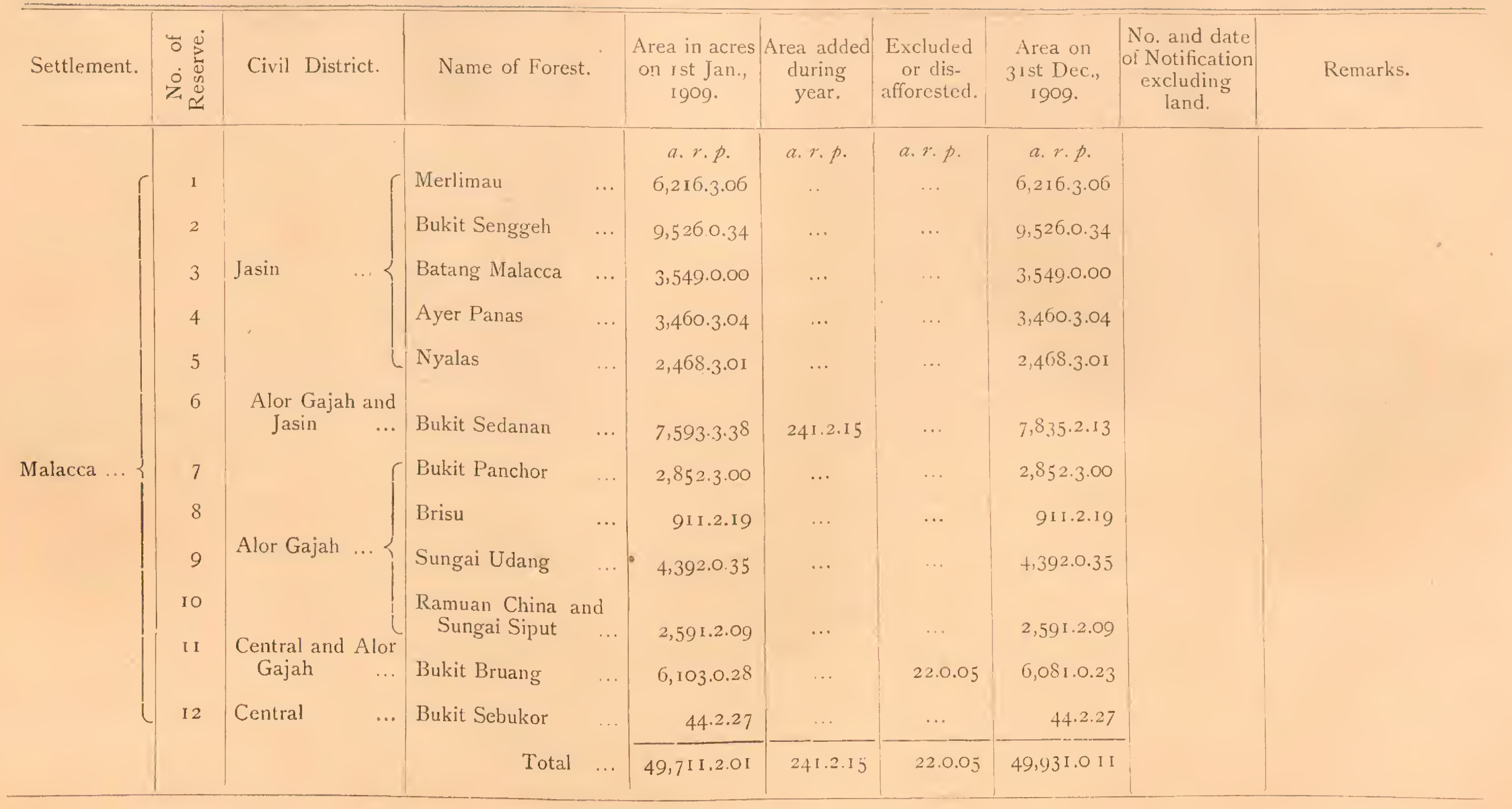


FORM NO. 2.

Statement showing Progress made in forming new Reserves during the Year 1909.

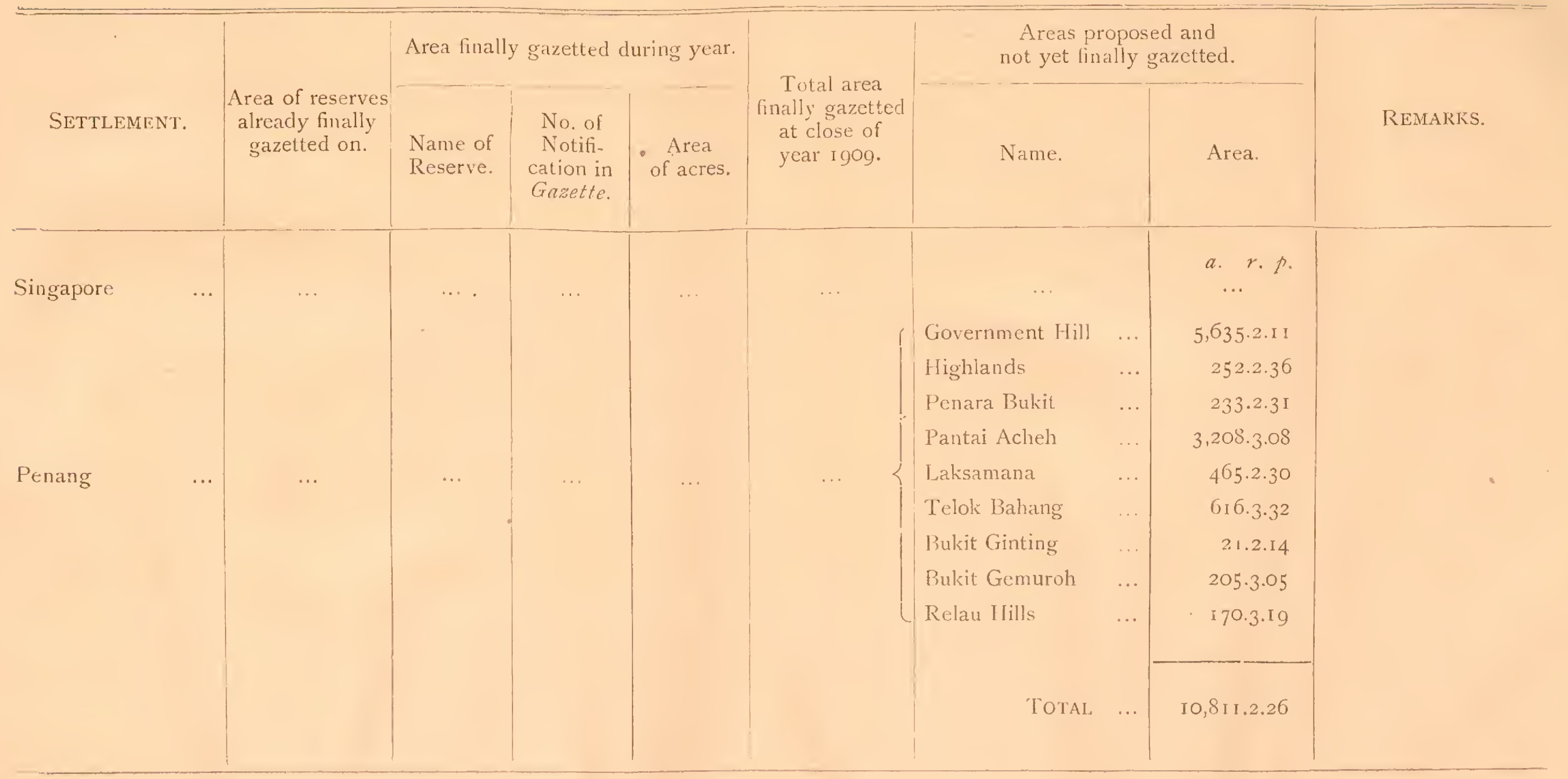


FORM No. 2--Continued.

Statement showing Progress made in forming new Reserves during the Year 1gog.-Continued.

\begin{tabular}{|c|c|c|c|c|c|c|c|c|}
\hline \multirow[b]{2}{*}{ SETTLEMENT. } & \multirow{2}{*}{$\begin{array}{c}\text { Area of reserves } \\
\text { already finally } \\
\text { gazetted on. }\end{array}$} & \multicolumn{3}{|c|}{ Area finally gazetted during year. } & \multirow{2}{*}{$\begin{array}{c}\text { Total area } \\
\text { finally gazetted } \\
\text { at close of } \\
\text { year rgog. }\end{array}$} & \multicolumn{2}{|c|}{$\begin{array}{l}\text { Areas proposed and } \\
\text { not yet finally gazetted. }\end{array}$} & \multirow{2}{*}{ REMARKS. } \\
\hline & & $\begin{array}{l}\text { Name of } \\
\text { Reserve. }\end{array}$ & $\begin{array}{l}\text { No. of } \\
\text { Notifi- } \\
\text { cation in } \\
\text { Gazette. }\end{array}$ & $\begin{array}{l}\text { Area of } \\
\text { acres. }\end{array}$ & & Name. & Area. & \\
\hline \multirow[t]{2}{*}{ Province Wellesley } & \multirow[t]{2}{*}{$\cdots$} & \multirow[t]{2}{*}{$\cdots$} & $\cdots$ & $\cdots$ & \multirow[t]{2}{*}{$\cdots$} & 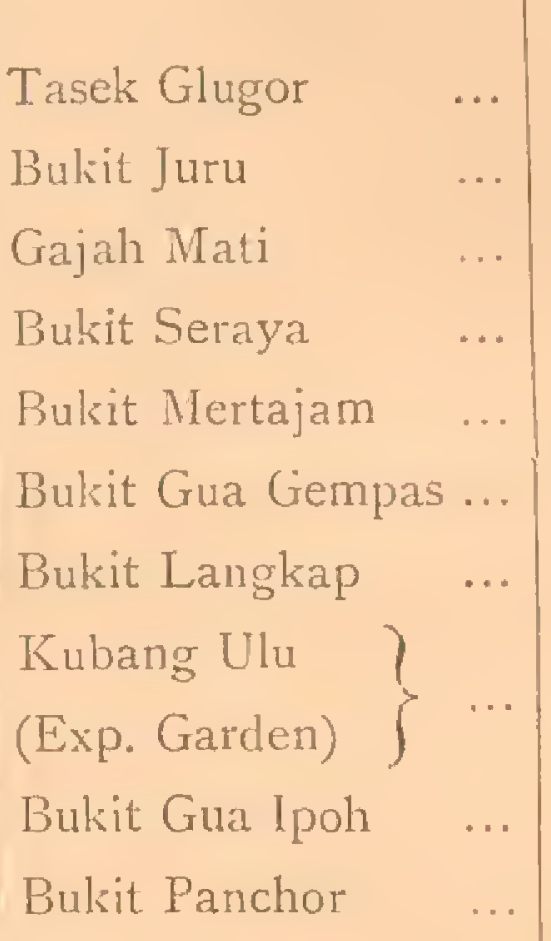 & $\begin{array}{r}a . r . p \\
\text { I,620.I.38 } \\
4 \mathrm{I} 7 \cdot 3 \cdot 14 \\
94.0 .3 \mathrm{I} \\
\mathrm{I} \mathrm{I} 2.0 .04 \\
\mathrm{I} 62 . \mathrm{I} .22 \\
\mathrm{I} 3.3 .20 \\
\text { I } 89.2 .10 \\
3.2 .03 \\
332.1 .2 \mathrm{I} \\
969.3 .24\end{array}$ & \\
\hline & & & & & & TOTAL $\ldots$ & $3,916.0 .27$ & \\
\hline
\end{tabular}


FORM NO. 2,-Continued.

Statement showing Progress made in forming new Reserves during the Year rgog.-Continued.

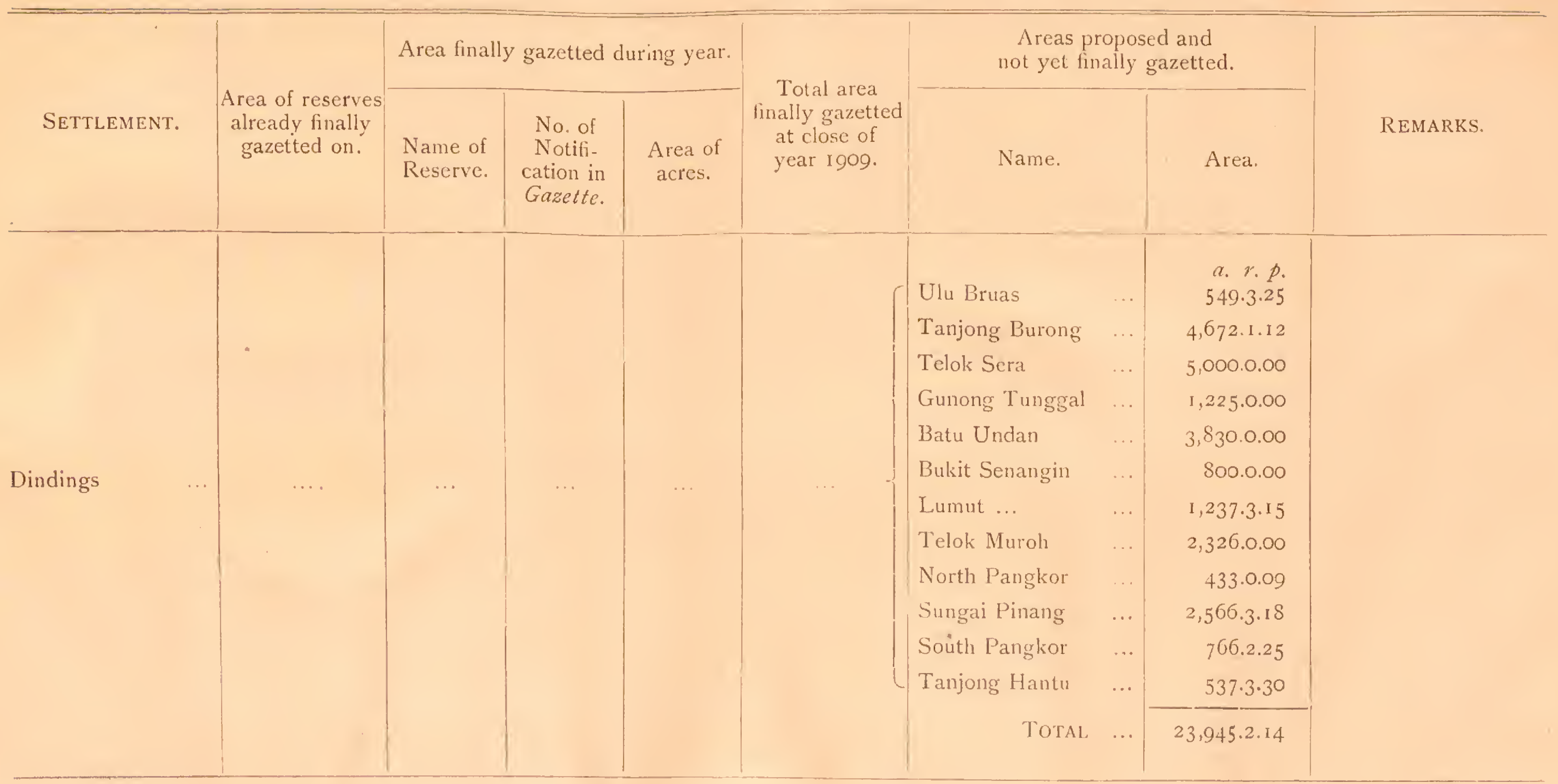


FORM No. 2.-concluded,

Statement showing Progress made in forming new Reserves during the Year Igog.-concluded.

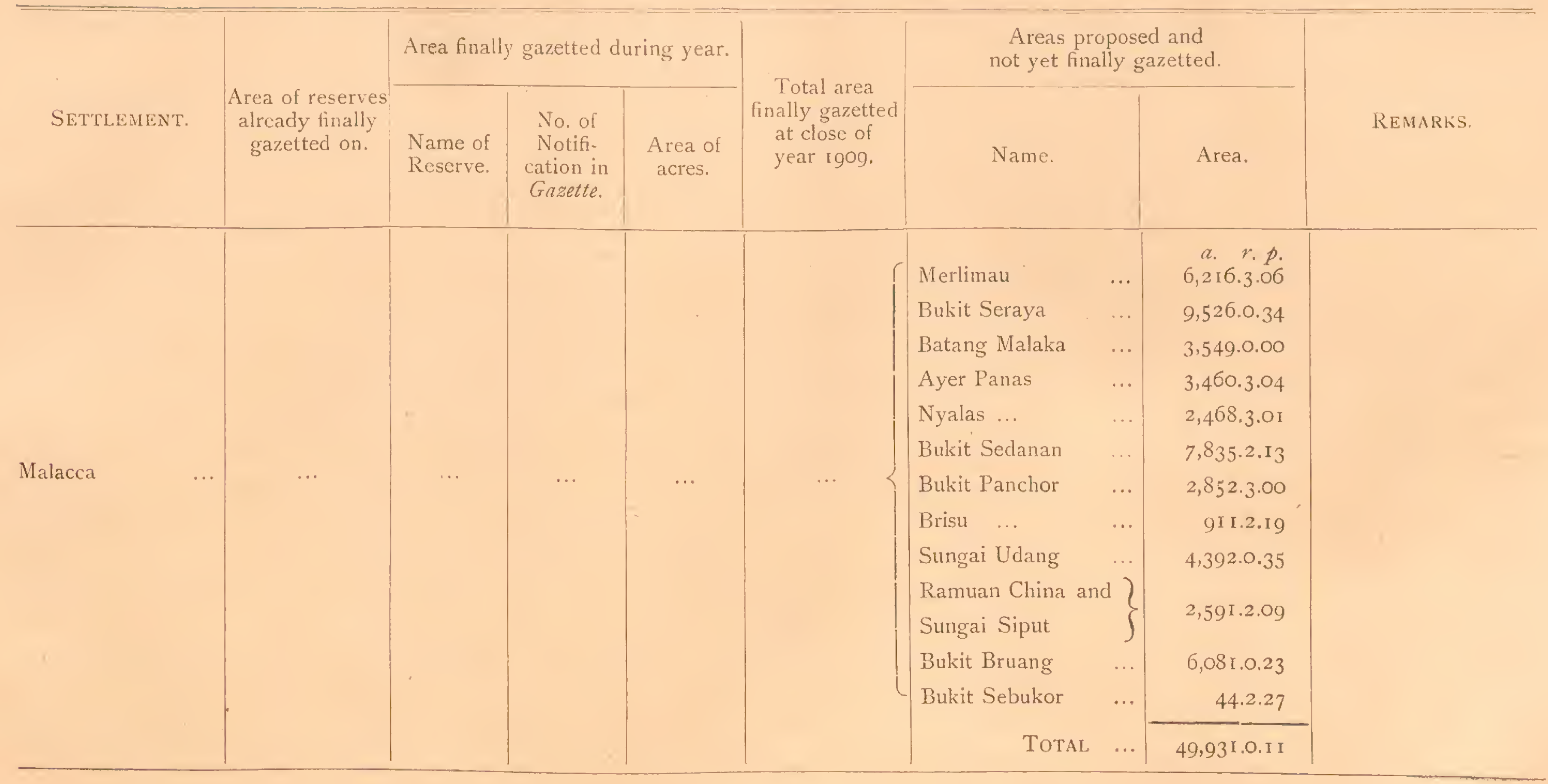


FORM NO. 8.

Area of Plantations.

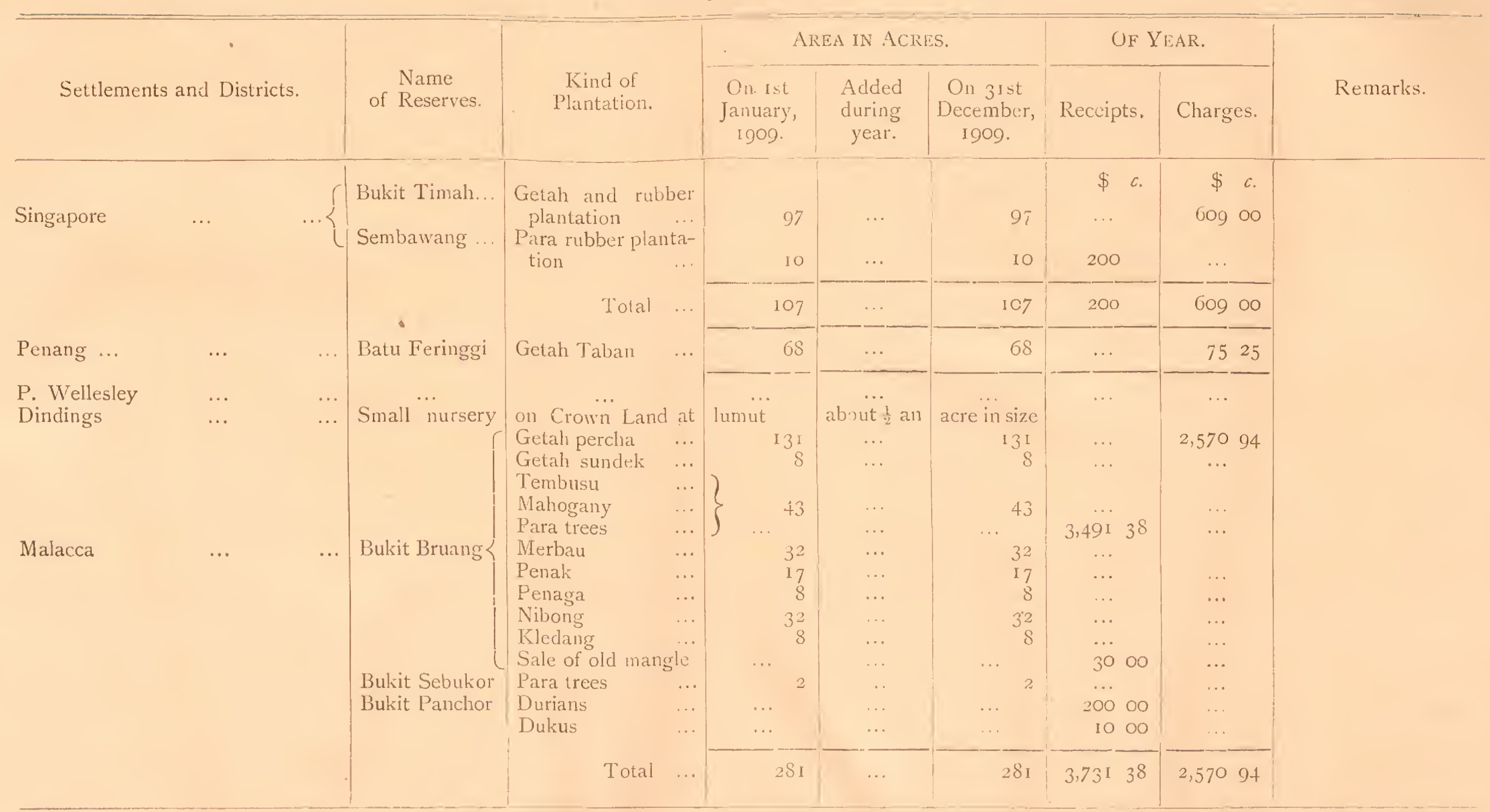


SINGAPORE,

FORM NO, II

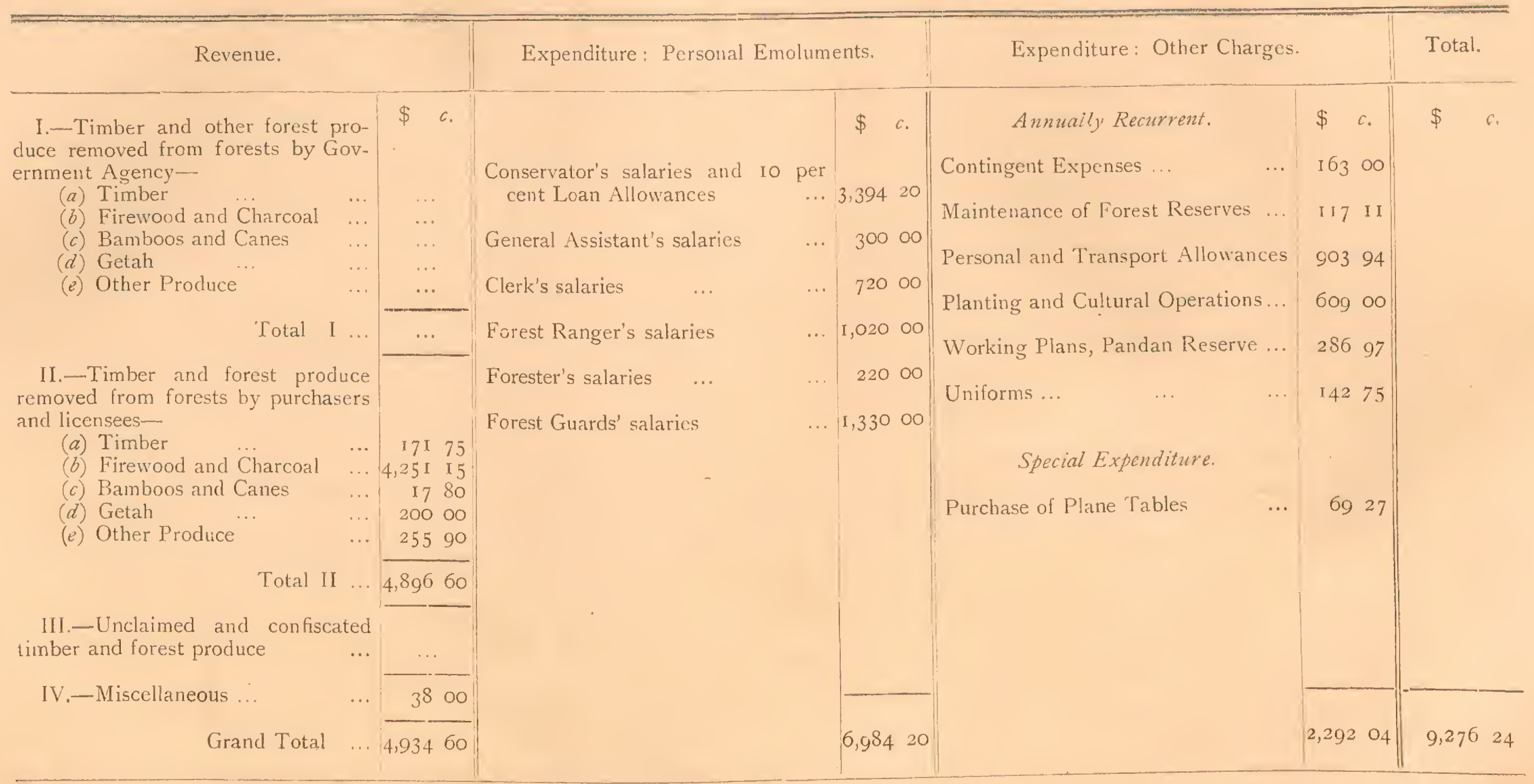


PENANG AND PROVINCE WELLESLEY.

Form No. I I-Continued.

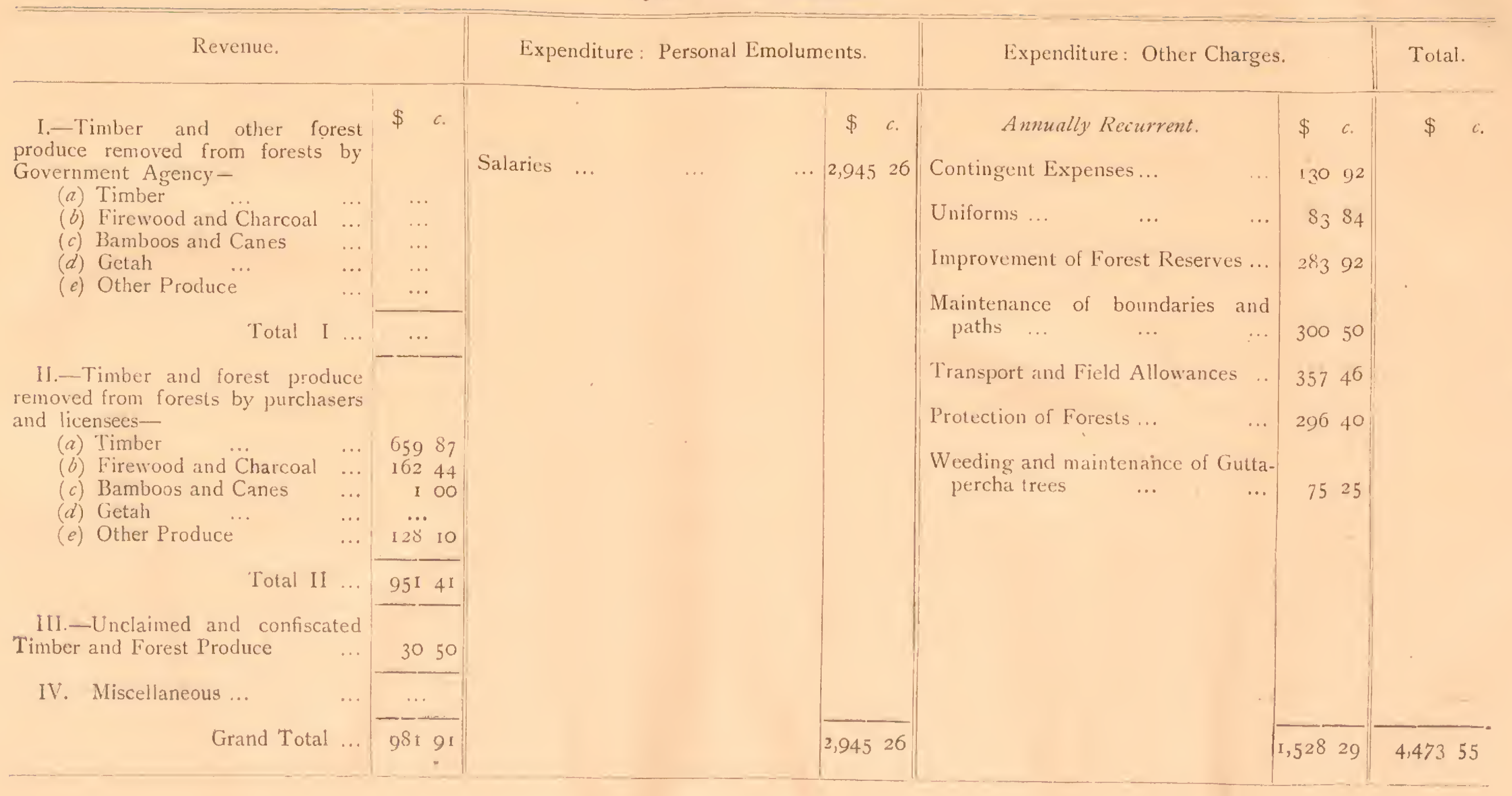


DINDINGS.

FORM No. II-Continued.

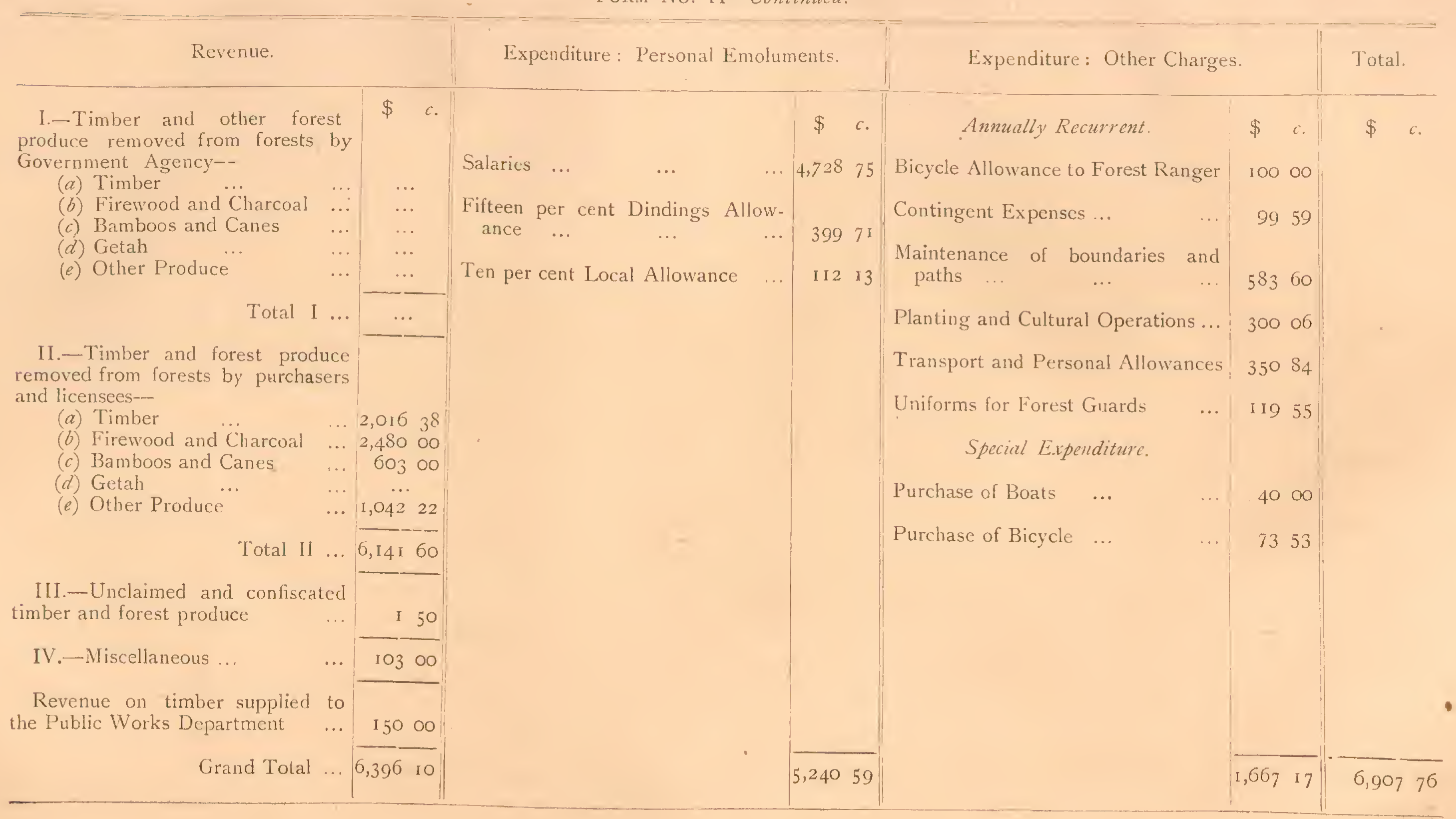


MALACCA

FORM NO. II.-Concluded.

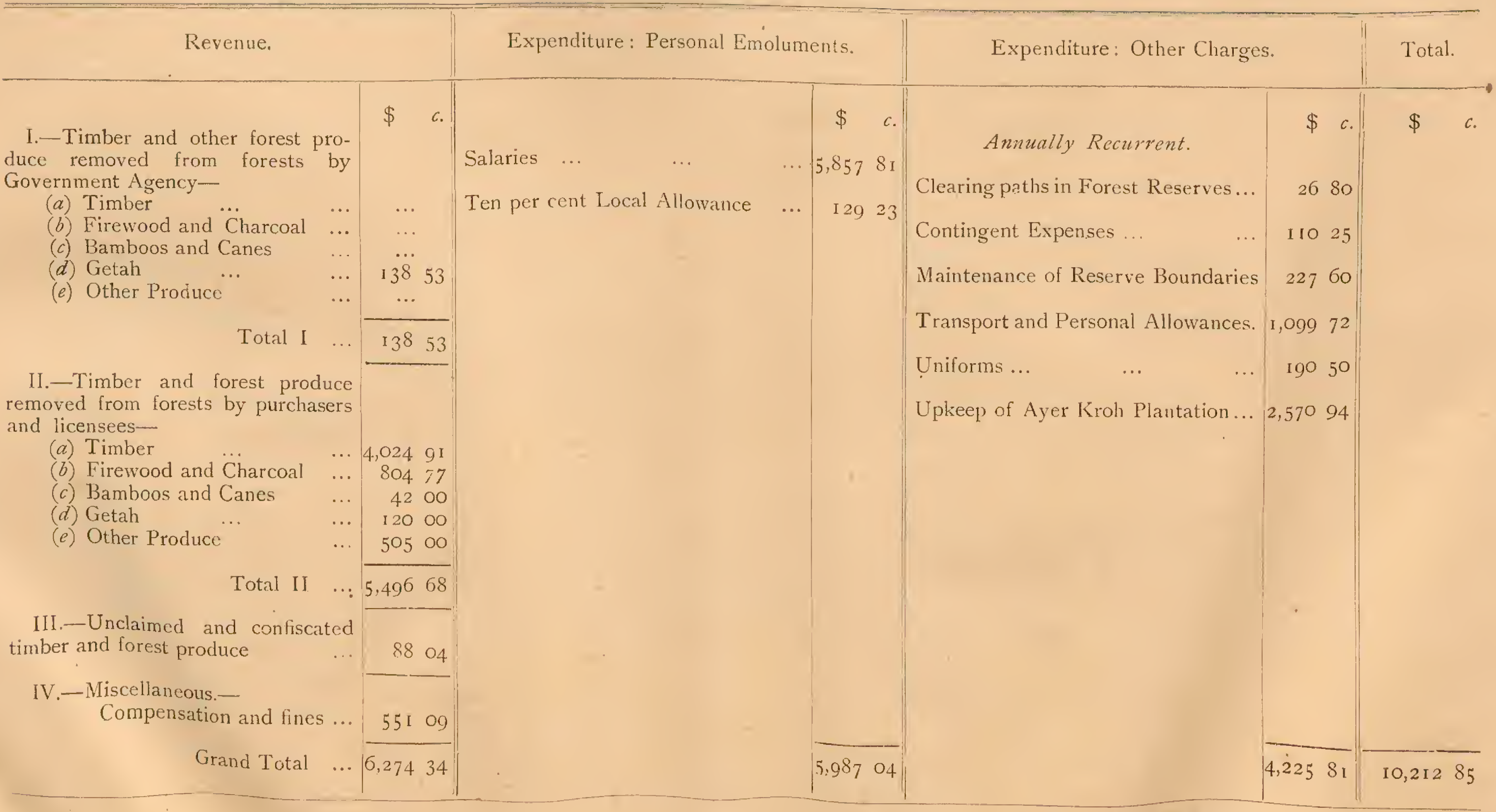


STRAITS SETTLEMENTS.

\title{
ANNUAL REPORT
}

ON

\section{FOREST ADMINISTRATION}

IN THE

\section{STRAITS SETTLEMENTS}

\author{
FOR THE YEAR
}

\section{0}

BI

A. M. BURN.MURDOCH,

Conseriator of Forests.

Federated Malay States and Straits Settlements.

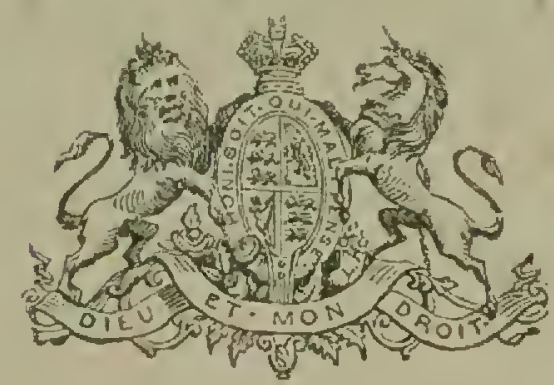

PUBLISHED BY AUTHORITY.

Sillgapole:

Printed at the GOVERNMENT PRINTING OFHICE, SINGAPORE, by J. E. TYLER, Government Printer.

1911. 


\section{Annual Report on Forest Administration in the Straits Settlements, for the Year 1910.}

\section{PART I.}

\section{Extension and Constitution of Reserved Forests.}

1. During the year progress was made in the legal constitution of the reserves as follows:-

Singapore, all reserves were preliminarily notified on $4^{\text {th }}$ March, 1910, and finally notified on 2 I st October, 1910.

In Penang and Province Wellesley the reserves preliminarily notified on 22nd October, rgog, had not been completely settled by the end of 1910 , but have since been finally gazetted on 22nd January, IgI I, except Bukit Juru and Bukit Panchor.

In the Dindings the reserves were not finally gazetted at the end of the year, but have since been notified, except Gunong Tunggal, Batu Undan and Bukit Senangin.

In Malacca the reserves have still to be finally notified.

The total area of all reserves in the Colony will be, when finally gazetted, IO2, I 56 acres as compared with a previous area of $102,35^{\circ}$ acres.

The following were the areas preliminarily and finally notified in the Gazette:-

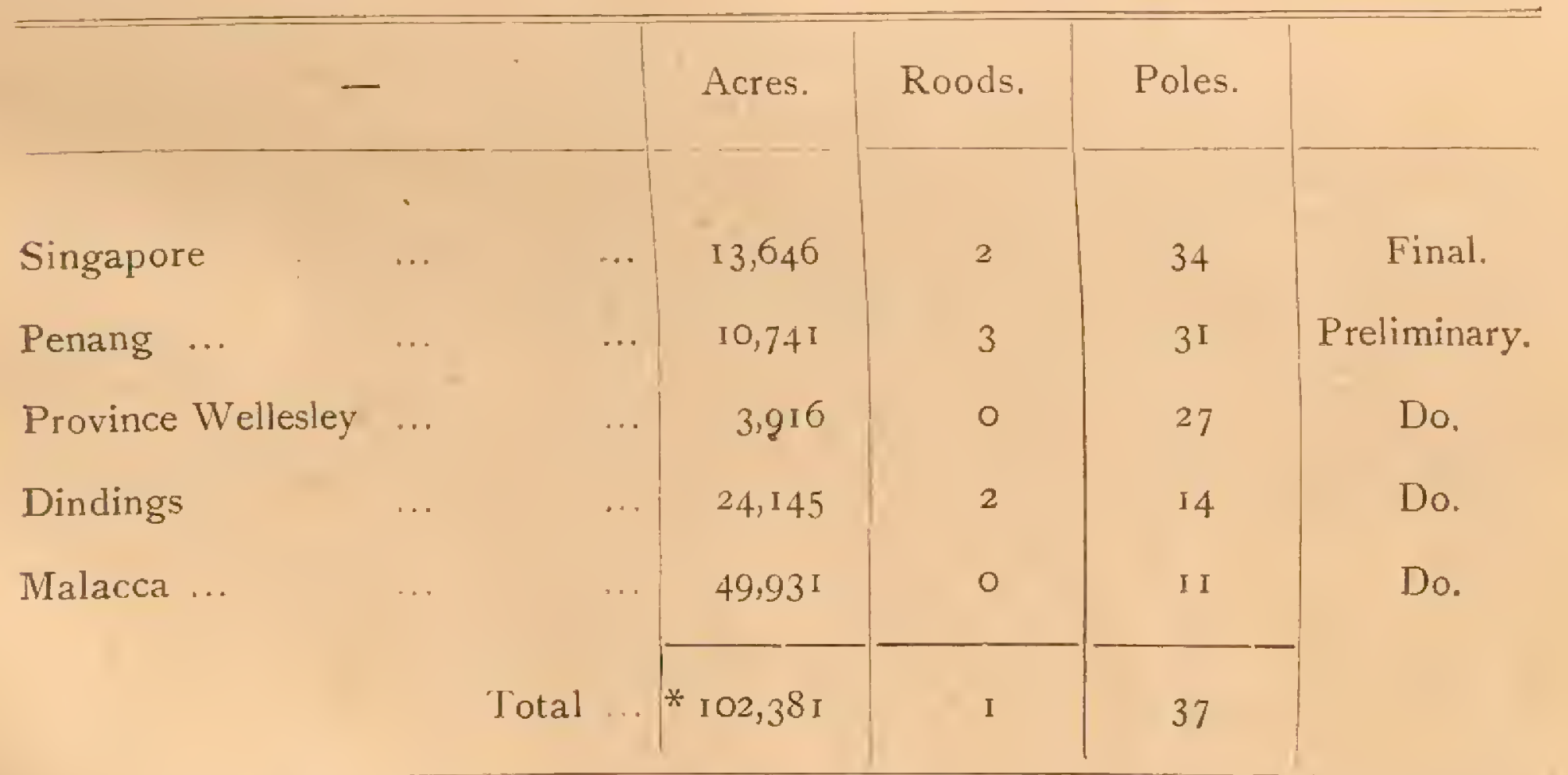

2. The delay in Bukit Juru and Bukit Panchor is due to the fact that parts of these reserves will have to be excluded. In the case of the three Dindings reserves above mentioned, due to the fact that they have not yet been surveyed and reliable descriptions could not be prepared. 204 acres were excluded from the Ulu Bruas reserve, and alieriated to the Sandycroft Rubber Co.

\footnotetext{
* Areas as preliminarily notified, subject to alteration before final notification.
} 
The delay in final notification of the Malacca reserves is due to some discussion as to the method of describing the boundaries, but descriptions were prepared and the
reserves are practically settled.

\section{Demarcation and Up-keep of Boundaries.}

3. The total length of artificial or cut boundaries of reserves in the Colony is 353 miles.

In Singapore 70 miles were kept clean by the forest guards.

In Penang and Province Wellesley 87 miles of boundaries were cleared on contract for \$272.94 or at \$3. I 4 per mile, and Telok Bahang, Pantai Acheh and Tasek Glugor boundaries were cleared by the forest staff. Notices were served on the owners of lands adjoining the Bukit Mertajam and Bukit Serayah reserves instructing them to clear their boundaries.

4. In the Dindings $59 \frac{1}{2}$ miles of boundaries were cleared departmentally at $\$ 305$, average of $\$ 5.12$ per mile.

In Malacca 86 miles of boundaries were re-cleared at $\$ 404.40$, average of about $\$ 4.70$ per mile, 22 miles were in good order and required no repairs.

The work under this head has been well and cheaply carried out.

\section{Surveys.} reserve.

5. In Singapore the Forest Ranger completed a rough survey of North Seletar

In the Dindings the Southern boundary of Telok Sera reserve and the Western boundary of Batu Undan reserve were surveyed. No other surveys were taken in hand and much remains to be done in the Dindings.

\section{PART II.}

\section{Management of Forests.}

\section{WORIING PLANS.}

6. In Singapore five Mangrove reserves were worked under a plan as shown in this table:-

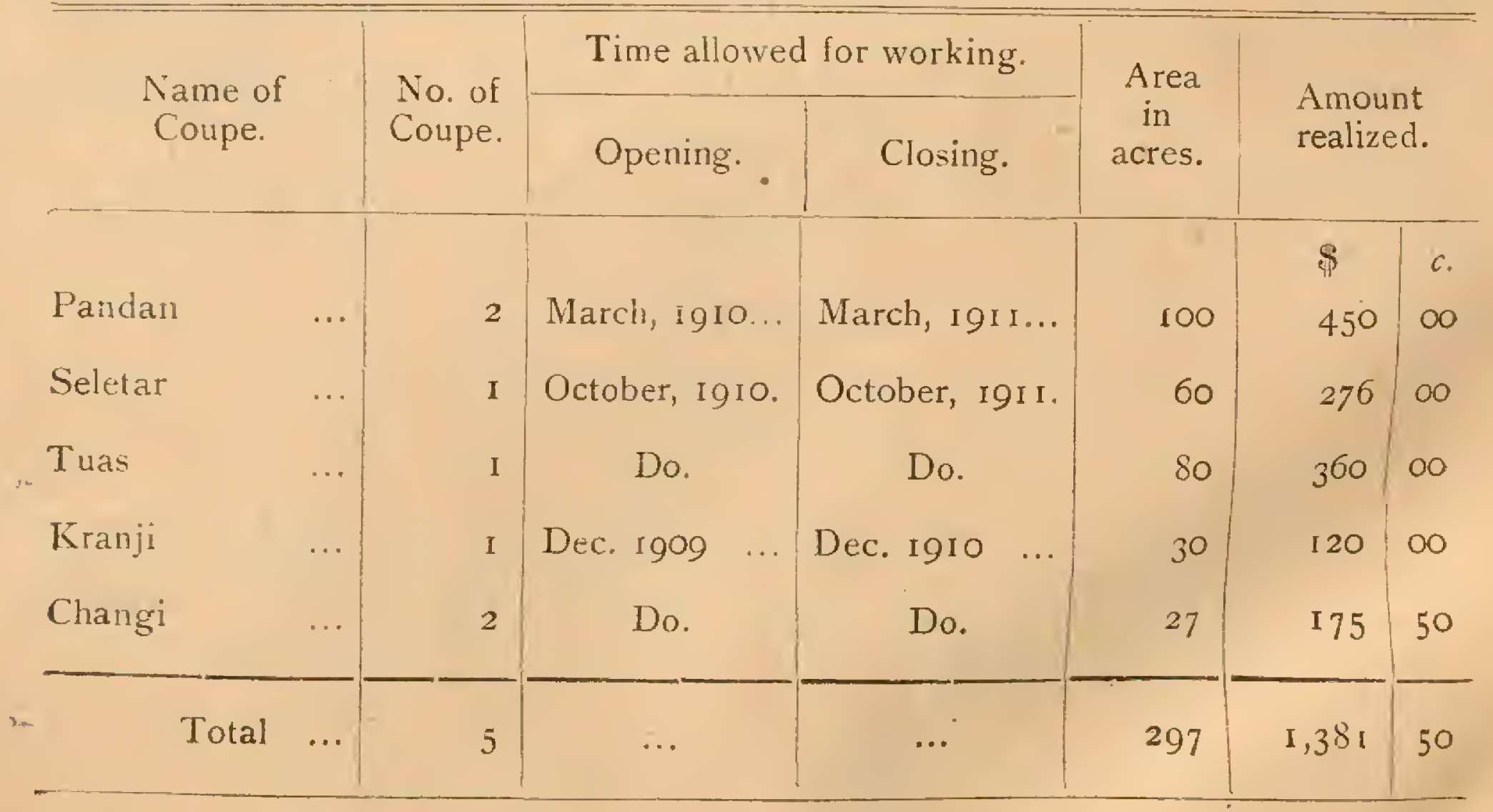


297 acres were leased for one year for $\$ 1,381.50$.

In Penang and Province Wellesley no working plans exist.

7. In Malacca the Merlimau, Ayer Panas and Sungai Udang reserves were worked under a rough plan for timber. Extraction of selected and marked trees of Class I being permitted.

Some large Meranti trees were also felled in Cape Rachado.

The following trees of Class I of not less than six feet in girth were selected and marked for felling :-

\begin{tabular}{|c|c|c|c|c|c|c|}
\hline Merlimau & $\cdots$ & $\cdots$ & $\cdots$ & 117 & realized & $\$ 190$ \\
\hline Ayer Panas & $\cdots$ & $\ldots$ & .. & $\mathrm{IO}_{4}$ & do. & 224 \\
\hline Sungai Udang & .. & $\cdots$ & .. & 44 & do. & 480 \\
\hline Cape Rachado & $\cdots$ & $\cdots$ & $\cdots$ & 9 & do. & 40 \\
\hline
\end{tabular}

\section{Paths in Reserves.}

8. Paths were made as follows:--

In Singapore from Kuala Sungai Tuas to Kuala Sungai Blukang at a cost of $\$ 42$.

In Penang the paths in the hill reserves are upkept by the Public Works Department.

In the Dindings existing paths were upkept by the forest guards.

In Malacca inspection paths were re-cleared during the year at a cost of \$I I5.95 and a new path opened across the Brisu reserve, costing $\$ 26.80$.

\section{Buildings.}

y. Temporary huts for forest guards in Singapore were erected at Tanjong Karang and cost $\$ 15$.

In the Dindings a rubber shed and store was built for $\$ 2$ IO

Forest guards' quarters and other buildings were kept in repair by the Public Works Department.

\section{Protection}

Io. No alterations were effected in the forest laws during the year.

The general protection of reserved forests by the staff has been good.

Fire Protection.

I1. A few small fires occurred in Singapore during the year, 10 acres in Ang Mo Kio and two acres in South Seletar reserves, and one man was fined $\$$ ro. A very small fire occurred in Sungai Buloh.

No fires are reported from Penang, Dindings or Malacca in reserved forests, but some lalang fires on Crown land were reported and the authors of them fined.

12. In Province Wellesley about 60 acres of lalang were burnt over in Tasek Glugor reserve on five occasions and $25^{\circ}$ acres of lalang in Bukit Panchor reserve on two occasions. Fines were inflicted in both cases, also in a case of fire on Crown land.

\section{Forest Offences.}

I3. The following were the cases taken to Court :-

\begin{tabular}{|c|c|c|c|c|c|}
\hline \multirow{2}{*}{$\begin{array}{l}\text { Cases pending } \\
\text { from igog. }\end{array}$} & \multirow{2}{*}{$\begin{array}{l}\text { New cases } \\
\text { of the year. }\end{array}$} & \multirow{2}{*}{$\begin{array}{l}\text { Total } \\
\text { cases. }\end{array}$} & \multicolumn{3}{|c|}{ Disposed of during year. } \\
\hline & & & $\begin{array}{l}\text { Convic- } \\
\text { tions. }\end{array}$ & $\begin{array}{l}\text { Acquit- } \\
\text { tals. }\end{array}$ & $\begin{array}{l}\text { Pending at } \\
\text { close of year. }\end{array}$ \\
\hline 2 & 153 & I 55 & I 37 & I 5 & 3 \\
\hline
\end{tabular}


Besides these I I cases were compounded for \$343 as follows:-

\begin{tabular}{llllr} 
In Singapore & I case was compounded for & $\ldots$ & $\ldots$ & Io \\
In Dindings 4 cases were compounded for & $\ldots$ & $\ldots$ & I I 5 \\
In Malacca 6 cases were compounded for & $\ldots$ & $\ldots$ & 2 I 8 \\
\hline & & & & $-\$ 343$
\end{tabular}

The percentage of convictions of cases tried is 88 per cent as compared with 78 per cent in 1909.

There were I 2 cases in Singrapore, 47 in Penang and Province Wellesley, 38 in the Dindings and 69 in Malacca.

I 4. In Penang and Province Wellesley there were 16 convictions for offences in reserved forests and 23 on Crown land, and forest damages amounted to \$1 19.77.

In the Dindings 21 persons were convicted for offences in reserved forests and 17 on Crown land, and $\$ 10$ realized as forest damages.

Four cases were compounded for $\$$ I I 5 .

I 5. In Malacca there were 63 prosecutions, and six cases were compounded for $\$ 2$ 18, and $\$ 72.94$ were awarded as damages to the department.

16. Fines realized by the Courts in all cases amounted to $\$ 1,590.45$. I 909 .

In Penang and Province Wellesley the number of cases was nearly double that in

In the Dindings it fell off, in Malacca there was an increase of $4 \mathrm{I}$ cases, owing, no doubt, to the increased demand for timber and fuel and the activity in opening out new country for planting.

\section{Improvement of Forests.}

\section{Natural Reprouuction.}

17. In Singapore natural reproduction of Tampines and of Getah Taban are reported as good.

In Penang seedlings of Gutta Percha have been noticed in Telok Bahang reserve and also small trees of Dacrydium elatum. Damar laut is well reproduced in the Dindings, in many places the ground being carpeted with young seedlings.

In Malacca a poor seed year is reported.

\section{Artificial Reproduction.}

\section{(Vide FORM 8).}

18. In Singapore one acre was added to the Gutta Percha plantation in Bukit Timah reserve and five acres planted with Para in South Seletar reserve. Ten acres of Para in Sembawang reserve were given up to the Municipality. The area of the Bukit Timah plantation at the close of the year was 98 acres, and was maintained at a cost of $\$ 576$. Thinnings of useless species were made to give more light to the young Gutta Percha trees, with very beneficial results. A Para nursery was also established.

19. It was decided to tap the Para trees at Bukit Timah and the Government advanced $\$ 360$. Preparations for tapping were made and it has since commenced.

20. In Penang small nurseries of hardwood trees were made in Tasek Glugor and Bukit Panchor reserves, and 400 Para rubber stumps were planted out in the experimental gardens on Penang Hill at 2,000 feet elevation. In Batu Feringgi the plantation of 68 acres was upkept, undergrowth interfering with Gutta Percha trees and Para being cleared. 
The Para planted here ten years ago has done very badly; 300 Para stumps were planted out. Total cost $\$ 146.65$. $\$ 80.40$ was realized on lease of some Para trees on Government Hill.

21. In the Dindings Io acres were planted with Para at Lumut, one acre with cocoa-nuts and one acre of fruit trees on reclaimed marsh land. The total cost was $\$ 370.50$ including nursery. The prisoners assisted by digging out lalang.

Sale of rubber from the trees near the rest-house yielded a revenue of $\$ 578.86$, out of which \$2ro was spent on making a drying shed and store, etc. \$I60 was realized by sale of plants and fruits.

22. In Malacca the area of plantations at Ayer Kroh and Bukit Sebukor was erroneously shown in the 1909 report as $28 \mathrm{r}$ acres at the close of 1909 , whereas it should have been 345 acres, as 64 acres were added in 1909. The area was further added to in r 9 Io by 10 acres of Merbau, Penaga and Nibong, vide Form 8.

This plantation was upkept by the Gardens Committee, from funds yielded by sale of rubber. The accounts of the Gardens Committee are appended.

$$
\begin{aligned}
& \$ c \\
& 2,468 \quad 22 \text { brought forward from } 1909 \\
& \text { 5.127 } 60 \text { receipts } 1910 \\
& \$ 7,59582 \quad \text { Lxpenditure during I9 Io was } \$ 2, \text { I I } 2.74 \text {. }
\end{aligned}
$$

The available ground on the Mahogany block was planted up with Para plants, nearly one-third have died out, but these were replaced. Those planted in the available ground in the Para block are-doing well.

A good many of the plants in the Penak, Penaga, Merbau and Nibong blocks proved failures, but were replaced. The Nibong plants in compartment 2 situated on hilly ground proved a failure, although still living, the plants being stunted, those growing in compartments $I$ and 3 on low-lying ground are thriving.

The Merbau block, compartments I and 3, Penak No. 7: Resak, Tembusu, Kledang, Mahogany, Gutta Percha and Getah Sundek show great improvement.

The hardwood timber nursery of Merbau, Penaga, Penak, Resak, Tembusu and Nibong are doing well, except Niatoh and Kledang which were abandoned, and these beds were converted into a Para nursery in which I9, I80 seeds were sown. These seeds were collected at the plantation.

During the last two months of the year, the Para block in the Bukit Sebukor reserve was divided into two compartments $(A$ and $B$ ) and all the trees, except those below 6 inches in girth were measured at 3 feet from the ground and numbered by the Forest Ranger and a record kept with sketches in a register. Blocks $C$ and $D$ situated at the sixth and seventh mile in the Bukit Bruang reserve were completed. A sample plot consisting of one hundred Getah Taban trees in the block at the seventh mile was measured, numbered and registered during June. The Para blocks $A, B, C^{\prime}$ and $D$ were attended to, drained, weeded, and lalang and undergrowth removed.

Failures were replaced, and planting up of available ground with Para seedlings was completed.

During the latter part of the year the block boundaries of Nibong, Penak, Merbau, Penaga, (compartments I, 2 and 3) Kledang, Resak, Penak No. 7, which were overgrown with lalang and resam were cleaned up. Bridging of swamps in some of the blocks was completed.

The unlergrowth round the Taban trees in the blocks was cleaned is inches round each tree.

The Merbau and Penak nursery in the Merlimau reserve did not prove a success, but the Tembusu seedlings are doing well, a good number of these have been planted 
out into the reserve. Fifty Penak, 100 Merbau and I 50 Resak seedlings were obtained from the Ayer Kroh plantation and planted out in the Merlimau reserve during October, by the Forester and forest guards.

During the year Merbau and Resak seedlings from the Sungai Udang nursery were transplanted into the reserve by the forest guards and are doing well.

Ayer Kroh Plantation.

Statement of Revenue and Expenditure for igio.

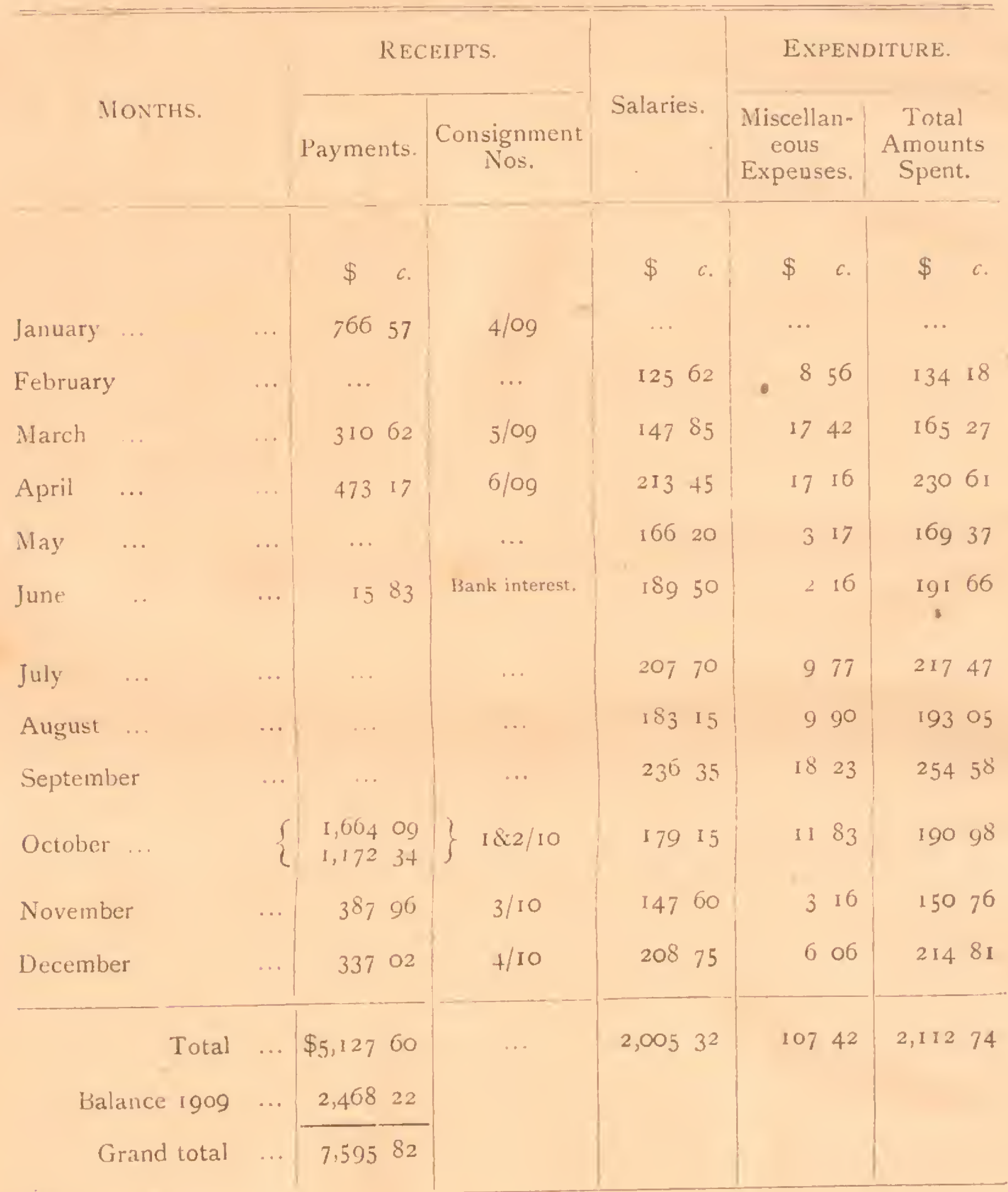

Out of $\$ 7,595.82, \$ 2,000$ has been placed in the bank on fixed deposit. 


\section{Exploitation.}

TIMBER AND FUEL.

From Reserved Forests.

23. This table shows the timber and firewood removed from reserved forests :-

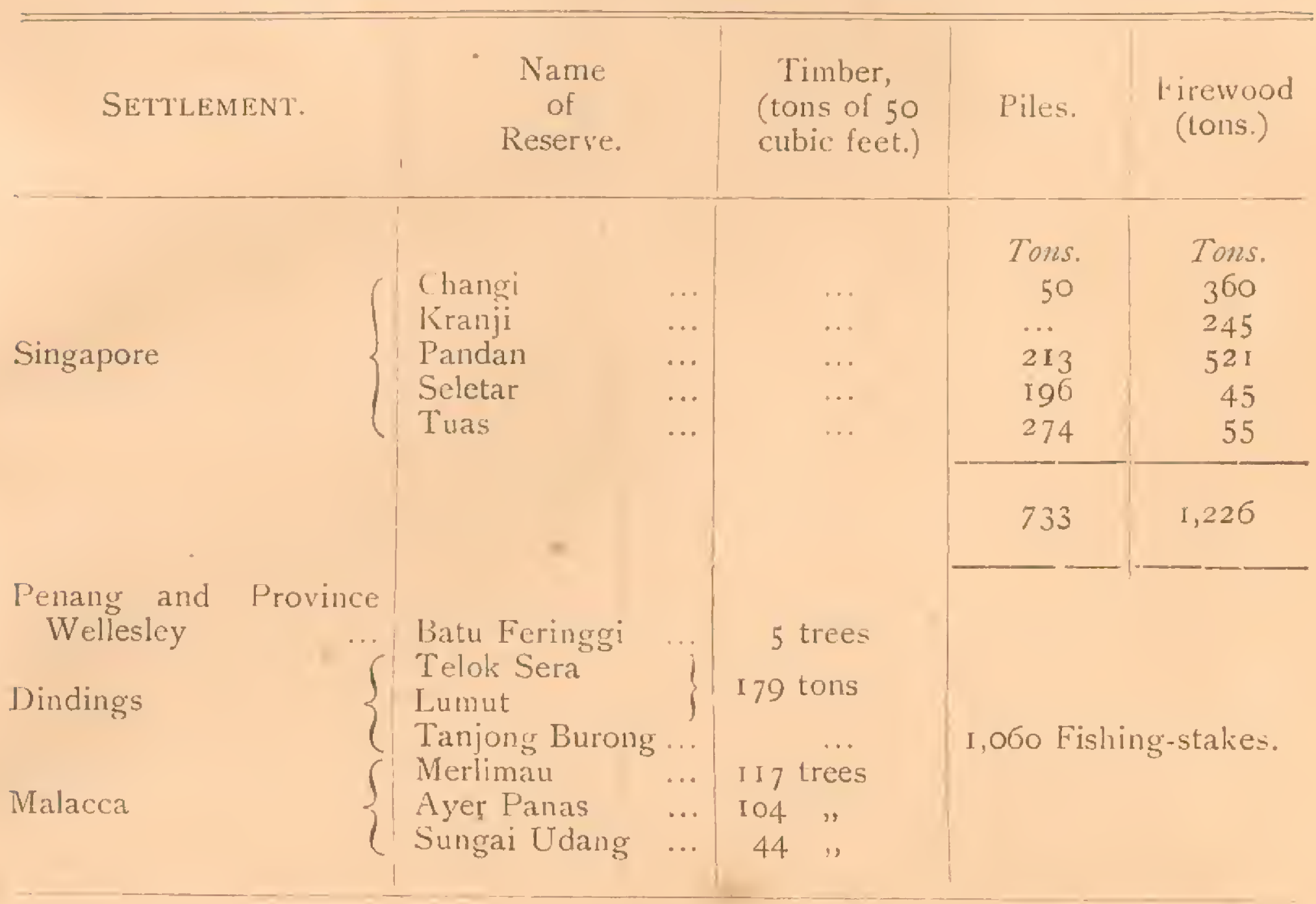

24. In Singapore 1,226 tons of firewood and 733 tons of piles were extracted from reserved forests, the revenue realized being $\$ 1,381.50$.

One hundred and seventy-nine tons of Class I timber were extracted in the Telok Sera and Lumut forest reserves, the former reserve being closed in June, and the latter in September, and timber cutting carried on on Crown land outside reserves. No tenders were received for the Mangrove reserve I9Io block, but 1,060 fishingstakes were taken out as thinnings and disposed of. $\$ 22$.

Five Class I trees wereeremoved from Batu Feringgi reserve, in Penang realizing

25. In Malacca 265 selected trees were cut in Merlimau. Ayer Panas and Sungai Udang reserves, realizing $\$ 989$, in Bukit Bruang reserve Class II trees were cut on permits.

$$
\text { From Crown and Alienated Lands. }
$$

26. This table gives the total for each Settlement:-

\begin{tabular}{|c|c|c|c|c|c|c|c|}
\hline \multirow{2}{*}{ SETTLEMENT. } & \multicolumn{2}{|c|}{ Timber. } & \multirow{2}{*}{ Poles. } & \multirow{2}{*}{$\begin{array}{c}\text { Total } \\
\text { timber in } \\
\text { tons. }\end{array}$} & \multirow{2}{*}{ Free grants. } & \multirow{2}{*}{$\begin{array}{l}\text { Fire- } \\
\text { wood. }\end{array}$} & \multirow{2}{*}{$\begin{array}{l}\text { Char- } \\
\text { coal. }\end{array}$} \\
\hline & $\begin{array}{c}\text { Class } \\
\mathrm{I} .\end{array}$ & $\begin{array}{c}\text { Class } \\
\text { II. }\end{array}$ & & & & & \\
\hline Singapore & $\cdots$ & $\begin{array}{c}\text { trees. } \\
102\end{array}$ & $\begin{array}{l}\text { No. } \\
\text { I } 7,270\end{array}$ & $\ldots$ & $\begin{array}{l}\text { No. } \\
\text { 1,79o rollers. }\end{array}$ & & \\
\hline $\begin{array}{l}\text { Penang and Pro- } \\
\text { vince Wellesley }\end{array}$ & & … & $\cdots$ & $\cdots$ & $\ldots$ & No, re & cord. \\
\hline Dindings & $\begin{array}{r}\text { tons. } \\
438 \\
\text { trees }\end{array}$ & $\begin{array}{r}\text { tons. } \\
167\end{array}$ & 21,825 & 1,041 & ... & & \\
\hline Nalacca & 9 & $\cdots$ & $\cdots$ & $\cdots$ & $\cdots$ & j & \\
\hline
\end{tabular}


(Tons of 50 cubic feet for timber. Poles for total tonnage are taken at I cubic foot each).

27. In Singapore permits were issued for IO2 Class II trees and 17,270 small poles, realizing \$122.10 revenue. 370 monthly permits were issued for Mangrove, realizing $\$ 1,850$ as compared with $\$ 4,251$ during the previous year, and free permits to native landholders for $\mathrm{r}, 790$ poles.

28. In the Dindings 328 tons of Class I timber, 8 I tons of Class 11 timber and 21,825 fishing-stakes were extracted from Crown land on payment of royalty, and 23 tons of timber taken by the Public Works Department free of royalty.

A great deal of good timber was wasted owing to the opening out of forest land for rubber cultivation.

20 tons of Class I and 29 tons of Class II timber were removed from alienated land and paid royalty, also 69 tons of Class 1 and 55 tons of Class II were removed free of royalty. Firewood realized $\$ 1,550.47$.

29. In Malacca nine Class I trees were selected in Cape Rachado and extracted. The total revenue from timber on Crown land was $\$ 3,748$ as compared with $\$ 3,3 I_{5}$ in I909. Firewood realized $\$ 295$ and charcoal $\$ 149 \cdot 75$, a big fall as compared with I gog.

\section{Minor Forest Produce.}

30. In Singapore bamboos and canes, nibongs, elc, realized $\$ 22$ I.I6 as against $\$ 287$ in 1909 .

3r. In Penang and Province Wellesley licences for rotan, bertam, langkap, akar gharu and nibong realized $\$ 337.48$ as compared with \$128.10 in 1909, mostly from reserved forests, and $\$ 65$ was realized by lease of a few rubber trees.

32. In the Dindings canes realized $\$ 845$, other produce $\$ 575$ and rubber $\$ 4+3.86$. For tin taken from the Telok Sera reserve $\$ 238.7$ I was paid to the department and $\$ 120.50$ from cocoa-nuts and fruits on Crown land. Sale of seedlings $\$ 40$.-

33. In Malacca minor produce realized $\$ 376.17$, a decrease as compared with 1909. The price paid for right to extract wood-oil fell during the year.

The Para rubber trees in Ayer Kroh and Bukit Sebukor were tapped departmentally, throughout the year. The yield was 1,7 I $2 \frac{3}{4} \mathrm{lbs}$. sheet and $329 \frac{1}{4} \mathrm{lbs}$. scrap as compared with $\mathrm{I}, \mathrm{r} 94^{\frac{3}{4}} \mathrm{lb}$. sheet and $29 \mathrm{I} \frac{1}{2} \mathrm{lbs}$. scrap in I909. The amount realized from sale of rubber was $\$ 5,127.60$ and was credited to the Gardens Committee account. About $85 \mathrm{lbs}$. of sheet rubber in the store at the Ayer Kroh plantation valued approximately $\$ 360$ were stolen between the 5 th and 7 th May.

34. The Conservator inspected this plantation in November, and found great improvement in tapping. Blanks in the plantation have been filled up and general improvement effected. The whole cost of plantations both of hard-ivood trees and rubber in the Bukit Sebukor plantation is now met from the proceeds of the sale of rubber.

\section{PART III.}

Financial Results.

35. This table shows the comparative revenue for Igog and I9I0:-

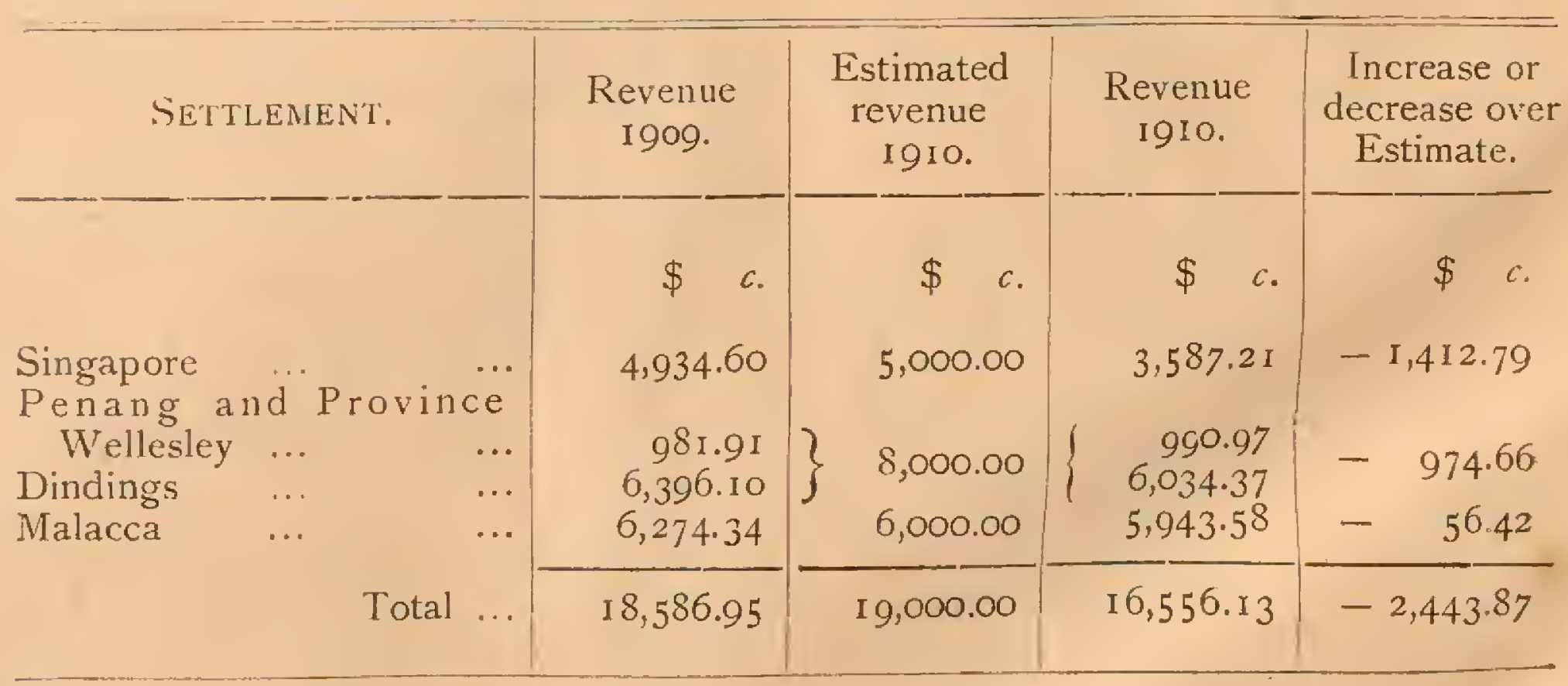


36. The fall in revenue over 1909 figures is $\$ 2,030.82$ due in all Settlements to heading, "Firewood and Charcoal," as may be seen from Form 1 I.

- The fall in royalty on fuel is undoubtedly due to the alienation of Crown land and felling of virgin forest. A certain amount of felled trees are converted into firewood, and in many cases the fuel is not chargeable with royalty.

37. Penłng and Province Wellesley showed a small increase in revenue, owing to the diligence of the Forest Ranger, Mr. BORGES, who has also done much to give an impetus to the revenue in the Dindings, and who maintained the timber revenue at its $r 909$ level in spite of a lowered rate of royalty. The large fall in revenue on tirewood in Singapore is chiefly due to the fact that most of the Mangrove on Crown lands is worked out and that the price for permits on Crown lands was raised.

\section{Expenditure.}

38. This statement show's the total expenditure in each Settlement, as compared with 1909 and estimates for 1910 :-

\begin{tabular}{|c|c|c|c|c|c|}
\hline \multicolumn{2}{|c|}{ SETTLEMENT. } & $\begin{array}{c}\text { Expenditure } \\
\text { I909. }\end{array}$ & $\begin{array}{l}\text { Estimated } \\
\text { expenditure }\end{array}$ & $\begin{array}{c}\text { Expenditure } \\
\text { 1910. }\end{array}$ & $\begin{array}{l}\text { Savings on } \\
\text { Estimates }\end{array}$ \\
\hline $\begin{array}{l}\text { Singapore } \\
\text { Penang and } \\
\text { Wellesley } \\
\text { Dindings } \\
\text { Malacca }\end{array}$ & $\begin{array}{r}\text { Province } \\
\quad \ldots \\
\ldots \\
\ldots\end{array}$ & $\begin{array}{r}\$ \quad c \\
9,276.24 \\
4,473.55 \\
6,907.76 \\
10,212.85\end{array}$ & $\begin{array}{c}\$ \quad c \\
9,440.00 \\
5,360.00 \\
7,430.00 \\
8,332.00\end{array}$ & $\begin{array}{c}\$ \quad 6 . \\
9,081 \cdot 97 \\
4,784 \cdot 34 \\
6,395 \cdot 05 \\
9,7=6.75\end{array}$ & $\begin{array}{r}\$ c_{0} \\
-\quad 358.03 \\
-\quad 575.66 \\
-\quad 1,034.95 \\
+\quad 1,384.75\end{array}$ \\
\hline- & Total & $30,870.40$ & $30,56 z .00$ & $29,978.1$ & $-\quad 5 \times 3.89$ \\
\hline
\end{tabular}

or $\$ 892.29$ less than in Igog.

As usual Singapore took one-third of Conservator of Forests' salary and a portion of his office establishment amounting to $\$ I, 080$ also of course the transport, field and other allowances of Conservator when on tour in the Colony, as shown in Form I I, but the Malacca plantations were not upkept from votes, but from proceeds of sale of rubber as already explained.

There was an increase in transport, field and other allowances in Penang, Province Wellesley, Dindings and Malacca.

\section{Administration.}

39. Mr. A. M. BURN-MURDOCH held the appointment of Conservator of Forests throughout the year and visited the lollowing reserves:-

Singrapore-Sembawang and Bukit Timah reserves.

Penang.-Government Hill and Telok Bahang reserves.

Province Wellesley.-Bukit Gua Ipoh and Bukit Langkap reserves.

Dindings,-Pangkor Island, Tanjong Hantu and Lumut reserves.

Malacca.-Bukit Bruang and Bukit Sebukor reserves.

40. Mr. BoRges returned from leave on 14th April, and took over charge of Penang, Province Wellesley and Dindings forests, his headquarters being fixed at Penang, and the Ranger, Grade I. Dindings" appointment transferred to Penang. $\mathrm{Mr}$. BORges has been given office accommodation in the Government Offices and quarters in the town. This new arrangement has proved satisfactory. The Superintendent of Forests and Gardens ceased to draw the allowance of $\$ 600$ per anuum on 7 th March, when he retired and this allowance will not be renewed.

41. In the Dindings, the District Officer had general direction of the department and was assisted by CHE IBRAHIM BIN AHMAT, Forest Ranger, Federated Malay States, until 2nd May, when he was relieved by Mr. BORGES. 
42. Mr. O'HARA, Forest Ranger, Grade J, was in charge of the Malacca forests throughout the year.

43. Mr. Malaya Pillai, Forest Ranger, Grade III, assisted the Collector of Land Revenue in charge of the Singapore forests.

\section{Subordinate Staff.}

44. In Singapore two forest guards resigned and two were dismissed.

45. In Penang and Province Wellesley, Mr. J. Abrams, Forest Ranger, Grade IV, retired on 3 Ist December, and his appointment was abolished. Forest Guard, H. PAUL, retired on Ist September. One forest guard was dismissed, one was fined, and the increment of another was withheld for six months.

46. In the Dindings, J. SAnIB, Forest Ranger, Grade IV, was dismissed on roth April, and succeeded by ANDAK who was transferred to Malacca in August. His place was taken up by SHEIK AHMAT from Malacca. One forest guard was dismissed.

47. In Malacca, SHeik Ahmat, Forest Ranger, Grade IV, was transferred from Ayer Kroh plantation to the Dindings in September, ANDAK coming from the Dindings. The latter suffered continuously from bad health in Malacca, and returned to the Dindings on 9th November, and died shortly after the close of the year. The appointment of Forest Ranger, Grade IV, Malacca, was kept vacant and a Mandor was appointed on $\$ 25$ per mensem. SHEIK AHMAT'S salary was reduced from $\$ 660$ to $\$ 5$ IO per annum on account of a theft of rubber from the Ayer Kroh store between the $5^{\text {th }}$ and 7 th May, in connection with which he was held to have been negligent. Mr. J. FELIX was appointed Forest Clerk, on 2 Ist January. Forest Guard, DUAlip BIN JATIM, retired on 3 Ist December, and two forest guards resigned.

48. The following was the staff employed during the year:-

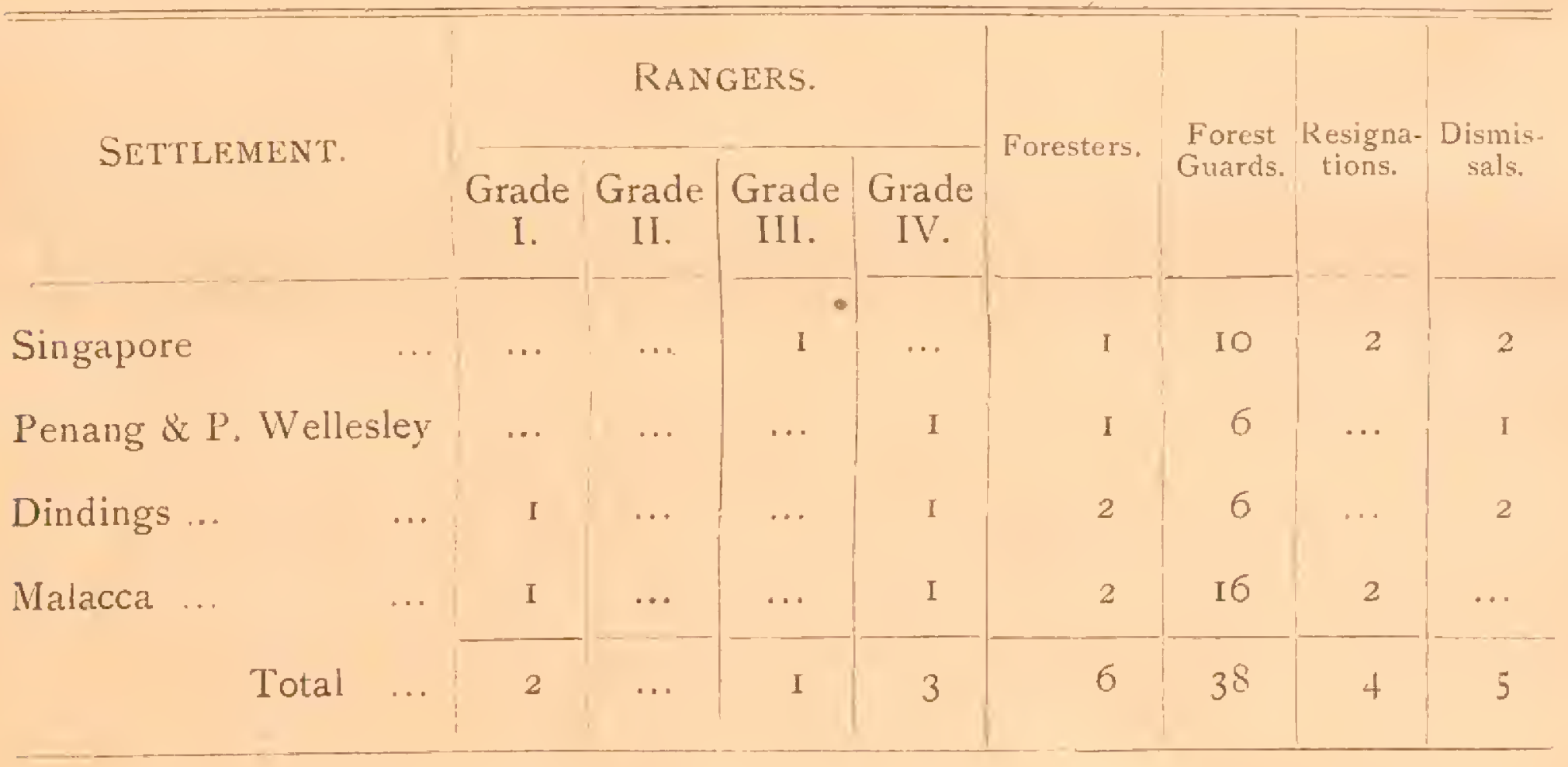

KUALA LUMPUR, I8th March, I gil.
A. M. BURN-MURDOCH, Conservator of Forests,

Federated Malay States and Straits Settlements. 


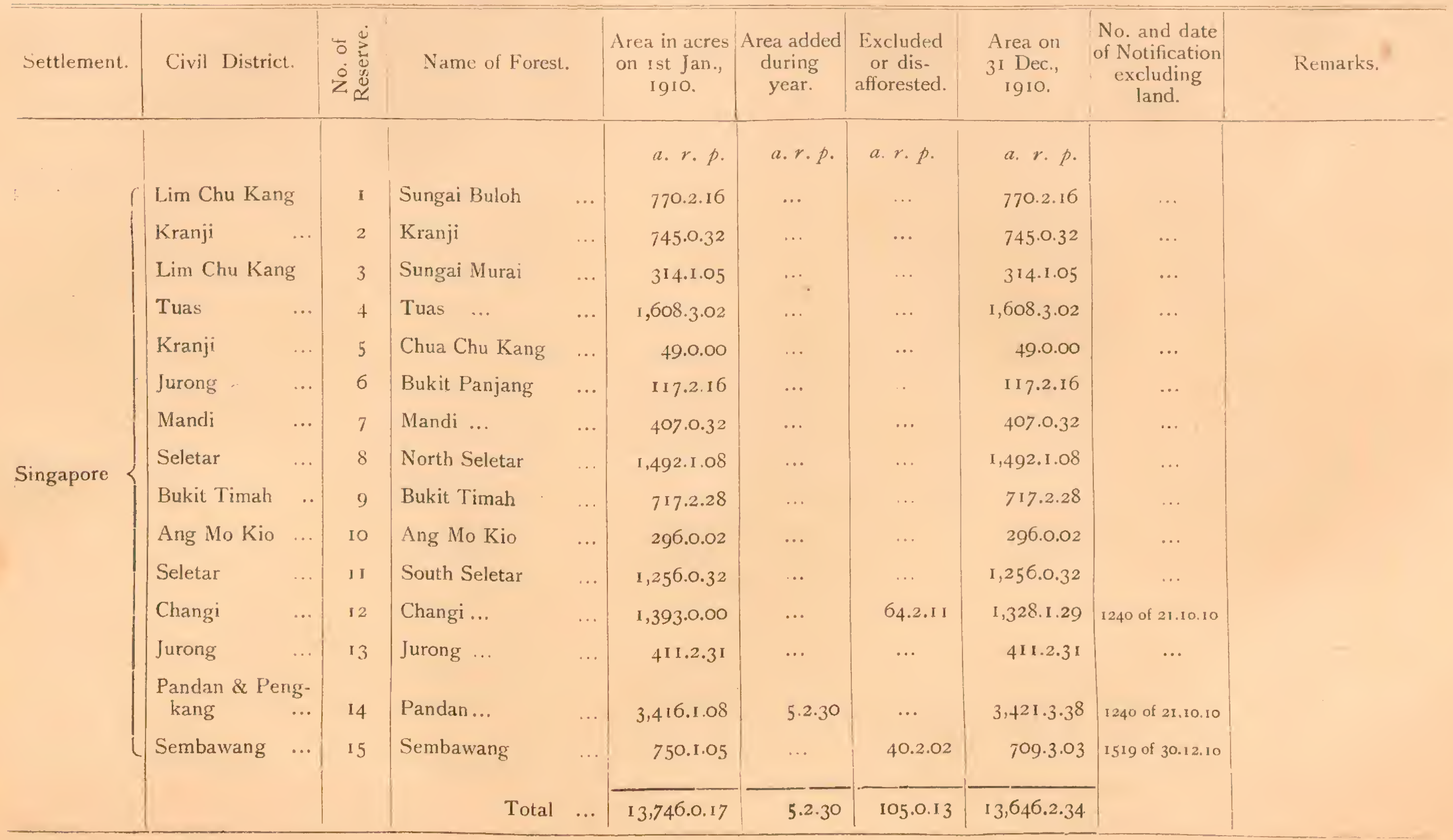


FORM NO. I.-Continued

\begin{tabular}{|c|c|c|c|c|c|c|c|c|c|}
\hline Settlement. & Civil District. & $\begin{array}{c}\text { No. of } \\
\text { Reserve. }\end{array}$ & Name of tiorest. & $\begin{array}{c}\text { Area in acres } \\
\text { on ist Jan., } \\
19 \text { IO. }\end{array}$ & $\begin{array}{c}\text { Area added } \\
\text { during } \\
\text { year. }\end{array}$ & $\begin{array}{l}\text { Excluded } \\
\text { or dis- } \\
\text { afforested. }\end{array}$ & $\begin{array}{c}\text { Area on } \\
\text { 3rst Dec., } \\
\text { 1910. }\end{array}$ & $\begin{array}{l}\text { No. and date } \\
\text { of Notification } \\
\text { excluding } \\
\text { land. }\end{array}$ & Remarks. \\
\hline Penang & $\begin{array}{l}\text { North-East } \\
\text { South-West ... } \\
\text { N.-E. S.-W. }\end{array}$ & $\begin{array}{l}1 \\
2 \\
3 \\
4 \\
5 \\
6 \\
7 \\
8 \\
9\end{array}$ & $\begin{array}{ll}\text { Government Hill } & \ldots \\
\text { Highlands } & \ldots \\
\text { Penara Bukit } & \ldots \\
\text { Pantai Acheh. } & \\
\text { Lalssamana } & \\
\text { Telok Bahang } & \ldots \\
\text { Bukit Ginting } & \\
\text { Bukit Gemuroh } & \\
\text { Relau Hills } & \end{array}$ & $\begin{array}{r}a . p . p . \\
5,6352.11 \\
252.2 .36 \\
233.2 .31 \\
3,208.3 .08 \\
4652.30 \\
616.3 .32 \\
21.2 .14 \\
205.3 .05 \\
1703.19\end{array}$ & $\begin{array}{l}a \cdot r \cdot p \cdot \\
\ldots \\
\ldots \\
\ldots \\
\cdots \\
\cdots \\
\cdots \\
\cdots \\
\cdots \\
\cdots\end{array}$ & $\begin{array}{l}\text { a. } r . p . \\
\ldots \\
\ldots \\
\ldots \\
69.2 \cdot 35 \\
\ldots \\
\ldots \\
\ldots \\
\ldots \\
\ldots\end{array}$ & $\begin{array}{r}a . r . p . \\
5,635.2 .11 \\
252.2 .36 \\
233.2 .31 \\
3,139.0 .13 \\
465.2 .30 \\
516.3 .32 \\
21.2 .14 \\
205.3 .05 \\
170.3 .19\end{array}$ & \multirow[t]{4}{*}{1066 of 9.9 .10} & \\
\hline \multirow{3}{*}{$\begin{array}{l}\text { Province } \\
\text { Wellesley }\end{array}$} & & & Total & $10,811.2 .26$ & $\cdots$ & 69.2 .35 & $10,741 \cdot 3 \cdot 31$ & & \\
\hline & $\begin{array}{l}\text { Northern } \\
\text { Central }\end{array}$ & $\begin{array}{r}1 \\
2 \\
3 \\
4 \\
5 \\
6 \\
7 \\
8 \\
9 \\
10\end{array}$ & $\begin{array}{l}\text { Tasek Gluyur } \\
\text { Bukit Juru } \\
\text { Gajah Mati } \\
\text { Bukit Seraya } \\
\text { Bukit Mertajam } \\
\text { Bukit Gua Gempas ... } \\
\text { Bukit Lartgkap } \\
\text { Kubang Ulu } \\
\text { Bukit Goa Ipoh } \\
\text { Bukit Panchor }\end{array}$ & $\begin{array}{r}1,620.1 .38 \\
4.17 \cdot 3 \cdot 14 \\
94.0 .31 \\
112.0 .04 \\
162.1 .22 \\
13 \cdot 3.20 \\
189.2 .10 \\
3.2 .03 \\
332.1 .29 \\
969.3 .24\end{array}$ & $\begin{array}{l}\cdots \\
\cdots \\
\cdots \\
\cdots \\
\cdots \\
\cdots \\
\cdots \\
\cdots \\
\cdots\end{array}$ & $\begin{array}{l}\cdots \\
\cdots \\
\cdots \\
\cdots \\
\cdots \\
\cdots \\
\cdots \\
\cdots\end{array}$ & $\begin{array}{r}1,6 \geq 0.1 \cdot 38 \\
417 \cdot 3 \cdot 14 \\
94 \cdot 0.31 \\
112.0 .04 \\
162.1 .22 \\
13 \cdot 3.20 \\
189.2 .10 \\
3.2 .03 \\
332.1 .21 \\
969.3 .24\end{array}$ & & \multirow{2}{*}{ t } \\
\hline & & & Total & $3,916.027$ & $\ldots$ & $\ldots$ & 3.916 .0 .27 & & \\
\hline
\end{tabular}


FORM No. I.-Continued.

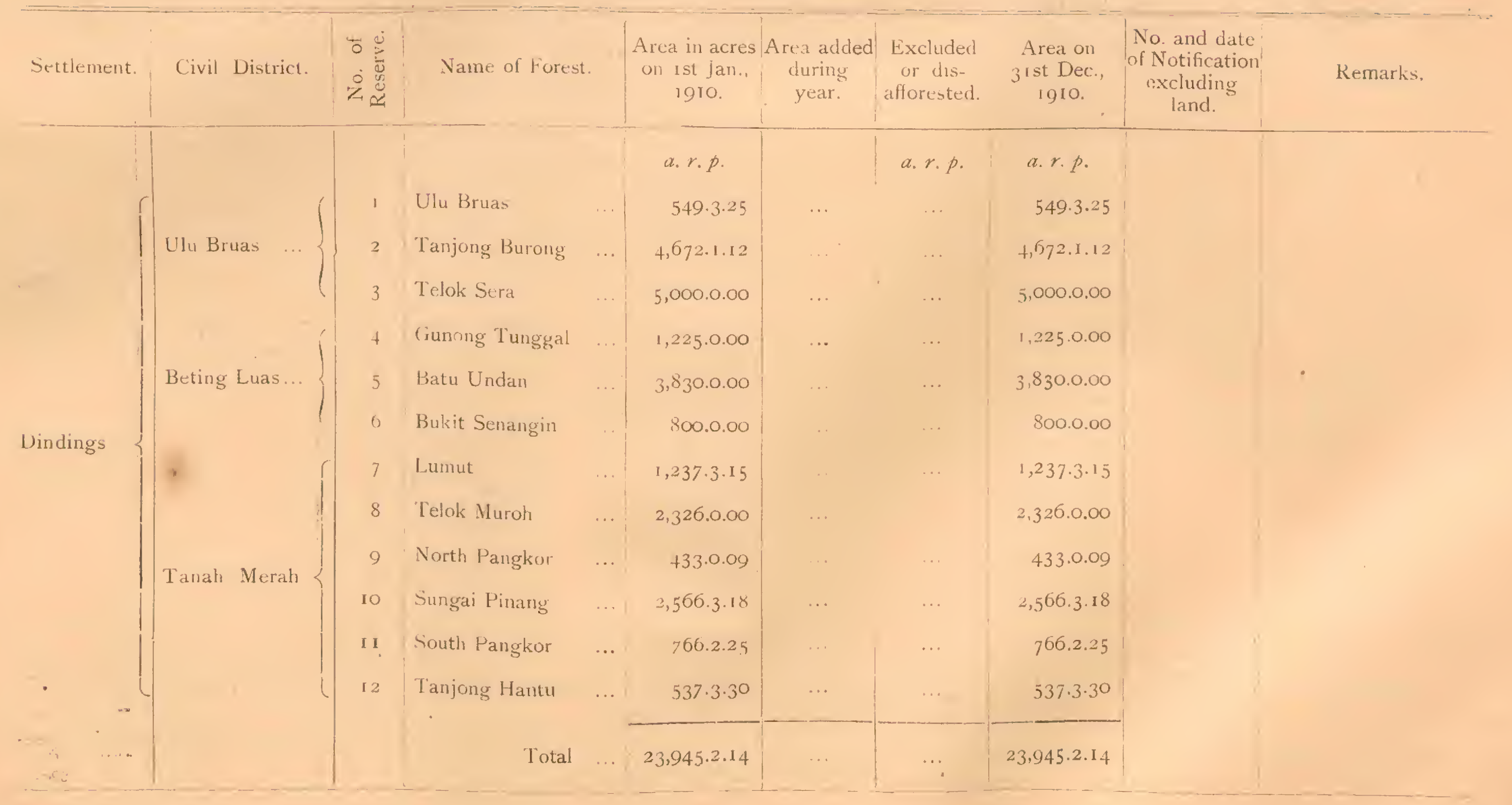


FORM No. 1.-Concluded.

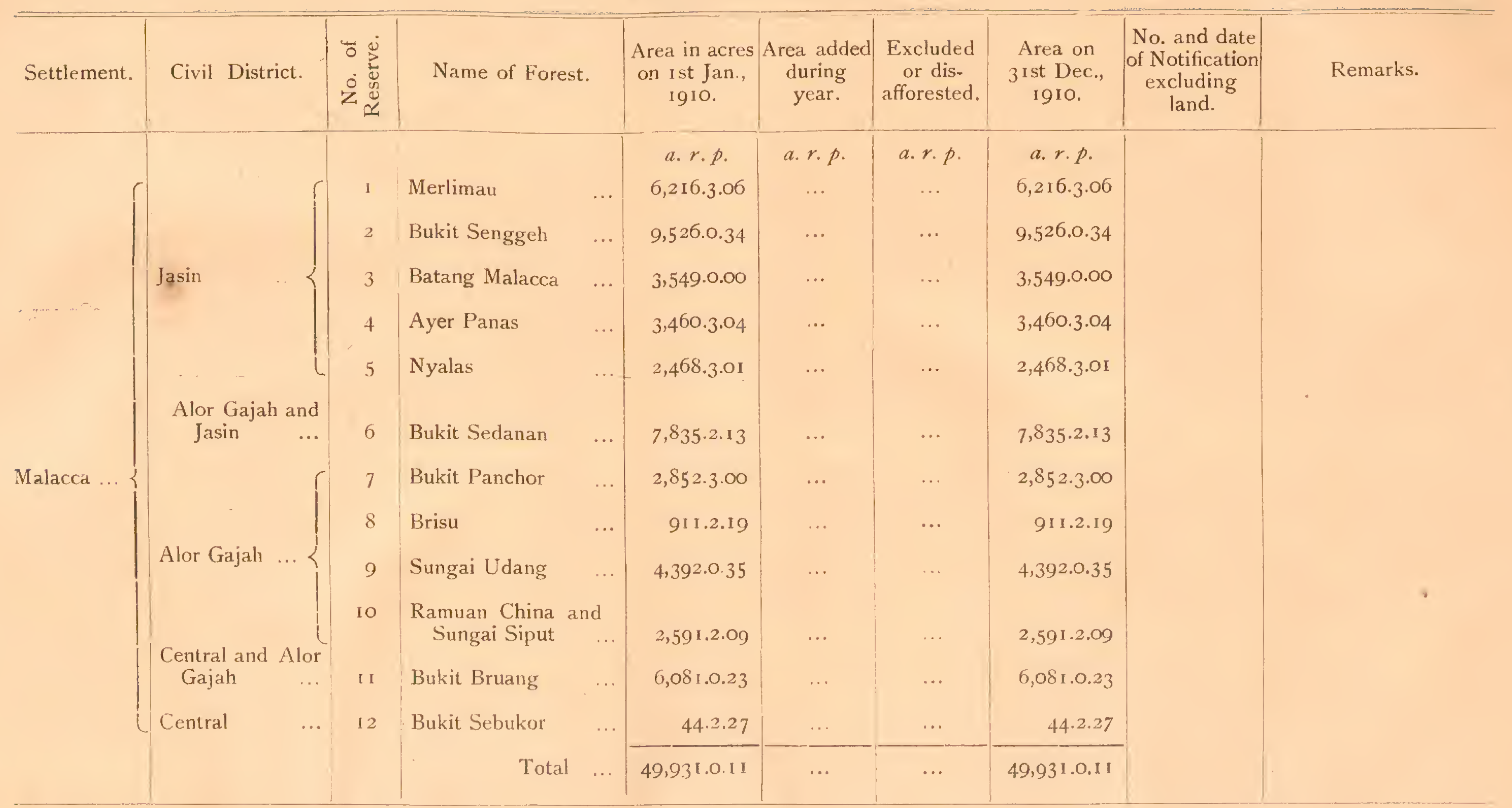


FORM NO. 2.

Statement showing Progress made in forming new Reserves during the Year 19 ro.

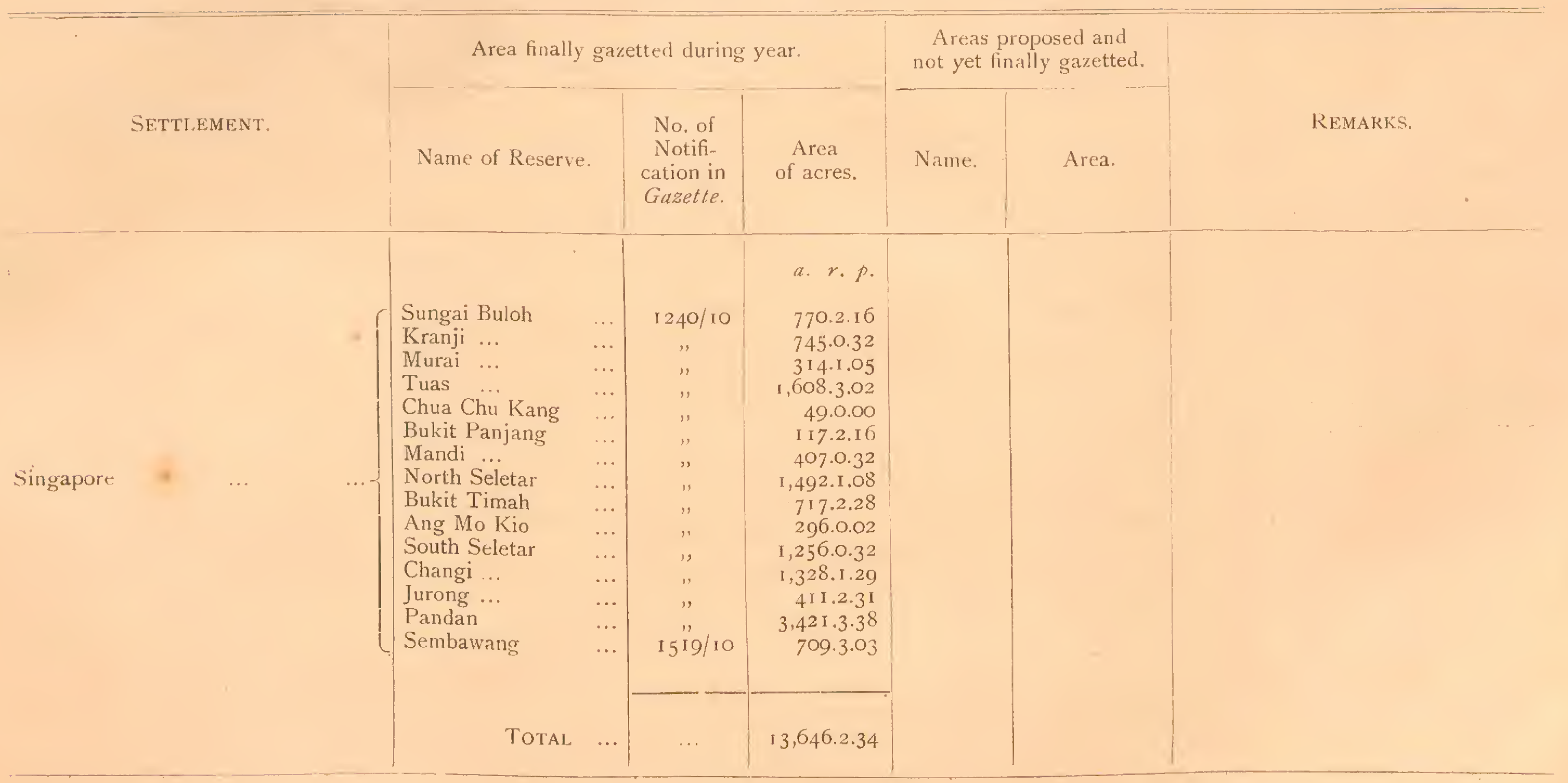


FORM NO. 8

Aręa of Plantations.

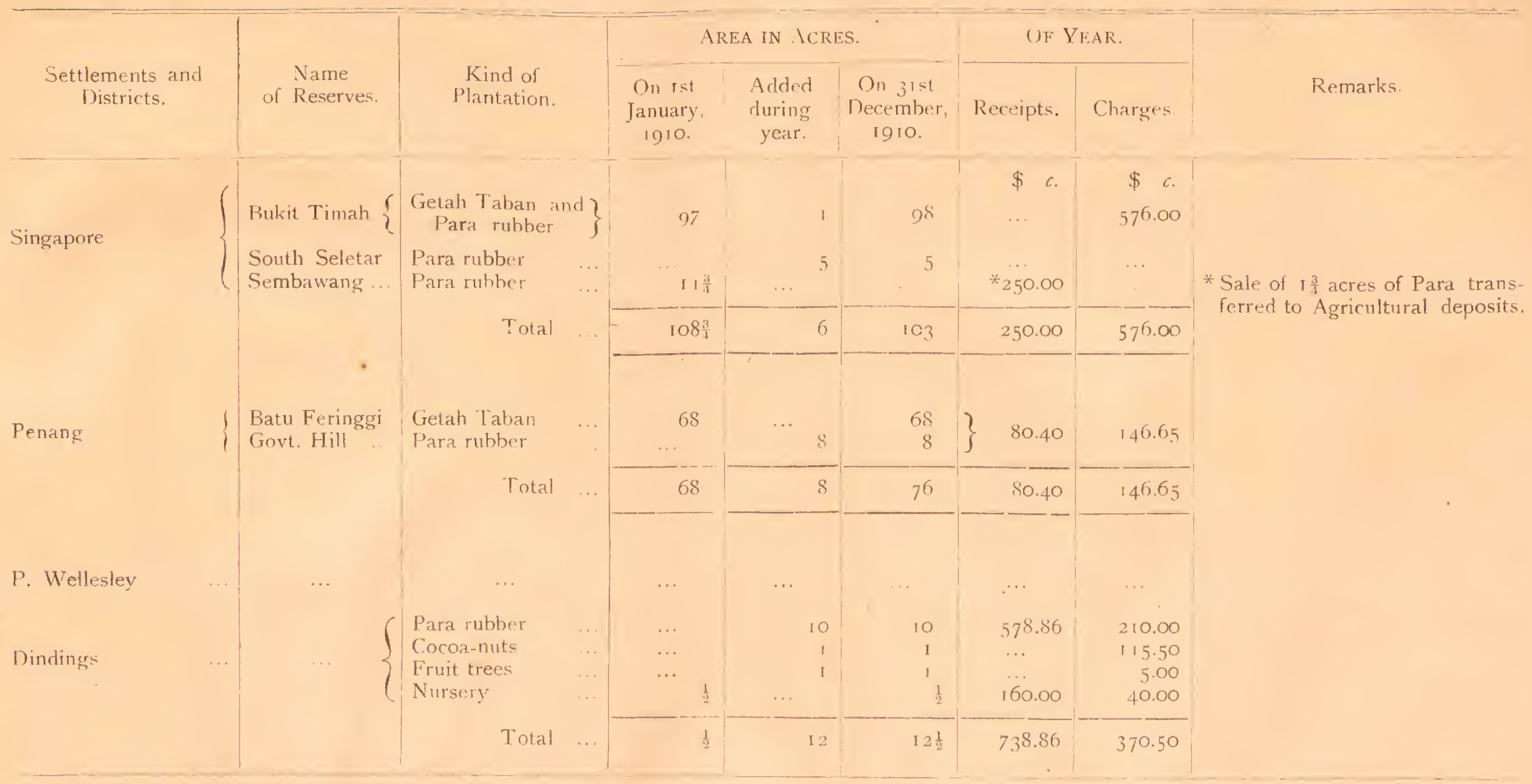


FORM NO. 8.- concluded.

Area of Plantations. - concluded.

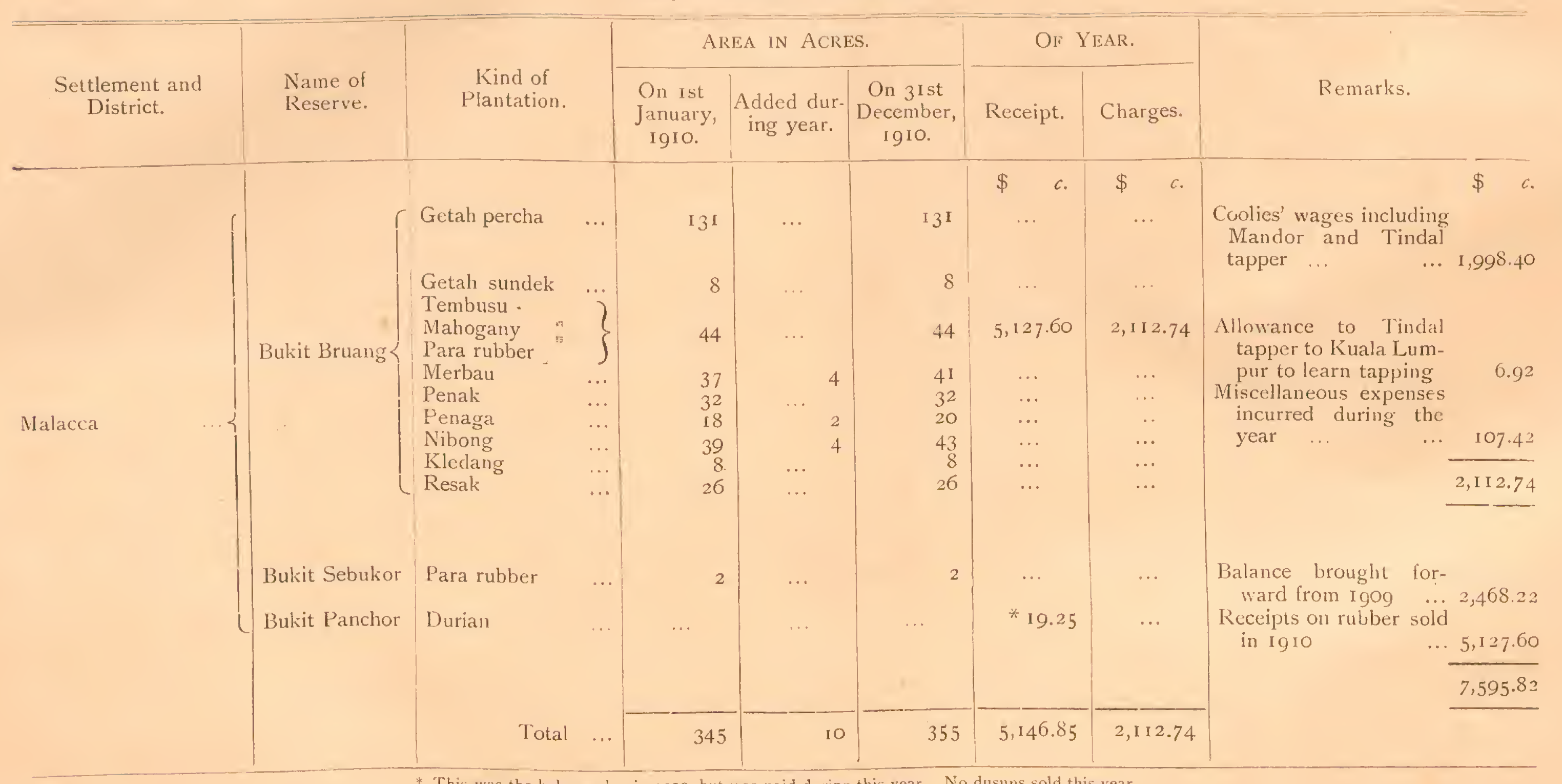

* This was the balance due in 1909 , but was paid during this year, No dusuns sold this year. 


\section{Singapore.}

FORM NO. II.

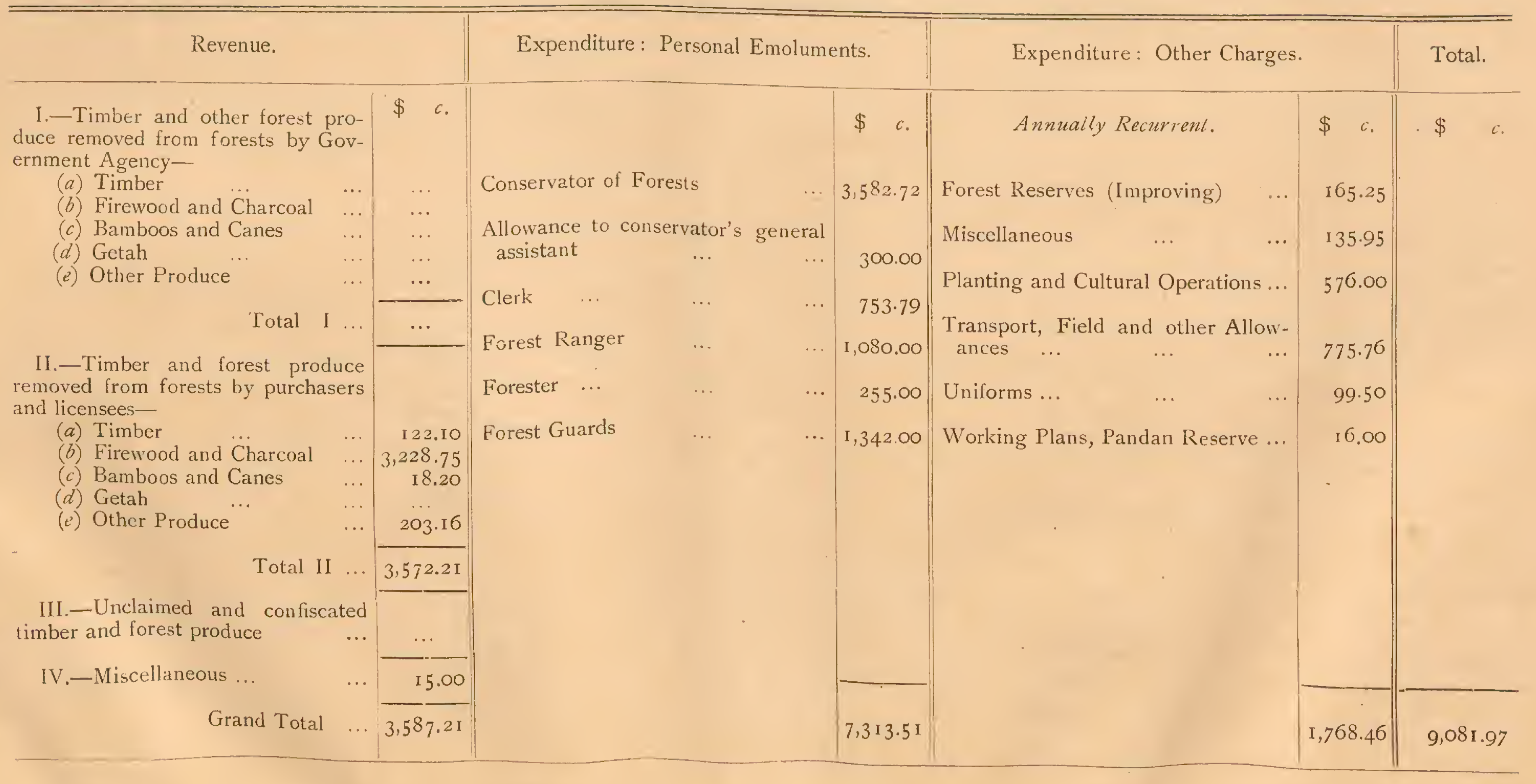


PEnang and Province Wellesley.

FORM No. I I-Continued.

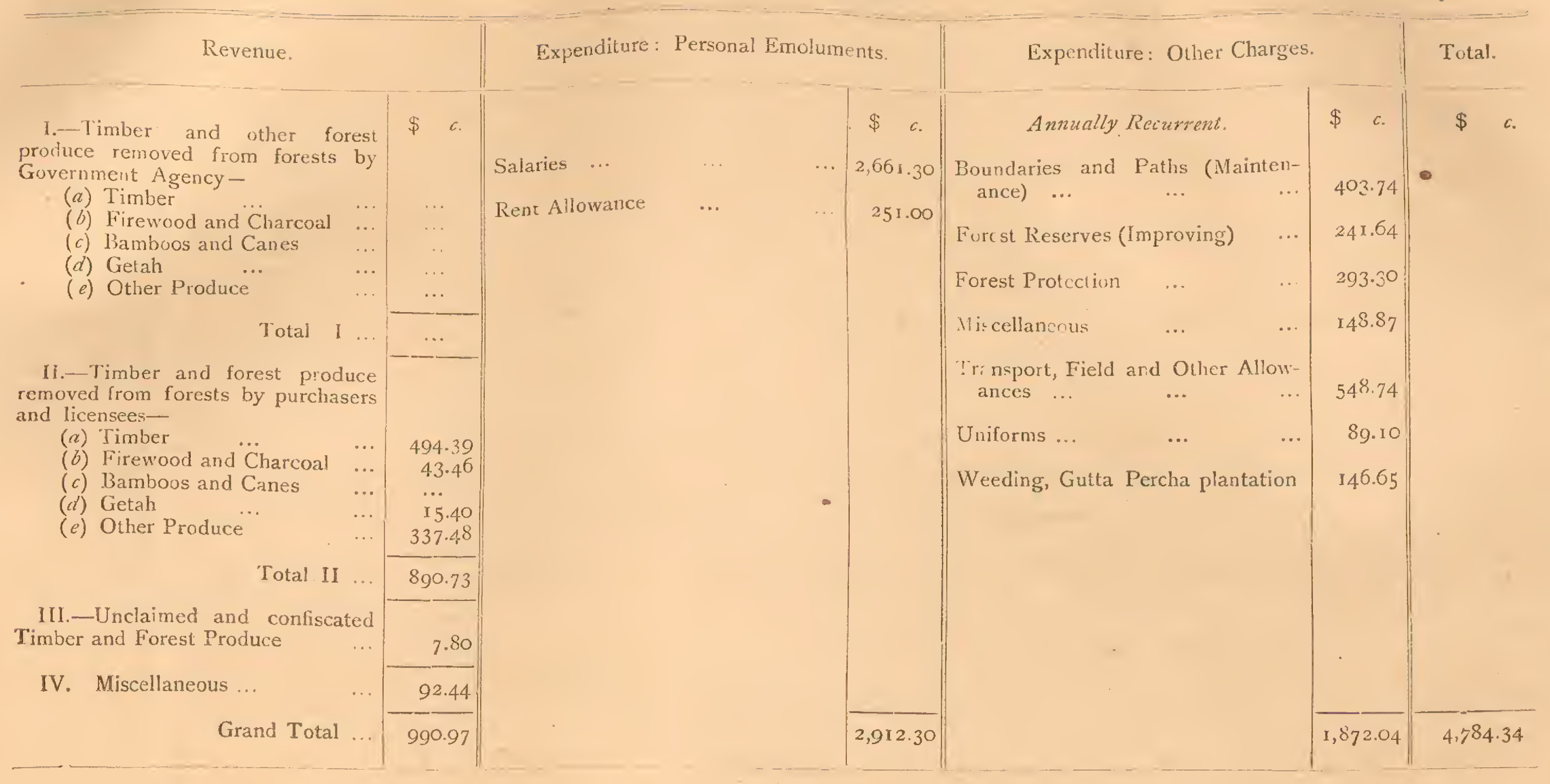




\section{Dindings.}

FORM No. II-Continued.

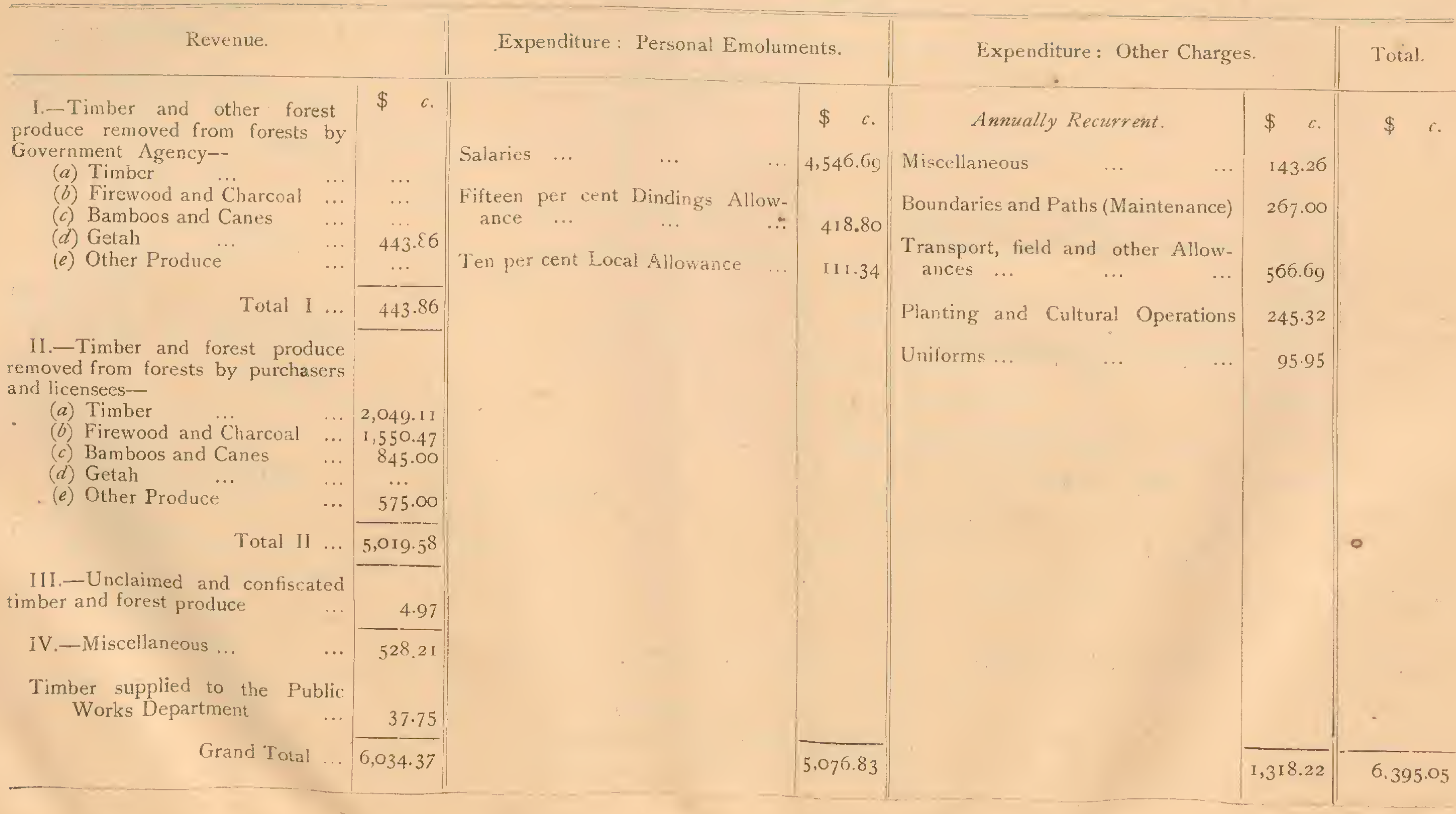


Malacca.

FORM No. I I.-Concluded.

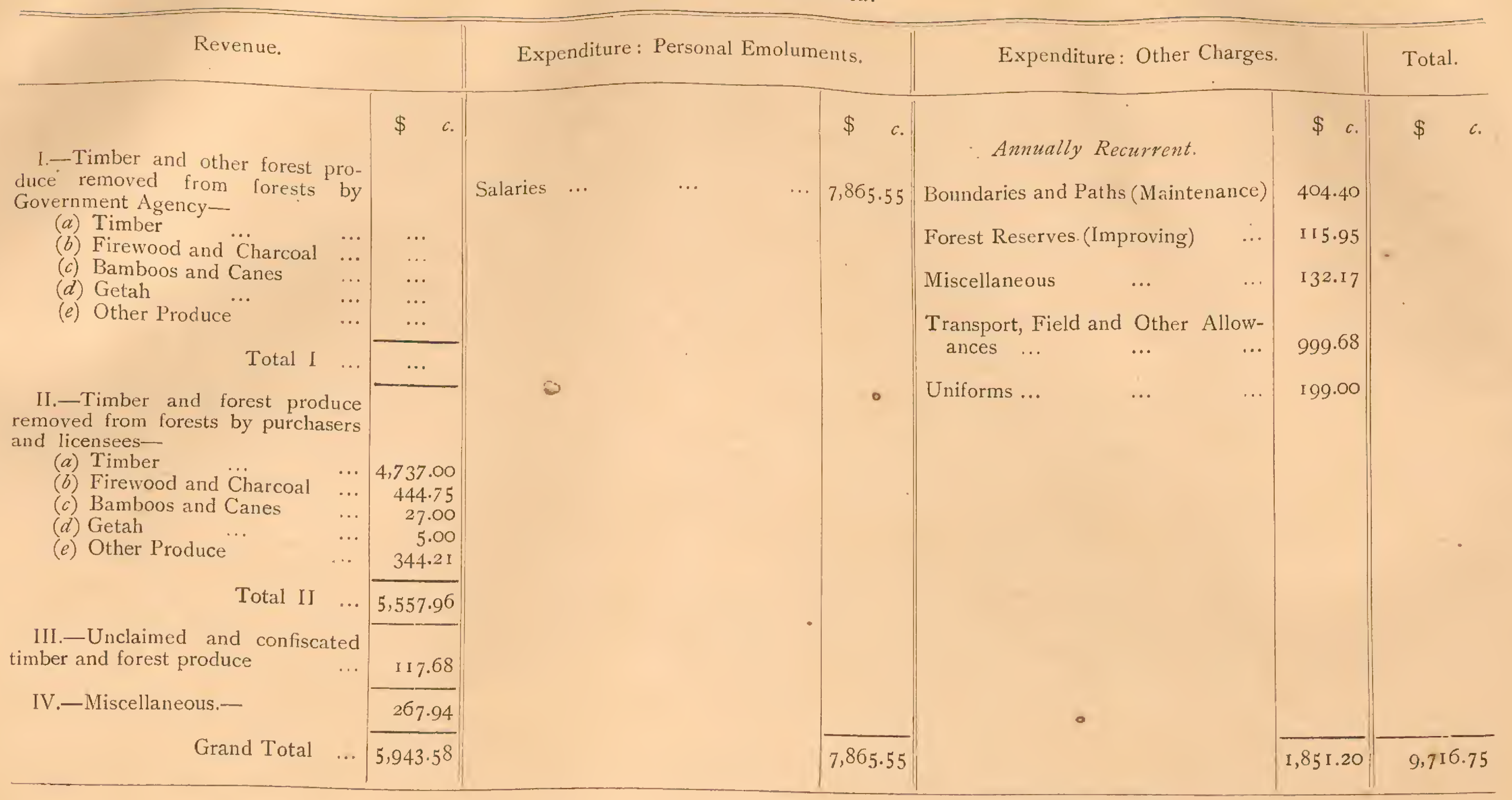




\section{Annual Report on Forest Administration in the Straits Settlements, for the Year 1911.}

\section{PART I.}

\section{Extension and Constitution of Reserved Forests.}

I. Form I shows progress made during the year in the final constitution of reserved forests.

All the reserves in the Colony have now been finally gazetted except three in the Dindings which await survey.

This table shows the areas finally gazetted, and preliminarily notified up to the end of I9II:-

\begin{tabular}{|c|c|c|c|c|}
\hline \multicolumn{2}{|r|}{ Settlement. } & $\begin{array}{l}\text { Area Preliminarily } \\
\text { Notified. }\end{array}$ & $\begin{array}{l}\text { Area Finally } \\
\text { Notified. }\end{array}$ & Total. \\
\hline Singapore & $\ldots$ & $\begin{array}{l}\text { Acres. } \\
\ldots\end{array}$ & $\begin{array}{l}\text { Acres. } \\
\text { 1 } 3,647\end{array}$ & $\begin{array}{l}\text { Acres. } \\
\text { I } 3,647\end{array}$ \\
\hline Penang & $\ldots$ & $\cdots$ & 10,744 & IO, 744 \\
\hline Province 1 & Wellesley & $\ldots$ & 3,934 & 3,934 \\
\hline Dindings & $\ldots$ & 5,855 & I 8,091 & 23,946 \\
\hline Malacca & $\cdots$ & $\cdots$ & 49,514 & $49,5^{I / 4}$ \\
\hline & Total & 5,855 & 95,930 & IOI, 785 \\
\hline
\end{tabular}

2. Besides these a large area in the Dindings has been explored and the demarcation nearly completed, lying between the Bruas-Lumut cart-road and the sea. It is chiefly hilly and contains fine forest.

3. During the year $\$ 2,283$ acres in Penang, Province Wellesley, Dindings and Malacca were finally constituted reserves. When the remaining reserves in the Dindings are finally notified we will have in the Colony about 106,000 acres or 165 square miles, about Io per cent of the area of the whole Colony. In Singapore there were no alterations in area. In Province Wellesley 23 acres were excluded from Bukit Juru reserve. In Malacca a reduction of $4 \mathrm{r} 6$ acres was effected in the Nyalas, Bukit Sedanan and Sungai Udang reserves.

\section{Demarcation and Upkeep of Boundaries.} miles.

4. The total length of artificially cut boundaries at the close of the year was 368

In Singapore, $55^{\frac{1}{2}}$ miles of boundaries were kept clean by the Forest Guards, the Seletar boundary was not cleared. 
In Penang and Province Wellesley 97 miles of boundaries were kept clean for $\$ 372.20$. Bukit Goa Ipoh reserve boundaries were not cleared owing to difficulty in obtaining labour.

Bukit Mertajam and Bukit Serayah reserves which are bounded by holdings were cleared by the owners, and I50 boundary notices were purchased for reserve boundaries. The boundaries of Tasek Glugor, Gajah Mati and Bukit Panchor reserves, where they adjoin Kedah State, were opened and cleared by the Survey Department, also the boundary between lot 210 and Highlands reserve in Penang.

In the Dindings, the Gunong Melintang proposed reserve was demarcated all but a couple of miles, and $28 \frac{\mathrm{T}}{2}$ miles of boundaries of existing reserves were re-cleared at a cost of $\$ 446.84$. Road reserves for Gunong Mlelintang and Gunong Tunggal were also demarcated.

In Malacca the boundaries of nine reserves were re-cleared during the year at a cost of $\$ 562.05$.

The total length of boundaries consisting of natural features is 128 miles, making a total mileage of boundaries of 496 miles.

\section{Surveys.}

5. In Penang and Province Wellesley, the Survey Department demarcated portions of boundaries of Tasek Glugor, Gajah Mati and Highlands reserves, and surveyed the Bukit Panchor reserve. In the Dindings, the Federated Malay States Survey Department made a topographical survey of the country and it is hoped that maps of the forest reserves will soon be available. The Straits Settlements Survey Department were also at work in the Dindings.

\section{PART II.}

\section{Management of Forests.}

\section{WORKING PLANS.}

6. In Singapore five Mangrove reserves were exploited for firewood as shown in this table:-

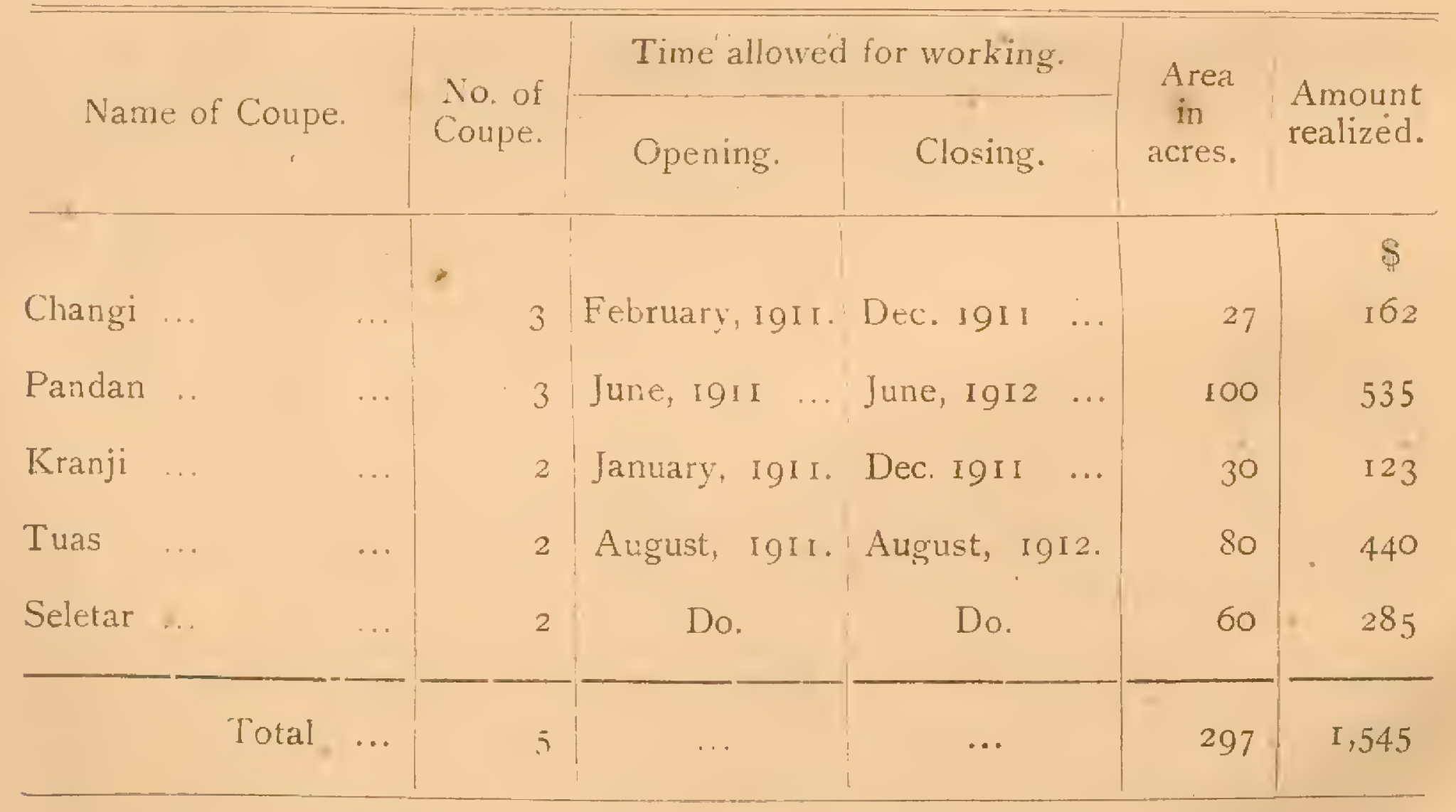

Two hundred and ninety-seven acres were leased in five blocks for $\$ 1,545$ for the year, as compared with \$I,38I.50 in I9ro, an average of $\$ 5.20$ an acre.

7. In Province Wellesley, Class I trees were selected by the Forest Ranger and marked for felling in Gajah Mati and Tasek Glugor reserves.

8. In the Dindings no tenders were received for the Tanjong Burong Mangrove reserve, but it was thinned out and fishing-stakes exploited. No other reserves in the Dindings were exploited. 
9. In Malacca, the following Class I trees over six feet girth were selected and marked for felling in a demarcated coupe in each of the following reserves:-

$\begin{array}{llllll}\text { Merlimau } & \ldots & \ldots & \ldots & \ldots & \text { I } 14 \\ \text { Bukit Sedanan } & \ldots & \ldots & \ldots & \ldots & \text { I } 32 \\ \text { Ayer Panas } & \ldots & \ldots & \ldots & \ldots & \text { 177 } \\ \text { Sungei Udang } & \ldots & \ldots & \ldots & \ldots & \text { I } 17\end{array}$

realizing $\$ 75$, and Class II trees were felled realizing $\$ 193$. Total Class 1 trees felled 540 , as compared with 274 in 1910.

\section{Paths in Reserves.}

IO. In Singapore, the path from Kuala Sungei Tuas to Sungei Blukang was repaired at a cost of $\$ I 6.50$, and another path made in Kranji reserve at a cost of $\$ 30$.

I I. In the Dindings \$I IO were expended in clearing the old road from Tanjong Hantu to Sungei Batu, from Sungei Puyu to Segari, a length of about Io miles, and $\$ 68$ on a path to Gunong Tunggal reserve from the sea-beach.

I2. In Malacca, inspection paths in five reserves were re-cleared, the other paths were in good order.

\section{Buildings.}

13. A halting bungalow and Forest Guards' quarters at Tuas in Singapore were erected for $\$ 200$.

14. In Penang, the forest stations at Balik Pulau and Penara Bukit were repaired by the Forest Department for $\$ 30.30$.

I5. In the Dindings quarters for a Forester and Forest Guard were erected at a cost of $\$ 200$ and other stations were kept in repair by the Public Works Department.

I6. In Malacca, Forest Guards' quarters were repaired by the Public Works Department where necessary.

\section{Protection.}

I7. No alterations or additions were made to the rules under the Forest Ordinance during the year.

\section{General Protection.}

18. The Forest Ranger, Singapore, reports that general protection of the forest reserves was adequate with the exception of Seletar.

19. In Province Wellesley the reserves were patrolled by Forest Guards, accompanied by coolies employed by the day when required.

20. In the Dindings and Malacca protection of reserves was efficient.

\section{Forest Fires.}

2I. In Singapore, in South Seletar reserve, there was a lalang fire over about 200 acres, and some few acres of fires of resam and small undergrowth in Tuas, Kranji, and Ang Mo Kio reserves. A small fire occurred in Sungei Buloh reserve. For these, fines were inflicted to the extent of $\$ 25$, besides $\$ 26.40$ received as compensation.

22. In Province Wellesley there were two cases of fire spreading into the Juru reserve, in both cases the men responsible were fined. A case of fire on Crown land was compounded for $\$ 70$ damages.

43. In the Dindings a small fire occurred in Pangkor reserve, and the offender fined. Forty-three dollars were awarded for damages in three cases of fire on Crown land.

24. In Malacca, about one acre was burnt in the Bukit Panchor reserve, and the case was compounded for \$25. Another case occurred on Crown land near Alor Gajah and the offender was fined \$20. 


\section{Forest Offences,}

25. The following cases were taken into courts :-

\begin{tabular}{|c|c|c|c|c|c|}
\hline \multirow{2}{*}{$\begin{array}{l}\text { Cases pending } \\
\text { from I9IO. }\end{array}$} & \multirow{2}{*}{$\begin{array}{l}\text { New cases } \\
\text { of the year. }\end{array}$} & \multirow{2}{*}{$\begin{array}{l}\text { Total } \\
\text { cases. }\end{array}$} & \multicolumn{3}{|c|}{ Disposed of during year. } \\
\hline & & & $\begin{array}{l}\text { Convic- } \\
\text { tions. }\end{array}$ & $\begin{array}{l}\text { Acquit- } \\
\text { tals. }\end{array}$ & $\begin{array}{l}\text { Pending at } \\
\text { close of year. }\end{array}$ \\
\hline - & 105 & 105 & 91 & IO & 3 \\
\hline
\end{tabular}

I case absconded.

$\$ c$.

26. Besides these

I 2 cases were compounded for 21592

In Singapore

3 " " 2640

In Penang and Province Wellesley I case was compounded for 70 oo

In the Dindings

In Malacca

I, case was compounded for 1600

7 . cases were compounded for 10352

12

$\$ 21592$

The percentage of convictions of cases tried in courts was 90 per cent, as compared with 88 in I9Io. There were 105 cases, as compared with 155 in I9IO, of which IOI were tried, with 9 I convictions, IO acquittals, three pending at the close of the year and one absconded.

Malacca had most cases with 85 per cent of convictions, the Dindings had 22 cases all convictions, Penang and Province Wellesley, 29 cases with only one acquittal, Singapore had only five cases of which four were tried and two acquitted.

27. Fines imposed by courts realized $\$ 794.85$.

In the three cases pending from Igro, summons could not be served as the offenders could not be found.

The reduction of cases was chiefly in Malacca.

\section{Improvement of Forests.}

\section{NATURAL REPRODUCTION.}

28. As in the Federated Malay States the year I9I I was a phenomenal one for fruiting of trees.

In Penang and Province Wellesley, Damar-laut and Resak fruited profusely in Pantai Acheh, Telok Bahang and Laksamana reserves, Penaga in Tasek Glugor, and Meranti in all reserves from October to December. Taban trees in the Botanical Gardens bore a good crop of seed. In Batu Feringgi and Pulau Jerejak, portions of the reserves were noticed to be carpeted with Taban seedlings. Fourteen thousand were collected and sent to the Dindings and 3,000 to the Deputy Conservator of Forests, Perak, for which $\$ 45$ was received.

In the Dindings, Damar laut, Meranti and Serayah were observed to seed profusely.

Malacca also reports a good seed year, Rambai daun and Meranti noticeably in Ayer Panas reserve, also Niatoh, Medang and Petaling. Keruing also seeded well in Sungei Udang reserve. Meranti, Rambai daun and Niatoh seedlings were observed well scattered over part of Merlimau reserve, and Resak seedlings in Bukit Sedanan. In Bukit Senggeh reserve, Penak and Merbau seedlings were noticed besides Resak and Keruing.

In Bukit Bruang reserve, Tampines is found to be re-produced extremely well, also Bintangor. 


\section{Artificial Reproduction.}

29. For particulars see Form 8 . The area of plantations was at the commencement of the year 546 acres to which was added 47 acres during the year, bringing the area at the close of the year to 593 acres.

The additions were, in Singapore five acres in Seletar reserve, Para rubber. Blanks in the Gutta percha plantation at Bukit Timah were planted up with Para. This plantation of 98 acres was upkept for $\$ 596$. The Para trees were tapped and the cost of tapping and upkeep of the Para areas was $\$ 624.63$ and yielded $\$ 586.3 \mathrm{I}$, of which buildings, including drying shed, store, and quarters for tapper cost $\$ 277.57$. Tapping of 80 trees was commenced in January, IgI I. The initial cost was met from an advance from Government to be paid back out of proceeds of tapping. The yield was 3 or lbs.

The accounts of this plantation are appended.

The ro acres of Para at Sembawang was leased for $\$ 300$, also credited to Agricultural Deposit.

30. In Penang, the experimental plantation at 2,000 feet elevation now contains I 2 tapable trees and 490 seedlings. \$107.73 was spent in clearing and supplying and they are doing well. The Batu Feringgi plantation of Gutta percha, 68 acres, was upkept for $\$ 97.45$. Two hundred and fifty Taban seedlings were planted and I,200 are on hand to supply failures. This plantation now contains I, I4I Taban (Gutta percha) and 53 I Para trees.

In Tasek Glugor, the small experimental teak plantation of 5 acres, 2 roods and 28 poles was chankolled and interplanted with 380 Tembusu at a cost of $\$ 26.60$.

The nursery here now contains I0,000 Penaga (Mesua ferrea) seedlings. The Tembusu seedlings in Bukit Panchor reserve will be used in planting up "lalang" areas.

At Penara Bukit at $\mathrm{r}, 600$ feet elevation 18 cedar seedlings were raised from the seed sent from Japan.

In the Dindings, two acres were added to the Para plantation at Lumut, two acres planted in 19 Io with coconuts and fruit trees are reported to have been a failure, which is regrettable.

The reason given is insufficiency of prisoners to keep them clean, but it appears that they were neglected in favour of the Para trees. The nurseries here contain some thousands of Tembusu seedlings, some Para and about 20,000 Taban merah. One thousand Merbau seedlings were planted out in the felling coupe of Lumut reserve. The total cost of planting and cultural operations was $\$ 57$ I.66. Eighty-two thousand Damar laut seed was sold to the Federated Malay States Government for $\$ 44.22$. Coconuts realized \$24.

Some Para trees at Lumut were tapped and yielded $185 \mathrm{lbs}$. of rubber, $\$ 270.66$ was realized by sale of rubber.

31. In Malacca, 40 acres in Ayer Kroh were planted during the year as follows:-

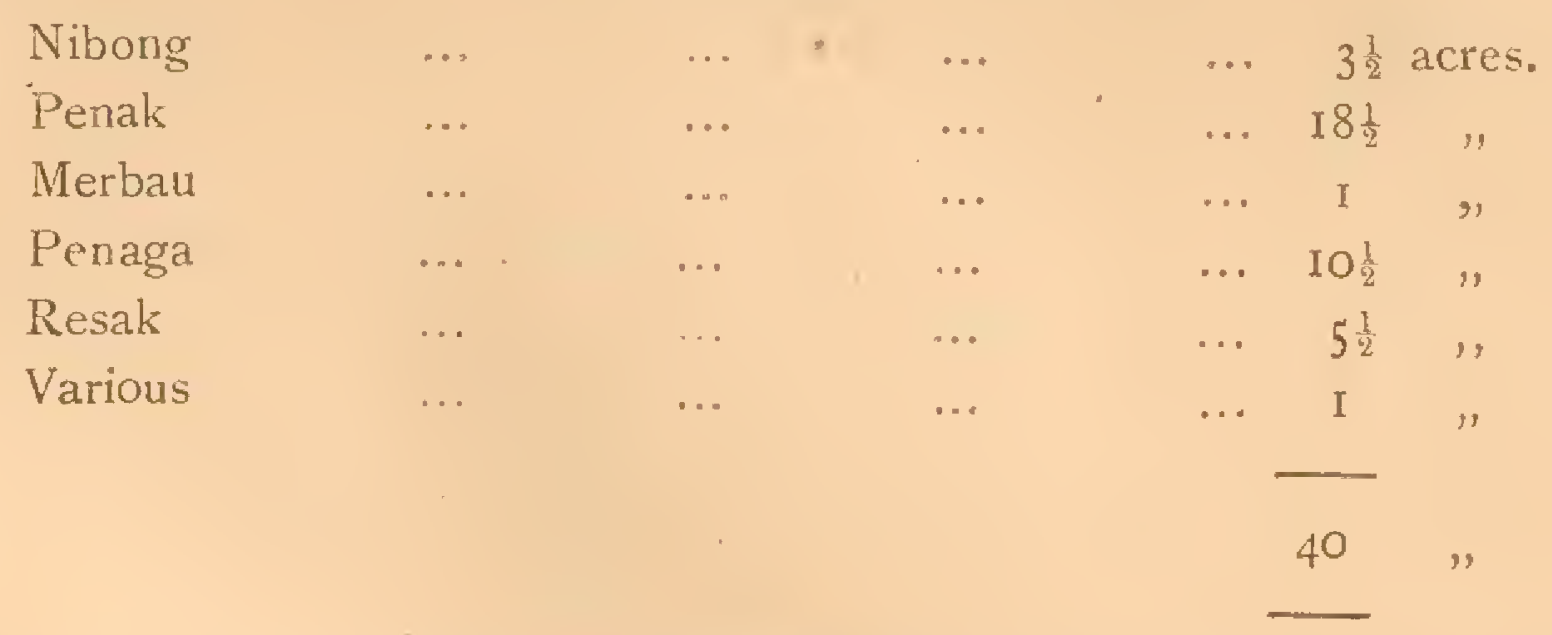

The area of these plantations at the close of the year was 395 acres. They are maintained from the Gardens Committee funds which are supplied by the sale of Para rubber from this plantation. A statement of account appears in paragraph 33 .

The expenditure during the year was $\$ 4,307.95$ and the receipts $\$ 4,485.33$.

The block boundaries of the plantation were cleared and undergrowth removed where necessary, and 1,383 failures replaced in Penak blocks, with seedlings from the nursery, 230 in the Merbau blocks and 408 in the Penaga blocks. 
In the Gutta percha plantation the trees were freed from undergrowth and inferior species of trees were thinned out, where necessary. The Para was drained and cleared.

Four hundred and twenty-seven Para trees were numbered and measured, and entered in a register, the balance was measured in IgIO. Thirty-four additional trees came into bearing, making a total of $86 \mathrm{I}$ tapable trees, and $3,300 \frac{1}{2} \mathrm{lbs}$. rubber were obtained as against 2,172 lbs. in Iglo. The Conservator paid two visits during the year. Over 30,000 Para seeds were sown in the nurseries and are doing well.

The 50 Penak and I50 Resak seedlings planted out in the Merlimau reserve in IgIO, did not prove a success. The IOo Merbau seedlings planted are doing well.

In the Sungei Udang reserve most of the Merbau seedlings planted out last year have been destroyed by rats. The Resak seedlings are doing well.

\section{Bukit Timah Plantation.}

32. Statement of Revenue and Expenditure for I9I.

\begin{tabular}{|c|c|c|c|c|c|c|c|}
\hline \multicolumn{3}{|c|}{ Nonth. } & \multicolumn{2}{|c|}{ Receipts. } & Details of Expenditure. & \multicolumn{2}{|l|}{ Amount. } \\
\hline & & & $\$$ & $c$ & & $\$$ & \\
\hline January & $\cdots$ & $\ldots$ & $\cdots$ & & Buildings $\quad \ldots$ & 2775 & 57 \\
\hline February & $\ldots$ & $\ldots$ & $\cdots$ & & Tools and Plants & I I 22 & 29 \\
\hline March & $\cdots$ & .. & 889 & 92 & Sundries $\quad .$. & 30 & 07 \\
\hline April & $\cdots$ & $\cdots$ & $\cdots$ & & $\left.\begin{array}{c}\text { Wages of tapper up to } \\
\text { the end of December }\end{array}\right\}$ & 2217 & 70 \\
\hline May & $\cdots$ & $\ldots$ & $8_{32} 2$ & & Transport $\ldots \quad \ldots$ & IO 0 & oo \\
\hline June & $\cdots$ & $\cdots$ & I I6 I & I 3 & & & \\
\hline July & $\cdots$ & $\cdots$ & 596 & 60 & & & \\
\hline August & $\cdots$ & $\cdots$ & & & & & \\
\hline September & $\cdots$ & $\cdots$ & 1246 & 58 & & · & \\
\hline October & $\cdots$ & $\cdots$ & $\cdots$ & & & & \\
\hline November & $\cdots$ & $\cdots$ & $\cdots$ & & & & \\
\hline December & $\cdots$ & $\cdots$ & $113 \%$ & 78 & & & \\
\hline & \multicolumn{2}{|c|}{ Total } & $\$ 586$ & & & $\$ 624$ & \\
\hline
\end{tabular}




\section{Ayer Kroh Plantation.}

Statement of Revenue and Expenditure for igi

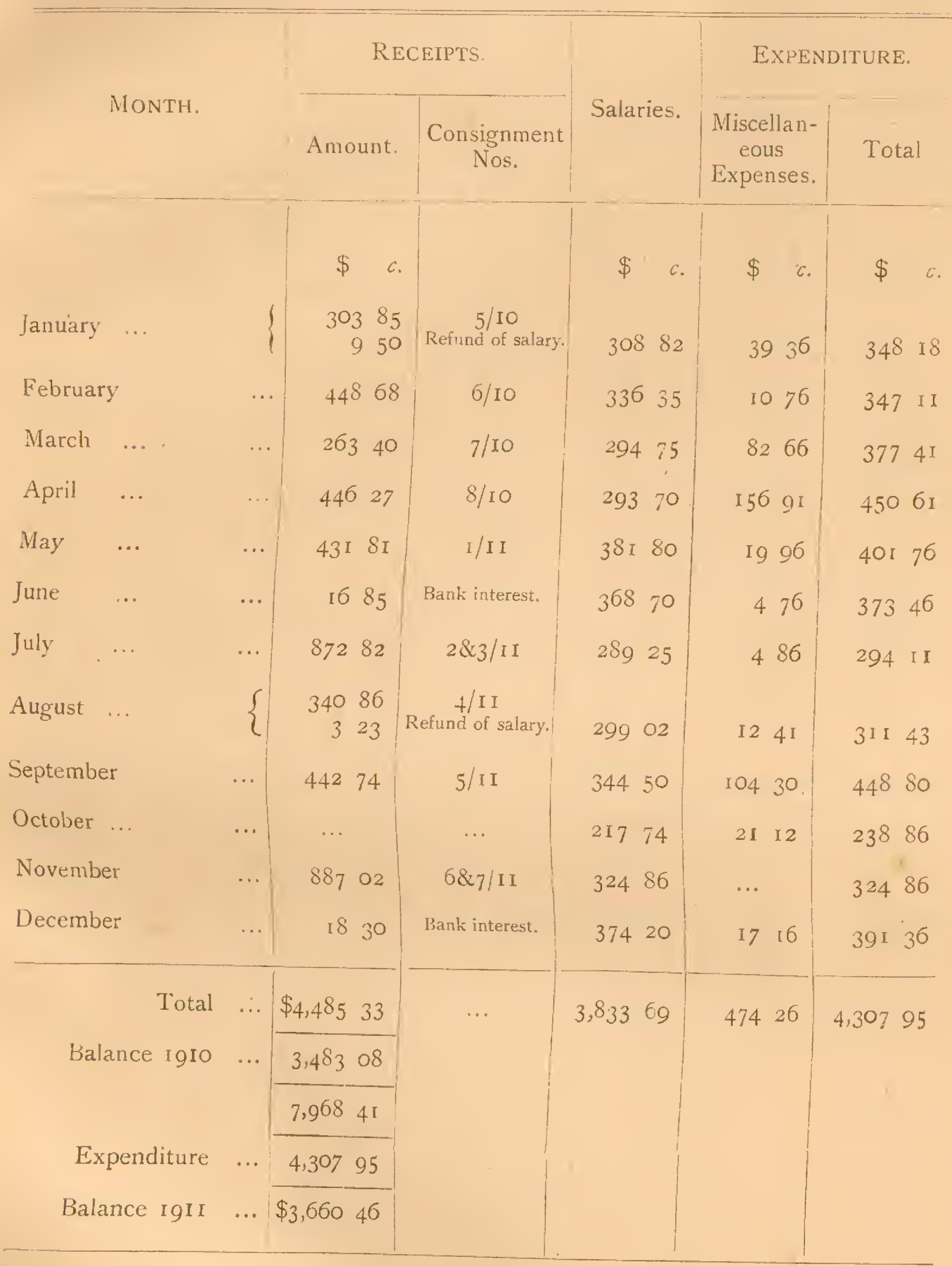




\section{Exploitation.}

TIMBER AND FUEL.

From Reserved Forests.

34. This table shows the timber and firewood removed from reserved forests:-

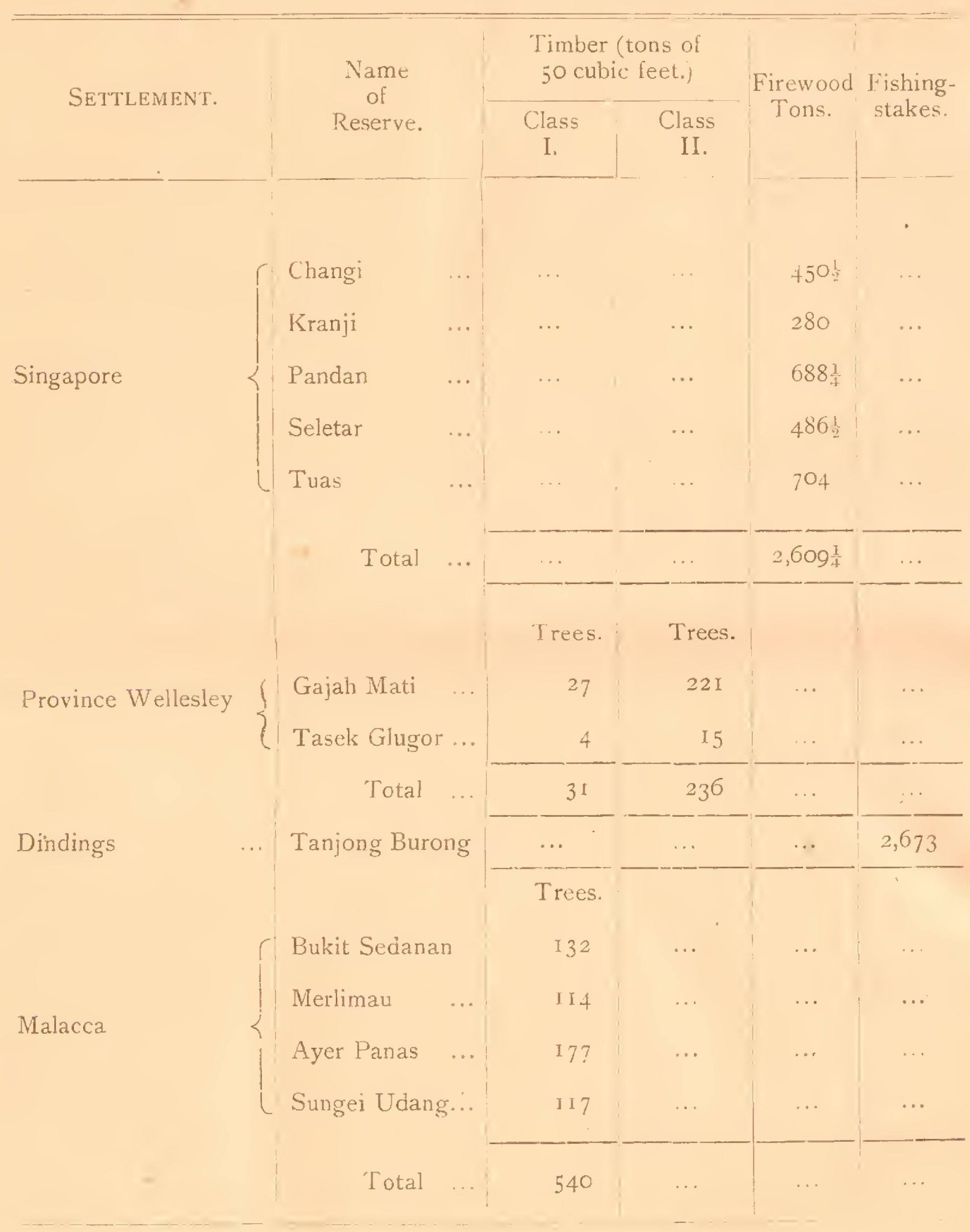




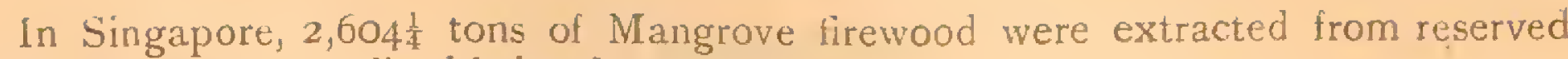
forests, the revenue realized being $\$ 1,545$.

In Province Wellesley, 3 I trees of Class I and 236 trees of Class II timber were extracted from Gajah Mati and Tasek Glugor reserves.

In the Dindings no tenders were received for the Mangrove reserve ig I block, but 2,673 fishing-stakes were taken out as thinnings and disposed of, the revenue realized being $\$ 55.62$.

In Malacca, 540 selected trees were cut in Bukit Sedanan, Merlimau, Ayer Panas and Sungei Udang reserves, realizing $\$ 938$, in Bukit Bruang, Sungei Udang and Nyalas reserves Class II trees were cut on permits.

\section{From Crown and Alienated Lands.}

35. This table gives the total for each Settlement so far as figures are available:-

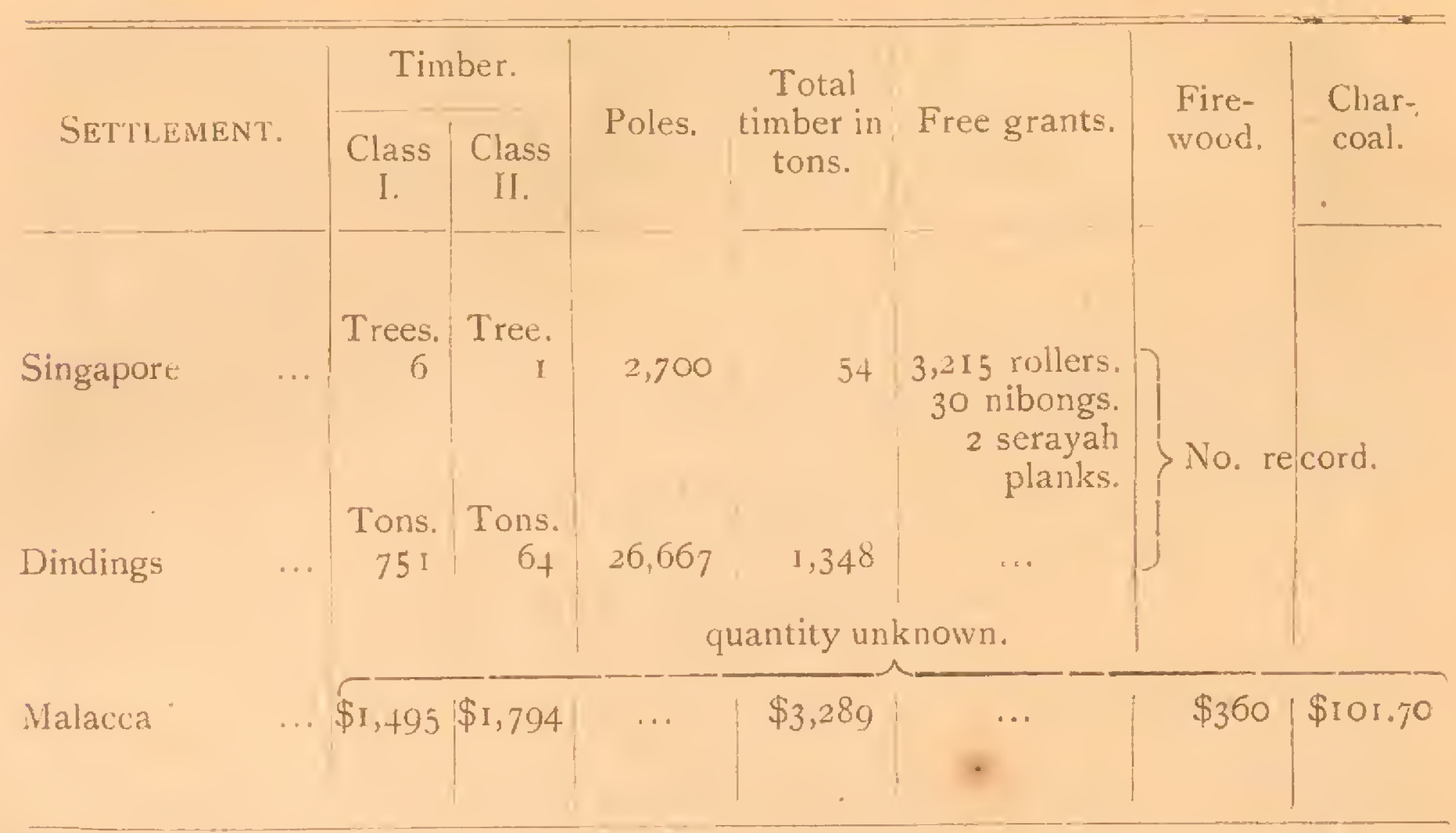

(Tons of 50 cubic feet for timber. Poles for total tonnage are taken at i cubic foot each).

In Singapore, permits were issued for six Class I, and one Class II trees and 2,700 small poles, realizing $\$ 58$. Four hundred and fifty-two monthly permits were issued for Mangrove, realizing $\$ 2,260$, as compared with $\$ 1,850$ during the previous year, and free permits to native land-holders for 3,2 I 5 poles, 30 Nibongs and two Serayah planks to the Police Department.

In the Dindings 635 tons of Class I timber and 26,667 fishing-stakes were extracted from Crown land on payment of royalty, and 23 tons of timber taken by the Public Works Department free of royalty, but a paper credit of $\$ 65.20$ is entered in Form II. Thirty-three tons of Class I and 54 tons of Class II timber were removed from alienated land and paid royalty, also 58 tons of Class I and 9 tons of Class II were removed free of royalty. Firewood realized \$1,501.77. In Malacca, the total revenue from timber on Crown land was $\$ 3,289$, as compared with $\$ 3,748$ in 19ro. Firewood realized $\$ 360$ and charcoal $\$ 101.70$, as against $\$ 295$ and $\$ 149.75$, respectively, in I910.

\section{Minor Forest Produce.}

36. In Singapore minor forest pröduce yielded $\$ 442.10$ mostly from Nibongs and royalty on sand in Changi reserve, as compared with \$203. I6 in 1910.

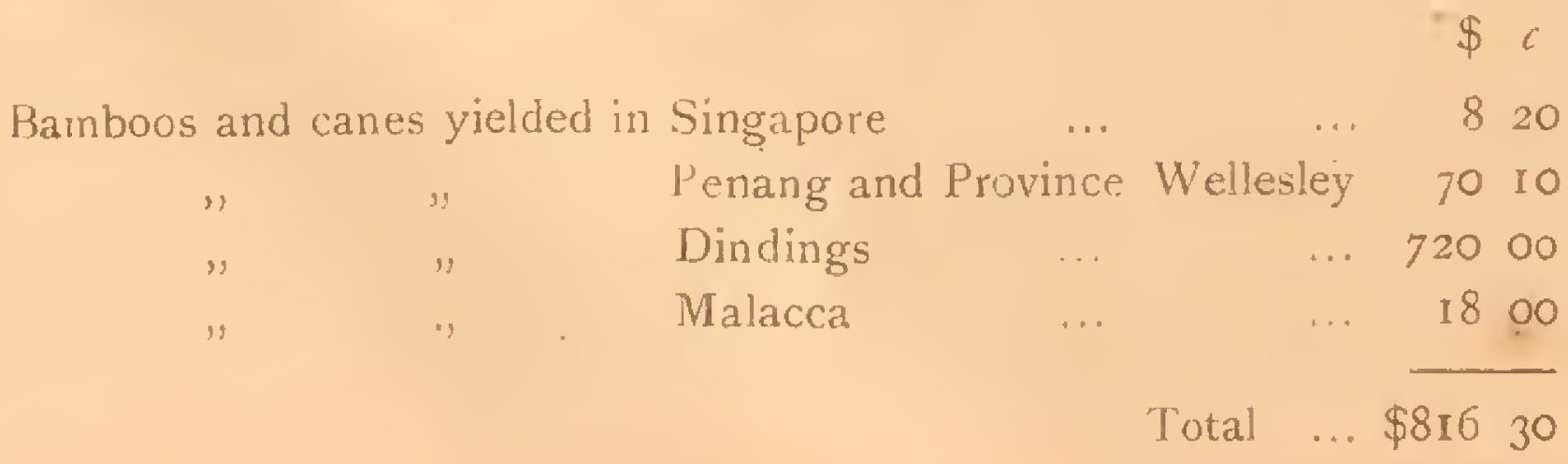


Other minor produce including wild rubbers yielded in :-

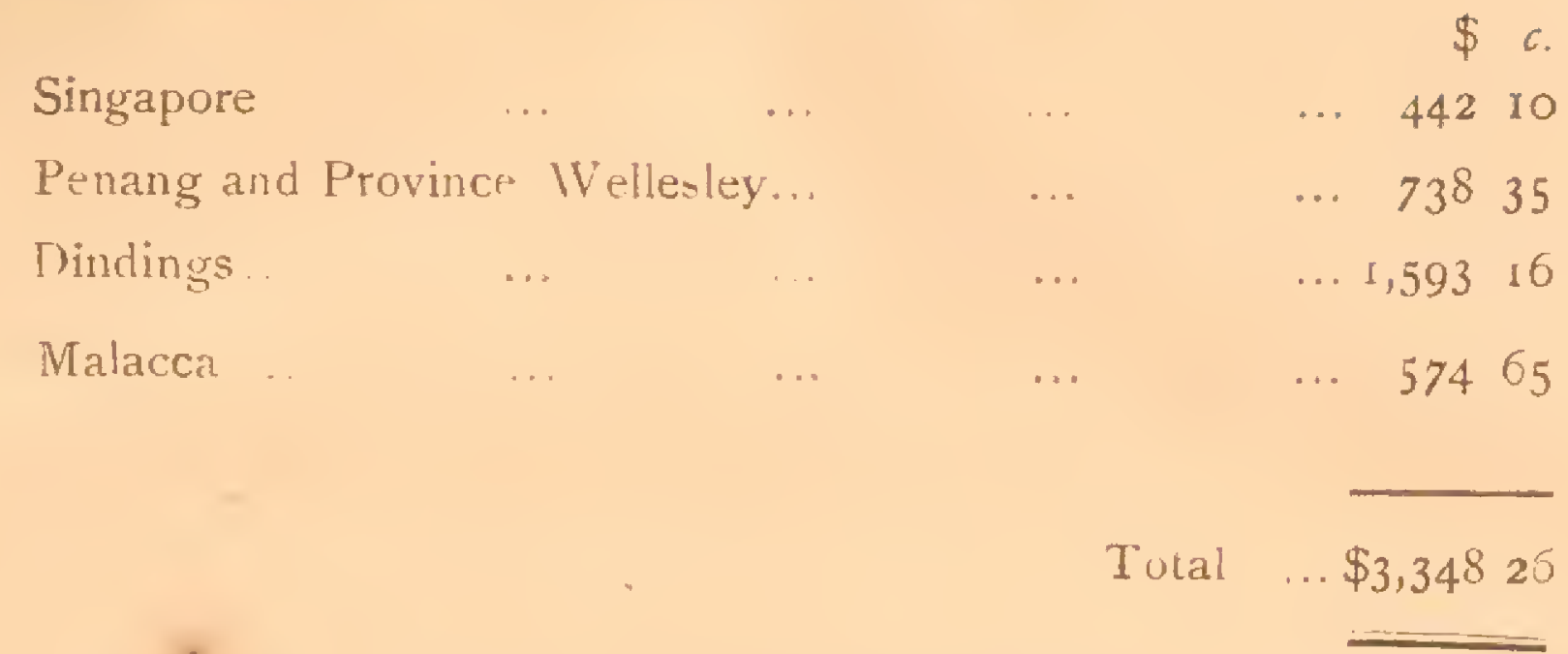

This shows an all round and very satisfactory increase.

The Para rubber trees in Ayer Kroh plantation, Bukit Timah and Lumut were tapped during the year by the department.

The yield in Ayer Kroh and Bukit Sebukor was 2,852 lbs. sheet and $447 \mathrm{lbs}$. scrap, as compared with 1,7 I2 lbs. sheet and 329 lbs. scrap in 19IO. The tapping of the trees has much improved. Sale of rubber realized $\$ 4,485.33$, credited to Gardens Committee account.

In Singapore, 80 trees were tapped at Bukit Timah. The yield was 30 I lbs. of rubber, realizing $\$ 586.31$.

In the Dindings some Para trees were tapped and yielded $185 \mathrm{lbs}$. of rubber, realizing $\$ 270.66$.

\section{PART III.}

\section{Financial Results,}

37. This table shows the comparative revenue for IgIo and IgI I:-

\begin{tabular}{|c|c|c|c|c|}
\hline SETTIEMENT. & $\begin{array}{c}\text { Revenue } \\
\text { I9Io. }\end{array}$ & $\begin{array}{l}\text { Estimated } \\
\text { revenue } \\
\text { I9I I. }\end{array}$ & $\begin{array}{c}\text { Revenue } \\
\text { I9II. }\end{array}$ & $\begin{array}{c}\text { Increase or } \\
\text { decrease over } \\
\text { Estimates. }\end{array}$ \\
\hline & $c$. & $c$. & c. & $\$$ \\
\hline Singapore $\quad \ldots$. & $3,5872 \mathrm{I}$ & 3,00000 & 4,30820 & $+1,30820$ \\
\hline $\begin{array}{c}\text { Wellesley } \\
\text { Dindings }\end{array}$ & $\begin{array}{r}99097 \\
6,03437\end{array}$ & 5,63000 & $\left.\begin{array}{ll}2,348 & 87 \\
6,816 & 26\end{array}\right\}$ & $+3,535$ I 3 \\
\hline Malacca $\quad \ldots$ & 5,94358 & 7,50000 & $5,542 \quad 77$ & $-\quad I, 95723$ \\
\hline Total ... & $16,55^{6}$ I 3 & 16,13000 & I9,0I 6 IO & $+2,886$ Iо \\
\hline
\end{tabular}

The rise in revenue in Singapóre is due to firewood, bamboos and canes, and other produce. A better price was obtained for the Mangrove coupes than in I910. The revenue realized from Para rubber was not credited to the department, but to the Agricultural Deposit.

In Penang and Province Wellesley there was a large increase in revenue due to timber, other minor produce, and compensation. Doubtless more efficient supervision has aided.

In the Dindings there was a rise of about $\$ 800$ due to timber, other minor produce and compensation.

In Malacca, the estimate was not reached and the revenue actually fell off by about $\$ 400$, chiefly on timber and other minor produce. The Forest Ranger gives as the reason the prevalence of Rinderpest and Foot-and-mouth diseases in Malacca in August and September, which killed about two-thirds of the buffaloes which are the only means of transporting timber in the forest. 


\section{Expenditure.}

38. This statement shows the total expenditure in each Settlement, as compared with I 910 and estimates for 1911 :-

\begin{tabular}{|c|c|c|c|c|}
\hline SETTLEMENT. & $\begin{array}{c}\text { Expenditure } \\
\text { I9 } 10 .\end{array}$ & $\begin{array}{c}\text { Estimated } \\
\text { expenditure } \\
\text { 1911. }\end{array}$ & $\begin{array}{c}\text { Expenditure } \\
\text { IgII. }\end{array}$ & $\begin{array}{l}\text { Savings on } \\
\text { Estimates }\end{array}$ \\
\hline $\begin{array}{llr}\text { Singapore } & \ldots & \ldots \\
\text { Penang and } & \text { Province } \\
\text { Wellesley } & \ldots & \ldots \\
\text { Dindings } & \ldots & \ldots \\
\text { Malacca } & \ldots & \ldots\end{array}$ & $\begin{array}{cc}\$ & c \\
9,081 & 97 \\
4,78+ & 34 \\
6,395 & 05 \\
9,716 & 75\end{array}$ & $\begin{array}{cc}\$ & c \\
10,300 & 00 \\
6,678 & 00 \\
6,249 & 00 \\
8,766 & 00\end{array}$ & $\begin{array}{cc}\$ & c \\
9,706 & 17 \\
6,403 & 58 \\
6,109 & 03 \\
8,260 & 87\end{array}$ & $\begin{array}{cc}\$ & c \\
593 & 83 \\
274 & 42 \\
139 & 97 \\
505 & 13\end{array}$ \\
\hline Total ... & 29,978 I I & $3^{1}, 993$ O0 & 30,47965 & 1.51335 \\
\hline
\end{tabular}

an increase of $\$ 501.54$, as compared with 1910 .

Increase in Singapore $\$ 624.20$ and in Penang and Province Wellesley $\$ 1,619.24$; decrease in Dindings $\$ 28602$ and Malacca $\$ 1,45^{6.88}$. Increase in Singapore was due to purchase of bicycle $\$ 60$, rest house at Tuas $\$ 200$ and extra expenditure on Conservator of Forests, travelling. Singapore as usual paid one-third of the salary of the Conservator of Forests, and his expenses under transport and personal vote, while travelling on duty in the Straits Settlements.

The increase in Penang over IgIo is chiefly in Personal Emoluments, partly compensated for by a decrease in the Dindings.

\section{Administration.}

39. Mr. A. M. BURN-MURdOCH held the appointment of Conservator of Forests till 27 th April, when he proceeded on leave and was relieved by Mr. B. H. F. BARNARD, Deputy Conservator of Forests. Perak, who acted as Conservator till the end of the year.

The following reserves were visited by the Conservator and Acting Conservator :-

Singapore.-Bukit Timah, Tuas, Kranji, Seletar and Sembawang.

Penang.-Batu Feringgi, Telok Bahang, Relau Hills and Government Hili

Dindings.-Lumut, l'anjong Hantu and Pangkor Island.

Malacca.-Bukit Bruang and Bukit Sebukor.

40. Mr. V. P. BuRges, Forest Ranger, Grade I, continued to be in charge of the forests of Penang and Province Wellesley throughout the year under the direction of the Conservator of Forests. In all matters not purely technical he is subject to the direction of the Resident Councillor, Penang.

41. In the Dindings, the District Officer had the general direction of the department, assisted by Mr. BorGuS.

42. In Malacca, Mr. G. M. O'Hara, Forest Ranger, Grade I, continued in charge throughout the year subject to the directions of the Resident, Malacca, and the Conservator of Forests.

The Resident, Malacea, and the Conservatur of Forests formed a Committee to manage the finances of the Ayer Kroh and Bukit Sebukor plantations, the funds being in the charge of the Gardens Committee.

43. - In Singapore, the Collector of Land Revenue administered the forest department with the assistance of Mr. T. C. Malaya PILlaI, Forest Ranger, Grade III. 


\section{Subordinate Staff.}

44. In Singapore, one forest guard resigned and one was dismissed.

45. In Penang and Province Wellesley, one forest guard was transferred to the Federated Malay States department by permission.

46. In the Dindings one forest guard resigned and the widow of ANDAK BIN SIDIK, deceased, Forest Ranger, Grade IV, was granted a gratuity of $\$$ Ioo.

47. In Malacca, Forester BABA BIN HuSSEIN was appointed Forest Ranger Grade IV, in place of ANDAK on IIth May, and the Senior Forest Gkard MANAP BIN LAM promoted to Forester. One forest guard was permitted to $\mathrm{r}$ sign, and one resigned on account of illness. The Tindal of Ayer Kroh plantation, HAJI SEMAN, was dismissed in September.

48. The following was the staff employed during the year:-

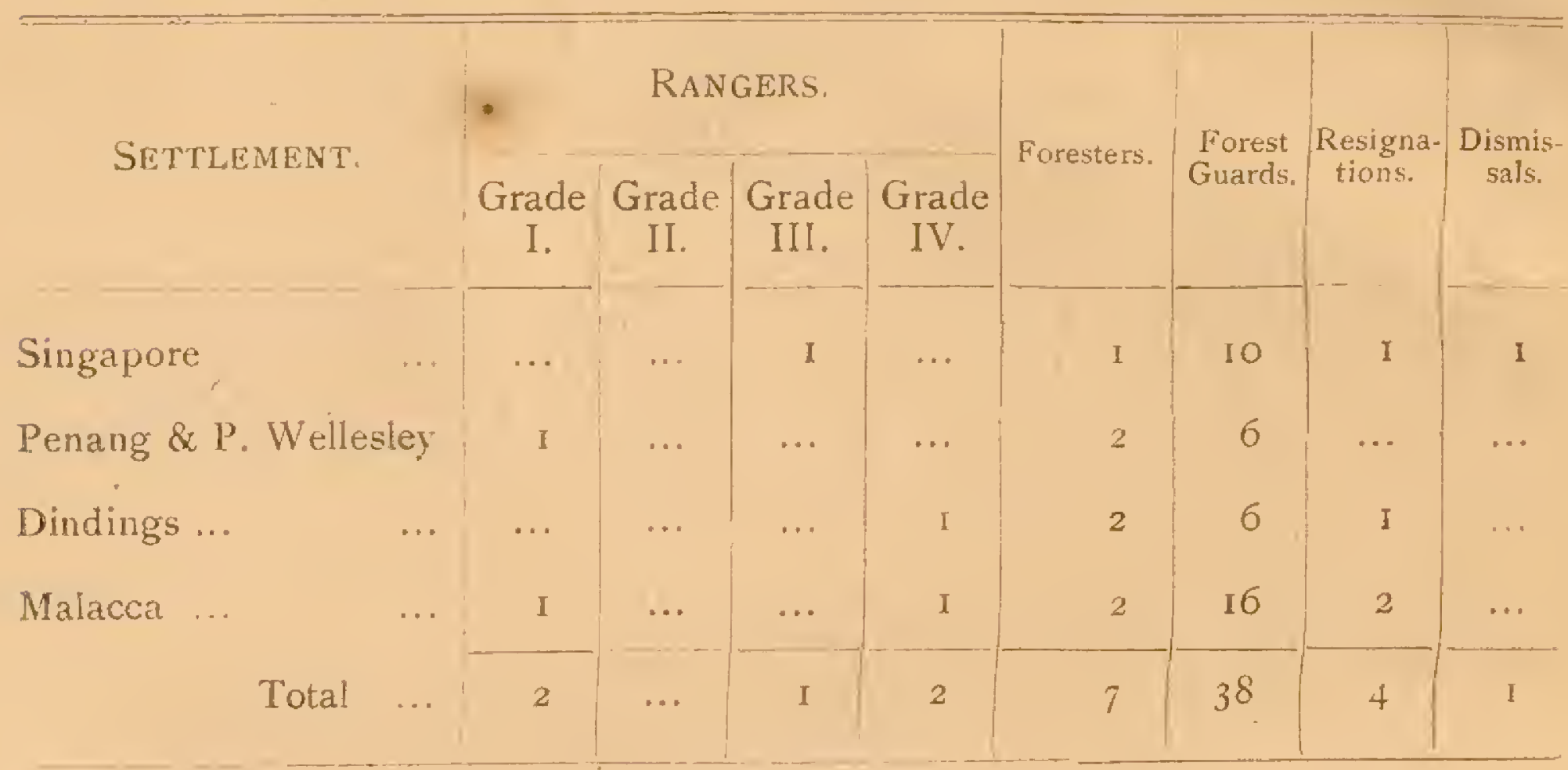

KUALA LUMPUR, . I7th March, IgI 2 .
A. M. BURN-MURDOCH,

Conservator of Forests, S. S. and F. M.S. 
FORM NO I.

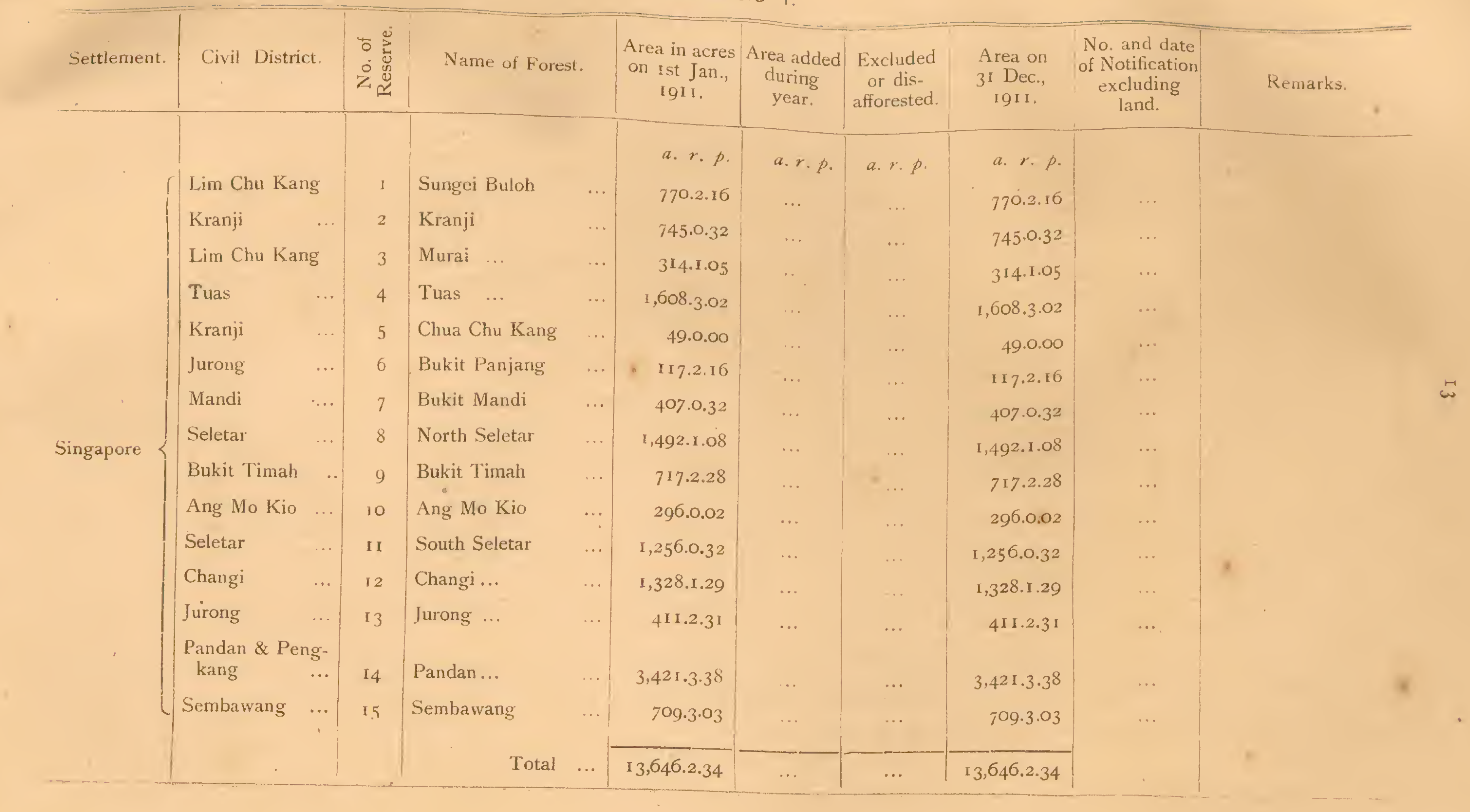


FOrm-No. 1.-Continued.

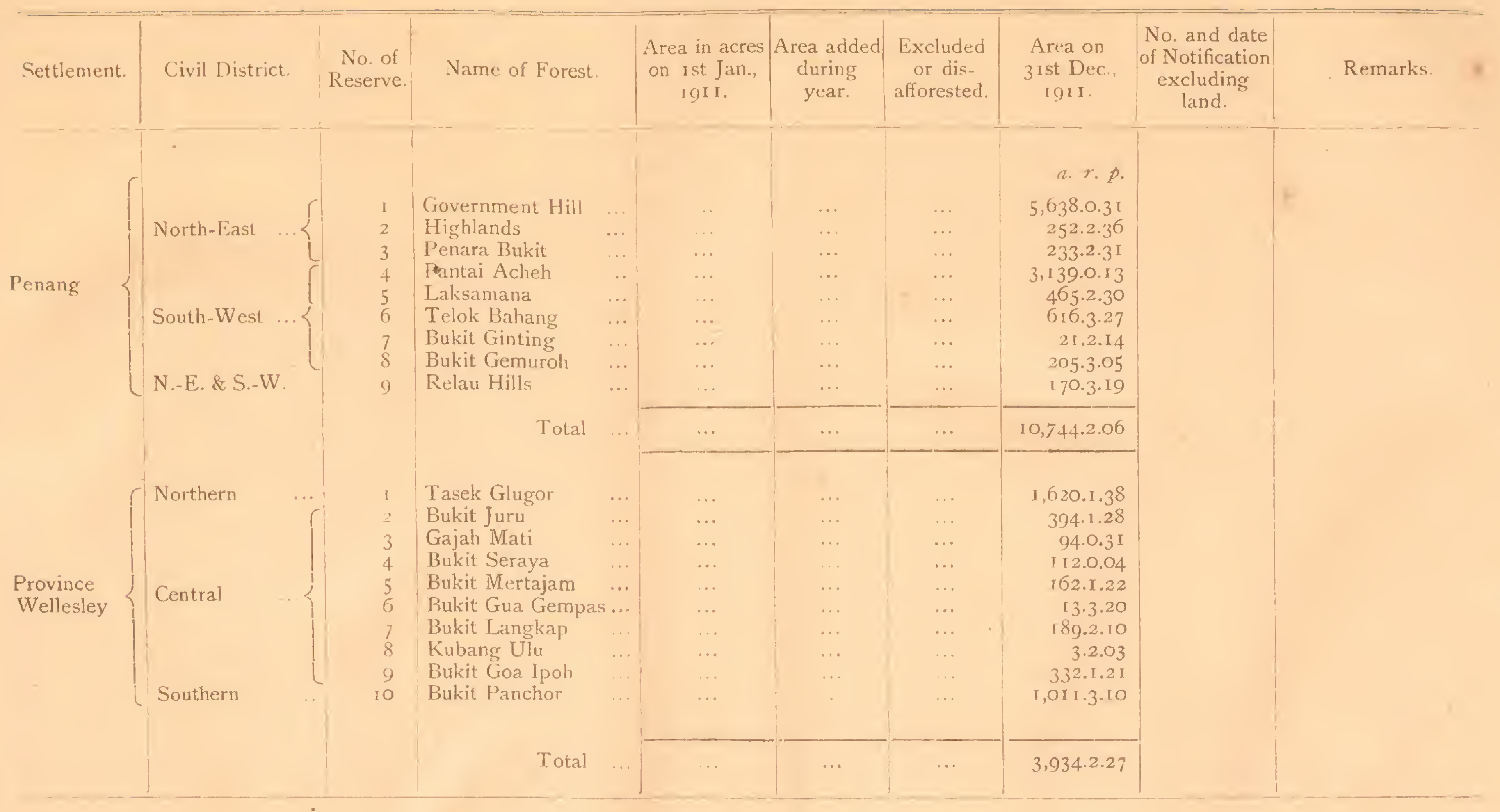


FORM No. I.-Continued.

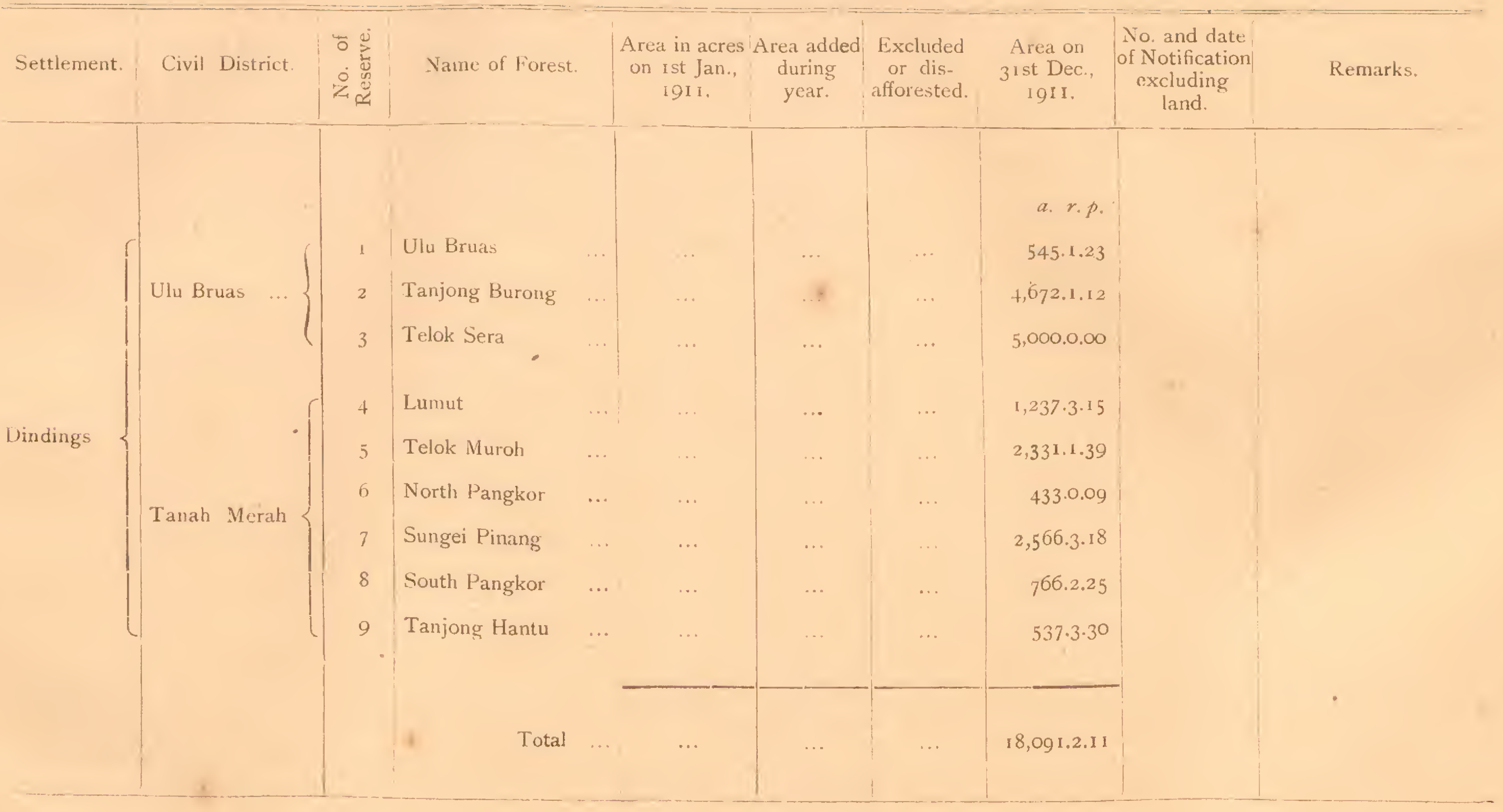




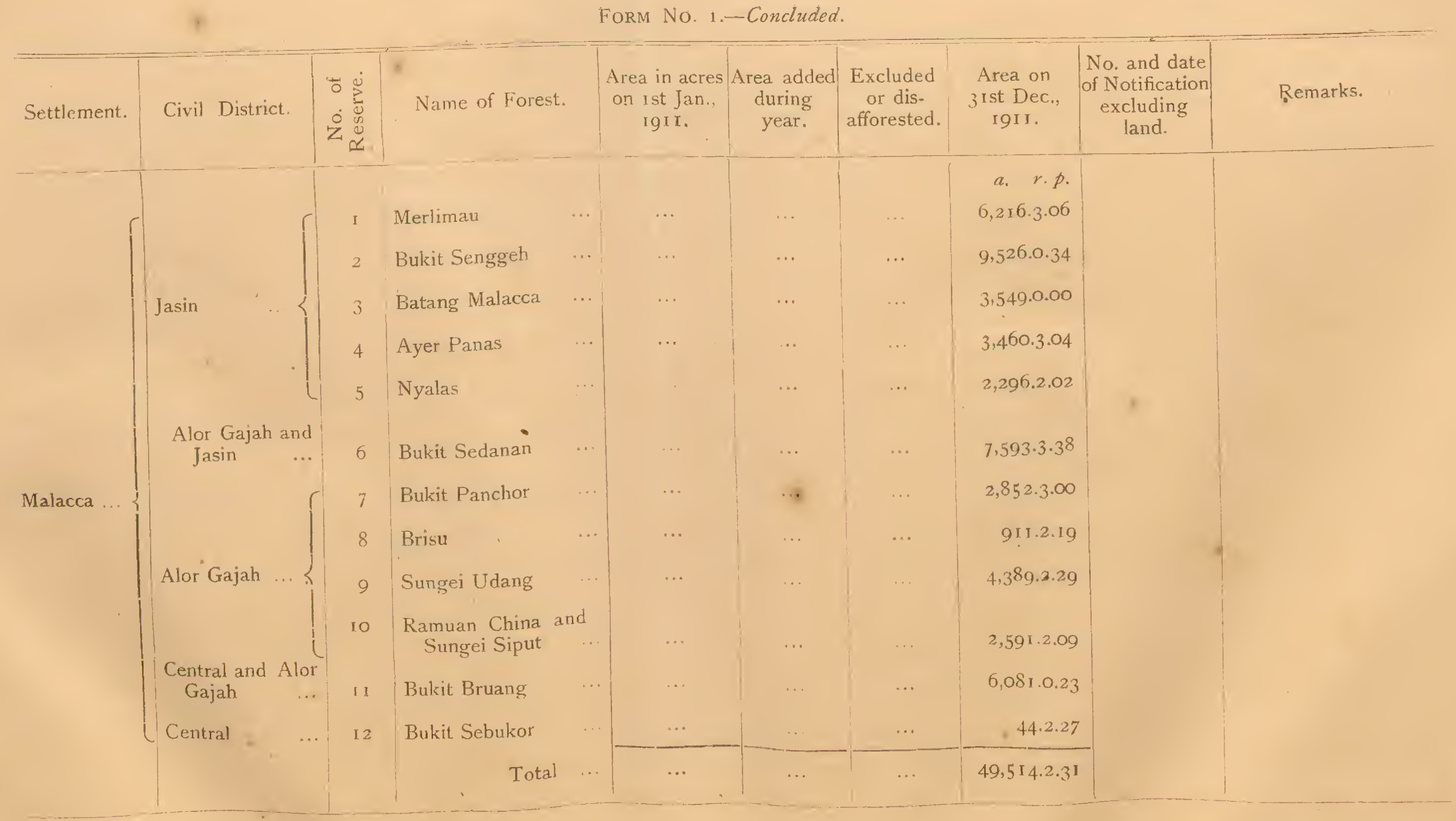



FORM No. 8 .

Area of Plantations.

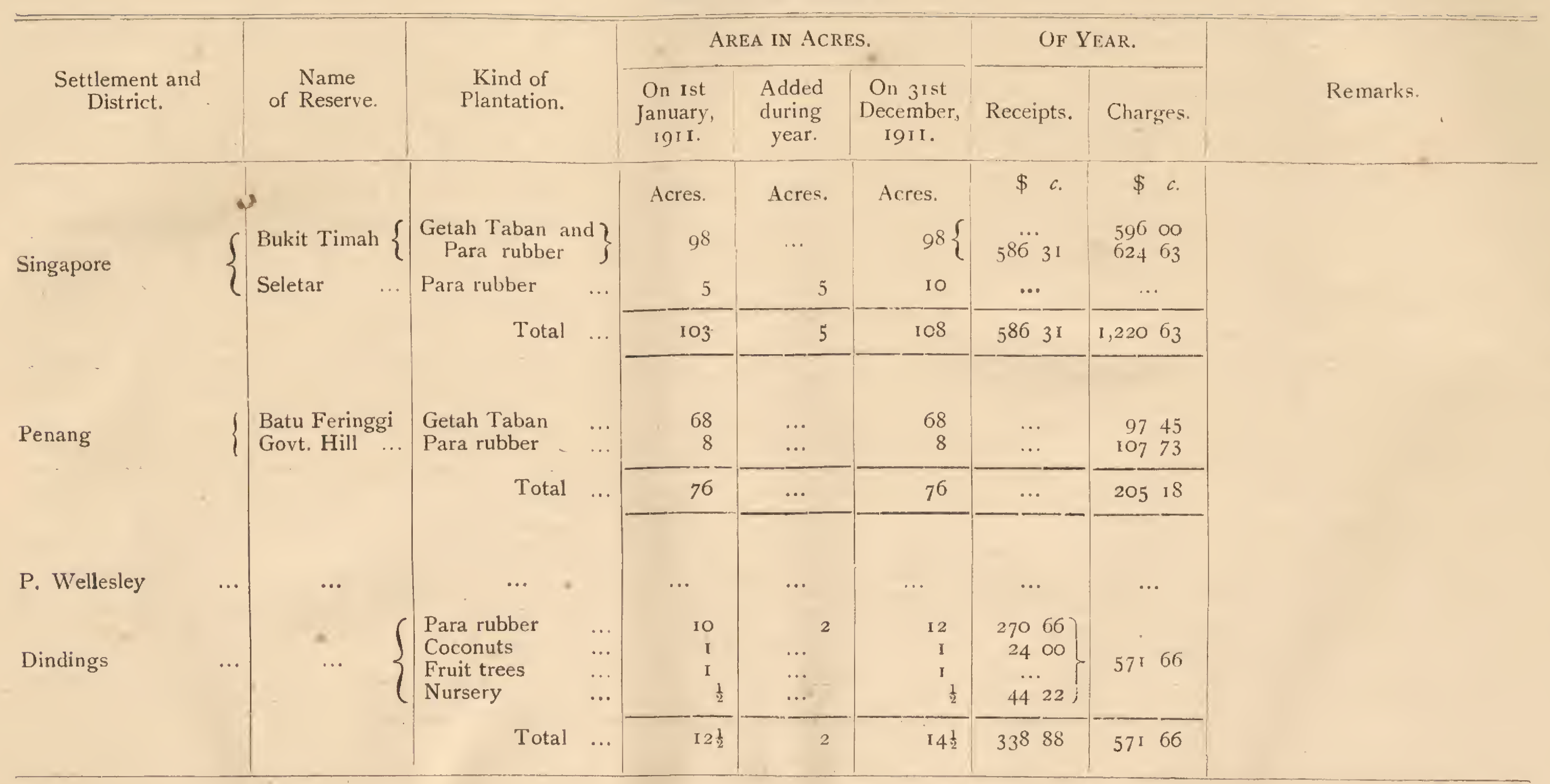


FORM No. 8.-concluded.

Area of Plantations.-concluded.

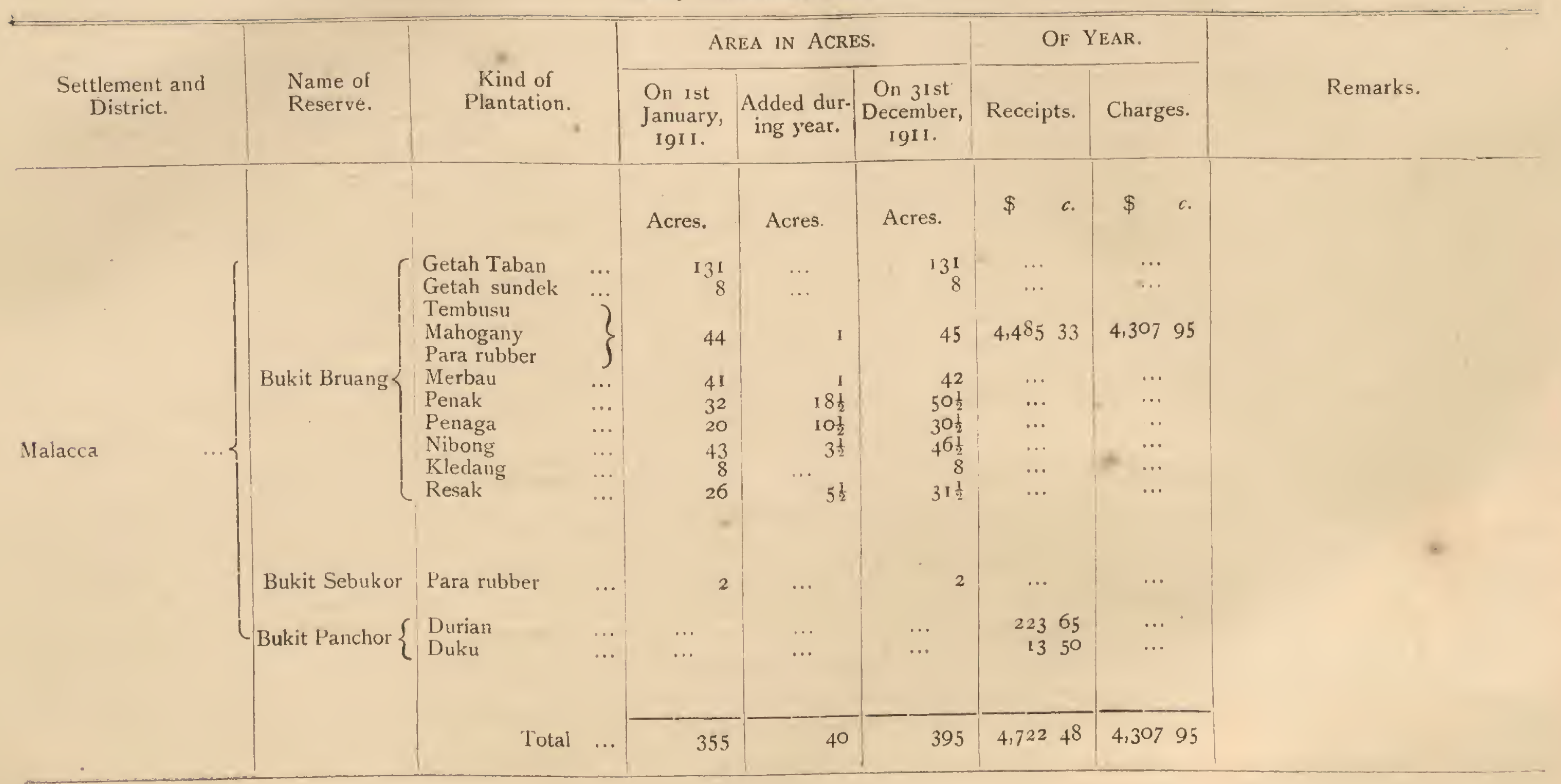




\section{Singapore.}

FORM NO. I I.

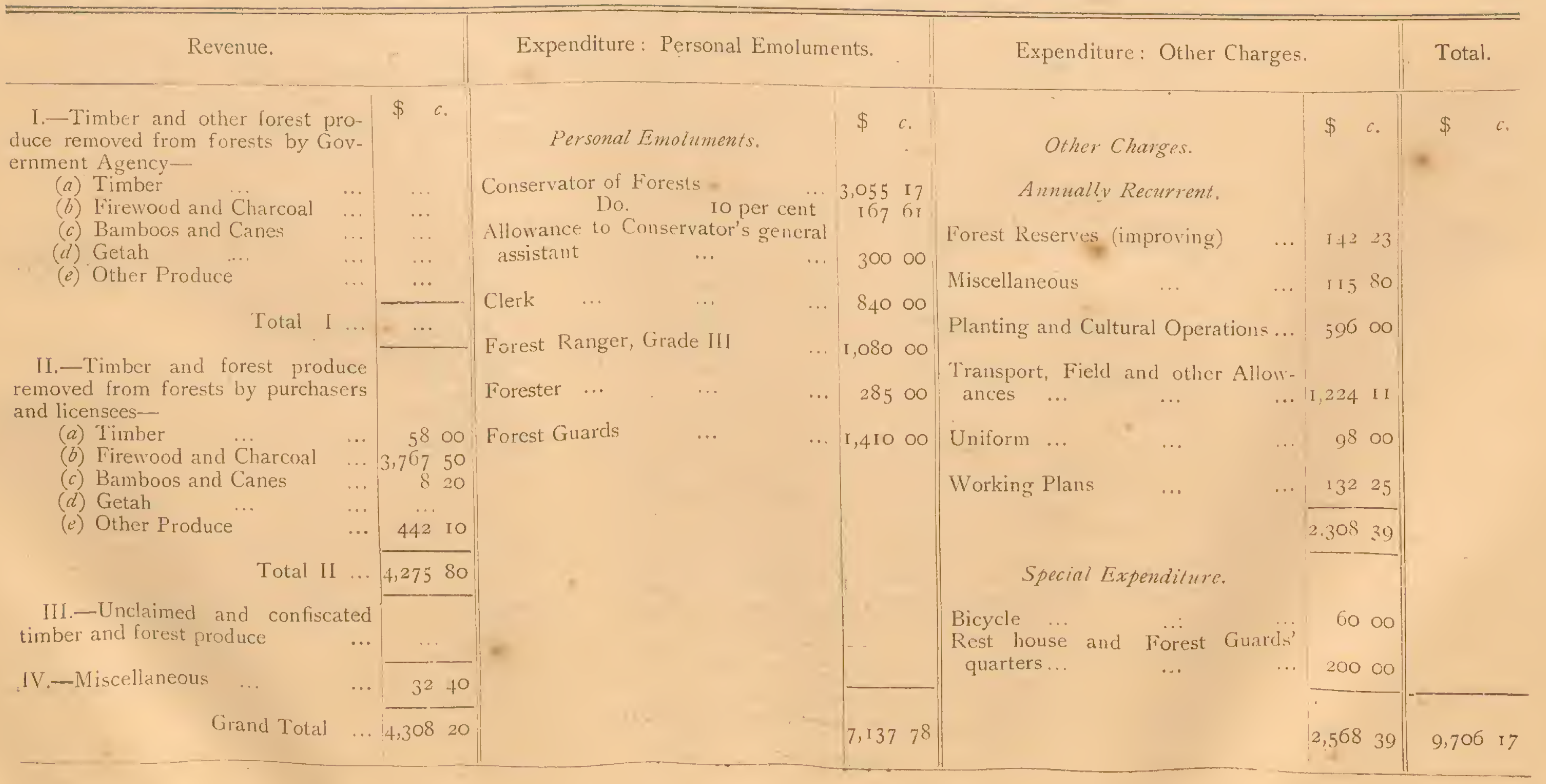


Penang and Province Wellesley.

FORM No. II-Continued.

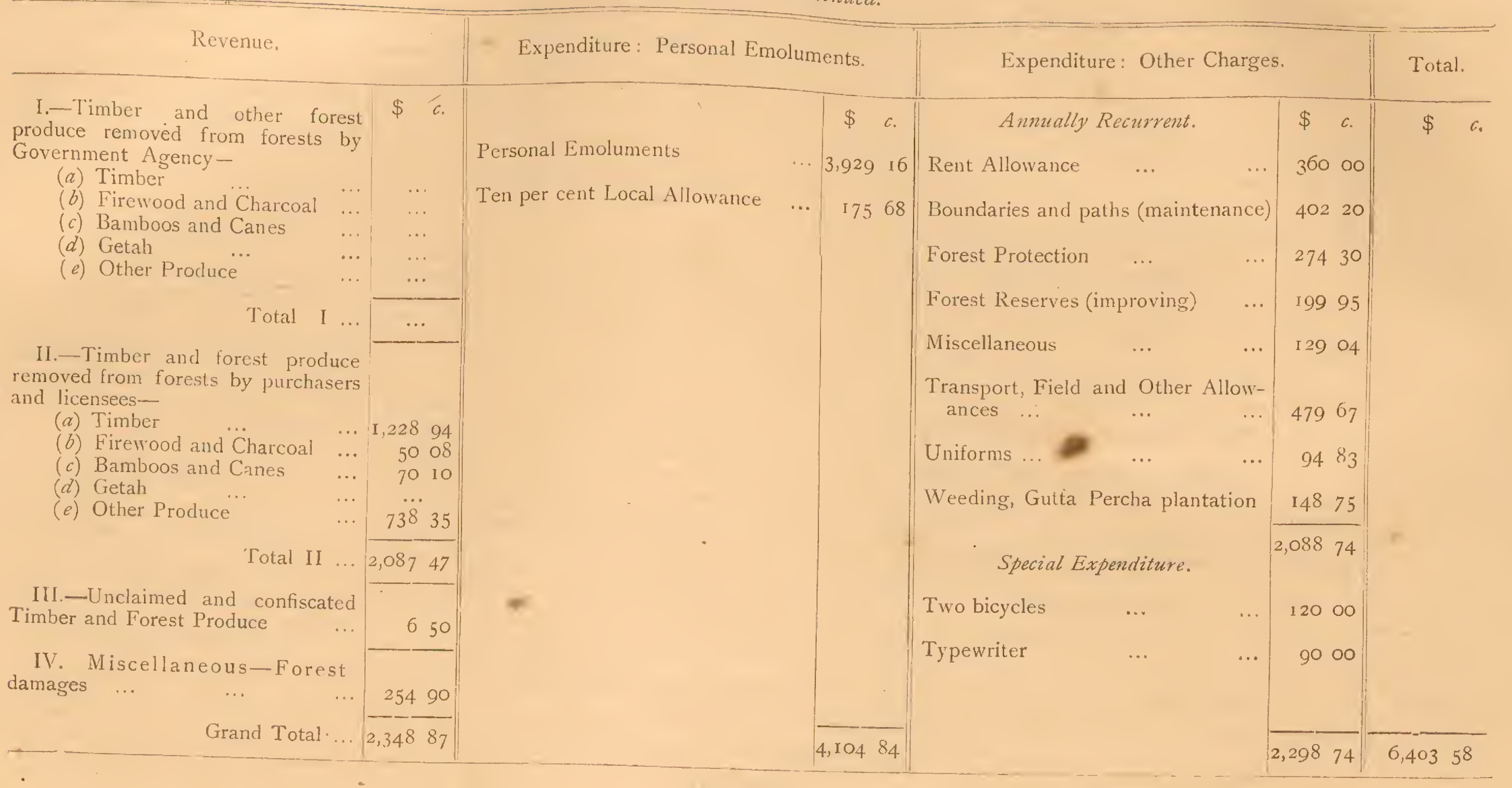


Dindings.

FORM NO. II-Continued.

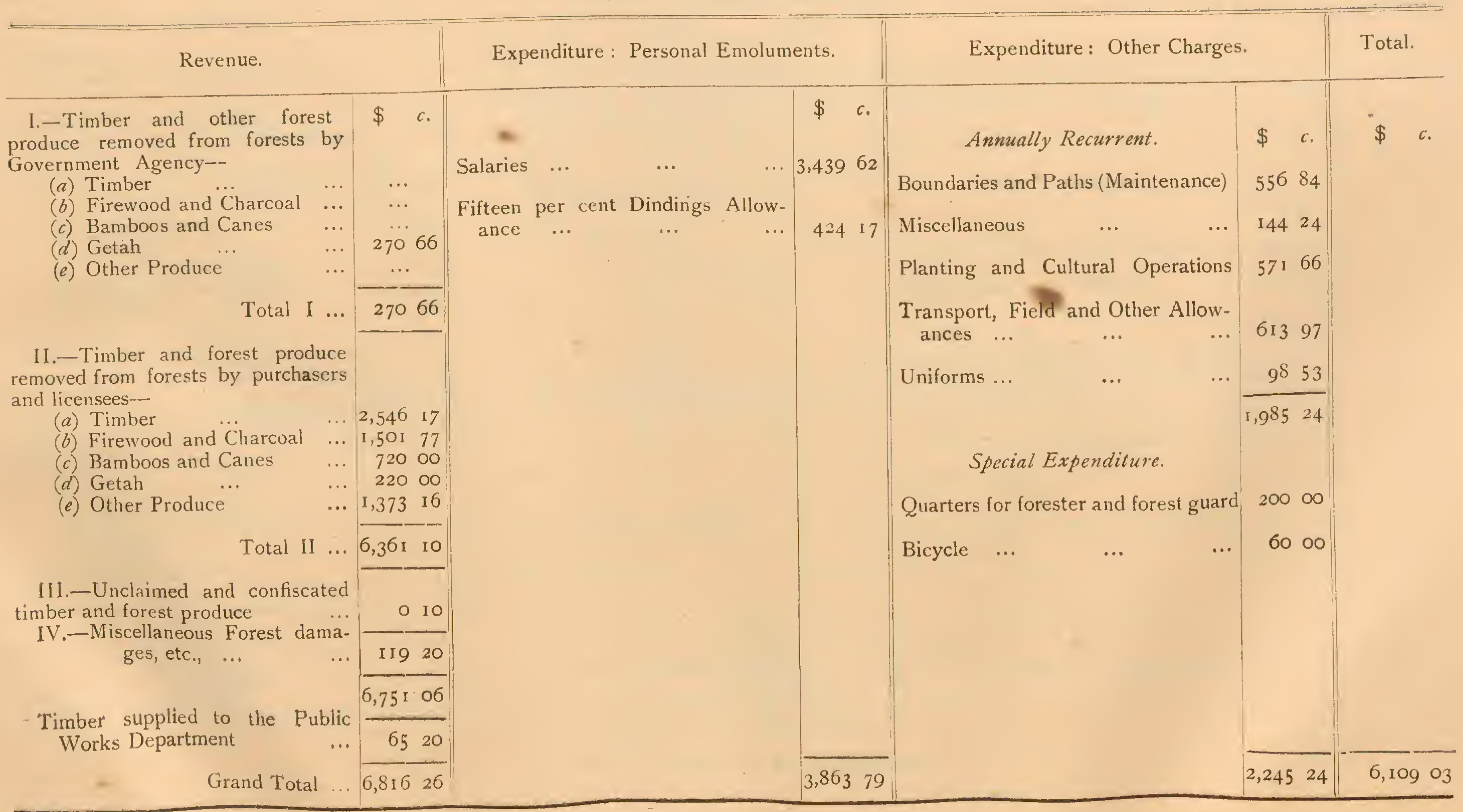




\section{Malacca}

FORM NO. I I.-Concluded.

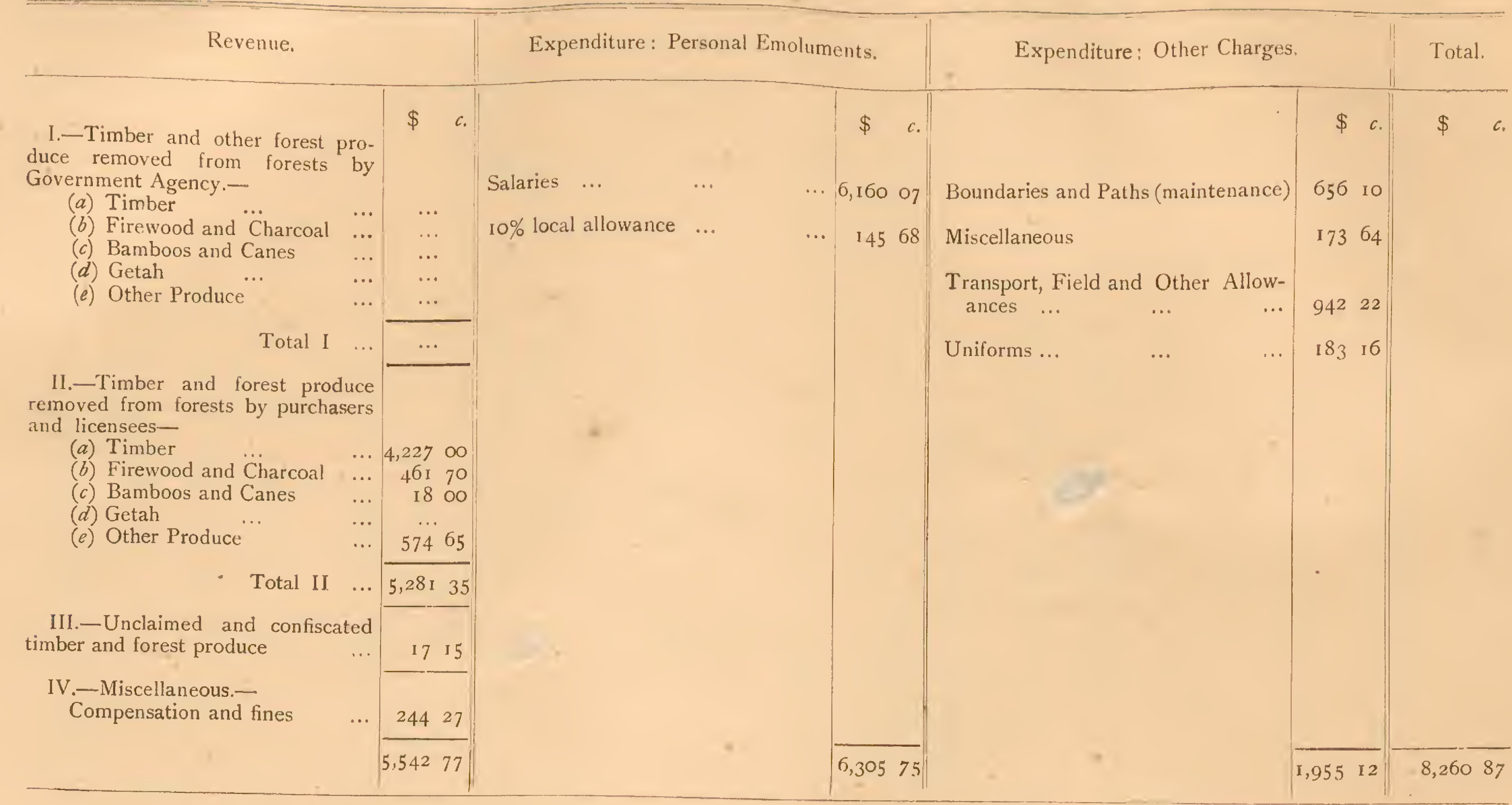

A. M. BURN-MURDOCH

Conservator of Forests, S. S. and F. M.S. 


\title{
STRAITS SETTLEMENTS.
}

\author{
Paper to be laid before the Legislative Council by Command of \\ His Excellency the Governor.
}

\section{Report on Labuan for the Year 1912.}

\section{Revenue and Expenditure.}

The Revenue for the year was $\$ 76,084.40$, as compared with $\$ 78,990.44$ in the previous year. The Expenditure amounted to $\$ 99,199 \cdot 32$, as against $\$ 105,989.87$ in $19 \mathrm{I}$.

Abstracts of Revenue and Expenditure are appended ( $A$ and $B$ ).

Trade.

The trade of Labuan showed an increase of $\$ 27,828$ under Imports and $\$ 72,105$ under Exports on that of IgII. The mines at Coal Point which were closed by the Labuan Coalfields Company, Limited, on the gth March, 19I I, have not yet been re-opened. This as was pointed out in the annual report seriously affected the pros. perity of the island as the Company formerly employed 13 Europeans and 800 Chinese and spent about $\$ 20,000$ per mensem in the place. follows :-

The comparative values of the trade of the island in the past three years were as

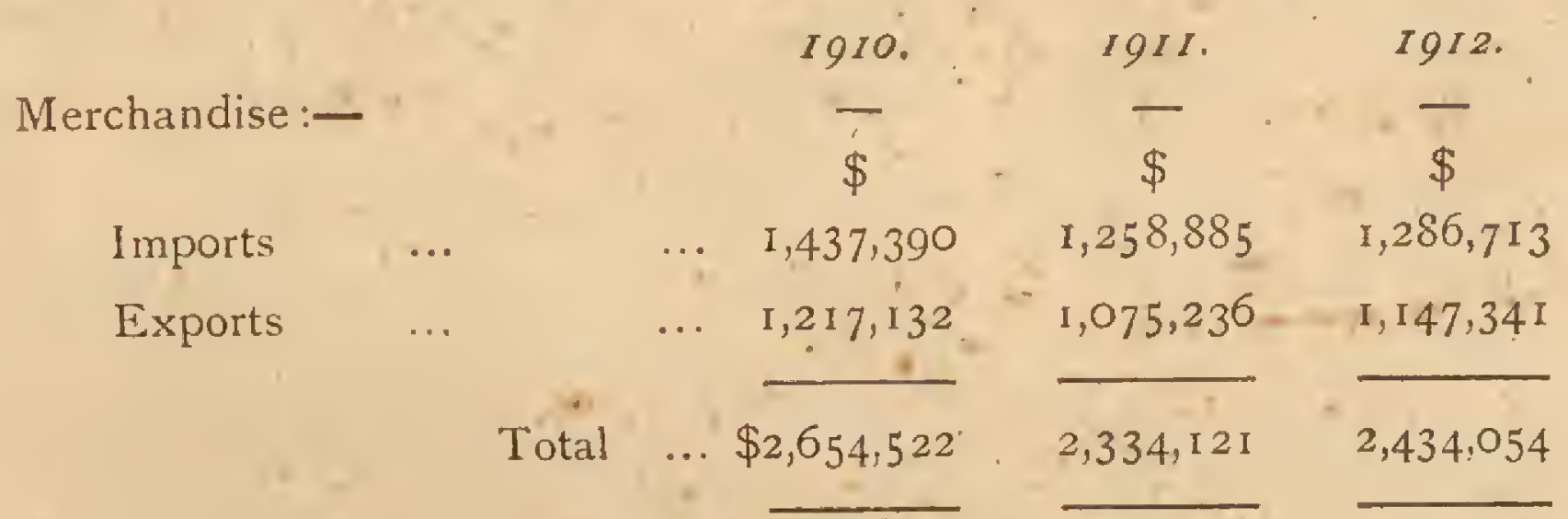

The imports and exports to ports other than the Straits Settlements ports were:-

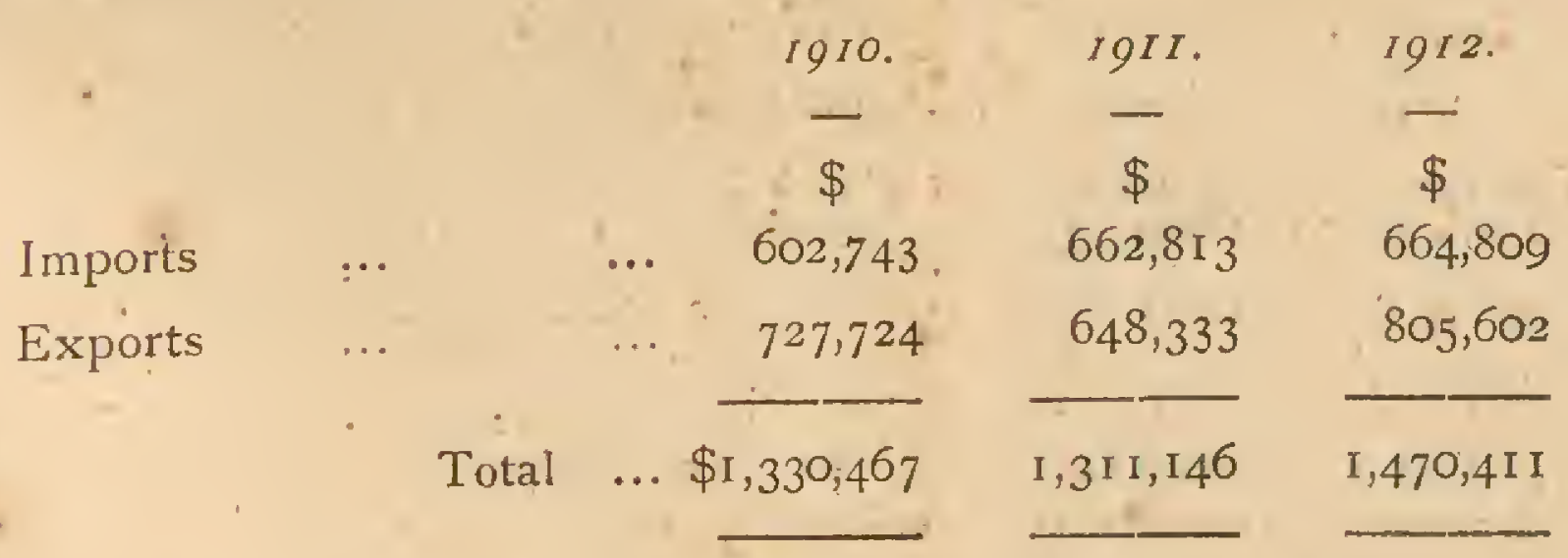

The importation of Brunei coal from the Sarawak Government mines decreased slightly during the year.

Eleven thousand six hundred and ninety-two tons were exported as cargoes and bunkers, being 656 tons less than in the previous year.

The import trade with Singapore increased in value by $\$ 25,832$.

The export trade with Singapore decreased $\$ 85,164$ and that with British North Borneo increased by $\$ 139,748$. The exports to Brunei and Sarawak show a slight decline. 
Considerable quantities of merchandise that formerly came from the neighbourhood of the Limbang, Temburong and other rivers for shipment in Labuan now go to Singapore viâa Kuching by a Sarawak steamer.

Imports of rice, sago flour, inferior getah and petroleum advanced.

\section{Marine.}

The tonnage of shipping which entered Port Victoria and cleared was I26,4 II (British 24,403 tons and foreign 102,008, tons), as compared with 136,884 (British 42,288 tons and foreign 94,596 tons) in $191 \mathrm{I}$, and 282,742 tons (British 152,668 tons and foreign 130,074 tons) in I910. The decrease of 10,473 tons on the previous year's returns is accounted for by the work having been stopped in the Labuan Coal Mines ard less number of steamers calling in for bunker coal.

Foreign tonnage which more than doubled that of British was mainly German (95, I 80 tons) as in I gO8, I 909 and I9II. This, as explained in last year's report, may be considered due to the monopoly enjoyed by the coast vessels of the Norddeutscher Lloyd which have for many years carried the mails, passengers and freight to and from Singapore. There is now a regular weekly service between Labuan and Singapore, maintained by four steamers of the company.

The number of vessels under the heading "Native Craft" trading between British North Borneo, Brunei and Sarawak, which entered and cleared was 4,080 , being 970 more than in I9I.

H. M. S. Merlin arrived on the station in April, and remained till the end of the year, surveying these and Brunei waters-several new rocks and coral patches were found. Two shipments of Welsh coal and Briquittes ( 1,350 tons) were specially imported for the use of this vessel.

H. M. S. Newcastle called on the 24th December, and sailed for Manila on the 27 th.

Small steam craft show an increase over IgI I. Several of the officers of these have obtained certificates of competency as required by the Labuan Ordinance No. III of IgII, which came into force at the end of the year.

The foundation for a steel light-house on Kuraman Island was commenced and completed during the year, and the light should be established in I9I3.

\section{Land and Re-survey.}

The total amount collected by the Land Department was $\$ 10,459.99$, being $\$ 2,999.55$ more than in I9I I, vide Statement $C$ appended.

The increase was due to land sales and survey fees.

A larger revenue was expected but owing to the new grant forms having to be altered and printed in Singapore the grants could not be issued before the end of the last quarter of $19 \mathrm{I} 2$.

The Re-survey which commenced in I9IO, was continued with a staff consisting of a Superintendent, two Draftsmen and two Demarcators.

The Superintendent writes as follows on the work done:-

"The Re-survey of the Island of Labuan, excluding the northern portion which is conceded to the Coal Company, was completed last year (I9I2).

A sum of $\$ 22,000$ was voted for this work which was started in April, 1910. The estimates provided for Cadestral survey, dividing the country into main and subcircuits with the theodolite and filling in the rest with the plane-table. Since it was considered that a complete theodolite survey of allotments would be more suitable to settle and define the various boundaries of lands in dispute and also to issue accurate title plans, a triangulation of the island was made with theodolite surveys of holdings as well as main and sub-traverses based on it.

The employment of a smaller staff of officers than was intended, dispensing with the services of higher salaried assistants, enabled this work to be executed within the original estimate of $\$ 22,000$.

Before the completion of the above survey, certain works for the Land Department were required to be taken up, for which a sum of $\$ 6,000$ was granted. Of these, all application surveys, most of the sub-divisions, and 400 title plans on grants, were completed during the year. 
Both the Re-survey and Land Office requirements were expected to end in November last. But, owing to the survey of the Coalfields Company's property being taken up in July last, on an estimate of $\$ \mathrm{I} 2,000$, to be carried out by men of the same staff, the sub-division surveys and the preparation of fresh titles could not be completed."

\section{Police.}

The Police Force, under the charge of one European Chief Inspector, was on the 3ist December, I9 I 2 , as follows :-

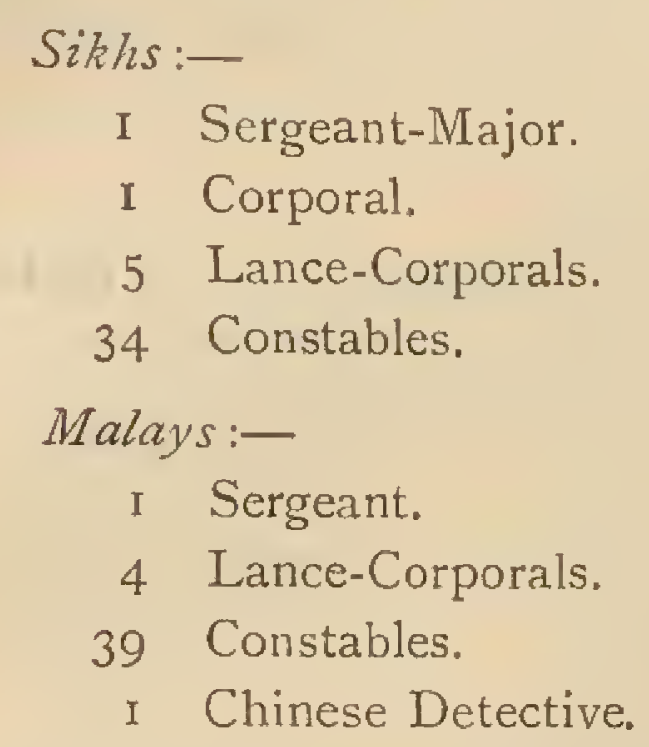

Of the above numbers I4 Sikhs (I Corporal, I Lance-Corporal and I 2 Constables), and 20 Malays ( 3 Lance-Corporals and I 7 Constables) did duty in Brunei.

Chief Inspector CRUMMEY reports that the conduct of both contingents was good. The Sikhs amongst whom there were many cases of drunkenness in I9I I have improved considerably in their behaviour.

The general health of the force has been extremely satisfactory. Only 4I cases were admitted to hospital as against 67 in I $9 \mathrm{I}$, and $\mathrm{I} 7 \mathrm{O}$ were treated as out-patients as against 3 I 8 in IgI I. The chief disease treated was Malaria. The percentage of sub-tertian cases appears to be gradually rising: this was specially noticed during the last three months of the year. No deaths occurred amongst the Police.

The Police received IIg reports as against 108 in IgI and I69 in IgIo. The 1912 reports included 9 of house-breaking and theft, 33 theft, 3 criminal breach of trust, 5 mischief, 9 voluntary causing hurt, 2 maiming cattle and 5 minor offences.

The offences reported against property for the last three years, showing value lost and recovered, were as follows :-

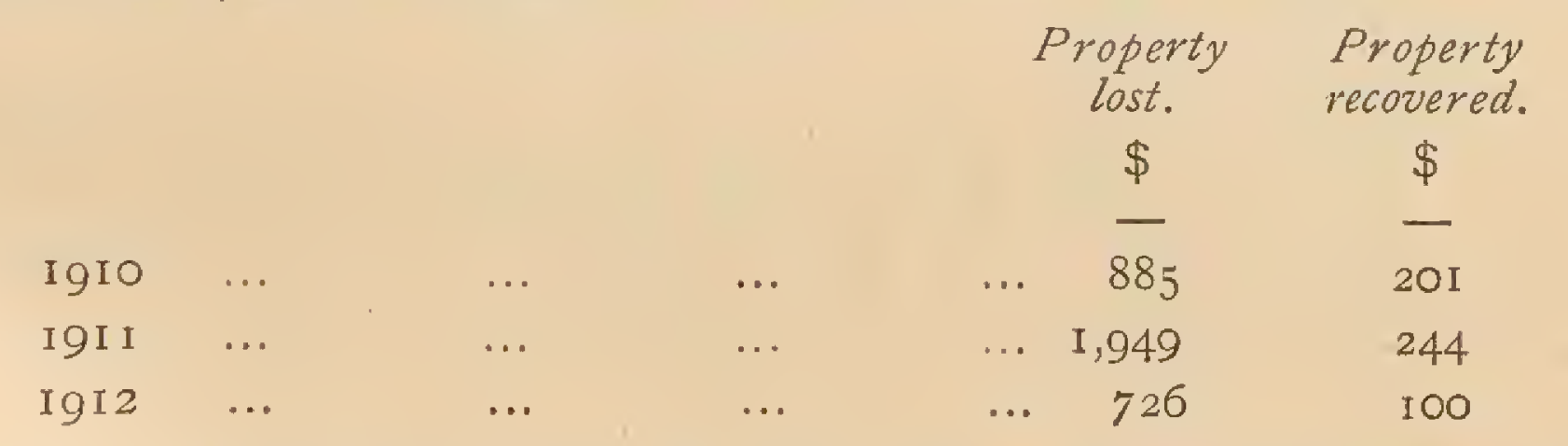

In all i 6 Police Court cases (69 Police prosecutions), 152 defendants came before the Police Magistrate. Of these $6_{5}$ persons were acquitted, 76 summarily convicted, 5 committed for trial to the District Court, the remaining 6 awaiting trial.

The following writs were issued by the Magistrate:-

Summonses 72, Subpœenas I08, Warrants of Arrest 4.

\section{Prisons.}

On the Ist January, I9I2, there were 20 male prisoners in gaol and 46 were received during the year. Of these 43 were discharged and 2 transferred to the Singapore Criminal Prison and 2 I remained on the 3 Ist December.

The daily average of prisoners was 22 'I3.

The Superintendent reports that their conduct was very good.

There was one European prisoner who was transferred to Singapore.

The Medical Officer writes that the health of the prisoners was good throughout the year. The short-ientence prisoners almost invariably increase in weight and health during their time in the gaol. No deaths occurred amongst the prisoners. 


\section{Census.}

The last census of the island was taken at midnight on the roth March, I9II, and the population was 6,546 persons, consisting of 3,662 males and 2,884 females. The European and allied races accounted for 34 (25 males and 9 females), Eurasians 20 (9 males and II females). Chinese I,799 (I,26I males and 538 females), Malays 3,163 ( 1,578 males and I,585 females), Malays of Archipelago I,27I (623 males and 648 females), Indians 193 (I40 males and 53 females), others 66 (males 26 and females 40 ).

About 1,000 Chinese and 7 Europeans employed in and about the coal mines left the island before the census was taken.

\section{Medical.}

The total number of births registered was 2 I I and deaths I 25 . The birth-rate was 31.80 and the death-rate I 8.84. Of the total number of deaths, Malaria accounted for 34, Pulmonary Tuberculosis for 17 , Old age and Debility for 16 , Beri-beri for 3 and Dysentery for 3. Of the infantile mortality one-third of the deaths were ascribed to "Fever" and one-fourth to "Convulsions."

The Medical Officer states that the birth-rate is the highest for the past ten years or more and the death-rate shows a distinct improvement. He attributes the satisfactory state of the general health of the community to the fact that no new coolies have been imported into Labuan, and of those who were originally imported nearly all have left the island, leaving behind only natives and Chinese who are well acclimatized. The whole year must be regarded as the most satisfactory on record from the Public Health view.

One mild case of small-pox was removed from the s.s. Mau Sang and isolated in the hospital buildings. She was detained at the quarantine anchorage for three days, during which time a temporary atap and kajang shed was erected on Pulau Papan for the accommodation of the 127 deck passengers, and all the members of the crew were re-vaccinated. After the removal of the deck passengers to Pulau Papan, on the fourth day, the s.s. Mau Sang was allowed to come alongside to discharge her cargo, being subject to daily inspection of the Medical Officer. No further cases of small-pox occurred, either amongst the crew or deck passengers. All the latter who did not bear obvious signs of recent small-pox were re-vaccinated on Pulau Papan.

The total number of patients treated in hospital was 2 ro as against. 296 in 19 II and 338 in 1910 .

Dr. Cleverton writes as follows regarding Malaria:-

"There has been much less sickness from this disease and the percentage of deaths from this infection was only $27^{\circ} 2$ of the total death-rate, as against $3 I^{\circ} \mathrm{I}$ in IgI I. Only 58 cases were admitted to hospital as against II 8 in I9I I and only 198 cases of Malaria were treated as out-patients as against 479 in IgII. This shows a very considerable decrease on all cases of Malaria but the percentage of sub-tertian cases has risen throughout the year. About $\$ 2,000$ were spent by the Public Works Department upon anti-malarial works: these included further concrete drains in the town of Victoria: the filling up of a large area of swampy and uneven land at the eastern extremity of the town: the cutting and burning of large areas of jungle (secondary) in the suburbs. These works have been of real benefit to the health of the town and suburbs. Ninety-seven ounces of quinine were used as a curative and prophylactic agent during the year. The Sanitary Inspector has been instructed to see to the removal of empty tins, bottles, coconut shells, etc., in the town."

Only 16 cases of Beri-beri were treated in hospital as against 44 in I9I I and there were only 3 deaths attributed to this disease as against Io in IgII. Parboiled rice was used throughout the year.

The chief diseases treated in hospital during the year were:-Malaria 58 with 2 deaths, Beri-beri I6 with I death, Pulmonary Tuberculosis I3 with 4 deaths, Dysentery. 9 with 2 deaths and Venereal diseases 2 I with no deaths.

The total number of vaccinations done were- 459 as against 229 in I9I I. The number of vaccinations was considerably larger than last year owing to the vaccinating of the deck passengers and crew of the Mau Sang from Hongkong infected with small-pox.

Meteorological. - The North-east Monsoon blew from January to the beginning of May: during this season the supply of water for domestic purposes began to fail, until in April the Reservoir supplying the town of Victoria completely failed and trains were requisitioned to bring water down from Coal Point Reservoir, a distance of eight to 
nine miles. The hospital well was dry from January to April, with short intervals of water immediately after rain. The South-west Monsoon blew from the beginning of May to the middle of November, when the wind blew from the North-east and Southwest about equally, the morning records showing South-west and the evening records North-east.

The total rainfall was II 7.54 inches as compared with $09^{\circ} 82$ inches in I9II and 151.25 inches in I9IO. The wettest month was May with 20.67 inches: the greatest rainfall in 24 hours was on the 8 th of June, when 6.02 inches fell. The mean temperature of the air was $81^{\circ} 9^{\circ} \mathrm{F}$. (mean maximum $87^{\circ} 9^{\circ} \mathrm{F}$. and mean minimum $73^{\circ} 6^{\circ} \mathrm{F}$.), as compared with $8 \mathrm{I}^{\circ} 5 \mathrm{I}^{\circ} \mathrm{F}$. (maximum $87^{\circ} 47^{\circ} \mathrm{F}$. and minimun $75^{\circ} 76^{\circ} \mathrm{F}$ ) in I $1 \mathrm{I}$, and $83.5 \mathrm{I}^{\circ} \mathrm{F}$. (maximum $83.55^{\circ} \mathrm{F}$. and minimum $76.38^{\circ} \mathrm{F}$ ) in 1910 . The highest temperature recorded was $95^{\circ} 5^{\circ} \mathrm{F}$. and the lowest $7 \mathrm{I}^{\circ} \mathrm{F}$., as against $94^{\circ}, \mathrm{F}$. and $7 \mathrm{I}^{\circ} \mathrm{F}$. in $19 \mathrm{Ir}$, and $93^{\circ} \mathrm{F}$. and $72^{\circ} \mathrm{F}$. in 1910 .

\section{Post Office.}

The District Officer was in charge of the Department throughout the year.

The nett receipts for the year amounted to $\$ 2,276.77$ as against $\$ 2,686.80$ in I9II. The expenditure was $\$ 2, \mathrm{I} 75.7 \mathrm{O}$, being $\$ 28.4 \mathrm{I}$ less than in the previous year.

The total number of postal articles dealt with including those received for transmission to other countries was $\mathrm{I} 25,056$, as compared with I04,947 in I9II. The registered articles numbered 7,642 , as against 7,050 in 19I I. The parcels delivered numbered 923 and those despatched 378. The total Money Order transactions (issued and paid) amounted to $\$ 40,943.46$, an increase of $\$ 7,622$.0I as compared with the previous year. The principal increase was in the remittance to Singapore which amounted $\$ 19,678.23$, as against $\$ 10,643.12$ in I I I I, an increase of $\$ 9,035$. I I.

The sale of British Postal Orders amounted to $\$ 3,330.24$, a decrease of $\$ 2.93$. Local Postal Orders showed a decline, closing with a decrease of $\$ 98$.

Insured articles of a total value of $\$ 5,164.08$ were handled. The cash-on-delivery work has slightly increased since I9 I I, 48 packets valued at $\$ 489$. I4 were received from London, and 82 packets valued at $\$ 633.07$ from Singapore.

A regular weekly mail service with Singapore was maintained by the Norddeutscher Lloyd steamers Darvel, Sandakan, Marudu and Chow Fa which reached Labuan on Tuesdays and Wednesdays.

\section{Public Works Department.}

The total expenditure of the Department including $\$ 3,650.42$ for Personal Emoluments was $\$ 32,640.99$ as against $\$ 35,378$ in I9I I.

Several lengths of street drains were regraded and 300 lineal feet of concrete drains were constructed in the town during the year. Several existing timber culverts and bridges were repaired.

A new Contagious Ward for the hospital (a steel skeleton structure) and the stonebuilt quarters for the crew of the Kuraman Light-house were the only important works carried out during the year.

The number of contracts entered into were I2, and I i were completed.

\section{Schools.}

The number of boys on the register of Victoria (S. P. G.) School, which is still in charge of Mrs. FELL, was $2 S$ on the Ist January and 32 on the 3 Ist December, I9 12. The daily average attendance was 27 . The total on the roll of the Government Vernacular School was 49 on the Ist January and $5^{I}$ on the 3 Ist December, I9I2. The average daily attendance was 40.

\section{General.}

His Excellency F. R. Ellis, C. M. G., Governor of British North Borneo, paid the Settlement a brief visit on the 5 th February.

MOHAMED YUSOFF and his son who were committed for trial at the Singapore Assizes for the murder of a Sikh Police Constable in I9I I were found not guilty and discharged.

The following officers went to Singapore in connection with the above-mentioned murder case :-

Messis. S. E. Dennys, J. R. Dissanaike, Chief Inspector Crummey and Dr. Cleverton, Dr. Gibbs from Singapore acted as Medical Officer during the absence of the latter. 
Mr. E. ROBERTS, Executive Engineer, went on long leave on the I8th April and returned to duty on the 6th December. Mr. N. WiLkinson, Assistant Engineer, Singapore, acted for him during his absence.

Mr. J. K. Webster, Harbour Master, went on long leave on the 25th June and returned to duty at Singapore on the 5 th December. During his absence Mr. H. Walpole of the Colonial Yacht Sea Mezw acted for him.

His Excellency F. R. ELLIS, C.M.G. and Mrs. ElLIS passed through here en route for Europe on the 27th June.

The following Heads of Departments visited the Settlement on inspection duty during the year:-

Thè Inspector-General of Police, the Auditor-General, and Mr. H. V. Towner, Executive Engineer, Singapore, who came on behalf of the Colonial Engineer.

Dr. R. E. ADAMSON, the only private medical practitioner, who had been ailing for some weeks, died on the 24th July much to the regret of all. Dr. ADAMSON, first came to Labuan in I 894 as Colonial Surgeon but resigned the service in 1908.

Mr. S. E. Dennys, District Officer, was granted I4 days casual leave on the 5 th August to proceed to Singapore.

His Excellency J. SCOTT MASON, the newly appointed Governor of British North Borneo, with Mrs. SCOTT Mason, passed through Labuan to take up his appointment on the 3 oth October. On the 6th December the sad news of his sudden death was received here by telegram.

\section{HARVEY CHEVALLIER, Acting Resident, Labuan.}

\section{A}

Abstract of Revenue, Labuan,-1912.

\begin{tabular}{|c|c|}
\hline & $\$$ \\
\hline Port, Harbour, Wharf and Light Dues & $2,7207 c$ \\
\hline $\begin{array}{c}\text { Licences, Excise and Internal Revenue } \\
\text { not otherwise classified... }\end{array}$ & 49,5 I 77 \\
\hline $\begin{array}{l}\text { Fees of Court or Office, payments for } \\
\text { Specific Services, and Reimburse- } \\
\text { ments in aid }\end{array}$ & I I $_{4}$, O I 4 \\
\hline Posts and Telegraphs $\quad \ldots$ & 2,2767 \\
\hline Rents on Government property & 4,7677 \\
\hline $\begin{array}{lll}\text { Interest } & \ldots & \ldots\end{array}$ & I $06 \mathrm{I}$ \\
\hline Miscellaneous Receipts & 6246 \\
\hline Land sales $\ldots$ & 2,0564 \\
\hline
\end{tabular}

Total Revenue for the year $\ldots \$ \frac{\$ 7,08440}{}$

* $\$ 5.142 .88$ contribution from Imperial Funds towards expenses of Consulate. \$1,600 Hospital Board, Government contribution. 
B

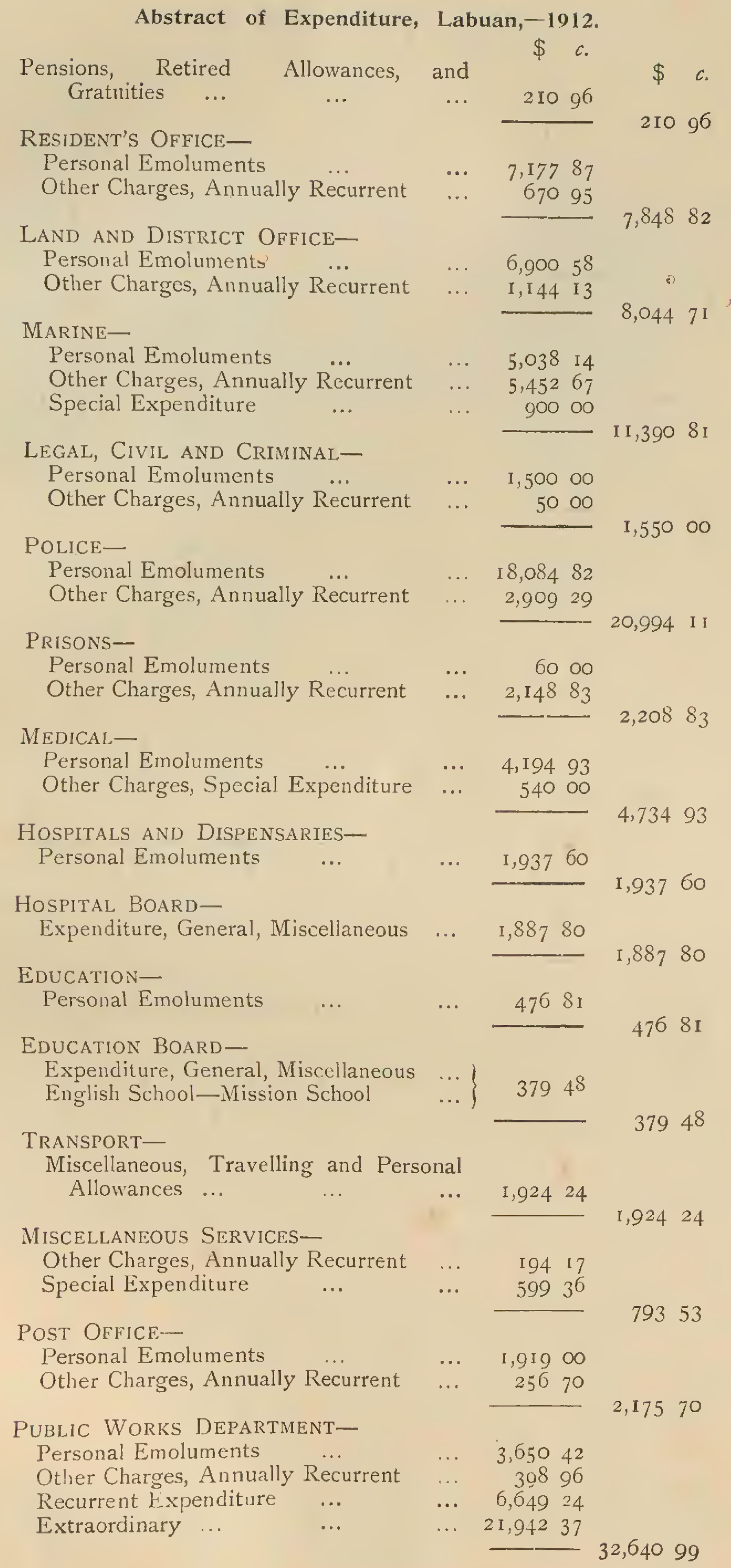

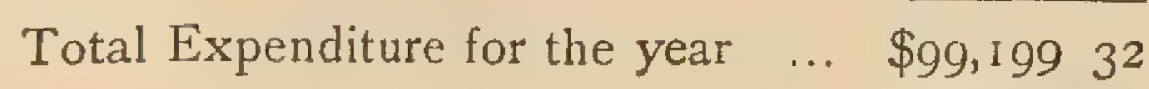


C.

ABSTRACT OF LAND DEPARTMENT, I I 2.

\begin{tabular}{|c|c|c|c|c|c|c|c|c|c|c|c|c|c|c|c|}
\hline Month. & & 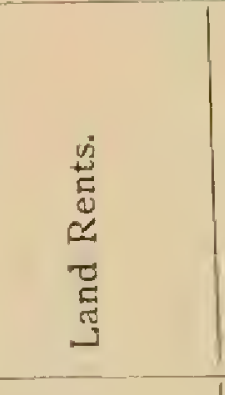 & 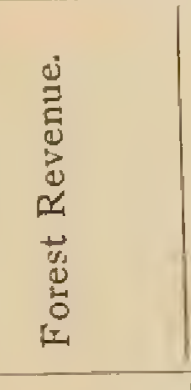 & 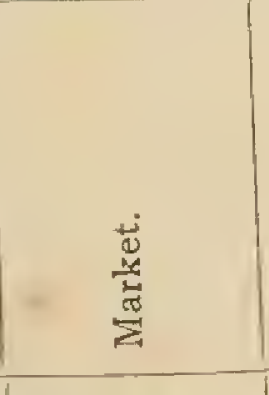 & 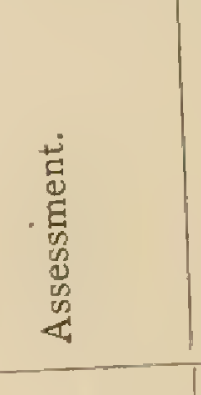 & 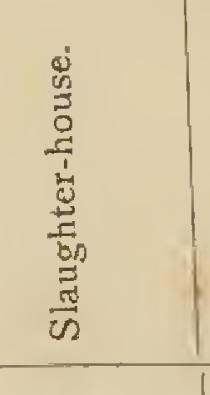 & 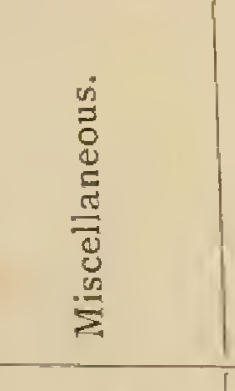 & 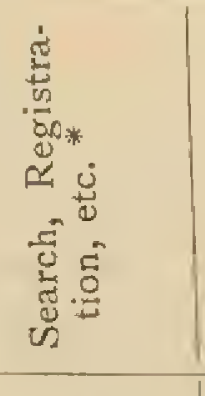 & 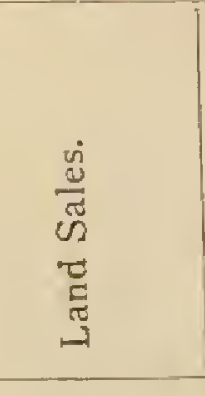 & 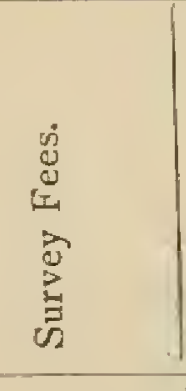 & 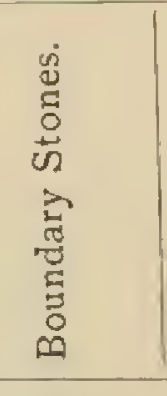 & 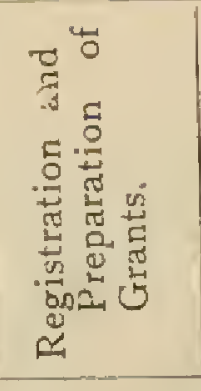 & 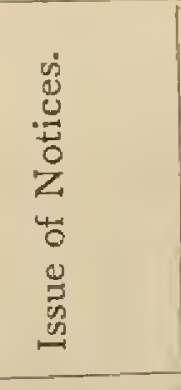 & 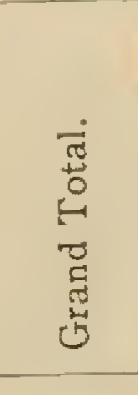 & $\mathrm{E}$ \\
\hline & & $\$ \quad c$ & $\$ c$ & $\$ r$ & $\$ c$ & $\$ c$. & & & & & $\$ c$. & $\$ c$. & $\$ c$. & $\$$ & $c$. \\
\hline January & $\cdots$ & $1,45^{6} \quad 82$ & 382 & 8000 & 21749 & 1200 & 1925 & 1650 & $\cdots$ & $\cdots$ & $\cdots$ & $\cdots$ & & 1,805 & 88 \\
\hline February & $\cdots$ & I4I 94 & $4 \cdot 68$ & 80 oo & 28406 & 800 & 1716 & 1000 & $\cdots$ & $\cdots$ & $\cdots$ & $\ldots$ & I 00 & 546 & 84 \\
\hline March & $\cdots$ & 48747 & 628 & 8000 & 91930 & 800 & 2882 & 1000 & $\cdots$ & $\cdots$ & $\cdots$ & $\cdots$ & $45^{\circ}$ & I, 544 & 37 \\
\hline April & $\ldots$ & $7^{6} 50$ & 497 & 8000 & 11003 & 700 & 1000 & 1400 & $\cdots$ & $\cdots$ & $\cdots$ & $\cdots$ & ${ }^{\circ}{ }^{\circ}$ & 303 & 300 \\
\hline May & $\ldots$ & 14670 & 479 & So oo & 2453 & 1200 & $156=$ & 3000 & $\cdots$ & $\cdots$ & $\cdots$ & $\cdots$ & I 50 & 315 & 14 \\
\hline June & $\ldots$ & 1867 & 335 & 100 oo & $937^{6}$ & 1300 & 2000 & 600 & $\cdots$ & $\cdots$ & $\cdots$ & $\ldots$ & $\cdots$ & 254 & 78 \\
\hline July & $\cdots$ & 3217 & 329 & 9000 & 184 IO & 700 & 500 & 025 & $\cdots$ & $\cdots$ & $\cdots$ & $\therefore$ & $\cdots$ & $3^{21}$ & $8 \mathrm{I}$ \\
\hline August & $\cdots$ & 4150 & 633 & 8000 & 8057 & $\cdots$ & 2160 & 500 & $\cdots$ & $\cdots$ & $\cdots$ & $\cdots$ & $\cdots$ & 235 & 00 \\
\hline October & $\cdots$ & $\begin{array}{l}600 \\
300\end{array}$ & $\begin{array}{l}802 \\
1 \text { or }\end{array}$ & $\begin{array}{l}8000 \\
8000\end{array}$ & 11612 & $\ldots$ & I3 Io & 1200 & $\ldots$ & $\ldots$ & $\ldots$ & & $\ldots$ & 225 & 523 \\
\hline $\begin{array}{l}\text { November } \\
\text { December }\end{array}$ & $\cdots$ & $\begin{array}{ll}61 & 32\end{array}$ & 80.5 & 8000 & $89 \mathrm{II}$ & 5 oo & * $\quad 125$ & & $\cdots$ & 5000 & 2975 & 6 oo & ○ 50 & & 873 \\
\hline & & 3,12909 & $5^{8} 68$ & 99000 & 2,79344 & 8600 & I $5^{8} 38$ & II 400 & $2,05^{6} 4^{0}$ & 1,01950 & $3^{800}$ & 800 & 850 & 10,459 & 999 \\
\hline
\end{tabular}




\section{Annual Report on Forest Administration in the Straits Settlements, for the Year 1913.}

\section{PART I.}

\section{Extension and Constitution of Reserved Forests.}

I. The area of reserved forests finally gazetted under section 7 of "The Forest Ordinance Igo8" was 96,644 acres or $15 \mathrm{I}^{\circ} \mathrm{O}$ square miles, and the area of reserves preliminarily gazetted under section 5 was 9,555 acres or $14^{\circ} 9$ square miles. Including the latter the proportion of reserved forests to the area of each Settlement is shown in the following table:-

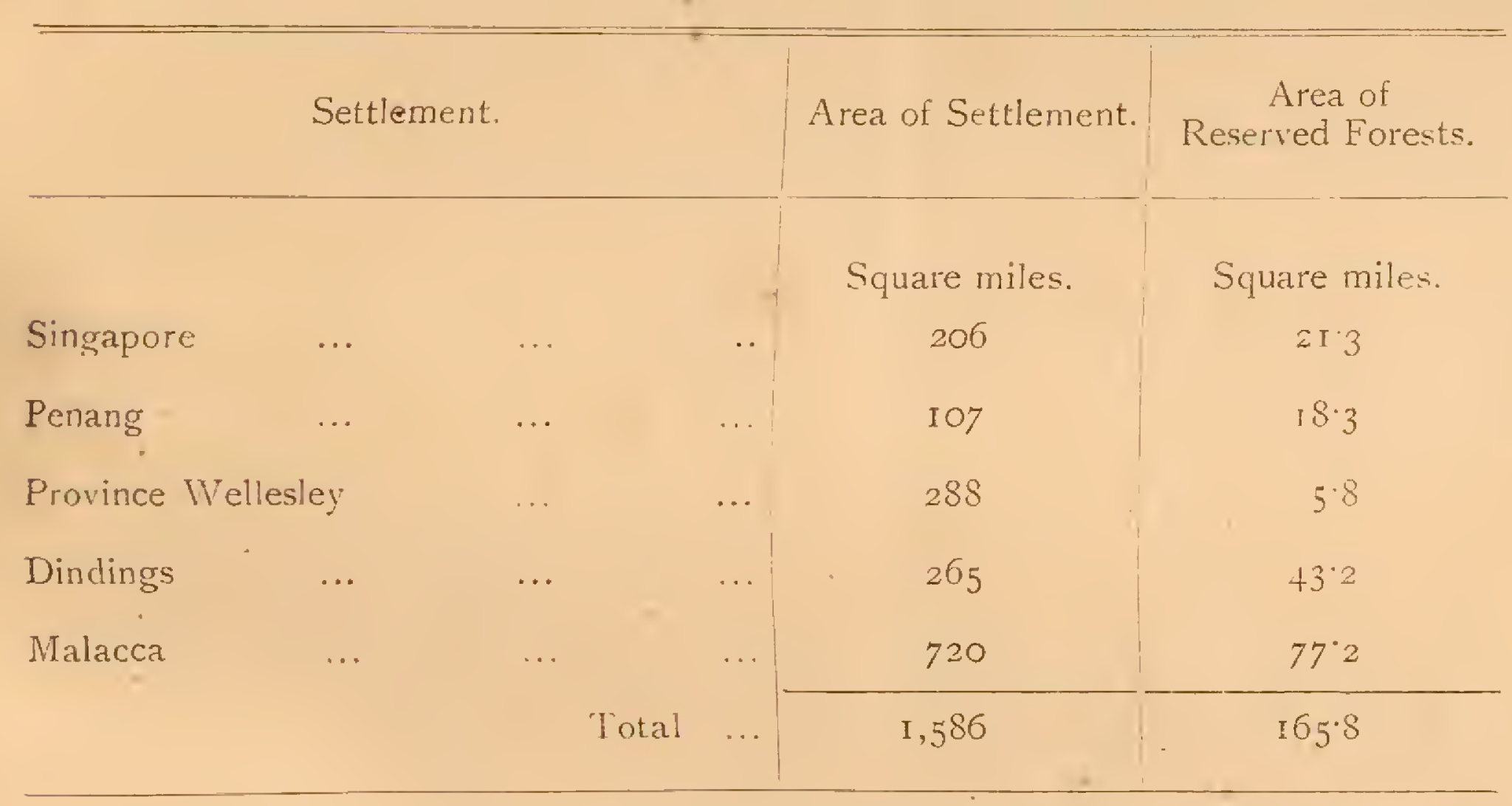

The proportions of reserved forests, and forests in course of reservation, to the area of each Settlement, were as follows:-

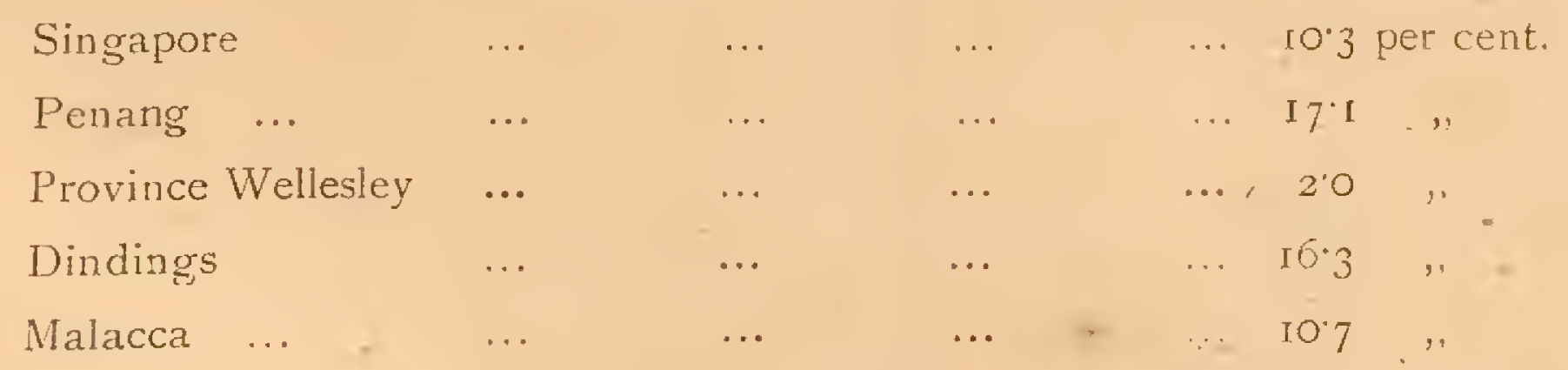

The proportion for the whole Colony was 10. 5 per cent.

2. Additions and alterations are shown in Form ${ }^{*}$. The most important changes were 874 acres of Taban forest added to the Telok Bahang Reserve in Penang, and 125 acres to Government Hill in the same Settlement. Total additions 999 acres. Eighty-six acres were excluded from Bukit Bruang Reserve in Malacca. Twelve acres were excluded from Bukit Mandi in Singapore and I4 acres from Bukit Gua Gempas in Province Wellesley. Total exclusions I 12 acres. 
3. Nezs proposals for reservation. - These will be found in Form 2.* Gunong Tunggal and Batu Undan Reserves in the Dindings are awaiting final notifications but are, really old reserves. The proposed Gunong Melintang Reserve of 4,500 acre, ivas also awaiting final notification throughout the year.

\section{Demarcation and Upkeep of Boundaries.}

4. The total length of artificial boundaries at the close of the year was $39 \mathrm{I}$ miles, and natural boundaries not requiring upkeep 134 miles- 525 miles in all.

5. In Singapore $97^{\frac{1}{2}}$ miles of boundarie; were kept clean by the forest staff.

In Penang the Highlands Reserve was upkept by the staff, the remaining reserve boundaries, about 75 miles, were kept clean on contract for $\$ 228$, oi $\$ 3.04$ per mile. Three miles of new boundary were cleared in Pantai Acheh Reserve at a cost of \$17.60. The boundary of Kubang Ulu Reserve in Province Wellesley was cleared departmentally and the rest were cleared at $\$ 208.60$, an average of $\$ 6.32$ per mile.

In the Dindings 70 miles of boundaries were re-cleared at a cost of $\$ 417$, or $\$ 5.96$ per mile, and one mile of new boundary cut in Gunong Tunggal Reserve for $\$ 25$. During the year 57 reserve signboards were purchased for $\$ 26.50$.

In Malacca 99 miles of boundaries were upkept at a cost of $\$ 600.30$, the average cost per mile being $\$ 6.06$.

\section{Surveys.}

6. In Singapore the Forest Ranger made a rough surrey of the Sungai Buloh Reserve forming part of the Kranji working circle.

In the Dindings the survey of the Batu Undan Reserve was undertaken by the Survey Department and completed at the close of the year, and those of Gunong Melintang and Telok Sera Reserves were nearly finished.

\section{PART II.}

\section{Management of Forests. \\ WORKING PLANS.}

7. In Singapore five reserves were worked for Mangrove fuel under plans as follows:-

\begin{tabular}{|c|c|c|c|c|c|c|c|}
\hline \multirow{2}{*}{\multicolumn{2}{|c|}{ Reserve. }} & \multirow{2}{*}{$\begin{array}{l}\text { Coupe } \\
\text { No. }\end{array}$} & \multicolumn{2}{|c|}{ Time allowed for working. } & \multirow{2}{*}{$\begin{array}{l}\text { Area } \\
\text { in } \\
\text { acres. }\end{array}$} & \multirow{2}{*}{$\begin{array}{l}\text { Amount } \\
\text { at which } \\
\text { leased. }\end{array}$} & \multirow{2}{*}{$\begin{array}{c}\text { Total } \\
\text { Revenue } \\
\text { from } \\
\text { Reserves, } \\
\text { Igr3. }\end{array}$} \\
\hline & & & Opening. & Closing. & & & \\
\hline Pandan & $\cdots$ & V & 6th May, I9I 3 & 6th May, Igr4 & 100 & $\begin{array}{r}\$ c \\
\mathrm{I}, \mathrm{I} 7500\end{array}$ & $\begin{array}{r}\$ c \\
1,50000\end{array}$ \\
\hline Changi & & $\mathrm{V}$ & I7th Feb., I9I3 & Isth Dec., igI3 & 30 & 30450 & 33375 \\
\hline Kranji & $\cdots$ & IV & 2oth Feb., I9I 2 & Igth Nov., I 93 & 32 & I 7920 & 9300 \\
\hline Seletar & .. & IV & 3rd Sept., I9I3 & 2nd Sept., I9I 4 & 60 & 30900 & I 5450 \\
\hline Tuas . & $\cdots$ & IV & 3rd Sept., I9I3 & 2nd Sept., 1914 & 80 & 42400 & 42000 \\
\hline 'Total & ... & $\cdots$ & - & $\cdots$ & 302 & $2,39170 \mid$ & 2,50125 \\
\hline
\end{tabular}

The average price realized per acre was $\$ 7$ as against $\$ 5.7 \mathrm{~S}$ in IgI $_{2}$.

8. In the Dindings Tanjong Burong Reserve was worked during the year under a working plan. Four coupes-those of 1910-1913-amounting to Soo acres were leased in 1912 at $\$ 3$ per acre. The agreement expired on 3Ist December, I9I3. LiM JoO GHEE, the lessee, gave a great deal of trouble by felling undersized trees and was fined on two or three occasions, under the terms of the agreement. 
9. In Malacca trees of Class I were selected and marked by the Forest Ranger for felling as follows:-

\begin{tabular}{|c|c|c|c|c|c|c|c|}
\hline \multicolumn{3}{|c|}{ Bukit Sedanan Reserve... } & $\cdots$ & $\ldots$ & & 257 & trees \\
\hline Bukit Senggeh & $"$ & $\ldots$ & $\cdots$ & $\ldots$ & & I 7 & " \\
\hline Batang Malaka & $"$ & $\cdots$ & $\cdots$ & $\cdots$ & 1 & 48 & $"$ \\
\hline Merlimatı & $"$ & $\cdots$ & $\cdots$ & $\cdots$ & & 57 & $"$ \\
\hline Ayer Panas & $"$ & $\cdots$ & $\cdots$ & $\cdots$ & & 148 & $"$ \\
\hline Sungai Udang & $"$ & $\cdots$ & $\cdots$ & $\cdots$ & & $5 \mathrm{I}$ & $"$ \\
\hline & & & & Total & ... & 578 & $"$ \\
\hline
\end{tabular}

Io. Only trees of six feet girth and over were marked. These trees were felled and extracted by licensees, and Class II trees were felled without marking.

Class I trees yielded $\$ 1,350$ revenue, Class II $\$ 538$ as against $\$ 1,160$ and $\$ 465$, respectively, for I9I 2.

\section{Pathis in Reserves.}

I. In Singapore the path from Tanjong Tuas to Sungai Blukang was upkept by the forest guards.

A cart track was constructed along the boundary of the Tasek Glugor Reserve in Province Wellesley.

In the Dindings all the paths were kept clean by the forest staff.

The inspection paths in Malacca reserves were upkept for $\$ 97.20$.

\section{Buildings,}

12. In Singapore the forest guards' quarters were upkept by the Public Works Department. $\$ 43.50$.

Repairs to Forest Stations in Penang cost $\$ 177.96$ and in Province Wellesley

In the Dindings and Malacca the necessary repais were made by the Public Works Department.

\section{- Protection of Forests.}

I3. The Forest Laws remained unaltered. Protection was effectually carried out by the staff of forest guards patrolling the reserves.

14. In Penang a case of illicit felling of timber on Pulau Jerejak was taken before the Court and damages to the amount of $\$ 1,32 I .33$ were awarded to the department. One hundred and nirety-six dollars and ninety-five cents were expended on coolies to accompany forest guards on patrol duty in the isolated forest reserves.

\section{Forest Fires.}

I5. Small fires occurred in Telok Bahang Reserve in Penang and in Telok Sera Reserwe in the Dindings. Thirty dollars was awarded by the Courts to the department as compensation for damage.

\section{Forest Offences.}

I6. Form $7^{*}$ gives particulars as to the number of offences. The following cases were dealt with by Courts:-

\begin{tabular}{c|c|c|c|c|c}
\hline $\begin{array}{c}\text { Cases pending } \\
\text { from rgr2. }\end{array}$ & $\begin{array}{c}\text { New cases } \\
\text { of the year. }\end{array}$ & $\begin{array}{c}\text { Total } \\
\text { cases. }\end{array}$ & \multicolumn{2}{|c|}{ Disposed of during year. } \\
$\begin{array}{c}\text { Convic- } \\
\text { tions. }\end{array}$ & $\begin{array}{c}\text { Acquit- } \\
\text { tals. }\end{array}$ & $\begin{array}{c}\text { Pending at } \\
\text { close of year. }\end{array}$ \\
\hline 6 & 54 & 60 & 47 & 9 & 4 \\
\hline
\end{tabular}

* Not printed. 
Besides these 8 cases were compounded for $\$ 205.80$ as follows :-

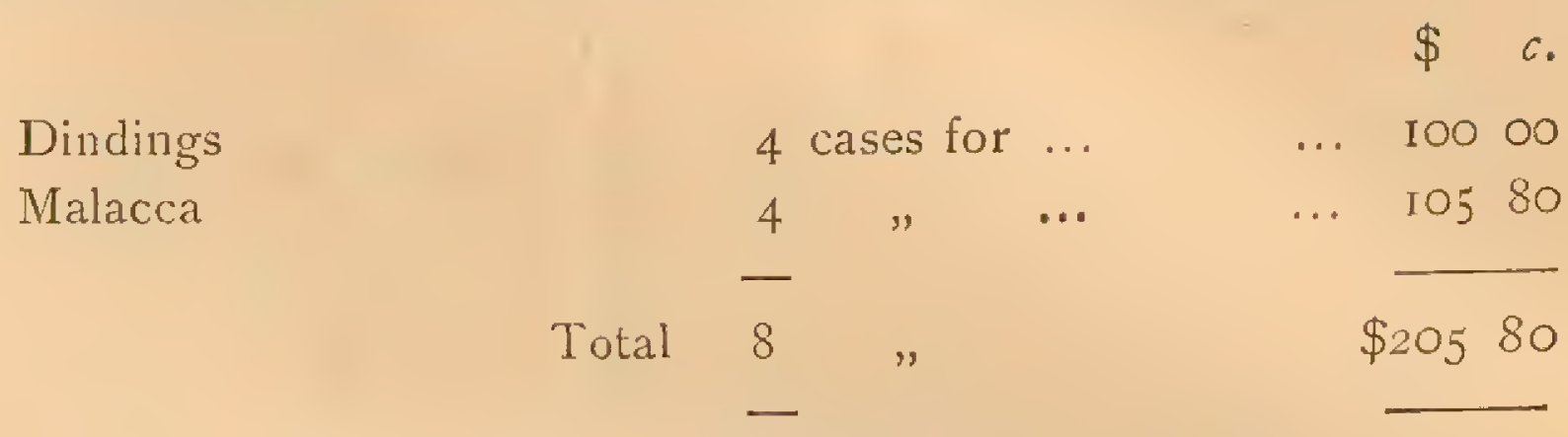

The percentage of convictions of cases tried in Courts was 84 per cent, as compared with 94 in IgI2. There were 60 cases, as against go in I9I2.

Singapore had 7 cases with all convictions; Penang and Province Wellesley, 2I cases with 20 convictions and only I acquittal; the Dindings, 14 cases with 7 convictions and 7 acquittals; and Malacca, I4 cases with 13 convictions and I acquittal.

1 7. Fines imposed by Courts realized $\$ 659.49$ as compared with $\$ 707$ in I912.

The reduction in cases was chiefly in Penang and Province Wellesley. The Forest Ranger believes that this is due to the increased vigilancy of the staff and to a corresponding reduction of opportunity for evasion of the regulations.

\section{Improvement of Forests.}

\section{NATURAL REPRODUCTION.}

18. In Singapore Meranti (Shorea sp.), Kemuning (Murraya exotica), Serayah (Shorea sp.), Taban (Palaquium) and Tampinis (Slotia sideroxylon) have reproduced well in all the reserves. The mangrove in the old coupes has also reproduced well.

- Class II trees in the Telok Bahang and Government Hill Reserves in Penang were girdled in order to give more room and light to the more valuable species, such as Taban, etc. The natural reproduction of dacrydium in the Government Hill Reserve was reported as good.

In the Dindings, Meranti (Shorea sp.), Damar laut (Parashorea stellata) and Resak (Vatica sp.) fruited well.

The Forest Ranger, Malacca, reports that the natural reproduction in the various reserves was not so good as that of I9I2.

\section{Artificial Reproduction.}

19. Form $8 *$ shows particulars. The area of plantations was increased by 48 acres making the total area 672 acres.

The plantations in Singapore, Penang and Malacca contain chiefly Getah Taban (Palaquium oblongifolium). There are also Para rubber (Havea braziliensis), Teak (Tectona grandis), Getah Sundek (Payena Leerii), Tembusu (Fagroea fragrans), Mahogany (Swietonia sp.), Merbau (Afzelia palembanica), Penak (Balanocarpus sp.), Penaga (Mesua ferrea), Nibong (Oncosperma tigillaria), Kledang (Artocarpus lancifolius) and Resak (Vatica sp.).

Blanks in the Bukit Timah plantation in Singapore were interplanted with Para and Durian seedlings. This plantation of 98 acres was upkept for $\$ 817.44$. The revenue realized from the yield of rubber was $\$ 525.24$ which was credited to Agricultural Deposits. The accounts of this plantation are shown in paragraph 20.

Six thousand two lundred and thirty teak seeds from Burma were sown in Penang and Province Wellesley in the Penara Bukit and Bukit Serayah Reserves but all of them proved failures. Casuarina and Cedar (Acrocarpus) seeds were planted in the Penara Bukit Reserve and met with the same results. One thousand seven hundred and thirty-eight Taban seedlings in the Batu Feringgi nursery and 707 stumps in Telok Bahang Reserve are doing well, the cost for upkeeping the former was \$I 35.20 and the latter \$3O. One thousand nine hundred and sixty-one Taban trees in the Telok Bahang Reserve were upkept departmentally.

The teak plantation in the Tasek Glugor Reserve was re-cleared during the year at a small cost. About 250 'Tembusu (Fagroea fragrans) seedlings were planted out in the Telok Mu:oh Reserve. 
Blanks in the Tanjong Burong Reserve in the Dindings were planted with 8,200 seeds of bakau (Rhizophora conjugata). The Para plantation (I 8 acres) in the Lumut Keserve was upkept during the year at a cost of $\$ 826.27$. The greater part of this amount was spent on machinery, tools and tapping materials. The receipts from the sale of rubber were $\$ 16 \mathrm{r} .06$ which was credited to the Gardens Committee fund. The plantation was in an unsatisfactory condition at the close of the year. Expenditure and revenue are shown in paragraph $2 \mathrm{I}$.

In Malacca, 48 $\frac{1}{2}$ acres were added to the Ayer Kroh and Bukit Sebukor plantations during the year as follows:-

Ayer Kroh ...
Bukit Sebukor $\quad\left\{\begin{array}{lllll}\text { Merbau } & \ldots & \ldots & \frac{1}{2} & \text { acre } \\ \text { Penaga } & \ldots & \ldots & 5 \frac{1}{2} & \text { acres } \\ \text { Para } & \ldots & \ldots & 2 \frac{1}{2} & , " \\ \text { Para } & \ldots & \ldots & 39 & \text { " } \\ \text { Mangosteen } & \ldots & \text { I } & \text { acre }\end{array}\right.$

These plantations are upkept by the Gardens Committee, from the funds yielded by the sale of rubber which amounted to $\$ 4,127 \cdot 5^{8}$, during the year. The expenditure was $\$ 6,631.67$. The accounts of the Gardens Committee appear in paragraph 22.

Eight hundred and fifteen trees were tapped and produced $3,668 \frac{1}{4}$ lbs. of rubber as against 3,90 I Ibs, in IgI2. The decrease in the yield is said to be due to bad tapping.

Failures in the Penak, Resak, Penaga and Para blocks were replaced. Improvement fellings were carried out during the year in the Taban blocks.

The Bukit Sebukor Reserve of 44 acres was cleared and planted with Para $I 5^{\prime} \times I 5^{\prime}$ and $I$ acre of swamp with mangosteens $I 2^{\prime} \times I 2^{\prime}$ at a cost of $\$ 800$. One thousand and thirty Para trees were numbered and measured, and entered in a register. The tapping of $\mathrm{I} 20$ trees in block $D$. was discontinued on account of the carelessness of the tappers in the past. Twenty thousand Para seeds were sown in the nursery at Ayer Kroh and about I 7,500 seedlings were planted up in the Bukit Sebukor Reserve; 2,500 were used as supplies. The Merbau and Resak seedlings planted in the Merlimau and Sungai Udang Reserves are doing well.

Bukit Tinah Plantation.

20. Statement of Receipts and Expenditure for igi3.

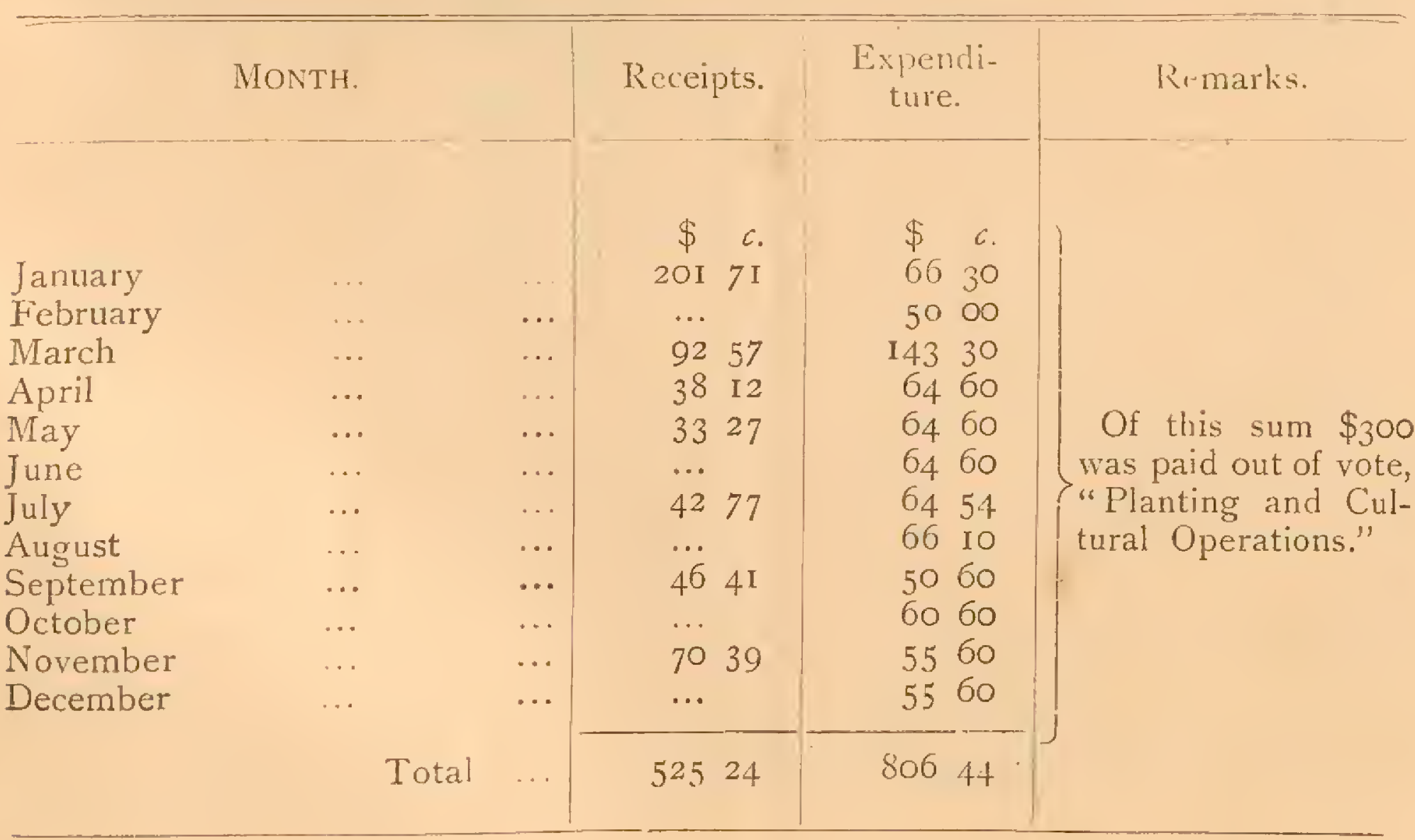


Lumut Plantation.

2r. Statement of Receipts and Expenditure for igi3.

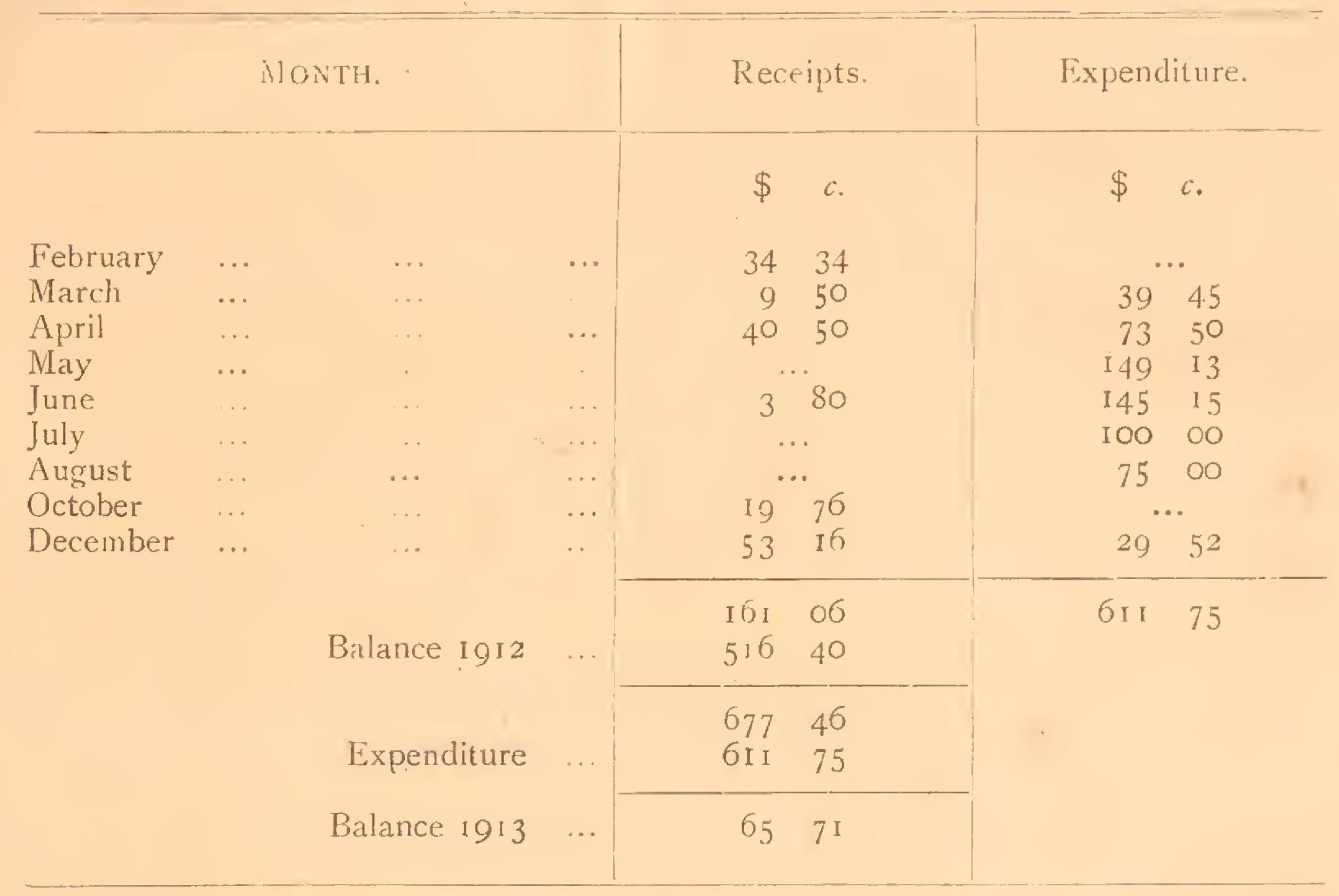

22.

Ayer Kroh Plantation.

Statement of Receipts and Expenditure for igi 3.

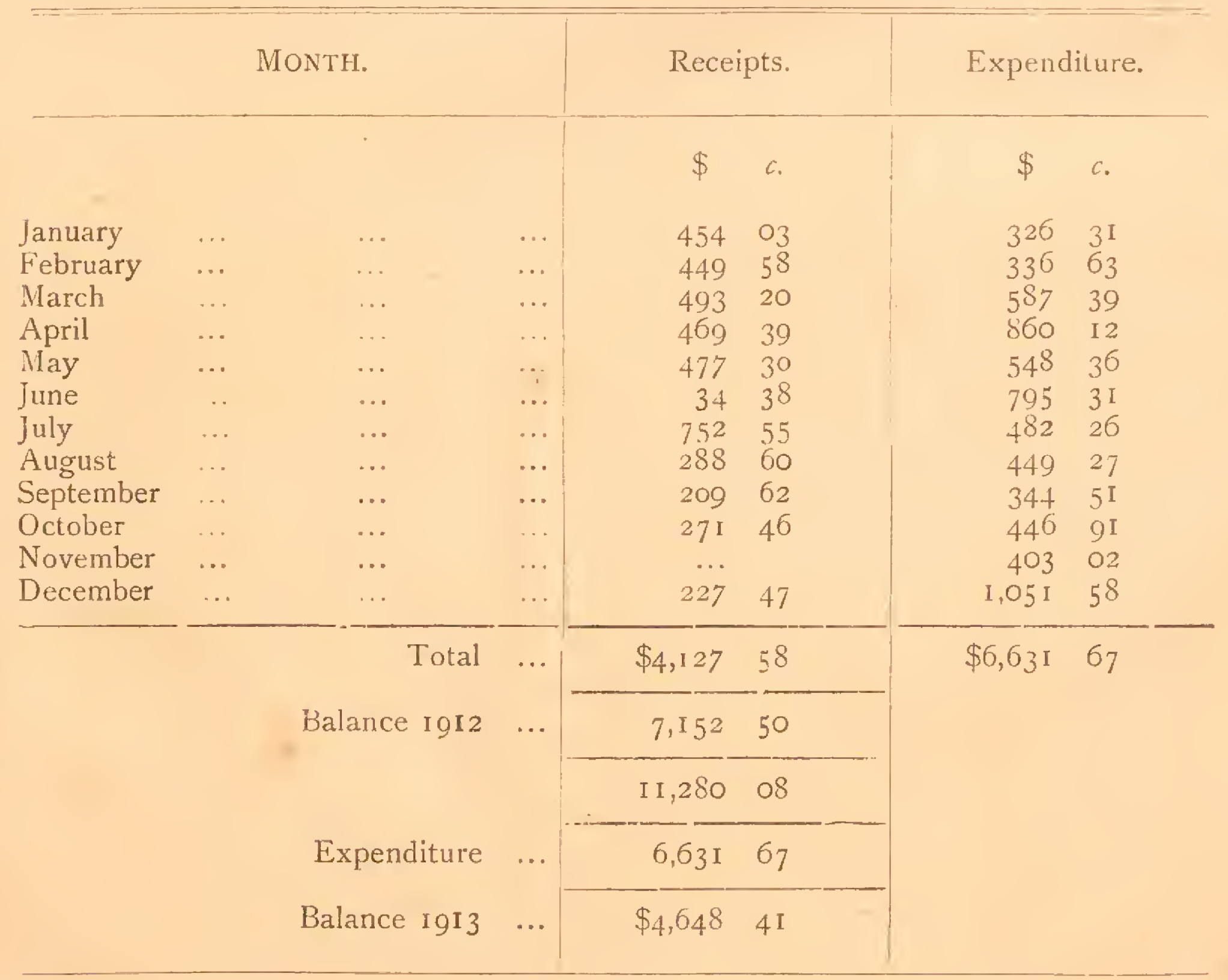




\section{Exploitation.}

\section{TIMBER AND FuEL.}

\section{From Reserved Forests.}

23. The following statement shows the timber and firewood removed from reserved forests :-

\begin{tabular}{|c|c|c|c|c|c|}
\hline \multirow{2}{*}{ SETTLEMENT. } & \multirow{2}{*}{ Reserve. } & \multicolumn{2}{|c|}{$\begin{array}{l}\text { Timber (tons of } \\
50 \text { cubic feet.) }\end{array}$} & \multirow{2}{*}{$\begin{array}{l}\text { Firewood } \\
\text { Tons. }\end{array}$} & \multirow{2}{*}{$\begin{array}{l}\text { Stakes or } \\
\text { Poles. }\end{array}$} \\
\hline & & $\begin{array}{l}\text { Class } \\
\text { I. }\end{array}$ & $\begin{array}{c}\text { Class } \\
\text { II. }\end{array}$ & & \\
\hline \multirow{6}{*}{ Singapore } & Changi & $\ldots$ & $\cdots$ & $4^{2} 3$ & $\ldots$ \\
\hline & Pandan & $\ldots$ & $\cdots$ & $\mathrm{I}, \mathrm{I} 44$ & .. \\
\hline & Tuas & $\ldots$ & $\cdots$ & 769 & 340 tons \\
\hline & Kranji & $\ldots$ & $\cdots$ & 290 & $\cdots$ \\
\hline & Seletar & $\ldots$ & $\cdots$ & $44^{2}$ & $60 "$ \\
\hline & Total $\ldots$ & $\ldots$ & $\ldots$ & 3,068 & 400 \\
\hline \multirow[t]{2}{*}{ Penang } & \multirow{2}{*}{$\begin{array}{l}\text { Govt. Hill } \\
\text { Tanjong Burong }\end{array}$} & I tree & $\cdots$ & \multicolumn{2}{|c|}{2,000 billets } \\
\hline & & $\ldots$ & $\cdots$ & $3,362,285$ & $5, \ldots$ \\
\hline \multirow[t]{2}{*}{ Dindings } & Pangkor & 3 tons & $\ldots$ & & $\cdots$ \\
\hline & Batu Undan ... & $\ldots$ & $\ldots$ & 609 tons & $\ldots$ \\
\hline \multirow{7}{*}{ Malacca } & Bukit Sedanan & 257 trees & $\ldots$ & $\cdots$ & \\
\hline & Bukit Senggeh & I7 " & $\cdots$ & $\cdots$ & $\cdots$ \\
\hline & Batang Malaka & $48 \quad$, & $\cdots$ & $\ldots$ & $\cdots$ \\
\hline & Merlimau & $57 \quad$, & $\cdots$ & $\cdots$ & $\cdots$ \\
\hline & Ayer Panas ... & I $48 \quad$, & $\cdots$ & $\cdots$ & $\cdots$ \\
\hline & Sungai Udang & $51 \quad "$ & $\cdots$ & $\cdots$ & $\cdots$ \\
\hline & Total & 578 trees & $\cdots$ & $\ldots$ & $\cdots$ \\
\hline
\end{tabular}

In Singapore the output from the five mangrove reserves was 3,068 tons as against 1,617 tons in 1912 , the increase was due to the conversion of the tops of the trees cut for engine fuel into small firewood.

The outturn of firewood from the Tanjong Burong Reserve in the Dindings was $3,362,285$ billets.

In Malacca the output of Class I trees was 578 , as compared with 988 trees in 1912. These were selected and marked by the Forest Ranger. Class II trees were also removed, but no figures are available. 


\section{From Crown and Alienated Lands.}

24. In Singapore 285 permits were taken out for firewood as against 266 in $\mathbf{r} 9$ I 2. The cutturn of timber was insignificant.

In Penang and Province Wellesley $\$ 2,198.93$ was realized in royalty on timber and $\$ 606.13$ on firewood and charcoal as against $\$ 1,006$ and $\$ 264$, respectively, in 19 I2.

In the Dindings I, 824 tons of Class I and I 7 tons of Class II timber and 3 I,534 fishing-stakes were extracted on payment of royalty. Firewood realized $\$ 2,563.30$. Four tons of Class I timber were taken by the Public Works Department free of royalty. From alienated land there were removed 126 tons of Class I and 42 tons of Class II timber. On the greater part of this timber no royalty was paid, in accordance with the terms of old grants.

In Malacca Class I tim ber realized $\$ 685$ and Class II $\$$ r,73I. Firewood brought in $\$ 290$ and charcoal $\$ 20$.

\section{Minor Forest Produce.}

25. In Singapore other produce realized \$192.IO.

In Penang and Province Wellesley, bamboos and canes realized $\$ 158$ and other produce $\$+58$, a rise of $\$ 74$ and $\$ 78$, respectively, as compared with 1912 .

In the Dindings bamboos and canes realized $\$ 726$, getah $\$ 65$, tengah bark $\$ 285.95$ and other produce $\$ 1,504.32$, of which $\$ 5.44 .57$ was derived from the tin in the Telok Sera Reserve.

In Malacca bamboos and canes realized $\$ 62$ and other produce $\$ 276$. Wcod-oil realized $\$ 80$ and wild rubbers $\$ 10$.

\section{PART III}

\section{Financial Results.}

26. This table shows the comparative revenue for I9I 2 and I9I3:-

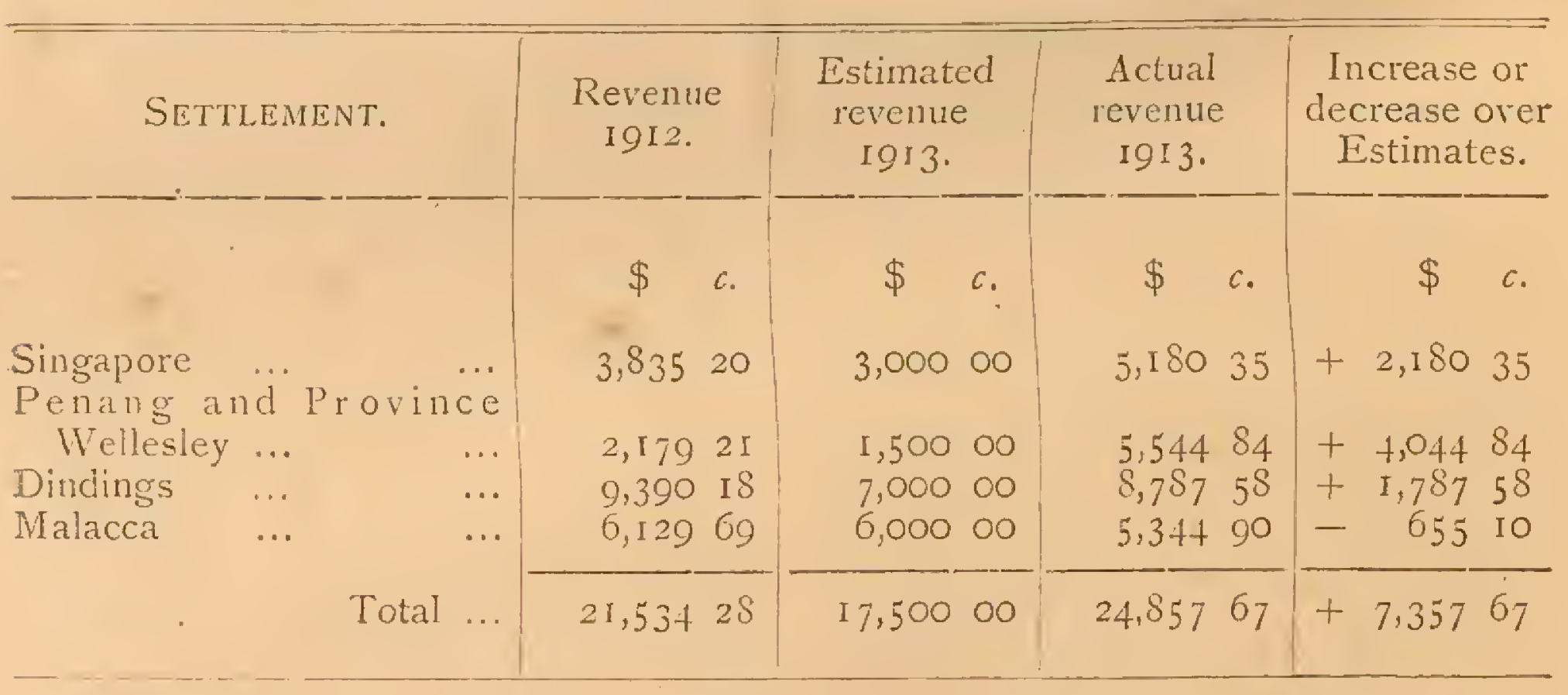

an increase of $\$ 3,323.39$ over I9 12 revenue.

The increase in Singapore was due to the good demand for mangrove firewood, and consequent increase in the prices obtained for the annual coupes.

In Penang and Province Wellesley the increase in revenue was chiefly due to the large amount of compensation paid for illicit felling of timber on Pulau Jerejak and the increased number of permits issued for cutting timber for the construction of the railway in Kedah.

In the Dindings the revenuc exceeded the estimated revenue by $\$ 1,7 S 7.58$ and a slight decrease of the receipts as compared with 19 r 2 was due to the small output of timber on Crown Land on which royalty was payable.

There was a decrease in Malacca of $\$ 7 \$ 4.79$ as compared with I912, and the estimated revenue was not reached. This is attributed to the prevalence of disease among cattle and the consequent restrictions in their movement. Buffaloes and bullocks are the only means of transporting heavy timber, both in the forest and on the roads. 


\section{Expenditure.}

27. This statement shows the total expenditure in each Settlement, as compared with I9 2 and estimates for I9I3:-

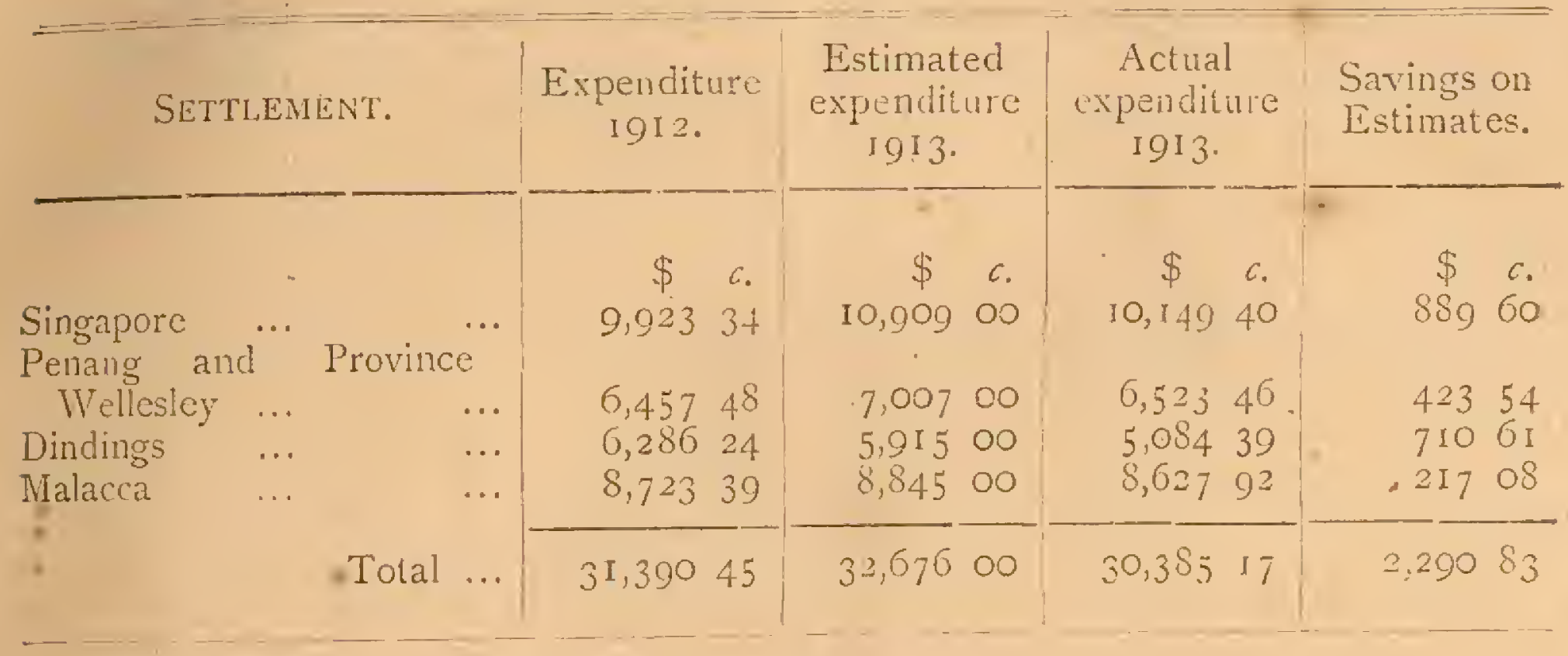

Personal Emoluments amounted to $\$ 22,235.39$

Other Charges $\quad$ " $8,149 \cdot 78$

Total $\$ 30,385.17$ as compared with $\$ 35390.45$ in 19 I2.

\section{Administration.}

28. Mr. A. M. BURN-Murdoch held the appointment of Conservator of Forests until the I 4 th of August, when he procecded on leave and was relieved by Mr. C. Hummel who remained in charge till the end of the year.

The following reserves were visited by the Conservator and Acting Conservator of Forests :-

Singapore-Jurong, Pandan, Bukit Timah, Seletar, Sembawang, Kranji and Chua Chu Kang.

Penang and Province Wellesley.-Government Hill, Telok Bahang, Tasek Glugor and Kubang Ulu. Burong.

Dindings.—Lumut, Gunong Melintang, Telok Sera, Tanjonşr Hantu and Tanjong

Malacca.-Bukit Bruang, Bukit Sebukor and Merlimau.

In Singapore the Collector of Land Revenue administered the Forest Department with the assistance of Mr. T. C. MaLAya Piludi, Forest Ranger, Grade III.

Mr. V. P. BoRges, Forest Ranger, Grade I, Penang, held the appointment until the 2 oth of June, when he left for the Federated RIalay States on promotion and was relieved by Mr. G. C. KEUN who held charge till the end of the year.

In the Dindings the District Officer dealt with forest matters assisted by the Forest Ranger. the year.

Mr. G. M. O'HARA, Forest Ranger, Grade I, was in charge in Malacca throughout

\section{Subordinate Staff.}

29. In Singapore one Forest Guard was dismissed. There was one resignation and one retirement of Forest Guards in Penang.

Sheik Ahmat bin Imam Mudin, Forest Ranger, Grade IV, Dindings, was retired on pension and relieved by ITAM BIN UDA BANDAR from the Federated Malay States. Forester SAHID BIN MAIDIN'S salary was reduced for neglect of duty and one Forest Guard resigned. The Forest Ranger, Dindings, reports that the health of the staff throughout the year was very bad. 
In Malacca one Forest Guard was dismissed for absence from duty without leave. The staff on the whole have given general satisfaction throughout the year.

30. The following shows the staff employed during the year:-

\begin{tabular}{|c|c|c|c|c|c|c|c|c|c|c|}
\hline \multirow{2}{*}{\multicolumn{3}{|c|}{ SETTLEMENT. }} & \multicolumn{4}{|c|}{ RANGERS. } & \multirow{2}{*}{ Foresters. } & \multirow{2}{*}{$\begin{array}{l}\text { Forest } \\
\text { Guards. }\end{array}$} & \multirow{2}{*}{$\begin{array}{l}\text { Resigna- } \\
\text { tions. }\end{array}$} & \multirow{2}{*}{$\begin{array}{l}\text { Dismis- } \\
\text { sals. }\end{array}$} \\
\hline & & & $\begin{array}{c}\text { Grade } \\
\text { I. }\end{array}$ & $\begin{array}{c}\text { Grade } \\
\text { II. }\end{array}$ & $\begin{array}{c}\text { Grade } \\
\text { III. }\end{array}$ & $\begin{array}{c}\text { Grade } \\
\text { IV. }\end{array}$ & & & & \\
\hline Singapore & & $\ldots$ & $\ldots$ & $\ldots$ & I & $\ldots$ & I & IO & $\ldots$ & I \\
\hline Penang \& P. & Welle: & ley & I & $\ldots$ & $\cdots$ & $\ldots$ & 2 & 6 & I & $\cdots$ \\
\hline Dindings ... & . & $\cdots$ & $\cdots$ & $\cdots$ & $\ldots$ & I & 2 & 6 & I & $\ldots$ \\
\hline Malacca ... & & $\cdots$ & I & $\ldots$ & $\ldots$ & I & 2 & I6 & $\cdots$ & I \\
\hline$=$ & Total & .. & 2 & $\ldots$ & I & 2 & 7 & 38 & 2 & 2 \\
\hline
\end{tabular}

\section{Kuala Lumpur, .} 25th March, IgI4.
B. H. F. BARNARD,

Acting Conservator of Forests, S. S. and F. M. S. 


\section{S'TRAITS SET T L E M E N T S.}

Paper to be laid before the Legislative Council by Command of His Excellency the Governor.

\section{Annual Report on Forest Administration in the Straits Settlements, for the Year 1914.}

\section{PART I.}

\section{Extension and Constitution of Reserved Forests.}

1. The total area of reserved forests at the close of the year was 99,631 acres, or I $55^{\circ} 7$ square miles. Five thousand and fifty-five acres, or 7.8 square miles were notified in the Gazette as proposed reserves. Particulars as to areas of reserved forests, and those in course of settlement appear in the following table:-

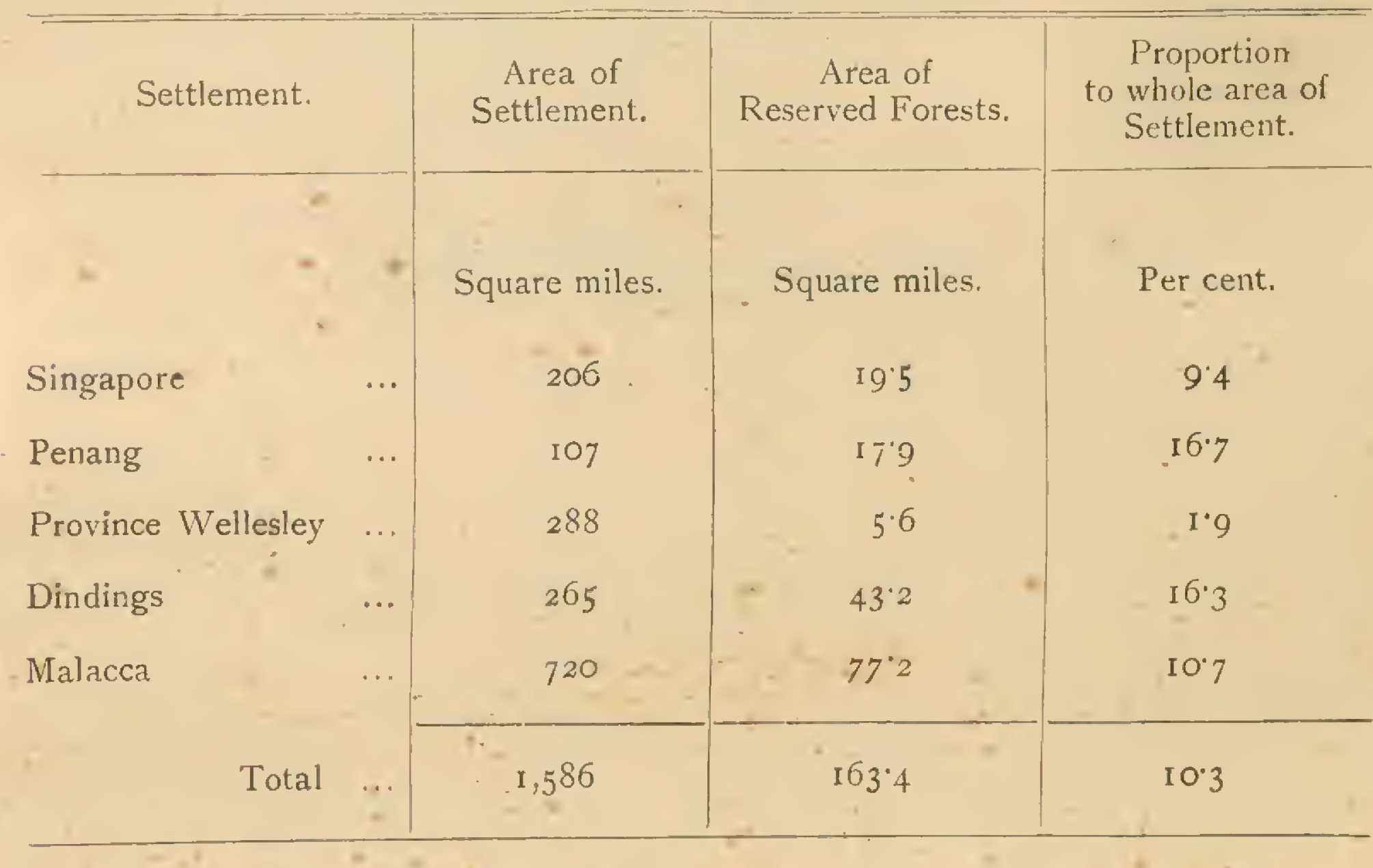

2. Details of alterations in area are shown in Form I.* The only new area finally gazetted was that in the Dindings known as the Gunong Melintang Reserve.

The total area disforested was I,5 I 2 acres, of which I, I 20 acres were excluded from the Sembawang and Mandi Reserves in Singapore for military purposes. Twenty acres.were excised from the Murai Reserve for agricultural purposes. In Penang 240 acres were excluded from the Government Hill Reserve. The hill railway passed through this area, some of which is likely to be required for residential buildings. In Province Wellesley areas of 82 acres and 39 acres were excluded from the Tasek Glugor and Bukit Gua I poh Reserves respectively, for purposes of railway construction. The Bukit Bruang Reserve in Malacca was reduced by eight acres, as a result of an encroachment by a neighbouring estate.

3. Proposals for reservation (Form 2).*-Gunong Tunggal and Batu Undan, which were shown at the end of 1913 as awaiting survey, were still unsettled at the end of 1914 . The surveys were completed. 


\section{Demarcation and Upkeep of Boundaries.}

(FORM $\left.3^{*}\right)$.

4. The total length of artificially marked boundaries of reserves is 368 miles, and that of natural boundaries $\mathrm{I} 32$ miles. Total 500 miles. The reduction from the figures of $19 \mathrm{r} 3$ is due to the reductions in area referred to in paragraph 2.

5. Boundaries in Singapore were kept in repair by the Forest Guards,

In Penang 73 miles of boundary was kept clean at a cost of $\$ 208$, in Province Wellesley 32 miles cost $\$ 148$, in the Dindings 75 miles was maintained at a cost of $\$ 347$, and in Malacca Iog miles cost $\$ 403$. There was generally a slight reduction in the cost of this work compared with former years.

\section{Surveys.}

6. The only survey completed during the year was that of Gunong Tunggal. Work on the Gunong Melintang and Telok Sera Reserves was held up owing to alterations in the boundary lines which were found to be necessary.

\section{PART II}

\section{Management of Forests.}

\section{WORKING PLANS.}

7. The result of the working of the Singapore Mangrove Reserves is shown in the following table:-

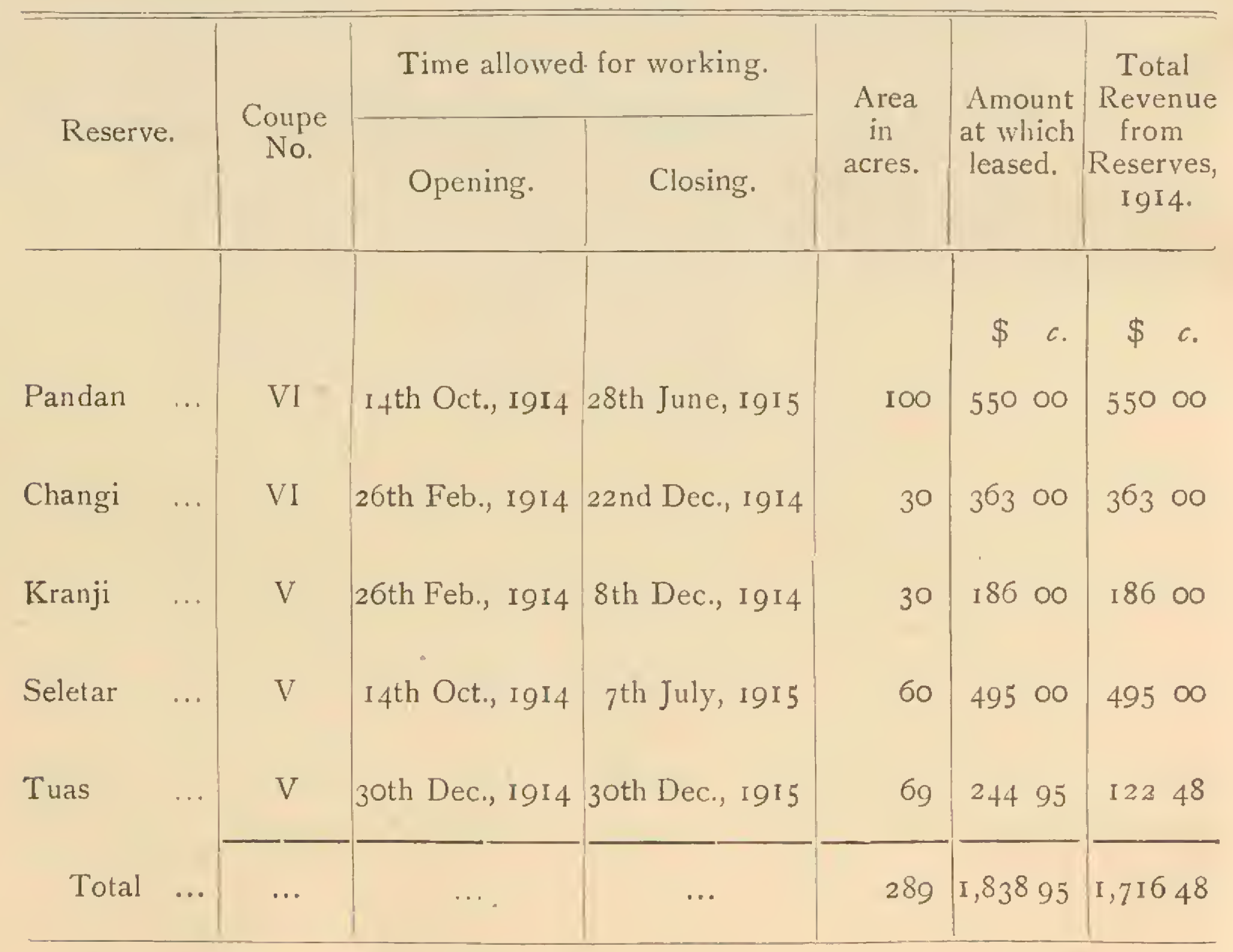

The difference between the figures in columns 6 and 7 is explained by the fact that the prices paid for the coupes are paid in two instalments, and these are not always both received in the same financial year. The average price obtained was $\$ 6.36$ per acre.

8. No offers were received for the mangrove coupe in the Tanjong Burong Reserve, Dindings. 
9. In the forest reserves in Malacca 47 I Class I trees were marked by the Forest Ranger and felled by permit holders. The number of trees so felled in each reserve was as follows:-

\begin{tabular}{|c|c|c|c|c|}
\hline Merlimau & eserve & $\Leftrightarrow$ & $\cdots$ & ... \\
\hline Ayer Panas &, & $\cdots$ & ... & .. \\
\hline Bukit Sedanan & ", & $\cdots$ & ... & ... \\
\hline Sungai Udang & ," & .. & $\ldots$ & ... \\
\hline Batang Malaka &, & .. & .. & ... \\
\hline Bukit Senggeh & $"$ & ... & $\ldots$ & $\ldots$ \\
\hline Ramuan China & $"$ & ... & ... & $\ldots$ \\
\hline & & & & Total \\
\hline
\end{tabular}

Trees of Class II were also felled, but without the restrictions imposed in the case of Class I.

IO. The revenue derived from Class I trees in reserves was $\$ 1,326$, and that from Class II, $\$ 663$. This is much less than it should be, having regard to the value of the timber taken by the permit holders.

\section{Paths in Reserves.}

II. A path 2 miles and I5 chains in length was constructed in Tasek Glugor Reserve in Province Wellesley.

In the Dindings Io miles of existing paths were maintained at a cost of $\$ 33.50$, and in Malacca $\$ 56.25$ covered the cost of upkeep of all paths. A great deal of this work is done by the Forest Guards without expense to Government.

\section{Buildings.}

12. A halting bungalow was built in the Pandan Reserve in Singapore: cost $\$ 737.33$. There were no other new buildings. General repairs to buildings throughout the Colony cost $\$ 965.47$. All work was carried out by the Public Works Department.

\section{Protection of Forests.}

13. There was no alteration in the Forest Laws.

I4. Fifty-one prosecutions under the Forest Ordinance were brought before the Courts. In 45 cases convictions were obtained, in four cases the defendants were acquitted, and two cases were pending at the end of the year.

Nine cases were compounded, two in Singapore by the Collector of Land Revenue, and seven in Malacca by the Resident.

The percentage of convictions-88.2 -in Court cases is creditable to the staff, except in the Dindings, where there were 3 acquittals out of 14 cases.

Fines imposed by the Courts amounted to $\$ 664 ; \$ 38 y$ was awarded to Government as compensation for damage, and $\$ 474$ was paid as compensation in compounded cases.

\section{Improvement of Forests.}

\section{NATURAL REPRoduction.}

15. Chengal and Sama Rupa are reported to have seeded well in the Dindings, and Resak and Meranti fairly well.

In Malacca most of the more important species appear to have seeded freely in forest reserves. Meranti, Serayah, Rambai Daun, Resak, Nyato, Medang and Bintangor are specially mentioned. It is also reported that a large proportion of the seedlings of 19 I 2 , which was a prolific seed year, are thriving.

\section{Artificial Reproduction.}

16. There was no increase of importance in the area of plantations. One acre was planted with Merbau at Bukit Bruang in Malacca, to complete a block partly planted in former years. Three acres of lalang land at Tasek Glugor, in Province Wellesley, was planted with Tembusu, partly with nursery plants, and partly by broadcast sowing. The result of the latter experiment is not yet known. 
One thousand two hundred and fifteen seedlings of gutta-percha were taken from Pulau Jerejak, near Penang, and planted in the Batu Ferringhi and Telok Bahang Reserves.

I7. The rubber and Gutta-percha plantation at Bukit Timah was kept in order at a cost of $\$ 620$. The receipts from rubber were $\$ 234$. Tapping was stopped entirely in August, when the price of rubber was low. Many of the trees required resting to renew their bark. The young gutta-percha trees at Bukit Timah have made very poor progress.

The Penang plantations required very little maintenance; $\$ 122$ covered the cost of all work.

The rubber plantation at Lumut was upkept almost entirely by the staff. Sales of rubber realized $\$ 235$.

I8. On the Malacca plantations the total charges for the year were $\$ 4,979$, of which sum \$I, I25 was paid on account of first clearing and planting of rubber at Bukit Sebukor. An inspection in July showed that the old rubber trees at Bukit Sebukor had been heavily over tapped. The trees were too closely planted with the result that the bark renewal was very slow. Tapping was stopped, and the plantation was thinned. Owing to the scattered positions of the rubber trees at Bukit Bruang the plantation must always be expensive to upkeep. Supervision also is difficult. The sum mentioned above as the total expenditure includes expenditure on the hardwood plantations. The yield of rubber for the year was 3, I 34 lbs., a decrease of 534 as compared with the previous year. This decrease was due to reduction in the number of trees tapped.

I9. In Tanjong Burong Mangrove Reserve, in the Dindings, I6,000 mangrove seeds were planted in situ in the areas on which clear fellings had been made in previous years. This method of regenerating mangrove has been found to be both cheap and effective. The area thus planted is not included in the return of plantations, as the areas, which are unsurveyed, are irregular and scattered.

20. In the Merlimau Reserve, Malacca, Merbau seedlings were planted in openings in the forest caused by the felling of large trees. The experiment was on a small scale only and was carried out by the Forest Guards.

Bukit Timah Plantation.

21. Statement of Receipts AND Expenditure For I9I4.

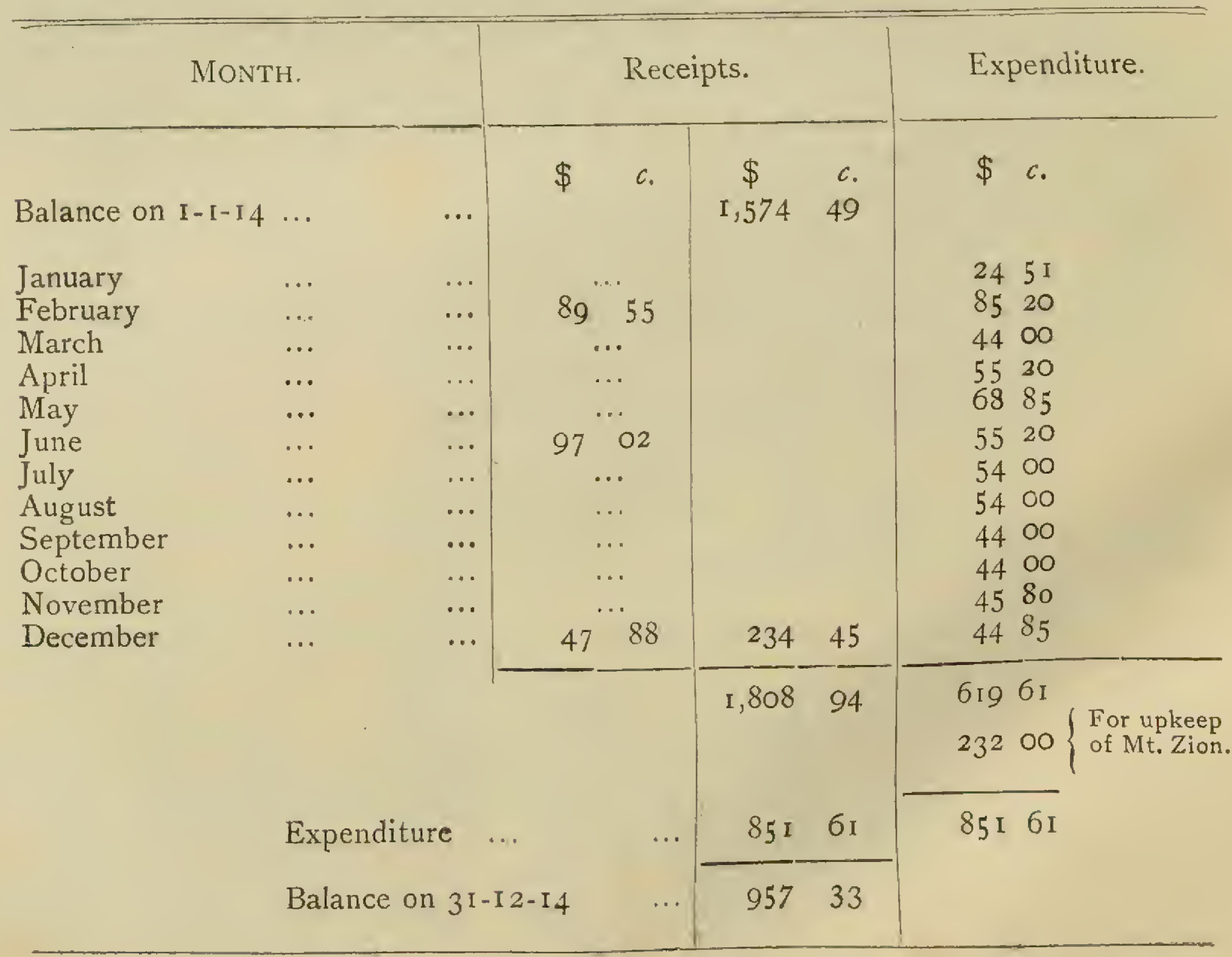




\section{Lumut Plantation.}

22 .

Statement of Receipts and Expenditure For igi4.

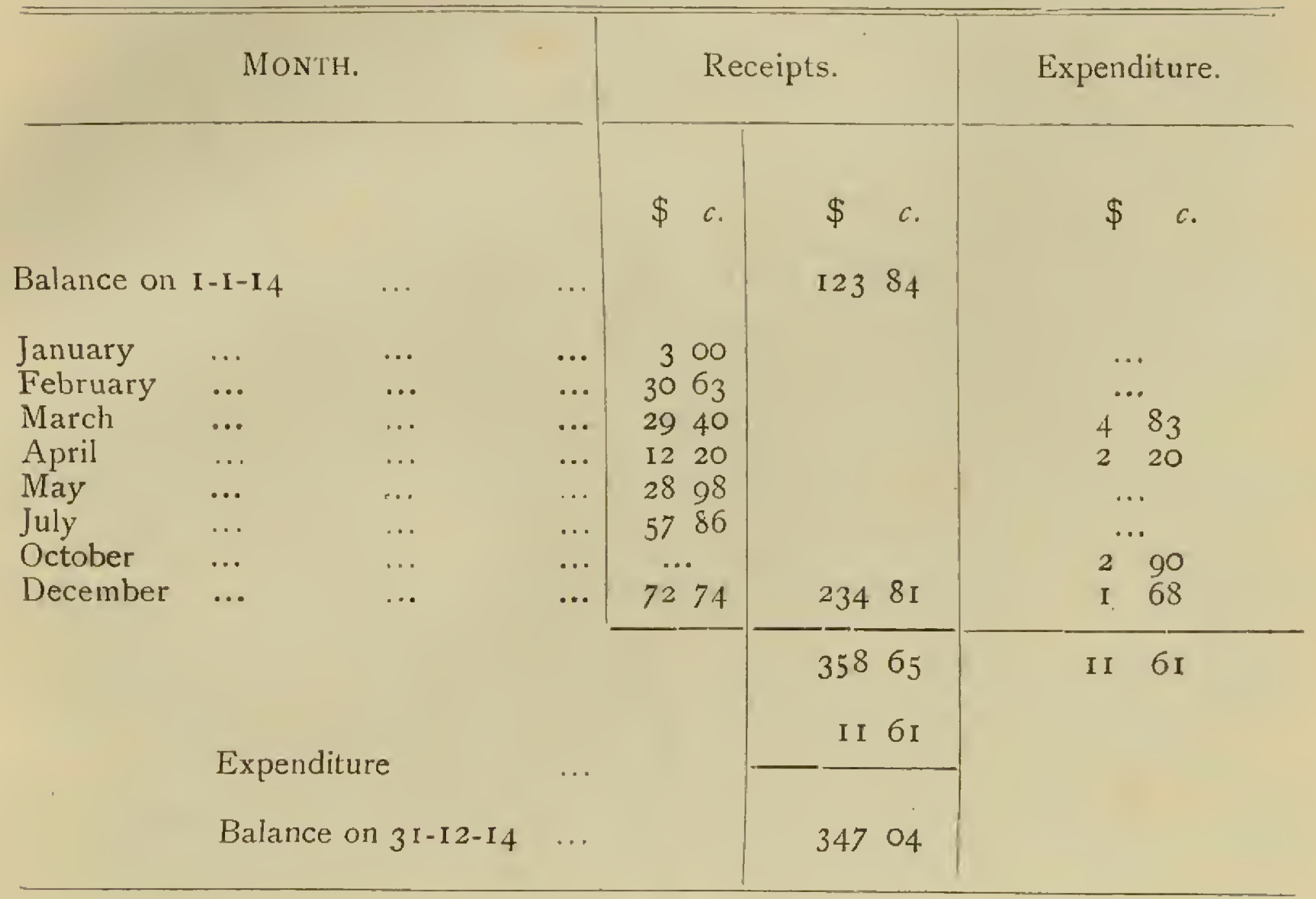

Ayer Kroh and Bukit Sebukor Plantations.

23. Statement OF Receipts AND EXPENDItURE FOR I9I4.

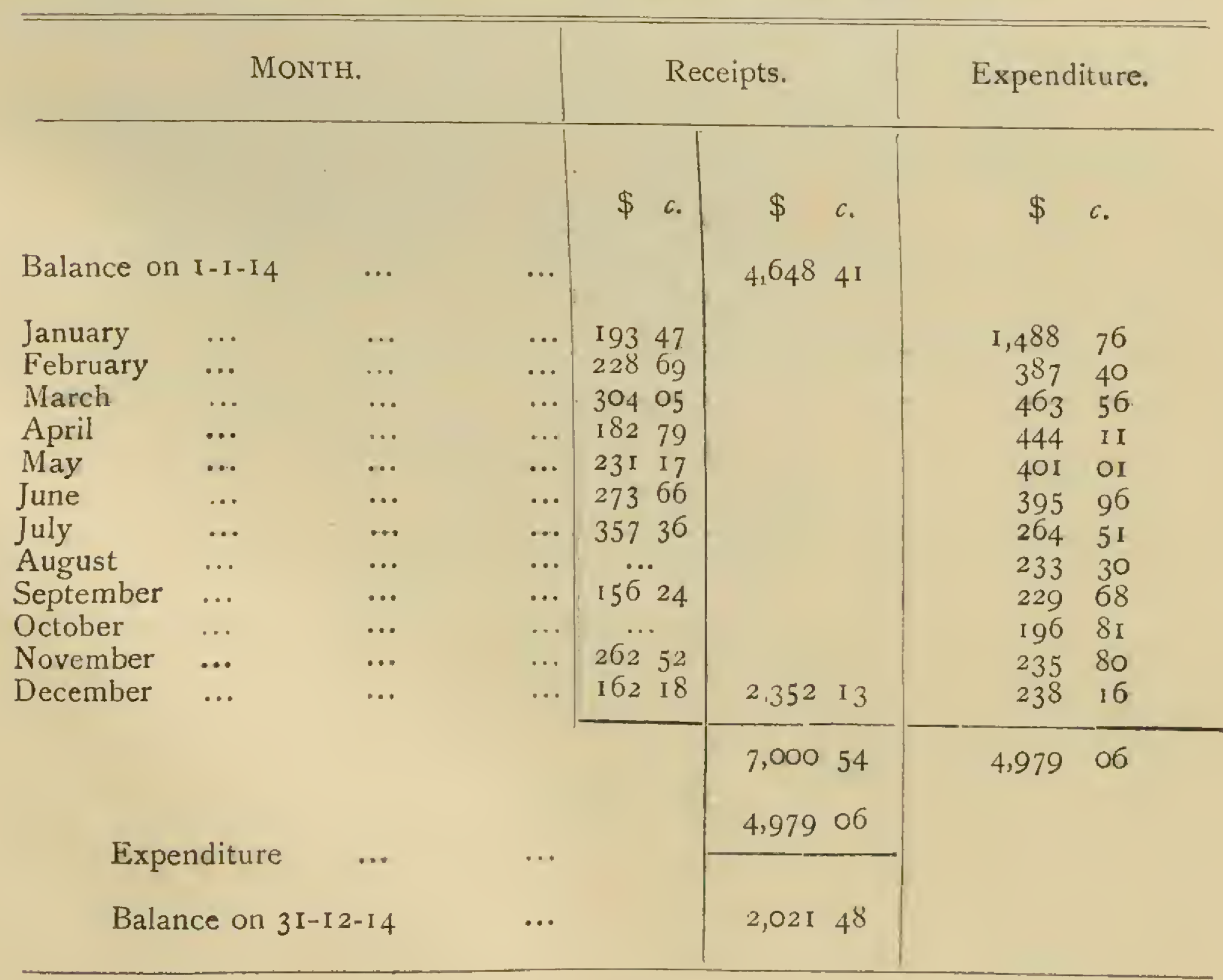




\section{Exploitation.}

TIMBER AND FUel.

From Reserved Forests.

24. The outturn of firewood from the Singapore mangrove coupes was 2,873 tons, or Io tons per acre.

So long as the permit system is in force in the Malacca reserves it is impossible to record the outturn by volume.

There was a marked decrease in timber cutting during August and September. During the last quarter business improved.

In the Batu Undan mangrove reserve, in the Dindings, 46 I tons (approximately) of firewood was cut under permits.

\section{From Crown Land and Alienated Land.}

25. Two hundred and sixty-three monthly permits to cut firewood on Crown Land were issued in Singapore.

In Penang and Province Wellesley $\$ \mathrm{I}, 854.68$ was realized in royalty on timber and $\$ 782.43$ on firewood and charcoal as against $\$ 2,198.93$ and $\$ 606$. I 3 , respectively, in 1913 .

In the Dindings $\mathbf{I}, 866$ tons of Class I timber, 27 tons of Class II, and 33,897 poles for fishing stakes were cut on Crown Land, and paid royalty.

One thousand one hundred and thirteen (approximate) tons of firewood was taken from Crown Land under permit. One hundred and eighty-five tons of timber was removed from alienated land, of which royalty was payable on 8 tons only. One thousand six hundred and eighty-two poles were also cut on alienated land free of duty.

In Malacca royalty from timber permits amounted to $\$ 1,860$. Firewood $\$ 260$.

It is to be regretted that royalty is not payable on all timber and forest produce removed from alienated lands.

\section{Minor Forest Produce.}

26. In Singapore minor produce realized $\$ 247$, in Penang and Province Wellesley, $\$ 578$, the chief items of which were rattans and bertam ataps. In the Dindings the revenue on minor produce fell from $\$ 2,286$ in 1913 to $\$ 1,678$. The decrease is due to the fact that no tin was worked in the Telok Sera Reserve as in former years. Minor produce in Malacca realized $\$ 382$.

\section{PART III.}

Financial Results.

27. The following table shows the total revenue from 1912 to 1914 :-

\begin{tabular}{|c|c|c|c|c|c|}
\hline SETtLEMENT. & $\begin{array}{l}\text { Revenue } \\
\text { I9I } 2 .\end{array}$ & $\begin{array}{c}\text { Revenue } \\
\text { I9I3. }\end{array}$ & $\begin{array}{l}\text { Estimated } \\
\text { revenue } \\
\text { I9I } 4 .\end{array}$ & $\begin{array}{c}\text { Actual } \\
\text { revenue } \\
\text { I9I4. }\end{array}$ & $\begin{array}{c}\text { Increase or } \\
\text { decrease orer } \\
\text { Estimates. }\end{array}$ \\
\hline & $\$ \quad c$. & $c$. & $\$$ & $\$ \quad c$. & $c$. \\
\hline $\begin{array}{l}\text { Singapore } \\
\text { Penang and Province }\end{array}$ & $3,835 \quad 20$ & $5,180 \quad 35$ & 3,50000 & 4, I $44 \quad$ I9 & $+\quad 644$ I9 \\
\hline Wellesley & 2,17921 & $5,544 \quad 84$ & $\mathrm{I}, \mathrm{OOO} 00$ & 3,43240 & $+2,43240$ \\
\hline Dindings & $9,390 \quad 18$ & $8,787 \quad 5^{8}$ & 7,00000 & 8,00977 & $+\quad \mathrm{I}, 00977$ \\
\hline Malacca & 6,12969 & 5.34490 & 5,50000 & $5,174 \quad 77$ & $-\quad 3^{2} 523$ \\
\hline Total ... & $2 \mathrm{I}, 53428$ & $24,857 \quad 67$ & 17,00000 & $20,76 \mathrm{I} \quad \mathrm{I} 3$ & $+3,76 \mathrm{I}$ I 3 \\
\hline
\end{tabular}

A decrease of $\$ 4,096.54$ as compared with the previous year. 
The fall in revenue was slight only in Malacca. Penang shows a decline of $\$ 2,000$. Of this about $\$ 200$ only is a decrease in royalty on forest produce, the revenue in 1913 having included an abnormal payment of $\$ 1,800$. In Singapore there was a decline of $\$ 1,000$ under mangrove firewood, one coupe remained unsold; another of these coupes was only paic for in part, the balance being paid after 3 ist December, 19 I 4 .

Royalty on timber in the Dindings shows an increase of $\$ 1,400$, which is more than counterbalanced by a fall of $\$ I, 660$ under firewood, due to the Tanjong Burong Mangrove Coupe being unsold.

\section{Expenditure.}

28. The following statement shows expenditure from ig 2 to $1914:-$

\begin{tabular}{|c|c|c|c|c|c|}
\hline SETTLEMENT. & $\begin{array}{l}\text { Expendi- } \\
\text { ture } \\
\text { 1912. }\end{array}$ & $\begin{array}{c}\text { Expendi- } \\
\text { ture } \\
\text { r9I3. }\end{array}$ & $\begin{array}{c}\text { Estimated } \\
\text { expenditure } \\
\text { I } 914 .\end{array}$ & $\begin{array}{c}\text { Actual } \\
\text { expenditure } \\
\text { I } 914 .\end{array}$ & $\begin{array}{l}\text { Savings on } \\
\text { Estimates. }\end{array}$ \\
\hline \multirow{6}{*}{$\begin{array}{lc}\text { Singapore } & \ldots . \\
\text { Penang and Province } \\
\text { Wellesley } & \ldots \\
\text { Dindings } & \ldots \\
\text { Malacca } & \ldots\end{array}$} & $c$ & $\$ \quad c$. & $\$$ & $\cdot \$$ & $c$ \\
\hline & $9,9^{2} 3 \quad 34$ & 10,14940 & 10,86200 & 9,455 II & 1,40689 \\
\hline & $6,457 \quad 4^{8}$ & $6,5^{2} 34^{6}$ & 5,53300 & $5,3893^{6}$ & 14364 \\
\hline & $6,286 \quad 24$ & 5,08439 & $6,545 \circ 0$ & 6,10627 & $43^{8} 73$ \\
\hline & $8,723 \quad 39$ & 8,62792 & $9,045 \quad 00$ & $8,495 \quad 77$ & 54923 \\
\hline & $3 I, 39045$ & $30,3^{8} 5 \quad 17$ & 31,98500 & $29,446.51$ & $2,538 \quad 49$ \\
\hline
\end{tabular}

Personal Emoluments

Other Charges

$$
\begin{aligned}
& \text {... } 7,375 \cdot 77 \\
& \text { Total ... } \$ 29,446.5 \text { I }
\end{aligned}
$$$$
\text { ‥ } \$ 22,070.74
$$

\section{Administration.}

20. Mr. C. Hummel acted as Conservator of Forests until inth January, when Mr. A. M. BuRn-Murdoch resumed duty on his return from leave. The death of Mr. BURN-MURDOCH, which occurred on $5^{\text {th }}$ March, is recorded with great regret. The late Conservator of Forests was the first officer to hold the appointment of Conservator of Forests, Federated Malay States and Straits Settlements, to which he was appointed in 1904, having previously acted in the appointment for three, years on deputation from Burna.

For the remainder of the year Mr. B. H. F. BARNARD acted as Conservator of Forests.

The following reserves were visited by the Conservator and Acting Conservators of Forests:-

Penang.-Government Hill and Telok Bahang.

Dindings.-Pangkor, Gunong Melintang, Lumut, Ulu Bruas, Telok Sera and Gunong Tunggal.

Malacca.-Bukit Sebukor, Bukit Bruang, Sungai Udang, Merlimau, Bukit Senggeh and Bukit Panchor.

In Singapore the Collector of Land Revenue administered the Forest Department with the assistance of Mr. T. C. Malaya PILI.AI, Forest Ranger, Grade III, who was retired on pension after three months' half-pay leave. Since the end of October the supervision of forest reserves has been undertaken by the three Land Bailiffs, who were granted each a monthly allowance of \$15. Penang.

Mr. G. C. KEUN, Forest Ranger, Grade I, held charge throughout the year in 
In the Dindings the District Officer dealt with forest matters assisted by the Forest Ranger who attended to field work.

Mr. G. M. O'HARA, Forest Ranger, Grade I, was in charge of the department in Malacca, when he proceeded on long leave on Ist April, and was relieved by Mr. A. S. Mitchell from the Federated Malay States until 3oth September, when $\mathrm{Mr}$. O'HARA returned and resumed charge.

\section{Subordinate Staff.}

30. During the year there were three resignations of Forest Guards in Singapore.

Forester BAHARI BIN DIN of Province Wellesley died on 22 nd January and his widow was granted a gratuity of $\$ 60$. One Forest Guard resigned in Penang.

ITAM BIN UdA BANDAR, Forest Ranger, Grade IV, Dindings, was transferred to the Federated Malay States, and was replaced by Mohamed RipIN BIN AMAN on 26th September. There was one resignation of Forest Guard. The health of the staff is reported to have been unsatisfactory.

3I. The following statement shows the staff employed during the year:-

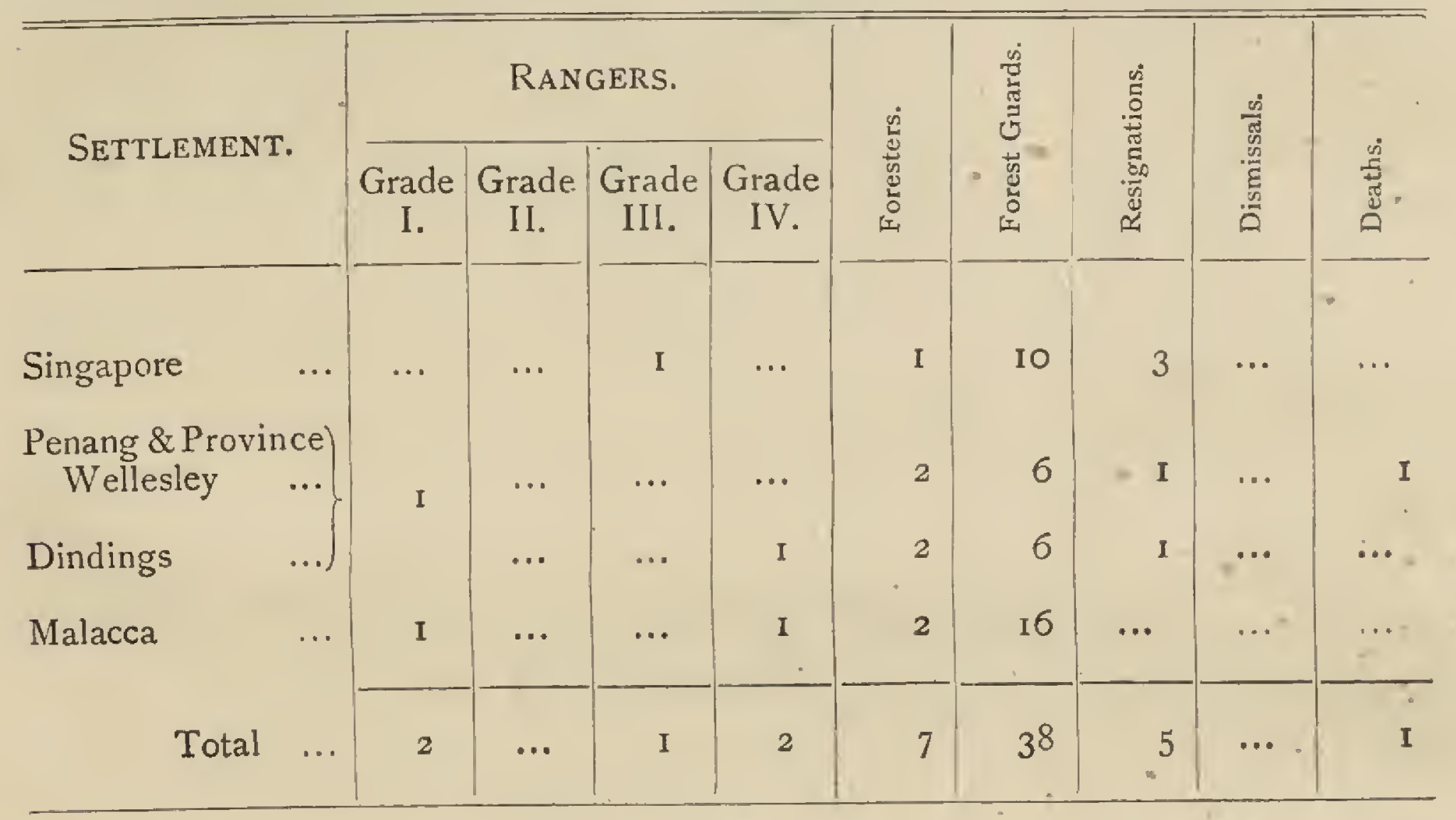

KUALA LUMPUR,

I6th March, 1915.
B. H. F. BARNARD,

Acting Conservator of Forests, S.S. and F.M.S. 


\title{
STRA I T S SETTLEM E N T .
}

\author{
Paper to be laid before the Legislative Council by Command of
}

His Excellency the Governor.

\section{Annual Report on Forest Administration in the Straits Settlements, for the Year 1915.}

\section{PART I.}

\section{Extension and Constitution of Reserved Forests.}

I. The total area of reserved forests at the end of the year was 100,31 1 acres or I 56.7'square miles. Three thousand eight hundred and thirty acres in the Dindings were notified in the Gazette as proposed reserves but remained unsettled at the end of the year. Particulars as to areas of reserved forests in the different parts of the Colony appear in the following table:-

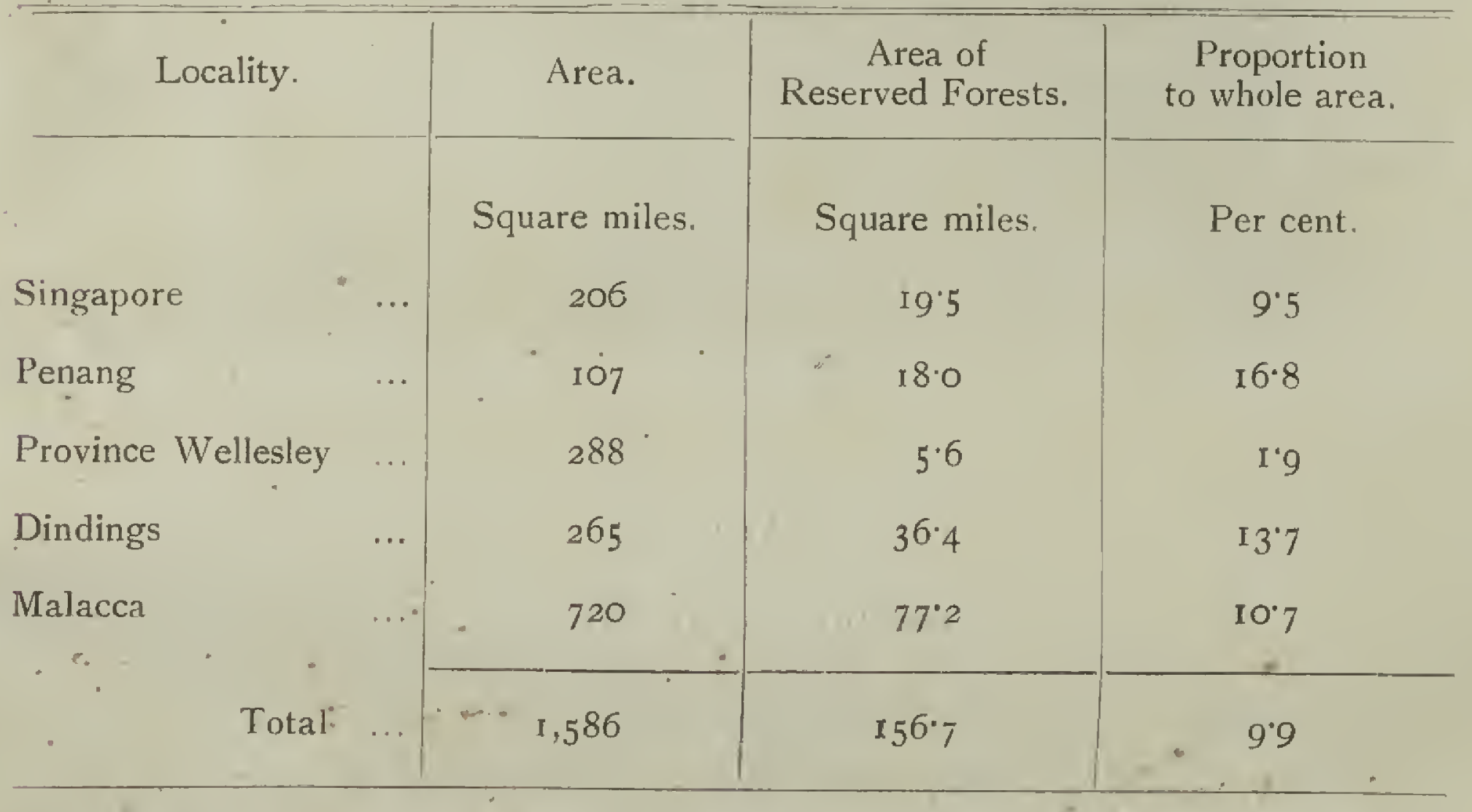

2. The only new area finally gazetted was one of 680 acres in the Dindings known as the Gunong Tunggal Reserve.

No further areas were disforested, the apparent reduction in the area of reserves in the Dindings as compared with I9I4 being due to the erroneous inclusion of the proposed Batu Undan Reserve (see section 3) in the I9I4 report. The land disforested from the Sembawang and Mandi Reserves in Singapore for military purposes in I 9 I 4 remained unused and in the same condition as before it was taken over.

3. The proposed Batu Undan Reserve in the Dindings, which was surveyed in I9I4 and found to contain 3,830 acres, was still unsettled at the end of I9I5. The reservation of a few other small areas was under consideration at the close of the year. These include an addition of about 340 acres of mangrove to the South Seletar Reserve in Singapore, a strip of mangrove of unascertained extent on the West coast of Penang Island, and an extension of about 130 acres to Government Hill Reserve, also in Penang, the object of the latter being to retain for protective purposes what little forest still remains on the crests of the hills in the Balik Pulau District.

The extension of cultivation in the south-west corner of Singapore Island again attracted attention to the forests in that part of the Settlement, and it is desirable that the tops of the higher hills, some of which are covered with virgin forest, should not be alienated, even if they are not included in forest reserves. One prominent hill near 
Pulau Damar has now been practically defined by the survey of adjoining lands, and the reservation of the hills adjoining Pasir Laba and of the mangrove along the north bank of the Sungei Tengeh to the Tuas Reserve should in the opinion of the Collector of Land Revenue be considered. There is also a considerable area of mangrove adjoining some of the streams between Tanjong Kling and Tanjong Gul and on some of the larger islands, which might prove worth reserving.

\section{Demarcation and Upkeep of Boundaries.}

4. The total length of reserve boundaries is 488 miles $7 \mathrm{I}$ chains, of which 128 miles 26 chains are natural and require no demarcation, and 360 miles 45 chains artificial.

5. In Singapore the boundaries were kept in repair by the Forest Guards. In Penang 73 miles I I chains were maintained for $\$ 244.20$, in Province Wellesley $3^{\mathrm{I}}$ miles 56 chains for $\$ 142.40$, in the Dindings 74 miles 77 chains (including 7 miles 5 chains of the Proposed Batu Undan Reserve) for $\$ 218.35$, and in Malacca I04 miles for $\$ 503.55$, the total expenditure being $\$ \mathrm{I}, \mathrm{IO} 8.50$ on 283 miles 64 chains, or \$3.9I, per mile. This expenditure excludes the cost of boundary boards, paint, etc., which amounted to $\$ 19 \mathrm{r} .55$ in Penang and Province Wellesley, and $\$ 435.3 \mathrm{I}$ in the Dindings. The cost of maintenance is much too high and can easily be reduced, if the subordinate staff are made to do a fair share of the work themselves, as in Singapore and the Federated Malay States.

\section{Surveys.}

6. No surveys were completed during the year.

\section{PART II.}

\section{MANAGEMENT OF FORESTS.}

\section{Working Plans and Plans of Operations.}

7. A working plan was drawn up for the reserved forests of Malacca in 1903, but is no longer in force, its existence having apparently been forgotten. It is however not entirely satisfactory.

8. The mangrove forests of Singapore are worked according to a rough scheme of annual coupes, which were disposed of as usual. A similar scheme is nominally in force in the Dindings, but no coupe has been disposed of for two years.

9. Annual plans of operations have hitherto only been drawn up for Penang, Province Wellesley, and the Dindings, but will in future be drawn up for Malacca also. In Singapore no such plan is necessary.

\section{Communications.}

IO. An inspection path one mile in length was constructed in the Tanjong Burong Reserve in the Dindings at a cost of $\$ 5.20$, and sites for several access roads to reserves were chosen.

I I. The maintenance of existing paths cost $\$ 194.30$, namely, $\$ 180$ for I 5 miles in Malacca and $\$ I_{4} .20$ for 3 miles in Penang. In the other Settlements paths were kept in repair by the subordinate staff without expense to Government beyond their pay. 


\section{Buildings.}

I2. No new buildings were erected. General repairs were carried out by and at the expense of the Public Works Department except in Penang and Province Wellesley, where repairs to buildings at Penara Bukit and 'Tasek Glugor cost the Forest Department \$II

\section{Protection of Forests.}

13. No changes were made in the forest laws.

I4. Forty-four cases were taken to Court, convictions being secured in 38 , or 86.4 per cent. Two cases pending from 1914 were abandoned as the accused absconded. Fines amounting to $\$ 439.70$ were inflicted in addition to $\$ 464.18$ awarded to the department as compensation for damage to forest property. The latter sum includes \$roo as damages for a fire in the Sungei Pinang Kechil Reserve. The percentage. of convictions in the Dindings was again very low, 3 cases out of 9 being acquitted.

15. Eleven cases were compounded for $\$ 180.93$, namely, 3 in Malacca by the Resident for $\$ \mathrm{I} I 9.93,3$ in Singapore by the Collector of Land Revenue for $\$ 30$, and 5 in the Dindings by the District Officer for $\$ 3 \mathrm{r}$. It is not clear on what authority cases are disposed of in this way, as the compounding of forest offences is not provided for in the Forest Ordinance.

\section{IMPROVEMENT OF FORESTS.}

\section{Natural Reproduction.}

I6. Reports from Malacca show that I9I5 was an exceptionally good seed year, many of the Dipterocarps producing heavy crops of seed, especially Meranti, Merawan, Rambai Daun, and Resak. There are no reports from the other Settlements.

\section{Plantations.}

17. The area of regular plantations remained unaltered. The experimental planting of Tembusu on lalang land was continued on a small scale at Tasek Glugor in Province Wellesley, but the results cannot be considered satisfactory.

I8. The Lumut Para Rubber Plantation was farmed out for six years with effect from the Ist January, I915, for the sum of $\$ 400$ to be paid in instalments. Sales of rubber remaining from $19 I_{4}$ brought in $\$ 38.59$.

I9. In the Tanjong Mangrove Reserve in the Dindings 18 , 000 mangrove seedlings were planted in areas which had been clear felled in previous years. The major part of this work, on which only $\$ 9.20$ were spent, was done by the staft. The areas so treated cannot be included in the return of plantations, as the blanks treated were scattered and undefined.

20. The Bukit Timah Rubber and Gutta-percha Plantation, which is financed from the Agricultural Improvement Deposit Account, was brought into good order, and tapping, which was discontinued in August, 1914, owing to the low price of rubber, was resumed in March, 1915 . The sale of $521 \frac{1}{4} \mathrm{lbs}$. of rubber realized $\$ 384.76$, IOO Ibs. remaining in hand at the close of the year. The expenditure was considerable, namely $\$ 755.25$, but the extra outlay and attention devoted to the plantation during the year should make future upkeep considerably less expensive. The small plantation at Seletar was allowed to rest.

2I. In Malacca the total expenditure on plantations was $\$ 2,344.24$. The yield of rubber obtained from the Ayer Kroh and Bukit Sebukor plantations was 2,907 lbs., a decrease of 227 lbs. compared with the previous year. This is explained by the adoption of new tapping methods and resting of some of the older trees, which had been tapped too heavily in the past. The revenue from sales of rubber amounted to $\$ 2,932.59$. These plantations are managed by the Forest Department on behalf of the Gardens Committee, who provide the money for maintenance and are credited with all revenue realized. The work is a great tax on the time of the Forest Ranger in charge, and, so far as the rubber is concerned, is outside the scope of a forest officer's duties. It is therefore proposed to lease the rubber plantations, or the right to tap the trees in them, and to transfer the area planted with forest trees to the Forest Department. 
22. A detailed statement of accounts of the plantations is appended.

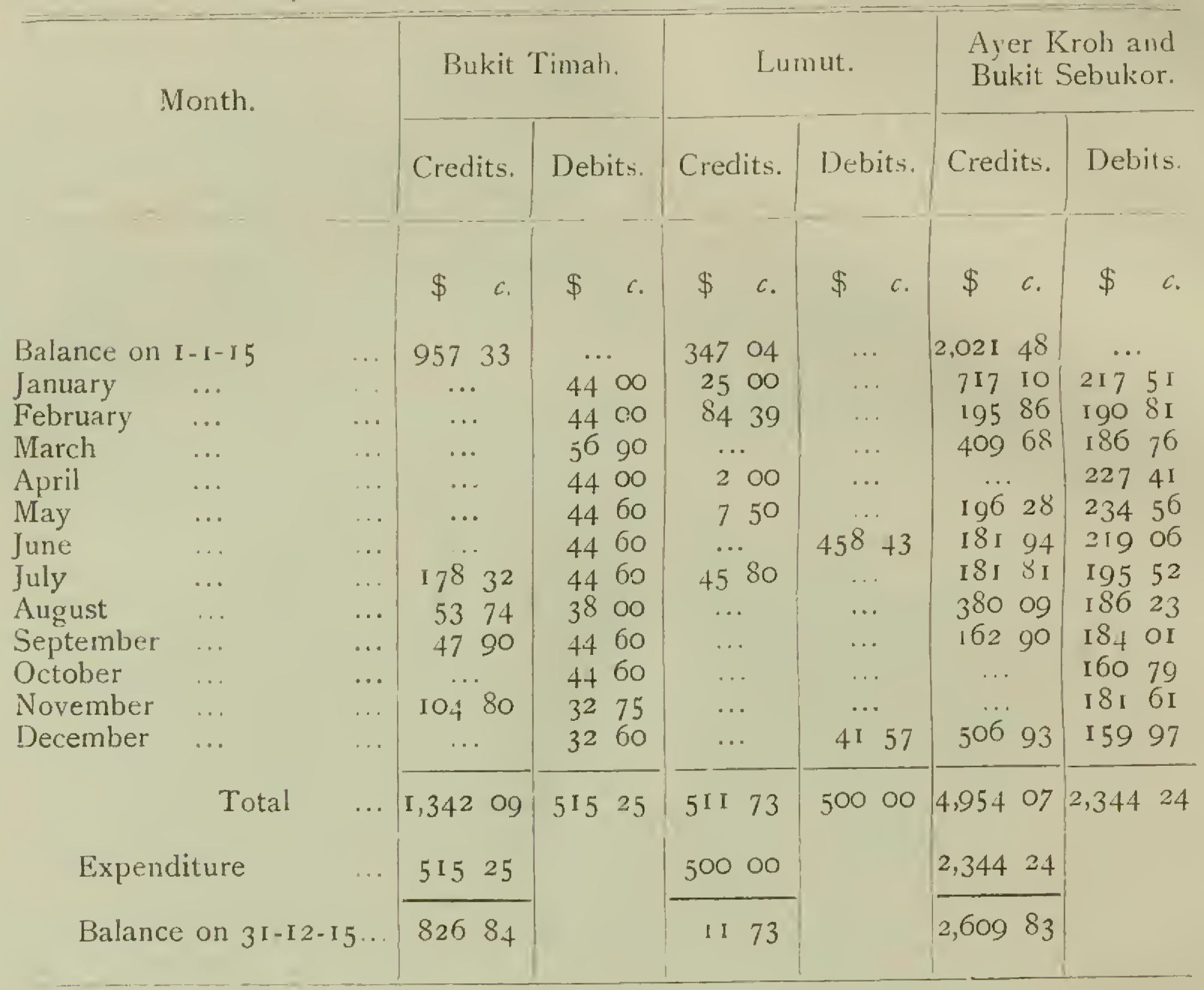

\section{Improvement Fellings.}

23. In the Dindings 500 acres in the Gunong Melintang Reserve were Lreated in favour of Class I trees at a cost of $\$ 523.90$, but the results were not entirely satisfactory, and future operations will be carried out on a smaller scale so that the work can be supervised more thoroughly.

\section{Exploitation.}

Timber and Fuel.

(a) From Reserves.

24. The following table gives the result of the working of the Singapore Mangrove Reserves:-

\begin{tabular}{|c|c|c|c|c|c|c|c|}
\hline \multirow{2}{*}{ Reserve. } & \multirow{2}{*}{$\begin{array}{l}\text { Coupe } \\
\text { No. }\end{array}$} & \multicolumn{2}{|c|}{ Time allowed for working. } & \multirow{2}{*}{$\begin{array}{l}\text { Area } \\
\text { in } \\
\text { acres. }\end{array}$} & \multirow{2}{*}{$\begin{array}{l}\text { Amount } \\
\text { at which } \\
\text { leased. }\end{array}$} & \multirow{2}{*}{$\begin{array}{c}\text { Total } \\
\text { Revenue } \\
\text { from } \\
\text { Reserves, } \\
\text { IgI } 5 .\end{array}$} & \multirow{2}{*}{$\begin{array}{l}\text { Out- } \\
\text { turn } \\
\text { Tons }\end{array}$} \\
\hline & & Opening. & Closing. & & & & \\
\hline & & & & & & $\$$. & \\
\hline Tuas & $\mathrm{V}$ & 3oth Dec., 1914 & 3oth Dec., 19 I 5 & 69 & $2+495$ & 12248 & 545 \\
\hline Kranji & VI & Irth Jan., I9I 5 & I7th Jan., I 910 & 30 & 15000 & I 5000 & 295 \\
\hline Changi & VII & 3rd May, I9I5 & 3ist Dec., I915 & 26 & 10000 & 10000 & I 57 \\
\hline Paindan & VII & 9th Aug., I9I 5 & I 5 th July, 1916 & 100 & $5^{60} 00$ & 56000 & 690 \\
\hline Seletar. & VI & 23rd Nov., 19I5 & 7th Sept., I9I6 & 50 & 19000 & 9500 & 180 \\
\hline lotal ... & $\cdots$ & & $\cdots$ & 275 & I , 24495 & 1,02748 & 1,867 \\
\hline
\end{tabular}


The difference between the figures in the sixth and seventh columns is explained by the fact that the purchase price of the coupes is paid in two instalments which are not always received in the same financial year. The average price obtained for the new coupes was only $\$ 4.85$ per acre compared with $\$ 6.36$ in I9I 4 , and the out-turn 6.79 tons per acre against $9^{\circ} 94$ tons.

25. In Malacca 437 Class $I$ trees exceeding $6^{\prime}$ in girth were marked in reserves by the Forest Ranger for felling and extraction by permit holders, 423 trees, including some marked in 1914 , being removed during the year. A detailed statement is appended:-

\begin{tabular}{|c|c|c|c|c|c|}
\hline \multicolumn{2}{|c|}{ Reserve. } & \multirow{2}{*}{$\begin{array}{l}\text { No. of } \\
\text { trees. }\end{array}$} & \multirow[t]{2}{*}{ Revenue. } & \multirow[t]{2}{*}{ Trees. } & \multirow{2}{*}{$\begin{array}{c}\text { Estimated } \\
\text { out-turn. } \\
\text { Tons. }\end{array}$} \\
\hline & & & & & \\
\hline Merlimau & $\cdots$ & 94 & & 93 & 29230 \\
\hline Ayer Panas & $\cdots$ & 47 & & 34 & 126.09 \\
\hline Bukit Sedanan & $\cdots$ & 24 & & 54 & $140^{\circ} 76$ \\
\hline Sungei Udang & $\cdots$ & 205 & $\begin{array}{l}\text { Details not } \\
\text { available. }\end{array}$ & I 68 & $560 \cdot 96$ \\
\hline Batang Malaka & $\cdots$ & 9 & & 9 & $533^{\circ}$ \\
\hline Bukit Senggeh & $\cdots$ & $5^{8}$ & & 61. & $225^{\circ} 43$ \\
\hline \multirow[t]{3}{*}{ Ramuan China } & $\cdots$ & $\cdots$ & & 4 & $10 \cdot 80$ \\
\hline & & 437 & $\$ 980$ & 423 & $1,409.80$ \\
\hline & $\ln 1914$ & $47 \mathrm{I}$ & $\$ 1,326$ & .. & Not known. \\
\hline
\end{tabular}

It is estimated that I 35 trees and 37,279 poles of Class II species were aIso felled, mainly in the interest of trees of Class I and without previous marking, the revenue realized being $\$ 669$ compared with $\$ 66_{3}$ the previous year, and the estimated out-turn $\mathrm{I}, \mathrm{I} 3 \mathrm{I}^{\circ} 87$ tons. The revenue from charcoal was $\$ \mathrm{I} 2 \mathrm{O}$.

26. In Penang, I4 permits at $\$ 5$ each were issued for the extraction of Class II timber from the Telok Bahang Reserve, and one permit for $\$ 5$ to collect dead wood from the Government Hill Reserve. A Dacridium tree from Government Hill plantation was sold for $\$ 2$. The revenue realized was $\$ 77$, but the quantity of timber extracted cannot be given.

27. The question was raised during the year whether Government obtained a fair return on the timber exploited in Malacca and proposals were made to raise the rates. It was however decided to postpone action partly on account of the war and the generally depressed state of the timber market partly because no data were available as to the quantity of timber extracted under each permit, and partly because it was found necessary to insist on less wasteful methods than had hitherto obtained and it was thought that a sudden raising of rates in addition to much closer supervision would result in many permit holders giving up work altogether. Account is now kept of all timber extracted from reserves, and the figures so far as they go show that the revenue realized on first class timber is only 7 I cents a ton, which is absurdly low considering the quality of the timber. If this result is confirmed by those of the first few months of I 916 the matter of rates will have to be reconsidered.

$$
\text { (b) -From Crown Land. }
$$

28. In Singapore, 4 tons of Class I timber were extracted, and I 6 r $\$ 5$ permits to cut mangrove firewood were issued. The total out-turn of firewood is estimated to have been 3,220 tons, compared with 5,260 tons the previous year. The demand was poor, and during part of the year large accumulations of firewood seemed almost unsaleable. I5.37 I were removed, of which 2,9 I5 were cut under free permits. The out-turn of charcoal was rotons. The total revenue realized was $\$ 1,077.42$. 
In Penang and Province Wellesley $\$ 902.03$ were realized on timber and $\$ 431.55$ on firewood, but the quantities extracted cannot be given.

In the Dindings royalty was paid on I,O39.I 4 tons of Class I timber, II*37 tons of Class II timber, I,6Io tons of firewood, and 27,760 fishing-stakes. $5^{\circ} 95$ tons of Class I timber and 300 tons of firewood were removed free for use by Government departments.

In Malacca the revenue on Class I timber was $\$ 445$ and on Class II timber $\$ 1,404$. The whole of this timber was extracted under monthly permits, but quantities cannot be stated. Charcoal realized \$2 ro.

The above figures do not take into account timber and firewood removed free by Asiatic landholders for their own use.

\section{(c) From Alienated Land.}

29. There is no record of timber and firewood removed from alienated lands in Singapore, Penang, and Province Wellesley.

In the Dindings io per cent royalty was paid on $45^{2} 3$ tons of timber and 185 fishing-stakes.

In Malacca the timber on land to be alienated is now valued by the Forest Ranger and ro per cent royalty demanded. The revenue from this source was $\$ 3$ I $7 \cdot 70$.

\section{Minor Forest Produce.}

\section{(a) From Reserves.}

30. A sum of $\$ 116.66$ was received for the removal of sand in Singapore and 6,056 cubic yards of road metalling were extracted free by the Public Works Department from the Bukit Gua Ipoh and Kubang Ulu Reserves in Province Wellesley.

(b) From Crowen Lands.

3I. From Crown Lands there was a general decrease in out-turn, the revenue realized in the different Settlements being as follows:-

In Singapore \$57.30; in Malacca $\$ 271$ chiefly on wood-oil and nipah; in Penang and Province Wellesley $\$ 237.65$ chiefly on bertam; and in the Dindings $\$ 1,588.75$. The last-mentioned sum includes $\$ 318.70$ paid for granite from the proposed Batu Undan Reserve, $\$ 546$ on bamboos and canes, and $\$$ III.55 on tengah bark.

\section{PART III.}

\section{Financial Results.}

32. The following table shows the total revenue from igi 3 to rgi5:-

\begin{tabular}{|c|c|c|c|c|c|c|}
\hline SETTLEMENT, & $\begin{array}{l}\text { Revenue } \\
\text { I9I3. }\end{array}$ & $\begin{array}{c}\text { Revenue } \\
\text { I9I } 4 .\end{array}$ & $\begin{array}{c}\text { Estimated } \\
\text { revenue } \\
\text { I915. }\end{array}$ & $\begin{array}{l}\text { Actual } \\
\text { revenue } \\
1915\end{array}$ & $\begin{array}{c}\text { Increase or } \\
\text { decrease } \\
\text { over } \\
\text { Estimates. }\end{array}$ & $\begin{array}{l}\text { Increase or } \\
\text { decrease } \\
\text { over I } 9 \text { I } 4 \\
\text { actuals. }\end{array}$ \\
\hline & $\$ \quad c$. & $\$ \quad r$. & $\$ \quad c$. & $\$ \quad c$ & $\$ \quad c$. & $\$ c$. \\
\hline $\begin{array}{l}\text { Singapore ... } \\
\text { Penang and }\end{array}$ & 5,18035 & $4,144 \quad I 9$ & 4,00000 & 3,37094 & -62906 & -77325 \\
\hline $\begin{array}{l}\text { Province } \\
\text { Wellesley }\end{array}$ & $5,544 \delta_{4}$ & $3,+32 \quad 40$ & $2,400 \quad 00$ & $2,256 \quad 4 \mathrm{I}$ & - I 4359 & -I, I 75 99 \\
\hline Dindings $\quad \ldots$ & $8,787 \quad 58$ & 8,00977 & $8,500 \quad 00$ & 6,51995 & $-1,98005$ & $-I, 48982$ \\
\hline Malacca ... & 5,34490 & 5,17477 & 6,00000 & 4,57083 & $-1,429 \quad 17$ & - 60394 \\
\hline Total ... & $24,857 \quad 67$ & 20,76 I $\quad$ I 3 & 20,90000 & I6,7 I8 I3 & $-4, I 8 I 87$ & $-4,043$ OO \\
\hline
\end{tabular}

In Singapore the decrease is attributable to a falling off in the demand for mangrove firewood, due partly to the exhaustion of timber of good quality on Crown lands. The price realized for coupes in reserved forests was also unusually low. 
There was an increase of $\$ 521.36$ on permits for temporary cultivation in reserved forests, and an unusual item of \$ri 6.66 on account of sand taken from the Changi Reserve.

In Penang, Province Wellesley, and the Dindings almost all hearls of revenue show a decrease due to the general depression in the trade in timber and forest produce caused by the war. A similar decrease in Malacca is to some extent counterbalanced by the Io per cent ad valorem tax on timber on newly alienated land.

\section{Expenditure.}

33. The following statement shows expenditure from 1913 to 1915 :-

\begin{tabular}{|c|c|c|c|c|c|}
\hline \multirow[t]{2}{*}{ SETTLEMENT. } & $\begin{array}{l}\text { Expendi- } \\
\text { ture } \\
\text { I } 913 .\end{array}$ & $\begin{array}{c}\text { Expendi- } \\
\text { ture } \\
\text { rgr } 4 .\end{array}$ & $\begin{array}{c}\text { Estimated } \\
\text { expenditure } \\
1915 .\end{array}$ & \multirow{2}{*}{$\begin{array}{l}\text { Actual } \\
\text { expenditure } \\
\text { I } 9 \text { I } 5 . \\
\$ \quad c .\end{array}$} & $\begin{array}{l}\text { Savings on } \\
\text { Estimates, }\end{array}$ \\
\hline & $\$ \quad c$ & $\$ \quad c$. & $c$. & & $c$. \\
\hline $\begin{array}{l}\text { Singapore } \\
\text { Penang and Province }\end{array}$ & 10,14940 & 9,455 I I & I 1,962 OO & 9,75146 & 2,21054 \\
\hline $\begin{array}{l}\text { Wellesley } \quad \ldots \\
\text { Dindings }\end{array}$ & $6,5234^{6}$ & $\begin{array}{l}5,38936 \\
6.106 \\
27\end{array}$ & 5,699 00 & 5,08 I 85 & 617 I5 \\
\hline Malacca & $8,6279^{2}$ & 8,49577 & 9,51600 & 9,43933 & $\begin{array}{ll}76 & 67\end{array}$ \\
\hline Total & 30,385 I 7 & $29,446 \quad 5 \mathrm{I}$ & 34,660 oo & $3 I, 12600$ & 3,53400 \\
\hline
\end{tabular}

The expenditure of the year, which amounted to $\$ 31,126$ included $\$ 22,967.16$ for Personal Emoluments, and \$8, I 58.84 for Other Charges, the savings on the estimates being $\$ 2,0 \mathrm{I} 7.84$ and $\$ \mathrm{I}, 5 \mathrm{I} 6.16$ respectively. The savings on staff are chiefly due to the abolition of the post of ranger in Singapore and the appointment of a new clerk in Penang on a lower salary than that drawn by his predecessor. On Other Charges the savings, of which two-thirds were in Singapore, are distributed mainly over the heads connected with the maintenance and improvement of forests.

34. The net result is a loss of $\$ 14,407.87$. The department should however pay its way, if the Malacca and Dindings forests are developed.

\section{Administration.}

35. Mr. B. H. F. BARnARD acted as Conservator up to and including the I 6 th April.

Mr. G. E. S. CuBitT arrived from India and took over charge on the I 7 th of the same month.

Mr. KEun held charge in Penang till the $\mathrm{I}$ th December and went on leave the following day, when he was relieved by Mr. AsKey from the Federated Malay States. These officers were also responsible for field work in the Dindings.

Mr. O'HARA was in charge in Malacca throughout the year. In Singapore the Collector of Land Revenue administered the Department with the help of the Land Bailiffs and Forester, who shared the travelling allowance allotted to the post of Forest Ranger vacated by Mr. T. C. Malaya PllLaI, which it is not proposed to fill.

36. These arrangements are adequate as far as Singapore is concerned and no change is recommended. Matters are however not so satisfactory in regard to Penang, the Dindings, and Malacca. The forests in the Dindings are of considerable value and importance, but it is impossible to look for much development either there or in Malacca so long as a ranger is in almost independent charge. The annual expenditure, especially in Malacca, is ludicrously low, and has unfortunately not always been laid out to the best advantage. The Ranger in Malacca is also hampered by the supervision of the rubber plantations. It is becoming increasingly evident that a thorough re-organization of forest administration in the Colony (except Singapore) is necessary, and the lines on which re-organization can probably best be effected are the fusion of the services in the Federated Malay States and 
Straits Settlements at any rate down to Ranger Grade I, and the subordination of the officers in charge of the different Settlements to one or other of the Deputy Conservators in the Federated Malay States. It is hoped in due course to submit a scheme to give effect to these suggestions.

37. During the year the Conservator as usual made tours of inspection to each of the Settlements.

38. The following table gives particulars of the staff employed at the end of the year:-

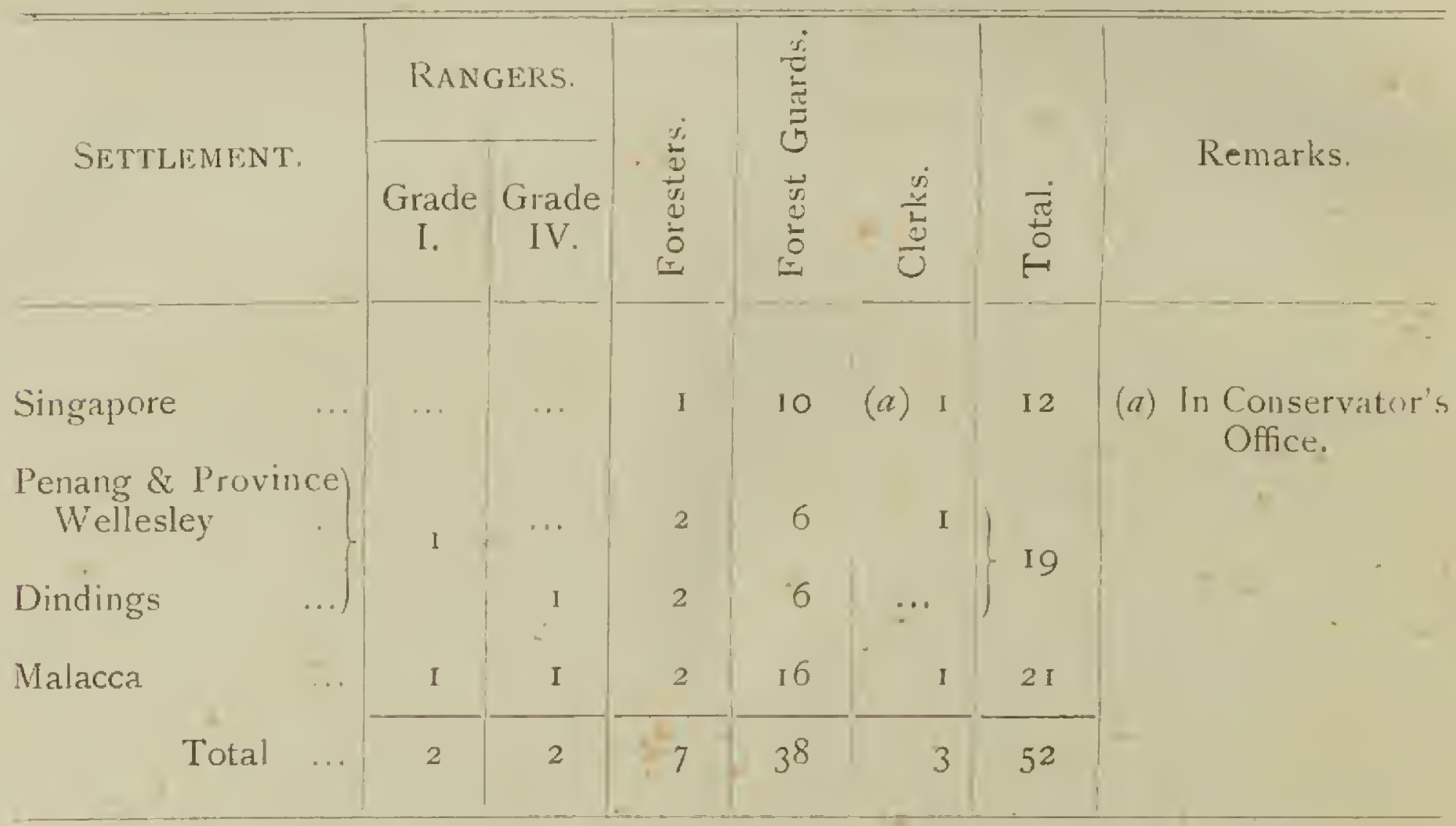

39. Two Foresters retired and one resigned: one Forest Guard resigned and one absconded. There were no deaths. The work and health of the staff were on the whole satisfactory.

KUALA LUMPUR, 27 th March, 1916.
G. E. S. C.UBITT

Conservator of Forests, S. S. and F.M.S. 
Pequot' for the Years. 1916 m917 not waviturle.

$\Delta /\langle\Delta|$ 


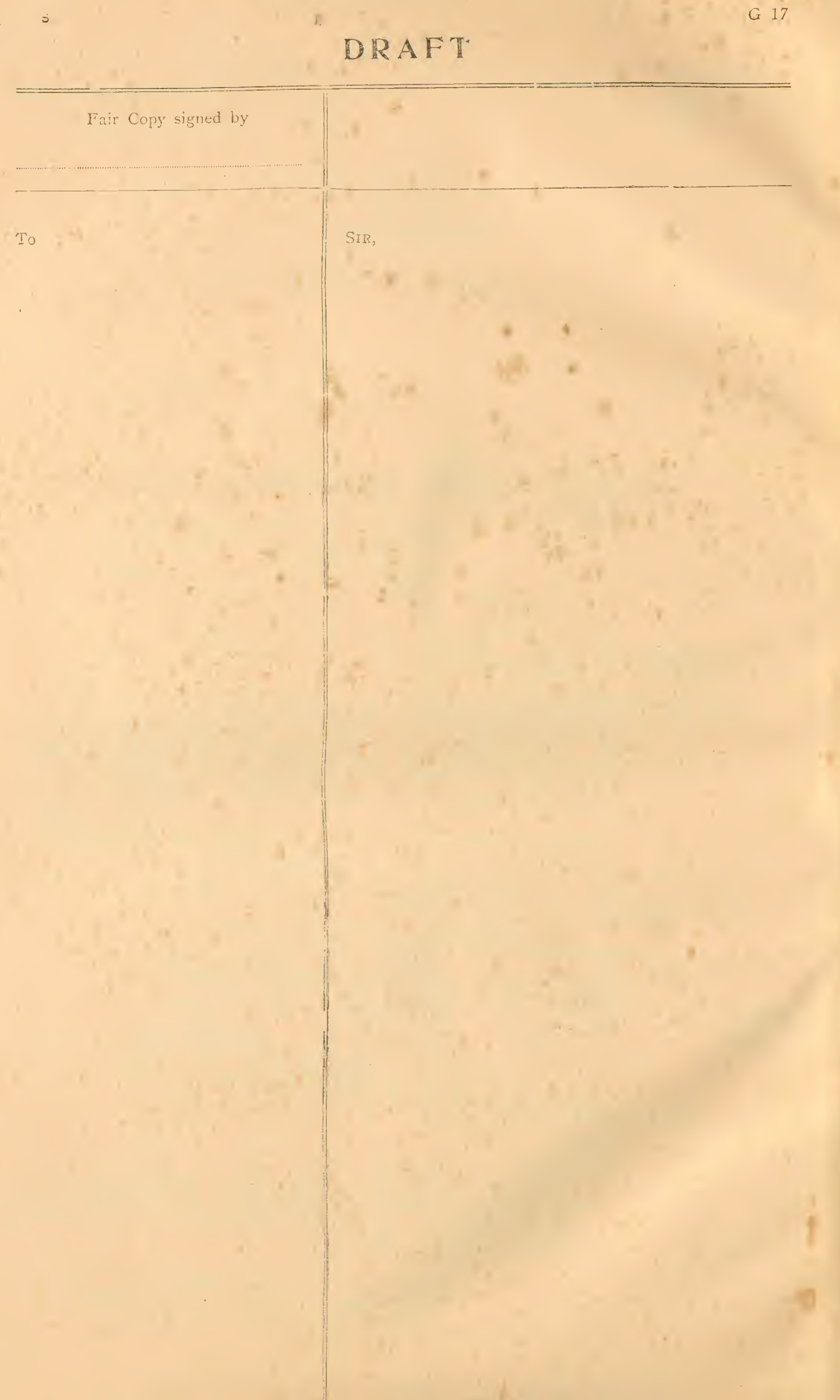




\section{Annual Report on Forest Administration in the Straits Settlements, for the Year 1918.}

\section{PART I.}

\section{Extension and Constitution of Reserved Forests.}

Proposals which had been made in roI7, for the extension of the Sungei Buloh and Kranji Forest Reserves in Singapore were carried out and an area of about 358 acres was added to the former and of about 202 acres to the latter. These areas, which consist entirely of mangrove on the banks of tidal rivers, have not yet been fully defined, though a great part of their boundaries has been surveyed in connection with the recent alienation of Crown land. No progress could be made towards further extensions owing to delay in survey Wolis.

2. There was no change in Penang or in the Dindings, but in Province Wellesley the Sungei Acheh Reserve, comprising about 358 acres of mangrove forest, was constituted. The contemplated excision of 300 acres from the Taseh Glugor. Reserve has not yet been carried into effect, but the timber on the area is being remored in anticipation of its early excision and alienation.

3. The revocation of the Bukit Sebukor Reserve in Malacca, which was soli in I0T7, was formally gazetted, thus reducing the area of reserved forests in that Settement by about 44 acres.

4. The statement below gives the proportion of reserves to the whole area of the Colony. the areas of the Settlement differing from those in the forest report for 1917 . but agreeing with those on page $\mathrm{O}_{2}$ of the Blue Book for that year. Details are given in Form I*

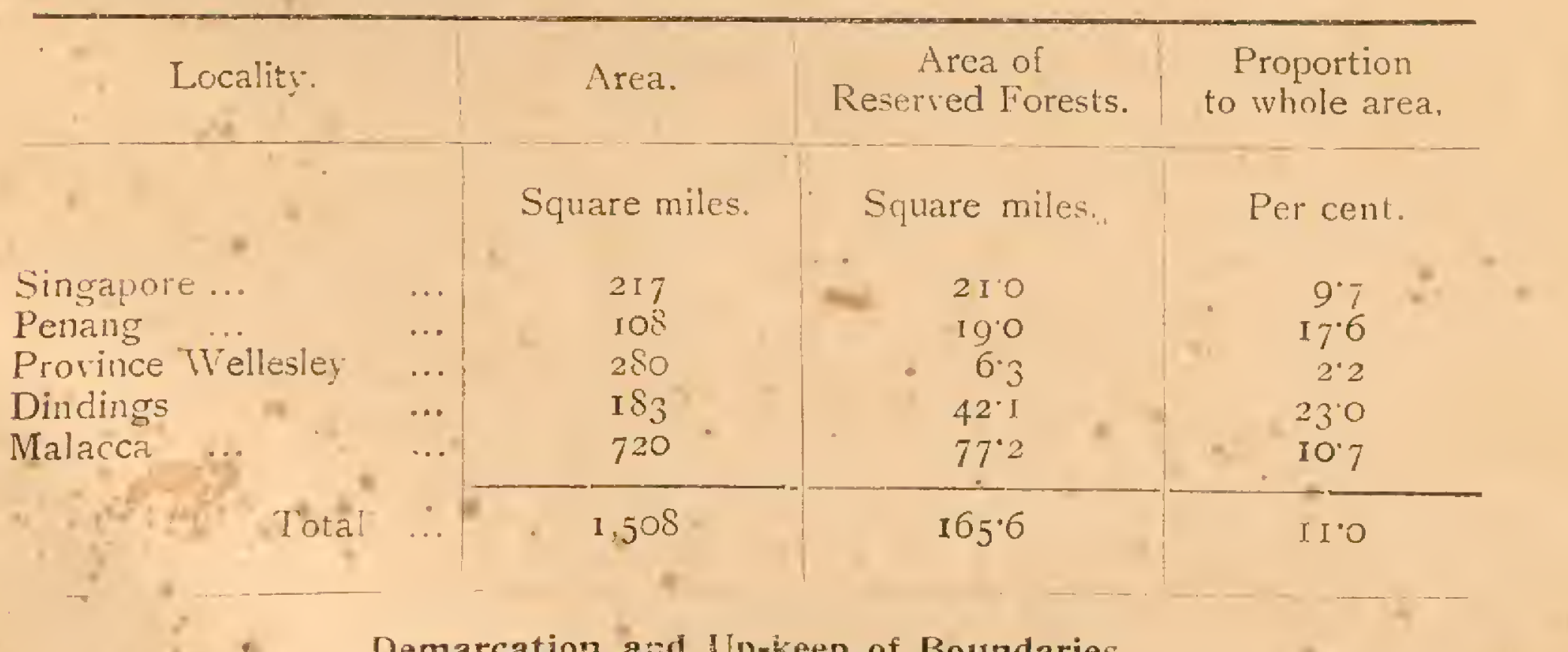

2. Demarcation and Up-keep of Boundaries.

5. In Singapore the boundaries of the newly constituted Sungei Buloh and Kranii Extension Reserves were demarcated and the boundaries of all other reserves were maintained by the subordinate staff without exfense. In Penang repairs to 81 miles 22 chains cost $\$ 78.15$; in Province Wellesley 35 miles 49 chains $\$ 45.35$; in the Dindings 74 miles 66 chains $\$ 148.70$; and in 
Malacca 84 miles 30 chains $\$ 564.50$. The figures include in each case the cost of boundary plates, which was unusually heavy, but exclude the salaries and night allownces of the subordinate staff employed who personally did murh of the work. In all, 358 miles 36 chains were repaired for $\$ 836.70$ or $\$ 2.34$ per mile, compared with SI.8I per mile in I9I7. Details will be found in Form $3^{*}$.

\section{Surveys.}

6. In August a beginning was made with the survey of comnunications in reserves, the Sungei Udang Reserve in Malacca being taken in hand and I7 miles 60 chains of cart and buffalo tracks surveyed at a cost of \$294.47, a far too heavy expenditure for the amount of work accomplished.

\section{PART II.}

\section{MANAGEMENT OF FORESTS.}

\section{Working Plans and Plans of Operations.}

7. There are still no regular working plans. Plans of operations were drawn up for all the Settlements except Singapore and were adhered to.

\section{Communications.}

8. No new communications were opened and existing paths in charge of the department were maintained without expense by the subordinate staff.

\section{Buidings.}

9. New quarters were built at Bukit Mertajam by the Public Works Department at a cost of $\$ 473$ for forest departinent boatmen. Repairs were also carried ont where necessary by that department. Details are given in Form $6^{*}$.

\section{Protection of Forests.}

ro. There were no changes in the forest law. Forty-three breaches of the forest rules were reported, of which twenty-six were dealt with in Court the forest rules were repled. Convictions were secured in but two cases. The hnes inflicted amonnted to $\$ 393.75$, in addition to compensation of $\$ 782.56$ faid to the department for damage done to the forest. One offender elected to cro to gaol. The compensation in compounded cases amounted to $\$ 365.68$. None of the offences were of sufficient importance to require separate mention. Details are given in Form $7^{*}$.

\section{IMPROVEMENT OF FORESTS.}

Natural Reproduction.

IT. From such reports as are available and from personal observation it would seem that the reproduction of Class $I$ irees is adequate wherever there is sufficient light. Damarlaut reproduces itself freely in the Dindings, and in Malacca the cutting of second class timber has undoubtedly stimulated the growth of first class seedlings.

\section{Plantations and Cultural Operations.}

12. No additions vere made to the area of regular plantations. Tapping was carried on at Bukit Timaln until August, when it was discontintued owing to the low price of rubber. The output-546 1bs. of rubber and $461 \mathrm{bs}$. of crap-was sold for $\$ 265.42$, but owing to an oversight $\$ 28.70$ of this amount vas not collected until I9I9. Maintenance charges were \$3II.88. The small flantation at Seletar was again leased to the Mandai Tekong Company, for $\$ 350$.

T3. In Province Wellesley and the Dindings bakan minyak was planted Taroe scale 100,000 seed were planted in the Sungei Acheh Reserve at a cost of $\$ 42$, but 50 per cent of these were washed away by a rough sea; the 
remander atie doing well. Another 400.000 were planted in blanks in the Tanjong Burong Reserve at a cost of $\$ 276.49$, of which 80 per cent are thriving. The plants put down in 1916 in the same reserve are reported to be now 8 feet in height. Lastly 83,000 were planted in the 20-acre block on the Bruas River which was exploited in 1917. Most of the work was done by forest guards and boatmen, and more would lave been accomplished but for the serious outbreak of infiuenza.

I4. A small area in the Bukit Panchor Reserve was cleared of bertam by a contractor in return for permission to sell the palm without payment of roylty. In this area a sum of $\$ 54.84$ was spent in clearing the ground and sowing about 50,000 seeds of valuable species. Small sums were also spent in clearing bertam from an area in the Sungei Pinang Reserve where damarlaut is plentiful but regeneration poor, and in removing piai rava from the Tanjong Burong Reserve.

15. The Para rubber in the Ayer Kroh plantation was leased ont for tapping at the rate of 5 cents per tree, but at the end of September the lessec stopped tapping as he found it was no longer profitable. Revenue of $\$ 349.20$ was realized on $I, 164$ tappable trees. The output is said to have been $2,2 \mathrm{I} 6 \frac{1}{2} \mathrm{lbs}$. of sheet rubber and $246 \frac{3}{4} \mathrm{lbs}$. of scraf, which sold for $\$ 93^{2}$. I5.

56. The Lumut rubber plantation was still held on lease, for which the lessee paid during the year $\$ 75$. The plantation is badly maintained and other arrangements will probably have to be made when the present lease lapses.

\section{EXPLOITATION.}

\section{Timber and Fuel.}

\section{(a) From Reseries.}

I7. Ten mangrove coupes in Singapore with a total area of 465 acres were ofen to regular exploitation during the year. For five coupes of 235 acres leased during the year $\$ 10.83$ Fer acre was realized, compared with $\$ 6.06$ in I9I7 and $\$ 4.64$ in I9I6. The total out-turn from leased coupes was 4,740 tons, an increase of 1,302 tons over 1917. In addition four old coupes were open to exploitation nnder monthly permits. One hundred and twenty-one permits were issued for the removal of mangrove firewood and 6I to cut nyireh, the estimated out-turn being 2,42I and I,220 tons respectively, and the revenue thereon $\$ 789$. Out-turn from other sources was about Ioo tons, representing revenue of $\$ 94.36$, and not needing mention in detail. The following table summarises the result of the year's work in the mangrove forests:-

\begin{tabular}{|c|c|c|c|c|c|c|c|c|}
\hline \multicolumn{3}{|c|}{ Reserve. } & $\begin{array}{c}\text { Coupe } \\
\text { No. }\end{array}$ & $\begin{array}{l}\text { Area in } \\
\text { acres. }\end{array}$ & $\begin{array}{c}\text { Amount at } \\
\text { which } \\
\text { leased. }\end{array}$ & $\begin{array}{l}\text { Total } \\
\text { revenue rea- } \\
\text { lized during } \\
1918 .\end{array}$ & $\begin{array}{c}\text { Approximate } \\
\text { out-turn } \\
\text { during } 191 \mathrm{~S} .\end{array}$ & Remarts. \\
\hline $\begin{array}{l}\text { Pandan } \\
\text { Pandan } \\
\text { Changi } \\
\text { Changi } \\
\text { liranji } \\
\text { Krangi } \\
\text { Seletar } \\
\text { Seletar } \\
\text { Tuas } \\
\text { Tuas }\end{array}$ & $\begin{array}{l} \\
\ldots \\
\ldots \\
\ldots \\
\ldots \\
\ldots \\
\ldots \\
\ldots \\
\ldots \\
\ldots\end{array}$ & $\begin{array}{l}\ldots \\
\ldots \\
\ldots \\
\ldots \\
\ldots \\
\ldots \\
\cdots \\
\ldots \\
\cdots \\
\ldots\end{array}$ & $\begin{array}{r}9 \\
10 \\
9 \\
10 \\
9 \\
10 \\
8 \\
9 \\
8 \\
9\end{array}$ & $\begin{array}{l}80 \\
80 \\
10 \\
18 \\
30 \\
30 \\
45 \\
42 \\
65 \\
65\end{array}$ & 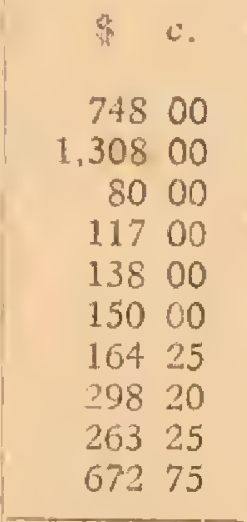 & $\begin{array}{rc}\$ & c \\
\ldots & \\
1,308 & 00 \\
\ldots & \\
117 & 00 \\
69 & 00 \\
75 & 00 \\
82 & 13 \\
149 & 10 \\
131 & 63 \\
336 & 38\end{array}$ & $\begin{array}{r}\text { Tons. } \\
\begin{array}{r}1,020 \\
800 \\
60 \\
240 \\
440 \\
240 \\
480 \\
\ldots \\
1,340 \\
120\end{array}\end{array}$ & $\begin{array}{l}\text { Old. } \\
\text { New. } \\
\text { Old. } \\
\text { New. } \\
\text { Old. } \\
\text { New. } \\
\text { Old. } \\
\text { New. } \\
\text { Old. } \\
\text { New. }\end{array}$ \\
\hline & Total & $\ldots$ & $\ldots$ & 465 & 3,93945 & $2,268 \quad 24$ & 4,740 & $\ldots$ \\
\hline $\begin{array}{l}\text { Pandan } \\
\text { Pandan } \\
\text { l'andan } \\
\text { Tuas }\end{array}$ & $\begin{array}{l}\cdots \\
\cdots \\
\cdots \\
\cdots\end{array}$ & $\begin{array}{l}\cdots \\
\cdots \\
\cdots \\
\cdots\end{array}$ & $\begin{array}{l}6 \\
8 \\
9 \\
7\end{array}$ & $\begin{array}{r}100 \\
105 \\
80 \\
65\end{array}$ & $\begin{array}{l}\cdots \\
\cdots \\
\cdots \\
\cdots\end{array}$ & $\begin{array}{r}18000 \\
15600 \\
9000 \\
18000\end{array}$ & $\begin{array}{l}720 \\
621 \\
360 \\
720\end{array}$ & $\begin{array}{l}\text { Open under } \\
\text { month } 1 \text { y } \\
\text { permits. }\end{array}$ \\
\hline & Total & $\cdots$ & $\ldots$ & 350 & $\ldots$ & 60600 & 2,421 & ... \\
\hline
\end{tabular}


I8 The reserves in Penang, Province Wellesley, and the Dindings were more treely opened to exploitation than in the past, and the revenue rose in consequence from \$I,499.I5 to \$I0,0I4.06. Four hundred and ten tons, mostiy poles, were extracted from the reserves on Penang Island. The Province Wellesley reserves yielded 242 tons of timber, 340 tons of nirewood, and some charcoal, most of the timber coming from the portion of the Tasek Glugor Reserve, which it is proposed to rescind. In the Dindings there was an output of 1,242 tons of timber and 7,429 tons of firewood, a quarter of the timber and all the frewood coming from the Tanjong Burong mangrove reserve, and most of the rest of the timber from the Segari-Melintang Reserve.

19. In Malacca the system of marking trees in reserves for felling was continted, and the output, I,752 tons of timber and I7I tons of charcoal, slightly exceeded that of IgI7. Efforts have been made to secure more economical working, and some measure of success seems to have been attained, for the yield per tree of Class I timber rose from $2^{\circ} 9$ to $3^{.6}$ tons.

20. The out-turn from the reserved forests in all Settlements was 3,742 tons of timber, I6, I54 tons of firewood, and I7I tons of charcoal, on which revenue to thie amount of $\$ I 5,519.66$ was realized. Further details are given in Form 9*,

\section{(b) From Croun Lands.}

21. The number of permits issued in Singapore to collect mangrore and nyirch frewood rose from 227 in 1917 to 250 in the year of report, which, at 20 tons per permit, represent an output of 5,000 tons. Other firewood accounts for the additional 203 tons shown in Form $9^{*} .75^{6}$ tons were taken out in the form of poles. The revenue realized was $\$ 2,141.60$.

22. In Penang and Province Wellesley there was a decrease in the output of poles, but this was counterbalanced by an increased out-turn of Class I timber. In the Dindings there was an increase in output both of timber and firewood, the latter showing a rise of over i 5 per cent. The total yield from the two Settlements was 2,578.38 tons of timber and 6,959 tons of firewood, conpared with $2,133.8 \mathrm{I}$ and $4,2 \mathrm{II}$ tons respectively in I9I7, with a corresponding rise in revenue from $\$ 6,718.08$ to $\$ 7,808.04$.

23. In Malacca also all classes of timber and fuel were worked in increased quantities, the out-turn being I, IO8 tons of timber and 255 tons of firewood, compared with 861 and 122 tons respectively in 1917 , the reventue rising from $\$ 1,279$ to $\$ 2,038$.

24. The total revenue on timber and fuel from Crown lands in all. Settlements was $\$ I I, 987.64$, details of the quantities extracted, amounting in all to 4,442 tons of timber and 12,4 I 7 tons of frewood, being given in Form $9^{*}$.

\section{(c) From Alienated Lands.}

25. No reliable figures can be given of the yield of timber from alienated land. Royalty at the rate of to per cent ad valorem, as nearly as can be estimated, is paid in Malacca on forest produce, when land is alienated, and from this source a sum of \$T,819.99 was realized. Crown lands are now rousty classified and the royalty payable fixed for each class, thus saving the time and trouble involved by an inspection of each parcel of land disposed of.

26. In the Dindings 40 tons of timber and 25 tons of firewood from alienated land brought in $\$ 78.72$.

\section{Minor Forest Produce.}

\section{(a) From Reserves.}

27. Minor forest produce from reserved forests paid revenue of $\$ \mathrm{I}, 306.50$ as follows:-

Singapore $\$ 8$ for nibong, Penang \$26I chiefly for bertam and rotan, Province Wellesley $\$ 79.30$ almost entirely for bertam, the Dindings $\$ 457.50$, of which $\$ 263$ were for road metal, and Malacca $\$ 500.70$ including $\$ 349.20$ 
fo: Jara rubber, and SIO2.50 for durians from the dusuns in the Bukit Panchor Reserve. $3,8+3$ cubic yards of road metal were taken free by the Public Works Department from the Bukit Goa Ipoh and Kubang Ulu Reserves 11 Province Wellesley. Other produce extracted besides those mentioned include climbers of various sorts, bamboos, betel-nuts, dukus, damar, langkap, mongkuang, and krang shell.

\section{(b) From Croin Lands.}

25. I'here was a further slight decrease from SI, Ig6.79 to SI,II4.74 in the revenue on minor forest produce from Crown lands, the Settlements contributing as follows:-Singapore \$4.60, Penang \$37.20, Province Wellesley $\$ 28.50$, the Dindings $\$ 7+2.14$, and Malace $\$ 302$. The only items of importance are nibong (\$200.40), canes (\$379.80), nncultivated rubber (SIs)). mingkuang (\$II5), bertam (\$88.75), and tengar bark (\$60.96).

(c) From Alienuted l.ands.

29. The only revenue under this head was SIS.SF collected on bitam and canes in the Dindings.

\section{PART III. \\ FINANCIAL RESULTS.}

\section{Revenue.}

30. The following statement shows the total revenue from igi6 to igis:-

\begin{tabular}{|c|c|c|c|c|c|c|}
\hline SETTIEMENTS. & $\begin{array}{l}\text { Revenue } \\
1916 .\end{array}$ & $\begin{array}{l}\text { Revenue } \\
1917\end{array}$ & $\begin{array}{l}\text { Esti- } \\
\text { mated } \\
\text { revenue } \\
\text { Iols. }\end{array}$ & $\begin{array}{l}\text { Actual } \\
\text { revenue } \\
\text { IgIS. }\end{array}$ & $\begin{array}{c}\text { Increase } \\
\text { or decrease } \\
\text { over } \\
\text { Estimates. }\end{array}$ & $\begin{array}{c}\text { Increase } \\
\text { or decrease } \\
\text { over I9I7. } \\
\text { actuals. }\end{array}$ \\
\hline \multirow[t]{2}{*}{ v } & " & & & & & \\
\hline & $\$ \quad c$. & $\$ c$ & $\$$ & $\$$ & & $\$ c$ \\
\hline Singapore & 4,846, II & 6,26499 & 3,500 & 7,85263 & $4,3.52 \quad 63$ & $+1,58_{7} 64$ \\
\hline $\begin{array}{c}\text { Penang and }-? \\
\text { Wellesley }\end{array}$ & $2,297+0$ & $2,6+31+$ & 1,750 & 5,30879 & 3,55879 & $+2,66565$ \\
\hline Dindings & 5,10089 & $.7,755 \delta_{2}$ & 7,520 & 14,5 I 80 & 6,998 o7 & $+6,76225$ \\
\hline Malacca & $11,127 \quad 15$ & 8,92995 & 6,500 & 7,7996 & I, 29964 & $-\mathrm{I}, \mathrm{I} 303 \mathrm{I}$ \\
\hline TOT:1. & 23,37 I 55 & 25,593 go & 19,270 & $35.479 \quad I$ & $I_{3} \quad I 6,209 \quad 13$ & $+0,8 \times 5=3$ \\
\hline
\end{tabular}

31. In Singafore the increase orer IgIT is due to the larger demand for frewood and to the much better prices paid for the mangruve conpes, the results perhaps of the high price of coal. A greater number of permits than in 101 , were issted for the removal of nvirch and other old timber from compes leased in former years, and there was ansextension of regetable cultivation in the Sotrin Seletar Reserve.

In Ponang, Province Wellesley, and the Dindings, the reserves have been operied more freely to exploitation, the chief contributors to the increased revenue being the Pantai Acheh Reserve in Penang, the Tasek Glugor Ruserve in Province Wellesley, and the Segri-Nelintang and Tinjong Burong Reserves on the Dindings.

The decrease in Malacca is more than accounted for by the sale of the Bukit Sebulor rubber plantation and the small price paid for the lease of the plantation: at Ayer Kroln. If interest on the furchase price of the Bukit Sebukor plantation is allowed for the decrease is converted into an increase. 
Expenditure.

32. The following table shows the expenditure from 1916 to I918:-

\begin{tabular}{|c|c|c|c|c|c|c|}
\hline SETTLEMENT. & $\begin{array}{c}\text { Expenditure, } \\
1916 .\end{array}$ & $\begin{array}{c}\text { Expenditure, } \\
1917 .\end{array}$ & $\begin{array}{c}\text { Estimateđ } \\
\text { expenditure, } \\
1918 .\end{array}$ & $\begin{array}{c}\text { Expenditure } \\
1918\end{array}$ & $\begin{array}{l}\text { Savings on } \\
\text { Estimates. }\end{array}$ & $\begin{array}{c}\text { Increase or } \\
\text { decrease } \\
\text { over } 1917 \\
\text { actuals. }\end{array}$ \\
\hline \multirow{4}{*}{$\begin{array}{l}\text { Singapore } \\
\text { Penang and Province } \\
\quad \text { Wellesley } \\
\text { Dindings } \\
\text { Malacca }\end{array}$} & $\$ \quad c$. & $\$ \quad c$. & $\$$ & $\$ \quad c_{1}$ & $\$ c$. & $\$ \quad c$. \\
\hline & 9,60208 & $9,549 \quad 17$ & 11,140 & 10,12695 & 1,01305 & $\begin{array}{l}+\quad 57778 \\
\end{array}$ \\
\hline & $5,020 \quad 40$ & 4,86398 & 5,950 & 5.51119 & 43881 & 64721 \\
\hline & $\begin{array}{rr}5,664 & 18 \\
10,684 & 57\end{array}$ & $\begin{array}{r}5,997 \\
11.95326\end{array}$ & $\begin{array}{r}7,497 \\
12,120\end{array}$ & $\begin{array}{r}6,44850 \\
11,48937\end{array}$ & $\begin{array}{r}1,04850 \\
63063\end{array}$ & $\begin{array}{ll}451 & 34 \\
463 & 89\end{array}$ \\
\hline Total & 30,97123 & $32,363 \quad 57$ & 36,707 & $33,576^{\circ} 01$ & 3,13099 & +1.21244 \\
\hline
\end{tabular}

3. Of the total of $\$ 33,576.01, \$ 25.278 .51$ were spent on personal emoluments and $\$ 8.297 .50$ on other charges, compared with $\$ 23,845.90$ and $\$ 8,517.67$ in I9I7. The savings on the estimates are due chiefly to faulty estinating, which it is hored to avoid in future. The increas'es over the actuals of roI7 are acconnted for in Singapore chiefly by the payment of arrears of the Conservator's pension contribution. In the other Settlements nearly all heads show increased expenditure. but especially transport, uniforms, and salaries of boatmen. Increases in Malacca were however more than counterbalanced by the cessation of expenditure on rubber plantations, and the sharing with the Federated Malay States of the salary of the clerk.

34. The rear's mork shows for the first tine since Igo4, and for only the third time in the history of the department; a small surplus, amounting for the rear of report to Si,go3.12. Mich more money should be spent on the derelopment of the forests, especially in the Dindings, and this surplus may not be repeated. but there seems to be no reason why they should not become regularly remunerative in or is years.

\section{PARTIV IV.}

\section{Administration.}

35. The Singapore forests were as in past years administered by the Collector of Land Rerenue with the help of the Land Bailiffs and a small staff of forest subordinates; the appointment of Ranger ceased to appear in the estinates. The Forest Ranger in charge of Malacca was transferred to Tampin and stbordinated to the Deputy Conservator of Forests, Negri Sembilan, the Malacca and Tampin district forest officers being combined, and the salary of the clerk shared by the Federated Malay States and the Colony. The Forest Ranger is in charge of the Tampin office and gives such time as he can spare to field work in the forests of that district. This arrangement has not worked as smoothly as it should have done, but there can be no doubt that it is a great improrement on the old one. To compensate him for the increased expense of living at Tampin the Ranger in charge was given a personal allowance of $\$ 50$ per mensem. No change was made in the administration of the Penang and Dindings forests, but everything points to the desirability of placing, the ranger in charge under the direct supervision of a senior officer as soon as this can be arranged.

36. A pressing question in Singapore is the maintenance of the regetable suptly. To ease the situation parts of the Ang Mo Kio and North Seletar Reserves. which have no particular sylvicultural value, are being let out to market gardeners.
LLMPUR,

\author{
E. CUBITT, \\ Conscruator of Forests, \\ $S . S$. and F.M.S.
} $4^{\text {th }}$ March, Igrg. 


\section{Annual Report on Forest Administration in the Straits Settlements, for the Year 1919.}

\section{PART I.}

\section{Extension and Constitution of Reserved Forests.}

There was no change during the year in the area of reserved forests, but an extension of about 1,260 acres of mangrove forest to the Tanjong Burong Reserve in the Dindings was preliminarily notified under the Forest Ordinance for reservation. The proposal to exchange some alienated mangrove forest in Province Weliesley for a portion of the Tasek Glugor. Reserve in the same Settlement has for the time being been abandoned owing to the impossibility of coming to terms with the owners of the mangrove.

2. The revocation of a part of the Pandan Reserve in Singapore is under consideration, and its occupation for the construction of cement works was permitted in anticipation of the completion of the survey of the boundaries of the land to be excised from the reserve.

3. The total area of reserved forest is 106,013 acres distributed as follows :-

\begin{tabular}{|c|c|c|c|c|}
\hline Locality & & Area. & $\begin{array}{l}\text { Area of } \\
\text { Reserved Forests. }\end{array}$ & $\begin{array}{c}\text { Proportion } \\
\text { to whole area. }\end{array}$ \\
\hline 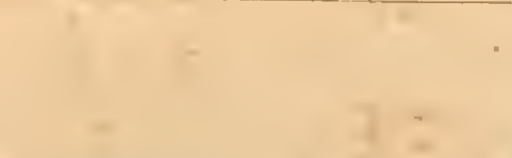 & 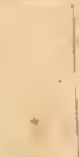 & Square miles. & Square miles. & Per cent. \\
\hline Singapore ... & & 217 & 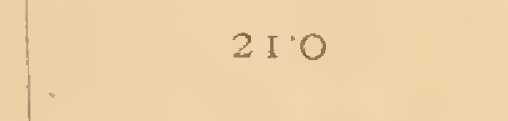 & $9 \%$ \\
\hline Penang $\quad \ldots$ & $\cdots$ & 108 & 190 & I $7 \cdot 6$ \\
\hline Province Wellesley & $\ldots$ & 280 & $6 \cdot 3$ & $2 \cdot 2$ \\
\hline Dindings & $\cdots$ & I $8_{3}$ & $42 \cdot 1$ & $23^{\circ} \mathrm{O}$ \\
\hline Malacca $\quad \ldots$ & .. & 720 & $77^{\circ} 2$ & 107 \\
\hline Total. & $\cdots$ & 1,508 & $165 \cdot 6$ & $I 10$ \\
\hline
\end{tabular}

Demarcation and Up-keep of Boundaries.

4. The boundaries of the reserved forests, amounting in all to about 534 miles, were for the most part maintainerl by the subordinate staff. Nothing was spent in Singapore, and the only expenditure in Malacca and the Dindings was $\$ 150$ and $\$ 30$ respectively on the purchase of boundary plates and boards. In Penang repairs cost $\$ 38.20$ for 83 miles 8 chains, and in Province Wellesley $\$ 22.50$ for 35 miles 49 chains. The total expenditure on 431 miles 63 chains of boundary repaired was $\$ 240.70$, equivalent to 56 cents per mile, compared with $\$ 2.34$ in I9I 8 and $\$ 1.81$ in $1917.1 \mathrm{n}$ all cases the salaries and night allowances of the staff are excluded. Details will be found in Form $3^{*}$. 
Surveys.

5. The survey of the paths in the Sungei Udang Reserve was completed, and of those in the Bukit Sedanan Reserve begun. Both these reserves are in Malacca.. $\$ 734.77$ in all were spent on 28 miles Io chains, which seems excessive.

\section{PART II.}

\section{MANAGEMENT OF FORESTS.}

\section{Working Plans and Plans of Operations.}

6. There are still no regular working plans, but plans of operations were drawn up for all the Settlements except Singapore and were closely adhered to.

\section{Communications.}

7. The only expenditure on communications was the small sum of $\$ 1.88 \mathrm{in}$ Penang. With this exception all paths in charge of the department were maintained by the subordinate staff without expense.

\section{Buildings.}

8. These are for the most part built and maintained by the Public Works Department. New quarters for a Forester were completed at Jasin at a cost of $\$ 1,350$, and subordinates' quarters were under construction at the end of the year at Alor Gajah, Ramuan China, Balik Pulau, and Telok Bahang. In Malacca there was apparently some difficulty in getting work done, and urgent repairs are said not to have been executed. Details of work under this head are given in Form 6 *.

\section{Protection of Forests.}

9. There were no changes in the forest law. Forty-two breaches of the forest rules were reported, of which 35 were concerned with the unauthorised removal or appropriation of forest produce. Fifteen cases were taken to court and convictions were obtained in twelve, all three acquittals being in the Dindings, Fines amounting to $\$ 136$ were inflicted by the Magistrates, and compensation of $\$ 43$ awarded to the department for damage to the forest. The remaining $2+$ cases were compounded for $\$ 369.60$, of which $\$ 2$ I had not been paid at the close of the year. None of the offences require separate mention. Details are given in Form $7^{*}$.

\section{IMPROVEMENT OF FORESTS.}

\section{Natural Reproduction.}

10. Little is reported under this head. Generally speaking it was a bad seed. year. The removal of second-class trees from the Malacca reserves is said to have been beneficial to the seedlings of the more valuable species from former seed-years.

\section{Plantations and Cultural Operations.}

I. Tapping was stopped in the Bukit Timah rubber plantation in Singapore and the trees benefited considerably. At the end of the year it was decided to lease the tappable trees, but the agreement was not ready till after the close of the year. The revenue of the year amounted $\$ 28.70$, which, owing to an oversight, was not. collected in 1918 , and maintenance charges were $\$ 138.22$. The small plantations in the Seletar Reserve and on the Mandai Road were leased as usual, \$50o being realised and credited to the Agricultural Improvements Deposit Account. 
12. Mangrove was planted on a considerable scale in Province Wellesley and the Dindings, the Forest Ranger, Mr. ASKEY, devoting much time and attention to the work, which is reported to have been remarkably successful. Large quantities of seed were bought, but most of the planting was done either by the subordinate forest staff and boatmen, or by the lessees as part payment for the timber on the area planted. The following statement gives particulars of the work done. The area planted cannot be stated with any accuracy, but, if the estimate of the number of seeds planted is correct, it must be not less than 300 acres.

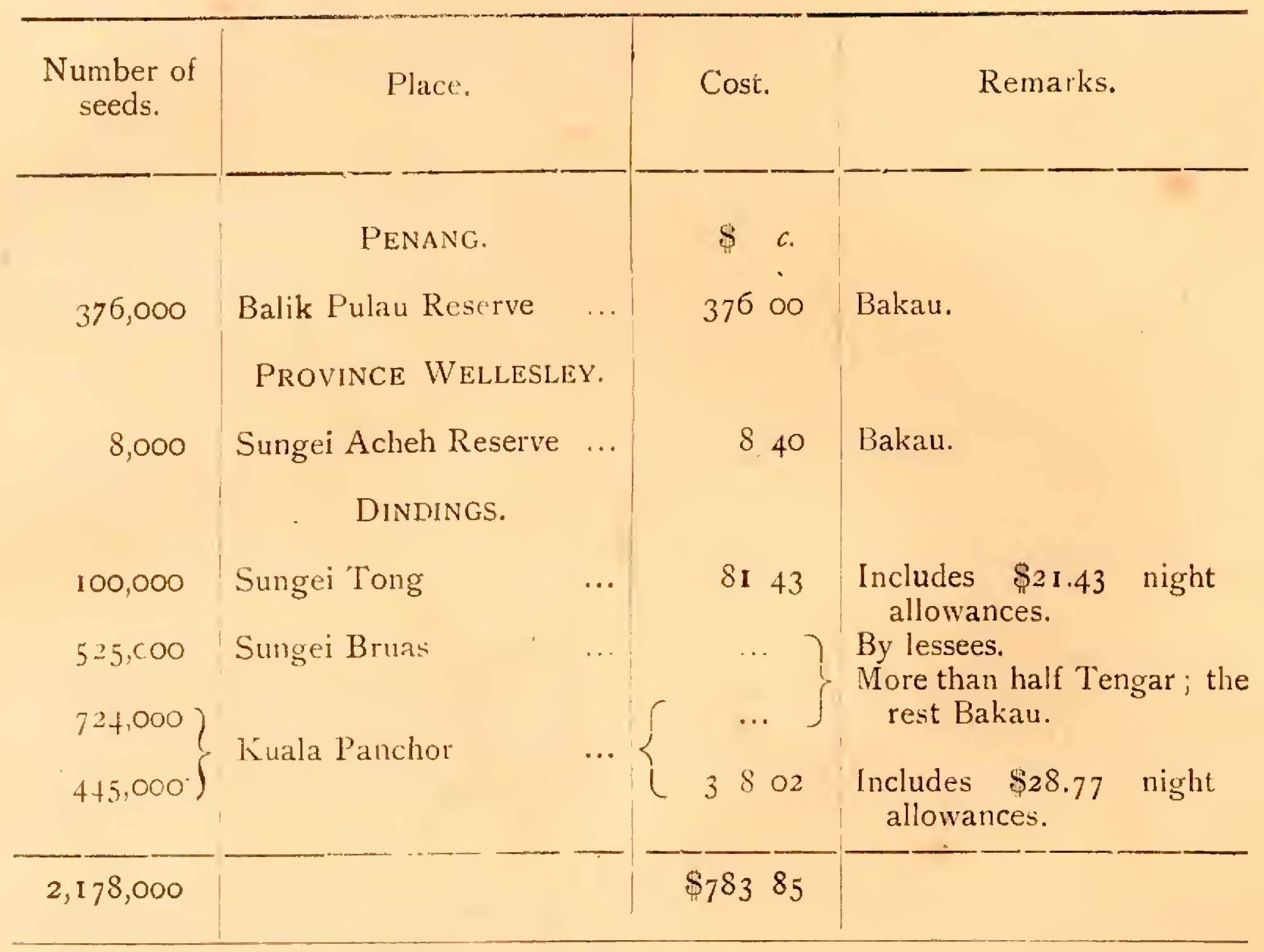

Small sums were also spent on the clearing of piai raya and the planting of tengar in the Tanjong Burong Reserve, on clearing round the Gutta-percha trees at Batu Ferringgi, and on a nursery for Petai (Albizzia moluccana), which it is thought may prove useful as a firewood crop on waste land. One hundred dollars were realised on account of rent for the small rubber plantation at Lumut, which is very badly maintained by the lessee.

13. In Malacca 1,I64 tappable trees in the Ayer Kroh rubber plantation were leased to a Malay at the rate of 5 cents per tree per mensem, $\$ 698.40$ being realised. The output is said to have been $2,215 \mathrm{lbs}$. of sheet and $258 \mathrm{lbs}$. of scrap rubber, of which $2,027 \mathrm{lbs}$. of sheet and $242 \mathrm{lbs}$. of scrap were sold for $\$ \mathrm{I}, 2 \mathrm{I} 4.32$.

\section{EXPLOITATION.}

\section{Timber and Fuel.}

\section{(a) From Reserves.}

14. Nine mangrove coupes with an area of $44 \mathrm{I}$ acres were open for exploitation in Singapore for the whole or a part of the year, and another was leased towards its close, but work in it was not begun. For the five coupes of 236 acres leased during the year the purchase price was $\$ 6,328$, equivalent to $\$ 26.8$ I per acre, compared with $\$ 10.83$ per acre in 1918 and $\$ 6.06$ in 1917 . The approximate output from the leased coupes was 4,280 tons, compared with 4,740 tons in 1918. In addition to the leased coupes, five old coupes were open to exploitation under monthly permits, of which II4, realising $\$ 594$, were issued, against 182 the previous year, the out-turn 
being estimated at 3,065 tons. The out-turn from other sources not needing separate mention was about I 16 tons, representing revenue of $\$ 34^{1} .50$ The following table summarises the results of the year's work in the mangrove forests:-

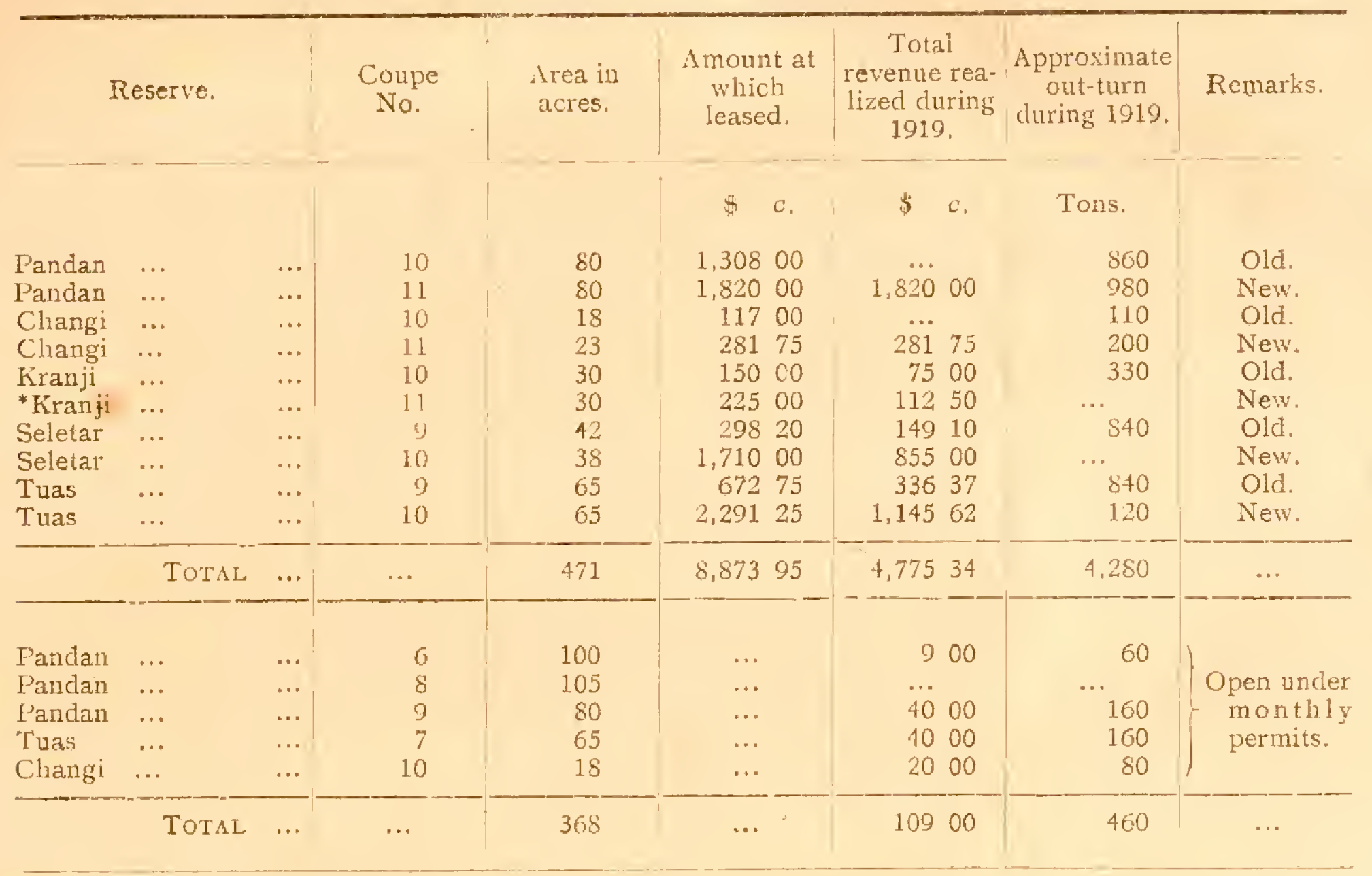

15. Owing chiefly to an increased demand for poles the out-turn of timber from the reserves of Penang, Province Wellesley, and the Dindings rose from 1,895 tons in 1918 to 2,219 tons in 1919 . There was also a large increase in the out-turn of fuel, especially from the Tanjong Burong Reserve in the Dindings, which accounted for 10,277 out of a total of IO,845 tons. Revenue increased from $\$ 10,014.06$ to $\$ 14$, I 2 I. 57 .

16. No change was made in the system in force in Malacca, under which Class 1 trees in reserves are marked for felling. The yield of timber per tree of Class I fell from $3^{.6}$ to $3^{.2}$ tons, and the waste is reported not to have been excessive. The total output was I,82 I tons of timber and 56 tons of charcoal, which differs little from that of the previous year. There was a fall in revenue of $\$ 95$.

I 7. The out-turn from the reserved forests in all Settlements was 4, 156 tons of timber, i 8,190 tons of fuel, and 56 tons of charcoal, on which revenue to the amount of $\$ 22,08$ I.4I was realised. The corresponding figures for 1918 are 3,742 tons of timber, I6, I 54 tons of firewood, I 7 I tons of charcoal, and \$15,5 I9.66 revenue.

\section{(b) From Crown Lands.}

18. The number of permits issued to collect firewood from the reserves in Singapore rose from 250 in 1918 to 323 in the year of report, which, at 20 tons per permit, represent an output of 6,460 tons. In addition 986 tons were removed in the form of poles. The revenue realised was $\$ 2,204.74$, compared with $\$ 2,141.60$ in I9 I 8 .

I9. The out-turn of timber from Penang, Province Wellesley, and the Dindings differed by only a few tons from that of the previous year, but the out-turn of firewood increased considerably. The total yield from the two Settlements was 2,555 tons of timber, 7,565 tons of firewood, and 6 tons of charcoal, and the revenue was $\$ 9$, IO I.49, compared with $\$ 7,804.04$ in 19 I 8 .

20. In Malacca the out-turn was 1,358 tons of timber and 311 tons of fuel, compared with 1,108 and 255 tons respectively in 1918 , but there was a slight fall in revenue from $\$ 2,038$ to $\$ \overline{1}, 993$, owing to the smaller out-turn of Class I timber.

21. The total revenue on timber, fuel, and charcoal from Crown Land in all the Settlements was $\$ 13,299.23$, details of the quantities extracted, amounting in all to 4,898 tons of timber, 14,336 tons of firewood, and 6 tons of charcoal being given in Form 9t. The corresponding figures for 19 is are 4,442 tons of timber, 12,417 tons of firewood, no charcoal, and $\$ 11,987.64$ revenue. 


\section{(c) From Alienated Land.}

22. Royalty of Io per cent is paid in Malacca on the estimated value of the timber on land to be alienated, and during the year amounted to $\$ 23,819.98$, an increase of $\$ 2$ I,999.99 over receipts for 19 I 8 , when very little land was alienated. There is now very little Crown Land left, and therefore receipts from this source cannot much longer be expected.

\section{Minor Forest Produce.}

(a) From Reserves.

23. Revenue on minor forest produce from reserves increased by $\$ 414.93$ and amounted to $\$ 1,721.43$ as follows :-

In Singapore, \$16 for nibong:

In Penang, $\$ 385.30$, chiefly for akar, bertam, and canes;

In Province Wellesley, \$30.30 for bertam and mengkuang;

In the Dindings, $\$ 580.43$, including $\$ 35$ I.20 for granite;

In Malacca, $\$ 70,40$, almost all for Para Rubber.

In addition, 440 cubic yards of road metal were taken free by the Public Works Department from the quarries in the Bukit joa Ipoh and Kubang Ulu Reserves in Province Wellesley. Other produce which was extracted besides the kinds already mentioned includes climbers of various sorts, krang shell, langkap, damar, nipah, cocoanuts, bamboos, and tengar bark. The durians in the dusuns in the Bukit Panchor Reserve in Malacca did not fruit and therefore yielded no revenue.

\section{(b) From Crown Lands.}

24. Theie was an increase from $\$ 1,114.74$ to $\$ 1,198$. I 3 in the revenue on minor produce from Crown Lands, contributed as follows:-Singapore, \$20.50; Penang, $\$ 38.08$; Province Wellesley, $\$ 13.20$; the Dinding's, $\$ 374.35$; and Malacca, $\$ 252.00$. The principal items were canes $(\$ 300.98)$, tengar bark $(\$ 276.73)$, uncultivated rubber $(\$ 165)$, nibong $(\$ 115.32)$, and kajung $(\$ 106.11)$.

\section{PART III.}

\section{FINANCIAL RESULTS,}

\section{Revenue.}

25. The following statement shows the total revenue from IgI7 to Iglg:-

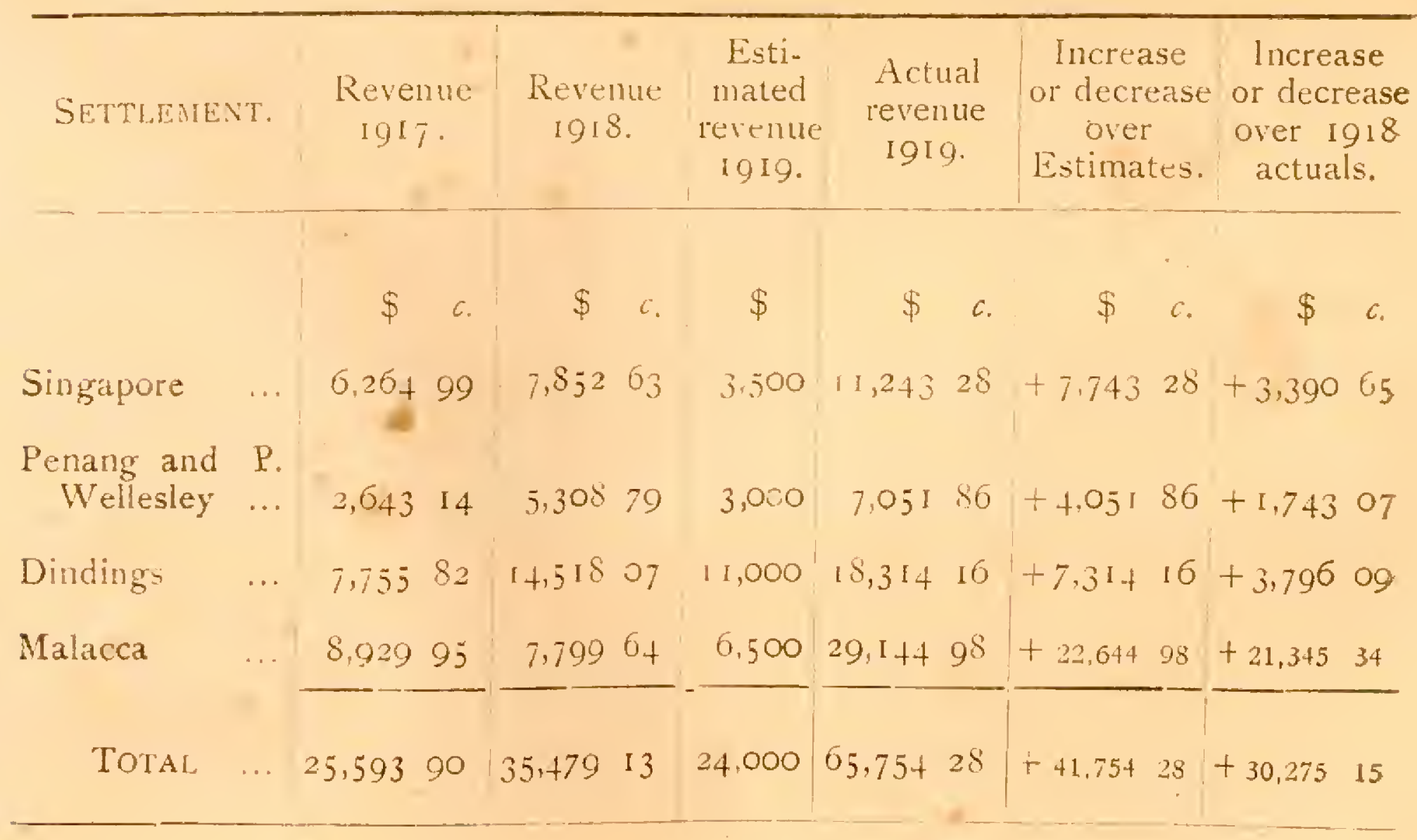


26. The increase in Singapore is due to the high price paic for the mangrove coupes and to the extension of vegetable cultivation in the reserves.

In Penang and Province Wellesley the reserves were more freely opened to the removal of second-class poles on the lines of an improvement felling, and in the Dindings there was a large increase in the output of mangrove fuel.

In Malacca the increase is due almost entirely to the unexpectedly large sums paid in premia for the timber standing on alienated land.

\section{Expenditure.}

27. The following table shows the expenditure from 1917 to 1919:-

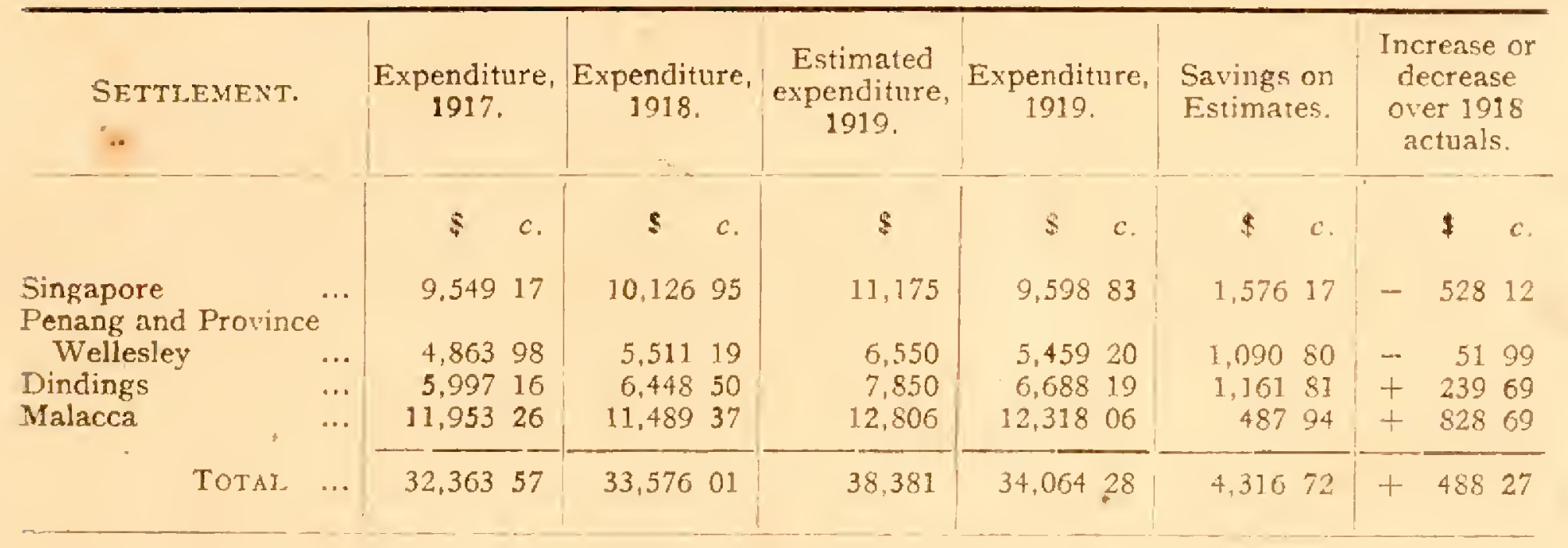

28. Of the total of $\$ 34,064.28, \$ 24,657.35$ were spent on personal emoluments and $\$ 9,396.93$ on other charges, compared with $\$ 25,278.5$ I and $\$ 8,297.50$ respectively in I918. War allowances are not included. The increased expenditure under other charges was incurred on planting and cultural operations, transport, and uniforms.

\section{Surplus.}

29. The surplus of revenue over expenditure was $\$ 31,690$ as shown in the following statement:-

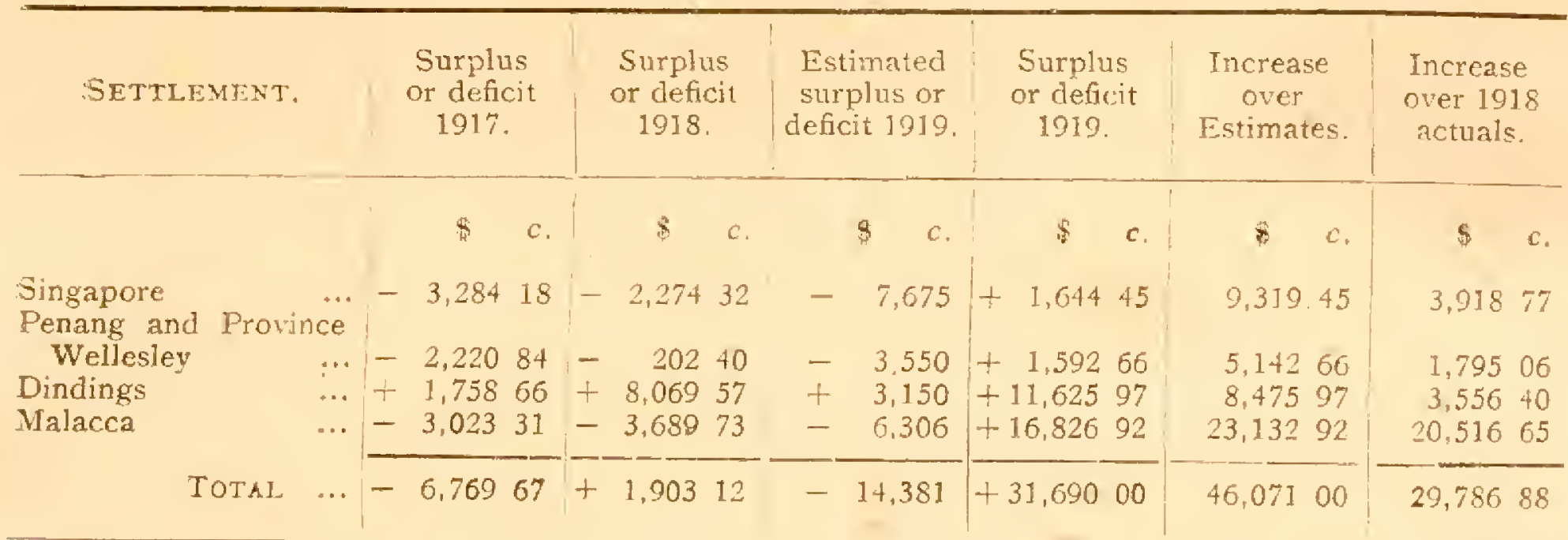

30. The reasons for the unusual surplus are given in paragraph 26, but as explained in paragraph 22, sucls a surplus is unlikely to be often repeated.

\section{PART IV.}

\section{Administration.}

3I. No change was made in the administration of the forests. The arrangement by which the Forest Ranger, Malacca, is subordinated to the Deputy Conservator, Negri Sembilan, is now working smoothly, but there was some difficulty (now over. come by the appointment of an additional clerk) in dealing with office work, owing to the differences of system in the Colony and in the Federated Malay States. With expansion of work the need is more and more felt of closer control in Penang and the Dindings by a senior officer.

E. CUBITT,

Conservator of Forests,

KUALA LUMPUR,

S. S. and F.M.S.

I 8th. Warch, I920. 


\section{STRAITS SETTLEMENTS.}

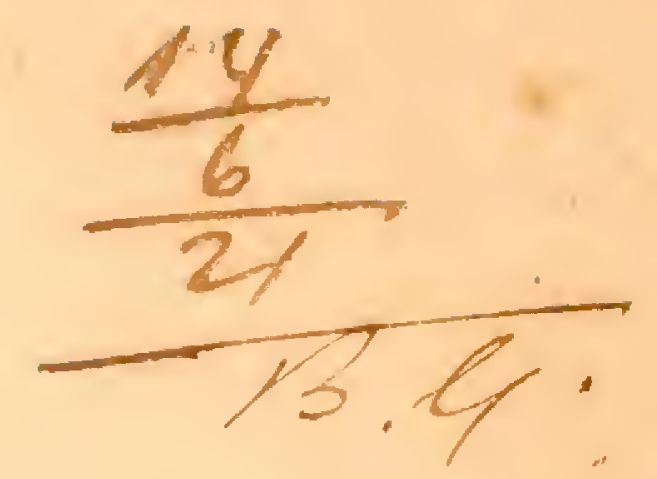

\section{Annual Report on Forest Administration in the Straits Settlements, for the Year 1920.}

\section{PART I.}

\section{Extension and Constitution of Reserved Forests.}

1. The only change in the area of reserved forests was the addition of $\mathbf{1 5 5}$ acres to the Tanjong Burong Reserve in the Dindings. The settlement of a further 754 acres was completed, but this addition had not been gazetted at the end of the year.

2. The total area of reserved forests is 106,168 acres, distributed as follows :-

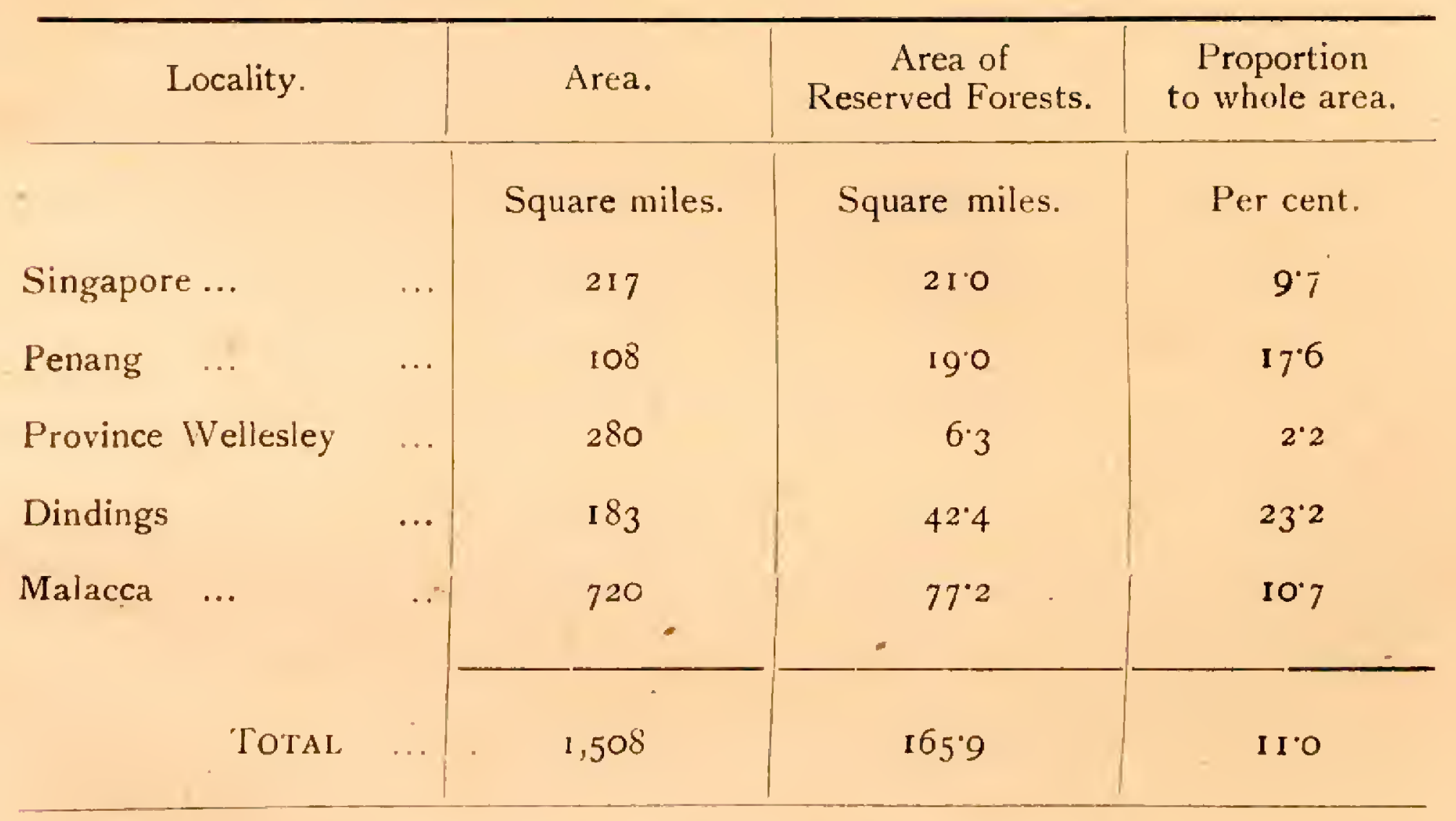

Demarcation and Upkeep of Boundaries.

3. Three hundred and eighty miles of forest reserve boundary are reported to have been repaired during the year at a cost of $\$ 183.24$. This work is for the most part done by the subordinate staff.

\section{Surveys.}

4. Proposed extensions to the Segari-Melintang Forest Reserve in the Dindings were surveyed by the Survey Department, but the computations were not complete at the end of the year.

\section{PART II.}

MANAGEMENT OF FORESTS.

Working Plans and Plans of Operations.

5. The plan of operations as regards planting was not adhered to. 


\section{Communications and Buildings.}

6. Thirteen miles and fifty-eight chains of inspection paths were constructed in Sungei Udang Reserve at a cost of \$5I.OI a mile and \$4I2.55 was spention the demarcation of paths in Sedanan Reserve.

7 New quarters for the subordinate staff were built at Balik Pulau, Telok Bahang and Segari.

8. The maintenance of buildings was undertaken by the Public Works Department.

\section{Protection of Forests.}

g. Forty-six forest offences were reported, of which 23 were compounded, and 23 were taken into court. Of the latter one case was dismissed. Fines inflicted by the Magistrates amounted to $\$ 524.50$, and $\$ 211.58$ was awarded as compensation for damage to the forests. Compensation paid in compounded cases amounted to $\$ 625$. For details see Form 7 .

\section{IMPROVEMENT OF FORESTS.}

\section{Natural Reproduction.}

10. The latter part of the year was remarkable for an exceptionally heavy fruiting of nearly all kinds of forest trees. The fine dipterocarp forest of the Telok Muroh Forest Reserve in the Dindings was particularly prolific. Exploitation on a limited scale has been going on in this reserve for several years, and on this area there is a fine crop of young Class I trees. An inspection of the Merlimau Reserve in Malacca also showed that the removal of selected Class I trees had a beneficial effect on the forest as regards regeneration. Meranti and Keruing establish themselves quickly in any opening in the canopy marie by the felling operation. The fate of seedlings of the slower growing Class 1 trees is not so certain. In the absence of some artificial assistance they are liable to be suppressed by the quick growing Class II trees which have also benefited by the admission of light to the ground.

\section{Plantations and Cultural Operations.}

II. Five hundred and eighty-five dollars and five cents were expended on the Para Rubber Plantations at Bukit Timah and Seletar, Singapore, and revenue from these sources amounted to $\$ 1,062.50$. Six hundred and twenty-eight dollars and fifty-six cents were paid by the lessee of the Bukit Bruang Para Rubber Plantation in Malacca.

12. Mangrove seed was planted in the Sungei Acheh Reserve in Province Wellesley about a foot and a half apart at a cost of \$ 110 over an area of eight acres. An inspection of the mangrove planting of former years in Tanjong Burong Reserve shows that this planting has been successful on the whole, but it has been somewhat expensive and it is probable that some of the planted areas would have been restocked naturally if left alone. Crabs have done much damage to seedlings, but the planting was close enough to allow for the loss.

\section{EXPLOITATION.}

\section{Timber and Fuel.}

(a) From Reserves.

13. On Singapore island firewood cutting was continued in five mangrove coupès worked in previous years, and four new coupès were opened. The total area under exploitation during the whole or part of the year was 427 acres. The new coupès comprising I9I acres, realised an average of $\$ 31.90$ per acre, compared with $\$ 26.81$ and $\$ 10.83$ per acre in 1919 and I9I 8 respectively. The estimated outturn from the leased coupès was 3,620 tons, as against 4,280 tons in 19r9. Permits were again issued to take firewood from coupès of former years which had not been completely exploited and from certain other parts of reserves. The estimated outturn of 140 
permits was 2,728 tons, and the revenue derived from this source was $\$ 50 I$. The outturn from other sources was 17 tons. The following table summarises the results of the year's work in the mangrove forests:-

\begin{tabular}{|c|c|c|c|c|c|c|c|c|}
\hline \multicolumn{3}{|c|}{ Reserve. } & $\begin{array}{l}\text { Coupè } \\
\text { No. }\end{array}$ & $\begin{array}{l}\text { Area in } \\
\text { acres. }\end{array}$ & $\begin{array}{c}\text { Amount at } \\
\text { which } \\
\text { leased. }\end{array}$ & $\begin{array}{l}\text { Total } \\
\text { revenue real- } \\
\text { ised during } \\
1920 .\end{array}$ & $\mid \begin{array}{c}\text { Approximate } \\
\text { outturn } \\
\text { during } 1920 .\end{array}$ & Remarks. \\
\hline $\begin{array}{l}\text { Pandan } \\
\text { Pandan } \\
\text { Changi } \\
\text { Changi } \\
\text { Kranji } \\
\text { Kranji } \\
\text { Seletar } \\
\text { Tuas } \\
\text { Tuas }\end{array}$ & $\begin{array}{l}\ldots \\
\ldots \\
\ldots \\
\ldots \\
\cdots \\
\cdots \\
\cdots \\
\cdots \\
\cdots \\
\end{array}$ & \begin{tabular}{l|}
$\ldots$ \\
$\ldots$ \\
$\ldots$ \\
$\ldots$ \\
$\ldots$ \\
$\ldots$ \\
$\ldots$ \\
$\ldots$
\end{tabular} & $\begin{array}{l}11 \\
12 \\
11 \\
12 \\
11 \\
12 \\
10 \\
10 \\
11\end{array}$ & $\begin{array}{l}80 \\
80 \\
23 \\
16 \\
30 \\
30 \\
38 \\
65 \\
65\end{array}$ & $\begin{array}{rc}\$ \quad c . \\
1,820 & 00 \\
3,768 & 00 \\
281 & 75 \\
640 & c 0 \\
225 & 00 \\
540 & 00 \\
1,710 & 00 \\
2,291 & 25 \\
1,046 & 50\end{array}$ & $\begin{array}{rc}s \quad c . \\
\ldots .768 & 00 \\
\ldots & \\
640 & 00 \\
112 & 50 \\
270 & 00 \\
855 & 00 \\
1,145 & 62 \\
523 & 25\end{array}$ & 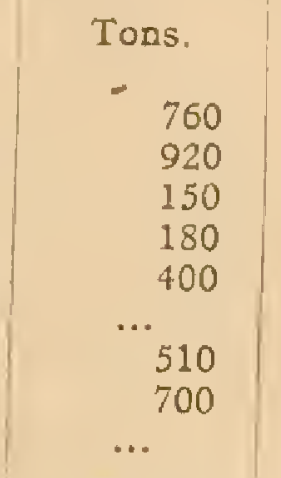 & $\begin{array}{l}\text { Old. } \\
\text { New. } \\
\text { Old. } \\
\text { New. } \\
\text { Old. } \\
\text { New. } \\
\text { Old. } \\
\text { Old. } \\
\text { New. }\end{array}$ \\
\hline Tuas & Total & $\cdots$ & $\cdots$ & 427 & $12.322,50$ & $7,314 \quad 37$ & 3,620 & $\cdots$ \\
\hline $\begin{array}{l}\text { Pandan } \\
\text { Tuas } \\
\text { Changi } \\
\text { Changi }\end{array}$ & $\begin{array}{l}\ldots \\
\ldots \\
\cdots \\
\cdots\end{array}$ & $\begin{array}{l}\ldots \\
\cdots \\
\cdots \\
\cdots\end{array}$ & $\begin{array}{r}9 \\
9 \\
10 \\
11 \\
\end{array}$ & $\begin{array}{l}80 \\
65 \\
18 \\
23\end{array}$ & $\begin{array}{l}\cdots \\
\cdots \\
\cdots \\
\cdots \\
\end{array}$ & $\begin{array}{rl}45 & 00 \\
5 & 00 \\
15 & 00 \\
50 & 00\end{array}$ & $\begin{array}{r}180 \\
20 \\
60 \\
200\end{array}$ & $\begin{array}{l}\text { Open under } \\
\text { montbly } \\
\text { permits. }\end{array}$ \\
\hline & TOTAL & $\ldots$ & $\ldots$ & 186 & $\ldots$ & 11500 & 460 & $\ldots$ \\
\hline
\end{tabular}

14. The outturn of timber and poles from Penang, Province Wellesley and the Dindings was 2, 137 tons, compared with 2,219 in the previous year. Firewood from the same Settlements fell from 10,845 tons in 1919 to 7,168 in 1920.

I 5. In Malacca the following forest reserves were under exploitation for trees of Class I and Class II, Bukit Sedanan, Bukit Senggeh, Batang Malaka, Nyalas, Ayer Parias, Merlimau, Sungei Udang and Ramuan China. Work in the last-named reserve was stopped during the year. Class II poles were exploited from Bukit Panchor and Bukit Bruang Reserves. The revenue from this source amounted to $\$ 5,296$. Charcoal permits produced $\$ 280$. Until more trained officers can be obtained accurate records cannot be expected.

\section{(b) From Crown Lands.}

16. In Singapore 405 permits were issued for firewood and pole cutting. The estimated outturn was 8,100 tons of firewood, and 611 tons of poles, the corresponding figures in 1919 being 6,460 and 986 . The revenue was $\$ 2,955.41$, compared with $\$ 2,204.74$ in 1919 .

I7. The outturn of timber from Penang, Province Wellesley and the Dindings was 2,99 ! tons, being 436 tons more than in the previous year. The Dindings is responsible for this increase. In the same Settlements the outturn of firewood declined from 2,99 I tons in I9I9 to 2,555 in 1920. No charcoal was manufactured. The revenue for the year was $\$ 9,003.59$, compared with $\$ 9$. 101.49 in 1919 .

I 8. In Malacca the outturn of timber was 1,038 tons and of fuel 65 tons, com. pared with I, 353 tons and 3 II tons respectively in I9I9. Revenue was $\$ 1,256$ as against $\$ \mathbf{I}, 993$ in the former year.

19. The total revenue derived from timber and fuel from Crown Lands was $\$ 13,2$ I5, and the total outturns were, timber 4,640 tons, and firewood I 3,826 tons. The corresponding figures for 1919 were, revenue $\$ 13,299$, and 4,898 tons and 14,336 tons for timber and firewood.

\section{(c) From Alienated Land.}

20. Fourteen thousand eight hundred and seventy-three dollars and ninety-fire cents were derived from the ten per cent charged on the estimated value of timber on land when alienated. The revenue from this source was $\$ 23,819.98$ in 1919 , and $\$ 1,819$ in 1918 . 


\section{Minor Forest Products.}

2I. The total revenue from both Forest Reserves and Crown Lands amounted to $\$ 3,734.56$, or $\$ 815$ more than in 1919. The chief increase was in tengar bark from Crown Land in the Dindings, which rose from $\$ 276.73$ to $\$ 537.97$. The items included under this head are nibong, bamboo, canes, nipah, bertam, granite metal (from reserved forests only), Para rubber (Malacca only), and jungle fruits.

\section{PART III.}

\section{FINANCIAL RESULTS.}

\section{Revenue.}

22. The following statement shows the total revenue from igis to 1920 :-

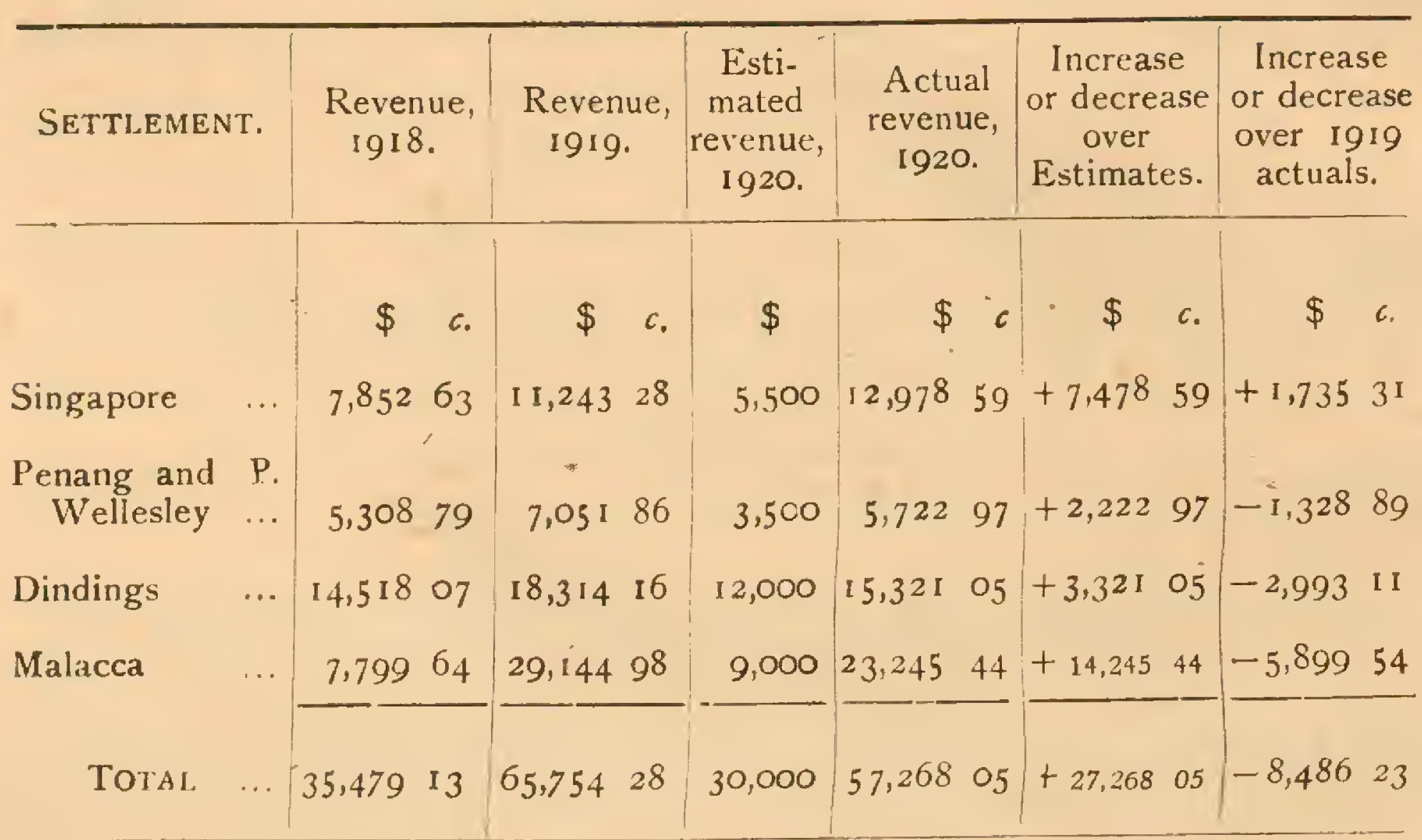

23. There was a fall of $\$ 1,557$ in firewood revenue, the increase in Singapore being more than set off by the decreases in Penang and the Dindings. The decrease of $\$ 7,300$ under timber is due to the item of Malaccd revenue referred to in paragraph 20.

\section{Expenditure.}

23. The following table shows the expenditure from I9 8 to I920:-

\begin{tabular}{|c|c|c|c|c|c|c|}
\hline SETTLEMENT. & $\begin{array}{c}\text { Expenditure, } \\
1918 .\end{array}$ & $\begin{array}{c}\text { Expenditure, } \\
1919 .\end{array}$ & $\begin{array}{c}\text { Estimated } \\
\text { expenditure, } \\
1920 .\end{array}$ & $\begin{array}{c}\text { Expenditure, } \\
1920\end{array}$ & $\begin{array}{l}\text { Savings or } \\
\text { excess over } \\
\text { Estimates. }\end{array}$ & $\begin{array}{c}\text { Increase or } \\
\text { decrease } \\
\text { over } 1919 \\
\text { actuals. }\end{array}$ \\
\hline & $\$ \quad c$ & $\$ \quad c$ & $\$$ & $\$ \quad c$ & $\$ \quad c$. & $\$ \quad c$. \\
\hline $\begin{array}{l}\text { Singapore } \\
\text { Penang and Province }\end{array}$ & 10,12695 & $9,598 \quad 83$ & 11,172 & 14,98260 & $-3,81060$ & $+5,38377$ \\
\hline Wellesley & $=5,51119$ & 5,45920 & 6,839 & 6,43303 & +40597 & +97383 \\
\hline Dindings & $6,448 \quad 50$ & 6,68819 & 8,329 & 7,19285 & $+1,13615$ & $\div 50466$ \\
\hline Malacca & $11,489 \quad 37$ & $12,318 \quad 06$ & 13,804 & $14,240 \quad 48$ & -43648 & $\div 1,92242$ \\
\hline TOTAL & 33,57601 & 34,06428 & 40,144 & * 42,84896 & $-2,70496$ & +8.78468 \\
\hline
\end{tabular}

24. Personal Emoluments amounted to $\$ 32,140.86$, being an increase of $\$ 7,473.51$ over the previous year, due to improvements in rates of pay. Under Other Charges there was a total increase of $\$ 1,311.17$, but there were no changes of importance.

\footnotetext{
- Excludes temporary allowances, but includes arrears of pay due under revised salary schemes.
} 
Surplus.

25. The surplus of revenue over expenditure was $\$ 14,419.09$ as shown in the following statement:-

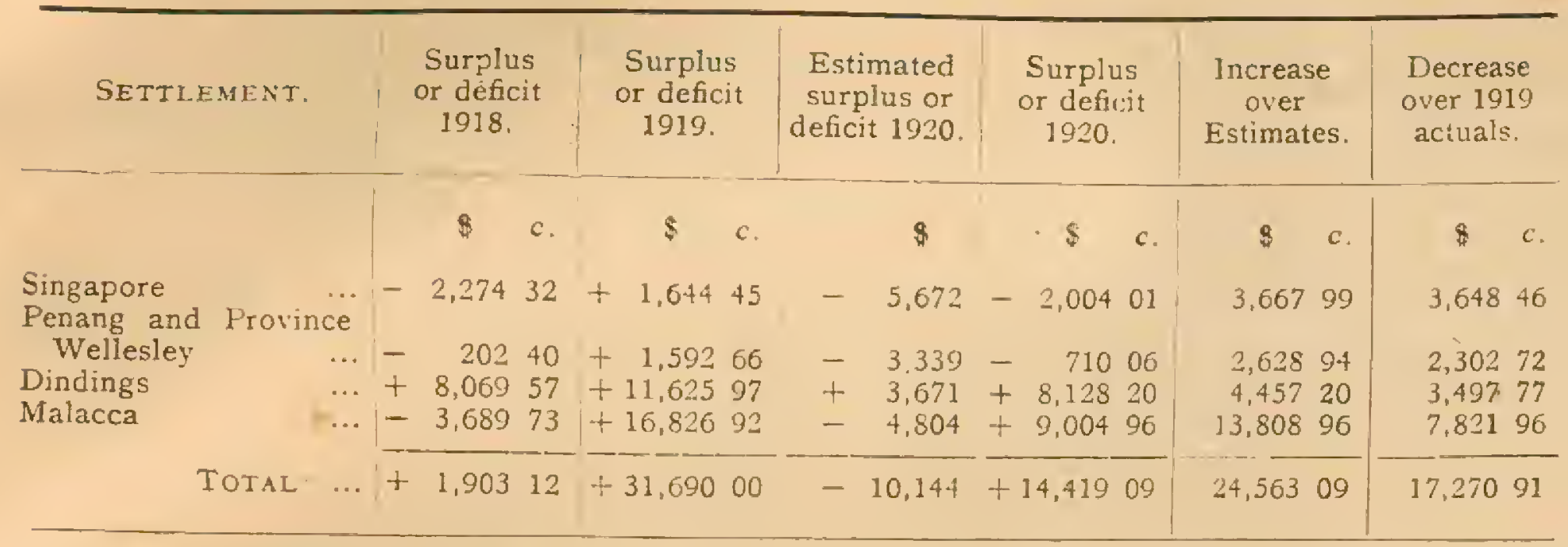

26. The surplus is $\$ 17,271$ less than in 1919 , but it is still much above the normal surplus. This is chiefly due to the item of revenue referred to in paragraph 20 .

\section{PART IV.}

\section{Administration.}

27. Towards the end of the year arrangements were made to place the control of forest work in Penang, Province Wellesley and the Dindings in the hands of senior officers of the Federated Malay States. The Deputy Conservator of Forests, Perak North, will supervise Penang and Province Wellesley and the Deputy Conservator of Forests, Perak South, will be in charge of the Dindings. There were no other changes.

KUALA LUMPUR,

I7th March, I921. [No. 2771/21.]
B. H. F. BARNARD,

Acting Conservator of Forests,

$S$. S. and F.M.S. 


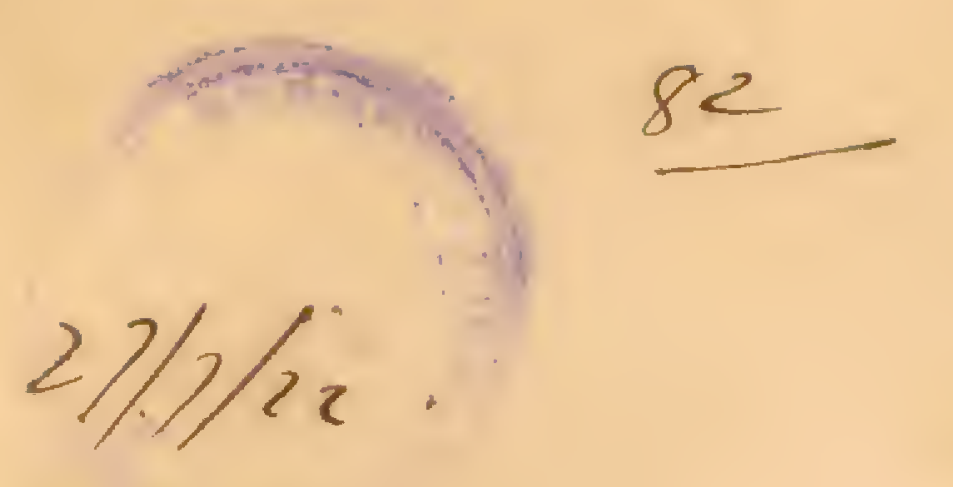

\section{Annual Report on Forest Administration in the Straits Settlements for the Year 1921.}

\section{PART I.}

\section{Extension and Constitution of Reserved Forests.}

1. A further addition of 754 acres, 2 roods, 14 poles was made to the Tanjong Burong Reserve in the Dindings, and a reserve was formed of the whole of the Crown Land at Cape Rachado belonging to the Settlement of Malacca. An extension of about 1,925 acres to the Segari-Melintang Reserve in the Dindings was preliminarily notified, and the reservation of Bukit Kopia in the same Settlement was under consideration at the close of the year. When these last two areas have been settled, reservation will be almost complete, but the needs of the Colony can never be met from the forests within its own boundaries. A small area of 2 roods, 22 poles was excised from the Changi Reserve in Singapore as of small value to the Government compared with its value to the holder of the adjacent property, but no further progress was made with the revocation of part of the Pandan Reserve for the construction of cement works.

2. The total area of reserved forest is now $167^{\circ} 3$ square miles distributed as shown in the following table. Details are given in Form I.*

\begin{tabular}{|c|c|c|c|c|}
\hline \multicolumn{2}{|l|}{ Locality. } & Area. & $\begin{array}{l}\text { Area of } \\
\text { Reserved Forests. }\end{array}$ & $\begin{array}{l}\text { Proportion } \\
\text { to whole area. }\end{array}$ \\
\hline & & Square miles. & Square miles. & Per cent. \\
\hline Singapore... & $\cdots$ & 217 & $2 I^{\circ} \mathrm{O}$ & $9 \cdot 7$ \\
\hline Penang $\quad \ldots$ & $\cdots$ & 108 & $19^{\circ} \mathrm{O}$ & $17^{\circ} 6$ \\
\hline Province Wellesley & $\cdots$ & 280 & $6 \cdot 3$ & $2 \cdot 2$ \\
\hline Dindings & $\cdots$ & 183 & $43^{\circ} 5$ & $23 \cdot 8$ \\
\hline Malacca $\quad \ldots$ & $\cdots$ & 720 & $77^{\circ} 5$ & $10^{\circ} 7$ \\
\hline TOTAL & .. & 1,508 & $167 \cdot 3$ & I I I I \\
\hline
\end{tabular}

3. There seems some doubt whether the military authorities will after all need the Mandai and Sembawang Reserves which were given up in 19r4, and, if they do not take them over, the question of their re-reservation should be considered. 


\section{Demarcation and Upkeep of Boundaries.}

4. The boundaries of the reserved forests are now estinated to annomint to 554 miles 29 chains as shown in detall in Form 3. " They were fur the most part maintained by the subordinate stafi, the total expenditure liang \$232.I9, of which $\$ 209.54$ was incurred in Malacca.

\section{Surveys.}

5. The only survey work of any importance was done in the Bukit Sedanan Reserve in Malacca, which has now been completely divided up into compartments to facilitate the organisation and supervision of exploitation. Similar work has been begun in the Ayer Panas Reserve. In these reserves 50 miles 33 chains were surveyed at a cost of $\$ 700.62$, which is a good deal cheaper than the work of the previous year, but still seems high. The only other work under this head was the survey of the annual coupe and certain plantations in the Tanjong Burong Reserve in the Dindings, 3 miles 61 chains being completed (mostly by the stibordinate staff) at a cost of \$I5.

\section{PART II}

\section{MANAGEMENT OF FORESTS.}

\section{Plans of Operations.}

6. The plans of operations were on a small scale and were adinered to.

\section{Communications.}

7. About $\mathrm{r} 3$ miles of paths were constructed in the Bukit Sedanan Reserve, and 9 miles 21 chains in the Sungei Udang Reserve, the cost being $\$ 282$ and $\$ 555.75$ respectively. Repairs to 22 miles 79 chains in the latter reserve were done by the subordinate staff. Only in Malacca has systematic work of this kind been begun, but it is becoming more and more necessary in the Dindings.

\section{Buildings.}

8. The construction and maintenance of buildings are for the most part in the hands of the Public Works Department. Quarters for a forester were completed at Telok Bahang for $\$ 3,600$, and a checking station and subordinates' quarters at Segari for $\$ 4,825$. Both are solid buildings fully adequate to requirements.

\section{Further details are given in Form V.*}

\section{Profection of Forests.}

1o. There were no changes in the forest Law. The number of offences reported rose from 46 in 1920 to 104 in the year of report, of which 95 were concerned with the unauthorised removal or appropriation of forest produce. Almost the whole of the increase is due to better supervision in Malacca, where 39 out of the 7 I offences reported were committed in reserved forests. Thirty-three cases were taken to court, and convictions were obtained in thirty, the fines inflicted amounting to $\$ 445$ (of which $\$ 533$ were paid to the Forest Department) in addition to $\$ 39.16$, the proceeds of the sale of confiscated property. The sum realised in the 67 cases compounded amounted to $\$ 872.50$. At the close of the year 4 cases were pending. Further details are given in Eorm 7.* 


\section{IMPROVEMENT OF FORESTS.}

\section{Natural Reproduction.}

I. Dipterocarps fruited fairly freely, and there was an average seed-year in the mangrove forests. Natural reproduction in Malacca is on the whole remarkably good, largely on account of the fellings of second-class trees which have taken place for many years in the reserves of that Settlement. The forests in the Dindings require systematic opening up, if seed-years are to be taken full advantage of. Improvement fellings were cari ied out over about 30 acres in the Bukit Sedanan Reserve in Malacca at a cost of \$r4 $\mathrm{r}$, the natural regeneration in the area chosen for treatment being particularly plentiful.

\section{Plantations and Cultural Operations.}

12. A recently exploited area of 246 acres in the Tanjong Burong Reserve in the Dindings was planted with Bakau minyak at a cost of $\$ 763.77$, but further expenditure will probably have to be incurred on the replacement of failures. In this plantation $\mathrm{I}, 020$ seedlings were protected from the attacks of crabs by means of pieces of tin bent round the stem just above the ground. At the end of the year it was found that 84 per cent of the protected seedlings had survived and only 60 per cent of the unprotected. Seventeen acres in the same reserve were planted with tengar. The whole of this planting should have been done by the felling contractors, who paid \$t,400 to Gorernment as compensation for their failure to do so.

I3. There was no change in the area of plantations in the other Settlements, and the only work done in them was the eradication of lalany at a cost of \$I51.50 from about 6 acres of Para rubber in the Bukit Bruang Reserve plantation in Malacca, and the cleaning of about $4 \mathrm{I}$ acres of Penaga in the same plantation by the subordinate staff. The taban, penaga, and merbau in this plantation are reported to be doing well, but the tembusu is sickly and hardly worth further expenditure.

14. In Singapore the area of the Bukit Timah plantation is likely to be affected by the proposals for the improvement of the Singapore-Kranji Railway. Owing to the state of the rubber industry the rubber was not tapped, but a sum of $\$ 3,000$ was transferred from deposits to revenue on account of previons working of the plantation.

\section{EXPLOITATION.}

\section{Timber and Fuel.}

(a) From Rescrues.

I5. In Singapore five reserves were wortied as usual for mangrove fuel under the coupe system, the area under exploitation during the whole or part of the year being 3 I.9 acres. In addition, seven old coupes, which had not been fully worked out, were open to exploitation under monthly permits. The 128 acres newly leased realised $\$ 25.64$ per acre compared with $\$ 31.38$ per acre for the coupes of the previous year. The estimated outturn from the leased coupes was 2,350 tons, and from the coupes open under permit $I, 220$ tons, compared with 3,620 and 460 tons respectively in 1920 . The outturn from other sources was 54 tons of timber and I,80r tons of firewood. The revenue fell from $\$ 8,03$ I.38 to $\$ 5.003 .05$. 
I6. The following table summarises the results of the year's work in the Singapore mangrove forests:-

\begin{tabular}{|c|c|c|c|c|c|c|c|c|}
\hline \multicolumn{3}{|c|}{ Reserve. } & $\begin{array}{c}\text { Coupe } \\
\text { No. } \\
12\end{array}$ & $\begin{array}{c}\text { Area in } \\
\text { acres. } \\
\\
80\end{array}$ & $\begin{array}{c}\begin{array}{c}\text { A mount at } \\
\text { whicl } \\
\text { leased. }\end{array} \\
\$ c .\end{array}$ & $\begin{array}{c}\text { Total } \\
\text { revenue real- } \\
\text { ised during } \\
1921 .\end{array}$ & $\frac{\mid \begin{array}{c}\text { Approximate } \\
\text { outturn } \\
\text { during } 1921 .\end{array}}{\text { Tons. }}$ & \multirow{2}{*}{$\begin{array}{c}\text { Remarks. } \\
\\
\text { Old. } \\
\text { New } \\
\text { Old. } \\
\text { New. } \\
\text { Old. } \\
\text { New. } \\
\text { Old. }\end{array}$} \\
\hline $\begin{array}{l}\text { Pandan } \\
\text { Pandan } \\
\text { Changi } \\
\text { Changi } \\
\text { Kranji } \\
\text { Seletar } \\
\text { Tuas }\end{array}$ & $\begin{array}{l}\cdots \\
\cdots \\
\cdots \\
\cdots \\
\cdots \\
\cdots \\
\cdots\end{array}$ & \begin{tabular}{l|}
$\ldots$ \\
$\cdots$ \\
$\cdots$ \\
$\cdots$ \\
$\cdots$ \\
$\cdots$ \\
$\cdots$
\end{tabular} & $\begin{array}{l}12 \\
13 \\
12 \\
13 \\
12 \\
11 \\
11\end{array}$ & $\begin{array}{l}80 \\
80 \\
16 \\
30 \\
30 \\
18 \\
65\end{array}$ & $\begin{array}{rc}\$ c & c . \\
3,768 & 00 \\
2,608 & 00 \\
640 & 00 \\
546 & 00 \\
540 & 00 \\
127 & 80 \\
1,046 & 50\end{array}$ & $\begin{array}{rr}\$ \quad c . \\
\ldots \\
2,608 & 00 \\
\ldots & \\
546 & 00 \\
270 & 00 \\
127 & 80 \\
523 & 25\end{array}$ & \begin{tabular}{|c|} 
Tons. \\
\\
620 \\
160 \\
180 \\
180 \\
360 \\
220 \\
630
\end{tabular} & \\
\hline & Total & $\ldots$ & $\cdots$ & 319 & $9,276 \quad 30$ & 4,07505 & 2,350 & $\ldots$ \\
\hline $\begin{array}{l}\text { Pandan } \\
\text { Pandan } \\
\text { Pandan } \\
\text { Pandan } \\
\text { Pandan } \\
\text { Tuas } \\
\text { Tuas }\end{array}$ & $\begin{array}{l}\cdots \\
\cdots \\
\cdots \\
\cdots \\
\cdots \\
\cdots \\
\cdots\end{array}$ & $\begin{array}{l}\cdots \\
\cdots \\
\cdots \\
\cdots \\
\cdots \\
\cdots \\
\cdots\end{array}$ & $\begin{array}{r}8 \\
9 \\
10 \\
11 \\
12 \\
9 \\
10\end{array}$ & $\begin{array}{r}105 \\
80 \\
80 \\
80 \\
80 \\
65 \\
65\end{array}$ & $\begin{array}{l}\cdots \\
\cdots \\
\cdots \\
\cdots \\
\cdots \\
\cdots \\
\cdots\end{array}$ & $\begin{array}{rl}10 & 00 \\
40 & 00 \\
15 & 00 \\
120 & 00 \\
95 & 00 \\
10 & 00 \\
15 & 00\end{array}$ & $\begin{array}{r}40 \\
160 \\
60 \\
480 \\
380 \\
40 \\
60\end{array}$ & $\begin{array}{l}\text { Open under } \\
\text { monthly } \\
\text { permits. }\end{array}$ \\
\hline & TOTAL & $\ldots$ & $\ldots$ & 555 & $\ldots$ & 30500 & 1,220 & $\ldots$ \\
\hline
\end{tabular}

I7. The outturn of timber on payment from the reserves of Penang, Province Wellesley, and the Dindings fell from 2,139.94 to I, I I4 30 tons, more than half of it being in the form of poles. The reduced output is due to the gradual closing down of work in the Dindings owing to the unsatisfactory methods followed by the permit holders. The outturn of firewood from the same Settlements fell from $7,168 \cdot 34$ to $4,077^{\circ} 5^{2}$ tons, and the revenue from $\$ 9,145.07$ to $\$ 6,680.59$.

I8. In Malacca 43 permit holders were working in the following reserves:- Sungei Udang, 8; Bukit Sedanan, II; Batang Malaka, 6; Bukit Sengreh, 9; Nyalas, 4; Ayer Panas, I; Merlimau, 3; and Bukit Bruang, I. In addition, one permit holder in the Bukit Sedanan Reserve was allowed to convert tops and branches into charcoal. The total outturn of timber, fuel and charcoal was $2,514^{\circ} 16$ tons, compared with 4,004.39 tons in 1920 , and the revenue fell from $\$ 5,576$ to $\$ 5,021$. Owing to the total absence of compartments in most of the reserves-a defect which is now being remedied - the work is very difficult to supervise, but, owing to its spasmodic nature, the forests have not suffered as much as might be expected. Class I trees are all marked before felling, and, as only a few trees are felled at one time, the result has been a gradual opening of the canopy and fairly satisfactory regeneration.

19. The outturn from the reserved forests in all the Settlements was $3,590^{\circ} 20$ tons of timber, $9,520^{\circ} 5^{2}$ tons of fuel, and $20^{\circ} 26$ tons of charcoal, on which revenue of $\$ 16,704.64$ was realised. The corresponding figures for 1920 are $6,197^{\prime} \mathrm{r} 3$ tons of timber, I $3,5333^{\circ} 3$ tons of firewood, $96^{\circ} 2$ tons of charcoal, and $\$ 22,752$.19 revenue. No account is taken of timber or fuel extracted free of royalty.

\section{(b) From. Crown Land.}

20. Monthly permits were issued as usual in Singapore for frewood and pole cutting, the revenue being \$5,49I. T6 and the estimated outturn 9,260 tons of firewood and $3,293^{\frac{1}{2}}$ tons of poles, compared with $\$ 2,955.4 \mathrm{I}$, and 8, IOO and 6 I I tons respectively in $\mathrm{r} 920$.

2I. The outturn of timber from Penang, Province Wellesley, and the Dindings was $2,312.65$ tons, being 678.56 tons less than in 1020 . The outturn of firewood was $5,594^{\circ} 80$ tons, compared with 5.66065 tons in 1920 . The revenue for the year was $\$ 6,42 \mathrm{I} . \mathrm{T}$, compared with $\$ 9.003 .59$ in 1920 . 
22. In Malacca 538.28 tons of timber were removed on payment of royalty, and 236,295 poles under free grant. The fall of $564^{\circ} 99$ tons in outturn was accompanied by a decrease of revenue from $\$ 1,256$ to $\$ 1,201$.

23. The total revenue on timber, fuel, and charcoal from Crown land in all the Settlements was $\$$ I 3 , II 3.27 , details of the quantities extracted, amounting in all to $6,144^{\circ} 43$ tons of timber and $14,854^{\circ} 80$ tons of firewood, being given in Form $9^{*}$. The corresponding figures for 1920 are $4,640 \cdot 48$ tons of timber, $3,825.65$ tons of firewood, and \$13,215 revenue.

\section{(c) From Alienated Land.}

24. The only record of outturn from alienated land is 10034 tons of timber in the Dindings, which realised $\$ 68.68$. The revenue derived in Malacca from the io per cent ad valorem tax on the timber on newly alienated land fell from $\$ 14,873.95$ to $\$ 2,848$. I3. This source of revenue is almost exhausted as there is little Crown land left to alienate. The system is one which might be followed with advantage elsewhere.

\section{Minor Forest Products.}

\section{(a) From Reserves}

25. Revenue on minor forest produce from reserves rose from $\$ 2,017.55$ to $\$ 4,195.88$, owing to the transfer of $\$ 3,000$ from deposit account to revenuie as mentioned in paragraph I4. Excluding this item there was a fall of $\$ 821.67$, accounted for by the impossibility of leasing the Para rubber plantation at Ayer Kroh in Malacca and the decrease in revente from canes in the Dindings. The revenue for each Settlement and the principal products from which it was derived are as follows:-

Singapore: $-\$ 1$ I , from nibong;

Penang and Province Wellesley: $-\$ 354$, chiefly from akar (\$2I0), canes $(\$ 66)$, and bertam and langkap $(\$ 50)$;

Dindings:-\$702, chiefly from krang shell (240), granite (\$ry), and kajang ( $\$ 70.80)$;

Malacca.-\$I37, chiefly from canes $(\$ 98)$.

\section{(b) From Crown Lands.}

26. There was a decrease from $\$ 1,717.01$ to $\$ 1,330.30$ in the reventue on minor produce from Crown lands, the principal items being $\$ 624.45$ for tengar bark in the Dindings, \$24r.08 for nibong, and \$197.63 for canes.

\section{PART III}

\section{FINANCIAL RESULTS.}

\section{Revenue.}

27. The following statement shows the total revenue from igrg to I92I :-

\begin{tabular}{|c|c|c|c|c|c|c|c|}
\hline \multicolumn{2}{|c|}{ SETTLEMENT. } & $\begin{array}{c}\text { Revenue, } \\
\text { I919. }\end{array}$ & $\begin{array}{l}\text { Revenue, } \\
\text { I920. }\end{array}$ & $\begin{array}{c}\text { Esti- } \\
\text { mated } \\
\text { revenue, } \\
\text { I } 92 \mathrm{r} .\end{array}$ & $\begin{array}{c}\text { Actual } \\
\text { revenue, } \\
\text { I92I. }\end{array}$ & $\begin{array}{c}\text { Increase } \\
\text { or decrease } \\
\text { over } \\
\text { Estimates. }\end{array}$ & $\begin{array}{l}\text { Increase } \\
\text { or decrease } \\
\text { over I } 920 \\
\text { actuals. }\end{array}$ \\
\hline & & $\$ \quad c$. & $c$ & $\$$ & $\$ c$ & $\$$ & $\$$ \\
\hline $\begin{array}{l}\text { Singapore } \\
\text { Penang and }\end{array}$ & $\dddot{p}$ & $1 \mathrm{I}, 243 \quad 28$ & I $2,978 \quad 59$ & 5,000 & 16,67797 & $+11,67797$ & $+3,6993^{8}$ \\
\hline Wellesley & $\ldots$ & 7,05 I 86 & 5,72297 & 3,310 & 3,016 II & -29389 & $-2,70686$ \\
\hline Dindings & $\cdots$ & 18,314 I 6 & $\mathrm{I} 5,32 \mathrm{I} \quad \mathrm{O}_{5}$ & I $1,37^{\circ}$ & 13,80 I II & $+2,43$ I I I & $-1,51994$ \\
\hline Malacca & $\cdots$ & 29,14498 & $23,245 \quad 44$ & 16,500 & $10,341 \quad 3^{8}$ & $-6,158 \quad 62$ & $-12,904 \quad 06$ \\
\hline Total. & ... & $65,754 \quad 28$ & $57,268 \bigcirc 5$ & 36,180 & $43,836 \quad 57$ & $+7,65657$ & $-13,431 \quad 48$ \\
\hline
\end{tabular}


28. Singapore is the only Settlement to show an increase over the previous year, due mainly to the transfer of $\$ 3,000$ from deposit account to revenue, but partly also to the issue of a large number of permits to cut firewood. The fall in Penang and Province Wellesley is attributed to the general trade depression; in the Dindings to the temporary closure of the forest reserves to the timber cutter; and in Malacca to the exhaustion of Crown land and the consequent reduction in premia paid on forest !and when alienated.

\section{Expenditure.}

29. The following table shows the experditure from igI9 to I921:-

\begin{tabular}{|c|c|c|c|c|c|c|}
\hline SETTLEMENT. & $\begin{array}{c}\text { Expenditure, } \\
1919 .\end{array}$ & $\begin{array}{c}\text { Expenditure, } \\
1920 .\end{array}$ & $\begin{array}{c}\text { Estimated } \\
\text { expenditure, } \\
1921 .\end{array}$ & $\begin{array}{c}\text { Expenditure, } \\
1921 .\end{array}$ & $\begin{array}{l}\text { Savings or } \\
\text { excess over } \\
\text { Estimates. }\end{array}$ & $\begin{array}{c}\text { Increase or } \\
\text { decrease } \\
\text { over } 1920 \\
\text { actuals. }\end{array}$ \\
\hline & $c$ & $\$ c$. & $\$$ & $\$ \quad c$ & $c$. & $\$ \quad c$. \\
\hline Singapore ... & $9,598 \quad 83$ & 14,98260 & 20,351 & 18,65943 & $+1,69157$ & $+3,67683$ \\
\hline $\begin{array}{l}\text { Penang and Province } \\
\text { Wellesley }\end{array}$ & 545920 & 6,43303 & 7.300 & 6.05823 & +124177 & $-\quad 37480$ \\
\hline Dindings & $6,688 \quad 19$ & 7,19285 & 1.2, 281 & 10,38300 & $+2,19800$ & $+3,19015$ \\
\hline Malacca & 12,31806 & $14,240 \quad 48$ & 18,445 & 15,47131 & $+2,97369$ & $+1,23083$ \\
\hline Total & 34,06428 & 42,84896 & 58,677 & * 50,57197 & $+8,10503$ & $+7,72301$ \\
\hline
\end{tabular}

30. Almost the whole of the increase in expenditure is due to the increased cost of salaries, which rose from $\$ 32,140.86$ to $\$ 38,921.11$. The increased expenditure under other charges was incurred chiefly on transport, planting and cultural operations, and miscellaneous expenses.

Deficit.

31. There was a deficit of $\$ 6,735.40$ as shown in the following statement:-

\begin{tabular}{|c|c|c|c|c|c|c|c|c|}
\hline SETTLEN & MENT. & & $\begin{array}{c}\text { Surplus } \\
\text { or deficit } \\
1919 .\end{array}$ & $\begin{array}{c}\text { Surplus } \\
\text { or deficit } \\
1920 \text {. }\end{array}$ & $\begin{array}{l}\text { Estimated } \\
\text { surplus or } \\
\text { deficit } 1921 .\end{array}$ & $\begin{array}{c}\text { Surplus } \\
\text { or deficit } \\
1921 .\end{array}$ & $\begin{array}{c}\text { Increase } \\
\text { or decrease } \\
\text { over } \\
\text { Estimates. }\end{array}$ & $\begin{array}{l}\text { Increase or } \\
\text { decrease } \\
\text { over } 1920 \\
\text { actuals. }\end{array}$ \\
\hline \multirow{6}{*}{$\begin{array}{l}\text { Singapore } \\
\text { Penang and } \\
\text { Wellesley } \\
\text { Dindings } \\
\text { Malacca }\end{array}$} & & & $\$ \quad c$ & $c$ & $c$. & c. & $c$. & $\$$ \\
\hline & Provin & & $+1,64445$ & $-2,00401$ & $-15,35100$ & $-1,98146$ & $+13,36954$ & 2255 \\
\hline & & ... & $+1,59266$ & $-\quad 71006$ & $3,990 \quad 00$ & $-\quad 3.04212$ & 94788 & $-\quad 2,33206$ \\
\hline & & $\cdots$ & $+11,62597$ & $+8,12820$ & $\begin{array}{lll}- & 1,211 & 00\end{array}$ & $+3,4$ & $+\quad 4,62911$ & $-\quad 4,71009$ \\
\hline & & $\cdots$ & $+16,82692$ & $+9,00496$ & $-\quad 1,94500$ & $-5,12993$ & $-\quad 3,18493$ & $-14,13489$ \\
\hline & OTAL & $\ldots$ & $+31,69000$ & $+14,41909$ & $-22,497.00$ & $-6,73540$ & $+15,76160$ & $-21,15449$ \\
\hline
\end{tabular}

32. If temporary allowances are taken into consideration the deficit is $\$ 16,766.39$. During seven-and-a-half months of the year of report the writer was on leave and the salary of his locum-tenens, amounting to $\$ 3,65$ I.62, had to be paid in addition to his own. This charge should not recur for some time. There is every reason also to believe that, with the return of more prosperous conditions, the revenue from the Dindings and Malacca forests should again rise. The present deficit should therefore certainly be reduced during 1922, though it may be some time before it is converted into a surplus. It is thought that in Penang and Province Wellesley some economies might be effected, and this matter is under consideration. 
7

PART IV.

Administration.

33. A complete scheme for the amalgamation of the department with that of the Federated Malay States was drawn up, and was carried into effect in anticipation of formal sanction to certain financial arrangements on which orders have not yet been passed. The two senior Rangers were transferred to the Federated Malay States and the forests of the Colony are now under the direct control of senior officers of those States. Penang, Province Wellesley, and the Tanjong Barong Reserve in the Bindings are now in charge of the Deputy Conservator of Forests, Taiping; the rest of the Dindings is in charge of the Deputy Conservator of Forests, Batu Gajah; Malacca, as before, is attached for administrative purposes to Neg Semtilan; and it is expected that Singapore island will shortly be placed in charge of the Conservator of Forests, Johore. The beneficial result of these changes is most marked in Malacca. which now has the services of a trained Assistant Conservator.

E. CUBIT, Conservator of Forests, S. S. \& F. M. S.

Kite. L.UMPUR, I7 th March, 1922. [No. 2450/22.] 


\section{Annual Report on Forest Administration in the Siraits Settlements, for the Year 1922.}

\section{PART I.}

\section{Extension and Constitution of Reserved Forests.}

I. The forest reserves were increased by an addition of $2,527 \frac{1}{2}$ acres in the Dindings, partly by an extension of the Segari-Melintang Reserve

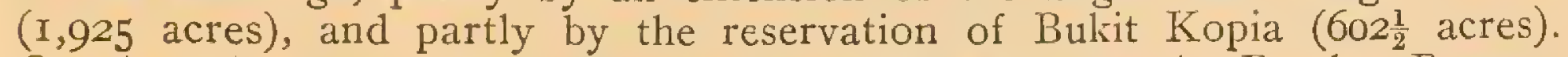
On the other hand about I56 acres were excised from the Pandan Reserve in Singapore for the Pasir Panjang Cement Works.

2. No formal proposals were made during the year for the constitution of new reserves, but the reservation of about 800 acres of mangrove swamp on the Sungei Linggi in Malacca seems desirable and was under consideration.

3. The Mandai and Sembawang Reserves, which were given up in I9I4 at the urgent request of the military authorities, have never been used, and are now said not to be wanted for military purposes. It is not yet decided whether they shall again be constituted reserved forests.

4. The total area of reserved forest is now I7I'I square miles distributed as shown in the following table.

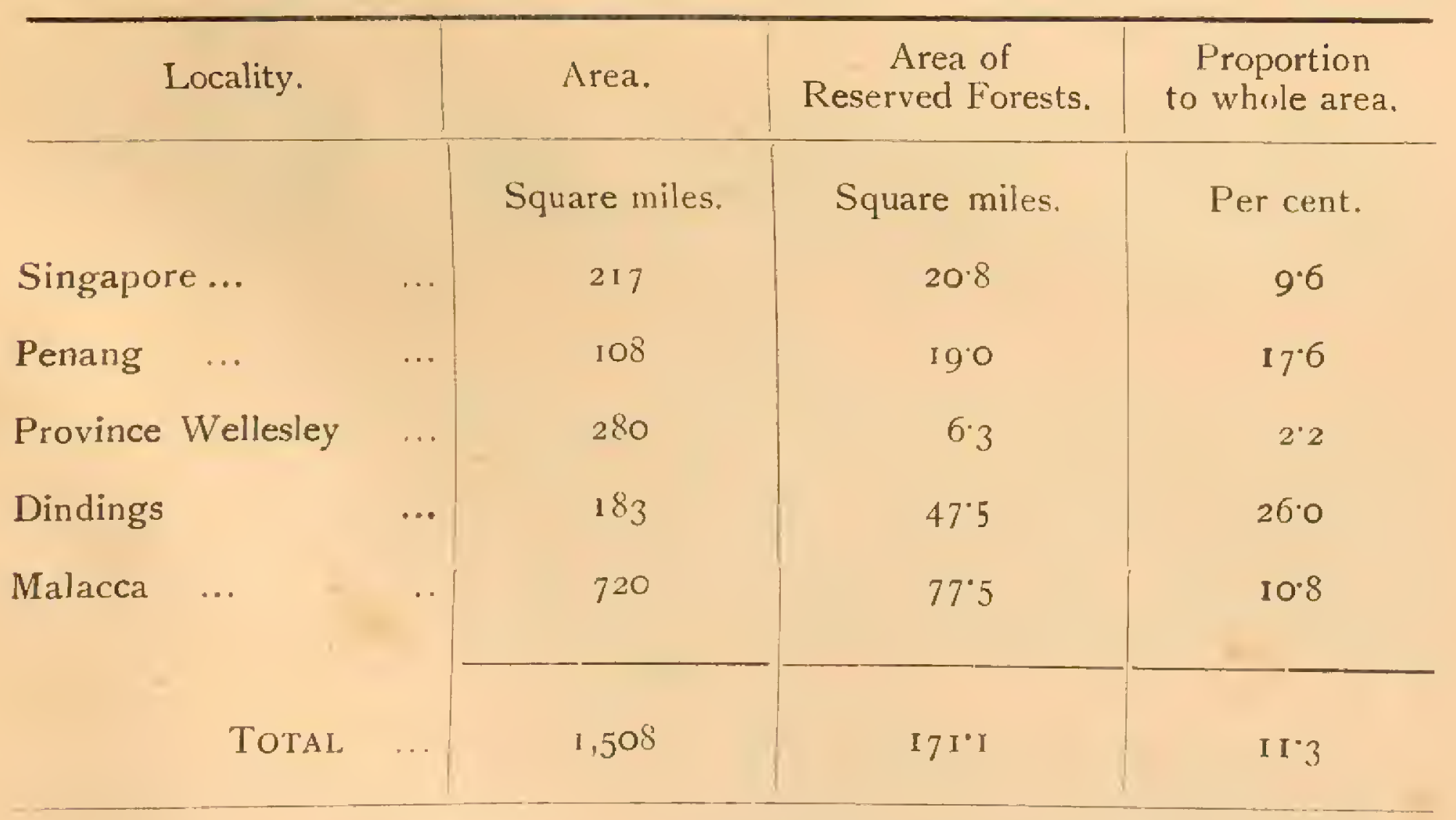

Demarcation and Upkeep of Boundaries.

5. The length of reserve boundaries is now estimated to be about 555 miles, the greater part of which was maintained in good order by the subordinate staff, the total expenditure being $\$ 277$, of which $\$ 208$ were spent 
in Malacca. In addition SI7 were spent on demarcating $2 \frac{1}{2}$ miles of boundary of the suggested reserve on the Sungei Linggi. In Malacca the boundaries were more clearly defined than before by the erection of 138 new and clearly marked boundary plates.

\section{Surveys.}

6. About 8 miles of the southern boundary of the Sungei Pinang Reserve and the northern boundary of the South Pangkor Reserve, both in the Dindings, were surveyed by the Survey Department with a view chiefly to locating the situation of certain blocks of alienated land. The only other survey work of importance was carried out departmentally in the Bukit Senggeh, Ayer Panas, Batang Malaka, and Bukit Sedanan Reserves in Malacca, where timber extraction tracks or specially selected cut and graded lines were surveyed and adopted as compartment boundaries. About 59 miles were surveyed for this purpose at a cost of $\$ 380$, which compares favourably with $\$ 701$ for 50 miles of similar work in I92I.

\section{PART II.}

\section{MANAGEMENT OF FORESTS.}

\section{Working Plans and Plans of Operations.}

7. There are at present no regular working plans, but the breaking up of the Malacca reserves into compartments is a necessary preliminary to their compilation. The plans of operations were on a small scale and were generally adhered to, the only important exception being the proposed enumeration surveys in the Lumut Reserve, which could not be carried out for want of an experienced officer.

\section{Communications.}

8. A mile of path costing $\$ 23$ was constructed to give access to the taban plantation in the Telok Bahang Reserve in Penang, and about $2 \frac{1}{2}$ miles of rough paths were made at a cost of $\$ 22$ round the reservoir in the Panchor Reserve in Province Wellesley to facilitate the protection of the water catchment area. The latter path also gives access to a felling area.

9. In Malacca 36 miles of path were constructed, mostly along old extraction tracks, at an average cost of $\$ 4.76$ a mile, the distances being 17 , Io, $\mathrm{I}$, and 8 miles in the Ayer Panas, Bukit Senggeh, Merlimau, and Batang: Malaka Reserves respectively. Repairs were carried out to 25 miles in the Sungei Udang Reserve and 2 miles in the Bukit Bruang Reserve at a cost of \$I.58 a mile.

\section{Buildings.}

Io. The construction and maintenance of Forest Department buildings are for the most part in the hands of the Public Works Department. New quarters were erected for forest guards in Malacca at Merlimau (\$950), Selandar $(\$ 1,330)$, and Sungei Udang $(\$ 1,093)$, and quarters for a forester at Alor Gajah were begun. In addition a sum of $\$ 1,180$ was spent on latrines at Balik Pulau, Bukit Mertajam, and Jasin, on wells at Telok Bahang and Sungei Udang, and on a fence at Telok Bahang.

\section{Protection of Forests.}

II. There were no changes in the Forest Law. The number of offences reported, none of which were serious, fell from IO4 in I92I to 64 in the year of report, of which 60 were concerned with the unauthorised removal or appropriation of forest produce. The fall is accounted for entirely by the reduction in the number of offences in Malacca, where the stricter supervision enforced in I92I has evidently had a salutary effect. Four cases were pending at the beginning of the year. 
12. Convictions were obtained in 40 out of 42 cases taken to court, the fines inflicted amounting to $\$ 887$ in addition to $\$ 240$ compensation for damage to the forest, and $\$ 25$ realised from the sale of confiscated property. Cases were compounded only in Malacca, where 22 cases were dealt with, and compensation of $\$ 478$ accepted. In the Dindings $\$ 33$ were paid for breaches of permits to exploit forest produce, and $\$ 2$ were realised by the sale of seized property in two undetected cases. At the close of the year two cases were pending.

I3. Squirrels did very considerable damage to the seed crop of guttapercha in the Ayer Kroh plantation, and shooting them had little effect. Rhodaneura larvae did a small amount of damage in the gutta-percha nursery, and a few trees in the plantation were attacked by borers. The most serious damage so far reported is due to the presence of resam, which is spreading to the drier portions of the Ayer Kroh plantation and the Sungei Udang Reserve, and against which remedial measures have not yet been devised.

I4. In the Tanjong Burong Reserve in the Dindings several patches of pure lenggadai forest died, but no signs of disease were discovered by the Mycologist to whom specimens were submitted.

\section{IMPROVEMENT OF FOREST.}

\section{Natural Reproduction.}

I5. Dipterocarps are reported to have flowered and fruited freely in the Dindings; Keruing and Meranti Rambai Daun fruited plentifully, and Merawan to a limited extent in Malacca; and Meranti flowered well in the Bukit Panchor Reserve in Province Wellesley, but it is not yet known whether seed resulted. About 30 taban trees bore a moderate crop of fruit in the Ayer Kroh plantation; elsewhere it failed to flower. Mangrove reproduction in the Tanjong Burong Reserve was rather below the average.

\section{Plantations and Cultural Operations.}

I6. The gutta-percha and rubber plantations in Singapore were maintained at a small cost of $\$ 32$, but no tapping was done owing to the depressed state of the rubber industry.

I7. Considerable attention was paid to gutta-percha in Malacca, and more would have been done if seed had been available. Naturally grown seedlings were collected from the Ayer Kroh plantation, and about $I^{\circ} 6$ acres of Para rubber were underplanted with them in baskets at intervals of $6^{\prime} \times 6^{\prime}$. Efforts to improve the soil by growing green manures were only partially successful, but on the whole the seedlings did well. A small nursery was established at the Sungei Anak Ayer Bengkuang, and r,253 seedlings from 2 , OIO seeds sown survived at the end of the year. The total cost of these operations, including the remoral of 32 superfluous Para rubber trees, was. $\$$ I94, which is very heavy.

I8. In the Telok Bahang Reserve in Penang 514 gutta-percha seedlings were moved from overstocked to blank areas. In the same reserve a small experiment at a cost of only $\$ 4$ was made in the planting of bamboo, for which there is a considerable demand, met at present chiefly by imports from Kedah and to a small extent by the little that is grown in kampongs. If bamboos can be grown cheaply they should be profitable to the Government and of benefit to the local population.

I9. The mangrove plantations in the Tanjong Burong Reserve in the Dindings were increased by 7 I acres at a cost of $\$ 4.07$, but owing to damage by crabs replacements on a large scale will be necessary and further expenditure be incurred. Attempts to protect the seedlings by planting them in sections of bamboo failed; the crabs climbed the bamboos and did damage above them, and, if there was room, took up their permanent habitation inside. Fifteen acres of the plantations of I92I which had been ravaged by crabs were re-stocked. The total cost of the work was $\$ 300$. 


\section{Improvement Fellings.}

20. In the Government Hill Reserve (Batu Feringgi) in Penang improvement fellings were carried out free of cost by the subordinate staff over about 68 acres of gutta-percha forest. Ten acres of gutta-percha were similarly treated in the Telok Bahang Reserve at a cost of \$I4I, including the cost of moving seedlings referred to in paragraph 18.

2I. In Malacca a sum of $\$ 205$ was spent on the improvement of about 93 acres of gutta-percha in the Ayer Kroh plantation. Poles which hindered the development of the gutta-percha trees were felled, and larger trees were ringed and killed by the application of Atlas preservative. This small plantation promises to be an important source of supply for gutta-percha seed.

22. In the Ayer Panas, Merlimau, Ramuan China, and Sungei Udang Reserves improvement fellings in favour of the regeneration of first class trees were carried out over about 76 acres by timber licensees.

\section{EXPLOITATION.}

Timber and Fuel.

(a) Firom Reserves.

23. In Singapore five reserves were worked as usual for mangrove fuel under the coupe system, the area under exploitation during the whole or part of the year being 333 acres. In addition, five old coupes which had not been fully worked out, were open to exploitation under monthly permits. The 205 . acres newly leased realised \$25.I7 per acre, compared with $\$ 25.64$ per acre for the coupes of the previous year. The estimated outturn from the leased coupes was 4,700 tons, and from the coupes open under permit 880 tons, compared with 2,350 and 1,220 tons respectively in I92r. The outturn from other sources was 45 tons of timber and 600 tons of fuel. The revenue rose from $\$ 5,003$ to $\$ 5,740$.

24. The following table summarises the results of the year's work in the mangrove forests:-

\begin{tabular}{|c|c|c|c|c|c|c|c|c|}
\hline \multicolumn{3}{|c|}{ Reserve. } & $\begin{array}{l}\text { Coupe } \\
\text { No. }\end{array}$ & $\begin{array}{l}\text { Area in } \\
\text { acres. }\end{array}$ & $\begin{array}{l}\text { Amount at } \\
\text { which } \\
\text { leased. }\end{array}$ & $\begin{array}{c}\text { Total } \\
\text { revenue real- } \\
\text { ised during } \\
1922 .\end{array}$ & $\begin{array}{c}\text { Approximate } \\
\text { outturn } \\
\text { during } 1922 .\end{array}$ & Remarks. \\
\hline $\begin{array}{l}\text { Pandan } \\
\text { Pandan } \\
\text { Changi } \\
\text { Kranji } \\
\text { Seletar } \\
\text { Seletar } \\
\text { Tuas }\end{array}$ & $\begin{array}{l}\ldots \\
\ldots \\
\ldots \\
\ldots \\
\cdots \\
\ldots \\
\ldots\end{array}$ & \begin{tabular}{c|}
$\ldots$ \\
$\ldots$ \\
$\ldots$ \\
$\ldots$ \\
$\ldots$ \\
$\cdots$ \\
$\ldots$
\end{tabular} & $\begin{array}{l}13 \\
14 \\
13 \\
13 \\
11 \\
12 \\
12\end{array}$ & $\begin{array}{l}80 \\
80 \\
30 \\
30 \\
18 \\
30 \\
65\end{array}$ & $\begin{array}{rc}\$ \quad c . \\
* 2,808 & 00 \\
2,488 & 00 \\
546 & 00 \\
600 & 00 \\
127 & 80 \\
427 & 50 \\
1,644 & 50\end{array}$ & $\begin{array}{rl}\$ \quad c . \\
200 & 00 \\
+2.513 & 00 \\
\ldots & \\
600 & 00 \\
\ldots & \\
427 & 50 \\
\ldots & \end{array}$ & $\begin{array}{l}\text { Tons. } \\
\qquad \begin{array}{r}1,560 \\
640 \\
280 \\
720 \\
20 \\
600 \\
880\end{array}\end{array}$ & $\begin{array}{l}\text { Old. } \\
\text { New } \\
\text { Old. } \\
\text { ö. } \\
\text { Old. } \\
\text { New. } \\
\quad . .\end{array}$ \\
\hline & Total & $\cdots$ & $\cdots$ & 333 & 8,64180 & $3,740 \quad 50$ & 4,700 & $\ldots$ \\
\hline $\begin{array}{l}\text { Pandan } \\
\text { Pandan } \\
\text { Pandan } \\
\text { Tuas } \\
\text { Changi }\end{array}$ & $\begin{array}{l}\cdots \\
\cdots \\
\cdots \\
\cdots \\
\cdots\end{array}$ & \begin{tabular}{l|}
$\cdots$ \\
$\cdots$ \\
$\cdots$ \\
$\cdots$ \\
$\cdots$
\end{tabular} & $\begin{array}{r}9 \\
11 \\
12 \\
9 \\
12\end{array}$ & $\begin{array}{l}80 \\
80 \\
80 \\
65 \\
16\end{array}$ & $\begin{array}{l}\cdots \\
\cdots \\
\cdots \\
\cdots \\
\cdots\end{array}$ & $\begin{array}{r}500 \\
4000 \\
14500 \\
2000 \\
1000\end{array}$ & $\left.\begin{array}{r}20 \\
160 \\
580 \\
80 \\
40\end{array}\right\}$ & $\begin{array}{l}\text { Open under } \\
\text { monthly } \\
\text { permits. }\end{array}$ \\
\hline & TOTAL & $\ldots$ & $\cdots$ & 321 & $\ldots$ & 22000 & 880 & $\cdots$ \\
\hline
\end{tabular}

25. The outturn of timber on payment from the reserves of Penang; Province Wellesley, and the Dindings fell from I, II to 649 tons, the bulk of the output being in the form of poles. The market for timber from the Dindings is in Penang, and, as the demand almost ceased, work in the reserved forests was as far as possible closed down. The outturn of firewood from the same Settlements rose from 4.078 to 5.598 tons, owing entirely to

* Includes $\$ 200$ paid for extension of contract. + Includes $\$ 25$ forfeiture of deposit for tender. 
more extensive work in the Tanjong Burong Reserve in the Dindings, to which however is credited this year 326 tons extracted, but not paid for, in I92I. Revenue rose from $\$ 6,68$ I to $\$ 6,994$.

26. In Malacca 33 licensees were working timber in the following reserves:-Ayer Panas, I; Bukit Sedanan, I2; Batang Malaka, 5; Bukit Senggeh, 5; Merlimau, 3; Sungei Udang, 6; and Ramuan China, I. Licensees in the Bukit Sedanan and Bukit Senggeh Reserves were also allowed to convert waste timber into charcoal. The total outturn of timber, fuel, and charcoal from reserves was I,53I tons, compared with 2,5I4 tons in I92I, and the revenue fell from $\$ 5,021$ to $\$ 5,019$. Of the total output of I, 486 tons of timber, 482 tons came from the Bukit Seclanan Reserve. This reserve is now divided into ig compartments, of which 8 were closed during the year to further exploitation, and one has not yet been opened. Now that compartments have been demarcated, exploitation is much more easily supervised and there are fewer breaches of the felling rules. It is of some interest to note that more than a third of the 240 class I trees felled were Durian Daun.

27. The outturn from the reserved forests in all the Settlements was 2, I80 tons of timber, II, 4 OI tons of fuel, and 24 tons of charcoal on which revenue of $\$ 17,753$ was realised. The corresponding figures for I92I are 3,590 tons of timber, 9,52I tons of fuel, 20 tons of charcoal, and $\$ 16,705$ revenue. No account is taken of timber or fuel taken free of royalty.

\section{(b) From Crown Land.}

28. Monthly permits were issued as usual in Singapore to remove firewood and poles from Crown land, and the figures for I922 and I92I are respectively as follows: - number of permits, 401 and 463 ; firewood removed,

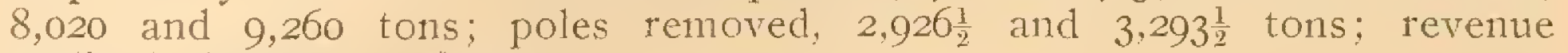
realised, $\$ 4,88 \mathrm{I}$ and $\$ 5,49 \mathrm{I}$.

29. In Penang, Province Wellesley, and the Dindings the revenue was $\$ 9,299$ on 2,988 tons of timber and 6,899 tons of fuel, compared with $\$ 6,42 \mathrm{~L}$, and $2,3 \mathrm{I} 3$ and 5,595 tons respectively in $\mathrm{I} 92 \mathrm{I}$. The increases are accounted for by improved demands for timber and frewood towards the closing months of the year and closer supervision by senior officers.

30. In Malacca I,057 tons of timber were removed on payment of royalty, and 9,257 poles under free grant. The output of timber having almost doubled, the revenue rose from $\$ \mathrm{I}, 20$ I to $\$ 2,075$.

3I. The total revenue on timber, fuel, and charcoal from Crown land in all the Settlements was $\$ 16,255$ details of the quantities extracted, amounting in all to 6,97 I tons of timber and 14,919 tons of firewood, being given in form 9. The corresponding figures for I921 are 6, 144 tons of timber. I4.855 tons of firewood, and \$I3. II3 revenue.

\section{(c) From Alienated Land.}

32. The only recorded outturn from alienated land is 394 tons of timber (mostly poles) and II tons of frewood in the Dindings, which realised $\$ 381$. In Malacca the $10 \%$ ad valorem tax on the timber on newly alienated land fell from $\$ 2,848$ to $\$ 1,540$, and little more can be expected from this source.

\section{Minor Forest Products.}

\section{(a) From Reserves.}

33. Revenue on minor forest produce from reserves fell from $\$ 4,196$ to $\$ 2,369$; the former figure however includes $\$ 3,000$ on rubber from the Bukit Timah plantation in Singapore, which was not tapped during the year under review. Actually there was more activity than usual in the exploitation of minor forest produce. There was a marked increase in the output of damar 
in Malacca, and gutta-percha trees were tapped for the first time in theAyer Kroh plantation and in Batu Feringgi and Telok Bahang as follows:-

\begin{tabular}{|c|c|c|c|}
\hline & & $\begin{array}{c}\text { Ayer Kroh. } \\
-\end{array}$ & $\begin{array}{c}\text { Batu Feringgi and } \\
\text { Telok Bahang. } \\
-\end{array}$ \\
\hline Number of trees tapped & $\cdots$ & 852 & 268 \\
\hline Yield ... $\quad \ldots$ & $\cdots$ & 343 pikuls. & I'45 pikuls. \\
\hline Cost of collection ... & .. & $\$ 612$ & $\$ 220$ \\
\hline Receipts Irom sale... & $\ldots$ & $\$ 996$ & $\$+28^{*}$ \\
\hline
\end{tabular}

34. The revenue for each Settlement and the principal products from which it was derived are as follows:-

Singapore: $-\$ 55$, almost entirely from nibong.

Penang and Province Wellesley :-\$328, chiefly from akar (\$I24), canes $(\$ 84)$, and bertam $(\$ 82)$.

Dindings: - \$54r, chiefly from krang shell (\$225), granite (\$I4I), and kajang (\$104).

Malacca :-\$I,445, chiefly from gutta-percha (\$996), damar (\$3I5), and fruits $(\$ 96)$.

(b) From Crown Lands.

35. There was an increase in the revenue on minor produce from Crown lands from $\$ \mathrm{I}, 330$ to $\$ 2,083$, to which the Dindings contributed $\$ \mathrm{I}, 9 \mathrm{I} 4$, including $\$ \mathrm{I}, 239$ on tengar bark, $\$ 320$ on canes, $\$ 2 \mathrm{r} 7$ on nibong, and $\$$ II 5 on mengkuang. The revenue of $\$ 509$ on 182 taban trees with an average girth of 40 inches which were tapped on Pulau Jerejak was not recovered during the year.

\section{PART III.}

FINANCIAL RESULTS.

Revenue.

36. The following statement shows the total revenue from ig20 to I922:-

\begin{tabular}{|c|c|c|c|c|c|c|}
\hline SETTLEMENT. & $\begin{array}{c}\text { Revenue, } \\
1920 .\end{array}$ & $\begin{array}{l}\text { Revenue, } \\
\text { I92I. }\end{array}$ & $\begin{array}{c}\text { Esti- } \\
\text { mated } \\
\text { revenue, } \\
1922\end{array}$ & $\begin{array}{c}\text { Actual } \\
\text { revenue, } \\
\text { I922. }\end{array}$ & $\begin{array}{c}\text { Increase } \\
\text { over } \\
\text { Estimates. }\end{array}$ & $\begin{array}{c}\text { Increase } \\
\text { or decrease } \\
\text { over } 1921 \\
\text { actuals. }\end{array}$ \\
\hline & $\$$ & $\$$ & $\$$ & $\$$ & $\$$ & $\$$ \\
\hline $\begin{array}{l}\text { Singapore } \\
\text { Penano and }\end{array}$ & I 2,979 & . 16,678 & 7,500 & 14,389 & $+6,889$ & $-\quad 2,289$ \\
\hline $\begin{array}{l}\text { Penang and } \\
\text { Wellesley }\end{array}$ & 5,723 & 3,016 & $3, \mathrm{OCO}$ & 3,003 & & - I3 \\
\hline Dindings & $\mathrm{I} 5,32 \mathrm{I}$ & I 3,801 & 10,000 & I 6,9 I 6 & $+6,916$ & $+3,115$ \\
\hline Malacca & 23,245 & $10,3+1$ & 5,000 & 10,705 & $+\quad 5,705$ & $+\quad 364$ \\
\hline TOTAL & 57,268 & $43,83^{6}$ & 25,500 & 45, O 3 & $+19,513$ & $+\quad \mathrm{I}, \mathrm{I} 77$ \\
\hline
\end{tabular}

37. These figures are on the whole satisfactory and are undoubtedly the results of more efficient administration, which not only prevents the loss of revenue but taps new sources of revenue. 


\section{Expenditure.}

38. The following table shows the expenditure from 1920 to I922:-

\begin{tabular}{|c|c|c|c|c|c|c|}
\hline SETTLEMENT. & $\begin{array}{c}\text { Expenditure } \\
1920\end{array}$ & $\begin{array}{c}\text { Expendituce, } \\
1921 .\end{array}$ & $\begin{array}{c}\text { Estimated } \\
\text { expenditure, } \\
1922 .\end{array}$ & $\begin{array}{c}\text { Expenditure, } \\
1922 .\end{array}$ & $\begin{array}{l}\text { Savings on } \\
\text { Estimates. }\end{array}$ & $\begin{array}{c}\text { Decrease } \\
\text { over } 1921 \\
\text { actuals. }\end{array}$ \\
\hline & $\$$ & $s$ & $s$ & $\$$ & $\$$ & $\$$ \\
\hline $\begin{array}{l}\text { Singapore } \\
\text { Penang and Province }\end{array}$ & 14,983 & 18,659 & 16,148 & 14,776 & 1,372 & 3,883 \\
\hline Wellesley & 6.433 & 6,058 & 7,346 & 5,782 & 1,564 & 276 \\
\hline Dindings & 7,193 & 10,383 & 12,357 & 9,157 & 3,200 & 1,226 \\
\hline Malacca & 14,240 & 15,471 & 19,248 & 14,704 & 4,544 & 767 \\
\hline TOTAL & 42,849 & 50,571 & 55,099 & $* 44,419$ & 10,680 & 6,152 \\
\hline
\end{tabular}

39. These figures also are satisfactory, and are evidence that economy was practised.

\section{Surplus.}

40. The surplus of revenue over expenditure was $\$ 594$ as shown in the following statement:-

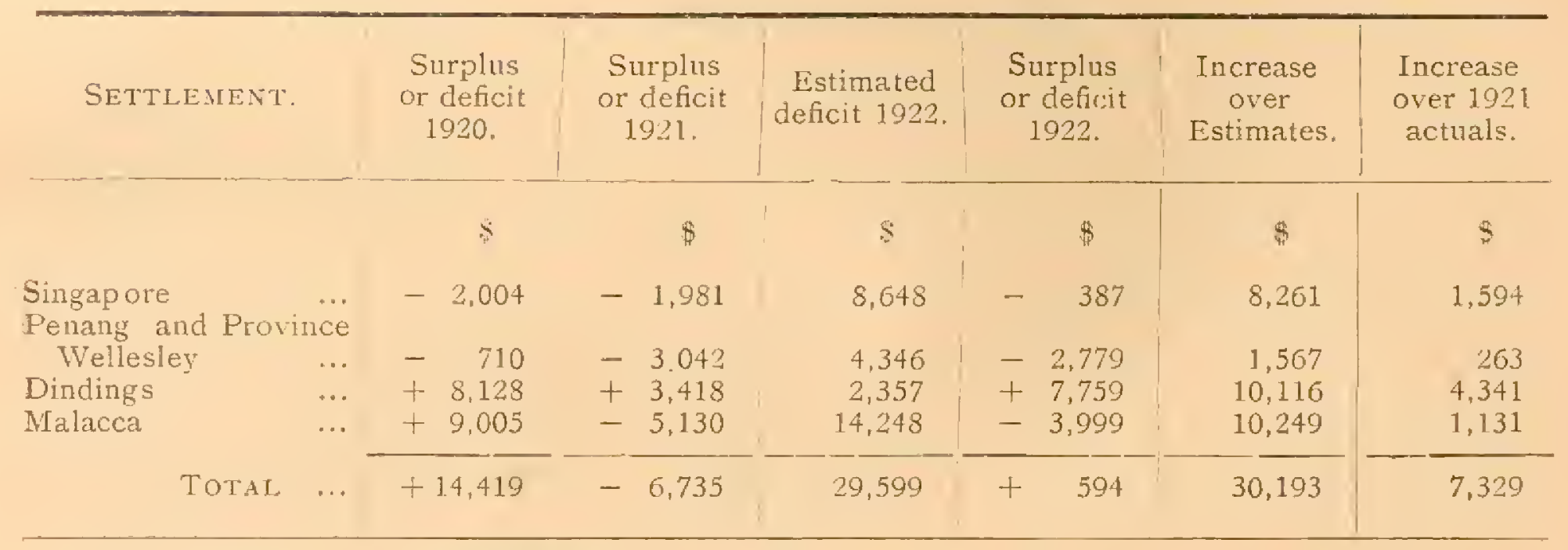

4I. If temporary allowances are taken into consideration there is a deficit of $\$ 5$, I46, which is less than was expected when last year's report was written. If, as is hoped, there is a renewed demand for timber in the current year, the deficit should be wiped off.

\section{PART IV.}

\section{Administration.}

42. The writer was in charge of the department throughout the year, and no change was made in the administrative arrangements in the different Settlements. The scheme for the amalgamation of the Forest Departments of the Straits Settlements and Federated Malay States was the subject of further correspondence, but final orders were not passed.

\section{E. CUBITT,}

Conservator of Forests,

Kuala Lumpur, 4th April, i923.

$$
\text { S. S. and F. M. S. }
$$

- Excludes temporary allowances amounting to $\$ 5,740$. 


\section{Annual Report on Forest Administration in the Straits Settlements, for the Year 1923.}

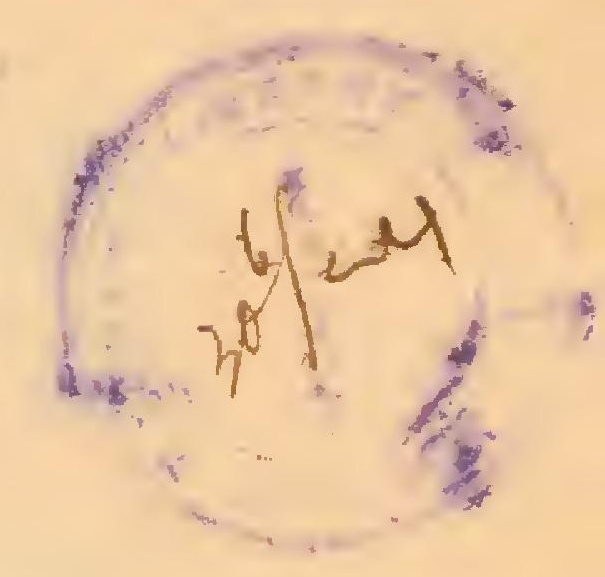

PART I.

\section{EXTENSION AND CONSTITUTION OF RESERVED FORESTS.}

r. During the year the old Sembawang and Mandi Reserves in Singapore covering I, II9 acres, which had been given up at the request of the military authorities, together with an area of about IIo acres of Crown land between the latter reserve and the municipal catchment area, were gazetted a reserved forest under the name Mandi Reserve. About 800 acres of mangrove forest on the Linggi River in Malacca were also reserved to maintain a supply of fishing stakes and firewood for the inhabitants of Kuala Linggi. On the other hand the Kubang Ulu Reserve of $3 \frac{1}{2}$ acres in Province Wellesley was abandoned and handed over to the Agricultural Department. No further reservation is at present under consideration, and certain revocations of reservation will probably be necessitated by the development of Penang Hill as a residential area.

2. The total area of reserved forest is $110 \mathrm{~W}$ I 74.2 square miles distributed as shown in the following table:-

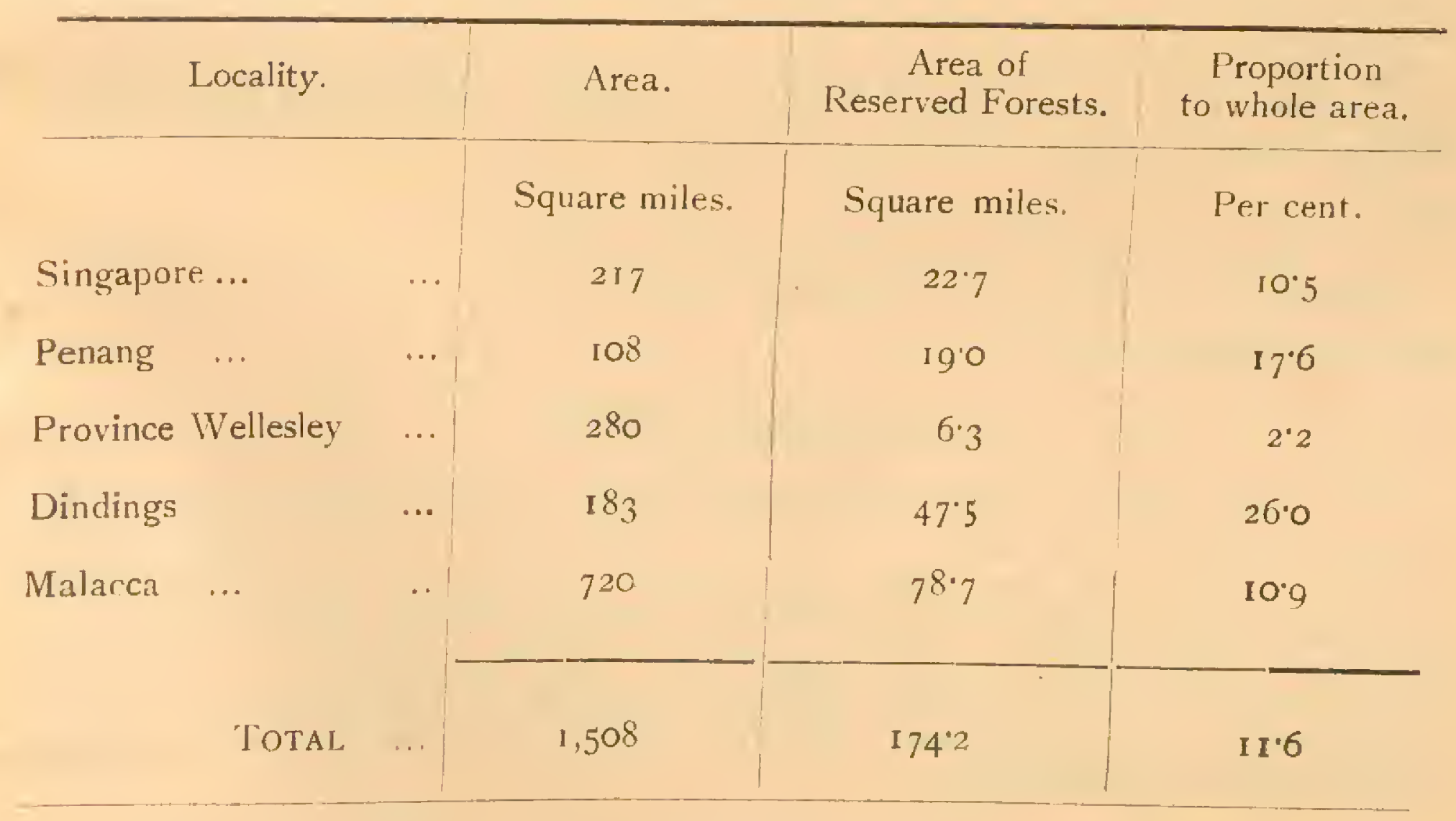

\section{DEMARCATION AND UPKEEP OF BOUNDARIES.}

3. The length of reserve boundaries is now estimated to be about 572 miles. It is considered that 145 miles do not need to be demarcated; the greater part of the rest is reported to lave been maintained by the 
subordinate staff, whose work is, however, not always satisfactory. The total expenditure was $\$ 338$, of which $\$ 259$ were spent in Malacca, where the boundaries have received special attention.

\section{SURVEYS.}

4. A complete re-survey of the settlement of Malacca is, it is understood, being carried out by the Survey Department. There is considerable doubt as to the exact alignment of some of the forest reserve boundaries, and no detailed topographical maps exist. Detailed topographical maps on a scale of 4 inches to the mile are urgently needed for many of the reserves, especially in Malacca and the Dindings, in order that proper plans may be drawn up for their exploitation.

5. The department carried out a number of rough compass traverses in Penang and Malacca, chiefly of paths, extraction tracks, compartment bonndaries, and taban areas. Details are given in Form III, which shows an expenditure of $\$ 195$ on I9 miles, compared with $\$ 380$ on 59 miles in I922. The increased cost is accounted for by the fact that in the case of compartment boundaries the cost of demarcation is included.

\section{PART II.}

\section{MANAGEMENT OF FORESTS.}

\section{Working Plans and Plans of Operations.}

6. There are at present no regular working-plans, but a great step forward was made in Malacca, where enmmeration surveys were carried ont in all the better reserves, namely Merlimau, Pukit Senggelı, Pukit Sedanan, Batang Malaka, Sungei Udang, and Brisu. The work was entrusted to Mr. Whitry, who has had several years' experience in the Federated Malay States, assisted by Mr. STrouts, Assistant Conservator of Forests, also from the Federated Malay States, and for part of the time by the District Forest Officer. The work was still proceeding at the end of the year, and reports were submitted shortly after its close. Its value cannot be exaggerated; we have for many years been working in the dark, and the enumerations now made will provide fairly accurate information as to the topography of the reserves and the stock of timber on the ground, and enable felling schemes to be drawn up. During the year a stum of \$I,29r was spent.

7. Plans of operaticns were in general adhered to except for certain modiffations in Malacca to provide funds for the enumeration surveys mentioned in paragraph 6.

\section{COMMUNICATIONS.}

8. Two miles of track were converted by the staff into a rough path to give access to the areas now under exploitation in the Pantai Achels Reserve in Penang, and \$234 were spent on 28 miles of compartment boundary paths in the Bukit Sedanan, Batang Malaka, Bukit Senggeh, Merlimau, and Ramuan China Reserves in Malacca. Repairs to 93 miles of paths, including 89 miles in Malacca, cost $\$ 186$, including the cost of 50 compartment boundary posts. Much of the work of path repair is done by subordinates and licensees.

\section{BUILDINGS.}

9. Buildings are erected and maintained almost entirely by the Public Works Department. The only new buildings of the year were forest guards' quarters at Ramuan China and Forester's quarters at Alor Gajah, costing $\$ 1,845$ and $\$ 2,875$ respectively. General repairs cost $\$ 683$. 


\section{PROTECTION OF FORESTS.}

10. The forest laws remained unaltered, but changes are necessary in order to prevent unavoidable waste of timber and other forest produce by licensees. An assimilation of the laws of the Colony to those of the Federated Malay States with a careful avoidance of complexity is indicated.

II. The number of offences reported, none of which were serious, rose from 64 in 1922 to 98 in the year of report, of which 95 were concerned with the unauthorised removal or appropriation of forest produce. The rise is accounted for chiefly by the increase to 22 in the ntumber of undetected cases, principally in Province Wellesley. It is certain that there were far more undetected cases even than this: the temptation to commit small thefts is considerable and the chances of detection are small; and places on the coast are difficult to patrol with a limited staff. Two cases were pending at the beginning of the year.

12. Convictions were obtained in 39 out of 43 cases disposed of in court, the fines inflicted amounting to $\$ 54 \mathrm{I}$ in addition to $\$ 447$ compensation for damage to the forest. Compensation amounting to a total of $\$ 474$ was accepted departmentally in 24 cases, and I case dealt with departmentally was acquitted. Sales of confiscated property realised \$i4. At the close of the year to cases were pending.

I3. The death of the trees over an area of about 800 acres in the Tanjong Burong Reserve in the Dindings was further investigated, and the cause is thought to be the deposit by the sea of a layer of mud at the foot of the trees. Seedlings grow freely on the top of the mud.

14. Taban layers and seedlings suffered from the attacks of mouse-deer at Ayer Kroh. Seedlings were also destroyed or badly damaged by molecrickets, and were partially defoliated by Rhodoneura. Taban seed was taken by squirrels, which were shot with salutary results.

I5. Climbers, resam, bertam, palas and other weeil's were dealt with as far as possible in operations for the improvemeit of the growing stock.

16. Some damage was done to taban at Ayer Kroh by a whirlwind, which blew down a number of trees.

\section{IMPROVEMENT OF THE FORESTS.}

Natural Reproduction.

17. The year was not a good one for seed. A small supply of taban. seed was obtained from Pulau Jerejak. At Ayer Kroh the results were better; 117 taban trees seeded and 80,540 seeds were collected, of which 3,640 were used locally and the remainder sold for $\$ 384$, the cost of collection being $\$ 4 \mathrm{I}$.

\section{PLANTATIONS AND CULTURAL OPERATIONS.}

18. In Singapore the Para rubber trees in the Bukit Timaln plantation were let from May to November; and the plantation at East Seletar from May to the end of the year. The receipts are credited to the Agricultural Improvements Deposit Account.

19. In the Telok Bahang Reserve in Penang 37 I taban seedlings were moved from overstocked to blank areas. Of the seedlings so transplanted in 192284 per cent have survived. An experimental planting of bamboo stumps in the same reserve was partially successful. About half the stumps were alive and healthy at the end of the year, and the experiment is being continued. 
20. In the Tanjong Burong Reserve in the Dindings 70 acres of recently cxploited forest were planted $3^{\prime} \times 3^{\prime}$ with bakan mimyai at a total cost to the department of $\$ 100$, half the work being done by the subordinate staff.

21. In Malacca the under planting of taban in the Para rubber block at Ayer Kroh was continued, and blanks in the previous year's planting were supplied. Patch-sowing of taban was also tried and seems likely to prove successful in spite of damage by mouse-deer and mole-crickets. The total cost incurred was $\$ 192$.

In the Sungei Udang Reserve four acres were patch sown with maranti tombaga in cleared lines 20 feet apart with the patches 20 feet apart in the lines. The cost was only $\$ 450$, and the experiment promises to prove successful.

\section{IMPROVEMENT IELLINGS.}

22. The taban at Batu Feringgi and in the Telok Bahang Reserve in Penang were looked after by the subordinate staff. The result of the improvement fellings of 1922 is satisfactory.

23. In Malacca more extensive operations were undertaken. The work of clearing the taban merah and getah sundik blocks in the Ayer Kroh plantation was finished, 49 acres being treated at a cost of $\$ 44$. Heavy pole-fellings of inferior species were made and the larger trees interfering with the growth of the taban were ringed. In the Ayer Panas Reserve 40 acres in compartment 8 were improved at a cost of $\$ 80$. The undergrowth was cleared and the ground is now covered with meranti regeneration. The cutting or ringing of inferior species is now necessary, and this has been begun under permit, government thus making revenuc out of the operation. In the Bukit Senggeh Reserve a beginning was made to free profuse seedling growth of resak, scraya, and moranti from suppression, II acres being completed at a cost of $\$ 57$, which seems expensive, althongh all weeds were removed and large class II trees ringed. Permit holders dealt with further small areas in the Bthit Sedanan, Merlinat, and Ramuan China Rescrves. In the Bukit Bruang Reserve permit holders were admitted to cut frewood in the tempinis area, the firewood cutting being followed by the cleaning of the area and the ringing of the class II species which remained. A sum of $\$ 3.50$ was spent, and work on 9 acres was completed, but firewood was removed from many acres more. The operation was a profitable one, the firewood permits realising \$I68. Till recently permit holders and licensees in reserves have been allowed too free a hand; they felled only the most valuable species and wasted much of the material from these, with the result that the forest was being depleted of its valuable growing stock. Since October all licensees have been compelled to extract class II trees as well as class I in order to enconrage the natural regeneration of the latter.

\section{EXPLOITATION.}

TimeER AND TUEL.

\section{(a) From Reserved Forests.}

24. In Singapore four reserves were worked as msual for mangrove fuel under the conpe system, the area under exploitation during the whole or part of the year being $3^{1} 5$ acres. In addition, Io old coupes, which had not been fully worked out, were open to exploitation under monthly permits. The 205 acres newly leased realised \$21.40 per acre, compared with \$25.I7 per acre for the coupes of the previous year. The estimated outturn from the leased coupes was 3,660 tons, and from the coupes open under permit 3,020 tons, compared with 4,700 and 880 tons respectively in 1922 . The outturn from other sources was 2 tons of poles and I, 280 tons of fuel. Revenue fell from $\$ 5.740$ to $\$ 5.345$. 
25. The following table summarises the results of the year's work in the Singapore mangrove forests :-

\begin{tabular}{|c|c|c|c|c|c|c|c|c|}
\hline \multicolumn{3}{|c|}{ Reserve. } & $\begin{array}{c}\text { Coupe } \\
\text { No. }\end{array}$ & $\begin{array}{l}\text { Area in } \\
\text { acres. }\end{array}$ & $\begin{array}{c}\text { Amount at } \\
\text { which } \\
\text { leased. }\end{array}$ & $\begin{array}{c}\text { Total } \\
\text { revenue real- } \\
\text { ised during } \\
1923 .\end{array}$ & $\begin{array}{c}\text { Approximate } \\
\text { outturn } \\
\text { during } 1923 .\end{array}$ & Remarks. \\
\hline \multirow[t]{2}{*}{$\begin{array}{l}\text { Pandan } \\
\text { Pandan } \\
\text { Kranji } \\
\text { Seletar } \\
\text { Seletar } \\
\text { Tuas }\end{array}$} & $\begin{array}{l}\cdots \\
\cdots \\
\cdots \\
\cdots \\
\cdots\end{array}$ & \begin{tabular}{c|}
$\ldots$ \\
$\cdots$ \\
$\cdots$ \\
$\cdots$ \\
$\cdots$ \\
$\cdots$
\end{tabular} & $\begin{array}{l}14 \\
15 \\
14 \\
12 \\
13 \\
13\end{array}$ & $\begin{array}{l}80 \\
80 \\
30 \\
30 \\
30 \\
65\end{array}$ & $\begin{array}{rc}\$ & c . \\
2,488 & 00 \\
3,292 & 00 \\
180 & 00 \\
427 & 50 \\
454 & 50 \\
461 & 50\end{array}$ & $\begin{array}{rc}\$ c & c \\
\ldots & \\
3,292 & 00 \\
180 & 00 \\
\ldots & \\
454 & 50 \\
461 & 50\end{array}$ & $\begin{array}{l}\text { Tons. } \\
\qquad \begin{array}{r}940 \\
960 \\
640 \\
80 \\
300 \\
740\end{array}\end{array}$ & $\begin{array}{l}\text { Old. } \\
\text { New } \\
\text { New. } \\
\text { Old. } \\
\text { New. } \\
\text { New. }\end{array}$ \\
\hline & TOT^L & $\ldots$ & $\cdots$ & 315 & 7,30350 & 4,38800 & 3,660 & $\cdots$ \\
\hline $\begin{array}{l}\text { Pandan } \\
\text { Pandan } \\
\text { Pandan } \\
\text { Pandan } \\
\text { Tuas } \\
\text { Tuas } \\
\text { Tuas } \\
\text { Seletar } \\
\text { Changi } \\
\text { Changi }\end{array}$ & $\begin{array}{l}\ldots \\
\ldots \\
\ldots \\
\ldots \\
\ldots \\
\ldots \\
\ldots \\
\ldots \\
\ldots \\
\ldots\end{array}$ & $\begin{array}{c}\ldots \\
\ldots \\
\ldots \\
\ldots \\
\ldots \\
\ldots \\
\ldots \\
\ldots \\
\ldots \\
\ldots\end{array}$ & $\begin{array}{l}11 \\
12 \\
13 \\
14 \\
11 \\
12 \\
13 \\
12 \\
12 \\
13\end{array}$ & $\begin{array}{l}80 \\
80 \\
80 \\
80 \\
65 \\
65 \\
65 \\
30 \\
16 \\
30\end{array}$ & $\begin{array}{l}\cdots \\
\cdots \\
\ldots \\
\cdots \\
\cdots \\
\cdots \\
\cdots \\
\cdots \\
\cdots\end{array}$ & $\begin{array}{rl}190 & 00 \\
85 & 00 \\
80 & 00 \\
95 & 00 \\
70 & 00 \\
15 & 00 \\
5 & 00 \\
60 & 00 \\
60 & 00 \\
95 & 00\end{array}$ & $\left.\begin{array}{r}760 \\
340 \\
320 \\
380 \\
280 \\
60 \\
20 \\
240 \\
240 \\
380\end{array}\right\}$ & $\begin{array}{l}\text { Open under } \\
\text { monthly } \\
\text { permits. }\end{array}$ \\
\hline & TotaL & $\ldots$ & $\ldots$ & 591 & $\cdots$ & 75500 & 3,020 & $\ldots$ \\
\hline
\end{tabular}

Recent more careful control resulting from the appointment of the Conservator of Forests, Johore, to exercise supervision over the Singapore forests shows that the mangrove forests are not being worked to the best advantage; there is a great deal of waste and a good deal of theft, and sufficient attention is not being paid to the reproduction of the forest. Steps axe being taken to remedy this state of affairs, and some reduction in the area exploited will probably be necessary.

26. The outturn of timber on payment from the reserves of Penang, Province Wellesley, and the Dindings rose from 649 to 705 tons, practically all in the form of poles of class 11 timber. An examination of a part of the Pantai Acheh Reserve shows that the exploitation of these poles is doing no harm to the forest, and that in many places there is a good stock of class I poles on the ground, with a fair supply of class I trees $30^{\prime \prime}$ to $40^{\prime \prime}$ in girth. There was a fall from 5,200 to 978 tons in the output of fuel from the same settlements owing to the almost entire cessation of work in the Dindings, where it is thought better to await a closer examination of the forests than is possible with the present staff. On the other hand there was an increase of 66I tons in Penang and Province Wellesley, chiefly from the Balik Pulau mangrove reserve. Revenue fell from $\$ 6,994$ to $\$ 2,068$.

27. In Malacca the number of permit holders working in forest reserves was gradually reduced from 33 to 21 cliefly owing to the unsatisfactory nature of their work. The outturn of timber consequently fell from 1,486 to $\mathrm{I}, 259$ tons, but there was much less waste. Most of the output came from the Bukit Sedanan, Bukit Senggeh, and Merlimau Reserves. Class I trees were as usual marked for felling by a forest officer. Eight tons of charcoal were extracted, but no fuel. The revenue rose from $\$ 5,021$ to $\$ 8,335$.

28. The outturn from the reserved forests in all the Settlements was 1,976 tons of timber, 8,938 tons of fuel, and 8 tons of charcoal, on which revenue of $\$ 15,748$ was realised. The corresponding figures for 1922 are 2, I80 tons of timber, $x I, 40 r$ tons of fuel, 24 tons of charcoal, and $\$ x 7,753$ revenue. No account is taken of timber or fuel taken free of royalty. 
(b) From Crown and Alienated Land.

29. Monthly permits were issued as usual in Singapore to remove firewood and poles from Crown land, and the figures for 1923 and 1922 respectively are as follows:-Number of permits 323 and 401 ; firewood re-

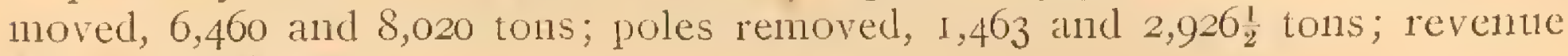
$\$ 5,345$ and $\$ 4,88 \mathrm{I}$.

30. In Penang, Province Wellesley, and the Dindings the revenue was $\$ 12,410$ on 5,332 tons of tmber and 7,466 tons of fuel, compared with $\$ 9,299$, and 2,988 and 6,899 tons respectively in 1922 . The increased output was entirely from the Dindings, and was due to a better market and closer supervision.

3I. In Malacca I, 484 tons of timber and 644 tons of firewood and charcoal were removed, compared with 1,057 tons of timber and no firewood or charcoal in 1922 . The revenue rose from $\$ 3,6$ I 5 to $\$ 6,979$.

32. The total revenue on timber, fuel, and charcoal from Crown and alienated land in all the settlements was $\$ 22,435$, details of the quantities extracted, amounting in all to 8,279 tons of timber and 14,570 tons of lirewood, being given in Form 9. The corresponding figures for 1922 are 7,366 tons of timber and 15,030 tons of firewood, and $\$ 18,176$ revenue. No account is taken in the figures of revenue of $\$ 2,029$ and $\$ 1,540$ paid in 1923 and 1922 respectively for standing timber on land about to be alienated.

\section{MINOR FOREST PRODUCTS.}

\section{(a) From Reserved Forests.}

33. Reventue on minor forest produce from reserved forests fell from $\$ 2,369$ to $\$ 1,885$. There was an increase of revenue in Penang owing to the sale of gutta-percha tapped in 1922; in the other settlements there were decreases owng chiefly to no royalty having been conlected on granite in the Dindings, and to the decreased output of damar and the completion of taban tapping in Malacca. A satisfactory item of revenue was $\$ 584$ for taban seeds and seedlings from the Ayer Kroh plantation in Malacca.

34. The revenue for each settlement and the principal products from which it was derived are as follows:-

Singapore:-\$24 almost entirely from nibong.

Penang and Province Wellesley: $\$ 779$, chiefly from bertam (\$101), sutta-percha $(\$ 428)$, and canes (\$126).

Dindings: - $\$ 341$, chiefly from krang shell $(\$ 300)$.

Malacca: $-\$ 740$, chiefly from taban seeds and seedlings ( $\$ 584)$.

\section{(b) From Crown Lands.}

35. There was a small decrease from $\$ 2,083$ to $\$ 2,013$ in the revenue on minor produce from Crown land. To this the Dindings contributed $\$ 1,360$, including $\$ 742$ on tengar bark, $\$ 203$ on nibong, $\$ 179$ on canes, and $\$$ II5 on kajang; Penang collected $\$ 595$, of which $\$ 509$ was for gutta-percha tapped in 1922 on Pulau Jerejak; Singapore and Malacca contributec the balance of $\$ 5^{8}$. 
PART III.

FINANCTAL RESULTS.

Revenue.

36. The following statement shows the total revente from 1921 to I923:-

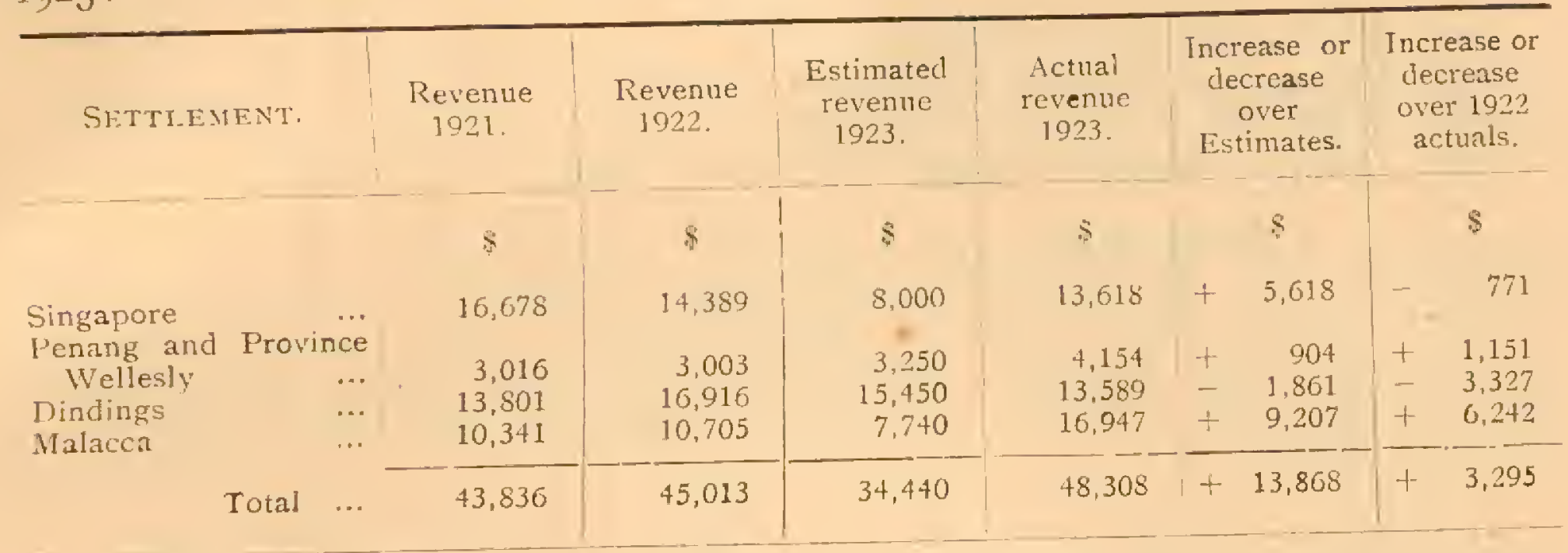

37. These figures are on the whole satisfactory, but a fall in revenuc for a few years is likely until better systems of working can be introduced. In the meantime a cautious policy is necessary.

\section{EXPENDITURE.}

38. The following table shows the expenditure from ro2 to ro23:-

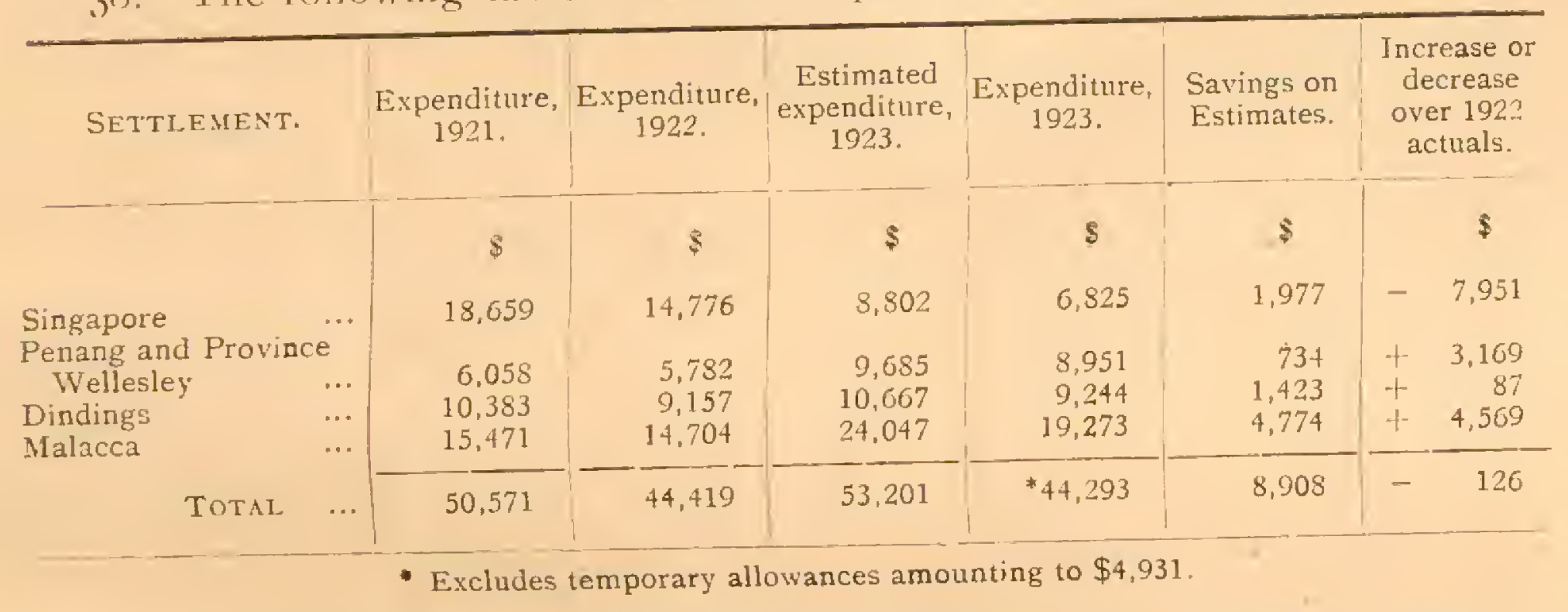

39. The Iump sum payable to the Federated Malay States under the amalgamation scheme is distributed amongst the different settlements in proportion to their area, and this accounts largely for the increases and decreases in the last column of the table. In former years administrative charges have been paid from the Singapore vote.

\section{SURPIUS AND DEFICIT.}

40. The surplus of revenue over expenditure was $\$ 4.015$ as shown in the following statement:-

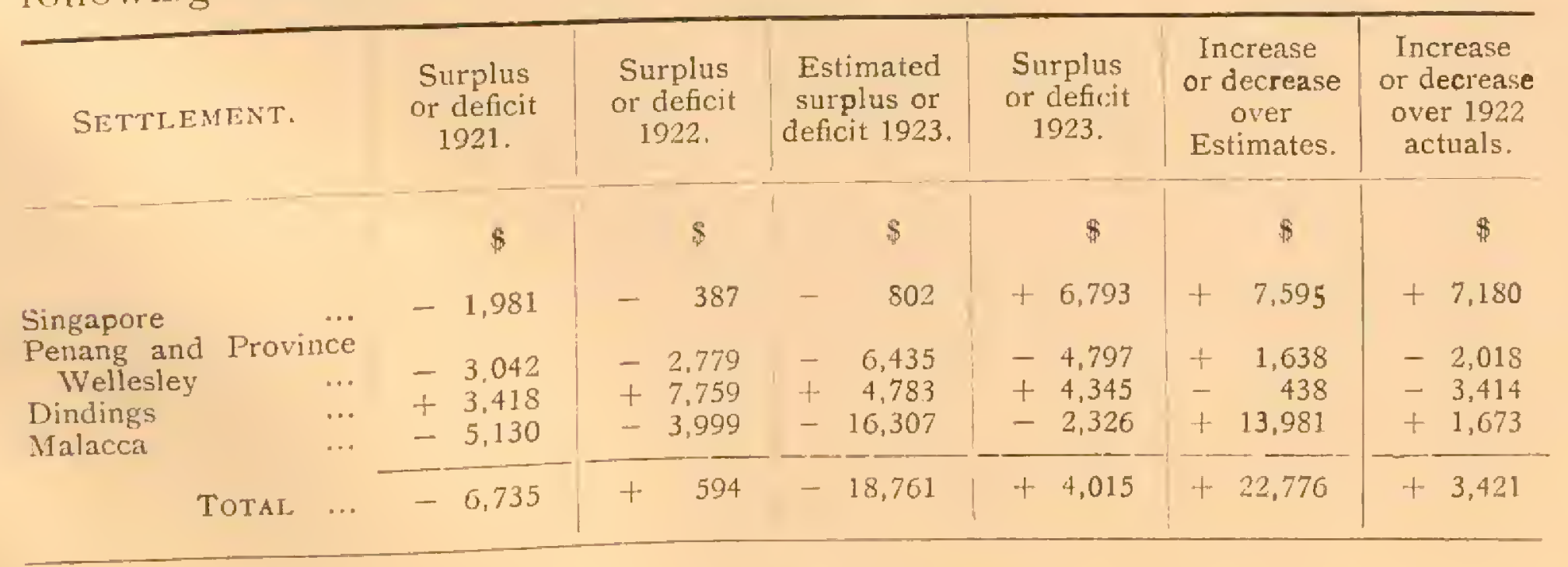


4I. If temporary allowances are taken into consideration there is a deficit of $\$ 916$, compared with $\$ 5$, I46 in 1922 , which is in accordance with last year's anticipations.

\title{
PART IV.
}

\section{ADMINISTRATION.}

42. The writer was in charge of the department thronghout the year except during his absence at the Biritish Empire Forestry Conference in Canada from the 2Ist June to the 7 th October, when Mr. A. E. SancierDAviEs acted for him.

43. The amalgamation of the forest departments of the Straits Settlements and the Federated Malay States, which took effect from the Ist May, marks a most important step in advance, and its good effects are already being felt. Complete efficiency will, however, not be possible until all the subordinate. staff can be placed under the full direct control of technical officers.

\author{
G. E. S. CUBITT, \\ Conservator of Forests, \\ $S . S$. and $F . M . S$.
}

KuAla Lumpur,

I9th March, 1924. [No. 2390/24.] 


\section{Annual Report on Forest Administration in the Straits Settlements, for the Year 1924.}

\section{PART I.}

\section{EXTENSION AND CONSTITUTION OF RESERVED FORESTS.}

I. No new reserves were made. Nine and a half acres were excised from Tanjong Burong Reserve for native settlement, and 2 acres were excised from Lumut Reserve for a Hindu Temple site. Both these reserves are in the Dindings. A small area wrongly included at the time of settlement was excised from Ramuan China Reserve in Malacca. The total reduction in the area of forest reserves was $I 3 \frac{1}{2}$ acres.

2. The following statement shows the present area and distribution of forest reserves:-

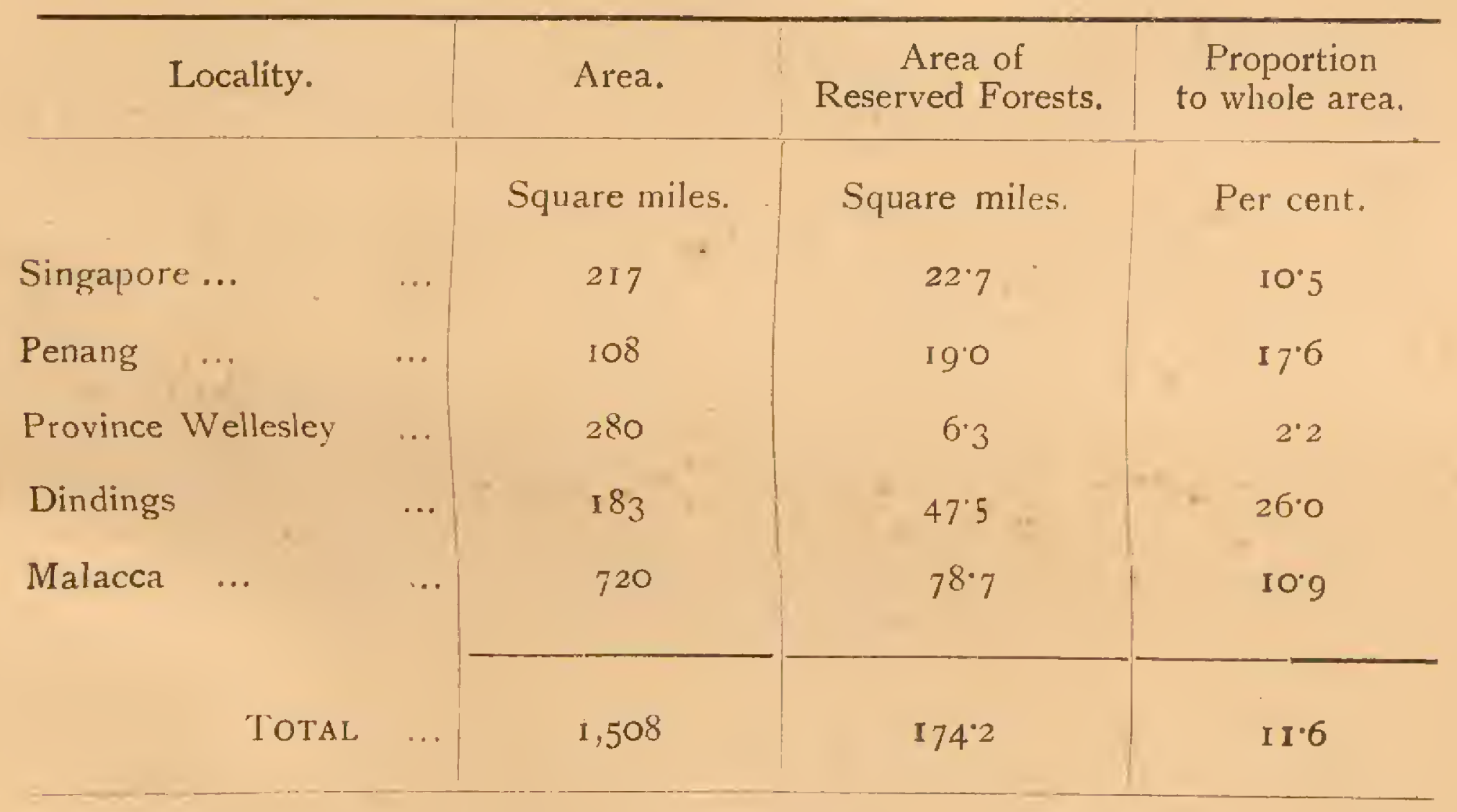

\section{DEMARCATION AND UPKEEP OF BOUNDARIES.}

3. The total length of reserve boundaries is approximately 572 miles. These are for the most part maintained by the subordinate staff. Apart from salaries the cost of upleep was $\$ 433$, which includes the purchase of boundary posts and notice boards.

\section{SURVEYS.}

4. Various small compass surveys were carried out departmentally in connection with exploitation, works of forest improvement and path making. The total length of traverses was 30 miles and the cost, exclusive of salaries, $\$ 185$. 
PART IT.

\title{
MANAGEMENT OF FORESTS.
}

\author{
Working Plans and Plans of Operations.
}

5. The preparations for drawing up a working plan for one or more of the Malacca reserves were continued and are now awaiting survey, without which no progress can be made. Provision has been made in the I925 Estimates for a topographical survey of about I5 square miles on the scale of 4 inches to the mile.

6. Data were collected for the preparation of a working plan for Tanjong Burong mangrove reserve in the Dindings, but the work was not complete at the end of the year.

7. The plan of operations for the year was adhered to in all essentials.

\section{COMMUNICATIONS.}

8. Twelve miles and sixty-one chains of compartment boundaries in Bukit Senggeh and Bukit Sedanan Reserves in Malacca were converted into inspection paths at a cost of $\$ 8 \mathrm{r}$, much of the work being done by the subordinate staff. Thirty-five chains of inspection path were made in Tanjong: Burong Reserve in the Dindings. In Malacca reserves the upkeep of 64 miles of paths cost $\$ 180$. Elsewhere such upkeep as was necessary was done by subordinate staff.

\section{BUILDINGS.}

9. A halting bungalow and water tank were built at Selandar in Malacca at a cost of $\$ 2,072$, and have already proved a great convenience to the District Forest Officer, effecting economy in both time and travelling expenses.

I0. The other new itens were a boatshed at Sungei Pinang in Penang, and a water tank for the Forester's quarters at Bukit Mertajam. These cost $\$ 100$ and $\$ \mathrm{I} 8$ respectively.

II. Repairs to buildings cost $\$ 502$.

\section{PROTECTION OF FORESTS.}

12. No alterations were made in the forest laws. The Forest Rules and The Muda River Timber Rules were republished incorporating past amendments: Govermment Gazette Notifications Nos. 507, 508 and 509 of 2Ist March, r924.

13. The number of forest offences reported was I43, compared with 98 in the previous year and 64 in 1922 . The increase is almost entirely in Singapore and is probably due to increased activity on the part of the subordinate staff rather than an actual increase in the number of offences. It is noticeable that of the 24 offences in which the offenders were not found none were in Singapore. No serious cases were reported. Convictions wer? obtained in 74 of the 86 cases disposed of by the courts. Fines were imposell to the amount of $\$ \mathrm{I}, 82 \mathrm{I}$, and $\$ 868$ was paid as compensation for damage to the forests.

Resam has done much harm in certain forest reserves, noticeably in Pantai Acheh in Penang and Bukit Bruang in Malacca. This vigorous fern establishes itself in open spaces in the forest or encroaches from adjoining waste lands. It causes damage by suppressing all young tree growth, and though its action is slow it is very sure. It is also a source of danger owing to its inflammability. Means of eradication and control of this pest are under investigation. 


\section{IMPROVEMENT OF FORESTS.}

Natural Reproduction.

I4. Although $\operatorname{taban}^{*}$ fruited heavily in parts of the Federated Malay States it was reported that no fruit set on the taban trees on Pulau Jerejak or at Telok Bahang or Batu Feringgi. Trees fruited at Ayer Kroh in Malacca, but owing to the depredations of birds and animals no seed was obtained. Protection can only be successfully undertaken at prohibitive ex pense. There is nothing to record as to other species.

\section{PLANTATIONS AND CULTURAL OPERATIONS.}

I5. Five acres were planted approximately $\mathrm{IO}^{\prime} \mathrm{x} \mathrm{IO}^{\prime}$ with taban merah seedlings in the Telok Bahang Reserve. This is an extension of the work of filling the blanks in natural taban forest. Cost \$2I.

16. Five hundred cuttings of bamboo (buluh belat) were also planted in Telok Bahang, in continuation of the experiment begun in I923.

17. There were no other additions to plantations.

18. For many years scrub jungle has been allowed to grow up with the timber trees planted in Bukit Bruang Reserve in Malacca, Quick growing species which had overtaken the merbau were cut out.

I9. Plantation uplieep was carried out by the staff with the exception of $\$$ I 8 spent in Malacca, and $\$ 55$ in Penang.

20. Receipts from the Singapore Para rubber plantations amounted to \$r,o4I. The Malacca mixed plantations' revenue was \$308.

\section{IMPROVEMENT FELLINGS.}

21. Clearings were done over 122 acres in Bukit Senggeh, Ayer Panas and Ramuan China Reserves in Malacca at a cost of $\$ 255$. This operation consists in freeing class I saplings and seedlings in areas which have been lately exploited by wood-cutters. The light admitted by the opening of the forest benefits the less valuable, and usually quicker growing trees, as much as it does the class I trees. In consequence the latter require assistance until they are well established and able to hold their own in the struggle for supremacy.

\section{EXPLOITATION.}

$$
\text { Timber and Fuel. }
$$

\section{(a) From Reserved Forests.}

22. In Singapore exploitation continued in the 1923 mangrove coupes in Pandan and Seletar Reserves. As was foreshadowed in previous year's report, no new coupes were leased. Arrangements have now been made whereby the supervision of exploitation in these reserves should be more efficient and when it is certain that these arrangements will be effective the question of opening new coupes will be again considered. In the meantime the only prudent course is to close the forest to further commercial cutting. The outturn of poles was estimated at 92 tons and that of frewood at 5,590 tons, of which I, I Io tons was taken from the 1923 mangrove coupes, and the balance from other parts of mangrove and inland reserves under monthly permits. Revenue $\$ \mathrm{I}, 053$ as against $\$ 5,345$ in 1923 .

\footnotetext{
* The botanical names of the trees, etc., mentioned in this Report are given in Appendix $A$.
} 
23. The following table summarises the results of the year's work in the Singapore mangrove forests:-

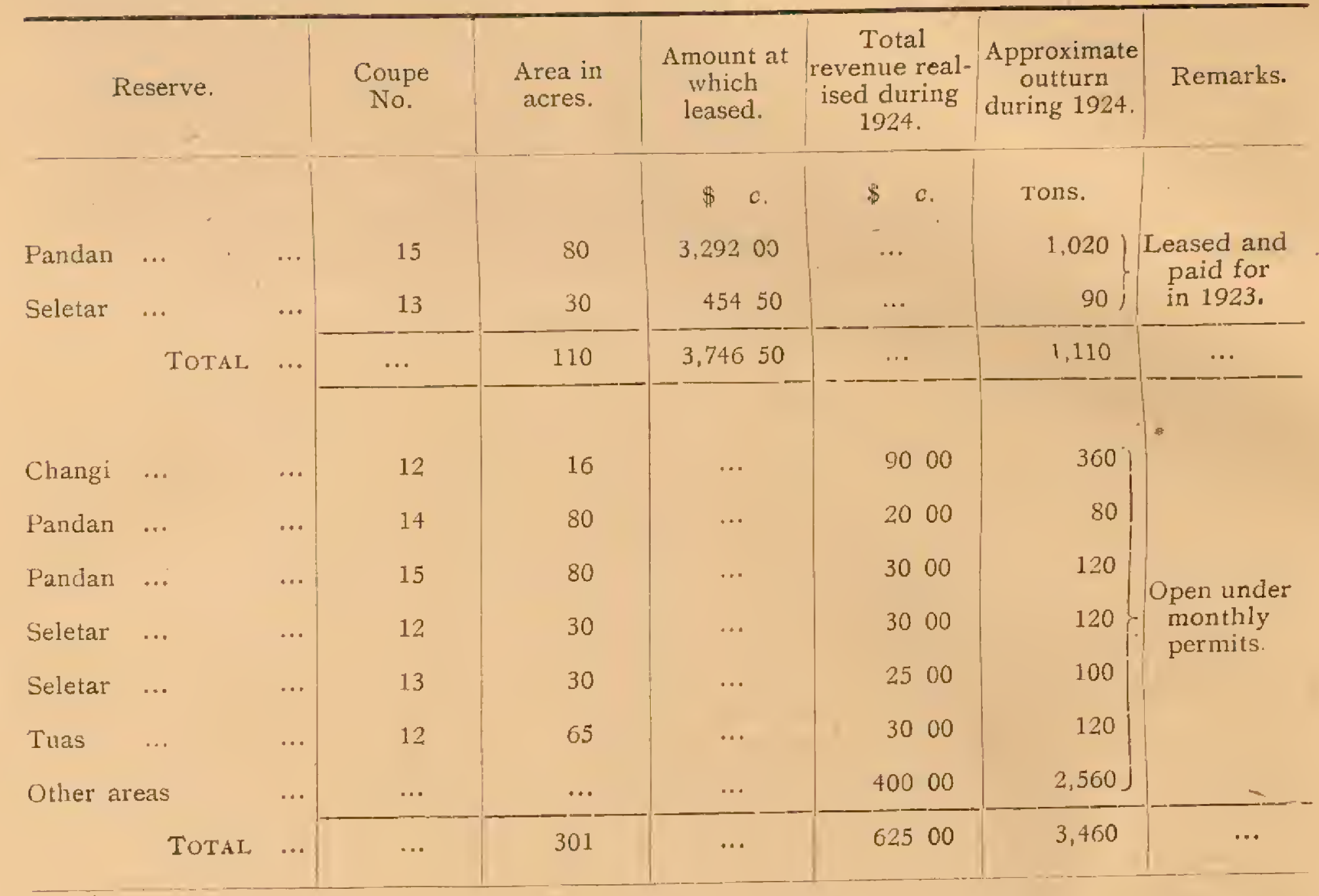

24. Six hundred and twelve tons of timber were taken from forest reserves in Penang and Province Wellesley. This was mostly in the form of class II poles, and the principal sources were Pantai Acheh and Government Hill Reserves. In the same Settlements the outturn of firewood from reserves rose from 912 tons in 1923 to 2,233 tons in the year under report. More than half of this came from Pulau Burong mangrove reserve. Revente totalled $\$ 2,374$, being an increase of $\$ 707$ over the previous year.

25. The outturn from the Dindings reserves was 87 tons of timber and I43 tons of firewood. These reserves will not be opened to regular exploitation so long as there is Crown land forest available.

26. Malacca reserves yielded 445 tons of timber and 224 tons of firewood. Revente $\$ 3,090$, being $\$ 5,245$ less than in 1923. As regards timber this is a big decrease on former years, the figures for 1922 and 1923 being 1,486 tons and 1,259 tons respectively. The reason for the reduced outturn is the decision to limit exploitation to local needs until the working plan is complete. see paragraph 5 .

27. The outturn from all reserves in all Settlements was 1,236 tons of timber and 8, I9I tons of firewood on which revenue of $\$ 6,689$ was realised. No charcoal was made. The corresponding figtures for I923 were I,976 tons of timber, 8,938 tons of firewood and \$I 5,748 revenue.

\section{(b) From Cromn and Aitenated Land.}

28. Crown land in Singapore was estimated to have produced 5,7r4 tons of poles and 14,740 tons of firewood as against 1,463 tons of poles and 6,460 tons of firewood in 1923. Revenue \$9, I06. The outturn includes an allowance of 20 tons an acre for timber on all Crown land alienated during the year. A charge of $\$ 5$ an acre is made.

29. In Penang, Province Wellesley and the Dindings the outturn from Crown and alienated land was 5,248 tons of timber, 8,704 tons of firewood and 42 tons of charcoal. Reventue $\$ 8,354$. These figures show no marked changes from the previous year.

30. Tn Malacca 806 tons of timber and 348 tons of firewood were taken from Crown land. The corresponding figures for 1923 were 1,484 and 644 . 
In spite of these reductions in outturn revenue rose from $\$ 6,979$ to $\$ 16,646$. The increase is entirely due to compensation paid for timber on alienated land. There was also an increase of $\$ I, 436$ on timber and firewood actually removed from Crown land although the quantity removed was less than in the previous year. This is due to the fact that on Crown land timber is now more difficult of access owing to the forests near the road having been worked out.

3r. The total revenue from timber, fuel and charcoal from Crown and alienated land in all Settlements was $\$ 34,106$, compared with $\$ 22,435$ in 1923 .

\section{MINOR FOREST PRODUCE.}

(a) From Reserved Forests.

32. Revenue under this head was $\$ 2,02 \mathrm{I}$, which shows no marked difference from previous years. The leasing of the Para rubber plantations at Bukit Timah and South Seletar in Singapore accounted for half the total revenue. The balance is made up of a number of small items.

33. Experiments were begun in tapping kemenyan (gum benjamin) of which there is a considerable number of trees in Malacca reserves. So far the results have been disappointing, but as the local tree is identical with that from which commercial gum is obtained elsewhere there seems to be no reason why success should not ultimately be obtained.

\section{(b) From CROWN LANDS.}

34. The revenue for the year was $\$ I, 496$, being $\$ 5 I 7$ less than in the previous year. This is entirely due to no taban having been tapped in Penang Taban is not tapped annully. The resting interval is not less than two years. The biggest item is \$6I9 paid on tengar bark in the Dindings. Other products taken in small quantities were nibong, langkap, akar, resam, bertam, mengkuang, mipah, rembia, bambo, samak, jelutong, kabong and rotan.

\section{PART III.}

\section{FINANCTAL, RESULTS.}

\section{REVENUE.}

35. The following statement shows the total revenue from I922 to I924:-

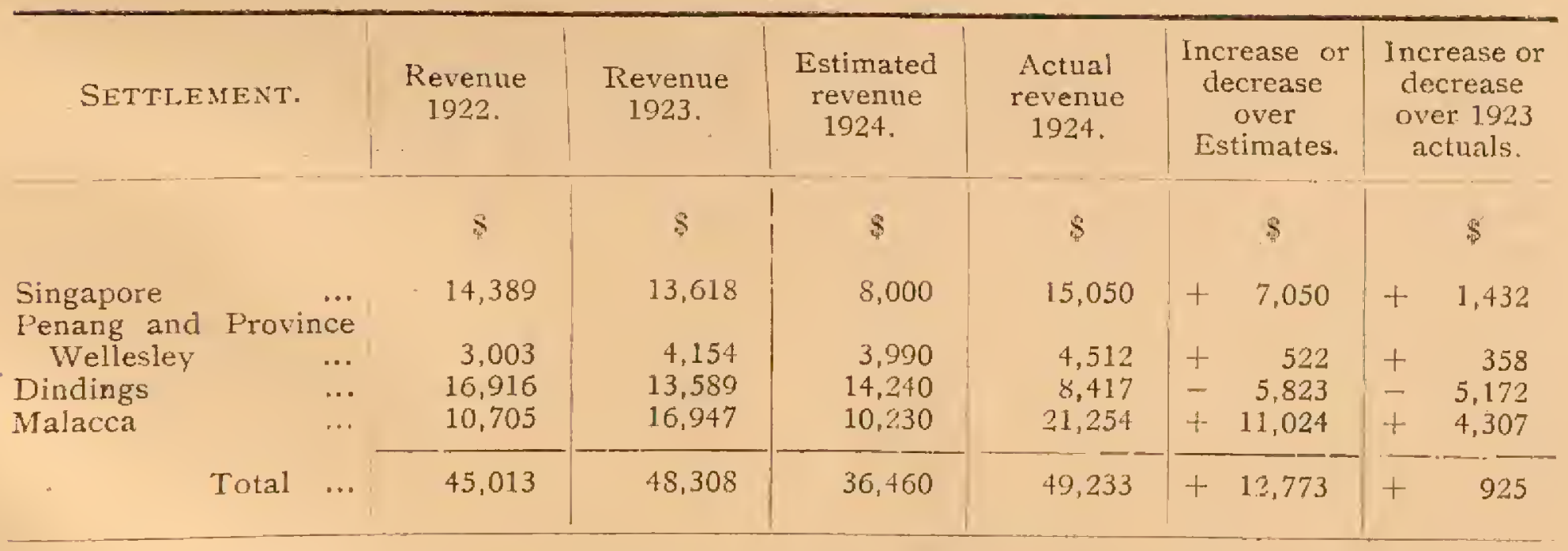

36. The fall in revenne in the Dindings is chiefly due to a change in the system of collection of royalties. Formerly all royalty was paid in advance and at once credited to revenue. Now a cash deposit is made as security for payment of revenue, and this deposit is not credited to revenue. Royalty accounts are settled monthly.

37. The increase in Malacca revenue is due to the extent of $\$ 10,260$ to the amount paid as compensation for trees standing on land alienated for agricultural purposes. 


\section{EXPENDITURE}

38. The following table shows the Expenditure from 1922 to 1924 :-

\begin{tabular}{|c|c|c|c|c|c|c|}
\hline SETTLEMENT. & $\begin{array}{c}\text { Expenditure, } \\
1922 .\end{array}$ & $\begin{array}{c}\text { Expenditure, } \\
1923 .\end{array}$ & $\begin{array}{c}\text { Estimated } \\
\text { expenditure, } \\
1924 .\end{array}$ & $\begin{array}{c}\text { Expenditure, } \\
1924 .\end{array}$ & $\begin{array}{l}\text { Savings on } \\
\text { Estimates. }\end{array}$ & $\begin{array}{c}\text { Increase or } \\
\text { decrease } \\
\text { over } 1923 \\
\text { actuals. }\end{array}$ \\
\hline & $\$$ & $\$$ & $\$$ & $\$$ & $\$$ & $\$$ \\
\hline Singapore $\quad \ldots$ & 14,776 & 6,825 & 9,219 & 7,835 & 1,384 & $+\quad 1,095$ \\
\hline $\begin{array}{l}\text { Penang and Province } \\
\text { Wellesley }\end{array}$ & 5,782 & 8,951 & 12,526 & 10,750 & 1,776 & 1,799 \\
\hline Dindings & 9,157 & 9,244 & 10,280 & 8,760 & 1,520 & 484 \\
\hline Malacca & 14,704 & 19,273 & 23,588 & 20,809 & 2,779 & 1,536 \\
\hline TotaL & 44,419 & 44,293 & 55,613 & ${ }^{*} 48,154$ & 7,459 & $+3,861$ \\
\hline
\end{tabular}

* Excludes temporary allowances $(\$ 2,369)$ and various refunds amounting to $\$ 1,628$.

\section{SURPLUS AND DEFICIT.}

39. The surplus of revenue over expenditure was $\$ 1,079$ as shown in the following statement:-

\begin{tabular}{|c|c|c|c|c|c|c|}
\hline SETTLEMENT. & $\begin{array}{c}\text { Surplus } \\
\text { or deficit } \\
1922 .\end{array}$ & $\begin{array}{c}\text { Surplus } \\
\text { or deficit } \\
1923 .\end{array}$ & $\begin{array}{l}\text { Estimated } \\
\text { surplus or } \\
\text { deficit } 1924 .\end{array}$ & $\begin{array}{c}\text { Surplus } \\
\text { or deficit } \\
1924 .\end{array}$ & $\begin{array}{c}\text { Increase } \\
\text { or decrease } \\
\text { over } \\
\text { Estimates. }\end{array}$ & $\begin{array}{c}\text { Increase } \\
\text { or decrease } \\
\text { over } 1923 \\
\text { actuals. }\end{array}$ \\
\hline & $\$$ & $\$$ & $\$$ & $\$$ & $\$$ & $\$$ \\
\hline Singapore $\quad \ldots$ & 387 & $+6,793$ & $-\quad 1,219$ & $+\quad 7,215$ & +8.434 & 422 \\
\hline $\begin{array}{rr}\text { Penang and } & \text { Province } \\
\text { Wellesley } & \ldots\end{array}$ & $-\quad 2,779$ & $-\quad 4.797$ & 8,536 & $-\quad 6,238$ & 2,298 & $-\quad 1,441$ \\
\hline Dindings & $+7,759$ & $+4,345$ & $+\quad 3,960$ & $-\quad 343$ & $-\quad 4,303$ & $=4,688$ \\
\hline Malacca & $-3,999$ & $-2,326$ & $-1.3,358$ & 445 & $+13,803$ & $+2,771$ \\
\hline TOTAL & 594 & $+4,015$ & $-19,153$ & $+1,079$ & $+20,232$ & $-2,936$ \\
\hline
\end{tabular}

40. "If temporary allowances are included the year shows a deficit of $\$ 1,290$.

\section{PART IV.}

\section{ADMINISTRATION.}

4T. Mr. G. E. S. CubitT was in charge until going on leave on the $4^{\text {th }}$ July, I924, when he handed over to the writer. The only change in administrative arrangements was that whereby the care of the Dindings was transferred from Perak South to Perak North and thus came now under the same supervision as Penang and Province Wellesley, the latter Settlement being in immediate charge of an Assistant Conservator of Forests. The change is undoubtedly one for the better.

B. H. F. BARNARD, Acting Conservator of Forests, S. S. and F. M. S.

Kuala Lumpur 4 th March, 1925. 
APPENDIX $A$.

List OF Trees, etc., MENTIONED in the REPORT.

Vernacular Name.

Akar

Bertam

Bulul

Jelutong

Kabong

Langkap

Mengkuang

Merbau

Nibong

Nipah

Rembia

Resam

Rotan

Samak

Taban

Taban merah

Tengar
Botanical Name.

Climbers, all kinds.

Eugeissonia tristis.

Bamboo, all species.

Dyera costulata.

Arenga saccharifera.

Arenga Westerhontii.

Pandanus atrocarpus.

Afzelia Palembanica.

Oncosperma tigillaria.

Nipa fruticans.

... Metroxylon sagus.

... Gleichenia linearis.

... Rattans, all kinds.

... Bark extract

... Palaquinm and Payena spp.

... Palaquitum oblongifolium.

... Ceriops Candolleana. 


\section{Annual Report on Forest Administration in the Straits Settlements for the Year 1925.}

\section{PART I.}

\section{FXTFNSTON AND CONSTITUTION OT RESERVED FORESTS.}

I. The only alteration in area was an excision of 337 acres from the Tasek Glugor, Reserve in Province Wellesley. The land affected adjoins the road and, as it carried no forest of any ralue, it was considered it wonld be better under cultivation.

2. The area of 2 acres excised from the Lumut Reserve in the Dindings for a Hindu temple was not taken up, as it was said to be too small, and an extension to the area was still under consideration at the end of the year.

3. The following statement shows the present area and distribution of reserved forests:-

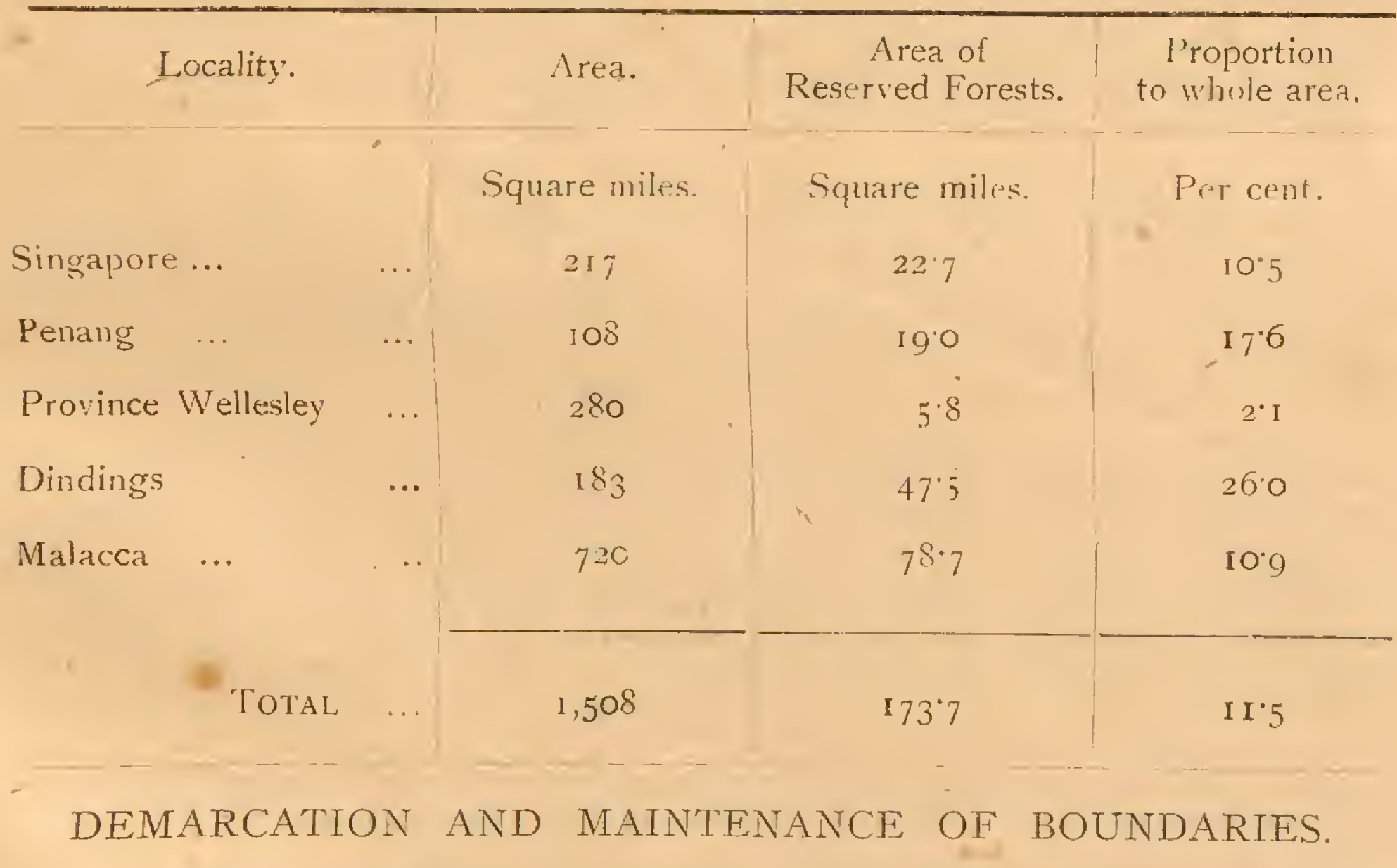

4. The total length of forest reserve boundaries is now estimated to be about 570 miles, of which about 4 I 5 miles are demarcated. The boundaries of the Gunong Tunggal and Kopia Reserves in the Dindings were remeasured and found to differ considerably in length from previous estimates. The excision from the Tasek Glugor Reserve necessitated a re-adjustment of the boundary of that forest, the length of which was slightly reduced.

5. Much of the work of boundary maintenance is done by the staff. The expenditure incurred was \$98 in Penang and Province Wellesley, \$I 6 in Malacca, and $\$ 38$ in the Dindings. As a restult of accretion from the sea 
the lanciward portion of the Sungei. Icheh Reserve in I'rovince Wellesley lias become more suitable for agriculture than for the production of mangrove, and a provisional boundary, excluding the best of the potential agricultural land, was cut at a cost of $\$ 20$ with the idea of excising this land from the reserve. The rentis of about Io $\frac{1}{2}$ miles round catchment area boundaries at Penara Bukit and Govermment Hill on Penang Island were, at the request of the Municipal Water Engineer, not maintained owing to the risk of contamination of the water supply.

\section{SURVEYS}

6. The Survey Department completed a topographical survey on the scale of 4 inches to a mile of the Bukit Sedanan Forest Reserve at a cost of $\$ 7,683$, and maps were supplied at the end of the year.

7. The staff surveyed about 5 miles of inspection paths in the Ulu Bruas and Gunong Tunggal Reserves and did minor surveys in connection with the Tanjong Burong working plan. No expenditure was incurred.

\section{PART II.}

\section{MANAGEMENT OF FORESTS.}

\section{Working Plans and Plans of Operations.}

8. No regular working plans are in force. A rough plan for the Tanjong Burong Reserve in the Dindings was compiled by $\mathrm{Mr}$. H. C. DoLMAN, Assistant Conservator of Forests, and will be brought into force next year. Mr. Dolman took considerable interest in the Dindings reserves and was considering more extensive operations; but, without more supervision than is possible at present, it is doubtful whether it is desirable to risk over exploitation mainly for the benefit of persons outside the Colony.

9. The preparation of a working plan for the $\dot{M}$ alacca reserves awaits the preparation of stock maps. In the meantime data regarding the requirements of the Settlement are being collected.

Io. In Penang and Province Wellesley very little timber is left on Crown land, and the problem of placing the reserves under more systematic management was receiving attention at the end of the year.

II. Annual plans of operations were in general adhered to.

\section{COMMUNICATIONS.}

I2. About 5 miles of inspection paths were constructed in the Ulu Bruas and Gunong Tunggal Reserves in the Dindings at a cost of $\$ 58$. Existing inspection paths were as a rule maintained by the subordinate staff. The only important item of expenditure on repairs was $\$ 73$ for the maintenance of about 32 miles of compartment boundaries in Malacca.

\section{BUILDINGS}

I3. Buildings are erected and maintained by and at the cost of the Public Works Department. The only departmental expenditure was $\$ 5$ for repairs to the boat-shed at Lumut.

1. In Singapore new double quarters were built for forest guards on the Mandai Road at a cost of $\$$ I, 805, replacing old and delapidated quarters at Seletar which were beyond repair.

15. The forest guard's quarters at Telok Bahang in Penang were replaced by a permanent structure, and extensive alterations were carried out to the guard's quarters at Bukit Panchor in Province Wellesley. The expenditure incurred was $\$ 5,446$.

16. Minor items do not need mention. 


\section{PROTECTION OF FORESTS.}

17. No changes were made in the forest law's.

18. The number of oflences reported was 85, compared with I43 in I924. In no less than 40 ot these cases the orenders were not round, and oi these 40 cases 31 were in singapore. 111924 there were 24 undetected cases, of which none were in singapore. In 1924 there were 56 detected cases in Singapore: in 1925 there were only 5 . Inese variations are quite 1nexpircable. All that is reported abont the undetected cases is that they were nearly all cases of thelts of poles or firewood.

During the year 19 cases were taken to court, of which 3 ended in acquittal; 24 cases were dealt with departmentally, of which 22 were compounded. Lines of $\$ 706$ and compensation of $\$ 235$ were paid by order of the courts, and a stim of $\$ 55^{\circ}$ was realised (mostly 11 Malacca) in compounded cases. Seized and conhscated property realised \$145. Hour cases were pending at the close of the year.

Compensation and fines paid for breacin of conditions of permits amounted to $\$ 93$.

19. In Miarch a fire kilied 15 taban merah" and 20 iaban percha (a variety of taban puteh) in tie Lukit I mah Reserve.

\section{IMPROVEMENT OF FORESTS.}

\section{Natural Reproduction.}

20. It was a poor seed-year for most of the important commercial species. Guta-percha fruited sparingly at lelok Bahang in Penang, and opportunity was taken to replenish the nursery and to dispose of the remaining seed by sale. Five trees yielded 8,400 seeds, and 7,400 of them were sold for $\$ 74$. In the Ayer Kron plantations near Malacca gutta-percha seeded fairly freely, and 157,700 seeds were sold to the Selborne Plantations at $\$ \mathrm{I}$ per I,OOO.

\section{PLANTING AND CULTURAL UPERATIONS.}

21. The Para rubber trees in the Chua Chu Kang Reserve were leased for the year for $\$ 480$, and those in the Bukit Timah Reserve for $\$ 1,065$. The receipts in both cases were credited to the Agricultural Improvement Deposit Trust.

22. Existing plantations in Penang were maintained, but the teak and timbusu plantations in the Taseh Glugor Keserve in Province Wellesley were not considered worth retention and were included in the 337 acres excised from the reserve. Few of the bamboo cuttings planted in bclukar at Telok Bahang established themselves. Rooted plants gave better results, but their cost is prohibitive. An attempt to strike cuttings in better soil in shade, with a view to transplanting later, was not conspictrously successful.

23. About 6 acres of blanks in the Janjong Rurong mangrove reserve were planted up with bakau minyak at a cost of $\$ 50$, and about 5 acres of, damar laut. regeneration in a formerly worked area of the Telok Muroh Reserve were assisted at a cost of \$II. Some neglected merbau in the Iumut Reserve were freed from surrounding vegetation at a cost of $\$ 4$.

24. Para trees in the Bukit Brtang Reserve in Malacca which were under-planted with gutta-percha were topped to admit light to the young plants, which are doing well. Receipts from the Bukit Bruang plantations amourrted to $\$ 348$, and the cost of maintenance to $\$ 3 I$.

* The botanical names of trees etc. mentioned in this Report are given in Appendix $A$. 


\section{IMPROVEMENT FETILINGS.}

25. Two permits were issued to remove firewood from an area of about Io acres of the Bukit Timah Reserve in which young gutta-percha was plentiful. This arrangement proved satisfactory, but permit holders require careful watching or they remove too much. Similar work was done on a small scale in Malacca. The cradication of api-api at Sungei Acheh in Province Wellesley was not continued to any appreciable extent, this operation being of doubtful sylvicultural value.

\section{EXPLOITATION.}

\section{TIMBER AND FUEL. \\ (a)-From Reserved Forests.}

26. In Singapore no new coupes were opened. Permits to remove bakan stumps from old coupes were issued, but these were gradually reduced, permit holders being allowed to take nyirch instead. In the inland reserves a number of permits were issued for the removal of firewood. The outturn of poles and firewood from reserved forests is estimated to have been I7 8 and 6,913 tons respectively, the revenue derived being $\$ 1,899$, compared with \$I,053 in 1924.

27. One thousand five hundred and forty-five tons of timber were taken from the forest reserves in Penang and Province Wellesley, which is more than double the ontturn of I924. Half the total came from the Pantai Acheh Reserve in Penang, where there is a considerable quantity of damar laut of excellent quality. The outturn from the Tasek Glugor Reserve in Province Wellesley would have been larger but for the financial troubles of the permit holder. The outturn of frewood from the two Settlements was 3,693 tons, compared with 2,233 tons in 1924, the Bukit Goa Ipoh Reserve in Province Wellesley heading the list with 1,780 tons. There was a decrease of 40 per cent in the outturn of mangrove firewood from the Pulat Burong Reserve in Province Wellesley. Revenue amounted to $\$ 4,592$, an increase of $\$ 2,2 \mathrm{I} \&$.

28. In the Dindings, exploitation was almost entirely confined to poles and firewood from the mangrove reserves at Tanjong Burong and Batu Undan. In the latter reserve an unsuccessful attempt was made to introduce pole-cutting by the "stick" method, which has proved so successful in the Federated Malay States, and by which a stick of a prescribed length determines the distance between felled and unfelled trees. The felling permit was, therefore, cancelled. The householders of Pantai Remis continued to avail themselves of the privilege granted them in 1924 of taking mangrove poles for their domestic requirements from a specified area in the Tanjong Burong Reserve on payment of \$I per house, and \$6I was collected in fees. The total outturn from the Dindings reserves was 308 tons of timber and 240 tons of firewood, and the total revenue realised thereon $\$ 5$ I2, compared with \$172 in T924.

29. Extraction of Class I timber from the Malacca reserves was linited to dead and fallen trees, and to trees removed for sylvicultural reasons. Owing to the scarcity of Class I timber free use was made of planks of Class II timber for light construction. The total ontturn was 748 tons of timber and 483 tons of firewood, which is more than in J924. but less than in I922 and r923. An increased output will, it is hoped, be possible when a working plan has been drawn 11 . The revente for the year was $\$ 3,575$, compared with $\$ 3,090$ in I924.

30. The outturn from all reserves in all the Settlements was 2.779 tons of timber and II,329 tons of fuel, and the revenue realised was $\$ 10,578$. The corresponding figtres for 1924 were I,236 tons of timber, 8, I9T tons of firewood, and $\$ 6.689$ revenue. 


\section{(b)-From Cromn and Alimated Land.}

3I. Crown land in Singapore is estinated to have produced I6, I64 tons of poles and Io,8I7 tons of firewood against 5,7 $\mathrm{I} 4$ tons of poles and 14,740 tons of firewood in 1924 . The reventue was $\$ 6,997$, compared with $\$ 9$, 106 the previous year.

32. In Penang, Province Wellesley, and the Dindings the output of timber ( 5, or 5 tons) differed little from that of I.924, but firewood fell by nearly 3,000 tons to $5: 777$ tons. Charcoal to the amount of 49 tons was extracted in the Dindings. Revenue rose from $\$ 8,354$ to $\$ 10,097$.

33. In Malacca the total outturn of timber of all classes was 1,058 tons,

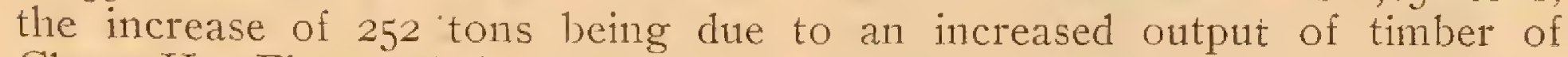
Class II. Firewood increased by 120 tons to 468 tons. The revenue realised fell from $\$ 6,386$ to $\$ 6,075$, the decrease being due to the smaller number of permits issued for Class I timber. The ten per cent royalty on timber on newly alienated land amounted only to $\$ 5.301$, or a little more than half of what was realised in 1924. This is naturally a decreasing sonrce of reventue.

34. The total revenue from timber, fuel, and charcoal from Crown and alienated land in all Settlements was $\$ 28,470$, compared with \$34, ro6 in I924.

\section{MINOR FOREST PRODUCE.}

\section{(a) From Reserved Forests:}

35. The total revenue under this head was $\$ 2,969$, compared with $\$ 2,021$ in I924. The principal items are $\$ 468$ on gutta-percha in Singapore; $\$ I, I 50$ on kerang shell, \$24I on canes, \$II7 on bertam, and \$96 on nibong in Penang, Province Wellesley, and the Dindings; and \$I 80 on rubber, \$r 58 on gutta-percha seeds, and \$IO4 on getah jelutong in Malacca.

\section{(b) From Crown Land.}

36. The only items of importance in a revenue of $\$$ r,ogo are $\$ 4$ I5 on tcugar bark and \$196 on nibong from the Dindings. In I924 the total revente was $\$ \mathrm{I}, 496$.

\section{PART III.}

IIINANCIAL, RESULTS.

\section{Revenue.}

37. The following statement shows the total revenue from ig23 to I925:-

\begin{tabular}{|c|c|c|c|c|c|c|}
\hline SETTLEMENT. & $\begin{array}{c}\text { Revente } \\
1923 .\end{array}$ & $\begin{array}{c}\text { Revenue } \\
1924 .\end{array}$ & $\begin{array}{l}\text { Estimated } \\
\text { revenue } \\
1925 .\end{array}$ & $\begin{array}{l}\text { Actual } \\
\text { revenue } \\
1925\end{array}$ & $\begin{array}{l}\text { Increase or } \\
\text { decrease } \\
\text { over } \\
\text { Estimates. }\end{array}$ & $\begin{array}{l}\text { Increase or } \\
\text { decrease } \\
\text { over } 1923 \\
\text { actuals. }\end{array}$ \\
\hline & 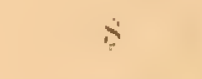 & 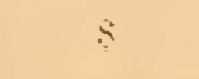 & $s$ & $\hat{S}$ & 8 & $s$ \\
\hline $\begin{array}{l}\text { Singapore } \\
\text { l'enang and Province }\end{array}$ & 13,618 & 15,050 & 8,000 & 12,098 & 4,998 & 2,052 \\
\hline $\begin{array}{ll}\text { Wellesley } & \ldots \\
\text { Dindings } & \ldots \\
\text { Walacca } & \ldots\end{array}$ & $\begin{array}{r}4,154 \\
13,589 \\
16,947\end{array}$ & $\begin{array}{r}4,512 \\
8,417 \\
21,25 !\end{array}$ & $\begin{array}{r}5,130 \\
11,980 \\
6,150\end{array}$ & $\begin{array}{r}7,317 \\
11,062 \\
16,605\end{array}$ & $\begin{array}{r}+\quad 2,187 \\
-\quad 918 \\
+\quad 10,455\end{array}$ & $\begin{array}{l}2,805 \\
2,645 \\
4,649\end{array}$ \\
\hline Total ... & 48,308 & 49,233 & 31.260 & 47.982 & $+16,722$ & 1,251 \\
\hline
\end{tabular}

38. The actual revenue differs little from that of the previous two years. The surplus over estimates is due chiefly to faulty estimating in the case of Singapore, to the ligher royalty rates paid on produce from forest reserves in Penang, and to the nunexpectedly large sum realised as compensation for trees nin newly alienated land in Malacca. 


\section{EXPENDITURE.}

39. The following table shows the expenditure from I923 to I925:-

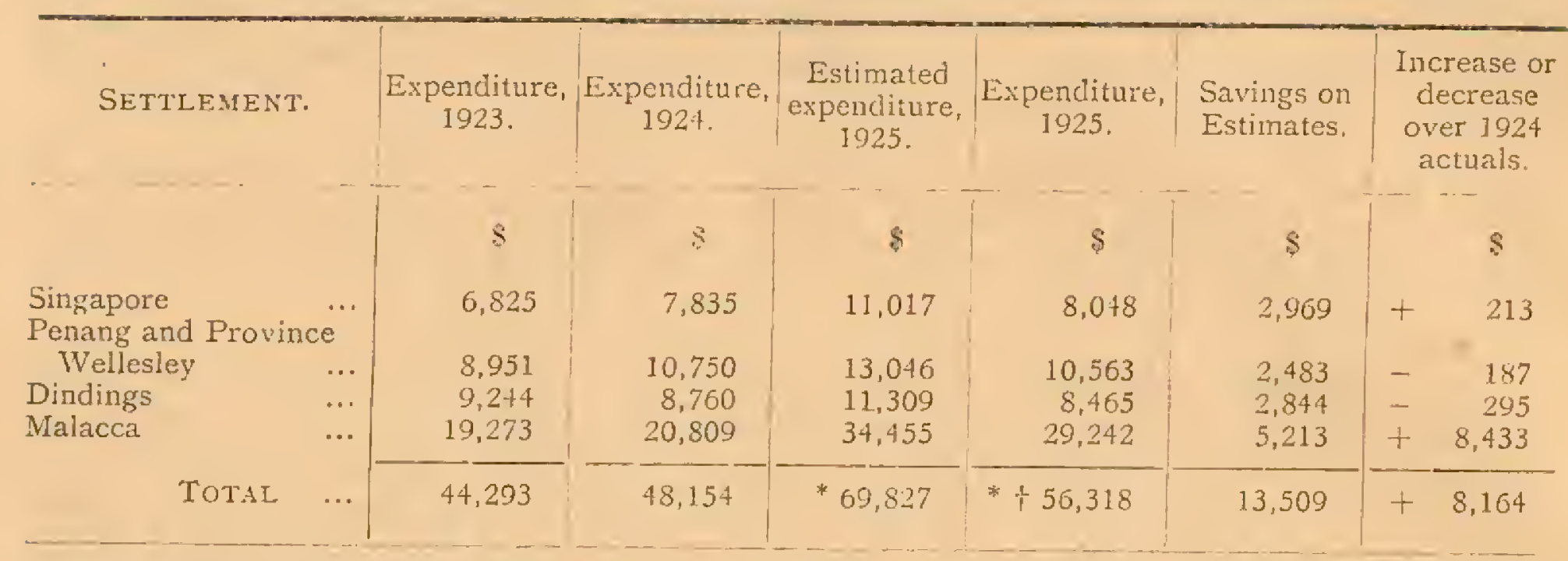

"Includes share of head office expenses, of cost of training forest officers, and of contribution to Imperial Forestry Institute.

† Excludes temporary allowances amounting to $\$ 2,+40$.

40. The savings on estimates are chiefly on account of salaries of subordinate staff, transport, topographical surveys, and improvement of forests. The cost of the surveys accounts for the increase of expenditure over the actuals of 1924 .

\section{SURPLUS AND DEFICIT.}

41. The net loss on the year's working was $\$ 8.336$ as shown in the following statement:-

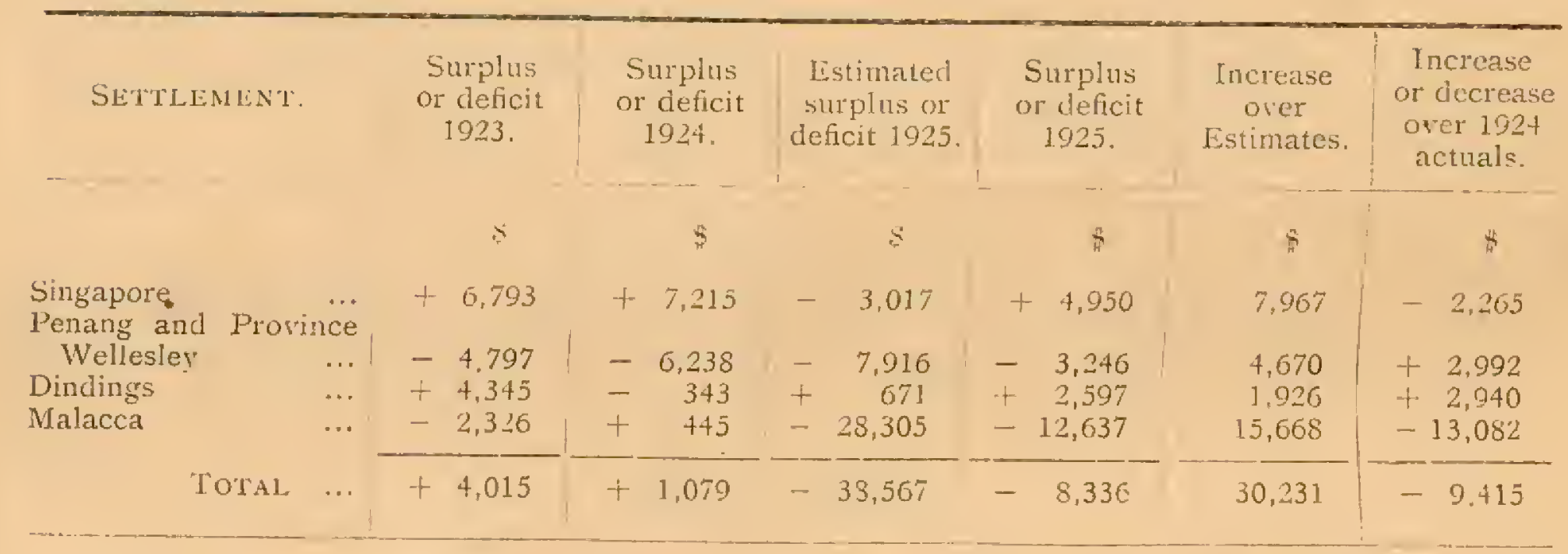

42. If temporary allowances are included the loss is \$10,776, chiefly owing to the expenditure on topographical surveys in Malacca.

\section{PART IV.}

\section{ADMINISTRATION.}

43. Mr. B. H. F. Barnard was in charge till the 13th August, 1925, when the writer returned from leave. In order to secure closer control, and also, if possible, to effect economies, the Singapore forests were at the beginning of the year placed in charge of the Conservator of Forests, Johore, who was given the powers of a Deputy Conservator in the Colony. At the same time a reduction was made in the staff of forest guards and the payment of allowances to the bailiffs ceased, savings being utilized to give the Deputy Conservator extra clerical assistance. The arrangement was not an unqualified success. Really effective management of the Singapore forests is possible only at a cost which the forests themselves do not seem to justify. Maps of the reserves on the scale of 4 inches to a mile are now available, and it is proposed in the course of the next few months to have a careful examination made of each of the reserves with a view to deciding on a definite policy for the future. None of the reserves are of any great value, and considerable areas in them are already leased out on temporary occupation 
licences to vegetable gardeners. It has been suggested that the cultivation of vegetables is of greater importance to Singapore than the production of timber, and, if this is so, it may be desirable to give up at any rate part of the reserves for this form of cultivation, after removing all the existing timber. The reserves can never supply more than a small part of Singapore's demand for timber and firewood, and large regular supplies of the latter can be made available only if the Government is prepared to incur heavy initial expenditure.

\section{G. E. S. CUBITT, Conservator of Forests, S. S. and F.M.S.}

Kuala Lumpur, 9 th March, 1926. 
APPENDIX $A$.

List of 'Trees etc. mentioned in the Report.

\begin{tabular}{|c|c|c|c|}
\hline VERNACULAR & Name. & & Botanical Name. \\
\hline Api-api $\quad \ldots$ & $\ldots$ & $\ldots$ & Avicennia spp. \\
\hline Trakan & $\ldots$ & $\ldots$ & Rhizophora spp. \\
\hline Bakau minyak & $\ldots$ & $\ldots$ & Rhizophora conjugata. \\
\hline Bertam $\quad \ldots$ & $\ldots$ & $\ldots$ & Engeissonia tristis. \\
\hline Damar laut & $\ldots$ & $\ldots$ & Shorea utilis. \\
\hline Getah jelutong & $\ldots$ & $\ldots$ & Dyera costulata. \\
\hline Merbat1 ... & $\ldots$ & $\ldots$ & Afzelia palembanica. \\
\hline Nibong & $\ldots$ & $\cdots$ & Oncosperma filamentosa. \\
\hline Nyireh & $\cdots$ & $\cdots$ & Xylocarpus (Carapa) spp. \\
\hline Taban merah & $\cdots$ & $\ldots$ & Palaquium oblongifolium \\
\hline Taban percha & ... & $\cdots$ & Palaquium obovatum. \\
\hline Taban puteh & $\cdots$ & $\cdots$ & \\
\hline Tembusu & $\ldots$ & $\cdots$ & Fagraa spp. \\
\hline Tengar $\quad \ldots$ & $\ldots$ & $\ldots$ & Ceriops Candolleana. \\
\hline
\end{tabular}




\section{Annual Report on Forest Administration in the Straits Settlements for the Year 1927.}

\section{PART I.}

\section{EXTENSION AND CONSTITUTION OF RESERVED FORESTS.}

I. No new reserves were constituted. A small excision was made from Government Hill Reserve, Penang, for house sites.

2. An extension to the existing Gunong Tunggal reserve in the Dindings of approximately 2,768 acres was preliminarily notified, but settlement awaits survey. A proposal to reserve about 375 acres of damar laut forest at Pasir Panjang in the Dindings is under discussion: the forest has been explored and a 7 per cent. enumeration survey made.

3. Excisions of about 52 acres from Lumut Forest Reserve and of $3 \mathrm{I}$ acres from Teluk Muroh Forest Reserve await survey. Further excisions of about 300 acres of worthless forest from Batu Undan Forest Reserve and of 16 acres from Tanjong Burong Forest Reserve are under consideration. All are in the Dindings, and the land will be used, if disforested, for kampong and bendang.

4. The total area and the distribution of reserved forests are shown in the following statement:-

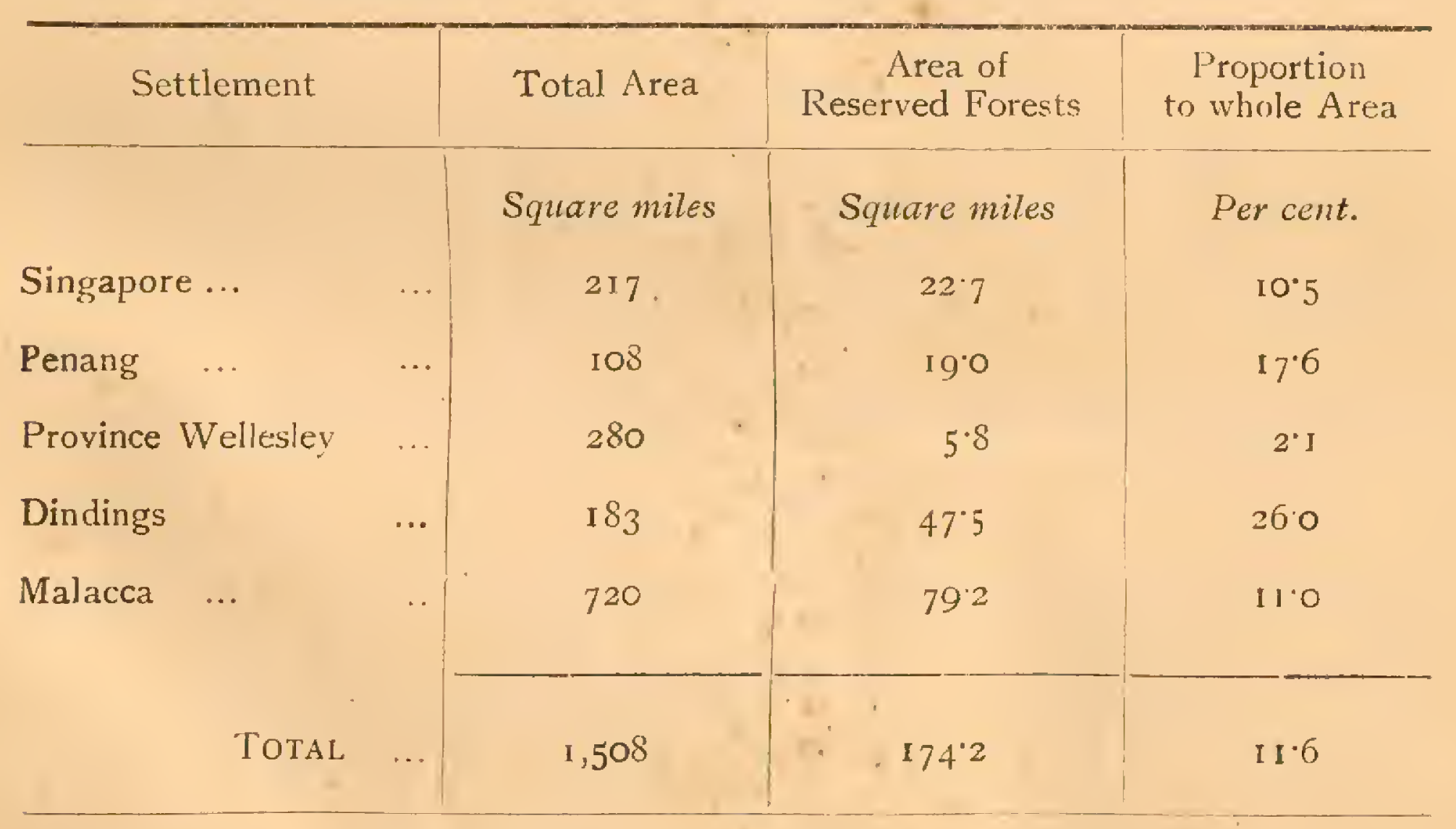

DEMARCATION AND MAINTENANCE OF BOUNDARIES OF FOREST RESERVES.

5. The total length of boundaries remains approximately 570 miles, as the small excision on Penang Hill hardly affected the total. Three hundred and five miles of these were cleared, I23 were not cleared, and r 42 miles, being natural, need no attention. The work cost $\$ 521$, but a very great 
deal was done by the subordinate staff. It is reported that the latter will not be able to do much of the work in future, as the increase of exploitation in reserves occupies a greater proportion of their time than in the past.

\section{SURVEYS.}

6. The Topographical Survey Department surveyed all forest reserves in Penang Island, with the exception of Pantai Acheh, Penara Bukit and parts of Bukit Gemuroh, Government Hill, and Highlands.

7. The Air Survey Company took the photographs for plans of Tanjong Burong Forest Reserve (Dindings) and of Kuala Linggi Forest Reserve (Malacca). The plans are not available yet.

8. The subordinate staff carried out the demarcation and survey of new compartments and felling areas in many reserves.

\section{PART II.}

\section{MANAGEMENT OF FORESTS.}

9. Mr. J. P. Enwaros, Assistant Conservator of Forests, was engaged for a considerable period towards the end of the year in making a close examination of the Malacca forests. He prepared a scheme for future working which is still under consideration.

Io. A considerable part of the inland forest reserves in Singapore, much of which is blukar. are being used for the cultivation of vegetables by squatters on temporary permits. The mangrove forests. having been heavily orercut in the past. are now being rested and will have to remain closed to felling for some years. No working plans or schemes are necessary for the present.

II. There are 110 working plans or schemes in Province Wellesley or Penang. No new ones were prepared for forests in the Dindings: that for Tanjong Burong Reserve could not be adhered to, owing to the absence of a market for firemood and poles.

I2. There were no important deviations from the plan of operations.

\section{COMMUNICATIONS.}

I3. Eight and a half miles of new inspection paths were made, in most cases by the subordinate staff; but the 4 miles in Bukit Sedanan reserve cost $\$ 300$ as outside labonir was needed. Repairs to 120 miles of paths in the Malacca forests cost $\$ 274$. while the patls in the other Settlements were cleared by the subordinate staff.

14. Eighty-five reserve notice plates were purchased from this vote for the Singapore forests, and this is accordingly shown in Form IV.

\section{BUILDINGS.}

I5. The P. W. D. built quatters for the Ranger at Lumut (Dindings). and for guards at Tanjong Karang (Singapore), and at Chabau, Bukit Bruang, and Malaka Pindah (Malacca). The Forest Department erected two sets of tempntary coolie lines in Malacca. All existing buildings were kept in repair. The new work cost the $\mathrm{P}$. W. D. votes $\$ \mathrm{~T} 4,975$ and Forest rotes $\$ 805$, and repairs cost the P.W. D. $\$ 765$.

\section{PROTECTION OF FORESTS.}

I6. New Rules under the Forest Ordinance vere approved, published and brought into operation. The whole of the Straits Settements is now under one forest law, and procedure is better understood as a result. The new rules are more like those of the Fedesated Malay States than were the old. 
I7. There were seven cases ponding from Ig26, and It2 new ones in I927, compared with 125 and 85 in 1926 and ro25. Forty-four cases were taken to the Magistrates Courts, where 40 convictions were obtained. Three cases were acquitted and one is still pending. Fines amounted to \$1,09o or $\$ 27$ per case, and $\$ 125$ was paid as compensation.

I8. Sixty-two cases were dealt with departmentally; fifty-five resulted in convictions, one is still unsetiled and six were written off by the Resident Councillor, Malacca, as the offenders had absconded. Compensations amounted to $\$ \mathrm{I}, \mathrm{I} 85$ or $\$ 2 \mathrm{I} .50$ per conviction.

19. There were I3 undetected cases, seven of them in Singapore, compared with 44 and 33 last year. As the total nmber of cases had remained almost unaltered, this looks as if the measures for the protection of the forests had improved.

20. Two hundred and eighty-three dollars were ohtained from the sale of confiscated property and seized forest produce.

2I. No serious fires were reported in 1927. Two hundred dollars were paid as compensation for the fire in? Pantai Acheh repnited last year.

22. Wild pig did some danage to the plantations at Bukit Goa Ipoh, but no special measures had to he taken. Specimens of fungoid fructifications from chengal trees in Segari-Melintang reserve, which were tapped for damar, were identified as Sterenm.

\section{IMPROVEMENT OF FORESTS}

\section{Nateral Reprotuction.}

23. There was no wealth of seeds in 1927. Chongal fruited fairly well in Segari-Melintang reserve (Dindings), and angsana in Penang. Taban flowered in Telok Bahang (Penang) in December. The taban at Ayer Kroh fruited earlier in the year, and 30,000 seeds were collected and sold for $\$ 92$.

\section{PLANTING AND CULTURAT, OPERATIONS.}

24. The experimental planting and sowing of forest trees together with the cultivation of vegetables vas continued at Bulit Goa Ipoh (Province Wellesley). Nearly the whole area allotted to this was sown up in I926 with seed, mostly chengal from Pondok Tanjong. Germination was excellent and the seedlings did well for a time, but later suffered from drought and insolation. A good deal of supplying will be needed in I928. Nurseries of angsana were sown for this purpose. Meranti continued to do well.

Further experiments are in progress in this reserve, and in Bukit Langkap in the same Settlement.

25. Direct sowings of chongal and angsana were made in the Io acres of Pantai Acheh burnt in 1025. Only abont 25 per cent. of the chengal germinated. Some angsana was sown in blukar areas in Bukit Juru reserve where firewood is being exploited.

26. Taban seedlings were planted out in blukar areas in Telok Bahang reserve.

27. The above artificial reproduction in Penang and Province Wellesley was mostly done by the staff or hy regetable planters. Only \$75 was expended from the votes.

28. The area in Telok Sera reserve (Dindings) burnt over in 1926 was sown up, but drought killed the seedlings and weeds are very strong.

29. In Malacca 15 acres of the Ayer Kroh tabon plantation was cleared of blukar at a cost of Si87. The Ayer Kroh plantations of other species were not treated in any way, as the condition of both crops and soil do not warrant expenditure. Téprosia candida was snwn as a corer crop under young taban, but progressed very slowly. 


\section{WORKS OF IMPROVEMENT.}

30. Cleanings were made in Penang:-

(a) In favour of resak and damar laut in Bukit Juru reserve.

(b) Do. meranti and jangkang in Pantai Acheh reserve.

(c) Do. taban in Telok Bahang reserve.

(d) Bertan cutting was done by local Malays in compartments 4 and 5 of Bukit Panchor reserve on free passes over rather more than ro acres.

3I. Charcoal burners carried out regeneration fellings in Pantai Acheh, and a timber and frewood licensee is doing similar fellings in Tasek Glugor reserve. Class IT poles were extracted from Pantai Acheh, Telok Bahang, and Government Hill reserves.

32. The regeneration fellings at Telok Bahang and Pangkor reserves (Dindings) were never carried out, owing to the poor market. The cleanings which should have followed them were therefore not made.

33. In Malacca a labour force of 60 to 70 was kept together all the latter part of the year, and improvement fellings were carried out in :-

Compartments $7 a, 7 b$ and $13 a$ Bukit Sedanan reserve.

Compartments ic Bulit Senggeh reserve.

Compartments $z^{a} \quad$ Ayer Panas reserve.

Compartment $4 a \quad$ Merliman reserve.

Four hundred and fifteen acres were treated at a cost of $\$ 3,079$ or $\$ 7.42$ per acre.

\section{EXPLOTTATION.}

TtMBer and Fuel.

(a)-From Reserved Forests.

34. The outturn of timber from the Singapore forests decreased from I66 tons in 1926 to 7 tons in 1927 , and this was confiscated as a result of a forest offence. The fact is that there is little timber left. The outturn of firewood fell from 2,520 tons to 42 tons as no new coupes were opened. The mangrove reserves have been badly cut about and little can be hoped from them for some time, but they are not ruined and will recover with rest. Revenue rose from $\$ 1,796$ to $\$ 5.916$, owing to payments by squatters for timber on their allotments.

35. In Penang and Province Wellesley the outturn of timber was $57^{2}$ tons and of firewood 2,604 tons compared with 1,356 tons and 5,229 tons respectively in I926. This was due to the fact that the fellings of Class I timber in Bukit Juru and Tasek Glugor were closed, and those in Pantai Acheh greatly reduced; also there was little or no market for Class II poles. The fall in firewood is due to the fact that the 1926 totals were greatly swollen by the clearing of the land to be excised from Tasek Glugor reserve. Reventue fell from $\$ 4.373$ to $\$ 2,477$.

36. In the Dindings the outturn of timber and fuel from reserves was 265 tons and 421 tons compared with 96 and 146 tons respectively in 1926 , the revenue increased from $\$ 358$ to $\$ 48 \mathrm{I}$. Two fellings were leased in the Tanjong Burong reserve and the rillagers of Pantai Remis had a pole coupe under permit; a free pole coupe for fishermen was also opened: these two latter are thinnings on the "stick" method. Further pole coupes were opened in Batu Undan reserve. Regeneration fellings in Telok Muroh and Pangkor reserves were very unsatisfactory.

37. In Malacca the outturn of timber and fuel was 764 and 71 tons comnared with 858 and 866 tons respectively in I926. Revenue fell from $\$ 4,5$ I 2 to $\$ 877$. No Class I timber, except from fallen trees, was allowed to be removed and there was no market for firewood. 
38. The figures for the whole Straits Settlements were:-1,608 tons of timber and 3,r39 tons of firewood compared with 2,476 and 8,762 tons respectively in I926. The outturn of Class I timber fell from 766 tons to 228 tons. Revenue on these heads decreased from $\$$ II,039 to $\$ 9,752$.

\section{(b)-From Crown and Alienated Land.}

39. In Singapore the outturn of timber and firewood was estimated as nil and 17,300 tons compared with 946 and 21,997 tons respectively in 1926 . Revenue on these heads fell from $\$ 6$, I04 to $\$ 4,464$.

40. In Penang and Province Wellesley fellings on Crown and alienated land produced 207 tons of timber and 3,482 tons of firewood compared with 147 and 2,184 tons respectively in 1927. Revente on these heads rose from $\$ 1,047$ to $\$ 1,699$.

4I. In the Dindings the outturn of timber was 6, I95 and of firewood 2,583 tons compared with 5,040 and $\mathrm{I}, 943$ tons respectively in 1926 . Revenue increased from $\$ 8,070$ to $\$ 10,87 \mathrm{I}$. The amount of Class I timber removed rose from 1,217 tons to 2,539 tons.

42. In Malacca, the outturn was 1,668 tons of timber and 736 tons of firewood compared with $2,21 \mathrm{I}$ and 985 tons respectively in 1926 . Rerenue from these sources amounted to $\$ 9,336$ compared with $\$ 8,834$ in 1926 . Royalty on the timber on land alienated for planting amounted to $\$ 3,968$ compared with $\$ 13,377$ in 1926 .

43. The total revenue derived from the exploitation of timber and firewood on: Crown and Alienated land fell from $\$ 37,432$ to $\$ 30,338$ : if the amounts referred to in the last sentence of paragraph 42 are excluded, the fall in revenue is replaced by a rise in royalty from $\$ 24,055$ to $\$ 26.370$.

\section{MINOR FOREST PRODUCE. \\ (a)-From Reserved Forests.}

44. Revenue from this source increased from $\$ 2,989$ to $\$ 3,247$. There was a small increase in the Dindings revenue and a subtantial increase in Malacca. The Malacca increase was due to fees on permits to prospect for tin and to the sale of taban seeds collected in 1926 and I.927, which more than made up for a falling off in rubber sales.

45. Damar tapping has been started in Segari-Melintang reserve in the Dindings, where I8I chongal and 30 tomak trees have been opened. The latter, which is a species of Shorea, has not yet been botanically identified, but it produces an unusually valuable pale damar.

\section{(b)-Form Crown and Altenated Land.}

46. Revenue increased from $\$ 8$ I5 to $\$$ I, II6. The increase was chiefly in the Dindings, but the details are of no importance.

PART III.

FINANCIAL RESULTS.

REvenue.

47. The following statement shows the total revente from I925 to I927.

\begin{tabular}{|c|c|c|c|c|c|c|}
\hline SETTLEMENT & $\begin{array}{c}\text { Revenue } \\
1925\end{array}$ & $\begin{array}{c}\text { Revenue } \\
1926\end{array}$ & $\begin{array}{l}\text { Estimated } \\
\text { revenue } \\
1927\end{array}$ & $\begin{array}{l}\text { Actual } \\
\text { revenue } \\
1927\end{array}$ & $\begin{array}{c}\text { Increase or } \\
\text { decrease } \\
\text { over } \\
\text { Estimates }\end{array}$ & $\begin{array}{c}\text { Increase or } \\
\text { decrease } \\
\text { over } 1926 \\
\text { Actuals }\end{array}$ \\
\hline & $\$$ & $\$$ & $\$$ & $\$$ & $\$$ & $\$$ \\
\hline $\begin{array}{l}\text { Singapore } \\
\text { Penang and Province }\end{array}$ & 12,998 & 12,443 & 7,000 & 17,073 & $+10,073$ & $+\quad 4,630$ \\
\hline $\begin{array}{c}\text { Penang and Province } \\
\text { Wellesley }\end{array}$ & 7,317 & 6,844 & 6.650 & 5,628 & 1,022 & 1,216 \\
\hline Dindings & 11,062 & 9,879 & 9,960 & 13,305 & 3,345 & $\begin{array}{r}3,426 \\
+\quad 1\end{array}$ \\
\hline Nalacca & 16,605 & 29,093 & 16,450 & 16,757 & $+\quad 307$ & $-12,336$ \\
\hline TOTAL $\quad \ldots$ & 47,982 & 58,259 & 40,060 & 52.763 & $+12,703$ & $-\quad 5.496$ \\
\hline
\end{tabular}


48. The excess over the estimates is mostly due to compensation paid by squatters for timber destroyed in the Singapore reserves: the rise in the Dindings is due to better supervision.

\title{
EXPENDITURE.
}

49. The following table shows the expenditure from 1925 to $1927:-$

\begin{tabular}{|c|c|c|c|c|c|c|}
\hline SETTLEMENT & $\begin{array}{c}\text { Expenditure } \\
1925\end{array}$ & $\begin{array}{c}\text { Expenditure } \\
1926\end{array}$ & $\left\{\begin{array}{c}\text { Estimated } \\
\text { Expenditure } \\
1927\end{array}\right.$ & $\begin{array}{c}\text { Expenditure } \\
1927\end{array}$ & $\begin{array}{l}\text { Savings on } \\
\text { Estimates }\end{array}$ & $\begin{array}{c}\text { Increase or } \\
\text { decrease } \\
\text { over } 1926 \\
\text { Actuals }\end{array}$ \\
\hline & 8 & $\$$ & $\$$ & $\$$ & $\$$ & $\$$ \\
\hline Singapore & 8.048 & 7,833 & 7,942 & 9,411 & $-\quad 1,469$ & $+\quad 1,578$ \\
\hline $\begin{array}{l}\text { Penang and Province } \\
\text { Wellesley }\end{array}$ & 10.563 & 16,697 & 8,069 & 11,346 & $-\quad 3,277$ & 5,351 \\
\hline Dindings & 8,465 & 8,051 & 7,820 & 8,577 & 757 & 526 \\
\hline Malacca & 29.242 & 20,819 & 24.493 & 25,664 & $-\quad 1,171$ & 4,845 \\
\hline TOTAL & 56,318 & 53,400 & 48,324 & $*+54,998$ & $-\quad 6,674$ & +1.598 \\
\hline
\end{tabular}

* Excludes temporary allowances amounting to $\$ 2,418$.

fincludes share of head office expenses, of cout of training forest officers and of contribution to Imperial Forestry Institute.

50. The increase of expenditure over estimates is due to the greatly increased work put in by the senior stafi in the Forests of the Straits Settlements and will bear good fruit in the future.

\section{SURPLUS AND DEFICIT.}

51. The results of the year's working are shown in the following statement :-

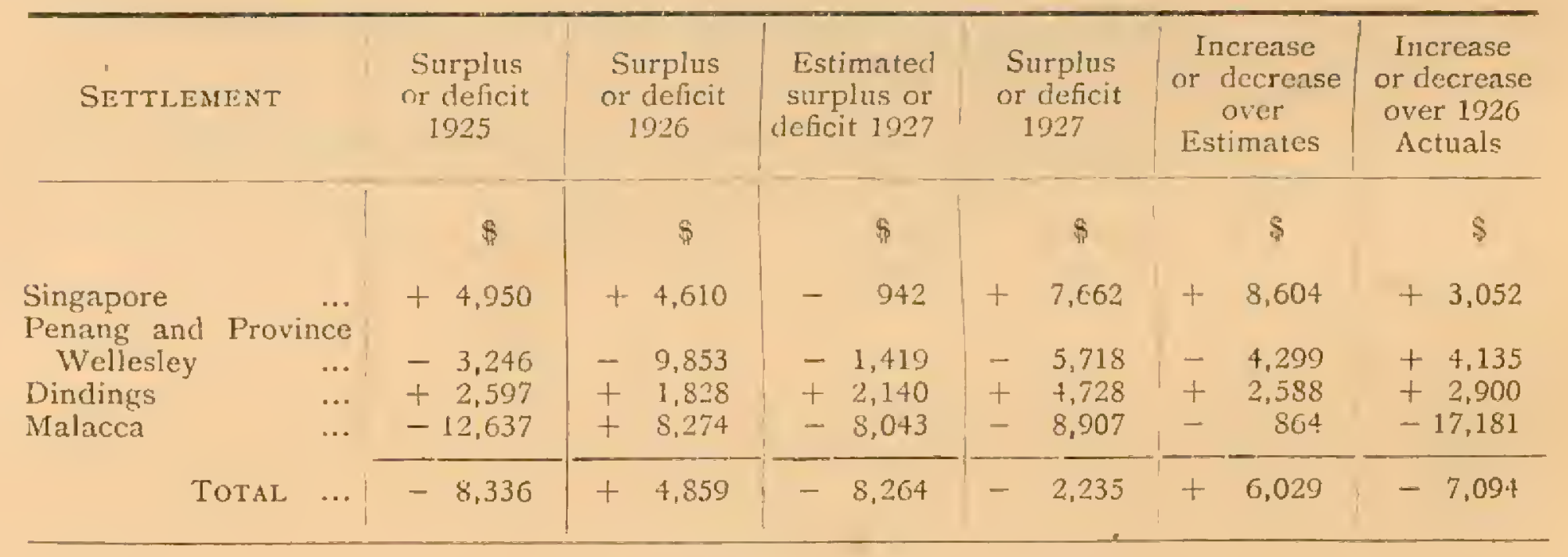

\section{PART IV.}

\section{ADMINISTRATION.}

52. The writer was in charge throughout the year. The Singapore forest. were placed in charge of a Sulh-Assistant Conservator of Forests working under the Personal Assistant to the Conservator of Forests, who has the powers of a Deputy Conservator of Forests. Other arrangements remained as before.

\author{
G. E. S. CUBITT, \\ Conservator of Forests, \\ S.S. and F.M.S.
}

Kunla Lumpur, 2nd March, 1928. 
APPENDIX $A$.

List of Trees, Etc., Mentioned in the Report.

\begin{tabular}{llll|l}
\hline Vernacular & or & English & Name. & Botanical Name. \\
& & & & \\
& & & & \\
Angsana & $\ldots$ & $\ldots$ & $\ldots$ & Pterocarpus indicus \\
Chengal & $\ldots$ & $\ldots$ & $\ldots$ & Balanocarpus Heimii \\
Damar-laut & $\ldots$ & $\ldots$ & $\ldots$ & Parashorea stellata \\
Jangkang & $\ldots$ & $\ldots$ & $\ldots$ & Hopea spp. \\
Meranti & $\ldots$ & $\ldots$ & $\ldots$ & Shorea spp. \\
Taban & $\ldots$ & $\ldots$ & $\ldots$ & Palaquium and Payena \\
Temak & $\ldots$ & $\ldots$ & $\ldots$ & Shorea spp. \\
\hline
\end{tabular}




\section{Annual Report on Forest Administration in the Straits Settlements for the Year 1928}

\section{PART I}

\section{EXTENSION AND CONSTITUTION OF RISERVED FORESTS.}

I. The extensions of forest reserves in the Dindings referred to in last year's report were both constituted. They are 375 acres of damar laut forest at Tanjong Hantu and 2,950 acres of fair timber forest at Gunong Tunggal.

2. A proposed extension to the Balik Pulau reserve in Penang was preliminarily notified, but was not finally gazetted at the end of the year. This is a mangrove forest on newly formed mud banks.

3. A proposal to reserve the mangrove forests around the Berih river in Singapore has been discussed but not yet approved. This forest has been heavily overcut, but has regenerated well and is very suited to carry a permanent forest crop.

4. A number of small excisions totalling 220 acres, were gazetted. The excision from Tanjong Burong Reserve in the Dindings was for agricultural purposes as was that from Pantai Acheh in Penang; those from Ramuan China and Bukit Sedanan, both in Malacca, were for agriculture, and that from Bukit Bruang, also in Malacca, for a burial ground; and the excision from the Bukit Timah Reserve in Singapore was for a quarty.

5. Further excisions for agriculture are under consideration in the Dindings and in Malacca.

6. The total area and the distribution of reserved forests are shown in the following statement:-

\begin{tabular}{|c|c|c|c|c|}
\hline Settlement & & Total Area & $\begin{array}{c}\text { Area of } \\
\text { Reserved Forests }\end{array}$ & $\begin{array}{l}\text { Proportion } \\
\text { to whole Area }\end{array}$ \\
\hline & & Square miles & Square miles & Per cent. \\
\hline Singapore... & $\ldots$ & $\quad 217$ & $22 \cdot 5$ & $10^{\circ}+$ \\
\hline Penang $\quad .$. & $\ldots$ & 108 & $19^{\prime} \mathrm{O}$ & $17 \cdot 6$ \\
\hline Province Wellesley & $\cdots$ & 280 & $5 \cdot 8$ & $2 \cdot 1$ \\
\hline Dindings & ... & $18_{3}$ & $52^{\prime} 7$ & $28 \cdot 8$ \\
\hline Malacca $\quad .$. & .. & 720 & $79 \cdot 0$ & II 0 \\
\hline TOTAL & $\ldots i$ & 1,508 & $179^{\circ} 0$ & Ir'9 \\
\hline
\end{tabular}




\section{DEMARCATION AND MAINTENANCE OF BOUNDARIES OF FOREST RESERVES.}

7. The total length of boundaries increased from 570 miles to 585 . Of the new boundaries $77^{3}$ miles were artifical and about 4 natural. The large number of small excisions made practically no difference to the totals. About $3353 / 5$ miles of artifical boundaries were cleaned at a cost of $\$ 43 \mathrm{I}$, but a good deal of such work was done by guards when patrolling. The new work cost $\$ 85 / 50$ or $\$ 1 \mathrm{I} / 72$ per mile.

8. Parts of the boundaries of the mangrove forest in Singapore are sited in the mangrove swamp itself, which makes inspection of boundaries difficult Small readjustments of these swamp boundaries would put this matter right.

\section{SURVEYS.}

9. The Survey Department published the 4 " topographical maps of the Tanjong Burong Reserve in the Dindings drawn from the mosaic photographs made by the Air Survey Company.

Io. The general survey of Malacca is well in hand and will clear up a number of doubtful reserve boundaries.

II. In Singapore a forester lent from the F. M. S. demarcated I5 miles of interior details in reserves for the purpose of siting areas for market gardeners. A number of new compartments in the Penang and Malacca reserves and two excisions in the Dindings were demarcated and surveyed by the local staff.

\section{PART II}

\section{MANAGEMENT OF FORESTS.}

\section{Working Plans or Schemes.}

12. The plan for the Malacca forests, prepared by Mr. J. P. EDWARDS, Assistant Conservator of Forests, last year, was approved by the Government as a whole and is gradually being brought into operation. The plan for Tanjong Burong in the Dindings was not carried out, owing to the lack of markets for forest produce. No other plans or schemes have been prepared.

\section{COMMUNICATIONS.}

13. All existing paths in Singapore, Penang and the Dindings were kept up by the staff without any special expenditure. In Malacca 124 miles of existing paths were repaired at a cost of $\$ 350$ and II miles of new paths constructed at a cost of $\$ 670$. From the same vote 66 reserve notice boards for the Singapore forests were purchased.

\section{BUILDINGS.}

14. A house was built for the Sub-Assistant Conservator of Forests at singapore. Temporary coolie lines were put up in Malacca to provide accommodation for the coolies employed on improvement fellings.

55. The Public Works Department spent $\$ 3,45$ I on the repair of a number of forest department buildings as shown in Form IV.

\section{PROTECTION OF FORESTS.}

16. The Ordinance remained unaltered during the year, although severat annendments were under consideration. Particularly important is the proposal to allow forcst officers to compound minor offences as is allowed in the Federated Malay States. 'To take an ignorant peasant before the Magistrate for some minor offence of which he is clearly guilty is hard on him and very costly on account of taking up the time of highly paid senior ufficers. 
I7. The Rules were amended by certain alterations in the charges for mangrove permits and royalties on other forest produce. Further amendments are contemplated.

I8. There was one case pending from 1927 and there were 75 new cases in 1928 making 76 cases for that year as compared with II2 in I927 and I25 in 1926. All were dealt with during the year. There was a decrease in the number of cases in Malacca, possibly due to the start in exploiting the forests in that settlement. Unworked forests are always robbed, while, when the forests are worked, the public can buy what it wants cheaply. In addition, a worked forest is full of guards, coolies and permit-holders, who all assist in its protection.

I9. The Magistrate dealt with 29 cases and convicted in 25. One case was withdrawn. In three cases the accused were discharged. Fines inflicted amounted to $\$ 462$ or $\$ 18 / 48$ per conviction as compared with $\$ 1,090$ and $\$ 27$ in 1927. Nineteen cases were dealt with departmentally, and $\$ 606$ or $\$ 3 \mathrm{I} / 89$ per case was paid as compensation for damage. The corresponding figures for the previous year were $55, \$ 1,185$ and $\$ 2 \mathrm{I} / 54$.

20. There was an increase in the number of undetected cases, which were 28 as compared with 13 in the previous year. Confiscated property was sold for $\$ 263$ compared with $\$ 283$ last year.

21. There were no serious forest fires. Pigs and kera monkeys raided the market garden at Bukit Goa but left the trees alone. Monkeys destroyed a number of seedlings of bakan minvak at Changi and crabs did similar damage at Tuas.

\section{IMPROVEMENT OF FORESTS.}

NATURAT, REPRODUCTION.

22. Damar lant flowered in July, and fruited profusely in October in Bukit Juru in Penang. Damar lant fruited in August in Bukit Senggeh in Malacca, but the seed was not fertile. Taban fruited in July-August in Ayer Kroh in Malacca: II5,700 seeds were sold to an estate in Pahang for $\$ 253 /$ - A fair number of other Class I trees fruited lightly in the Malacca forests in January.

\section{PLANTING AND CULTURAL OPERATIONS.}

23. At Bukit Goa Ipoh a Chinaman who is trying to combine market gardening with the planting of forest trees (Taungya) cleared and planted his area and the forest department interplanted sena and mahogany. The blanks mentioned last year were supplied with sena and mahogany.

24. Ten Malays in Bukit Langkap reserve and one in Bukit Juru reserve in the Province, have taken up leases for similar work. Nurseries have been started, but no planting of trees has yet been done. An attempt to sow angsana direct in belukar at Bukit Juru failed and the area has been handed to a Malay to grow vegetables in the same manner.

25. A small plantation of angsana was made in Telok Bahang in Penang on poor soil where taban falled before. The bamboo plantation in the same reserve, made in 1922 and 1924. was supplied with an undentified species, called the "golden bamboo"

26. The ten acre plantation of chengal and angsana in the area burnt in Pantai Acheh in I925 has been abandoned. What was done in the past has failed completely and it is considered that the difficulty of access and the rankness of the existing belukar (jungle grass) would make the cost of a plantation here prohibitive.

27. The plantation of taban at Ayer Kroh in Malacca was cleaned and some thinnings were made where the taban was too crowded. The Tephrosia candida which was sown in 1927 as a corer crop failed to establish itself, being unable to compete with lalang and other weeds. This is perhaps not to be marvelled at, as the area was under a crop of para rubber for vears and the surface soil has vanished as the result of clean weeding. 


\section{WORKS POF IMPROVEMEN'T.}

28. An attempt was made to begin regeneration fellings on the F.M.S. lines in Bukit Juru Reserve in Province Wellesley. Similar fellings in Tasek Glugor were continued. Bertam may now be taken free from forest reserves and this should assist natural regeneration.

29. Improvement fellings were carried out over the following compartments of Malacca forest reserves:--

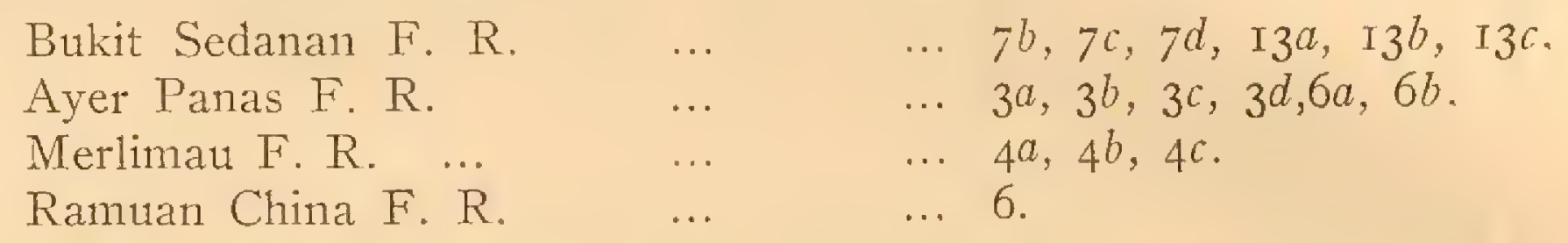

The cost was $\$ 6 / 85$ per acre which is not unduly high.

\section{EXPLOITATION.}

TIMBER AND FUet.

(a)-From Reserved Fiorests.

30. Only $3 \frac{1}{2}$ tons of timber (poles) and no firewood were removed from ordinary fellings in Singapore forest reserves, compared with 7 and 42 tons in 1927 . The forests will have to be rested for some time to come. Squatters paid $\$ 9,8$ I 2 as commuted royalty on the timber on their allotments compared with $\$ 5,916$ in 1927 .

31. In Penang and Province Wellesley the outtunn of timber was 386 tons and of frewood I,445 tons compared with 572 and 2,604 tons in I927. The fall in timber is in poles only. The forests are not in a condition to be heavily exploited and unless some expenditure is undertaken to replace what is taken out, exploitation will lead to their destruction. Revenue decreased from $\$ 2,477$ in 1927 to $\$ 1,379$.

32. In the Dindings, the outturn of timber and firewood was I, 232 tons and 321 tons compared with 265 and $42 \mathrm{I}$ tons in 1927 . Revenue increased from $\$ 48 \mathrm{I}$ to $\$ 2,96 \mathrm{I}$. The increase was chiefly in respect of poles.

33. In Malacca the outturn of timber and firewood was 2,332 tons and I.875 tons compared with 764 and 7 I tons in I927. Revenue increased from $\$ 877$ to $\$ 3,878$. The Assistant Conservator of Forests remarks that the trade in forest produce suffered from the trade depression and the increase would have been larger in normal circumstances.

34. The figures for the whole S. S. were 3,953 tons of timber and 3,641 tons of firewood compared with 1,608 and 3,139 tons in 1927 . Class I timber rose from 228 tons to 550 . Revenue under these heads increased from $\$ 9,75^{2}$ to $\$ 18,030$.

\section{(b)_From Crocon and Alienated Lands.}

35. In Singapore the outturn of timber was again recorded as nil and that of frewood estinnated to be 22,700 tons compared with 17,300 tons in 1927 . Revenue increased from $\$ 4,464$ to $\$ 5,675$.

36. In Penang and Province Wellesley the outturn of timber was $3 \mathrm{I} 7$ tons and that of firewood 1,464 tons compared with 207 and 3,482 tons in 1927 . Revenue fell from \$1,699 to $\$ 984$.

37. In the Dindings the outturn of timber was 4,444 tons and that of frewood 2,010 tons compared with 6,195 and 2,583 tons in 1927. Revenue increased from $\$ 10,8 \% 1$ to $\$ 12.835$. The outturn of Class I timber fell from 2.539 tons to 2,422 .

38. In Malacca the ontturn of timber was 774 tons and of firewood 873 tons compared with $\mathrm{x}, 668$ tons and 736 in i927. Revente fell from $\$ 9,336$ to $\$ 5,437$. Revenue on land alienated for planting increased from $\$ 3,968$ to $\$ 4,969$. 
39. The total revenue derived from the exploitation of timber and firewood on Crown and Alienated land fell from $\$ 30,338$ to $\$ 29,900$. But if the figures mentioned in the last sentence of 38 are excluded, royalty has fallen from $\$ 26,370$ to $\$ 24,931$.

\section{MINOR FOREST PRODUCE.}

\section{(a)-From Reserved Forests.}

40. Revenue from this source fell from $\$ 3,247$ to $\$ 2,580$. The fall was due almost entirely to the cessation of rubber tapping in Malacca and the general fall of revenue in Penang and Province Wellesley. The other two Settlements showed an increase.

4I. Damar tapping in the forests in the Dindings is in progress, and results to date are encouraging. In Segari-Melintang reserve 75 temak and r48 chengal trees have been opened and there is another lease-holder who has just started work in Gunong Tunggal reserve.

$$
\text { (b)-From Crown and Alienated Land. }
$$

42. Revenue increased from \$I,II6 to $\$ I, 235$, the increase being in the Dindings.

PART III

IFINANCIAL RESULTS.

REVENUE.

43. The following statement shows the total revenue from 1926 to 1928.

\begin{tabular}{|c|c|c|c|c|c|c|}
\hline SETTLEMENT & $\begin{array}{l}\text { Revenue } \\
1926\end{array}$ & $\begin{array}{c}\text { Revenue } \\
1927\end{array}$ & $\begin{array}{l}\text { Estimated } \\
\text { revenue } \\
1928\end{array}$ & $\begin{array}{l}\text { Actual } \\
\text { revenue } \\
1928\end{array}$ & $\begin{array}{c}\text { Increase or } \\
\text { decrease } \\
\text { compared } \\
\text { with } \\
\text { Estimate }\end{array}$ & $\begin{array}{c}\text { Increase } \\
\text { or } \\
\text { decrease } \\
\text { compared } \\
\text { with } 1927\end{array}$ \\
\hline & $\$$ & $\$$ & $\$$ & $\$$ & $\$$ & $\$$ \\
\hline $\begin{array}{l}\text { Singapore } \\
\text { Penang and Province }\end{array}$ & 12,443 & 17,073 & 10,000 & 26,074 & $+16,074$ & 9,001 \\
\hline Wellesley $\quad$... & 6,844 & 5,628 & 5,875 & 3,401 & 2,474 & 2,227 \\
\hline Dindings & 9,879 & 13,305 & 12,000 & 18,300 & 6,300 & 4,995 \\
\hline Malacca & 29,093 & 16,757 & 6,150 & 15,533 & 9,383 & 1,224 \\
\hline TOTAL $\quad \ldots$ & 58.259 & 52,763 & 34,025 & 63,308 & $+29,283$ & $+10,545$ \\
\hline
\end{tabular}

44. The increase in the Singapore figures over those of 1927 and over the estimates is due to the squatters fees. These cannot be foreseen. The increases in the Dindings and Malacca are probably due partly to closer supervision, consequent on the stationing of senior officers in those Settlements.

\section{EXPENDITURE.}

45. The following statement slows the expenditure from 1926 to I928:-

\begin{tabular}{|c|c|c|c|c|c|c|}
\hline SETTLEMENT & $\begin{array}{c}\text { Expenditure } \\
1926\end{array}$ & $\begin{array}{c}\text { Expenditure } \\
1927\end{array}$ & $\begin{array}{c}\text { Estimated } \\
\text { Expenditure } \\
1928\end{array}$ & $\begin{array}{c}\text { Actual } \\
\text { Expenditure } \\
1928\end{array}$ & $\begin{array}{l}\text { Increase or } \\
\text { decrease } \\
\text { compared } \\
\text { with } \\
\text { Estimate }\end{array}$ & $\begin{array}{c}\text { Increase } \\
\text { or } \\
\text { decrease } \\
\text { compared } \\
\text { with } 1927\end{array}$ \\
\hline \multirow{5}{*}{$\begin{array}{l}\text { Singapore } \\
\text { Penang and Province } \\
\text { Wellesley } \\
\text { Dindings } \\
\text { Malacca }\end{array}$} & $\$$ & $\$$ & $\$$ & $\$$ & $\$$ & $s$ \\
\hline & 7,833 & 9,411 & 8,430 & 10,083 & $+\quad 1,653$ & 672 \\
\hline & 16,697 & 11,346 & 8,343 & 11,488 & 3,145 & 142 \\
\hline & 8,051 & 8,577 & 10,553 & 8,773 & $-\quad 1,780$ & $+\quad 196$ \\
\hline & 20,819 & 25,664 & 23,507 & 35,897 & $+12,390$ & $+10,233$ \\
\hline Total. & 53,400 & 54,998 & 50,833 & $*+66,241$ & $+15,408$ & $+11,243$ \\
\hline
\end{tabular}

* Excludes temporary allowance amounting to $\$ 3,147$.

Includes share of head office expenses, of cost of training forest officers and contribution to Imperial Forestry Institute. 
46. The increases over both the estimate for 1928 and the 1927 figrres are due almost entirely to the fact that it has been decided to work the Malacca forests under close management. These forests are very valuable, both from the character of the growing stock and from their position in a heavily populated Settlement. Money spent on such a property will repay the Government handsomely.

\section{SURPLUS AND DEFICIT.}

47. The results of the year's working are shown in the following statement.-

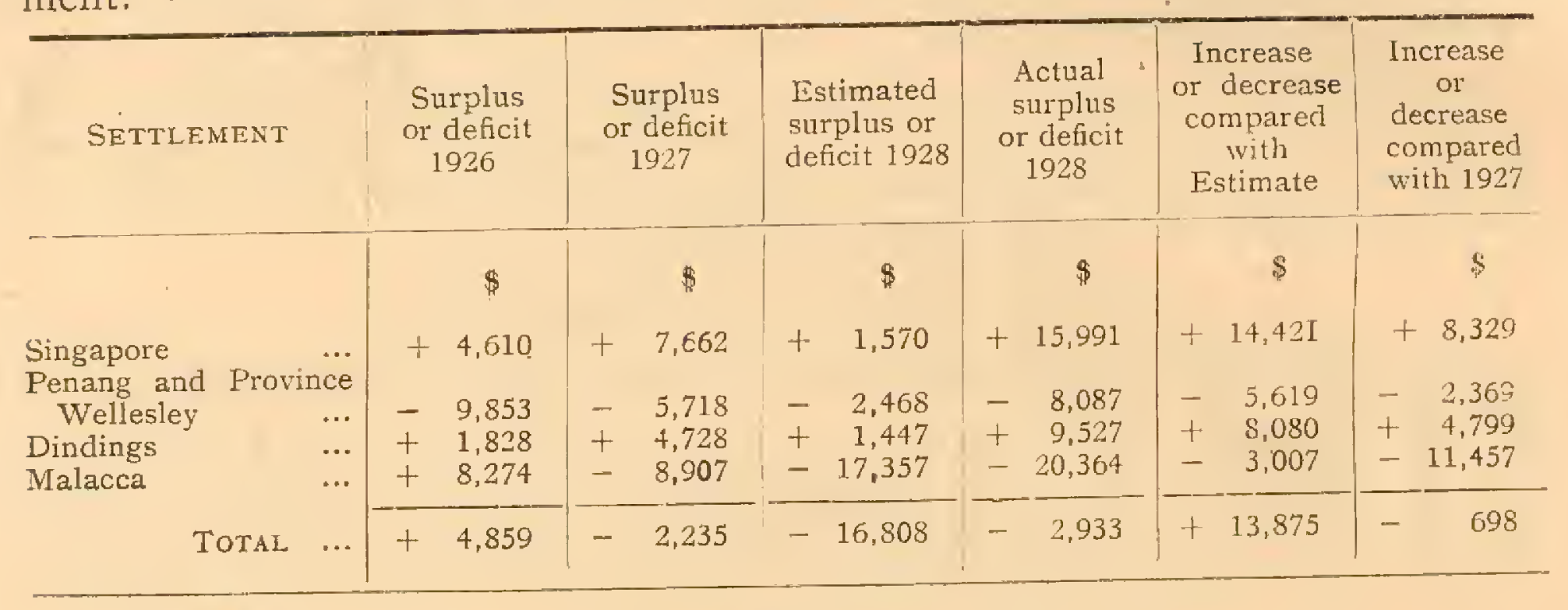

\section{PART IV}

\section{ADMINISTRATION}

48. Mr. Curitt was in charge until he left, in August, to attend the Empire Forestry Conference in Australia, thence proceeding on long leave. The writer was in charge thereafter.

49. Singapore remained in charge of a Sub-Assistant Conservator of Forests with the Personal Assistant to the Conservator as Deputy Conservator of Forests. Malacca was made a forest district under an Assistant Conservator of Forests stationed at Jasin, working under the Deputy Conservator of Forests, Negri Sembilan. A new forest district including the Dindings and parts of Perak was made with its headquarters at Lumut. Penang and Province Wellesley were under the District Forest Officer, Matang. The Deputy Conservator of Forests, Perak North remained in charge of these Settlements.

\section{B. H. F. BARNARD,}

Ag. Conserator of Forests,

$S . S$. and F. M. S.

Kuala I,umpur, ioth March, 1929. 
APPENDIX $A$.

List of Trees, ETC., MENTIONED IN THE Ke'ORT.

Vernacular or English Names.

Angsinala

Bakan Minyak

\section{Bertam}

Chengal

Damar

Dama1 Latut

Mahogany

Lalang

P'arat

Sena

Taban

Temak

Kachang bubu
Butanical Names.

.. Pterocarpus indicus

.. Rhizophora conjugata

Eugeissona triste

Balanocarpus Heimii

Shorea Sp.

Shorea glanca

Swietenia Sip.

Inperatat Sp.

Hevea braziliensis

Pterocarpus indicus

Palaquium and Payena

Shorea Sp.

Tephrosia candida. 


\section{Annual Report on Forest Administration in the Straits Settlements for the year 1929}

\section{PART I}

\section{EXTENSION AND CONSTITUTION OF RESERVED FORESTS.}

I. In Singapore the Sungei Berih mangrove forest with an area of 1,3 I 5 acres was constituted a reserve and two areas of 292 and 65 acres respectively were added to the Tuas and Pandan mangrove reserves. All three areas carry a crop of good but immature bakau. *

2. In Penang 29 acres of mangrove were added to the Balik Pulaui reserve.

3. In Singapore 53 acres were excised from the Bukit Timah reserve for a rifle range, and 25 acres from the Pandan reserve for a residential purpose.

4. In the Dindings excisions for agriculture of 3 acres and 180 acres were made from the Lumnt and Batu Undan reserves.

5. In Malacca the area of the Merlimau reserve was reduced by 8 acres, as it was found on resurvey that an adjoining estate had encroached to this extent.

6. An enquiry into the value of the Penang and Province Wellesley reserves was made and as a result it was decided to abandon the Bukit Goa Ipoh and Bukit Langkap reserves in Province Wellesley. It was further decided to maintain as forest reserves all water catchment areas, with the exception of such land as has already been acquired by the Municipal Commissioners. In accordance with this policy it will be necessary to extend the reserves adjoining the Balik Pulau and Bukit Mertajam water catchment areas.

7. The total area and distribution of reserved forests are shown in the following statement:-

\begin{tabular}{|c|c|c|c|c|}
\hline \multicolumn{2}{|l|}{ Settlement } & Total area & $\begin{array}{l}\text { Area of } \\
\text { reserved forests }\end{array}$ & $\begin{array}{l}\text { Proportion } \\
\text { to whole area }\end{array}$ \\
\hline & & Square miles & Square miles & Per cent. \\
\hline Singapore... & $\ldots$ & 217 & $25^{\circ} \mathrm{O}$ & $\mathrm{II} \cdot 5$ \\
\hline Penang $\quad \ldots$ & $\cdots$ & 108 & $19^{\circ} \mathrm{I}$ & $17^{\circ} 7$ \\
\hline Province Wellesley & $\ldots$ & 280 & $5 \cdot 8$ & $2 \cdot \mathrm{I}$ \\
\hline Dindings & $\ldots$ & 183 & $52 \cdot 4$ & 286 \\
\hline Malacca $\quad .$. & .. & 720 & $79^{\circ} \mathrm{O}$ & I I ${ }^{\circ} \mathrm{O}$ \\
\hline TOTAL. & & 1,508 & $181 \cdot 3$ & I $2^{\circ} \mathrm{O}$ \\
\hline
\end{tabular}

\footnotetext{
* For hotanical names of trees, etc., mentioned in this report and forms see Appendix.
} 


\section{DEMARCATION AND MAINTENANCE OF BOUNDARIES OF FOREST RESERVES.}

8. The total length of boundaries increased from 585 miles to 606 miles. Of the new boundaries about 18 miles are artificial, and the remainder are formed by natural features. A length of 359 miles of boundaries was repaired at a cost of $\$ 708$, i.c., $\$ 1.97$ per mile, but a good deal of cleaning was done by patrol guards. This cost is for labour and material only and does not include overhead charges for supervising staff. The new work was cartied out by the staff.

\section{SURVEYS.}

9. A sum of $\$ 264.87$ was spent in Malacca by the Survey Department on work preparatory to the topographical survey programme for I930.

Io. In the Dindings the Survey Department surveyed the external boundary of the Gunong Tunggal reserve and excisions from the Telok Muroh and Lumut reserves at a cost of $\$ 1,657$.

I I. Departmental surveys of compartment boundaries, coupes and paths were made in the Penang, Province Wellesley, and Malacca reserves by the subordinate staff.

\section{PART II}

\section{MANAGEMENT OF FORESTS.}

I2. Satisfactory progress was made with the scheme of improvement for the Malacca forests, and the prescriptions were, with minor exceptions, adhered to.

I3. The working scheme for the Tanjong Burong reserve in the Dindings could not be followed owing to the lack of demand for firewood.

I4. A preliminary investigation of the mangrove area of the Kuala Linggi reserve in Malacca was made with a view to bringing this reserve under working scheme control.

\section{COMMUNICATIONS.}

15. Existing inspection paths in the Singapore, Penang and the Dindings reserves were upkept by the staff. In Malacca II4 miles of existing paths were repaired at a cost of $\$ 63 \mathrm{I} .50$ and $20 \frac{1}{4}$ miles of new paths were constructed at a cost of $\$ 2,056$

\section{BUILDINGS.}

16. In Singapore the Public Works Department removed the forest guards' quarters from Mandai road and re-erected them at Kranji, and built a garage for the District Forest Officer, at Barker road.

I7. In the Dindings \$I8,890 was spent by the Public Works Department on quarters for the District Forest Officer at Lumut, but the building was still unfinished at the end of the year.

I8. In Malacca the Public Works Department built a district forest office and quarters for the forest clerk at Jasin and quarters for forest guards at Kesang, Nyalas and Tebong.

Temporary quarters for staff and coolies employed on improvement fellings cost \$in, 086.78 .

19. The Public Works Department spent \$T, r20.83 on the general repair of a number of Forest Department buildings. 


\section{PROTECTION OF FORESTS.}

20. Minor alterations were made to the Ordinance and Rules, the most important being an amendment to rule 18 enpowering the Conservator of Forests to fix royalties and fees for leases of forest produce in reserves. The proposal to allow senior forest officers to compound minor offences referred to in paragraph i6 of last year's report failed to meet with approval.

21. No cases were pending from I928. There were 103 new cases compared with 76 cases in I928 and II2 in I927. All were disposed of during the year. There was a marked increase in forest offences in Singapore, but these were principally petty thefts of poles and firewood by squatters occupying land adjoining the mangrove forest. In all the other Settlements there was a decrease.

22. Twenty-nine cases were taken to court, convictions being obtained in 26 cases, the accused being discharged in the remainder. Fines inflicted totalled $\$ \mathrm{I}, 5 \mathrm{I}$ I8.20, i.e., $\$ 58.39$ per conviction compared with $\$ 462$ and $\$ 18.48$ in I928. Thirteen cases were dealt with departmentally and $\$ 137$ was paid as compensation for damage. The corresponding figures for 1928 were I9
and $\$ 606$.

There was a large increase of $6 \mathrm{I}$ in the number of uncletected cases as compared with 28 in I 928 . This increase was almost entirely in Singapore where petty thefts from the mangrove cannot be prevented without a disproportionate increase in staff.

In Malacca there were 3 I breaches of felling leases and fines amounting to $\$ 223$ were imposed.

There were several small fires in Penang and the Dindings, but the damage was not extensive.

Crabs did very heavy damage to the newly planted bakau seedlings in the Pulau Burong reserve.

\section{SIIVICULTURE.}

Natural Rerroduction.

23. Except in Malacca little seed was produced. Mclantai fruited in the Pantai Acheh reserve in Penlang during July. Some of it was collected and sown in the Bukit Goa Ipoh reserve, but failed to establish itself. In Malacca there was an excellent seed crop, especially from the dipterocarps. Meranti, keruing and mersare fruited, most noticeable being the profuse fruiting from Jume to September of meranti tembaga in all the reserves in the Settlement. In the Singapore mangrove forests bakan minvak and bakan kurap fruited, and in December scraya fruited in the Bukit Timal reserve. Taban fruited in the Bukit Bruang reserve in Malacca and the Telok Ballang reserve in Penang, and a sum of $\$ 174$ was realised by the sale of 87,000 seeds to estates in Pahang.

\section{PLANTING AND CULTURAL PLANTATIONS.}

24. The reafforestation experiments referred to in paragraphs 23 and 24 of last year's report in the Bulit Goa Ipoh, Bukit Langkap and Bukit Juru reserves were continued. Operations in the last mentioned reserve ceased in September as the cultivator, a Malay, was mable to carry on. The species planted is sena and has done moderately well. It is reported that the results seem to show that tapioca should not be planted until an interval of at least six months after planting the trees. In the interval any low-growing annual crop may be planted, and for this purpose ubi kcmbili is rery sutitable. Seren out of the ten Malays who took up leases in the Bukit Langkap reserve gave up during the year. The taban and sena areas in the Telok Bahang reserve were cleaned. Four acres of mangrove forest in the Pulau Burong reserve were planted with bakau obtained from Port Weld. In the Malacca plantations 60 acres of taban and 33 acres of merbau were cleaned and 108 taban seedlings were planted by the coolies engaged in the cleaning operations. An estate in Pahang bought I,050 tabah stumps from an ofd abandoned nursery: The Para rubber in the Yeo Chu Kang plantation in Singapore and the Ayer Kroh plantation in Malacca were tapped during the year. 


\section{WORKS OF IMPROVEMENT.}

25. Departmental improvement fellings were made over 40 acres in the lasek Gelugor reserve at a cost of $\$ 238.80$, i.c., \$5.97 per acre. The trees ringed and felled in this operation were later extracted by a contractor, royalty amounting to $\$ I 52.87$ being paid. The net cost per acre thus amounted to $\$ 2$.I5. The improvement fellings started in the Bukit Juru reserve in 1928 were completed over 35 acres, the cost for the year amounting to $\$ 57.80$, bringing up the total cost for the whole area to $\$ 6.49$ per acre.

In Malacca improvement fellings were continued and completed over the following areas :-

Bukit Sedanan 1, I84 acres, Bukit Senggeh 167 acres, Ayer Panas 859 acres, Merlimau 348 acres, Ramuan China 980 acres and Sungei Údang 494 acres, in all 4,032 acres at a cost of $\$ 35.780 .80$, i.c., $\$ 8.87$ per acre. The cost is high but the forest, in the absence of a market for the inferior species, cannot be improved in any other way.

Bcrtam cutting on free permit continued in the Bukit Panchor and Ramuan China reserves.

\section{EXPLOITATION.}

TIMBER AND FUEL.

(a)-From reserved forests.

26. No timber and 56 tons of frewood were removed under ordinary fellings from the Singapore reserves, compared with $3 \frac{1}{2}$ tons of timber and no firewood in I928. A considerable amount was cut by squatters on the areas given up to them for vegetable cultivation, but no record of quantities was kept as commuted royalty was paid. The total revenue for the year was $\$ 89$ I compared with $\$ 9,812$ in 1928 . The large decrease is accounted for by the much smaller area given up to squatters, wiz. I80 acres as compared with 1,408 acres in 1928 .

27. In Penang and Province Wellesley the outturn of timber and firewood was 3.5 tons and 1,4 Io tons as compared with 386 and I,445 tons in 1928 . Most of the firewood came from the mangrove reserve at Balik Pulau, from the improvement fellings in Tasek Geligor, and from the leased workings in Bukit Goa Ipoh. The revente decreased from \$1,379 in 1928 to \$I, I52.

28. In the Dindings the outturn of class I timber increased from 12.5 tons to rgo tons. None of the reserves are open to regular cutting of this class of timber, and it was produced entirely by areas destined for excision from the reserves. The outturn of class 2 timber and poles decreased to I40 tons as compared with I, IO9 tons in 1928. This decrease is accounted for by the closing down of the mangrove pole cutting in the Batu Undan reserve. The ontturn of firewood rose from 321 tons in 1928 to 7 ig tons. The revenue decreased from $\$ 2,961$ in 1928 to $\$ 2,284$.

29. In Malacca there was a general all round increase in the outturn of timber and firewood accounted for by the increased demand and the opening wip of the reserves. The ontturn of class 1 and 2 timber was 2,083 and 3, 142 tons compared with 408 and 1.923 tons in 1928. The stimulus given to the inland firewood trade by the part remission of royalty in 1928 resulted in a markedly improved outturn, and the demand has increased to such an extent that full royalty will be reimposed for all accessible areas as from ist January, I030. The total onttuin was 12,737 tons compared with 1,875 tons in 1928 and 7 I tons in 1927 . The revenue increased from $\$ 3.878$ in ig2 8 to $\$ 16,025$.

30. The total outturn of the Straits Settlements was 5,870 tons of timber and I4.922 tons of firewood as compared with 3,953 and 3,64 I tons in I928. The outturn of class I timber rose from 550 to 2,280 tons. Revenue under these heads increased from \$i\$,030 to $\$ 20,352$ 
(b)-From Crown and alienated Lands.

3I. In Singapore the outturn of timber and firewood was I and 54,400 tons compared with no timber and 22,700 tons of firewood in 1928. The decrease in firewood was partly due to the reservation of the mangrove at Sungei Berih, but is chiefly accounted for by the exploitation of inland firewood that was paid for in 1928 . Revenue decreased from $\$ 5,675$ to $\$ 3,601$.

32. In Penang and Province Wellesley the outturn of timber and firewood was I68 tons and I,5I6 as compared with 317 and I,464 tons in I928. Revenue fell from $\$ 984$ to $\$ 830$.

In the Dindings the outturn of timber and firewood was 2,044 tons and 2,017 tons compared with 4,444 and 2,010 tons in 1928. Charcoal increased from I6o tons to 398 tons. Revenue fell from $\$ 12,835$ to $\$ 6,934$.

33. In Malacca timber increased from 774 tons to 3,485 tons and firewood from 873 tons to 3,302 tons. Revenue from Crown land fell from $\$ 5,437$ to $\$ 5$, I I 9 but revenue from alienated land increased from $\$ 4,969$ to $\$ 5,619$. The total revenue fell from $\$ 29,900$ to $\$ 22,103$.

\section{OTHER FOREST PRODUCE.}

\section{(a)-From reserved forests.}

34. Revenue rose from $\$ 2,580$ to $\$ 4,001$. There were increases in the Dindings and Malacca, in the former from damar, granite, and shell-sand, and in Malacca from jelutong and Para rubber.

The other Settlements showed slight decreases.

35. In the Dindings the tapping of temak trees for damar, which was started in 1928, is progressing satisfactorily. The revenue from this source rose from $\$ 67$ to $\$ 362$. It is expected that, when the new cuts, which have been opened, give full yields, the outturn will again show a considerabla increase.

For the first time jelutong tapping was commenced in Malacca.

$$
\text { (b)-From Crown and alicnated Lands. }
$$

36. There was an increase of $\$ 182$, accounted for by the tapping of Para rubber in Malacca.

\section{PART III}

\section{FINANCIAL RESULTS,}

Revenue.

37. The following statement shows the revente from 1927 to 1929 :-

\begin{tabular}{|c|c|c|c|c|c|c|}
\hline SETTLEMENT & $\begin{array}{c}\text { Revenue } \\
1927\end{array}$ & $\begin{array}{c}\text { Revenue } \\
1928\end{array}$ & $\begin{array}{l}\text { Estimated } \\
\text { revenue } \\
1929\end{array}$ & $\begin{array}{c}\text { Actual } \\
\text { revenue } \\
1929\end{array}$ & $\begin{array}{c}\text { Increase or } \\
\text { decrease } \\
\text { compared } \\
\text { over } \\
\text { Estimates }\end{array}$ & $\begin{array}{l}\text { Increase } \\
\text { or } \\
\text { decrease } \\
\text { over } 1928 \\
\text { actuals }\end{array}$ \\
\hline & $\$$ & $s$ & $\$$ & $\$$ & $\$$ & s \\
\hline $\begin{array}{l}\text { Singapore } \\
\text { Penang and Province }\end{array}$ & 17.073 & 26,074 & 15,000 & 16,107 & 1,107 & $-\quad 9,967$ \\
\hline Wellesley $\quad$.. & 5,628 & 3,401 & 3,625 & 2,870 & 755 & 531 \\
\hline Dindings & 13,305 & 18,300 & 15,020 & 11,895 & 3,125 & $-6,405$ \\
\hline Malacca & 16,757 & 15.533 & 28,700 & 29,554 & 854 & $+14,021$ \\
\hline TOTAL $\quad \ldots$ & 52,763 & 63,308 & 62,345 & 60,426 & 1,919 & 2,882 \\
\hline
\end{tabular}

The principal reasons for increase in Malacca have been stated in paragraph 29 . 


\section{EXPENDITURE.}

38. The following statement shows the 'expenditure from 1927 to 1929 :- -

\begin{tabular}{|c|c|c|c|c|c|c|}
\hline SETTLEMENT & $\begin{array}{l}\text { Expenditure } \\
\quad 1927\end{array}$ & $\begin{array}{l}\text { Expenditure } \\
1928\end{array}$ & $\begin{array}{l}\text { Estimated } \\
\text { expenditure } \\
1929\end{array}$ & $\begin{array}{c}\text { Actual } \\
\text { expenditure } \\
1929\end{array}$ & $\begin{array}{l}\text { Savings on } \\
\text { estimates }\end{array}$ & $\begin{array}{c}\text { Increase } \\
\text { or } \\
\text { decrease } \\
\text { over } 1928 \\
\text { actuals }\end{array}$ \\
\hline & $\$$ & $\$$ & $\$$ & $\$$ & $\$$ & $\$$ \\
\hline $\begin{array}{l}\text { Singapore } \\
\text { Penang and Province }\end{array}$ & 9,411 . & 10,083 & 9,955 & 11,216 & $-\quad 1,261$ & $+\quad 1,133$ \\
\hline $\begin{array}{l}\text { Wellesley } \\
\text { Dindings } \\
\text { Malacca. }\end{array}$ & & $\begin{array}{r}11,488 \\
8,773 \\
35,897\end{array}$ & & $\begin{array}{r}12,308 \\
9,099 \\
72,458\end{array}$ & $\begin{array}{l}-\quad 4,363 \\
+\quad 1,126 \\
-\quad 9362\end{array}$ & $\begin{array}{r}+\quad 820 \\
+\quad 326 \\
+\quad 36561\end{array}$ \\
\hline TOTAL & 54,998 & $66,241^{\circ}$ & 91,221 & $* \dagger 105,081$ & $-13,860$ & $+38,840$ \\
\hline
\end{tabular}

* Excludes temporary allowances amounting to $\$ 4,317$

f Includes share of headquarters expenses, of training of local forest officers and contribution to the Imperial Forestry Institute, Oxford.

\section{COMPARATIVE STATEMENT.}

39. The results of the year's working are shown in the following statement:-

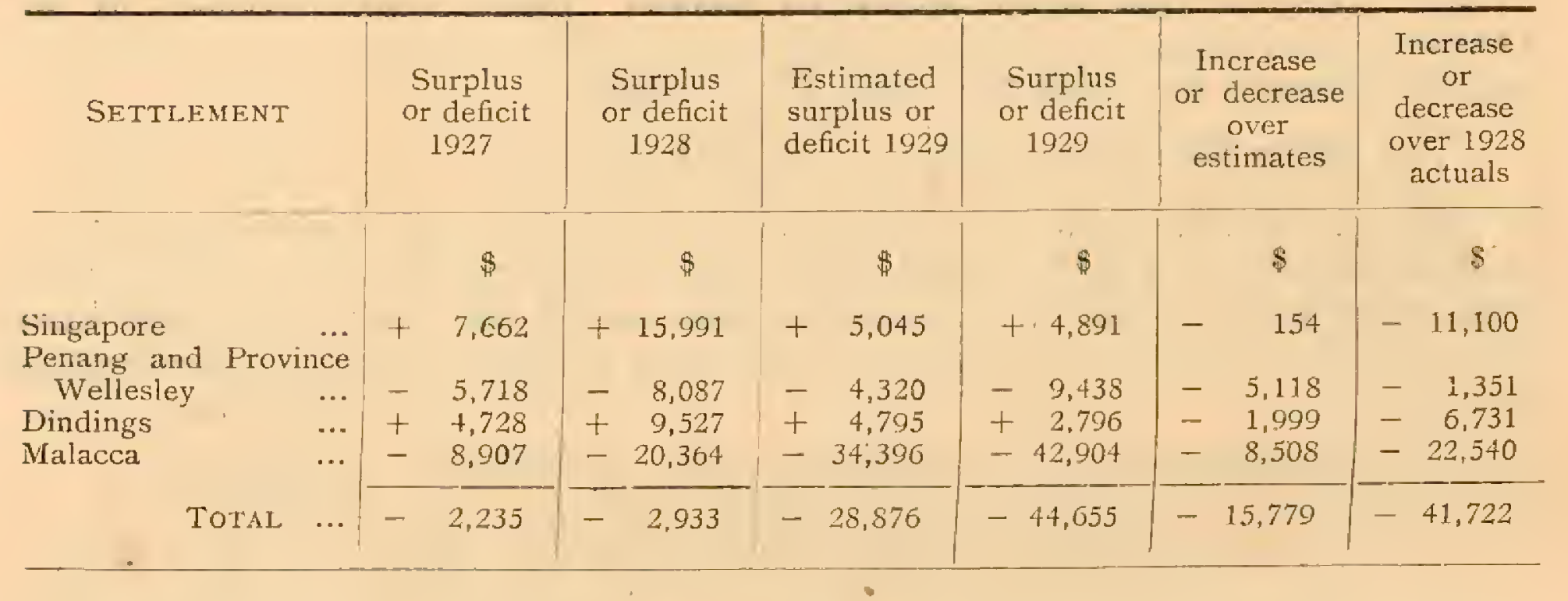

\section{PART IV}

\section{ADMINISTRATION}

40. Mr. G. E. S. Cunitr, с.в.E., continued in charge of the department until his retirement on 1 $3^{\text {th }}$ December, when the writer succeeded him.

Singapore remained under the charge of a Sub-Assistant Conservator of Forests under the general supervision of the Personal Assistant to the Conservator (now Deputy Director). Malacca remained under the sole charge of an Assistant Conservator of Forests, with headquarters at Jasin, working under the State Forest Officer, Negri Sembilan and Malacca. The State Forest Officer, Perak North, continued to supervise the forests of Penang and the Dindings. An Assistant Conservator of Forests with headquarters in Taiping was in charge of Penang throughout the year, but the work in the recently-constituted Dindings district suffered from changes.

\section{J. P. MEAD,}

Director of Forestry.

F. M. S. and S.S.

Kuala Lumpur, i3th March, i93o. 
APPENDIX

LIST OF TREES ETC., MENTIONED IN THE REPORT AND FORMS.

\begin{tabular}{|c|c|c|c|c|}
\hline $\begin{array}{l}\text { Vernacular or } \\
\text { English name }\end{array}$ & & Botanical name & & Uses \\
\hline Bakau & .. & Rhizophora spp. $\quad$.. & ... & Firewood, poles \& cutch \\
\hline Bakau kurap & ... & Rhizophora mucronata Lam. & $\ldots$ & Do. do. \\
\hline Bakau minyak & .. & Rhizophora conjugata Linn. & $\ldots$ & Do. \\
\hline Bertam & & Eugeissonia tristis Griff $\ldots$ & $\ldots$ & Thatch \\
\hline Chengal & .. & Balanocarpus Heimii King & ... & Timber and damar \\
\hline Jangkang & ... & Dillenia reticulata King ... & ... & Timber \\
\hline Jelutong & ... & Dyera spp. $\quad \ldots$ & $\ldots$ & $\begin{array}{l}\text { Timber; veneers for } \\
\text { matches; clogs; chew- } \\
\text { ing gum }\end{array}$ \\
\hline Keledang & & Artocarpus lanceaefolia Roxb. & 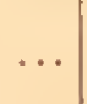 & Timber \\
\hline Keruing & & Dipterocarpus spp. $\quad \ldots$ & & Timber and wood oil \\
\hline Melantai & ... & Shorea macroptera Dyer. ... & ... & Timber \\
\hline Mengkuang & $\cdots$ & Pandaniss spp. $\quad \ldots$ & ... & Mats \\
\hline Meranti & & Shorea spp. & ... & Timber \\
\hline Meranti tembaga & ... & Shorea leprosula Miq. ... & $\cdots$ & Do. \\
\hline Merbau & & Intsia (Afzelia) spp. $\quad \ldots$ & ... & Do. \\
\hline Mersawa & & Anisoptera thurifera Bl. ... & ... & Do. \\
\hline Nibong & . & Oncosperma filamentosa $\mathrm{B} 1$. & & House posts, flooring \\
\hline Nipah & .. & Nipah fruticans Wurmb. ... & $\ldots$ & Thatch and alcohol \\
\hline Para rubber & .. & Hevea brasiliensis M. A. ... & $\cdots$ & Rubber \\
\hline Penaga & .. & Mesua ferrea Linn. $\quad \ldots$ & $\ldots$ & Timber \\
\hline Pinang raja & .. & Cyrtostachys Lakka Becc. & $\ldots$ & Ornamental palm \\
\hline Resak & ... & Vatica spp. $\quad \ldots$ & $\ldots$ & Timber \\
\hline Rotan & $\cdots$ & Climbing palms, var. spp. & .. & Canes \\
\hline Sena & $\ldots$ & Pterocarpus indicus Willd. & $\ldots$ & Timber \\
\hline Seraya & $\ldots$ & Shorea Curtisii Dyer $\quad \ldots$ & .. & Do. \\
\hline Sundek & $\cdots$ & Madhuca and Payena spp. & .. & Gutta percha \\
\hline Taban & $\ldots$ & Palaquitim spp. $\quad \ldots$ & $\ldots$ & Do. \\
\hline Tapioca & $\cdots$ & Manihot utilissima Pohl. ... & $\ldots$ & Food \\
\hline Temak & ... & Shorea crassifolia Ridley ... & $\ldots$ & Timber and damar \\
\hline Tembusu & $\ldots$ & Fagraea gigantea Ridley ... & $\ldots$ & Timber \\
\hline Ubi kembili & $\therefore$ & Coleus tuberosus Benth. ... & ... & Food \\
\hline
\end{tabular}




\section{Annual Report on Forest Administration in the Straits Settlements for the Zear 1930}

\section{PART I}

\section{EXTENSION AND CONSTITUTION OF RESERVED FORESTS.}

r. In Singapore Island an extension of 682 acres of fairly grood, hut inmature, bakan* was added to the Tuas reserve.

2. In the Dindings, as the result of resurvey, the areas of the Gunong finggal and Tanjong Hantu reserves were found to have been underestimated by $\mathrm{I}_{4} 2$ and 20 acres respectively.

3. In Province Wellesley the Bukit Goa Ipoh and Bukit Langkap reserves, 292 and 231 acres respectively, were revoked and handed over to the Land Office for allotment to market gardeners.

4. In Singapore Island the Bukit Timah reserve was revolied and reconstituted to include only forest land, all those parts of the original reserve now occupied by squatters and the rifle range being excluded: 'The valley in the sonth-west near Hampstead Bath contains a number of plants that now occur nowhere else in the island, and it is therefore hoped that it will be found possible to retain the reconstituted reserve permanently unler forest.

5. Minor decreases totalied 94 acres, being accounted for by excisions for house sites and kampongs and by revisions of area on resurvey.

6. The total area and distribution of reserved forests are shown in the statement below :-

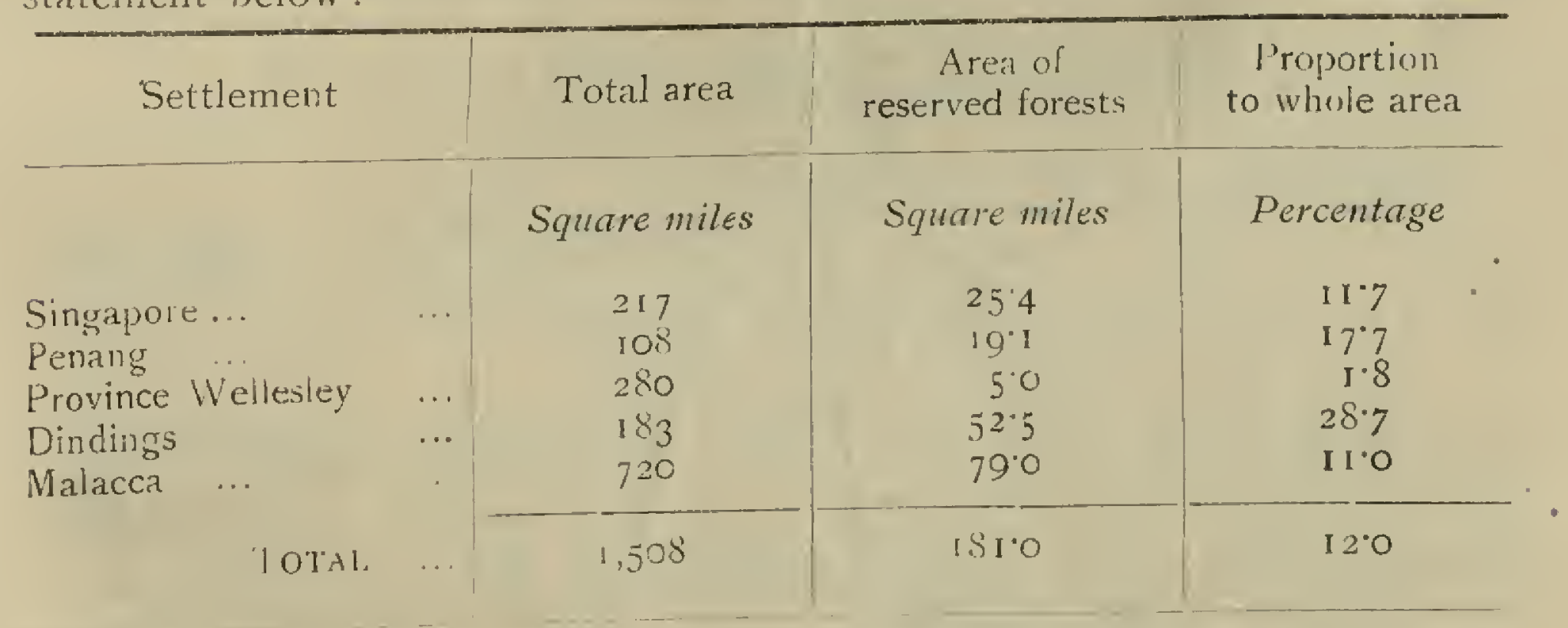

7. I'roposals for the abandonment of all the reserves in Singapore Island, Bulkit Timah excepted. were put nip to the Governinent during the year and are still under consideration. Apart from Bukit Timah as reconstituted, the remaining forests are either given orer to occupation by syuatters or consist of scattered areas of immature mangrove, which have been badly damaged by past overcutting. Even conld the difficulties of protecting these forests against the depredations of fishermen and squatters be overcome, it is doubtful whether they could ever be mate to pay.

For botanical names of trees etc., mentioned in this report sec Appendix. 


\section{DEMARCATION AND MAINTENANCE OF BOUNDARIES OF RESERVED FORESTS.}

8. The total length of boundaries decreased from 606 to 600 miles, of which about 130 miles are formed by natural features and require no upkeep. A length of 434 miles was repaired for $\$ 1,133$, i.c., \$2.6I a mile, much the same figure as in 1929.

\section{SURVEYS.}

9. By the Survey Department:-In Malacca complete topographical surveys on the $4^{\prime \prime}$ to I mile scale with 25 -foot contour intervals were made of the Ayer Panas, Batang Malaka, Berisu, Bukit Bruang, Bukit Senggel, Kuala Linggi, Merlimau, Nyalas, Ramuan China and Sungei Udang reserves, a total area of 39,595 acres, at a cost of $\$ 30,079$ or $\$ 486$ a square mile. These surveys will greatly facilitate the development of the reserves.

In the Dindings part of the boundaries of Segari Melintang and the whole of Tanjong Hantu were traversed at a cost of $\$ 2,21 \mathrm{I}$. The excision from the Batu Undan F. R. was also surveyed.

Io. By the Forest Department:-In Malacca various small departmental surveys were made of paths, swamps and the like at a total cost of $\$ 65$.

In Penang and Province Wellesley about 38 miles of enumeration surveys were made at a cost of $\$ 820$ over the Pantai Acheh, Telok Bahang, Bukit furu and Tasek Gelugor reserves to obtain data of the growing stock on which to base a scheme for the improvement of the forests. The total area covered was about 5, 100 acres.

The compartment boundaries of Pantai Acheh were surveyed for $\$ 22$.

\section{PART II}

\section{MANAGEMENT OF FORESTS.}

I1. The prescriptions of the approved working scheme for the Malacca forests were generally adhered to. All arrears from the previous year were cleared off and the work laid down for 1930 completed with the exception of two compartments in which work is still in progress.

The proposed compilation of a working scheme for the Kuala Linggi mangrove had to be postponed owing to delay in the survey of the revised botndaries.

12. In the Dindings it was not found possible to follow the approved scheme for the Tanjong Burong mangrove owing to the lack of demand for firewood and poles.

A proposal was approved to work on a 30 -year rotation the mixed crop of bakan and tongar on 380 acres in the Batu Undan reserve. Three subcoipes were opened but work was not started until mid-December, only 44 tons of firewood being removed during the year.

13. In Penang and Province Wellesley a scheme for the improvement of the growing stock of the Pantai Acheh, Telok Bahang, Bulkit Iuru and Tasek Gelugor reserves was approved by the Government, the necessary - funds to initiate the work being prorided for I93.. The entmeration surveys necessary to obtain data on which to base the scheme have already been referred to in paragraph Io.

In Pantai Acheh an exceptionally fine crop of bintangor, damar laut, moranti and moracian was found, although the larger girth classes, owing to heavy timber working in the past, are not well represented.

The stand in Telok Bahang was found to be somewhat poorer in established regeneration than that in Pantai Acheh, probably because there has not been the same long continued working of poles for fishing stakes, which has been such a feature in the former reserve. 
Tasek Gelugor was found to possess a much better crop than had been supposed, and, though the condition of the young regeneration cannot be regarded as satisfactory, there is every prospect of eventually converting the crop into a valuable commercial forest by silvicultural treatment.

Bukit Juru contains about 200 acres of good forest in which bintangor damar laut, medang and tampinis predominate.

It is thought that there is sufficient forest of good quality outside tlie catchment area in Bukit Panchor to justify an enumeration survey, and this will be done during the current year.

\section{COMMUNICATIONS.}

14. In Malacca i6 miles of new paths were constructed at a cost of $\$ 695$ and 146 miles of already existing paths were repaired at a cost of $\$ 1,420$.

I5. In Penang and Province Wellesley $8 \frac{1}{2}$ miles of new paths were constructed for $\$ 29 \mathrm{I}$ and $\mathrm{I}_{2}$ miles maintained at a cost of $\$ 4$.

16. In the Dindings $4 \frac{3}{4}$ miles of new paths were made in the Telor Muroh reserve for $\$ 25^{\circ}$.

17. All other existing paths were kept in repair by the subordinate staff.

\section{BUILDINGS.}

18. In Singapore new quarters to accomodate two forest guards were erected by the Public Works Department at Pandan at a cost of $\$ 1,850$.

19. In the Dindings the Public Works Department completed the District Forest Officer's quarters at Lumut at an additional cost of $\$ 2,736$ (the total expenditure being $\$ 2 \mathrm{I}, 626$ ) and a new forest office for $\$ 5,5 \mathrm{II}$.

A sum of $\$ 8,959$ was spent on quarters for two clerks, but the building was not ready at the end of the year.

Coolie-lines were erected departmentally in the Telok Muroh reserve.

so. Temporary quarters near the Bukit Beruang reserve to accomodate the subordinate in charge of the coolies were built departmentally at a cost of $\$ 36$.

2I. The Public Works Department spent \$I,526 on general repairs to a number of forest buildings. In Malacea a further sum of \$rog was spent out of forest rotes on repairs.

\section{PROTECTION OF FORESTS.}

22. The titles of various forest officers were changed in accordance with the instructions of the Secretary of State and effect was given to the change by Ordinance No. 4 of 1930

23. No cases were pending from I929. There were 86 new cases compared with 103 cases in 1929 and 76 in 1928. All were disposed of during the vear. There irere small increases in the numbers of offences in the Dindings and Malacca, but in Singapore the number of detected cases declined from $2 \mathrm{I}$ to 5 .

24. Twenty-five cases were taken to court, in 23 of which convictions were obtained. Fines inflicted totalled \$320, i.e., \$ $\$ 3.9 \mathrm{I}$ per conviction compared with \$I,5I8 and \$58.39 in I929. Twelve cases were dealt with departmentally and \$II6 was paid as compensation. The corresponding figures for I929 were 13 and \$I37.

There was a decrease of 12 in the number of undetected cases.

25. In Malacca there were 45 instances of breaches of felling leases and liquidated damages amounting to $\$ 42$ I were paid.

In 1929 there were 3 I breaches and damages amounted to $\$ 223$. 
26. Various small fires occurred in the Dindings and Penang but the damage caused was insignificant.

27. Crabs as usual did some damage to planted bakau seedlings in the Tanjong Burong reserve in the Dindings. The sea is eroding the forest in the north-west of this reserve from Sungei Bruas to Sungai Banting, a distance of about three miles. A strip of forest $I_{2}^{\frac{1}{2}}$ chains wide was washed away doring 1930.

\section{SILVICULTURE.}

\section{(i) Natural Rertoduction.}

28. Except in some parts of Malacca, the year 1930 was not a very good seed-year. In Malacca of the dipterocarps keming fruited prolifically, particularly in the Batang Malaka, Bukit Sedanan and Ramuan China reserves, and meranti in the Bukit Sedanan and Bukit Senggeh reserves. Mcrbau fruited well in Ayer Panas and Bukit Sedanan, while quantities of freshly-germinated seed of kempas and rengas were found in the Bukit Sedanan and Sungai Udang reserves. Taban fruited in May in the Telok Bahang reserve in Penang and in August in the Ayer Kroh plantations in Malacca. It is interesting to note that mahogany flowered in the Ayer Kroh plantations. Seraya fruited in the Bukit Timah reserve in Singapore. The Dindings report is vague, but in the latter part of the year meranti tembaga, merazun, penaga, sepetir, seraya and rengas are said to have fruited.

\section{(ii) Planting and Cultural Operations.}

29. No new planting was done in Penang. The plantations in Bukit Goa Ipoh and Bukit Langkap, referred to in paragraph 24 of the Ig29 report, were abandoned on the revocation of those reserves.

30. In the Dindings an area of I acre in coupe $\mathrm{I} / 27$ of the Tanjong Burong reserve, which had failed to regenerate itself naturally, was planted with bakau minyak by patrol guards. The seedlings were all badly attacked by crabs and only 57 were alive at the end of the year.

3r. In Malacca the plantations at Ayer Kroh are reported all to be in foo: condition. The nerbau and penaga plantations of $9^{\frac{1}{2}}$ acres were maintained at a cost of $\$ 339$.

An enumeration of all the trees in the plantations was made for \$II. A sum of \$I70 was realized for the right to tap the Para rubber plantation and a further \$III from royalty on firewood and sale of poles.

32. In Singapore the Para rubber plantation at Yeo Chu Kang was leased for 4 months only; the revenue realised being $\$ 120$ and maintenance costing $\$ 248$.

\section{(iii) Regeneration Fellings.}

33. These fellings are designed, by allowing the removal of unwanted species in the form of poles and firewood, to increase the proportion of valuable species, which are left to seed up the blanks caused by the removal of the unwanted species. Fellings of this type were in progress over a total area of 1,568 acres in the Pantai Acheh, Tasel Gelugor and Telok Bahang reserves in Penang and Province Wellesley.

\section{(iv) Regeneration Improvemext Fellings.}

34. In places where there is no market for firewood it is not possible to get inferior species removed by contractors and it is therefore necessary to effect their removal by means of departmental fellings and girdlings. These operations are known as "regeneration improvennent fellings". Schemes for work of this kind are now in operation in the Dindings and Malacca. the former having been newly started during the year, 
35. Tn the Dindings an area of 119 acres in Telok Muroln was treated at a cost of $\$ 1,600$, including the cost of tools and coolie-lines. The principal species faroured in these operations was damar laut, which is very abuntant and all size-classes being well represented. Other valuable species that aro fairly common are bintangor, rengas and scpetir.

36. In Malacca the scheme fellings originally started in 1928 were continued and completed over the following areas:-

Ayer Panas 736 acres, Batang Malaka 3 I4 acres, Bukit Sedanan I,7r4 acres, Bulit Senggeh i acre, Merlimau 97 I acres, Ramuan China 78 I acres and Sungai Udang 373 acres; in all 4,890 acres were treated at a cost of $\$ 26,502$, i.e., $\$ 5.42$ per acre. This figure is a reduction of $\$ 3.45$ per acre from 1929 and is accounted for largely by the increased experience of the labour force. A total area of 10,693 acres of the Malacca reserves had been treated with improvement fellings at the end of the year. The results of the work are now becoming apparent and show distinct promise of sticcess.

\section{EXPLOITATION}

\section{(i) Timber and Fuel.}

\section{(a) From rescrved forests.}

37. In Penang and Province Wellesley the outturn of timber and firewood was 367 tons and 499 tons as compared with 315 and I, 4 Io tons in 1929. The increased output of timber was due to the opening of the Telok Bahang reserve to pole working, and the large decrease in firewood is accounted for by decreased demand and by the revocation of the Bukit Goa Ipoh and Bukit Langkap reserve, the outturn from which (about 500 tons) is now recorded under that from "Crown and alienated lands".

38. In the Dindings the outturn of class I timber fell from 190 tons to $8 \mathrm{I}$ tons and that of class 2 timber and poles showed a small increase from I 40 tons to 155 tons. None of the reserves is open to regular cutting of class I timber and the whole ontturn is derived from the removal of dead and fallen chengal and other timber from Segari Melintang and the areas destined for excision.

A pole coupe was opened in Tanjong Burong for the supply of fishingstalies and 40 tons of l'nggadai poles were removed.

The ontturn of firewood dropped from 7 I9 to 427 tons. Charcoal to a weight of 15 tons was removed from a area in the Lumut reserve destined for excision.

39. In Malacca the steady demand for timber apparent at the end of r 929 continued through the best part of the year, but latterly fell off. The outturn of class $\mathrm{I}$ and 2 timber was $2,55 \mathrm{I}$ and $2,99 \mathrm{I}$ tons compared with 2,083 and 3,142 tons in 1929. There was a remarkable increase in the outturn of firewood, viz., from $\mathrm{I} 2,737$ tons in 1929 to 26,589 tons. It is chiefly acconnted for by the removal for firewood of trees of inferior species felled and girdled in the departmental operations. Two hundred and twenty-one tons of charcoal were produced in the Malacca reserves.

40. In Singapore 60 tons of class 2 timber were removed for trial in a local match factory. The outturn of frewood rose from 56 tons in 1929 to 10,907 tons in 1930 . This increase resulted from the sale of coupes in the most inaccessible of the mangrove forests, which it had been found impossible to protect.

4I. The total outturn of the Straits Settlements from reserved forests was 6,2 I 5 tons of timber and 38.422 tons of firewood as compared with 5,870 tons of timber and I.4,922 tons of firewood in 1929.

\section{(b) From Crooun and alienated land.}

42. In Penang and Province Wellesley the outturn of timber and fire wood was 297 and 1.789 tons as against 168 and 1.516 tons in 1929 . These increases are accounted for by the revocation of the Bukit Goa Ipoh and Bukit Langkap reserves, which were then exploited to their full capacity. 
43. In the Dindings the ontturn of timber and firewood was 1,787 tons and 1.928 tons as compared with 2,044 and 2,017 tons in 1929. Charcoal increased from 398 to 413 tons.

44. In Malacca the outturn of timber decreased by 1,896 tons to $[, 426$ tons, but firewood increased to 5,284 tons.

45. In Singapore the outturn of timber and firewood was 60 and 7,840 tons as compared with one and 14,400 tons in 1929 .

46. The total outturn of the Straits Settlements was 3,570 tons of timber, 16,842 tons of firewood and 431 tons of charcoal, as against $5,698,21,235$ and 398 tons respectively in 1929 .

(c) General.

47. The revente derived from timber, firewood and charcoal was as under: -

\begin{tabular}{|c|c|c|c|c|}
\hline$\ldots$ & & Timber & $\begin{array}{c}\text { Firewood \& } \\
\text { Charcoal }\end{array}$ & Total \\
\hline \multirow{6}{*}{$\begin{array}{lr}\text { Penang \& } & \text { Province } \\
\text { Dindings } & \ldots \\
\text { Malacca } & \ldots \\
\text { Singapore } & \ldots\end{array}$} & & $\$$ & $\$$ & $\$$ \\
\hline & Wellesley & I, I 54 & 769 & $\mathrm{I}, 923$ \\
\hline & & 5.320 & 1,922 & 7,242 \\
\hline & & 19,180 & I I , 624 & 30,804 \\
\hline & & 862 & 10,722 & II, 584 \\
\hline & TOTAL ... & 26,516 & 25,037 & $5^{1,553}$ \\
\hline
\end{tabular}

48. In Malacca many of the species in ciass 2 of the timber roll, which are not ordinarily in favour for conversion into timber, continue to he used. Notable amongst these are jambu kchang, which is generally preferred to the common meranti, and kedondong.

(ii). Other Forest Produce.

(a) From reserved forests.

49. Revente fell from $\$ 4,00 \mathrm{I}$ to $\$ 3,6 \mathrm{II}$. There was howerer an increase in the nutput of damar temak in the Dindings, the revenue derived from which rose from $\$ 362$ to $\$ 1,012$, as was anticipated in the 1929 report.

No jclutong tapping was done in Malacca: the contractor who took out a permit and paid premiums in 1929, returned the permit before a single tree had been tapped.

(b) From Croam and alienated land.

50. The revenue rose from $\$ \mathrm{I}, 4 \mathrm{I} 7 \mathrm{in} 1929$ to $\$ \mathrm{r}, 80 \mathrm{I}$.

\section{PART III}

FINANCIAL

(i) Revenue.

51. The following statement shows the revenue from 1928 to 1930 inclusive.

\begin{tabular}{|c|c|c|c|c|c|c|}
\hline SFTTLEMENT & $\begin{array}{c}\text { Revenue } \\
1928\end{array}$ & $\begin{array}{c}\text { Revenue } \\
1929\end{array}$ & $\begin{array}{l}\text { Estimated } \\
\text { revenue } \\
1930\end{array}$ & $\begin{array}{l}\text { Actual } \\
\text { revenue } \\
1930\end{array}$ & $\begin{array}{c}\text { Increase or } \\
\text { decrease } \\
\text { over } \\
\text { estimates }\end{array}$ & $\begin{array}{l}\text { Increase } \\
\text { or } \\
\text { decrease } \\
\text { over } 1929 \\
\text { actuals }\end{array}$ \\
\hline & 8 & $\$$ & $s$ & 8 & s & $s$ \\
\hline $\begin{array}{c}\text { Penang and Prorince } \\
\text { Wellesler }\end{array}$ & 3.401 & 2,870 & 2,865 & 2,552 & 313 & 318 \\
\hline Dindings & 18,300 & 11,895 & 14.580 & $10.8+9$ & 3,731 & 1.016 \\
\hline Malacca & 15.533 & 29.554 & 34,000 & 32.546 & 1,454 & 2.092 \\
\hline Singapore & $26,07+$ & 16.107 & 14,100 & 20,913 & 6,913 & 4.806 \\
\hline Total ... & 63.308 & 60.426 & 65,445 & 66,860 & 1,415 & 6.434 \\
\hline
\end{tabular}




\section{(ii) EXPENDITURE.}

52. The expenditure from I928 to 1930 inclusive is shown hereunder:-

\begin{tabular}{|c|c|c|c|c|c|c|c|}
\hline \multicolumn{2}{|l|}{ SETTLEMENT } & $\begin{array}{c}\text { Expenditure } \\
1928\end{array}$ & $\begin{array}{c}\text { Expenditure } \\
1929\end{array}$ & $\begin{array}{c}\text { Estimated } \\
\text { expenditure } \\
1930\end{array}$ & $\begin{array}{c}\text { Actual } \\
\text { expenditure } \\
1930\end{array}$ & $\begin{array}{l}\text { Savings on } \\
\text { estimates }\end{array}$ & $\begin{array}{c}\text { Increase } \\
\text { or } \\
\text { decrease } \\
\text { over } 1929 \\
\text { actuals }\end{array}$ \\
\hline & & $\$$ & $\$$ & $\$$ & $\$$ & $\$$ & $\$$ \\
\hline $\begin{array}{l}\text { Penang and Provin } \\
\text { Wellesley }\end{array}$ & & 11,488 & 12,308 & 8,199 & 10,645 & 2.446 & 1,663 \\
\hline Dindings & ... & 8.773 & 9,099 & 9,993 & 11,879 & $-\quad 1,886$ & $+\quad 2,780$ \\
\hline Malacca. & $\ldots$ & 35,897 & 72,458 & 88,343 & 92,196 & $-\quad 3,853$ & $+19,738$ \\
\hline Singapore & $\cdots$ & 10,083 & 11,216 & 9.573 & 11,052 & $-\quad 1.479$ & 164 \\
\hline TOIAL & $\ldots$ & 66,241 & 105,081 & 116,108 & $*+125,772$ & $-\quad 9,664$ & $+20,691$ \\
\hline
\end{tabular}

* Excludes temporary allowances amounting to $\$ 4,305$.

$\dagger$ Includes share of headquarters expenses, of local training of forest officers and the contribution to the Imperial Forestry Institute, Oxford.

\section{(iii) Comparative Statement.}

53. The results of the year's working are shown in the following statement:-

\begin{tabular}{|c|c|c|c|c|c|c|}
\hline SETTLEMENT & $\begin{array}{l}\text { Surplus } \\
\text { or deficit } \\
1928\end{array}$ & $\begin{array}{l}\text { Surplus } \\
\text { or deficit } \\
1929\end{array}$ & $\begin{array}{l}\text { Estimated } \\
\text { surplus or } \\
\text { deficit } 1930\end{array}$ & $\begin{array}{l}\text { Surplus } \\
\text { or deficit } \\
1930\end{array}$ & $\begin{array}{c}\text { Increase } \\
\text { or decrease } \\
\text { over } \\
\text { estimates }\end{array}$ & $\begin{array}{c}\text { Increase } \\
\text { or } \\
\text { decrease } \\
\text { over } 1929 \\
\text { actuals }\end{array}$ \\
\hline & $\$$ & $\$$ & \$ & $\$$ & s & $\$$ \\
\hline $\begin{array}{cr}\text { Penang and } & \text { Province } \\
\text { Wellesley } & \ldots\end{array}$ & $-\quad 8,087$ & $-\quad 9,438$ & $-\quad 5,334$ & 8,093 & 2.759 & $+\quad 1,345$ \\
\hline Dindings & $+\quad 9,527$ & $+2,796$ & $+\quad 4.587$ & $-\quad 1,030$ & $-\quad 5,617$ & $-\quad 3,826$ \\
\hline Malacca & $-20,364$ & $-42,904$ & $-54,343$ & $-\quad 59,650$ & $-\quad 5,307$ & $-\quad 16,746$ \\
\hline Singapore & +15.991 & $+\quad 4,891$ & $+\quad 4,427$ & $+\quad 9,861$ & $+\quad 5,434$ & $+\quad 4,970$ \\
\hline TOTAL & $-\quad 2,933$ & $-44,655$ & $-50,663$ & $-\quad 58,912$ & $-\quad 8,249$ & $-14,257$ \\
\hline
\end{tabular}

\section{PART IV}

\section{ADMINISTRATION.}

54. The writer was in charge of the department throughout the year. Singapore remained under the general supervision of the Deputy Director of Forestry with a Sub-Assistant Conservator in immediate charge. The State Forest Officer, Perak North, continued to supervise the forests of Penang and the Dindings. Throughout the year an Assistant Conservator with headquarters at Taiping was in charge of Penang and an Extra Assistant Conservator stationed at Lumut was in charge of the Dindings. Malacca continued to be in charge of an Assistant Conservator, with headquarters at Jasin, uncler the general supervision of the State Forest Officer, Negri Sembilan and Malacca.

J. P. MEAD,

Director of Forestry, F. M. S. and S. S.

Kunla Lumpur, 28th February, $193 \mathrm{I}$. 
APPENDIX.

LIST OF TREES, ETC., MENTIONED IN THE REPORT AND FORMS.

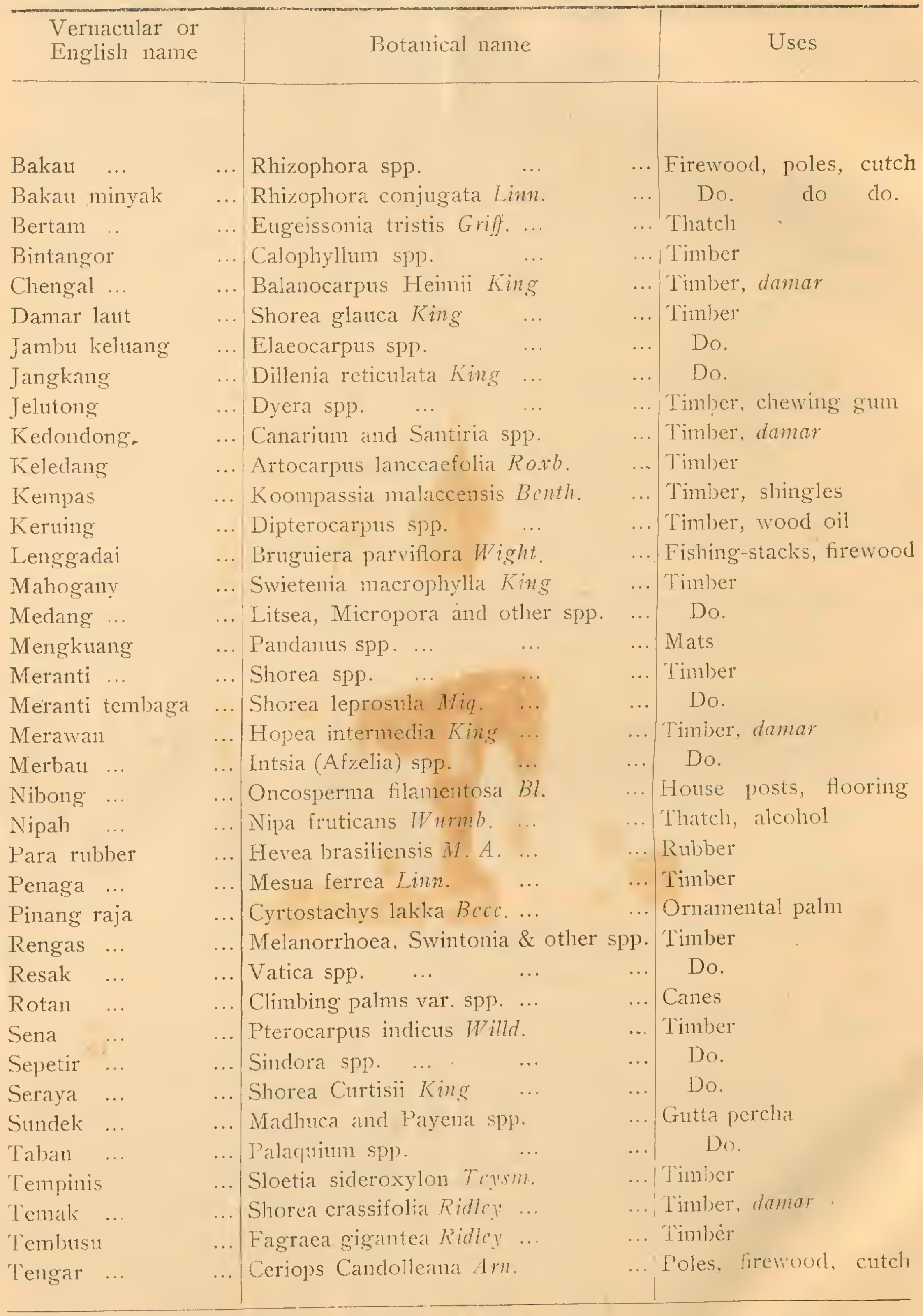



